\title{
Vrouwenmishandeling, strafrechtelijk afgedaan? : strafrechtelijke regulering van mannelijk geweld tegen vrouwen in de privésfeer
}

Citation for published version (APA):

Lünnemann, K. D. (1996). Vrouwenmishandeling, strafrechtelijk afgedaan? : strafrechtelijke regulering van mannelijk geweld tegen vrouwen in de privésfeer. [Doctoral Thesis, Maastricht University]. Gouda Quint. https://doi.org/10.26481/dis.19961220kl

Document status and date:

Published: 01/01/1996

DOI:

10.26481/dis.19961220kl

Document Version:

Publisher's PDF, also known as Version of record

Please check the document version of this publication:

- A submitted manuscript is the version of the article upon submission and before peer-review. There can be important differences between the submitted version and the official published version of record.

People interested in the research are advised to contact the author for the final version of the publication, or visit the DOI to the publisher's website.

- The final author version and the galley proof are versions of the publication after peer review.

- The final published version features the final layout of the paper including the volume, issue and page numbers.

Link to publication

\footnotetext{
General rights rights.

- You may freely distribute the URL identifying the publication in the public portal. please follow below link for the End User Agreement:

www.umlib.nl/taverne-license

Take down policy

If you believe that this document breaches copyright please contact us at:

repository@maastrichtuniversity.nl

providing details and we will investigate your claim.
}

Copyright and moral rights for the publications made accessible in the public portal are retained by the authors and/or other copyright owners and it is a condition of accessing publications that users recognise and abide by the legal requirements associated with these

- Users may download and print one copy of any publication from the public portal for the purpose of private study or research.

- You may not further distribute the material or use it for any profit-making activity or commercial gain

If the publication is distributed under the terms of Article $25 \mathrm{fa}$ of the Dutch Copyright Act, indicated by the "Taverne" license above, 
Vrouwenmishandeling, strafrechtelijk afgedaan? 
Illustratie omslag:

'Conny Janssen danst...': Monoloog voor twee helften.

Fotografie:

Peter Budwilowitz 


\section{Vrouwenmishandeling, strafrechtelijk afgedaan?}

Strafrechtelijke regulering van mannelijk geweld tegen vrouwen in de privésfeer

\section{Proefschrift}

ter verkrijging van de graad van doctor aan

de Universiteit Maastricht,

op gezag van de Rector Magnificus, Prof.mr. M.J. Cohen

volgens het besluit van het College van dekanen,

in het openbaar te verdedigen

op vrijdag 20 december 1996

door

Katinka Dorothé Lünnemann

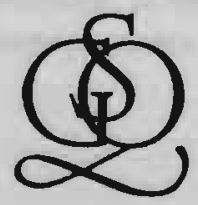

Gouda Quint bv

(S. Gouda Quint-D. Brouwer en Zoon)

Deventer 
Promotor:

Prof.mr. Th.A. de Roos

Co-promotor:

Dr. R.G. Römkens (Universiteit Utrecht)

Beoordelingscommissie:

Prof.mr. G.P.M.F. Mols (voorzitter)

Dr. P.L. Bal

Prof.mr. C.P.M. Cleiren (Erasmus Universiteit Rotterdam)

Met dank aan de J.E. Jurriaanse Stichting voor de financiële bijdrage. 


\section{Voorwoord}

Het boek dat voor $u$ ligt is het resultaat van een jarenlang project. De eerste aanzet is in 1986 gegeven door het onderzoeksproject entameringsstudie "opvang van mishandelde vrouwen" van de Leidse wetenschapswinkel. Deze projectgroep heeft in 1985 en 1986 onderzoek gestimuleerd binnen de Rijksuniversiteit Leiden op het terrein van geweld tegen vrouwen binnen relaties.' De onderzoeksgroep achtte het van groot belang dat de de wijze van reageren door justitiële autoriteiten zou worden onderzocht in aansluiting op het grootschalige onderzoek naar de aard en de omvang van fysiek geweld tegen vrouwen binnen heteroseksuele relaties en onderzoek naar het optreden van de politie in geval van vrouwenmishandeling. Nadat de eerste aanzet is gegeven heb ik het project, met wisselende ondersteuning, voortgezet als promotieonderzoek.

Voor het opstarten van dit onderzoek is een startsubsidie aangevraagd en verkregen bij het toenmalige STEO. De Leidse Rechtenfaculteit in samenwerking met het toenmalige onderzoekscentrum Sturing en Samenleving (tegenwoordig Recht en Beleid) hebben dit project vervolgens tot 1992 gefinancierd in het kader van een promotie-onderzoek. De Rechtenfaculteit Utrecht tenslotte heeft mij de gelegenheid geboden dit project af te ronden.

Het schrijven van een proefschrift, het is al zo vaak geschreven, is een individuele beproeving. Het is niet alleen een wetenschappelijke uitdaging om een maatschappelijke en juridische problematiek in de vingers te krijgen en een eigen visie op het geheel te ontwikkelen, het is ook een individuele beproeving die veel doorzettingsvermogen, acceptatie van eigen beperkingen en een open blik vergt. Maar misschien is voor mij nog wel het allerbelangrijkste dat door het schrijven van dit proefschrift een innerlijke omslag heeft plaatsgevonden: ik sluit niet meer mijn ogen voor het geweld in de privésfeer dat heeft plaatsgevonden en nog steeds plaatsvindt onder mijn en ieders ogen.

1 De wetenschapswinkel Leiden heeft hieromtrent de volgende brochures uitgegeven: Van de Linden \& Walaardt Sacré, Eindverslag Entameringsstudie 'Opvang van mishandelde vrouwen', 1987; Walaardt Sacre \& Portegijs, Wat komt zal de tijd wel leren, 1986; Ballering, Is het strafrechtelijk systeem te gebruiken als instrument voor het maatschappelijk probleem van vrouwenmishandeling?, 1986. Van de Linden \& Walaardt Sacré, Als je straks alleen woont, 1987. 
Zonder hulp en steun van velen, door wetenschappelijke ondersteuning of ondersteuning op het thuisfront, was dit individuele project nooit afgerond. Een aantal mensen wil ik speciaal noemen. Allereerst de collega's van de sectie Juridische Vrouwenstudies, die mij alle ruimte gegeven hebben om mijn 'deadline' te halen. Speciaal wil ik Dorie Moons noemen, die van onschatbare waarde is geweest in het updaten van literatuur, het aanpassen van mijn notenapparaat en andere hand en spandiensten. Jürgen Wöretshofer wil ik bedanken voor zijn zorgvuldige commentaar op een aantal hoofdstukken van dit boek. Marlon Steine en Carla Groenestein wil ik bedanken voor de wijze waarop zij het manuscript 'camera-ready' hebben gemaakt. Jos Teunen wil ik niet alleen bedanken voor zijn ondersteuning op het gebied van de statistische verwerking van het materiaal, maar vooral voor zijn nooit aflatende vertrouwen in mijn capaciteiten en de afronding van dit promotieonderzoek. Theo de Roos heeft mij met zijn vriendelijke commentaar mijn eigen weg laten gaan, terwijl Renée Römkens, die pas de rol van co-promotor op zich nam toen het empirische onderzoek lang en breed was afgesloten, door haar kritische, soms wat strenge commentaar, mijn wetenschappelijke houding heeft versterkt. Aan het einde van de rit hebben Gerard Mols en Tineke Cleiren eraan bijgedragen dat ik eindelijk kon voelen dat ik er in de wetenschap, met al mijn beperkingen, mag zijn.

Zonder Jonathan en Milou tenslotte was het mij nooit gelukt geen 'work-aholic' te worden; door hen bleef ik met beide benen op de grond en gunde ik mezelf de speelsheid van het leven. 


\section{Inhoudsopgave}

Voorwoord

1 Inleidend hoofdstuk

$1.1 \quad$ Inleiding

$\begin{array}{ll}1.2 \text { Hoe privé is de privésfeer? } & 2\end{array}$

1.2.1 De privésfeer tegenover de publieke sfeer 2

1.2.2 Privacy: legitimatie van geweld of vrijheidsbegrip? 4

1.2.3 Dilemma's van overheidsinterventie $\quad 8$

1.2.4 Strafrechtelijke regulering van geweld in de privésfeer?

$\begin{array}{lll}1.3 & \text { Strafrechtelijke interventie en rechtsbescherming } & 15\end{array}$

$\begin{array}{ll}\text { 1.3.1 De functie van het strafproces } & 16\end{array}$

$\begin{array}{ll}\text { 1.3.2 Rechtsbescherming in relationele zin } & 18\end{array}$

$\begin{array}{lll}\text { 1.3.3 Rechtsvrede als doel van het strafrecht } & 22\end{array}$

$\begin{array}{ll}\text { 1.3.4 Respect voor het rechtssubject } & 24\end{array}$

1.4 Vraagstelling en methodologische verantwoording 25

1.4.1 Binnen het kader van de feministische rechtswetenschap 25

$\begin{array}{ll}\text { 1.4.2 Definitie van vrouwenmishandeling } & 27\end{array}$

1.4.3 Ander onderzoek naar vrouwenmishandeling in Nederland $\quad 29$

1.4.4 Hypothesen en probleemstelling 31

$\begin{array}{lll}1.5 & \text { Onderzoeksmethode van het exploratieve onderzoek } & 34\end{array}$

1.5.1 Werkwijze kwantitatief en kwalitatief dossieronderzoek $\quad 34$

$\begin{array}{ll}\text { 1.5.2 Werkwijze interviews } & 41\end{array}$

1.6 De opbouw van dit boek $\quad 42$

2 Geweld tegen vrouwen en het strafrecht 45

$\begin{array}{lll}2.1 & \text { Inleiding } & 45\end{array}$

2.2 Geweld tegen vrouwen in de privésfeer $\quad 46$

2.2.1 De aard en omvang van vrouwenmishandeling $\quad 46$

2.2.2 Vrouwenmishandeling als een sekse-specifiek en maatschappelijk $\begin{array}{ll}\text { fenomeen } & 48\end{array}$

2.2.3 Asymmetrische machtsverhoudingen binnen man-vrouw relaties 51

$\begin{array}{ll}2.2 .4 \text { Waarom vrouwen (niet) weggaan } & 57\end{array}$

2.2.5 Vrouwenmishandeling is een specifiek geweldsdelict 59

2.3 De inzet van het strafrecht 61 
2.3.1 'Vrouwen moeten hun onafhankelijkheid bewaren'

2.3.2 'Liberalisering van het strafrecht zal de onderdrukking van vrouwen verscherpen'

2.3.3 Van radicale kritiek tot hervorming

2.4 Kritiek op de strafrechtelijke aanpak van geweld tegen vrouwen 68

2.4.1 Kritiek op politie en openbaar ministerie $\quad 68$

2.4.2 Aanbevelingen voor een andere strafrechtelijke aanpak $\quad 70$

2.5 Een gewijzigde positie van slachtoffers in het strafproces $\quad 75$

2.5.1 Slachtoffers binnen het strafproces: een nieuw beleid 77

2.5.2 Wettelijke regelingen voor slachtoffers in het strafproces $\quad 79$

$\begin{array}{ll}\text { Voeging als benadeelde partij } & 79\end{array}$

Sanctiemodaliteiten ten behoeve van de benadeelde partij $\quad 83$

Beklag tegen niet-vervolgen $\quad 85$

2.5.3 (G)een strafrechtelijk beleid ter bestrijding van vrouwenmishandeling 88

$\begin{array}{lll}2.6 & \text { Strafrechtelijke regulering van vrouwenmishandeling } & 91\end{array}$

3 Vrouwenmishandeling als strafbaar feit 93

3.1 Inleiding 93

$\begin{array}{ll}3.2 \text { Van bedreiging tot doodslag } & 97\end{array}$

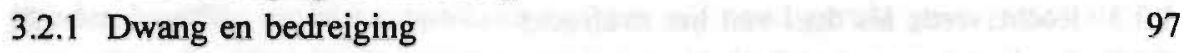

3.2.2 Mishandeling $\quad 99$

3.2.3 Van pogingen tot uitgevoerde doodslag of moord 103

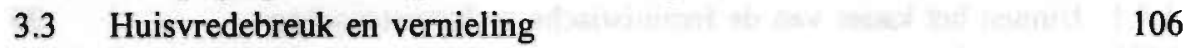

$\begin{array}{ll}\text { 3.3.1 Huisvredebreuk } & 107\end{array}$

$\begin{array}{ll}\text { 3.3.2 Vernieling } & 109\end{array}$

$\begin{array}{ll}3.4 \text { Verkrachting en aanranding } & 110\end{array}$

$\begin{array}{ll}3.4 .1 \text { Seksuele handelingen } & 110\end{array}$

3.4.2 Dwang door geweld of een feitelijkheid 114

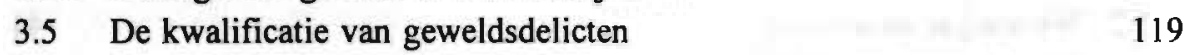

4 Het openbaar ministerie en zijn bevoegdheden 123

$\begin{array}{lll}4.1 & \text { Inleiding } & 123\end{array}$

4.2 Het gezag van het openbaar ministerie over de politie 125

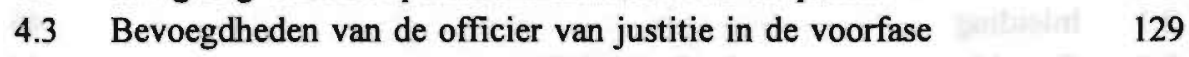

4.3.1 Bevoegdheden in het kader van de waarheidsvinding 129

4.3.2 De bevoegdheid van (verdere) vervolging af te zien 130

$\begin{array}{ll}\text { Sepotgronden } & 132\end{array}$

$\begin{array}{ll}\text { Berisping en waarschuwing } & 134\end{array}$

Voorwaardelijk sepot en transactie 135

$\begin{array}{lll}4.4 & \text { Bevoegdheden die samenhangen met dagvaarden } & 139\end{array}$ 
4.4.1 Dagvaarden van de verdachte

Snelrecht en vlugrecht

4.4.2 Het oproepen van het slachtoffer als getuige

4.4.3 Het requisitoir van de officier van justitie

5 Vrouwenmishandeling een zaak voor justitie

5.1 Inleiding

5.2 De vervolgingspraktijk van geweldsdelicten

5.2.1 Frequentie en vervolgingspraktijk in $\mathbf{1 9 7 5}$

Frequentie

De vervolgingspraktijk

Delictsoort

5.2.2 Frequentie en vervolgingspraktijk in het eerste kwartaal van $1985 \quad 154$

Frequentie

$\begin{array}{ll}\text { De vervolgingspraktijk } & 155\end{array}$

Delictsoort 157

$\begin{array}{ll}\text { 5.2.3 Enkele concluderende opmerkingen } & 159\end{array}$

$\begin{array}{lll}5.3 & \text { Een gevarieerd beeld van zaken van vrouwenmishandeling } & 160\end{array}$

5.3.1 Kenmerken van zaken van vrouwenmishandeling 161

$\begin{array}{ll}\text { 5.3.2 Vrouwenmishandeling is geen eenduidig begrip } & 164\end{array}$

$\begin{array}{ll}\text { Vernieling en huisvredebreuk } & 165\end{array}$

$\begin{array}{ll}\text { Mishandeling en bedreiging } & 167\end{array}$

$\begin{array}{ll}\text { Moord en doodslag } & 171\end{array}$

$\begin{array}{ll}\text { Verkrachting en aanranding } & 174\end{array}$

$\begin{array}{ll}\text { Een gevarieerd beeld } & 177\end{array}$

$\begin{array}{ll}\text { 5.4 De vervolgingspraktijk } & 177\end{array}$

$\begin{array}{ll}\text { De vervolgingspraktijk in het algemeen } & 178\end{array}$

De vervolgingspraktijk naar arrondissement $\quad 179$

De vervolgingspraktijk naar delictscategorie en naar relatie $\quad 181$

5.5 De beslissing omtrent vervolging door de officier van justitie 183

$\begin{array}{ll}5.5 .1 & \text { Inleiding } \\ 5.53\end{array}$

5.5.2 Afzien van vervolging om opportuniteitsredenen 184

Alcohol, recidive, leeftijd $\quad 184$

Duur en frequentie van het geweld 186

Een verbroken of voortdurende relatie 187

$\begin{array}{ll}\text { Intrekken van de aanklacht } & 189\end{array}$

Fysiek verweer van het slachtoffer $\quad 190$

5.5.3 Het afwegingsproces van officieren van justitie 192

Maviye en Glenn: een klassiek geval van vrouwenmishandeling 192

Lianne en Dick: inbreuk op de privacy 196

Anneke en Martin: verkrachting door de ex-partner 199 
Drie manieren van optreden $\quad 201$

$\begin{array}{lll}5.6 & \text { Samenvatting en knelpunten } & 202\end{array}$

6 Rechtsbescherming van slachtoffers 207

6.1 Inleiding 207

6.2 De interpretatie van geweld tegen vrouwen nader bekeken 209

6.2.1 Seksuele dwang binnen relaties en bescherming van de wilsvrijheid 209 $\begin{array}{ll}\text { Opvattingen over gedwongen seks binnen een relatie } & 209\end{array}$ $\begin{array}{ll}\text { Het inzichtvereiste nader beschouwd } & 216\end{array}$ $\begin{array}{ll}\text { Objectivering van de dwang } & 218\end{array}$

6.2.2 Fysiek geweld tegen vrouwen als inbreuk op de persoonlijke $\begin{array}{ll}\text { levenssfeer } & 222\end{array}$

Fysiek geweld binnen (huwelijkse) relaties $\quad 222$

$\begin{array}{ll}\text { Inbreuk op de privacy door de ex-partner } & 225\end{array}$

6.3 Rechtsbescherming door versterking van de rechtspositie 228

6.3.1 De rechtspositie van het slachtoffer als benadeelde van een misdrijf 228 Zeggenschap over strafvervolging? 230

6.3.2 Rechtsbescherming van de slachtoffer-getuige 235 $\begin{array}{ll}\text { Het recht te spreken } & 237\end{array}$

Het beroep op verschoning en 'gevaar voor de lichamelijke en $\begin{array}{ll}\text { geestelijke gezondheid' } & 238\end{array}$

Het recht op fair hearing en rechtsbijstand 243

6.3.3 Rechtsbescherming door verbetering van de rechtspositie van het slachtoffer

6.4 Een strafrechtelijke aanpak gericht op herstel van de rechtsvrede: enkele aanbevelingen $\quad 246$

6.4.1 Erkenning van vrouwenmishandeling als strafrechtelijk probleem 247

6.4.2 Preventief optreden ter bescherming van de persoonlijke levenssfeer 248

6.4.3 Een humane aanpak door officieren van justitie 254

6.5 Rechtsbescherming is meer dan het versterken van de rechtspositie 255

7 Conclusie: humaan strafrecht 257

$\begin{array}{ll}\text { Een terugblik } & 258\end{array}$

Getiteld 'Geweld in de privésfeer'

Een humane aanpak in een tijd van 'nieuwe zakelijkheid'? 265

$\begin{array}{ll}\text { Zoeken naar bescherming } & 267\end{array}$ 
Bijlagen:

1. Operationalisatie vrouwenmishandelingszaken 269

2. Selectieprocedure 273

3. Dossieronderzoek Justitie en Vrouwenmishandeling 277

4. Interviewlijst 27-7-1990 281

5. Tabellen I-IX 285

$\begin{array}{ll}\text { Summary } & 293\end{array}$

$\begin{array}{ll}\text { Literatuurlijst } & 299\end{array}$

$\begin{array}{ll}\text { Trefwoordenregister } & 319\end{array}$

$\begin{array}{ll}\text { Curriculum vitae } & 327\end{array}$ 


\section{Inleidend hoofdstuk}

Zomaar een krantenbericht eind mei 1996:

"De politie is niet berekend op privé-situatie met geweld Een jongen die zijn huisraad uit zijn flat naar buiten smijt en dreigt zichzelf op te hangen. Een man die zijn vriendin naar het leven staat en de buurman met een mes aamvalt. Een vrouw die zich in haar huis heeft verschanst achter torenhoge stapels oude rotzooi. Echtgenoten die elkaar de hersens in slaan. De Arnhemse politie heeft het afgelopen weekeinde haar handen vol gehad aan sociaal-maatschappelijke problemen. Met als treurig dieptepunt een 29-jarige vrouw die haar vierjarige zoontje door wurging om het leven bracht. (...) Rouwen: 'Een man bedreigt en slaat zijn vriendin en steekt de buurman met een mes. Zo iemand breng je naar het bureau, waar je proces-verbaal opmaakt. Maar daarna moet je hem toch weer laten gaan. Je kunt hem niet vastzetten. Na een paar maanden krijgt hij een acceptgiro, en daarmee is de kous af.' Als hij in de tussentijd zijn vriendin tenminste niet om zeep heeft geholpen. 'Wat je eigenlijk zou willen, is zo iemand eerst eens een tijdje vastzetten om zijn straf te laten ondergaan en daarna behandelen.' Maar zo werkt het systeem van rechtspraak niet. 'Zeker één of twee keer per week worden wij geconfronteerd met gevallen waarvan wij denken: als dat maar goed afloopt. We hebben te maken met een man die een vrouw achtervolgt. Hij heeft een straatverbod opgelegd gekregen. En wat moeten wij dan doen? Op elke hoek van de straat dag en nacht een agent neerzetten? Pakken we hem, dan wordt hij veroordeeld voor overtreding van het straatverbod. Maar een paar maanden later staat hij er weer. De wet kan in dit soort gevallen geen uitkomst bieden." "'

\subsection{Inleiding}

Geweld in de privésfeer is een veelvoorkomend probleem, waar de politie regelmatig mee wordt geconfronteerd, zoals het hierboven vermelde krantenbericht weergeeft. Dit geweld betreft zowel geweld tegen kinderen als geweld tegen vrouwen. De emotionele en loyaliteitsbanden binnen een persoonlijke levenssfeer, de machtsverhoudingen binnen de samenlevingsvorm, en het structurele karakter van het geweld 
onderscheiden dit geweld in de privésfeer van geweld door de buitenstaander. In deze studie gaat het om mannelijk geweld tegen vrouwen in de privésfeer (vrouwenmishandeling). Geweld tegen kinderen in de privésfeer wordt buiten beschouwing gelaten. Vrouwen die geweld ondervinden door hun (ex-)partner kunnen niet op dezelfde wijze bescherming genieten door justitiële interventie als kinderen die fysiek en seksueel geweld ondervinden door hun ouders, omdat man en vrouw gelijkwaardige rechtssubjecten zijn, die een huwelijks- of (informeel) samenlevingscontract zijn aangegaan, terwijl kinderen feitelijk en juridisch ongelijkwaardig zijn ten opzichte van hun ouders. ${ }^{2}$

De problematische verhouding tussen mannelijk geweld tegen vrouwen in de privésfeer en strafrechtelijke regulering staat in deze studie centraal. Als case-studie is het optreden van het openbaar ministerie genomen, gezien de cruciale rol die het openbaar ministerie vervult in het strafproces. Vanuit de rechtshandhavende taak van het openbaar ministerie wordt nader ingegaan op de (on)mogelijkheden van het strafrecht om aan vrouwen, die slachtoffer zijn van geweld door hun partner of expartner, rechtsbescherming te bieden.

Strafrechtelijke regulering lijkt, gezien de publieke en punitieve aard van het strafrecht, haaks te staan op conflictbeslechting in de privésfeer. Is er wel sprake van een algemeen belang dat strafrechtelijk ingrijpen rechtvaardigt? Dat is het eerste onderwerp ( $\S 1.2)$. Vervolgens zet ik in $\S 1.3$ uiteen vanuit welk perspectief ik de problematiek van vrouwenmishandeling in relatie tot strafrechtelijke regulering heb geanalyseerd. In $\S 1.4$ ga ik nader in op de vraagstelling en in $\S 1.5$ geef ik een methodologische verantwoording van het verkennende onderzoek naar de afhandeling van zaken van vrouwenmishandeling door het openbaar ministerie. Tot slot geef ik de opbouw van het boek weer in $\S 1.6$.

\subsection{Hoe privé is de privésfeer?}

\subsubsection{De privésfeer tegenover de publieke sfeer}

De privésfeer wordt in het Westerse denken over rechtvaardigheid en overheidsoptreden in een dichotome verhouding tot de publieke sfeer gedacht. De privésfeer wordt beschouwd als de sfeer van het familieleven, de huiselijke sfeer en de intieme persoonlijke sfeer. Deze sfeer wordt gekarakteriseerd met affectie, emotionaliteit, respect, harmonie en zorg voor elkaar. Tegenover de privésfeer staat de openbare

2 Ouders hebben een zorgverantwoordelijkheid en juridisch en feitelijk macht over hun kinderen. Daarom heeft de overheid een juridisch instrumentarium om te kunnen ingrijpen en het kind te beschermen als er sprake is van emstig fysiek geweld of seksueel misbruik. Zie over deze problematiek: Van Montfoort, Het topje van de ijsberg, 1994. 
of publieke sfeer. Dit is de sfeer van de economische markt, de politiek en het openbare leven. Deze sfeer wordt gekarakteriseerd met zakelijkheid, rationaliteit, machtsongelijkheid en belangenconflicten. In de publieke sfeer is overheidsinterventie gewenst, onder andere om de zwakkeren tegen de sterkeren te beschermen, terwijl de privésfeer juist wordt gekenmerkt door onthouding van overheidsinterventie. In de publieke sfeer heeft de mens rechten en sluit contracten af, daarentegen wordt in de privésfeer gehandeld uit liefde voor elkaar en wordt het goede nagestreefd. In de publieke sfeer wordt arbeid verricht en vindt de productie plaats, terwijl men in de privésfeer herstelt van het harde werken en zich reproduceert. ${ }^{3}$

Het idee dat de privésfeer de plek is waar affectie en harmonie overheersen, terwijl de publieke sfeer wordt overheerst door zakelijkheid en machtsverschillen, heeft ertoe geleid dat de privésfeer zelf niet ter discussie is komen te staan als sociale eenheid waar onrechtvaardigheid kan heersen: men gaat ervan uit dat sociale rechtvaardigheid heerst in het gezin. ${ }^{4}$ Dit is het speerpunt van de kritiek door feministische wetenschappers. Zij laten zien dat de neutrale begrippen als privésfeer en publieke sfeer verschillende betekenissen hebben voor mannen en vrouwen. Het begrippenpaar sluit aan bij de leefwereld van mannen: na werkzaam te zijn in de publieke sfeer van zakelijkheid en rationaliteit, kan uitgerust worden in de privésfeer waar affectie, zorg en geborgenheid heersen. Bovendien wordt door de dichotomie gemaskeerd dat binnen het gezin sprake is van een arbeidsdeling naar sekse die machtsongelijkheid tussen de seksen met zich meebrengt. Hoewel dit verschil in status en macht tussen mannen en vrouwen de afgelopen tientallen jaren in verandering is, de ongelijke machtsverhoudingen met andere woorden niet eenduidig en statisch zijn, hebben vrouwen doorgaans minder macht dan mannen, zowel op maatschappelijk niveau als op individueel niveau. Deze machtsongelijkheid is weer van invloed op de geweldsproblematiek binnen het gezin. ${ }^{5}$ Een tweede kritiekpunt op deze dichotomie is dat het onderscheid privé/publiek sterk wordt overdreven. Zowel in de publieke als in de privésfeer wordt door de overheid regelend opgetreden. Van oudsher wordt het gezin teschouwd als de grondslag van de maatschappij; een orderlijk en harmonieus gezin wordt van groot belang geacht voor de publieke orde. " "Of het huwelijk door de betrokkenen wordt gerespecteerd is van belang voor de staat aangezien de openbare orde er mede is gemoeid (...)." ${ }^{\text {7 }}$ Huwelijkswetgeving

3 Schneider, The violence of privacy, in: The public nature of private violence, 1994: 37-38; Thomton, The public/private dichotomy, Jrnl of Law and Society, 1991:448-463; Sevenhuijsen, Vadertje staat, moedertje thuis? Socialisties-feministiese teksten 1, 1978: 18-64.

4 Moller Okin, Justice, gender and the family, 1989: 8-13. Zie ook haar artikel: Justice and gender, Philosophy \& Public Affairs, 1987: 42-72.

5 Zie hoofdstuk 2, § 2.2.

6 "Preservation of the family was considered pivotal to social order, (...)." Hilton, One in ten: the struggle and disempowerment of the battered women's movement, Canadian Journal of Family' Law, 1989: 318.

7 Pitlo/Gerver e.a., Het systeem, 1995: 355. 
is een belangrijke bepalende factor in de wijze waarop het familieleven wordt genormeerd. Ook op andere terreinen van regelgeving heeft de overheid een sterke invloed op de wijze waarop mannen en vrouwen hun privéleven inrichten. "[T]o the extent that a more private, domestic sphere exist, its very existence, the limits that define it, and the types of behavior that are acceptable and not acceptable within it all result from political decisions". Beter kan gesproken worden van een continuüm tussen 'privé' en 'publiek'. ${ }^{10}$ Tot slot wordt gewezen op de vervlechting van beide sferen. De arbeidsdeling naar sekse in het gezin werkt door in andere sferen, waardoor vrouwen minder kans hebben op posities met status en macht op de arbeidsmarkt, in de politiek en binnen andere maatschappelijke organisaties. "[T]he division of labor within most families raises psychological as well as practical barriers against women in all other spheres."

Deze kritiek op het onderscheid tussen privésfeer en publieke sfeer wil overigens niet zeggen dat dit onderscheid geen analytische waarde heeft, of dat het onderscheid niet van essentieel belang is: een privésfeer waar de overheid terughoudendheid betracht, is essentieel voor de ontplooiing van mannen en vrouwen. De kritiek betreft met name de wijze waarop de dichotomie wordt geconstrueerd. "[B]oth challenging and aiming to restructure the public/domestic dichotomy are fundamental to the feminist enterprise." ${ }^{\prime 2}$ Het is belangrijk de begrippen privésfeer en publieke sfeer opnieuw te doordenken, waarbij arbeidsdeling naar sekse, verschillen in macht en erkenning van individuele rechten de te analyseren elementen zijn. En wellicht gaat het dan niet zozeer om de publieke en privésfeer, maar om publieke en private handelingen.$^{13}$ Tenslotte raken handelingen in de privésfeer de openbare orde, zoals geweld in de privésfeer, en zijn in de publieke sfeer noties van zorg en betrokkenheid van belang voor een goede uitvoering van publieke taken. ${ }^{14}$ Deze interessante, maar meer rechtspolitieke analyse valt overigens buiten het kader van dit onderzoek.

\subsubsection{Privacy: legitimatie van geweld of vrijheidsbegrip?}

Het juridische recht dat de privésfeer beschermt is het recht op privacy of eerbiediging van de persoonlijke levenssfeer. Mensen hebben het recht een eigen leven te leiden met zo min mogelijk inmenging van buitenaf, is een van de grondbeginselen van de rechtsstaat. Dit betekent dat de persoonlijke levenssfeer moet worden

8 Zie bijvoorbeeld: Elliot, The family: private arena or adjunct of the state?, Jrnl of law and society, 1989: 443-463; Dingwall \& Eekelaar, Families and the state, Law \& Policy, 1988: 341-361.

9 Moller Okin, Justice, gender and the family, 1989: 129.

10 Schneider, The violence of privacy, in: The public nature of private violence, 1994: 38.

11 Moller Okin, Justice, gender and the family, 1989: 132.

12 Ibidem: 127.

13 Raes, Minow, Okin, Rawls, Habermas en 'de anderen', in: Lof der verscheidenheid, 1993: 160.

14 Zie over een integratie van zorgethiek en rechtsethiek voor een humane wijze van strafrechtspleging bijvoorbeeld: Soetenhorst-de Savornin Lohman, Doe wel en Zie om, 1990. 
beschermd tegen inbreuken door de overheid en derden. Alleen in gevallen bij of krachtens de wet geregeld kan de overheid een inbreuk op dit recht maken (art. 10 Gw \& art. 8 EVRM). ${ }^{15}$

Wat onder de persoonlijke levenssfeer moet worden verstaan, is niet precies afgebakend. De persoonlijke levenssfeer omvat de individuele persoonlijke levenssfeer, of de levenssfeer van het gezin of het familieleven. Ook andere grondrechten, zoals het recht op onaantastbaarheid van het lichaam (art. $11 \mathrm{Gw}$ ), het huisrecht (art. $12 \mathrm{Gw}$ ) en het briefgeheim (art. $13 \mathrm{Gw}$ ) vallen onder het begrip persoonlijke levenssfeer. ${ }^{16}$ In gevallen van geweld tegen de vrouw door haar partner gaat het om een schending van het recht op onaantastbaarheid van het lichaam en het recht op een persoonlijke levenssfeer. ${ }^{17}$ Een verwant begrip is zelfbeschikking, de individuele vrijheid of autonomie om zelf te kunnen beslissen over het eigen lichaam en de wijze van leven. Dit zelfbeschikkingsrecht is als zodanig geen grondrecht, dat wil zeggen dat de vrouw geen beroep kan doen op een gepositiveerd subjectief recht 'zelfbeschikking'. Wel kan zelfbeschikking als een rechtsbeginsel worden beschouwd waar de rechter in zijn argumentatie gebruik van kan maken. ${ }^{18}$ Eerbiediging van de persoonlijke levenssfeer en zelfbeschikking geven in een notedop de twee manieren aan waarop het begrip privacy kan worden opgevat: enerzijds kan privacy worden opgevat als 'geen inbreuken van buitenaf' een passief recht, en anderzijds kan privacy worden opgevat als 'vrijheid in beslissen', een actief recht. ${ }^{19}$ Hoe verhouden deze privacybegrippen zich tot elkaar als er sprake is van geweld in de privésfeer?

In de bespreking van de dichotomie privé/publiek is naar voren gekomen dat de voorstelling van de privésfeer als de sfeer van affectieve relaties, zorgzaamheid en harmonie, de machtsverschillen tussen de seksen verdoezelt. De kritiek op het privacybegrip sluit hierbij aan: de persoonlijke levenssfeer van gehuwden en samenwonenden wordt voorgesteld als een eenheid zonder conflicterende belangen. Maar de bescherming van de persoonlijke levenssfeer van de samenlevingsvorm hoeft niet vanzelfsprekend de bescherming van de persoonlijke levenssfeer van de vrouw in te houden.

Historisch gezien is het huwelijk tot 1970 juridisch een eenheid. De gehoorzaamheidsplicht van de vrouw aan haar echtgenoot en de handelingsonbekwaamheid van

15 Gerbrandy \& Kroes, Grondrechten evaluatie onderzoek, documentatierapport 3, 1991: 10-3; Kleijn, \& Kroes, Mensenrechten in de Nederlandse rechtspraktijk, 1986: 136.

16 Verhey, Horizontale werking van grondrechten, in het bijzonder van het recht op privacy, 1992: 198-199.

17 In de regeringsnota 'Bestrijding van seksueel geweld tegen vrouwen en meisjes' worden deze twee grondrechten als uitgangspunt genomen. TK 1983-1984, 18.542, nrs. 1-2.

18 Goldschmidt \& Holtmaat, Vrouw en recht, 1993: 154-156; Verheij, Horizontale werking van grondrechten, in het bijzonder van het recht op privacy, 1992: 207-208.

19 Schneider, The violence of privacy, in: The public nature of private violence, 1994: 40. 
de gehuwde vrouw is weliswaar in 1957 opgeheven, ${ }^{20}$ maar tot 1970 is de man hoofd van het gezin. ${ }^{21}$ Pas in 1984 zijn de laatste resten van deze regel geschrapt ${ }^{22}$ en is de wettelijke maritale macht verdwenen. ${ }^{23} \mathrm{Bij}$ verschil van mening tussen de echtgenoten kan de rechter worden ingeroepen door (een van) beiden om over het geschil een beslissing te nemen (art. 84 boek $1 \mathrm{BW}$ ). Het recht van de vrouw op eerbiediging van haar persoonlijke levenssfeer binnen een samenlevingsvorm wordt tegenwoordig erkend. "[W]omen have some autonomy, at least vis-à-vis their husbands (...)". ${ }^{24}$

Hoewel de maritale macht wettelijk is afgeschaft, zijn verschillende vormen van mannelijke dominantie binnen het huwelijk niet verdwenen. Op gedragsniveau spelen manifeste macht, bijvoorbeeld fysiek geweld door de man, en latente macht, zoals het anticiperen op de wensen van de man uit angst, een rol in dit machtsproces. Daarnaast wordt de machtsongelijkheid op ideologisch niveau bevestigd en gerechtvaardigd door 'onzichtbare' macht: vanzelfsprekende waarden en normen over de maatschappelijke positie van mannen en vrouwen. ${ }^{25}$ Deze discrepantie tussen juridisch gelijkwaardige rechtssubjecten en feitelijke machtsprocessen binnen (huwelijkse) relaties heeft consequenties voor de uitwerking van het recht in de dagelijkse realiteit. Bovendien is de notie, dat het huwelijk een eenheid vormt, dat man en vrouw liefde en leed samen delen, en dat conflicten binnen een (huwelijkse) relatie privéproblemen zijn, een diepgewortelde opvatting. Ook geweld tegen de vrouw in de privésfeer wordt in eerste instantie opgevat als een privéprobleem, waar anderen, en zeker de overheid, buiten staan. Het geweld wordt geïndividualiseerd en teruggebracht tot een gelijkwaardige en individuele man-vrouw relatie, waarvoor geen maatschappelijke verantwoordelijkheid bestaat. ${ }^{26}$ De eerbiediging van de privacy van de samenlevingsvorm betekent in geval van geweld tegen de vrouw in feite dat de macht van mannen over vrouwen in de privésfeer wordt gelegitimeerd: niet de privacy van de samenlevingsvorm, maar de privacy van de man wordt beschermd. "The concept of privacy encourages, reinforces, and supports violence

20 Wet-Van Oven, 14 juni 1956, Sth. 343.

21 Invoeringswet Boek I nieuw BW, 3 april 1969, Stb. 167.

22 Dit betreft de bepaling dat de stem van de man de doorslag geeft in geval van 1 . onenigheid over de keuze van de woonplaats en 2 . bij een verschil in inzicht wat betreft de opvoeding. Wet van 30 augustus 1984 tot wegneming van een aantal ongelijkheden tussen man en vrouw in het personenen familierecht en in enige andere wetten, Stb. 404.

23 Braun geeft in haar boek De prijs van de liefde een rechtshistorische analyse van het regulerende en politieke karakter van de maritale macht. "Dat die macht lange tijd als belangrijk rechtsbeginsel heeft gefunctioneerd, lijkt uit het collectieve historische bewustzijn van de juridische wereld in Nederland te zijn verdwenen." Braun, De prijs van de liefde, de eerste feministische golf, het huwelijksrecht en de vaderlandse geschiedenis, 1992 (citaat: 6).

24 Freeman, But if you can't rape your wife, who(m) can you rape? Family Law Quarterby, 1981: 16.

25 Komter, Omstreden gelijkheid, 1990: 22-24. Zie ook hoofdstuk 2, \$2.2.3.

26 Schneider, The violence of privacy, in: The public nature of private violence, 1994: 42.

27 Of zoals Mackinnon het kort en krachtig uitdrukt: "This right to privacy is a right of men 'to be let alone' to oppress women one at a time." MacKinnon, Feminism unmodified, 1987: 102. 
against women. Privacy says that violence against women is immune from sanction, that it is permitted, acceptable and part of the basic fabric of American family life. Privacy says that what goes on in the violent relationship should not be the subject of state or community intervention. Privacy says that it is andividual and not a systematic problem. Privacy operates as a mask for inequality, protecting male violence against women."28

Het begrip privacy kan ook worden opgevat als een vrijheidsrecht. Privacy is een belangrijke voorwaarde voor het ontwikkelen van zelfrespect, zelfexpressie en zelfvertrouwen, kortom, voor het waarborgen van enige autonomie. ${ }^{29}$ Het is het recht van vrouwen om zelf beslissingen te nemen over de sociale contacten die zij aangaan, de opleiding die zij willen volgen, het voedsel dat zij willen eten of de wijze waarop zij hun kinderen willen opvoeden. Maar vrouwen kunnen niet in vrijheid beslissingen nemen als zij in de privésfeer worden geconfronteerd met fysiek geweld. "Zonder fysieke vrijheid geen autonomie van lichaam en geest. Insluiten, opsluiten, fysiek intimideren, gebruik van fysieke dwang en geweld behoren bij het instrumentarium van onderdrukking. Fysieke onderdrukking en verdrukking in geestelijke zin gaan vaak samen." 30 Geweld tegen de vrouw in de privésfeer voorkomt dat zij in vrijheid beslissingen kan nemen. Sterker nog, een sfeer van veiligheid is een noodzakelijke voorwaarde voor een mens om zich tot een zelfstandige persoonlijkheid te kunnen ontwikkelen. De persoonlijke vrijheid van de vrouw binnen de samenlevingsvorm dient door de overheid te worden beschermd tegen inbreuken door derden, in dit geval haar partner. Zoals vrouwen hun recht op abortus hebben bevochten door een beroep te doen op de persoonlijke vrijheid van vrouwen in de persoonlijke levenssfeer, ${ }^{31}$ zo kunnen vrouwen die worden mishandeld door hun partner dit ook doen. ${ }^{32}$ Aansluiting kan worden gezocht bij artikel 8 EVRM. Hoewel artikel 8 EVRM primair een onthoudingsplicht van de overheid regelt, biedt dit artikel ook een aanknopingspunt voor een positieve verplichting van de overheid om het privé- of gezinsleven te beschermen. ${ }^{33}$ Naar aanleiding van een klacht dat seksueel misbruik van een geestelijk gehandicapte minderjarige door een hulpver-

28 Schneider, The violence of privacy, in: The public nature of private violence, 1994: 43.

29 Ibidem: 51-54; Decew, The feminist critique of privacy, APA Newsletters, 1995: 42-45; Zie ook: Allen, Uneasy access. Privacy for women in a free society, 1988. Over het begrip autonomie, zie bijvoorbeeld: Schuyt, Emancipatie en autonomie, in: Publiek geheim, 1995: 15-29.

30 Ibidem: 22. Dit citaat betreft overigens geen vrouwenmishandeling, maar publiek geweld van totalitaire regimes. De gelijkenis is echter opvallend.

31 Het recht van de vrouw op eerbiediging van haar persoonlijke levenssfeer binnen een samenlevingsvorm is erkend in een viertal (niet in Nederland gewezen) arresten over abortuswetgeving. Het gaat om Supreme Court: Eisenstadt v. Baird, 405 U.S. 438 (1972), Roe v. Wade, 410 U.S. 113 (1973) en Planned Parenthood of Missouri v. Danforth, 428 U.S. 52 (1976). Daamaast de Europese Commissie: Hercz tegen Noorwegen, Europese Commissie RvdM, 19 mei 1992. Besproken in NJCM 1993: 65-73 (m.nt. Loenen).

32 Schneider, The violence of privacy, in: The public nature of private violence, 1994: 53.

33 Verheij, Horizontale werking van grondrechten, in het bijzonder het recht op privacy, 1992: 222. Zie ook: Forder, Over positieve verplichting en art. 8 EVRM, NJCM, 1992: 611-637. 
lener niet strafrechtelijk kon worden vervolgd, besliste het Europese hof dat een positieve verplichting kan bestaan tot het nemen van maatregelen die de privésfeer beschermen "even in the sphere of the relations of individuals". ${ }^{34} \mathrm{Je}$ zou hieruit kunnen afleiden dat alle vormen van geweld die strafbaar zijn, niet mogen worden uitgesloten voor de privésfeer: "that states have an affirmative obligation to criminalize domestic violence". ${ }^{35}$

Het recht op privacy, in de zin van zelfbeschikking, plaatst geweld tegen de vrouw in de privésfeer midden in het publieke debat over de inhoud en reikwijdte van mensenrechten. ${ }^{36}$ Dit rechtenvertoog geeft vrouwen de mogelijkheid zich uit te spreken over wat mag en niet mag, het legitieme en het illegitieme, over de inhoud van vrijheid en solidariteit in relatie tot conflicterende belangen in de privésfeer. ${ }^{37} \mathrm{Zo}$ kan gezocht worden naar nieuwe grenzen tussen publieke verantwoordelijkheid en privébelangen, vanuit de erkenning dat er een spanningsveld bestaat tussen privacy als passief recht, dat zich verzet tegen overheidsinmenging in de privésfeer, en privacy als actief recht, dat om bescherming van de overheid vraagt. $^{38}$

\subsubsection{Dilemma's van overheidsinterventie}

Een vrije samenleving heeft belang bij een gedegen bescherming van de persoonlijke levenssfeer, want alleen als sprake is van een vrije ruimte kan de mens zich tot een autonome en verantwoorde burger ontwikkelen. Geweld tegen de vrouw in de privésfeer is een inbreuk op haar lichamelijke integriteit en persoonlijke levenssfeer die verstrekkende gevolgen kan hebben voor de vrouw in questie en voor de aanwezige kinderen. ${ }^{39}$ Evenals het geweld in de openbare sfeer is dit geweld een maatschappelijk probleem dat serieus moet worden genomen. Bovendien rechtvaardigen de machtsverhoudingen in de privésfeer overheidsinterventie met als doel de vrijheid van de 'sterkere' ten voordele van de vrijheid van de 'zwakkere' te

34 EHRM 26 maart 1985, NJ 1985, 525 (m.nt. EAA). De zedenwetgeving is op dit punt aangepast.

35 Thomas \& Beasley, Domestic Violence as a human rights issue, Human Rights Quarterly, 1993: 49-50. In Nederland is diefstal (art. $310 \mathrm{Sr}$ ) en vernieling (art. $350 \mathrm{Sr}$ ) binnen huwelijk gepleegd niet strafbaar (artt. 316 \& $353 \mathrm{Sr}$ ). Dit kan worden beschouwd als in strijd met de positieve verplichting voortvloeiende uit 8 EVRM.

36 Zie: Thomas \& Beasley, Domestic Violence as a human rights issue, Human Rights Quarterly, 1993: 36-62; Vrouwenrechten, mensenrechten, vechten om de grenzen, Nemesis Essays 1996.

37 Raes, Variaties op het verschil-dilemma, Nemesis, 1991: 12-13.

38 Soetenhorst-de Savomin Lohman \& Jansz, Seksueel geweld zal de wetgever een zorg zijn, 1986: $1-2$.

39 Zie hoofdstuk $2, \S 2.2$. 
beperken. ${ }^{40}$ Deze overheidsinterventie is echter ook problematisch gezien het 'difference-dilemma'41 en het 'juridiserings-dilemma'. ${ }^{42}$

Het difference-dilemma in geval van vrouwenmishandeling komt op het volgende neer. Gezien de juridische gelijkwaardigheid ligt het niet voor de hand de vrouw extra juridische bescherming te geven en van buitenaf in te grijpen in de privésfeer. Niet ingrijpen door de overheid betekent echter dat vrouwen bescherming wordt onthouden en verschillen in macht tussen de seksen worden bevestigd. Als echter het verschil in macht tussen de seksen als juridisch relevant feit zou worden vastgelegd en deze gejuridiseerde zwakke positie van de vrouw tot extra rechtsbescherming zou gebieden, wordt de vrouw uitgesloten van een gelijkwaardige en volledige participatie; zij wordt beschouwd als zwak en slachtoffer. Zij heeft geen mogelijkheid meer om een gelijkwaardig rechtssubject te zijn. ${ }^{43}$ Anders gesteld, de gelijkwaardigheid van de rechtssubjecten in het huwelijk is een belangrijke verworvenheid omdat het de voorwaarden schept voor zelfbeschikking. Maar tegelijkertijd valt hierdoor de beschermingsgedachte weg, terwijl de feitelijke macht van de vrouw niet hoeft te zijn vergroot.4

Het tweede dilemma sluit hierop aan. Een terughoudende overheid in geval van geweld in de privésfeer betekent dat het ontbreken van privacy voor de vrouw wordt gelegitimeerd. Daarentegen betekent het inroepen van het recht niet dat de zeggenschap over het eigen het leven wordt vergroot. Integendeel, de persoonlijke levenssfeer wordt steeds gedetailleerder door overheidsregels en interventies gereguleerd. ${ }^{45}$ De afhankelijkheid van de vrouw van haar partner wordt ingeruild voor een afhankelijkheid van de overheid. ${ }^{46}$ Bovendien betekent het effectueren van een recht dat het oorspronkelijke probleem wordt geherdefinieerd in juridische termen. "Om je te bevrijden uit de handen van anderen, leg je voortaan de probleemdefinitie in handen van anderen." ${ }^{47}$ Juridisering van een probleem behoeft daarom niet te leiden tot meer autonomie. Een ander gevaar van juridisering is dat verwachtingen worden gewekt die de overheid niet kan waarmaken. Door bijvoorbeeld zelfbeschikking als een subjectief recht te formuleren, krijgt weliswaar het beginsel van zelfbeschikking meer status, maar tegelijkertijd wordt een illusie gecreěerd,

40 Raes, Variaties op het verschil-dilemma, Nemesis, 1991: 8-9; Schneider, The violence of privacy, in: The public nature of private violence, 1994: 53.

41 Minow, The Supreme court 1986 term. Harvard Law Review, 1987: 12.

$42 \mathrm{Zie}$ : Mossman, Feminism and legal method: the difference it makes, in: At the boundaries of law, feminism and legal theory, 1991: 290-298.

43 Zie bijvoorbeeld: Schneider, Describing and changing: Women's self-defense work and the problem of expert testimony on battering, Women's Rights Law Reporter, 1986: 195-222.

44 Bussemaker, Individualisering als paradox, in: Publiek geheim, 1995: $31-43$.

45 Dit is wat Smart noemt de disciplinerende werking van het recht. Smart, Feminism and the power of law, 1989.

46 Zie over de afhankelijkheid van (gescheiden) vrouwen van de bijstand. Holtmaat, Met zorg een recht?, 1992.

47 Schuyt, Emancipatie en autonomic, in: Publiek geheim, 1995: 24. 
omdat dit recht moet concurreren met andere rechten. Het recht op zelfbeschikking kan in de maatschappelijke werkelijkheid niet onverkort verwezenlijkt worden. ${ }^{48}$

Overheidsinterventie en juridisering van maatschappelijke problemen is om bovengenoemde redenen een problematisch instrumentarium. Maar geen aanspraak maken op bescherming door de overheid van het recht van privacy binnen de samenlevingsvorm is een luxe, die vrouwen, als verdrukte groep, zich niet kunnen veroorloven. ${ }^{49}$ Waar het op an komt in regelgeving, is het scheppen van voorwaarden die vrouwen de mogelijkheid geven hun recht op lichamelijke integriteit en privacy te effectueren, binnen en buiten de privésfeer. In de regeltoepassing komt het erop aan de context van de maatschappelijke sekseverschillen te betrekken, zonder deze context als vaststaand te beschouwen. Bovendien moet ervoor worden gewaakt dat de privacy van de vrouw ondergeschikt wordt gemaakt aan publieke, juridische of bureaucratische belangen.

\subsubsection{Strafrechtelijke regulering van geweld in de privésfeer?}

Geweld in de privésfeer is een maatschappelijk probleem, zo wordt in de jaren tachtig duidelijk. Eén op de vijf vrouwen is slachtoffer van eenzijdig geweld door haar mannelijke partner of ex-partner, waarbij het in ruim de helft van deze gevallen gaat om herhaald ernstig tot zeer ernstig geweld in een context van dreiging en angst. ${ }^{50}$ Dit geweld kan ernstige gevolgen hebben voor de geestelijke en lichamelijke gezondheid van de vrouw.

Dit maatschappelijke probleem vraagt om overheidsoptreden. ${ }^{51}$ Maar vergt het wel strafrechtelijke interventie? Ligt het niet meer voor de hand dat de overheid een voorwaardescheppend beleid voert, ${ }^{52}$ en een specifiek beleid ter voorkoming en bestrijding van vrouwenmishandeling? Om het recht op privacy van vrouwen in de privésfeer te kunnen verwezenlijken, is het noodzakelijk dat de overheid preventiemaatregelen neemt en zorg draagt voor goede opvangmogelijkheden en specifieke hulpverlening aan slachtoffers en daders van vrouwenmishandeling. Dit draagt bij aan het zichtbaar maken van geweld in de privésfeer als maatschappelijk probleem en daaarnaast kunnen hulpverlening en opvang de weerbaarheid van vrouwen versterken. Bovendien hebben deze maatregelen een vrijwillig karakter: er vindt geen gedwongen ingrijpen in de privésfeer plaats. Toch zijn deze maatregelen niet voldoende om in alle concrete gevallen van vrouwenmishandeling bescher-

48 Goldschmidt \& Holtmaat, Vrouw en recht, 1993: 154-156.

49 Raes, Variaties op het verschil-dilemma, Nemesis, 1991: 11.

50 Römkens, Geweld tegen vrouwen in heteroseksuele relaties, 1989: 106-109.

51 Dit wordt door de overheid erkend. Zie bijvoorbeeld de nota Beleid ter bestrijding van sexueel geweld tegen vrouwen en meisjes, TK 1983-1984, 18.542, nrs. 1-2.

52 Dat wil zeggen gericht op het opheffen van de machtsverhoudingen en de doorbreking van de stereotype beeldvorming over mannen en vrouwen. Vervolgnota Beleid ter bestrijding van sexueel geweld tegen vrouwen en meisjes, TK 1990-1991, 18.542, nr. 20: 7. 
ming te bieden. De vrouw kan, ondanks de opvang, hulp en steun door derden, slachtoffer blijven van gewelddadig gedrag door haar (ex-)partner, omdat de man niet vrijwillig ophoudt met geweldplegingen, noch hulp wil zoeken voor zijn gewelddadige gedrag. "Het beslechten van conflicten kan niet altijd worden overgelaten aan andere instituties dan het recht. De hulpverlening mist hiervoor de macht, de overheidscontrole, de gelijkheid in normen en de vastomschreven procedures." ${ }^{53}$ Alleen via het recht kan normconform gedrag worden afgedwongen.

Het recht heeft een repressieve, een individu beschermende en een conflictbeslechtende functie, maar de uitwerking van deze functies verschillen voor het civiele recht en het strafrecht. Het strafrecht heeft bij uitstek een repressieve functie, handhaving van rechtsnormen met dwang, en een individu beschermende functie, dat wil zeggen dat de individuele vrijheden van de burger worden beschermd tegen willekeurige overheidsinbreuken. Het civiele recht heeft bij uitstek een conflictbeslechtende functie. ${ }^{54}$

In geval van vrouwenmishandeling lijkt het starten van een civiele procedure het meest voor de hand liggende rechtsinstrument, aangezien het een procedure betreft tussen twee gelijkwaardige rechtssubjecten gericht op schadeherstel in de ruime zin des woords. Slachtofferbescherming staat voorop. ${ }^{55}$ Wanneer sprake is van een spoedeisend belang bij een onmiddellijke voorziening, kan de vrouw als eiseres een kort geding aanspannen. Zij bepaalt zelf de inhoud van het rechtsgeding. Als enige voorwaarde geldt dat sprake moet zijn van een onrechtmatige daad, dat wil zeggen van een onbehoorlijk handelen dat schade tot gevolg heeft en waaraan de man schuld heeft. Bovendien kan de vrouw een vorm van schadeherstel vragen die het meest tegemoetkomt aan haar behoefte. Naast financiële schadevergoeding voor materiêle en immateriêle schade kan ook schadevergoeding in de vorm van vermijdingsgedrag worden gevorderd, bijvoorbeeld een straat- of buurtverbod, een telefoon- of algemeen contactverbod. In een kort-gedingprocedure weegt de rechter de belangen van de eiseres af tegen de belangen van de gedaagde aan de hand van het door eiseres aannemelijk gemaakte onrechtmatige gedrag en het verweer van de gedaagde. Door de vrije bewijsvoering en de ruime omschrijving van de onrechtmatige daad is het onder $\S 1.2 .3$ genoemde gevaar van herdefiniëring van het probleem door anderen minder groot dan in een strafprocedure. Bovendien staan de eis van de vrouw en een toekomstgerichte oplossing voor het conflict centraal. Het civiele recht doet daardoor recht aan de autonomie van de vrouw. ${ }^{56}$ Daarmee lijkt het kort geding het rechtsinstrument bij uitstek.

53 Van Montfoort, Het topje van de ijsberg, 1994: 55.

54 Van Montfoort, Het topje van de ijsberg, 1994: 54.

55 Stutterheim \& Wiewel, Een variatie op het thema slachtofferbescherming, in: Dading in plaais van strafrecht, 1993: 15.

56 Verrijn Stuart, Naar een geciviliseerd recht tegen sexueel geweld, $A A$, 1992: 89-90; Hes \& Van Ringen, Bliff uit mijn buurt, het straatverbod in kort geding, 1986: 60-63. 
wraak wordt gekanaliseerd naar de maat van de politieke gemeenschap. Daarin wortelt de vergelding. ${ }^{\times 61}$ Door het straffen aan de individuele burger te onttrekken, wordt de mateloosheid van de wraak beteugeld, maar de oorspronkelijke behoefte aan wraak mag niet worden ontkend. De individuele en maatschappelijke afkeuring van geweld in de privésfeer moet daarom op een of andere manier tot uitdrukking worden gebracht in de wijze van strafoplegging, of in de wijze van rechtshandhaving. Dit zijn de twee belangrijkste argumenten die voor een strafrechtelijke reactie pleiten. Daarnaast kan strafrechtelijke regulering in gevallen van vrouwenmishandeling, waar vrouwen hun relatie met hun partner niet willen verbreken, het enige rechtsinstrument zijn ter bescherming van inbreuken op hun lichamelijke integriteit en privacy. Vrouwen willen dat een autoriteit van buiten, de politie, het openbaar ministerie, de rechter, het gewelddadig gedrag in de privésfeer afkeurt en zonodig de man bestraft. Op die manier wordt de verantwoordelijkheid voor het geweld bij de man gelegt. De macht van het strafrecht wordt ingezet tegen de macht van de man over de vrouw. ${ }^{62}$

Strafrechtelijke interventie kan in bovenstaande zin een positieve bijdrage leveren aan de bestrijding van mannelijk geweld tegen de vrouw in de privésfeer. Maar er zijn ook bezwaren aan te voeren. Het belangrijkste bezwaar is dat niet het belang van de benadeelde uitgangspunt is voor strafrechtelijk optreden, zoals in het civiele geding, maar het algemene of maatschappelijke belang. De overheid, in de gedaante van het openbaar ministerie, is aanklager en bepaalt de grondslag van het rechtsgeding. ${ }^{63}$ De verdachte is, evenals het openbaar ministerie, procespartij, waarbij de gelijkwaardigheid van de procespositie van de verdachte ten opzichte van het openbaar ministerie groeit naarmate het strafproces vordert. ${ }^{64}$ Tot slot is de rechter als enige bevoegd tot het opleggen van een straf waarmee leedtoevoeging wordt beoogd. Een straf is een non-reparatoire sanctie, in tegenstelling tot de civiele sancties, die reparatoir van aard zijn en gericht op herstel en nakoming. ${ }^{65}$ Het slachtoffer heeft een beperkte positie in het strafproces. Zij heeft geen invloed op het vervolgingsmonopolie van het openbaar ministerie, noch op de strafoplegging: zij neemt het initiatief om aangifte van geweld te doen bij de politie en daarna heeft zij geen actieve rol meer. Zij kan zich voegen in het strafproces om een schadevergoeding te vorderen wanneer de officier van justitie de zaak vervolgt, en zij kan

61 't Hart, Straf, recht en waarden, in: Hoe punitief is Nederland?, 1994: 35.

62 Van Montfoort, Justitisle interventie bij geweld in het gezin, TKC, 1995: 364.

63 Corstens, Het Nederlands strafprocesrecht, 1995: 2.

64 Cleiren, 'Kruisbestuiving': procespositie in strafrecht en privaatrecht, in: Over de grenzen van strafrecht en burgerlijk recht, 1995: 83.

65 Door haar aard (vergelding) is de straf bovendien gericht op algemene en bijzondere preventie. Remmelink, Hazewinkel-Suringa's Inleiding, 1994: 9-11. Tegenwoordig kent de straf ook conflictoplossing als doelstelling en wordt in het civiele recht leedtoevoeging in de sanctie verdisconteerd als sprake is van een 'privaatrechtelijke boete'. Stolker, Straffen met privaatrecht - of juist verzoenen?, in: Over de grenzen van strafrecht en burgerlijk recht, 1995: 31-33. 
wraak wordt gekanaliseerd naar de maat van de politieke gemeenschap. Daarin wortelt de vergelding. ${ }^{\times 61}$ Door het straffen aan de individuele burger te onttrekken, wordt de mateloosheid van de wraak beteugeld, maar de oorspronkelijke behoefte aan wraak mag niet worden ontkend. De individuele en maatschappelijke afkeuring van geweld in de privésfeer moet daarom op een of andere manier tot uitdrukking worden gebracht in de wijze van strafoplegging, of in de wijze van rechtshandhaving. Dit zijn de twee belangrijkste argumenten die voor een strafrechtelijke reactie pleiten. Daarnaast kan strafrechtelijke regulering in gevallen van vrouwenmishandeling, waar vrouwen hun relatie met hun partner niet willen verbreken, het enige rechtsinstrument zijn ter bescherming van inbreuken op hun lichamelijke integriteit en privacy. Vrouwen willen dat een autoriteit van buiten, de politie, het openbaar ministerie, de rechter, het gewelddadig gedrag in de privésfeer afkeurt en zonodig de man bestraft. Op die manier wordt de verantwoordelijkheid voor het geweld bij de man gelegt. De macht van het strafrecht wordt ingezet tegen de macht van de man over de vrouw. ${ }^{62}$

Strafrechtelijke interventie kan in bovenstaande zin een positieve bijdrage leveren aan de bestrijding van mannelijk geweld tegen de vrouw in de privésfeer. Maar er zijn ook bezwaren aan te voeren. Het belangrijkste bezwaar is dat niet het belang van de benadeelde uitgangspunt is voor strafrechtelijk optreden, zoals in het civiele geding, maar het algemene of maatschappelijke belang. De overheid, in de gedaante van het openbaar ministerie, is aanklager en bepaalt de grondslag van het rechtsgeding. ${ }^{63}$ De verdachte is, evenals het openbaar ministerie, procespartij, waarbij de gelijkwaardigheid van de procespositie van de verdachte ten opzichte van het openbaar ministerie groeit naarmate het strafproces vordert. ${ }^{64}$ Tot slot is de rechter als enige bevoegd tot het opleggen van een straf waarmee leedtoevoeging wordt beoogd. Een straf is een non-reparatoire sanctie, in tegenstelling tot de civiele sancties, die reparatoir van aard zijn en gericht op herstel en nakoming. ${ }^{65}$ Het slachtoffer heeft een beperkte positie in het strafproces. Zij heeft geen invloed op het vervolgingsmonopolie van het openbaar ministerie, noch op de strafoplegging: zij neemt het initiatief om aangifte van geweld te doen bij de politie en daarna heeft zij geen actieve rol meer. Zij kan zich voegen in het strafproces om een schadevergoeding te vorderen wanneer de officier van justitie de zaak vervolgt, en zij kan

61 't Hart, Straf, recht en waarden, in: Hoe punitief is Nederland?, 1994: 35.

62 Van Montfoort, Justitisle interventie bij geweld in het gezin, TKC, 1995: 364.

63 Corstens, Het Nederlands strafprocesrecht, 1995: 2.

64 Cleiren, 'Kruisbestuiving': procespositie in strafrecht en privaatrecht, in: Over de grenzen van strafrecht en burgerlijk recht, 1995: 83.

65 Door haar aard (vergelding) is de straf bovendien gericht op algemene en bijzondere preventie. Remmelink, Hazewinkel-Suringa's Inleiding, 1994: 9-11. Tegenwoordig kent de straf ook conflictoplossing als doelstelling en wordt in het civiele recht leedtoevoeging in de sanctie verdisconteerd als sprake is van een 'privaatrechtelijke boete'. Stolker, Straffen met privaatrecht - of juist verzoenen?, in: Over de grenzen van strafrecht en burgerlijk recht, 1995: 31-33. 
worden opgeroepen als getuige.$^{66}$ Een strafprocedure draagt door deze 'rolverdeling' het grote gevaar in zich dat de justitiële interventie een eigen leven leidt waar de vrouw geen enkele invloed op heeft, terwijl bovendien de interventie een inbreuk op haar persoonlijke levenssfeer met zich mee kan brengen.

Uit de hierboven besproken voor- en nadelen van verschillende manieren van overheidsinterventie wordt duidelijk dat het recht ter bescherming van de lichamelijke integriteit en persoonlijke levenssfeer van de vrouw van belang is. Naast buitenjustitiële conflictregulering en gedragsnormering is formele juridische interventie noodzakelijk. ${ }^{67}$ Vanuit maatschappelijk oogpunt biedt het civiele recht meer mogelijkheden om de autonomie van vrouwen te versterken. Daarentegen symboliseert een civiele procedure dat vrouwenmishandeling een probleem is tussen twee individuen, terwijl strafrechtelijke interventie aangeeft dat mannelijk geweld tegen vrouwen in de privésfeer een maatschappelijk probleem is. Strafrechtelijk optreden heeft daarentegen als groot nadeel dat de autonomie van de vrouw, door de beperkte positie van het slachtoffer in het strafproces, niet wordt versterkt. Aan beide rechtssystemen kleven bezwaren uit maatschappelijk oogpunt. Maar ook op individueel niveau is geen sprake van een eenduidige keuze voor de één of de ander. Afhankelijk van het soort geweld, de situatie waarin de vrouw verkeert en de persoonlijke ontwikkeling van de vrouw, zal informele conflictoplossing, civiel of strafrechtelijk ingrijpen de meest voor de hand liggende reactie zijn. Civielrechtelijke en strafrechtelijke aanpak kunnen ook samen gaan, ${ }^{68}$ en naast hulpverlening worden ingeroepen.

Het inzetten van het strafrecht wordt over het algemeen als 'ultimum remedium' beschouwd, omdat het opleggen van straf nog steeds het scherpste machtsmiddel is. ${ }^{69}$ Zeker in geval van mannelijk geweld tegen vrouwen in de privésfeer zullen buiten-juridische middelen vaak effectiever zijn, en komt strafrechtelijke optreden op de laatste plaats. De oplossing moet in eerste instantie gezocht worden binnen de context waar het probleem zich voordoet; daar waar het mogelijk is, kunnen vrouwen beter zelf en met behulp van anderen (familie, vrienden of hulpvierleners) het geweld van de partner keren. ${ }^{70}$ Maar in bepaalde gevallen van mannelijk geweld tegen vrouwen in de privésfeer is strafrechtelijke sanctionering gewenst; niet alle

$66 \mathrm{Zij}$ kan tevens een beklagprocedure starten. De positie van het slachtoffer in het strafproces wordt in hoofdstuk 2, $\$ 2.5$ beschreven.

67 Van Montfoor, Het topje van de ijsberg, 1994: 63.

68 In de praktijk heeft het slachtoffer als eiseres in een civiele procedure een sterkere (bewijs)positie als er een proces-verbaal van de politie ligt. Zie: Kool, Onvolmaakte genoegdoening, Nemesis, 1993: 149-157.

69 Remmelink, Haze winkel-Suringa's Inleiding, 1994: 17; Corstens, Het Nederlands strafprocesrecht, 1995: 215-216.

70 Van Rappard, Tot hier en niet verder, verzet van mishandelde vrouwen, 1988. In dit boek worden de mogelijkheden die mishandelde vrouwen zélf hebben om het geweld te stoppen, tot uitgangspunt genomen. 
gevallen van geweld tegen de vrouw in de privésfeer kunnen op een informele manier worden opgelost of in het civiele recht worden afgedaan. ${ }^{71}$

Strafrechtelijk ingrijpen is mogelijk als sprake is van gewelddadig gedrag dat onder een delictsomschrijving valt. Formeel zijn geen beletselen aanwezig om op te treden tegen het geweld dat de vrouw is aangedaan in de privésfeer; het justitiële optreden valt binnen de legaliteit. Of justitieel optreden ook legitiem is, hangt af van de gehanteerde visie op privacy. ${ }^{72}$ Wanneer privacy wordt opgevat als 'niet bemoeien met interne gezinsproblemen' en het geweld wordt beschouwd als 'een ruzie tussen gelijkwaardige mensen', zal strafrechtelijk optreden eerder als niet legitiem worden beschouwd, ${ }^{73}$ dan wanneer privacy wordt opgevat als vrijheidsbegrip. Hoewel ook dan strafrechtelijke interventie een problematisch instrument is.

\subsection{Strafrechtelijke interventie en rechtsbescherming}

De vrouw die slachtoffer is van geweld door haar partner, is de mens van vlees en bloed, een individu, die leed is berokkend door haar (ex-)partner, en tegelijkertijd is zij rechtssubject, burger, wiens recht op lichamelijke integriteit en privacy is geschonden. De vrouw die opkomt voor haar burgerschap wenst bescherming van haar burgerlijke vrijheid. "De individu die zich juridisch opstelt en een recht claimt, zich rechtvaardigt in termen van de wet, zich beroept op een beginsel, een exeptie aanvoert, rekenschap en verantwoording vraagt, iets niet meer néémt en voorlegt aan een onafhankelijke rechter, een belang als recht erkend wil zien, vindiceert zijn (haar, in dit geval, KL) burgerschap en constitueert zich als rechtssubject." geval van een beroep op het strafrecht legt de vrouw niet zelf het conflict aan de rechter voor, zij is geen procespartij, maar zij manifesteert zich wel als rechtssubject, wiens burgerlijke vrijheid is aangetast door een inbreuk erop door een ander. Het strafrecht dient er vervolgens toe een evenwicht te vinden tussen het belang van burgers bij de aanpak van strafwaardig gedrag en het belang van een niet te vergaand overheidsingrijpen in het privéleven van de burger. ${ }^{75}$

In deze $\S$ wordt hier nader op ingegaan. Eerst komt de functie van het strafrecht aan bod $(\S 1.3 .1)$, vervolgens de betekenis van rechtsbescherming voor verdachte

71 De Roos, Strafrecht en democratische legitimatie, $D D, 1983: 877$.

72 Zie over het verschil tussen legaliteit en legitimiteit: Ter Heide, Dejuridisering en dekriminalisering. $D D, 1972: 78$.

73 In de regeling van de relatieve klachtdelicten is terughoudendheid ten aanzien van de persoonlijke levenssfeer voor bepaalde delicten wettelijk vastgelegd. Diefstal en beschadiging zijn bijvoorbeeld niet vervolgbaar binnen het huwelijk, en bij scheiding van tafel en bed is er sprake van een klachtdelict (artt. 316 \& $353 \mathrm{Sr}$ ).

74 Peters, Recht als project, $A A$, 1979: 247.

75 Cleiren, Strafrecht als object van verlangen, in: Lof der verscheidenheid, 1993: 46. 
en slachtoffer $((\$ 1.3 .2)$ en tot slot wordt het doel van strafrechtelijk optreden in geval van vrouwenmishandeling uiteengezet.

\subsubsection{De functie van het strafproces}

Een belangrijk beginsel dat ten grondslag ligt aan het strafprocesrecht is dat 'schuldigen aan het plegen van een strafbaar feit moeten worden gestraft en onschuldigen zoveel mogelijk ongemoeid moeten worden gelaten'. Voorkomen moet worden dat onschuldige mensen willekeurig verzeild raken in een strafrechtelijke procedure en dat de overheid onevenredig inbreuk maakt op de grondrechten van burgers. Dit wordt ook wel de rechtsbeschermende taak van de overheid genoemd. "Een belangrijk fundament van onze strafrechtelijke beschaving ligt nog altijd besloten in de ernst waarmee wordt gestreefd naar de garantie, dat iemand niet op onjuiste gronden of met toepassing van onoirbare methoden wordt veroordeeld, zelfs indien de consequentie daarvan zou zijn dat schuldigen vrijuit gaan. Beperkingen als deze zijn met de conditie van de rechtsstaat gegeven." ${ }^{\text {" }}$ De organen die betrokken zijn bij de strafrechtspleging - politie, openbaar ministerie en de rechterlijke macht - zijn daarom aan regels gebonden in hun zoektocht naar de waarheid. Het gaat hierbij om de juridische waarheid, om de vaststelling van juridisch relevante feiten. De vaststelling van wat juridisch relevant is, is een proces - binnen bepaalde grenzen - van interpretatie. ${ }^{77}$ Tijdens dit proces van waarheidsvinding moet deugdelijke kennis worden vergaard. De middelen om de waarheid aan het licht te brengen moeten toelaatbaar zijn; de gegeven bevoedheid mag niet voor een ander doel worden gebruikt dan waarvoor de bevoegdheid is gegeven. ${ }^{78} \mathrm{Er}$ moet een 'fair trial' worden gegarandeerd (artt. 6 lid 1 EVRM \& 14 lid 1 IVBP). Dit betekent bijvoorbeeld dat 'een ieder tegen wie een vervolging is ingesteld, voor onschuldig wordt gehouden totdat zijn schuld in rechte is komen vast te staan (art. 6 lid 2 EVRM), de zogenaamde onschuldpresumptie, en dat de verdachte niet mag worden gedwongen aan zijn eigen veroordeling mee te werken. Daarnaast heeft de verdachte verschillende rechten, zoals het recht op verdediging en het recht te zwijgen (art. $29 \mathrm{~Sv}$ ). Het fair trial beginsel omvat overigens niet alleen wettelijk vastgelegde rechten. Een eerlijke procesvoering omvat meer, bijvoorbeeld dat op rechtmatige wijze bewijs wordt vergaard tijdens het gerechtelijk vooronderzoek en dat het openbaar ministerie beginselen van een behoorlijke strafrechtspleging hanteert. ${ }^{79}$ Tussen de bevoegdheden en middelen van organen van strafrechtspleging

76 Schalken, Strafrecht als systeem van rechisbetrekkingen, 1987: 6.

77 Zie: Melai, Het waarheidsprobleem in het strafrecht, in: Polariteit en tegenspraak, 1992: 85-104; Nijboer, De schijngestalte van de materiele waarheid, NJB, 1978: 749-757.

78 Melai, Inleiding: het strafgeding, in: Artikelsgewijs commentaar op het wetboek van strafvordering, losbladig, 1981: 101-120, 142; Groenhuijsen, Schadevergoeding voor slachtoffers van delicten in het strafgeding, 1985: 127.

79 Lensing \& Mulder, Hoofdbeginselen van strafprocesrecht, 1994: 28-33. 
om de juridische waarheid boven tafel te krijgen (normhandhaving) en de bescherming van de grondrechten van de verdachte (rechtsbescherming) bestaat een permanent spanningsveld. Vanuit de organen van het strafrechtelijke systeem wordt een immanente druk uitgeoefend om meer bevoegdheden te creerren, terwijl vanuit de rechten van de verdachte binnen het strafprocesrecht tegenwicht wordt geboden of zelfs bevoegdheden aan banden worden gelegd. ${ }^{80}$

Ter terechtzitting beschikken de officier van justitie en de verdachte beiden over een zekere vrijheid tot bepaling van hun processuele houding. Het is de officier van justitie die bijvoorbeeld door de formulering van de telastlegging de grondslag van het onderzoek bepaalt (art. $261 \mathrm{~Sv}$ ), die getuigen en deskundigen kan doen oproepen of dagvaarden (art. 260 lid $1 \mathrm{~Sv}$ ) en met het requisitoir een bepaalde einduitspraak adviseert (art. $311 \mathrm{~Sv}$ ). De processuele autonomie van de verdachte wordt gesymboliseerd door het feit dat hij niet alleen het voorwerp van waarheidsvinding is, maar tevens bepaalde rechten heeft vanuit de gedachte dat hij een vrij individu is. De processuele autonomie blijkt bijvoorbeeld uit het recht getuigen en deskundigen te (doen) ondervragen (art. 260 lid $3 \mathrm{~Sv}$ ) ${ }^{81}$ De rechtsbescherming van de verdachte is uitgangspunt ter zitting en het belangenconflict tussen individu (verdachte) en staat (openbaar ministerie) wordt erkend en "in het contradictoire proces tot structureel principe verheven". ${ }^{82}$ Op die manier wordt aan de individuele procespartij de mogelijkheid gegarandeerd om "de eigen positie, het eigen belang en het eigen verhaal een publieke stem te geven". ${ }^{3}$

De positie van het slachtoffer is in dit geheel een beperkte: zij kan aangifte doen van geweld door haar partner en vervolgens is zij afhankelijk van de politie en het openbaar ministerie. Zij heeft recht op bescherming van haar privacy, maar dit recht kan botsen met de regels van het strafproces. De inverzekeringstelling van de verdachte kan bijvoorbeeld worden opgeheven, omdat gronden ontbreken hem langer vast te houden, terwijl de vrouw die door deze verdachte (haar ex-partner) is verkracht, bescherming wil van haar recht op privacy en lichamelijke integriteit. Ter terechtzitting kan het slachtoffer meeliften met het strafproces door een civiele vordering in te stellen als benadeelde partij (zie hoofdstuk $2, \S 2.5 .2$ ). Ook kan zij door de verdachte (nogmaals, als zij al eerder voor de rechter-commissaris is verschenen) worden opgeroepen als getuige op de terechtzitting in het belang van het proces van waarheidsvinding. Zo'n (herhaald) optreden als getuige kan voor de vrouw die is mishandeld door haar partner ingrijpende gevolgen hebben voor haar

80 Ik denk dan aan ontwikkelingen op het gebied van de redelijke termijn, het onmiddellijkheidsbeginsel, onrechtmatig verkregen bewijs en de niet-ontvankelijkheidsverklaring van hetopenbaar ministerie wegens schending van de beginselen van behoorlijke strafrechtspleging. Zie cok: Cleiren, De openheid van de wet, de geslotenheid van het recht, 1992: 1-4.

81 Lensing \& Mulder, Hoofdbeginselen van strafprocesrecht, 1994: 25-30.

82 Peters, Het rechtskarakter van het strafrecht, 1972: 8. Zie ook: Melai, Inleiding: het strafgeding, in: Artikelsgewijs commentaar op het wetboek van strafvordering, losbladig, 1981: 111-120.

83 Foqué \& 't Hart, Instrumentaliteit en rechisbescherming, 1990: 127. 
psychisch welbevinden, waardoor zij het als een inbreuk op haar persoonlijke levenssfeer kan ervaren (art. $10 \mathrm{Gw}$ ). De afgelopen jaren is door slachtoffergetuigen, soms met succes, een beroep gedaan op bepaalde mensenrechten, zoals het recht op privacy of het recht op zelfbeschikking of op een fatsoenlijke behandeling tijdens het verhoor. Daarmee doen ook slachtoffers een beroep op rechtsbescherming. ${ }^{84}$

Het hiervoor beschrevene geeft aan dat regels ter bescherming van de burger in de hoedanigheid van verdachte kunnen botsen met de bescherming van de grondrechten van de burger in de hoedanigheid van slachtoffer. Dit levert een extra spanningsverhouding op.

\subsubsection{Rechtsbescherming in relationele zin}

Wat moet worden verstaan onder rechtsbescherming van het slachtoffer en hoever reikt die rechtsbescherming?

Het meest in het oog springende belang van het slachtoffer is dat zij wordt gezien als een rechtssubject met rechten en plichten. Dit lijkt een voor de hand liggende constatering, maar tot voor kort werd het slachtoffer vooral gezien als degene die aangifte doet en die als getuige optreedt in het belang van de waarheidsvinding; het slachtoffer werd beschouwd als 'instrument' en de verdachte als rechtssubject. Een visie die tegenwoordig overigens nog wordt gehuldigd, maar die steeds meer ter discussie komt te staan. In deze visie wordt het slachtoffer tegenover de verdachte gezet. Een toenemende aandacht voor het slachtoffer als rechtssubject binnen het strafproces betekent dan een afnemende aandacht voor de verdachte als rechtssubject, waardoor de verdachte in de positie van rechtsobject kan komen. ${ }^{85}$ Versterking van de positie van het slachtoffer wordt afgewezen: het zou afbreuk doen aan de rechtsbescherming van de verdachte. Het bezwaar tegen deze opvatting is dat strak wordt vastgehouden aan de rechtsbescherming van de verdachte zonder met open blik te onderzoeken hoe de rechtsbescherming van het slachtoffer kan worden versterkt, zonder dat dit ten koste gaat van de rechtsbescherming van de verdachte. Bovendien wordt voorbij gegaan aan het feit dat de oorsprong van het strafrecht is gelegen in de wraak van het individuele slachtoffer en dat het strafrecht een bemiddelende functie heeft tussen de wraak van het individu en de garantie van de grondrechten van de burgers.

84 Pessers, De vrijheid van oorverdovende seksuele expressie, $N J B$, 1991: 1782; Reactie hierop door Serrarens, Spronken \& Wolleswinkel, NJB, 1992: 521; Myjer, Slachtoffers van zedendelicten en Straatsburgse rechtsbescherming, $N J B, 1996: 437-442$.

85 Zie bijvoorbeeld: Buruma, Victimalisering van het strafrecht, in: Hoe punitief is Nederland? 1994: 211-133; Van Bavel \& Verbunt, Slachtoffer/getuige in zedenzaken en verhoor ter zitting, NJB, 1990: 1399-1404. 
Een diametraal tegenovergestelde opvatting is dat het leed van het slachtoffer, een 'gevictimaliseerde moraal', grondslag behoort te zijn van het strafrecht. ${ }^{86}$ "Het is niet zozeer de schending van de ideologisch verankerde norm die dient te worden hersteld, maar het concrete individuele leed waaraan moet worden rechtgedaan." In deze opvatting verdwijnen de rechtswaarborgen van het strafproces naar de achtergrond. Door het leed van het slachtoffer als uitgangspunt te nemen wordt de verwachting geschapen dat het strafrecht het leed van het individuele slachtoffer kan wegnemen. Maar het strafrecht is niet in staat de tragiek van het slachtoffer te vertolken, noch kan het strafrecht haar leed overnemen, haar waardigheid herstellen of haar krenkingen wegnemen. ${ }^{88}$ Bovendien wordt door de suggestie dat het strafrecht de pijn van het slachtoffer vertolkt, ingespeeld op de mateloze angst van burgers om zelf slachtoffer te worden van criminaliteit, waartegen de staat hen moet beschermen. Daarmee wordt de roep om repressiever optreden vergroot. ${ }^{89}$ Door uitbreiding van strafbaarstelling en uitbreiding van bevoegdheden om de criminaliteit te bestrijden wordt het strafrechtelijke klimaat punitiever en het strafrechtelijk optreden repressiever, waardoor uiteindelijk de rechtsstaat kan worden aangetast. ${ }^{90}$ Tot slot kan als bezwaar worden genoemd dat het leed van de ander als vertrekpunt voor een moraal zeer schraal is. ${ }^{91}$ Door leed, wreedheid en vernedering als uitgangspunt voor een bindende moraal te nemen, wordt voorbijgegaan aan de destructieve kracht hiervan, omdat het onmachtige van de mens wordt aangeraakt, in plaats van de positieve krachten van de mens. ${ }^{92}$ Een 'slachtoffermoraal' biedt geen positief perspectief: het herbergt geen idealen of utopie in zich, zoals rechtvaardigheid, vrijheid, zelfontplooiing en verantwoordelijkheid voor elkaar. Deze bezwaren geven aan dat het strafrecht meer moet zijn dan 'een geînstitutionaliseerde mogelijkheid om wreedheid, vernedering en leed af te wijzen'. ${ }^{93}$ Het moet allereerst de vrijheden van de burger garanderen. Het is de relationele opvatting van 't Hart die aanknopingspunten biedt om de rechtsbescherming van het slachtoffer

86 Boutellier, Solidariteit en slachtofferschap: 1993: m.n. 23-31, 101-126.

87 Ibidem: 29.

88 't Hart, Straf, recht en waarden, in: Hoe punitief is Nederland?, 1994: 38; Verrijn Stuart, Via onschuld naar macht, $J V, 1994: 94-114$.

89 Verrijn Stuart heeft op de onverzadigbaarheid van het slachtofferisme als levenshouding gewezen; aan elk leed wordt een recht gekoppeld en het strafrecht wordt ingeroepen om dit recht te beschermen. Verrijn Stuart, Naar een geciviliseerd recht tegen sexucel geweld, AA, 1992: 84. Zie ook haar artikel: Vrouwen en strafrecht, het onverzadigbare slachtoffer en de onverzadigbare justitie, in: $a$ Tort et à Travers, 1988: 215-221.

90 't Hart, Straf, recht en waarden, in: Hoe punitief is Nederland?, 1994: 39; Kool, Beleidswaarde van het slachtofferschap, Nemesis, 1995: 42.

91 Verrijn Stuart spreekt, in navolging van Berger, van 'verdorring'. Verrijn Stuart, Via onschuld naar macht, $J V$, 1994: 100.

92 Ibidem: 100-103. Op sociaal niveau kan deze lotsverbondenheid op grond van hetzelfde ervaren leed juist door de onderlinge herkenning wel de kracht van vrouwen versterken, maar dit is iets anders dan het slachtofferschap als grondslag voor een moraal.

93 Boutellier, Solidariteit en slachtofferschap, 1993: 30-31. 
in het strafproces in samenhang met de rechtsbescherming van de verdachte te doordenken.

't Hart vat het recht op als een systeem van relaties "waarin een omvattend structureel evenwicht tot uitdrukking komt waarbinnen de machtsuitoefening ingeperkt en gekanaliseerd kan worden". ${ }^{94}$ De bescherming van de vrijheid van de burger kan daarbij niet los worden gedacht van de maatschappelijke ordening van het recht. Het recht "kan zijn beschermende functie slechts daadwerkelijk vervullen indien het van de aanvang af aan ook in zijn instrumentele betekenis begrepen wordt". ${ }^{95}$ Hierin onderscheidt de relationele visie zich zowel van een instrumentalistische denkwijze, ${ }^{96}$ waar het recht als een neutraal instrument wordt ingezet om een door de politiek vastgestelde maatschappelijke ordening te bereiken, ${ }^{97}$ als van de machtskritische visie van Peters, waar de bescherming van de grondrechten van de burger tegen willekeurige inbreuken door de staat centraal staan, ook wel 'secundaire controle' genoemd. ${ }^{98}$ In beide opvattingen staan maatschappelijke ordening (normhandhaving) en individuele rechtsbescherming los van elkaar of zelfs tegenover elkaar, ${ }^{99}$ waardoor in het ene geval de rechtsbescherming onder druk kan komen te staan, terwijl in het andere geval de maatschappelijke normering kan worden weggedrukt door de strafprocessuele bescherming. "Instrumentaliteit zonder rechtsbescherming leidt dan tot ideologie zonder utopie, en rechtsbescherming zonder instrumentaliteit tot utopie zonder ideologie." 100

Het begrip rechtsbescherming is in de relationele visie van 't Hart ruimer omschreven dan in de instrumentalistische of machtskritische visie. In de eerste plaats omdat rechtsbescherming niet uitsluitend bescherming tegen machtsuitoefening door de overheid inhoudt, maar ook tegen machtsuitoefening door andere burgers: "tegen beide moet de burger met zijn samenlevingsverbanden worden beschermd". ${ }^{101}$ Het slachtoffer krijgt zo een rechtstheoretisch onderbouwde plaats

94 't Hart, Openbaar Ministerie en rechtshandhaving, 1994: 210. Het relationele karakter van het rechtsbegrip zet zich af tegen de verticale bevelsopvatting van het recht van het Ancien Régime.

95 Foqué \& 't Hart, Instrumentaliteit en rechisbescherming, 1990: 122. Ook Schalken ziet het strafrecht als een systeem van rechtsbetrekkingen waar een evenwicht tussen normhandhaving en rechtsbescherming van belang is. Schalken, Strafrecht als systeem van rechtsbetrekkingen, 1987.

96 Het instrumentalisme is eerder een manier van denken, dan dat het als een uniforme leer kan worden beschouwd. 't Hart, Openbaar Ministerie en rechishandhaving, 1994: 183.

97 Zie over instrumentalisme bijvoorbeeld: Schuyt, Sturing en het recht, in: Het schip van staat, 1985: 114-116.

98 Peters, Het rechtskarakter van het strafrecht, 1972.

99 't Hart, Openbaar Ministerie en rechtshandhaving, 1994: 198.

100 Foqué \& 't Hart, Instrumentaliteit en rechtsbescherming, 1990: 132 (noot 26). Het onderscheid tussen instrumentalistisch en instrumentaliteit is dat in het eerste geval het recht is losgekoppeld van iedere inherente waarde van het recht, terwijl in het tweede geval de maatschappelijk ordenende functie van het recht onlosmakelijk is verbonden met de intrinsieke waarden van rechtsbescherming. 't Hart, Openbaar Ministerie en rechtshandhaving, 1994: 217-218.

101 Ibidem: 264. Zie ook Schalken, Strafrecht als systeem van rechisbetrekkingen, 1987: 15-16; Corstens, Het Nederlands strafprocesrecht, 1995: 213. 
in de strafrechtspleging, zonder dat een tegenstelling wordt geconstrueerd tussen het belang van de verdachte bij rechtsbescherming en het belang van de burgers bij veiligheid. ${ }^{102}$ In de tweede plaats wordt rechtsbescherming ruimer gedefinieerd, omdat 'rechtsbescherming niet alleen verleend moet worden binnen een bepaald stelsel, maar ook tegen dat stelsel zelf ${ }^{103}$ Dit betekent dat de burger de mogelijkheid moet hebben de heersende interpretatie van het recht ter discussie te stellen. "De juridische begrippen en constructies mogen dus niet worden voorgesteld als afbeeldingen van de werkelijkheid; zij mogen ook niet geheel opgaan in hun empirisch-theoretische betekenis." ${ }^{104}$ Integendeel, het recht moet een plaats bieden aan denkbeelden die het dominante rechtsdenken aan de kaak stellen. Dit noemen 't Hart en Foqué 'contrafakticiteit'. ${ }^{105}$ Contrafactische begrippen zijn een 'constante bemiddeling tussen idealiteit en feitelijkheid, het zijn algemeen geldende begrippen, maar kennen geen eenduidige materiële invulling'. ${ }^{106}$ Juridische leerstukken en begrippen hebben de functie als interpretatiekader en als grondslag te dienen voor het garanderen van de burgerlijke vrijheden, terwijl deze begrippen tegelijkertijd in de materièle concretiseringen openheid moeten bewaren voor andere werkelijkheidsbeelden. ${ }^{107}$

Deze relationele visie kan worden beschouwd als een denkrichting, "het geeft richting aan de strafrechtshantering'. ${ }^{108}$ Deze denkrichting biedt naar mijn mening handvatten voor een nadere analyse van strafrechtelijke regulering in geval van mannelijk geweld tegen vrouwen in de privésfeer. Hoewel de relationele visie nauwelijks aangeeft hoe de rechtsbescherming van het slachtoffer vorm moet worden gegeven, en rechtsbescherming van het slachtoffer overeen lijkt te komen met normhandhaving, biedt deze visie wel een rechtstheoretische onderbouwing voor de positionering van het slachtoffer in de rechtshandhaving. "In een relationele visie krijgt de burger als slachtoffer weer een natuurlijke plaats in het strafrechtelijke gebeuren, net als de burger als verdachte. De kwestie is dan niet, dat een eigen plaats van het slachtoffer 'niet in strijd hoeft te zijn met het eigen karakter van het strafrecht', maar - veel positiever - dat die eigen plaats er juist in thuishoort."109

Tevens biedt de relationele opvatting een theoretische onderbouwing voor de noodzaak van alternatieve interpretaties om de vrijheid van burgers te kunnen garanderen. Concrete maatschappelijke vrijheid kan alleen bestaan als burgers die bekneld worden door de huidige interpretatie van het recht, de vrijheid hebben er

102 't Hart, Straf, recht en waarden, in: Hoe punitief is Nederland?, 1994: 37.

103 't Hart, Openbaar Ministerie en rechtshandhaving, 1994: 264.

104 't Hart, Recht als schild van Perseus, 1991: 50.

105 Foqué \& 't Hart, Instrumentaliteit en rechtsbescherming, 1990: 138-151 (voor een definitie zie pagina 139, noot 38); 't Hart, Recht als schild van Perseus, 1991: 50-51.

106 Ibidem: 51.

107 Ibidern: 52 .

108 't Hart, Openbaar Ministerie en rechtshandhaving, 1994: 231.

109 Ibidem: 284. 
een andere interpretatie tegenover te zetten. Zoals in $\S 1.2$ naar voren is gekomen, laat de rechtsbescherming van de vrouw die slachtoffer is van geweld in de privésfeer te wensen over. Om de rechtssubjectiviteit van de vrouw in de privésfeer te garanderen kan een alternatieve interpretatie van de geweldsdelicten noodzakelijk zijn. "De verstening van de wereld kan worden teniet gedaan en de Medusa van een totaal dominerende betekeniscode kan nog onthoofd worden door woorden te geven aan verdrukte alteriteit, door het verwoorden van een ander perspectief, van een andere werkelijkheid." ${ }^{10}$ Hierbij gaat het overigens niet alleen om de 'bemiddelende' functie van begrippen, maar juist ook om de interpretatie en toepassing ervan door mensenlijk handelen. Mensen leggen de verbinding tussen een 'werkelijkheidservaring' en de te hanteren juridische begrippen. ${ }^{\prime \prime}$

Deze relationele visie biedt tot slot een handvat voor de beoordeling van het optreden van het openbaar ministerie. Rechtshandhaving heeft tot doel de concrete vrijheid van mensen als rechtssubject te garanderen, zowel van de verdachte, als van de veroordeelde, als van het slachtoffer. Deze rechtsbescherming kan alleen worden gegarandeerd als het openbaar ministerie niet alleen uitvoerder is van een door de politiek bepaald beleid, maar tevens enige distantie heeft ten opzichte van het bestuur om toe te kunnen zien op de rechtsbescherming. ${ }^{1 / 2}$ Alleen dan kan het openbaar ministerie zijn taak, het dienen van het rechtsbelang, dat wil zeggen "het garanderen van een maatschappelijke orde die tevens als rechtsorde kan worden opgevat", 113 goed uitvoeren.

De relationele opvatting levert kortom een perspectief op om in de rechtshandhavende taak een evenwicht te vinden in de spanningsverhouding tussen normhandhaving, het vinden van de juridische waarheid, en de rechtsbescherming van de burger in de hoedanigheid van verdachte en de hoedanigheid van slachtoffer.

\subsubsection{Rechisvrede als doel van het strafrecht}

Het doel van strafrechtelijke regulering in geval van mannelijk geweld tegen vrouwen in de privésfeer omschrijf ik als 'herstel van de rechtsvrede'. Rechtsvrede omvat zowel een behoorlijk procesrecht, waarin het streven naar gerechtigheid, rechtszekerheid en waarheidsvinding een belangrijke plaats innemen, als het wegnemen van de door het strafbare feit veroorzaakte maatschappelijke onrust. ${ }^{114}$ Het wegnemen van deze onrust omvat niet alleen de strafdoelen vergelding van aangedaan leed, algemene afschrikking, het voorkomen van recidive (speciale preventie) en conflictsoplossing, maar ook het veelomvattender doel herstel van de

110 't Hart, Recht als schild van Perseus, 1991: 54-55.

111 Witteveen, Afdaling in de versteende wereld van het recht, $D D: 1111$

112 't Har, Openbaar Ministerie en rechishandhasing, 1994: 270-274.

113 Ibidem: 273-274.

114 Groenhuijsen, Schadevergoeding voor slachtoffers van delicten in het strafgeding, 1985: 271-277. 
deuk in de rechtsorde. Hiermee wordt het subsociale, dat wat het strafbare feit teweeg heeft gebracht in de naaste en meer verwijderde omgeving van het slachtoffer, meer naar de voorgrond geplaatst. ${ }^{115}$ De gevolgen van het geweld tegen de vrouw in de privésfeer voor het directe slachtoffer, voor haar naaste omgeving, en voor de maatschappij als geheel behoren als belangrijk aspect te worden meegewogen. "De straf als reactie op de schuld van de dader noopt tot verdieping van inzicht in de vragen van toerekeningsvatbaarheid, verantwoordelijkheid en verwijtbaarheid. De straf als reactie op het gepleegde onrecht doet naar de aard, de omvang en de repercussies van het onrecht vragen." 16 Doordat het doel, herstel van de rechtsvrede, alleen kan worden bereikt door een strafproces dat de vrijheden van de burger beschermt, sluit deze doelstelling aan bij de relationele opvatting.

Groenhuijsen voert het strafdoel van de rechtsvrede aan om de positie van het slachtoffer als benadeelde partij te verstevigen. "Naast elementen als het streven naar gerechtigheid, naar deugdelijke waarheidsvinding en naar een aannemelijke rechtsverhouding tussen de overheid en de verdachte in het geding, kan ook een kennelijke redelijk bejegening van de beledigde partij (nu benadeelde partij, KL) een bijdrage leveren aan het vereffenen van de maatschappelijke gevolgen van het delict." 117 Ik trek de positie van het slachtoffer ruimer, namelijk als rechtssubject. Herstel van de rechtsvrede kan alleen worden bereikt als de mens wordt bevestigd in zijn of haar hoedanigheid als burger. Dit geldt voor de verdachte en de veroordeelde, en ook voor het slachtoffer.

Respect voor de vrijheid van de burger brengt tevens met zich mee dat er sprake moet zijn van een humane aanpak. Het humane aspect kan worden omschreven als 'het ontmoeten van de ander als mens'. De dader behoort aangesproken te worden op zijn verantwoordelijkheid voor zijn daden, waarbij de mens achter de daad moet worden gezien. De mens is een gemeenschapswezen en behoort als evenmens te worden gerespecteerd en niet te worden verbannen uit de maatschappij. ${ }^{118}$ Pure repressie wordt daarom afgewezen. Het gaat niet alleen om afkeuring, maar ook om hulp en steun aan de dader, zodat hij de verantwoordelijkheid op zich kan nemen voor zijn daden en tot schuldverwerking kan komen. Schuldbeleving van de dader van zijn daad kan worden beschouwd als voorwaarde voor een zinvolle strafrechtsbedeling. ${ }^{119}$ De strafrechtelijke reactie behoort daarom gericht te zijn op een proces

115 De door het strafbare feit teweeggebrachte onrust wordt ook wel het subsociale element van het delict genoemd en wordt door Vrij naast de elementen schuld en wederrechtelijkheid geplaatst. Vrij, Ter effening, het subsaciale als het derde element van het delict, 1948; Van Veen, De betekenis van het 'subsociale' voor het straffen en het strafrecht, $T v S$, 1952: 122-138.

116 Van Veen, De betekenis van het strafproces voor onze samenleving, $T v S, 1969: 142$.

117 Groenhuijsen, Schadevergoeding voor slachtoffers van delicten in het strafgeding, 1985: 275.

118 Kelk, De menselijke verantwoordelijkheid in het strafrecht, 1994: 5-8.

119 Schuldverwerking is alleen mogelijk als sprake is van schuldbewustzijn, dat wil zeggen dat de man zijn schuld als iets concreets, als een 'tastbare grootheid' in relatie tot zichzelf kan zien. Dit onderscheid zich van schuldgevoel, dat meer een emotionele beleving, een gemoedsstemming is. Hiertussen bevinden zich vele gradaties van wat men schuldbesef zou kunnen noemen. Kelk, De 
van sociale reïntegratie, waarbij het verstevigen van zelfrespect van belang is. Een mens die de verantwoordelijkheid op zich neemt voor zijn daden, is aanspreekbaar op herstel van het leed dat hij heeft aangericht. Dit herstel kan liggen op menselijk niveau tussen dader en slachtoffer, maar ook op maatschappelijk niveau.

Een humane aanpak betekent voor het slachtoffer dat ook zij in haar ontmoeting met functionarissen werkzaam bij politie, openbaar ministerie of rechterlijke macht zorgvuldig wordt bejegend, dat zij als mens wordt benaderd. In de concrete toepassing van de regels gaat het om communicatief handelen en zorg voor de ander. $^{120}$

Respect voor de mens als rechtssubject en communicatief handelen in de menselijke ontmoeting zijn beiden voorwaarde voor een humane strafrechtsbedeling. Dit geldt zowel voor de mens als dader, als de mens als slachtoffer. Het gaat om een behoorlijk strafproces (voor verdachte en slachtoffer), dat de onrust in de maatschappij (en bij het slachtoffer in het bijzonder), veroorzaakt door het misdrijf, wegneemt.

\subsubsection{Respect voor het rechtssubject}

De vrouw die slachtoffer is van geweld door haar partner of ex-partner wordt leed berokkend als mens. Er wordt een inbreuk gemaakt op haar lichamelijke integriteit en haar privacy als rechtssubject. De mens van vlees en bloed komt niet geheel overeen met het rechtssubject. Het begrip rechtssubject, om het in de woorden van 't Hart te zeggen, is een contrafactisch begrip. Het is een algemeen geldend rechtsbegrip dat de mens voorstelt als een autonome en vrije burger, wiens grondrechten gerespecteerd dienen te worden, terwijl de materiële invulling van het begrip open staat voor alternatieve werkelijkheidsbeelden. Ik heb in $\S 1.2$ betoogd dat de vrouw in de privésfeer rechtssubject is: een autonoom en vrij gedachte persoon, die drager is van rechten en plichten. In $\S 1.3$ heb ik betoogd dat de vrouw als slachtoffer van geweld in de privésfeer ook moet worden beschouwd als rechtssubject. Vanuit die gedachte moeten de rechtsbetrekkingen tussen overheid en burger nader worden geanalyseerd. Op uitvoerend niveau dient de mens als individu met respect en zorg te worden benaderd: er behoort sprake te zijn van een humane aanpak. Deze humane aanpak is gebaseerd op respect voor de vrijheidsrechten van de burger, en in het concrete handelen zal dit respect zich moeten verwezenlijken. Noties als zorg, steun, hulp, het goede doen, zijn hier beter op zijn plaats dan het claimen van rechten.

Tussen de mens als individu en de mens als rechtssubject of burger bestaat een spanningsverhouding; het individu moet zich kunnen herkennen in het rechtssubject,

doorleving van de schuld in de strafrechtspleging, in: Met schuld beladen, 1992: 15-17; Zie ook:

Kelk, De menselijke verantwoordelijkheid in het strafrecht, 1994: 121-124.

120 Soetenhorst-de Savornin Lohman, Doe wel en Zie om, 1990: 21-37. 
maar komt niet overeen met het rechtssubject. Deze spanningsverhouding neemt verschillende gedaantes aan, bijvoorbeeld tussen ervaren leed en een inbreuk op de lichamelijke integriteit, tussen juridische gelijkwaardigheid en feitelijke machtsverschillen, tussen de rechtspositie en de concrete bejegening, tussen een sociologische analyse van het fenomeen vrouwenmishandeling en de juridische benadering van geweld in de privésfeer, tussen 'een recht hebben op' en 'de behoefte aan menselijk contact en respect'. Het formuleren van rechten is de motor achter de erkenning van de mens als autonoom individu, maar rechten kunnen zich alleen verwezenlijken in het menselijke contact. Alleen in de wisselwerking tussen 'recht' en 'het goede' kan een humaan strafrecht zich verwezenlijken.

\subsection{Vraagstelling en methodologische verantwoording}

Het onderzoek naar strafrechtelijke regulering van mannelijk geweld tegen vrouwen in de privésfeer heb ik verricht binnen het kader van de feministische rechtswetenschap (§ 1.4.1). In $\S 1.4 .2$ wordt vervolgens de begripsmatige afbakening van het fenomeen vrouwenmishandeling behandeld. Daarna wordt kort ingegaan op ander Nederlands onderzoek naar vrouwenmishandeling in $\S 1.4 .3$. Tot slot wordt in $\S$ 1.4.4 een aantal hypothesen van het verkennende onderzoek en de probleemstelling uiteengezet.

\subsubsection{Binnen het kader van de feministische rechtswetenschap}

Deze studie vindt plaats binnen het kader van een zich ontwikkelende feministische rechtswetenschap. Hoewel niet gesproken kan worden van een algemeen geldende feministische rechtstheorie, noch van een algemeen geldende feministische rechtsmethode, kan wel een aantal kenmerken worden genoemd die ook op dit onderzoek van toepassing zijn. Deze kenmerken zijn: recht is niet objectief en sekse-neutraal, onderzoek naar de invloed van het recht op het leven van vrouwen is contextgebonden en onderzoek vindt plaats vanuit een zekere persoonlijke betrokkenheid. $^{121}$

Dankzij de feministische rechtswetenschap is de invloed van het recht op de machtsongelijkheid tussen mannen en vrouwen blootgelegd; het recht is niet neutraal. Dat het recht niet neutraal is, is door de kritische rechtswetenschappers reeds menigmaal naar voren gebracht. De relationele opvatting geeft hier ook blijk van. Juridische begrippen en bepalingen gaan uit van het dominante waardepatroon in de maatschappij en sluiten zodoende aan bij situaties en behoeften van maatschap-

121 Scales, The emergence of feminist jurisprudence: an essay, Yale law Journal 1986: 1373-1403. Fineman \& Thomadsen, At the boundaries of law, feminism and legal theory, 1991: xi-xvi. 
pelijk dominante groepen. ${ }^{122}$ Maar feministische rechtswetenschappers voegen hieraan toe dat het recht tevens niet sekse-neutraal is. Het recht normeert de menselijke verhoudingen; de machtsverhoudingen tussen de seksen worden door het recht weerspiegeld en bevestigd, zoals in $\S 1.2$ naar voren is gekomen. Juridische vrouwenstudies zijn zich in de loop der tijd "(...) steeds meer gaan richten op het analyseren van de manieren waarop in het recht feiten geordend worden en begrippen worden ingevuld en wat hierbij de invloed is van de machtsverhoudingen tussen mannen en vrouwen". ${ }^{123}$

Het recht kan op drie verschillende manieren worden benaderd. Allereerst kan het recht worden beschouwd als discriminatoir: door onderscheid te maken tussen mannen en vrouwen in de regelgeving worden actief vrouwen benadeeld en de positie van mannen wordt beschermd. Dit wordt de 'recht is seksistisch'-benadering genoemd. Deze benadering is van belang geweest om de normatieve orde van het recht aan de kaak te stellen, maar heeft als nadeel dat de suggestie wordt gewekt dat door het opheffen van discriminerende bepalingen het recht sekse-neutraal zou kunnen worden. ${ }^{124}$ Ten tweede kan het recht worden beschouwd als mannelijk: de mannelijke waarden zijn dominant en worden voorgesteld als universele waarden. Weliswaar wordt de neutraliteit van het recht ontmaskerd in deze benadering, maar het nadeel van deze benadering is dat het ertoe neigt mannen en vrouwen als homogene groep voor te stellen. ${ }^{125}$ De benadering die hieraan ontkomt, is de 'recht is gendered'-benadering. "Maar terwijl onze gedachtenvorming over het recht in een impasse raakt met de bewering dat het recht mannelijk is, stelt de opvatting dat het recht geseksueerd is ons in staat het recht te zien in termen van processen die op velerlei manieren functioneren, zonder uit te gaan van de onbuigzame veronderstelling dat alles wat het recht doet in het nadeel is van vrouwen en in het voordeel van mannen." 126 In deze opvatting is geen sprake van "een vaste categorie of empirische referent van Man en Vrouw". ${ }^{27}$ Door recht als 'gendered' te beschouwen, is er "meer aandacht voor het complexe, samenhangende en procesmatig doorwerken van maatschappelijke sekseverhoudingen in het recht."128

Deze 'gender' benadering sluit aan bij de relationele opvatting. Het recht wordt beschouwd als complex en procesmatig, als een veelvoud van normen en praktijken, die elkaar kunnen aanvullen, en elkaar ook kunnen tegenspreken, of in de termen van 't Hart, rechtsbegrippen zijn contrafactisch van aard. Het recht bevestigt en reproduceert daarom niet alleen de machtsverhoudingen tussen de seksen, maar kan

122 Holtmaat, Met zorg een recht?, 1992: 23. Goldschmidt \& Holtmaat, Vrouw en recht, 1993: 1-56.

123 Goldschmidt, We need different stories, 1993: 10.

124 Smart, De vrouw in het juridische vertoog, $T V V, 1991$ : 501-502. Dit is de vertaling van: The woman in legal discourse, oratie RUU, 16 mei 1991.

125 Smart, De vrouw in het juridische vertoog. $T v V, 1991$ : 503-505.

126 Ibidem: 505.

127 Ibidem: 505.

128 Goldschmidt, We need different stories, 1993: 18. 
soms ook voorwaarden scheppen tot verandering van de machtsverhoudingen tussen de seksen. De mate waarin het recht maatschappelijke veranderingsprocessen kan bewerkstelligen hangt van verschillende factoren af, onder andere van druk vanuit maatschappelijke groeperingen en de openheid van het rechtssysteem. ${ }^{129}$ Hieruit volgt dat het recht sociale veranderingen kan weerspiegelen en zelfs vergemakkelijken, maar geen sociale veranderingen initierren. ${ }^{130}$ De rol van het recht in veranderingsprocessen is beperkt, maar deelname van zwakke maatschappelijke groeperingen aan het rechtenvertoog is tegelijkertijd essentieel. ${ }^{131}$ Dit geldt ook voor de wijze waarop het strafrecht wordt ingezet als het gaat om mannelijk geweld tegen vrouwen in de privésfeer, zoals in $\S 1.3$ uiteen is gezet. Deze studie is een poging een ander verhaal, namelijk het verhaal van de vrouw die geweld ondervindt door haar partner of ex-partner, te laten doorklinken in het strafproces. Een verhaal waarin het recht wordt geplaatst in de maatschappelijke context van de machtsongelijkheid tussen de seksen, waarbij wordt aangesloten bij de strategie van dejuridisering binnen het strafrecht. ${ }^{132}$

Daarnaast kan deze studie worden beschouwd als context gebonden onderzoek. Ik heb een exploratief empirisch onderzoek verricht om enig inzicht te krijgen in de omvang van zaken van mannelijk geweld tegen vrouwen in de privésfeer, die het openbaar ministerie bereiken, en in de wijze van beslissen door officieren van justitie in dit soort zaken. De problematiek van strafrechtelijke regulering in geval van vrouwenmishandeling is geanalyseerd door algemene noties over 'gendered' recht in relatie te brengen met geweld tegen vrouwen in de privésfeer, zonder overigens op zoek te zijn naar een algemene theorie die allesverklarend zou zijn. "De ontwikkeling van het denken over vrouwen en recht is vooral veranderd door toenemende aandacht voor de context van de feiten. Aandacht voor de empirische context, maar ook voor de achtergronden hiervan en de waarde die er in het recht aan wordt toegekend." 133

\subsubsection{Definitie van vrouwenmishandeling}

Mannelijk geweld tegen vrouwen in de privésfeer is een maatschappelijk verschijnsel dat in de jaren zeventig aan de kaak wordt gesteld door de vrouwenbeweging. ${ }^{134}$

129 Peters, Recht als vals bewustzijn, in: Recht, macht en manipulatie, 1976: 192.

130 Fineman \& Thomadsen, At the boundaries of law, feminism and legal theory, 1991 : xiv; Holtmaat, Met zorg een recht?, 1992: 31-33.

$131 \mathrm{Zij}$ bijvoorbeeld: Peters, Recht als project, $A A, 1979$.

132 Zie: De Roos, Strafbaarstelling van economische deliclen, 1987: 17-18; Ter Heide, Dejuridisering en dekriminalisering, $D D, 1972: 78-86$.

133 Goldschmidt We need different stories, 1993: 21.

134 De vrouwenbeweging is een sociale beweging die getypeerd kan worden als een (tijdelijkc) coalitie van pioniers, pressiegroepen, en beroepsgroepen. Niet alle mensen die tot de vrouwenbeweging behoren, zullen overigens zichzelf als zodanig in de vrouwenbeweging plaatsen. Zie hierover: Van Montfoorh, Het topje van de ijsberg, 1994: 24-25, 29-30. 
De term vrouwenmishandeling is een politieke term met een morele lading en staat voor geweld als uiting van macht van mannen over vrouwen in de privesfeer. ${ }^{135}$ Geweld tegen de vrouw door haar (ex-)partner 'is geen incidentele afwijking en uitzondering, maar een maatschappelijk probleem'. ${ }^{136}$

Vrouwenmishandeling is geen duidelijk afgebakend begrip, eerder vervult het begrip een symbolische functie, binnen de beweging, maar ook naar buiten toe, om veranderingen in de publieke moraal te markeren. De term vrouwenmishandeling werkt ook als een metafoor, als een eenduidig beeld over gevallen van mannelijk geweld tegen vrouwen in de privésfeer. Dit beeld betreft een specifiek 'topje van de ijsberg'. ${ }^{137}$ Tegenwoordig lijkt vrouwenmishandeling te worden geassocieerd met de vrouw die bont en blauw geslagen uit haar huis vlucht naar Blijf van m'n Lijf. ${ }^{138}$ De werkelijkheid van mannelijk geweld tegen vrouwen in de privésfeer is echter veel gewoner en alledaagser: ook vrouwen die niet naar een opvanghuis vluchten, of die niet jarenlang mishandeld worden binnen een relatie, evenals vrouwen die pas met geweld worden geconfronteerd na de scheiding, vallen onder de term vrouwenmishandeling. Maar deze meerduidigheid van de problematiek is moeilijk in een politieke term te vatten. Ik omschrijf daarom vaak de problematiek als 'mannelijk geweld tegen vrouwen in de privésfeer', maar omdat dit geen bondige term is, ${ }^{139}$ hanteer ik ook de term vrouwenmishandeling, in de hoop dat de huidige associatie wordt vervangen door een associatie die meer aansluit bij de werkelijkheidsbeelden van vrouwen die geweld ondervinden in de privésfeer. ${ }^{140}$

Deze studie naar mannelijk geweld tegen vrouwen in de privésfeer omvat verschillende vormen van geweld die aansluiten bij een strafbepaling. Onder vrouwenmishandeling versta ik: (dreigen met) fysiek geweld tegen vrouwen binnen een heteroseksuele relatie of ex-relatie. Psychische dwang valt niet onder mijn definitie van vrouwenmishandeling. Het gaat om gewelddadig handelen door de (ex-)partner waardoor een inbreuk op het lichamelijke (en seksuele) zelfbeschikkingsrecht en/of een inbreuk op de persoonlijke levenssfeer te weeg wordt gebracht. Deze inbreuk moet tevens strafbaar gedrag zijn, dat wil zeggen onder een strafbepaling vallen. Verschillende vormen van gewelddadig gedrag vallen onder strafbepalingen, zoals fysieke mishandeling als slaan, schoppen, brandende peuken in de huid drukken en

135 Meinen, Een kwestie van macht, strategieën van vrowwen tegen seksueel geweld, 1992: 15. Leuw, De traditionele en de feministische visie op (fysieke) seksuele victimisering, $T v C, 1982: 257-278$.

136 Romkens, Wie is bang voor geweld? in: Het klappen van de zweep, 1994: 127.

137 Van Montfoort, Het topje van de ijsberg, 1994: 44.

138 Romkens, Wie is bang voor geweld? in: Het klappen van de zweep, 1994: 127.

139 "The phrase 'male battering of women' is useful because it describes the problem more accurately, but is unwieldy." Schneider, The violence of privacy, in: The public nature of private violence, 1994: 54 (noot 1).

140 Een specifieke term vergroot de zichtbaarheid van de specifieke problematiek in het reguliere betoog. Herman, Trauma en herstel, 1993: 161-162. 
de strot dichtknijpen, het uiten van ernstige bedreigingen, pogingen de vrouw te doden of haar werkelijk doden, de vrouw verkrachten of andere vormen van seksuele dwang op haar uitoefenen, persoonlijke bezittingen van de vrouw vernielen en haar daarmee intimideren, en haar huis binnendringen. In deze studie heb ik mij beperkt tot de volgende strafbare feiten: mishandeling en zware mishandeling (artt. 300-304 Sr), dwang en bedreiging (artt. $284 \& 285 \mathrm{Sr}$ ), moord en doodslag (artt. 287 \& 289 $\mathrm{Sr}){ }^{14 !}$ verkrachting en aanranding (artt. 242 \& $246 \mathrm{Sr}$ ), vernieling (art. $350 \mathrm{Sr}$ ) en huisvredebreuk (art. $138 \mathrm{Sr}$ ). ${ }^{142}$

De term vrouwenmishandeling komt in het wetboek van strafrecht niet voor. ${ }^{143}$ Vrouwenmishandeling is evenmin te herleiden tot een strafbepaling, zoals verkrachting en aanranding (artt. $242 \& 246 \mathrm{Sr}$ ), vrouwenhandel (art. 250ter Sr) en seksueel misbruik van kinderen (art. $249 \mathrm{Sr}$ ). Er is één wetsartikel binnen het wetboek van strafrecht, artikel $304 \mathrm{Sr}$, waar mishandeling van de echtgenoot, de moeder, wettige vader of kind als strafverzwarende omstandigheid wordt aangemerkt. Dit artikel wordt wel tot 'vrouwenmishandelingsdelict' bestempeld. Maar deze strafverzwarende bepaling dekt allerminst de term vrouwenmishandeling en wel om een drietal redenen. De strafverzwarende bepaling betreft alleen mishandeling en geen andere vormen van geweld, zoals bedreiging, doodslag of verkrachting. Ten tweede is dit artikel alleen op mishandeling in de huwelijkse sfeer van toepassing, zodat niethuwelijkse relaties erbuiten vallen. Tot slot is artikel $304 \mathrm{Sr}$ geen delictomschrijving maar een strafverzwarende bepaling. ${ }^{144}$

Het specifieke van vrouwenmishandeling, relationeel geweld, is niet tot een delictsomschrijving te herleiden. Vrouwenmishandeling is daardoor binnen de juridische doctrine grotendeels onzichtbaar, in tegenstelling tot bijvoorbeeld verkrachting en seksueel misbruik van kinderen.

\subsubsection{Ander onderzoek naar vrouwenmishandeling in Nederland}

In Nederland is een grootschalig survey-onderzoek gedaan naar de omvang, de aard, de gevolgen en de achtergronden van geweld tegen de vrouw in heteroseksuele relaties. ${ }^{145}$ Tevens is er door Wostmann en Zoomer onafhankelijk van elkaar

141 Onder deze categorie vallen vooral pogingen tot doodslag. Toch reken ik ook de geslaagde pogingen ertoe. Dit wordt in de literatuur 'women killing' genoemd, ter onderscheiding van 'women abuse'.

142 Andere vormen van geweld, zoals vrijheidsberoving (art. $282 \mathrm{Sr}$ ) en dwang (art. $284 \mathrm{Sr}$ ), waren oorspronkelijk wel in het onderzoek betrokken, maar bleken altijd in combinatie met mishandeling of verkrachting voor te komen. Andere vormen van geweldpleging, zoals brandstichting (art. 157 $\mathrm{Sr}$ ), heb ik buiten het onderzoek gehouden omdat deze vorm van vrouwenmishandeling zelden lijkt voor te komen.

143 Evenmin in de Van Dale, die overigens wel de term Blijf van m'n Lijf kent: 'toevlucht voor door hun partner mishandelde of getergde vrouwen'. Romkens, Wie is bang voor geweld? in: Hel klappen van de zweep, 1994: 127.

144 In hoofdstuk 3, § 3.2 wordt nader ingegaan op de achtergrond van deze strafverzwarende bepaling.

145 Romkens, Geweld tegen vrouwen in heteroseksuele relaties, 1989. 
onderzoek gedaan naar het optreden van de politie in situaties van geweld tegen de vrouw door haar (ex-)man of (ex-)vriend. ${ }^{146}$

De onderzoeken van Wöstmann en Zoomer hebben uitgewezen dat de politie regelmatig met situaties van vrouwenmishandeling wordt geconfronteerd ${ }^{147}$ Het optreden van de politie wordt vooral gekenmerkt door terughoudendheid; de agenten bemiddelen, sussen en sturen de vrouw door naar de (slachtoffer)hulpverlening of opvangcentra. Er wordt veel minder vaak strafrechtelijk opgetreden in de zin van dreigen met een proces-verbaal, de man meenemen naar het politiebureau of de vrouw adviseren aangifte te doen. ${ }^{148}$ Een belangrijk argument om niet strafrechtelijk op te treden is het ontbreken van het openbare orde aspect in geval van vrouwenmishandeling. Andere redenen om niet strafrechtelijk op te treden zijn: de grote kans dat de vrouw de aangifte weer intrekt ${ }^{149}$ als de relatie voortduurt, ${ }^{150}$ strafrechtelijk optreden leidt tot escalatie en het openbaar ministerie zal een zaak van vrouwenmishandeling seponeren. ${ }^{\text {s1 }}$ De kans op een serieuze strafrechtelijke aanpak lijkt groter als de vrouw haar relatie wil besindigen. ${ }^{152}$ Wanneer de vrouw naar het bureau komt om aangifte te doen, wordt niet in alle gevallen daadwerkelijk een aangifte opgenomen, en als de aangifte is opgenomen, worden niet alle aangiften doorgestuurd naar het openbaar ministerie. ${ }^{153}$

De trechterfunctie van het strafrecht komt duidelijk naar voren uit de resultaten van het onderzoek van Römkens naar eenzijdig geweld tegen vrouwen in heteroseksuele relaties. Van alle door Römkens onderzochte vrouwen tussen 20 en 60 jaar heeft $21 \%$ ooit eenzijdig geweld van hun man in een (ex-)relatie meegemaakt. Hiervan heeft $18 \%$ eén keer of vaker contact met de politie gehad. Hoe ernstiger het geweld is, hoe sneller de vrouw hulp zal inroepen van een formele instantie zoals de politie. Eenderde van de vrouwen die het geweld heeft gemeld bij de politie doet

146 Wostmann, Politieoptreden bij vrouwenmishandeling, 1988; Zoomer, Vrouwenmishandeling; politiewerk, 1990.

147 Rekening houdend met het inwonertal geldt eenzelfde frequentie voor Utrecht, Zwolle en Eindhoven. Wostmann, Politieoptreden bij vrouwenmishandeling, 1988: 60, 120-12I.

148 Ibidem: 49-78. Zoomer, Vrouwenmishandeling; politiewerk, 1990: 17-58.

149 Officieel kan de aangifte niet worden ingetrokken omdat vrouwenmishandeling niet tot een klachtdelict behoort.

150 Wanneer de politieagent veel aandacht aan de vrouw heeft gegeven en een proces-verbaal heeft opgemaakt, dan wordt het niet zelden als een persoonlijke nederlaag ervaren als de relatie weer goedkomt en de vrouw de aanklacht komt intrekken; de agent voelt zich er persoonlijk door gekwetst. Zoomer, Vrouwenmishandeling; politie werk, 1990: 52-53. Wostmann, Politieoptreden bij vrousenmishandeling, 1988: 71-76.

151 Ibidem: 74; Zoomer, Vrouwenmishandeling; politiewerk, 1990: 52. Onderzoek naar intrafamiliaal geweld laat ook zien dat naast het argument "ernst van het misdrijf het argument 'geen succes bij vervolging' een rol speelt bij de beslissing van de surveillant om proces-verbaal op te maken. Steinmetz, Reacties op intrafamiliaal geweld, $J V, 1986: 480$.

152 Zoomer, Vrouwenmishandeling; politiewerk, 1990: 52.

153 Ongeveer de helft van de aangiften is niet doorgestuurd naar het openbaar ministerie. Montfort, Politie en vrouwenmishandeling, 1994: 38. 
officieel aangifte, waarvan de helft de aangifte weer intrekt. Uiteindelijk bereikt $3 \%$ van alle gevallen van vrouwenmishandeling het openbaar ministerie. ${ }^{154}$

Gezien de resultaten van de onderzoeken van Römkens, Wöstmann en Zoomer bereiken veel zaken van vrouwenmishandeling nooit het openbaar ministerie, wat overigens ook voor andere misdrijven geldt. ${ }^{155}$ Toch worden aangiftes gedaan en doorgezet. Er is geen systematisch onderzoek gedaan naar de wijze waarop het openbaar ministerie en de rechterlijke macht reageren op zaken van geweld tegen de vrouw binnen een heteroseksuele (ex-)relatie. In een artikel over de justitiële reactie op vrouwelijke slachtoffers uit 1979 blijkt dat het openbaar ministerie in het ressort Den Haag in de jaren zeventig terughoudend optreedt in geval van mishandeling als slachtoffer en dader bekenden of familie zijn van elkaar. ${ }^{156}$ Binnen de categorie familie en bekenden wordt significant vaker geseponeerd als het slachtoffer een vrouw is, terwijl dit niet door een verschil in letsel kan worden verklaard, concluderen Zoomer en Steinmetz. Over het beslissingspatroon van de rechterlijke macht is een verkennend onderzoek gedaan in 1992 door Slotboom. ${ }^{157}$ De zaken die zij heeft onderzocht betreffen ernstige gevallen van mishandeling, poging tot doodslag en verkrachting. $\mathrm{Zij}$ concludeert dat als de relatie van verdachte met slachtoffer voortduurt, dit strafvermindering tot gevolg lijkt te hebben.

\subsubsection{Hypothesen en probleemstelling}

Voorgaande onderzoeksresultaten geven aanleiding tot de volgende veronderstellingen.

1. Het openbaar ministerie wordt regelmatig (wekelijks in een middelgroot arrondissementsparket) met een zaak van vrouwenmishandeling geconfronteerd. Achtergrond: Vrouwenmishandeling is een veel voorkomend verschijnsel. Weliswaar meldt de meerderheid van de mishandelde vrouwen het geweld niet aan de politie (laat staan dat zij overgaan tot het doen van een officiële aangifte), maar gezien de grote schaal waarop vrouwenmishandeling voorkomt wordt ook het openbaar ministerie regelmatig met zaken van vrouwenmishandeling geconfronteerd. Op grond van de hiervoor genoemde onderzoeken verwacht ik dat in een middelgroot arrondissementsparket, zoals Utrecht, het openbaar ministerie wekelijks met een dossier vrouwenmishandeling wordt geconfronteerd. Voor een groter parket zal dit vaker zijn, en voor een kleiner parket minder vaak.

154 Romkens, Geweld tegen vrouwen in heteroseksuele relaties, 1989: 214-215, 220-222.

155 Van Kalleveen, Geweldsmisdrijven in de statistieken, Kwartaalrechisbescherming en veiligheid CBS, 1994: 19.

156 Zoomer \& Steinmetz, Vrouwelijke slachtoffers van misdrijven, TvC, 1979: 243-256.

157 Slotboom, De 'gevonden waarheid': beelden in het strafrecht. 1992. Op grond van deze scriptie is een artikel verschenen: Ketelaars \& Slotboom, De gevonden waarheid, beelden in het strafrecht bij vrouwenmishandeling, Nemesis, 1993: 108-115. 
2. Het openbaar ministerie doet zaken van vrouwenmishandeling vaker met een sepot af dan andere zaken van geweld, zelfs vaker dan zaken van geweld tussen bekenden. Er is sprake van een bekende als er enige intimiteit is tussen de verdachte en het slachtoffer, zoals tussen familieleden, huisgenoten, vrienden en buren. ${ }^{158}$

Belangrijkste bron voor deze veronderstelling is het artikel van Zoomer \& Steinmetz over de justitiele afhandeling van mishandelingszaken. ${ }^{159}$ Bovendien komt in vele publicaties over vrouwenmishandeling naar voren dat het openbaar ministerie meestal seponeert als het een zaak van vrouwenmishandeling betreft. ${ }^{160}$ Voor dit eventuele hoge sepotcijfer kunnen twee verklaringen worden genoemd. (a) Zaken van geweld binnen heteroseksuele relaties zullen relatief vaak wegens gebrek aan bewijs worden geseponeerd. Het geweld speelt zich in de privésfeer af, waardoor de kans op een andere getuige dan het slachtoffer gering is. Bij een ontkennende verdachte zal er snel te weinig bewijs voorhanden zijn, want de getuigeverklaring van het slachtoffer alleen is niet voldoende. ${ }^{161}$ (b) Officieren van justitie zullen zaken van geweld binnen een bestaande relatie over het algemeen seponeren omdat zij terughoudend zijn als het om de privésfeer gaat (beperkte kring). ${ }^{162}$ Over het algemeen heerst bij buitenstaanders, zoals hulpverleners en politiemensen, de opvatting dat de vrouw weg moet gaan bij haar man om het geweld tegen haar te stoppen. ${ }^{163} \mathrm{Ik}$ verwacht dat ook officieren van justitie deze opvatting hebben. Daarom veronderstel ik dat het openbaar ministerie vaker zal vervolgen als het geweld wordt gepleegd door de ex-partner; als de relatie is verbroken, heeft de vrouw duidelijk laten blijken dat ze zijn geweld niet accepteert. Ook het argument dat vervolging tot escalatie zal leiden, kan de officier van justitie ertoe brengen om een geweldszaak binnen een bestaande relatie die voortduurt te seponeren.

Deze hypothesen zijn door het verrichten van een empirisch verkennend onderzoek getoetst.

158 Zelden zijn slachtoffer en verdachte geheel ontekenden voor elkaar. Vaak kennen ze elkaar van gezicht omdat ze in dezelfde buurt of plaats wonen, of in hetzelfde bedrijf werken of in dezelfde kroeg komen. Er kan ook sprake zijn van een diensverleningsrelatie, zoals met het maatschappelijk werk of de sociale dienst.

159 Zoomer \& Steinmetz, Vrouwelijke slachtoffers van misdrijven, $T v C$, 1979: 243-256.

160 Zie hoofdstuk 2, $\$ 2.4$.

161 Rook, Openingsrede, in: Met het oog op de dader, 1990: 3; Brughuis, Vrouwenmishandeling in justitieel perspectief, in: Met het oog op de dader, 1990: 23, 26; Van der Steen \& Geurts, Politie en justitiebeleid in cijfers, in: Thuis geslagen, mevrouw, 1984: 54.

162 Rook, Openingsrede, in: Met het oog op de dader, 1990: 3.

163 Romkens, Het onbehagen over geweld tegen vrouwen, in: Agressie, 1991: 211-227. Zie hoofdstuk $2, \S 2.2 .3$ onder Fysiek geweld tegen vrouwen als uiting van macht. 
De probleemstelling van deze studie naar de strafrechtelijke regulering van mannelijk geweld tegen vrouwen in de privésfeer is als volgt geformuleerd:

Wat zijn de mogelijkheden van strafrechtelijke interventie, hoe worden deze' mogelijkheden gebruikt door het openbaar ministerie en is een andere wijze van strafrechtelijke interventie gewenst om het slachtoffer van vrouwenmishandeling rechtsbescherming te kunnen bieden?

In de analyse van de interventiemogelijkheden hanteer ik vier, met elkaar samenhangende, uitgangspunten, die ik in $\$ 1.3$ uiteen heb gezet: 1 . het specifieke karakter van het strafrecht als publiek- en sanctierecht mag niet worden aangetast; 2 . het gaat om rechtsbescherming van de burger, van verdachte en slachtoffer; 3 . het doel van strafrechtelijk optreden is gelegen in herstel van de rechtsvrede en 4. alleen door een humane aanpak kan respect voor het rechtssubject zich verwezenlijken.

Naast een juridische beschouwing van de strafbepalingen die relevant zijn in het kader van deze studie en van de moglijkheden van het openbaar ministerie om zaken van vrouwenmishandeling af te handelen, heb ik een verkennend onderzoek verricht naar de wijze waarop het openbaar ministerie zaken van vrouwenmishandeling afdoet, omdat nauwelijks informatie hierover aanwezig is. Het doel van het verkennende onderzoek is het verkrijgen van meer helderheid over het beslissingspatroon van het openbaar ministerie. Is het inderdaad zo dat het openbaar ministerie meestal zaken van vrouwenmishandeling seponeert? En waarom wordt er dan geseponeerd? Wegens gebrek aan bewijs, een terughoudende houding van officieren van justitie als het geweld in een bestaande relatie betreft, of zijn andere aspecten van invloed? Ik stel de volgende vragen:

a. Hoeveel geweldszaken bereiken de door mij onderzochte arrondissementsparketten in 1975 en het eerste kwartaal van 1985, hoeveel daarvan betreffen zaken van vrouwenmishandeling, en verschilt de sepotpraktijk tussen zaken van vrouwenmishandeling, zaken van geweld tegen bekenden en overige geweldszaken?

b. Wat voor soort zaken van vrouwenmishandeling bereikt het openbaar ministerie?

c. Hoe treedt het openbaar ministerie op in zaken van vrouwenmishandeling?

d. Welke invloed hebben bepaalde aspecten op de vervolgingsbeslissing omtrent zaken van vrouwenmishandeling?

Vervolgens is het gevonden materiaal gebruikt voor een juridische beschouwing over de wijze waarop het openbaar ministerie de rechtsbescherming van het slachtoffer zou kunnen concretiseren in het strafproces:

e. Kunnen andere opvattingen dan de dominante opvattingen over mannelijk geweld tegen vrouwen in de privésfeer doorklinken in het juridisch vertoog over de vaststelling en interpretatie van de feiten ?

f. Bieden de huidige strafrechtelijke voorzieningen, beschouwd vanuit een relationele opvatting, voldoende rechtsbescherming voor vrouwen die slachtoffer zijn van geweld door hun (ex-)partner? 
g. Hoe kan in het optreden van officieren van justitie een humane strafrechtspleging worden geconcretiseerd als het gaat om mannelijk geweld tegen vrouwen in de privésfeer?

\subsection{Onderzoeksmethode van het exploratieve onderzoek}

Het exploratieve onderzoek bestaat uit een kwantitatief dossieronderzoek naar de vervolgingspraktijk van het openbaar ministerie betreffende geweldsdelicten, uitgesplitst naar zaken van vrouwenmishandeling, zaken van geweld tegen bekenden en overige geweldsdelicten. Daarnaast zijn 150 dossiers van vrouwenmishandeling nader geanalyseerd: wat voor soort zaken van vrouwenmishandeling bereiken het openbaar ministerie en hoe beïnvloedt een bepaald aspect de vervolgingsbeslissing van officieren van justitie. ${ }^{164}$ Dit is het kwalitatieve dossieronderzoek, waarvan de gegevens vervolgens zijn gekwantificeerd om ze statistisch te kunnen verwerken. Tot slot zijn zes officieren van justitie geinterviewd. Deze drie vormen van onderzoek worden hieronder nader beschreven.

\subsubsection{Werkwijze kwantitatief en kwalitatief dossieronderzoek}

Het dossieronderzoek is verricht op de arrondissementsparketten Assen, Breda en Rotterdam. Gekozen is voor een gespreide ligging in het land - randstad, perifeer en op de grens met de randstad gelegen - en een spreiding in de grootte van het parket - klein, middel-groot en groot. Op die manier is de grootst mogelijke variatie in de arrondissementsparketten aangebracht.

Voor het kwalitatieve dossieronderzoek zijn per parket 50 dossiers van vrouwenmishandeling geanalyseerd. Deze vrouwenmishandelingszaken moesten van een zo recent mogelijke datum zijn en afgehandeld zijn door het openbaar ministerie of door de rechter bij de aanvang van het dossieronderzoek (1-1-1988). Op grond hiervan heb ik besloten om de eerste 50 dossiers te onderzoeken die vanaf 1 januari

164 Sinds de jaren zeventig zijn aan de parketsecretarissen steeds meer werkzaamheden gedelegeerd. Eerst al leen voor de overtredingen, daarna ook voor de eenvoudige misdrijven als diefstal, vernieling en mishandeling. Taken die worden gedelegeerd zijn: het maken van concept-tenlasteleggingen, sepotvoorstellen, en uittreksels van omvangrijke dossiers. Op het ene parket is in 1985 de delegatie verder doorgevoerd dan in het andere parket. Op het ene parket moeten bijvoorbeeld alle voorstellen tot een sepot worden voorgelegd aan de officier van justitie - de gedagvaarde zaken komen vanzelfsprekend bij de officier van justitie terecht -, terwijl op een ander parket de parketsecretaris alleen bij twijfel de officier van justitie moet raadplegen. Zie ook Van de Bunt, Officieren van Justitie, 1985: 142-146, 229. 
1985 op het parket staan geregistreerd. ${ }^{165}$ De periode om 50 gevallen van vrouwenmishandeling te vinden verschilt per parket, doordat het aantal misdrijven dat op een parket wordt geregistreerd per arrondissement verschilt. Het kwantitatieve dossieronderzoek beslaat de periode 1975 en het eerste kwartaal van 1985. Het eerste kwartaal van 1985 hangt samen met de periode voor het kwalitatieve dossieronderzoek; in Rotterdam waren binnen een kwartaal ruim 50 dossiers van vrouwenmishandeling geregistreerd. Het jaar 1975 is gekozen met in het achterhoofd de vraag of het zichtbaar worden van vrouwenmishandeling als maatschappelijk probleem van invloed is geweest op de vervolgingspraktijk van het openbaar ministerie; is er in het eerste kwartaal van 1985 een andere vervolgingspraktijk te constateren dan in 1975. Dat in 1975 een heel jaar is gekozen, heeft met de hoeveelheid geweldszaken te maken: in 1975 werden aanmerkelijk minder geweldszaken geregistreerd.

Voor ik in zal gaan op de selectieprocedure, nog een omschrijving van de voor dit onderzoek belangrijke begrippen.

Vrouwenmishandeling is omschreven als: (dreigen met) fysiek geweld tegen een vrouw door haar mannelijke partner of ex-partner. Van vrouwenmishandeling is sprake als in het dossier sprake is van:

- een vrouwelijk slachtoffer en een mannelijke dader;

- een relatie (of ex-relatie), dat wil zeggen dat de relatie als duurzaam moet worden ervaren en dat er sprake moet zijn van enige intimiteit. Dit zijn geen harde, objectieve criteria. ${ }^{166}$ Wanneer uit het dossier blijkt dat betrokkenen spreken over 'hun partner', dan is dat een voldoende voorwaarde om een relatie aan te nemen;

- een of andere vorm van (dreigen met) fysiek geweld. Dit geweld moet onder een van de volgende delictsomschrijvingen vallen: mishandeling (300-304 Sr), doodslag en moord (287-289 Sr), vernieling en beschadiging ( 350 \& $352 \mathrm{Sr}$ ), dwang en bedreiging ( $284 \& 285 \mathrm{Sr}$ ), huisvredebreuk (138 Sr), wederrechtelijke vrijheidsberoving ( $282 \mathrm{Sr}$ ), en verkrachting en aanranding ( $242 \& 246 \mathrm{Sr}$ ).

Bovendien moeten alle vormen van fysiek geweld en dreiging daarmee gericht zijn op de vrouw. Van belang is dat het (dreigen met) fysiek geweld nauw samenhangt met de relatie tussen het slachtoffer en de dader. Dreiging met fysiek geweld kan bijvoorbeeld blijken uit het vernielen van meubilair. Puur het vernielen van meubilair valt niet onder vrouwenmishandeling; er moet een

165 Aangezien geen sprake is van een steekproef, is de representativiteit niet gegarandeerd. Ter informatie: De eerste 50 zaken van vrouwenmishandeling betrof in Assen ongeveer de periode 1985 en het eerste kwartaal van 1986, in Breda het eerste halfjaar van 1985 en in Rotterdam het cerste kwartaal.

166 Rumkens, Vrouwenmishandeling: het miskende geweld in de familie Doorsnee, in: Geweld tegen vrouwen: (g)een zaak voor politie en justitie?, 1985: 15. 
samenhang zijn met de relatie. Voorwaarde hierbij is dat de vrouw slachtoffer is van de vernieling door haar (ex-)partner.

De beslissing of sprake is van vrouwenmishandeling is niet altijd eenvoudig. Wanneer onduidelijk is of beide partners de relatie als duurzaam, of niet vrijblijvend, ervaren of hebben ervaren, dan heb ik de zaak niet als een zaak van vrouwenmishandeling beschouwd. Een ander punt betreft de dreiging die gericht moet zijn op de vrouw. Als de ex-partner bijvoorbeeld de nieuwe vriend van de vrouw mishandelt, dan wordt de zaak niet als een vrouwenmishandelingszaak beschouwd, omdat de mishandeling niet direct de vrouw betreft, ook al kunnen dit soort situaties eveneens bedreigend zijn voor de vrouw (zie Bijlage 1).

De wijze van afhandelen door het openbaar ministerie is als volgt onderscheiden:

- Seponeren. Dit wordt onderverdeeld in een technisch sepot, een beleidssepot, een sepot onder voorwaarden en een sepot met een schriftelijke of mondelinge waarschuwing.

- Transigeren. Dit wordt onderverdeeld in het betalen van een geldsom, een transactie waaraan het betalen van een schadevergoeding aan het slachtoffer is verbonden of een transactie waaraan andere voorwaarden zijn verbonden. Een transactie is een schikking uitgaande van het openbaar ministerie en om die reden reken ik de transactie tot het sepotbeleid. ${ }^{167}$

- Vervolgen. Wanneer de zaak wordt vervolgd, vindt de beoordeling door de rechter plaats. Ook zaken die bij een andere zaak zijn gevoegd, worden vervolgd.

De aspecten die van invloed kunnen zijn op de beslissing van de officier van justitie heb ik op basis van de in de dossiers aangetroffen informatie als volgt omschreven:

- De bewijsmiddelen.

- Soort relatie. Dat er sprake is van een relatie is bij de selectie van vrouwenmishandelingszaken gebleken. De soort relatie kan ook van invloed zijn op de beslissing van de officier van justitie. Wanneer sprake is van een huwelijk, dan is vrouwenmishandeling via vernieling en beschadiging strafrechtelijk gezien niet mogelijk (350 en 352 juncto 316 lid $1 \mathrm{Sr}$ ), terwijl mishandeling door de echtgenoot daarentegen als strafverzwarend element geldt (304 Sr onder ten eerste).

- Het letsel van het slachtoffer. Het letsel is door mij ingedeeld in drie soorten: lichte mishandeling bestaande uit blauwe plekken, schrammen of een blauw oog; ernstige mishandeling bestaande uit kneuzingen, breuken, zwellingen, kraseffecten door een mes, lichte hersenschudding of striemen (de genezing duurt minder dan drie weken) en zware mishandeling, die bestaat uit gebroken

167 Sinds 1985 worden door het CBS het sepot en de transactie tot de afdoening door het OM gerekend. Daarvoor werd ook de voeging ertoe gerekend. Jaarverslag $O M$, 1985, TK 1986-1987, 19.700, hfst. VI, nr. 3: 93. 
ledematen, wonden, zware hersenschudding of een kapot gebit (de genezing duurt dan langer dan drie weken). ${ }^{168}$

- Geweldgebruik van de verdachte. Onderscheid is gemaakt in het soort geweld dat de verdachte gebruikt; lichamelijk geweld, gebruik van voorwerpen of anderszins.

- Verweer van het slachtoffer. Onderscheid is gemaakt tussen fysiek verweer of door het gebruik van voorwerpen.

- Geestestoestand van verdachte en slachtoffer. Bekeken is of de verdachte en/of het slachtoffer onder invloed waren van alcohol of drugs. Wanneer een medisch rapport of een proces-verbaal melding maakt van alcohol/drugsgebruik, wordt alcohol of drugs aangenomen. ${ }^{169}$ Uit een psychiatrisch rapport kan de (on)toerekeningsvatbaarheid blijken. ${ }^{170}$

- De geschiedenis van het delict. Onderzocht is of in het dossier informatie zit waaruit de voorgeschiedenis blijkt. Ik heb gekozen voor een driedeling: eenmalig, meermalen en structureel plegen van geweld. Onder eenmalige vrouwenmishandeling wordt dan de vrouwenmishandeling als incident verstaan, onder structurele vrouwenmishandeling de regelmatig terugkerende vrouwenmishandeling over een periode van minimaal drie maanden tot jarenlang en onder meermalen gepleegde vrouwenmishandeling vallen die gevallen waarin een vrouw meermalen is mishandeld binnen een periode van drie maanden.

Hierbij wil ik de kanttekening plaatsen dat de informatie in het proces-verbaal afhankelijk is van de hoeveelheid tijd die een politiefunctionaris in de zaak steekt, de vragen die worden gesteld aan het slachtoffer en de wijze waarop het proces-verbaal wordt opgesteld. Een belangrijke taak van de politie is het rond krijgen van het bewijs van het 'incident' waarvan aangifte is gedaan. Wat in het verleden verder nog heeft plaatsgevonden, lijkt minder relevant voor de bewijsbaarheid van het 'incident'. Structureel (dreigen met) fysiek geweld kan bijvoorbeeld blijken uit bijgevoegde mutaties die de politie heeft gemaakt van alle keren dat vrouwenmishandeling bij de politie werd gemeld. Door de gerichtheid op het rond krijgen van het 'incident' is het niet vanzelfsprekend dat mutaties erbij worden gevoegd.

- Registratie. De personalia van de verdachte en het slachtoffer, het strafrechtelijk verleden van de verdachte en of het slachtoffer zich heeft gevoegd als benadeelde partij, zijn geregistreerd.

168 Deze indeling komt niet overeen met de wettelijke indeling zwaar lichamelijk letsel of letsel en pijn. Zie hierover NLR, aantt. 1 \& 2 op art. 82 Sr: 622-624. Deze emstindeling van letsel wordt eveneens door Rðmkens gebruikt. Romkens, Gewoon geweld? 1992: 121.

169 Onder invloed zijn kan varieren van licht aangeschoten tot stomdronken.

170 De officier van justitie kan een psychiatrisch rapport over de verdachte aanvragen, via een vordering bij de rechter-commissaris. De officier van justitie kan geen psychiatrisch rapport over het slachtoffer aanvragen. Het slachtoffer kan wel vrijwillig meewerken aan een psychiatrische rapportage. 
Over de registratie van het strafrechtelijke verleden nog het volgende: Het strafrechtelijk verleden (recidive) is een aspect dat van invloed kan zijn op de beslissing van de officier van justitie. De categorie 'strafrechtelijk verleden' bevat mensen met een strafrechtelijk verleden van vervolgde misdrijven. De categorie 'geen strafrechtelijk verleden' bevat mensen die geen strafrechtelijk verleden en mensen die wel een strafrechtelijk verleden hebben uitsluitend op het gebied van overtredingen en geseponeerde zaken. ${ }^{171}$

Wanneer tot vervolging is besloten, is van belang hoe de officier van justitie het geweld kwalificeert, welke telastlegging wordt gekozen. De uitspraak van de rechter is bovendien interessant omdat dit aangeeft welke eis in dit soort zaken juridisch haalbaar is. ${ }^{172}$ Vandaar dat de telastlegging en uitspraak van de rechter volledigheidshalve zijn genoteerd.

- De formulering van de telastlegging. Wanneer de officier van justitie heeft besloten om tot vervolging over te gaan, is het noodzakelijk om een telastlegging te formuleren. De telastlegging bepaalt onder welke delictsomschrijving het feit valt. Elke delictsomschrijving heeft eigen beperkingen en mogelijkheden met betrekking tot bewijs, schulduitsluitingsgronden en rechtvaardigingsgronden. Met het formuleren van de telastlegging kiest de officier van justitie voor een bepaalde delictsomschrijving, waarmee de mogelijkheden voor het oordeel van de rechter zijn vastgelegd.

- De uitspraak van de rechter. Genoteerd is of de officier van justitie de verdachte voor de politierechter of meervoudige kamer heeft gedagvaard en wat de uitspraak van de rechter is.

De selectie van de geweldsdelicten en vervolgens van de zaken van vrouwenmishandeling ging als volgt:

In 1985 werd elk, naar het openbaar ministerie doorgestuurd, proces-verbaal geregistreerd in het parketregister onder een parketnumer. Dit parketregister vormde de basis voor de eerste selectie van dossiers; van alle geweldsdelicten gepleegd door een volwassen man noteerde ik het parketnummer, het wetsartikel en of het openbaar ministerie of de rechtbank de zaak had afgehandeld.

Deze geselecteerde parketnummers noteerde ik op speciale lijsten naar soort delict. Voor elke delictsoort heb ik een aparte lijst aangelegd zodat duidelijk is onder welke delictsoort vrouwenmishandeling binnenkomt. De delictsoorten zijn: (1) moord

171 Ook in het onderzoek van Zoomer worden de geseponeerde zaken niet meegerekend tot het strafrechtelijk verleden. Zoomer, De strafvordering en strafioemeting in gevallen van zware criminaliteit, 1981: 34.

172 Van de Bunt, Officieren van Justitie, 1985: 214-223. 
en doodslag, (2) mishandeling, ${ }^{173}$ (3) verkrachting en aanranding, (4) bedreiging, dwang, huisvredebreuk en vrijheidsberoving, en (5) vemieling en beschadiging. De gegevens die op de lijsten staan vermeld, zijn: het parketnummer, de datum van inschrijving in het parketregister, het wetsartikel, wie de zaak heeft afgehandeld (openbaar ministerie of rechtbank) en wanneer het is afgehandeld, sekse van verdachte en slachtoffer en of het een zaak van vrouwenmishandeling betreft. Het wetsartikel is het delict waarop de politie het geval heeft gekwalificeerd. De officier van justitie kan, als besloten wordt om tot vervolging over te gaan, een ander (vaak minder emstig) delict ten laste leggen. Ook kan de officier van justitie subsidiair een minder ernstig misdrijf ten laste leggen. Hierdoor kan een verschil ontstaan tussen het delict waarop de zaak op het parket binnenkomt en het delict waarop de verdachte wordt veroordeeld of vrijgesproken. Op de lijsten staan alleen de wetsartikelen waarop de zaak in het parketregister wordt ingeschreven. ${ }^{174}$

De tweede fase van de selectieprocedure gaat in als de dossiers uit het archief zijn gehaald, zodat de dossiers kunnen worden bekeken. Het vinden van de dossiers die in 1985 in het parketregister van het arrondissement zijn ingeschreven leverde geen moeilijkheden op. De dossiers zijn of in het archief van het openbaar ministerie of in het rechtbankarchief op parketnummer opgeborgen. De in 1975 ingeschreven dossiers waren moeilijker te vinden. In Rotterdam waren enerzijds de dossiers van de vervolgde zaken niet op parketnummer maar op jaar van rolnummer (1975 en 1976) en op bewaringstermijnen (vier) opgeborgen en anderzijds waren deze dossiers ergens in een kelder, niet zorgvuldig, weggezet. Door de ingewikkelde manier van archiveren en het niet zorgvuldig opbergen van de dozen met dossiers heeft het zoeken naar de dossiers van 1975 veel tijd gekost. ${ }^{175}$ In Breda waren de geseponeerde zaken uit 1975 al in de papiervernietiger verdwenen. De dossiers van geseponeerde zaken uit het eerstvolgende jaar dat wel beschikbaar was, was 1976 . Vandaar dat de dossiers uit 1976 zijn onderzocht.

Niet alle dossiers waren in de archieven te vinden. Tot de 'onvindbare dossiers' reken ik de niet aanwezige dossiers omdat ze bijvoorbeeld zijn uitgeleend, en de dossiers die zo onvolledig zijn dat uit de gegevens niet kan worden afgeleid of

173 Oorspronkelijk was categorie 2 onderverdeeld in eenvoudige en zware mishandeling, maar het parketregister vermeldt dit onderscheid meestal niet, waardoor maar én categorie mishandeling mogelijk is.

174 Soms staan verschillende wetsartikelen vermeld. Als het relevante en niet-relevante artikelen betreft, is er geen probleem als de relevante wetsartikelen én delictsoort betreffen. Betreft het meer delictsoorten dan neem ik die categorie waar de meeste wetsartikelen toe behoren en als het evenveel wetsartikelen per categorie zijn, dan neem ik het eerstgenoemde wetsartikel als uitgangspunt. Dus bij ' $350 \mathrm{Sr}, 300 \mathrm{Sr}, 310 \mathrm{Sr}$ ' zet ik het bij vernieling en bij ' $350 \mathrm{Sr}, 300 \mathrm{Sr}, 302 \mathrm{Sr}$ ' zet ik het bij mishandeling.

175 De medewerkers van het archief zijn mij hierbij zeer behulpzaam geweest. Zonder hun hulp was het dossieronderzoek niet mogelijk geweest. 
sprake is van vrouwenmishandeling. ${ }^{176}$ Het percentage niet gevonden vervolgde zaken is groter dan het percentage niet gevonden geseponeerde zaken. ${ }^{177}$ Dit betekent dat er rekening moet worden gehouden met een lichte vertekening: in werkelijkheid wordt er iets vaker gedagvaard.

De dossiers zijn vervolgens bekeken op sekse van de verdachte en het slachtoffer dat uit de informatiestaat ${ }^{178}$ van de verdachte en de processen-verbaal blijkt. Uit de processen-verbaal blijkt eveneens of het een geval van vrouwenmishandeling betreft (voor een nadere uiteenzetting van de selectieprocedure: Bijlage 2).

Tot slot nog een opmerking over het verschil tussen het kwantitatieve dossieronderzoek en het kwalitatieve dossieronderzoek.

Het kwantitatieve dossieronderzoek heeft tot doel inzicht te krijgen in de frequentie waarmee geweldszaken op de door mij onderzochte arrondissementsparketten zijn binnengekomen in 1975 en het eerste kwartaal van 1985. Basis voor het kwantitatieve dossieronderzoek vormen de eerder genoemde lijsten. Per delictscategorie kan op vrij eenvoudige wijze aan de hand van de lijsten worden vastgesteld hoeveel het aantal gevonden dossiers, verdeeld naar geseponeerde en vervolgde zaken, afwijkt van het aantal geselecteerde parketnummers. Ook kan vrij eenvoudig een tabel worden gemaakt waarbij de wijze van afhandelen in geval van vrouwenmishandeling wordt vergeleken met de afhandeling van niet-vrouwenmishandelingszaken, uitgesplitst naar geweld tegen bekenden en overig geweld.

Het doel van het kwalitatieve dossieronderzoek is het verkrijgen van informatie over de wijze van afhandelen door officieren van justitie van zaken van vrouwenmishandeling. De eerste 50 gevallen van vrouwenmishandeling vanaf januari 1985 die op het arrondissementsparket zijn geregistreerd heb ik in kaart gebracht op speciaal daarvoor ontworpen formulieren (zie Bijlage 3). De hoeveelheid in formatie verschilt per dossier en is mede afhankelijk van de ernst van de zaak. In het dossier zit altijd een informatiestaat van de verdachte en een (kort) proces-verbaal. Soms is een reclasseringsrapport of psychiatrisch rapport aangevraagd, of zijn verschillende processen-verbaal van getuigen opgemaakt. Vaak is in geval van mishandeling, (poging tot) doodslag, verkrachting of aanranding een (summier) medisch rapport in het dossier aanwezig. Af en toe zijn foto's van het letsel of van een gereconstrueerde situatie aanwezig. Als de man in voorlopige hechtenis is genomen, is de

176 Dit laatste kwam overigens niet vaak voor.

177 In 1975 is $6 \%$ van de geseponeerde zaken en $11 \%$ van de vervolgde zaken niet gevonden en in het eerste kwartaal van 1985 is $4 \%$ van de geseponeerde en $11 \%$ van de vervolgde zaken niet gevonden. Het hoge percentage vervolgde zaken kan te maken hebben met het feit dat een extra justitiele gang wordt doorlopen met een extra kans op kwijtraken, en tevens zijn de zaken die in hoger beroep zijn gegaan moeilijker terug te vinden omdat het dossier naar het hof is doorgestuurd.

178 De informatiestaat is een A4-velletje waarop de personalia van de verdachte staan, zoals naam, adres, geboortedatum en -plaats, nationaliteit, sekse, beroep en inkomen. 
officier van justitie direct betrokken bij de zaak en er wordt meestal een reclasseringsrapport of psychiatrisch rapport aangevraagd. Deze dossiers bevatten over het algemeen meer informatie dan wanneer sprake is van een zogenaamde 'loopzaak'. ${ }^{179}$

Tijdens de analyse van de 150 dossiers heb ik de indeling in vijf delictscategorieèn vervangen door een indeling in vier delictscategorieën, omdat deze vierdeling beter aansluit bij de feitelijke gebeurtenissen in geval van vrouwenmishandeling. Hoewel het uit juridisch oogpunt beter is om delicten die niet onder eenzelfde titel van het wetboek van strafrecht staan, niet bij elkaar in eenzelfde categorie te plaatsen omdat hun 'juridische verhaalsstructuur' verschilt, is het vanuit een sociologische benadering beter die delicten bij elkaar te groeperen die feitelijk nauw met elkaar samenhangen. In de praktijk gaat huisvredebreuk vaak gepaard met vernieling, terwijl bedreiging regelmatig gepaard gaat met mishandeling. Daarnaast komt het regelmatig voor dat de officier van justitie primair mishandeling ten laste legt en subsidiair bedreiging. De delicten vrijheidsberoving en dwang bleken als afzonderlijke delicten niet voor te komen, zodat de (rest)categorie kwam te vervallen. Deze vierdeling sluit overigens ook beter aan bij de ervaringswereld van betrokkenen. ${ }^{180} \mathrm{Ik}$ hanteer de volgende delictscategorieün:

1. vernieling $(350 \mathrm{Sr})$ en huisvredebreuk (138 Sr)

2. mishandeling (300-304 Sr) en bedreiging ( $285 \mathrm{Sr}$ )

3. moord ( $289 \mathrm{Sr})$ en doodslag $(285 \mathrm{Sr})$

4. verkrachting ( $242 \mathrm{Sr})$ en aanranding $(246 \mathrm{Sr})$.

\subsubsection{Werkwijze interviews}

Het doel van de interviews is meer informatie te verkrijgen over de aspecten die een rol spelen als een officier van justitie beslist in een zaak van vrouwenmishandeling en de afweging die officieren van justitie maken om tot een beslissing te komen. De interviews zijn een aanvulling op het dossieronderzoek. Het kwalitatieve dossieronderzoek kan weliswaar globaal inzicht geven in de aspecten die een rol spelen in de vervolgingsbeslissing van het openbaar ministerie, maar kan geen inzicht geven in het afwegingsproces van een officier van justitie. Om meer informatie te krijgen over het afwegingsproces zijn zes officieren van justitie geinterviewd.

In het najaar van 1990 zijn zes interviews afgenomen met officieren van justitie, verspreid over vier arrondissementen: Rotterdam (twee officieren van justitie), Assen

179 Deze loopzaken komen bij de parketadministratie binnen en de officier van justitie krijgt zo'n zaak pas maanden later onder ogen.

180 Hierbij moet wel worden bedacht dat de ervaringswereld al flink is teruggebracht in de processenverbaal tot een juridisch relevante werkelijkheid. 
(twee officieren van justitie), Breda (een officier van justitie) en Zwolle (een officier van justitie). ${ }^{181} \mathrm{Er}$ zijn vier mannen en twee vrouwen geïnterviewd.

De interviews zijn gehouden aan de hand van een open vragenlijst (zie Bijlage 4: Interviewvragen). Een deel van het interview betreft vragen over een casus (een zaak van mishandeling, vernieling en verkrachting), waarbij verschillende aspecten van de oorspronkelijke casus worden gevarieerd. Op die manier is een beeld te krijgen over de invloed van verschillende aspecten op de beslissing van de officier van justitie om te vervolgen of niet en op de strafeis. Voor deze vorm is gekozen in de veronderstelling dat aan de hand van een casus de afweging die een officier van justitie maakt, concreet naar voren komt. Een nadeel is dat in werkelijkheid het dossier meer informatie bevat en de afweging in werkelijkheid anders kan uitvallen, bijvoorbeeld omdat een officier van justitie door tijdsdruk niet alle aspecten even zorgvuldig afweegt, terwijl dit wel gebeurt in een interviewsituatie.

De interviews duurden gemiddeld twee uur en zijn uitgewerkt aan de hand van een bandopname. De uitgewerkte verslagen zijn door de betreffende officieren van justitie geautoriseerd. De goedgekeurde verslagen vormden het onderzoeksmateriaal. ${ }^{182}$ De aangehaalde citaten komen uit deze interviewverslagen. De namen van de officieren van justitie zijn geanonimiseerd door een letter uit het alfabet; de namen van de slachtoffers en verdachten door hen een andere naam te geven.

\subsection{De opbouw van dit boek}

De problematiek van geweld tegen vrouwen in de privésfeer en de discussie binnen de vrouwenbeweging over problematische kanten van de inzet van het strafrecht als het mannelijk geweld tegen vrouwen in de privésfeer betreft, staat centraal in hoofdstuk 2. Bovendien wordt weergegeven hoe in de jaren tachtig de strafrechtelijke aanpak van geweld tegen vrouwen in de privésfeer wordt bekritiseerd en hoe de bejegening van het slachtoffer door politie en openbaar ministerie, evenals de mogelijkheden tot vergoeding van de schade binnen het strafproces, mede naar aanleiding van deze kritiek, zijn verbeterd.

Vervolgens worden de juridische mogelijkheden die het strafrecht biedt, beschreven in de hoofdstukken 3 en 4 . In hoofdstuk 3 wordt ingegaan op de juridische interpretatie van de verschillende geweldsmisdrijven; wat zijn de juridische

181 Ik heb een brief aan de hoofdofficier van justitie geschreven met de vraag of ik een aantal officieren mocht interviewen over vrouwenmishandeling en seksueel geweld. Hierop kreeg ik bericht terug wie ik mocht interviewen. In Breda was er maar én officier van justitie beschikbaar, in Assen en Rotterdam twee. Zwolle kreeg een aparte brief, omdat ik met name geìnteresseerd was in de interne richtlijn vrouwenmishandeling. Alle officieren van justitie waren enigszins deskundig op het gebied van seksueel geweld, of omdat ze coßrdinator seksueel geweld zijn geweest, of omdat ze jeugden kinderzaken, waaronder veel incestzaken, tot hun takengebied hadden of hebben.

182 Overigens heeft geen van de officieren van justitie de uitgewerkte tekst gewijzigd. 
vereisten om het geweld van de man als strafbaar feit te kunnen kwalificeren. Deze kwalificatie van de situatie heeft weer invloed op de mogelijkheden die het openbaar ministerie heeft en de straf die uiteindelijk opgelegd kan worden. De mogelijkheden van de officier van justitie in het strafprocesrecht om op te kunnen treden tegen geweld in de privésfeer worden behandeld in hoofdstuk 4 .

$\mathrm{Na}$ deze twee juridisch beschrijvende hoofdstukken, worden de resultaten van het verkennende onderzoek naar het optreden van het openbaar ministerie geanalyseerd in hoofdstuk 5. De nadruk ligt op de beslissing of tot vervolging zal worden overgegaan of niet. Zowel de feitelijke sepotpraktijk, als de invloed van een aantal aspecten op deze beslissing en het afwegingsproces van officieren van justitie wordt geanalyseerd.

De juridische vraagstukken die samenhangen met de mogelijkheden om slachtoffers van vrouwenmishandeling rechtsbescherming te bieden, worden in hoofdstuk 6 behandeld. Zowel rechtsbescherming door feiteninterpretatie, als mogelijkheden van rechtsbescherming door rechtspositionele versterking, als rechtsbescherming door een aanpak gericht op rechtsvrede, komen aan bod.

In hoofdstuk 7 wordt een antwoord gegeven op de probleemstelling en kom ik tot een slotbeschouwing. 



\title{
2 Geweld tegen vrouwen en het strafrecht
}

\begin{abstract}
"What I wish to argue is that feminists who argue for decriminalization of certain offences are not necessarily confused when they also call for increased legal intervention for certain crimes against women and children. This state of affairs is not a contradiction, since there is no consistent, fixed relationship between the state, its law and social interests. As Tayler rightly points out: 'Nowhere is the contradictory character of law' as an oppressive instrument of a particular social interest as well as an immediately important area of struggle, more apparent than in the relationship of law to women."'1
\end{abstract}

\subsection{Inleiding}

De achtergrond van mannelijk geweld tegen vrouwen in de privésfeer en de discussie over de inzet van het strafrecht als het gaat om geweld tegen vrouwen, wordt in dit hoofdstuk voor het voetlicht gehaald.

Allereerst wordt de aard en omvang van fysiek geweld tegen vrouwen binnen heteroseksuele relaties geschetst in $\$ 2.2$.1, aan de hand van Nederlands onderzoek. Tevens wordt vrouwenmishandeling als een maatschappelijk en sekse-specifiek fenomeen geanalyseerd $(\S 2.2 .2$ ), waarbij wordt ingegaan op de machtsdynamiek tussen de partners $(\$ 2.2 .3)$ en de redenen om wel of niet weg te gaan bij de man die geweld pleegt ( $\$ 2.2 .4$ ).

Vervolgens wordt de inzet van het strafrecht, als het gaat om mannelijk geweld tegen vrouwen in de relationele sfeer, onder de loep genomen in $\$ 2.3$. Eind jaren zeventig en begin jaren tachtig vindt een debat plaats binnen de vrouwenbeweging tussen feministen die kritisch staan tegenover de inzet van het strafrecht en feministen die wel het belang van strafrechtelijke normering en bestraffing bepleiten. Aan de hand van dit debat schets ik de problematische relatie tussen claims van (groepen die opkomen voor de belangen van) slachtoffers van vrouwenmishandeling en het strafrechtelijke systeem. Daarna wordt de kritiek vanuit de vrouwenbeweging op de wijze waarop politie en justitie optreden tegen vrouwenmishandeling weergegeven in $\S 2.4$. Mede onder invloed van deze kritiek heeft een ombuiging van strafrechtelijk beleid ten aanzien van slachtoffers plaatsgevonden. Dit is het onderwerp van $\S 2.5$. Het hoofdstuk wordt besloten met een conclusie.

1 Edwards, Violence against women, in: Feminist perspectives in criminology, 1990: 146. 


\subsection{Geweld tegen vrouwen in de privésfeer}

"Op allerlei manieren oefenen mannen geweld uit tegen hun vrouw of vriendin. Om wat voorbeelden te geven: aan de haren door de kamer sleuren; op het hoofd slaan, al dan niet met een voorwerp; in rug, ledenen of buik slaan of schoppen; de trap afduwen of -gooien; schoppen; duwen en stompen; laten struikelen; een vork in de rug steken; met stoel en al achter over slaan; 'per ongeluk' zo duwen dat ze een pan hete soep over zich heen krijgt; de keel dichtknijpen; sigaretten op haar uitdrukken; met het hoofd tegen de muur bonzen; de kleren van het lijf scheuren; met een auto op haar inrijden; verkrachten of dwingen tot participatie aan seksuele activiteiten waar zij een hekel aan heeft; opzettelijk vernielen van persoonlijke bezittingen; nachtenlang wakker houden onder bedreiging van een wapen; haar huisdieren mishandelen; met voorwerpen gericht naar haar gooien (asbakken, planten); uren- of dagenlang opsluiten in een kast of kamer. (...) Veel voorkomende lichamelijke letsels zijn: bloeduitstortingen; gebroken ledematen (neus, ribben vingers); gescheurd trommelvlies en gestoorde gehoorfuncties; permanente hoofdpijn; geheugen- en concentratiestoornissen (niet meer kunnen lezen of handwerken); slaapstoornissen; verlies van gezichtsfuncties; schade aan mond en tanden; scheve vingers en neus; een miskraam of een doodgeboren kind; littekens van brandwonden - en soms komen vrouwen te overlijden."2

Vrouwenmishandeling omvat verschillende vormen van geweld, zoals hierboven is geschetst. Fysiek geweld en seksuele dwang binnen heteroseksuele relaties zijn beide beschadigend voor de vrouw, maar seksuele dwang betreft een eigen problematiek doordat seksualiteit vrije wil en genot impliceert, terwijl het geweld hier een inbreuk op maakt. Daar waar het relevant is, zal ik een onderscheid maken tussen fysiek geweld en seksuele dwang in (huwelijkse) relaties.

\subsection{De aard en omvang van vrouwenmishandeling}

Römkens concludeert op grond van een uitgebreid survey-onderzoek onder 1016 vrouwen dat eenzijdig geweld tegen de vrouw binnen een heteroseksuele relatie regelmatig voorkomt. $21 \%$ van de vrouwen tussen 20 en 60 jaar die in Nederland wonen en die een relatie met een mannelijke partner heeft (gehad), heeft ooit eenzijdig geweld van haar partner ervaren. Wanneer er alleen wordt gekeken naar het geweld binnen huidige relaties, dan blijkt dat $12 \%$ "ofwel een op de acht vrouwen die nu een relatie met een man heef - ooit met eenzijdig geweld van de 
partner (is) geconfronteerd". ${ }^{3}$ Dit geweld heeft zich bij bijna de helft van hen voorgedaan in het jaar voorafgaand aan het interview. ${ }^{4}$

Römkens maakt een onderscheid naar ernst van het geweld; licht geweld, matig ernstig geweld, emstig geweld en zeer ernstig geweld. Bijna de helft van de vrouwen (een op de elf ondervraagde vrouwen) die eenzijdig geweld (hebben) ervaren, hebben te maken (gehad) met licht geweld. Het gaat meestal om sporadisch voorkomend licht geweld (een klap, een duw of aan de haren trekken) waaraan meestal geen letsel wordt overgehouden. ${ }^{5}$ Ruim de helft van de vrouwen die eenzijdig geweld (hebben) ervaren (een op de negen ondervraagde vrouwen), valt onder een van de drie ernstige geweldscategorieën: matig, ernstig en zeer emstig geweld. Het emstige geweld onderscheidt zich van de categorie licht geweld het meest prominent in twee opzichten: het gaat overwegend om herhaald geweld en de vrouwen hebben vrijwel allemaal lichamelijk letsel opgelopen. "Binnen de drie zwaardere ernstcategorieën zien we (...) dat het geweld geleidelijk aan ingrijpender wordt. Zo is in de groep die matig geweld heeft meegemaakt meestal sprake van uitbarstingen die enkele keren per jaar voorkomen en af en toe tot matig letsel leiden (bloeduitstortingen, schrammen, snee). In de categorie ernstig geweld is vaak sprake van tenminste maandelijkse uitbarstingen die in veel gevallen ook tot ernstiger letsel leiden (kneuzingen, tanden door de lip e.d.). In de categorie zeer ernstig geweld gaat het om wekelijks tot dagelijks voorkomend geweld tegen de vrouw, dat vaak gepaard gaat met verkrachting. Het geweld zelf is ongecontroleerder van aard en staat in een context van permanent aanwezige dreiging en angst."

Het onderzoek van Römkens richt zich op lichamelijk geweld tegen vrouwen door hun partner of ex-partner. Zij heeft weliswaar ongewenste en gedwongen seks in haar onderzoek meegenomen, maar "gezien de specifieke aard en beladenheid van de problematiek" vergt dit een afzonderlijk onderzoek. De door Römkens gevonden resultaten met betrekking tot ongewenste seks in een heteroseksuele relatie moeten daarom worden beschouwd als een ondergrens. In het onderzoek van Römkens meldt ruim $7 \%$ van de ondervraagde vrouwen $(n=73)$ ooit door een partner te zijn gedwongen tot seks c.q. verkracht te zijn, dat wil zeggen dat de vrouw met geweld of dreiging met geweld wordt gedwongen tot seksuele gemeenschap of seksuele handelingen. ${ }^{8}$ Vaak gaat gedwongen seks en ander (emstig) lichamelijk geweld hand in hand. "Van de vrouwen die geweld hebben meegemaakt van de

\section{Römkens, Geweld tegen vrouwen binnen heteroseksuele relaties, 1989: 106-107.}

4 Römkens, Gewoon geweld?, 1992: 109. Deze dissertatie is een bewerking van het in voorgaande noot vermelde onderzoek.

5 Romkens, Gewoon geweld?, 1992; 109.

6 Ibidem: 109-110 (citaat pagina 110).

7 Ibidem: 134.

8 Ibidem: 134. Het onderzoek van Russell naar verkrachting binnen het huwelijk in San Francisco wijst uit dat $14 \%(n=87)$ van de geinterviewde vrouwen is verkracht tijdens hei huwelijk, varierend van een maal tot meerdere keren over een lange of korte periode. Russell, Rape in marriage, 1990: 2. 
partner, zegt bijna een op de vier (23\%) ook verkracht te zijn, tegenover minder dan een op de dertig (3\%) uit de groep die geen geweld heeft ervaren. (...) Naarmate de man emstiger fysiek geweld gebruikt, is de kans groter dat vrouwen ook verkracht zijn of onder druk zijn gezet om tegen hun zin te vrijen."

Römkens toont aan dat geweld tegen vrouwen door hun man of vriend niet kan worden afgedaan als een incidentele uitbarsting waar wat klappen vallen. De groep die herhaald eenzijdig geweld meemaakt en daarbij in veel gevallen gewond raakt, is groot: naar schatting heeft een op de negen vrouwen tussen de twintig en zestig jaar dit ooit meegemaakt. Bijna de helft hiervan wordt ook gedwongen tot seks. Het stereotype beeld van de 'mishandelde vrouw' die bont en blauw naar het Blijf van m'n Lijf huis vlucht doet geen recht aan de veel grotere groep vrouwen die eenzijdig geweld meemaakt maar die niet naar een opvanghuis vlucht. "Geweld tegen vrouwen door de partner is 'gewoner' dan dit beeld (het stereotype van de 'mishandelde vrouw', $\mathrm{KL}$ ) suggereert. Het komt 'onder onze eigen ogen' voor, maar wordt in de meeste gevallen zorgvuldig verborgen gehouden." 10

\subsubsection{Vrouwenmishandeling als een sekse-specifiek en maatschappelijk fenomeen}

Door zowel hulpverlening als wetenschap wordt geen acht geslagen op het seksespecifieke karakter van familiegeweld, tot het moment dat de vrouwenbeweging het geweld tegen vrouwen binnen het gezin als politiek strijdpunt oppakt." Hoewel ook vrouwen geweld gebruiken binnen heteroseksuele relaties, komt dit aanmerkelijk minder voor dan het geweld door mannelijke partners, zeker wat betreft het herhaaldelijk ernstig geweld. Bijna $11 \%$ van de vrouwen uit het survey-onderzoek van Römkens blijkt eenzijdig geweld te hebben gebruikt tegen de man, waarbij het vrijwel altijd gaat om lichtere vormen van geweld zoals het geven van een klap of met een voorwerp gooien. Daarnaast is een groep van ruim $5 \%$ betrokken geweest bij wederkerig geweld waarbij het geweld plaatsvindt in de context van duidelijke relatieproblemen. Gesteld kan worden dat het gepleegde geweld door vrouwen over het algemeen van minder emstige aard is en bestaat uit lichamelijk geweld zonder seksuele dwang. " "Zonder voorbij te gaan aan het feit dat vrouwen en mannen

9 Romkens, Gewoon geweld?, 1992: 131-132. De samenhang tussen fysiek geweld en seksuele dwang binnen heteroseksuele relaties wordt ook in buitenlands onderzoek gevonden. Ibidem: 31-33.

10 lbidem: 197-198. Dit zorgvuldig verborgen houden gebeurt door de mannen en vrouwen zelf, maar ook op maatschappelijk niveau heerst een groot stilzwijgen. "De drang en dwang tot zwijgen over geweld (tegen vrouwen door hun partner, KL) is diep verankerd en vervlochten op zowel sociaalcultureel en politiek vlak als in de relationele interactie tussen vrouwen en mannen en op intrapsychisch niveau bij betrokkenen zelf." Romkens, Wie is bang voor geweld? in: Het klappen van de zweep, 1994: 127-135 (citaat 135).

11 't Hart, van Rappard \& Robben, Visies op vrouwenmishandeling, Lover, 1979: 11-13; Walker, Family violence and the women's movement, 1990: 95-110. Romkens, Gewoon ge weld?, 1992: 116.

12 Romkens, Geschonden grenzen, in: Psychologie van het gezin, 1991: 139. Romkens, Gewoon geweld?, 1992: 119, 129, 199-201. 
op individucel niveau beiden vergelijkbaar ernstig geweld (kunnen) gebruiken, kunnen we er maatschappelijk gezien niet omheen dat geweld 'binnen relaties' een seksespecifiek probleem is waarvan vooral vrouwen het slachtoffer worden."13 Het feit dat (seksueel) geweld tegen vrouwen in de privésfeer sekse-specifiek geweld is, betekent niet dat alle vrouwen slachtoffer worden van dit soort geweld of dat er niet aan dit geweld valt te ontsnappen. Het betekent wel dat het met name mannen zijn die verantwoordelijk zijn voor het ernstige geweld dat plaatsvindt binnen de privésfeer.

Daarnaast wordt vanuit de vrouwenbeweging benadrukt dat het geweld tegen de vrouw weliswaar in de privésfeer plaatsvindt, maar dat dit niet betekent dat geweld tegen vrouwen een privéprobleem betreft. De aard en omvang van het fenomeen vrouwenmishandeling geeft aan dat er sprake is van een ernstig maatschappelijk probleem. Een maatschappelijk probleem waar de openbare orde nauwelijks door wordt verstoord omdat het geweld plaatsvindt in de privésfeer. "Een simpele rekensom wijst uit dat getrouwde of samenwonende vrouwen vijf tot zes keer zo groot risico lopen binnenshuis het slachtoffer te worden van ernstige mishandeling door haar mannelijke partner dan dat vrouwen het risico lopen slachtoffer te worden van mishandeling op straat door een onbekende."14 Dit geweld tegen de vrouw door haar man of vriend zijn geen toevallige incidenten - het geweld tegen de vrouw komt niet voort uit een toevallige emotionele uitbarsting - maar het geweld dient ertoe macht over de vrouw uit te oefenen (zie $\$ 2.2 .3$ ). Vrouwenmishandeling wordt als geweldsdelict gedefinieerd: "Wife-beating is an assault, not interaction gone wrong." ${ }^{15}$ Op die manier wordt vrouwenmishandeling als een maatschappelijk probleem naar voren gehaald en uit de sfeer van de relatieproblemen gehaald. ${ }^{16}$ Maar tegelijkertijd is vrouwenmishandeling geen gewoon geweldsdelict vanwege de intimiteit tussen slachtoffer en dader. "Wifebattering, treated as an equivalent to stranger-to-stranger assault, did not deal with

13 Römkens, Gewoon geweld?, 1992: 199. Tevens concludeert Romkens dat het als kind slachtoffer zijn van geweld voor mannen en vrouwen op latere leefijd andere gevolgen heeft. Voor mannen is dit geweld een risicoverhogende factor om later pleger van geweld tegen zijn partner te worden terwijl dit geweld voor vrouwen een risicoverhogende factor is om later slachtoffer van geweld door hasr partner te worden. Ibidem: 174; Dobash, Dobash, Wilson \& Daly, The myth of sexual symmetry in marital violence, Social Problems, 1992: 71-91.

14 Römkens, Vrouwenmishandeling: het miskende geweld in de familie Doorsnee, in: Geveld regen vrouwen, (g)een zaak voor politie en justitie?, 1985: 23.

15 Walker, Family violence and the women's movement, 1990: 48. Door te benadrukken dat het om een geweldsdelict gaat in plaats van een ruzie in huiselijke kring, wordt de weg geplaveid voor de verwachting dat er vaker strafrechtelijk moet worden opgetreden. Hier kom ik in $\$ 2.3$ en $\S 2.4$ op terug.

16 Er wordt op gewezen dat het geweld waar de man verantwoordelijk voor is vaak wordt weggemoffeld door het bij voorbaat als een individueel hulpverlenings- en relatieprobleem te definiëren. Van Blokland \& Geurts, Thuis geslagen mevrouw? Dan ... kunnen wij niets doen, in: Thuis geslagen mevroux?, 1984: 50. Corten, Geweld tegen vrouwen: (gleen zaak voor politie en justitie?, 1985:
17-18. 
dependence and the need for shelter and support for women and children."17 De complexiteit van een intieme relatie kan niet worden teruggebracht tot een simpel, eendimensionaal beeld over geweld binnen relaties. ${ }^{18}$

Door mannelijk geweld tegen vrouwen in de privésfeer als sekse-specifiek en maatschappelijk probleem te benoemen, wordt de suggestie gewekt dat vrouwen altijd kwetsbaar, afhankelijk, zwak en passief zijn. ${ }^{19}$ De onmacht en afhankelijkheid van vrouwen staat daardoor op de voorgrond en het gevoel van onveiligheid en machteloosheid bij vrouwen kan door deze probleemanalyse worden versterkt. ${ }^{20}$ Het is daarom van belang het probleem van mannelijk geweld tegen vrouwen in de privésfeer zowel op maatschappelijk niveau, als op individueel niveau te analyseren, waarbij de machtsverhoudingen tussen mannen en vrouwen als dynamisch proces in de analyse wordt meegenomen. Op die manier kan de weerbaarheid van vrouwen en de verschillende mogelijkheden tot verzet aandacht krijgen in de probleemanalyse. ${ }^{21}$ "No act of violence is simply the pitting of one individual against another; each contains deep cultural and psychological meanings. At the same time, no act of violence is merely the expression of a social problem (or a culture) such as poverty or unemployment or male dominance; each is also the personal act of a unique individual."22

De asymmetrische machtsverhouding tussen de seksen is een feit, maar tegelijkertijd wordt erkend dat deze machtsverhouding niet statisch is, maar onderhevig aan verandering. Vrouwen kunnen zich verzetten tegen het geweld dat hen wordt

17 Walker, Famity violence and the women's movement, 1990: 167

18 Ferraro \& Pope, Irreconcilable differences, battered women, police and the law, in: Legal responses to wife abuse, 1993: 121.

19 Dit wordt wel beschouwd als een radicaal-feministische visie: mannen en vrouwen worden als aparte categorieen gezien die min of meer biologisch bepaald zijn. Mannen zijn dan agressief, uit op macht, rationeel, terwijl vrouwen het vredelievende, het emotionele vertolken. Zie Naffine, Feminist excavations, in: Law and the sexes. Explorations in feminist jurisprudence, 1990: 1-23.

20 Meinen, Van slachtoffer naar boze vrouwen, Katij, 1985: 10-13. Jansen, Aanrander op vrije voeten, $T v V, 1984: 508-515 ;$ Los, Feminism and rape law reform, in: Feminist perspectives in criminology, 1990: 165 .

21 Meinen \& van der Vlugt, Strategieèn in de strijd tegen seksueel geweld en vrouwenmishandeling, 1986: 14. En in de Blijf van $m$ 'n Lijfhuizen is bijvoorbeeld de weerbaarheid van vrouwen uitgangspunt door het hanteren van het zelfhulpprincipe. Meinen \& van der Vlugt, Hebben we geen stenen meer? in: Mishandelen, 1987: 10.

22 Breines \& Gordon, The new scholarship on family violence, Signs, 1983: 530. Hoe machtsverschillen en geweld zich binnen heteroseksuele relaties tot elkaar verhouden is een moeilijke en complexe discussie. Het eenzijdige geweld tegen de vrouw binnen heteroseksuele relaties kan niet door machtsverschillen worden verklaard, want de meerderheid van de mannen pleegt tenslotte geen geweld tegen vrouwen. Dat maatschappelijk gezien meer mannen emstiger geweld plegen tegen hun vrouw of vriendin dan omgekeerd is daarom een sociologisch-descriptieve uitpraak. Romkens, Gewoon geweld?, 1992: 200. 
aangedaan. ${ }^{23} \mathrm{Zij}$ zitten op het moment waarop zij slachtoffer zijn van fysiek geweld of seksuele dwang, in een slachtofferpositie, maar zij kunnen zich wel onttrekken aan hun slachtofferrol; ${ }^{24}$ vrouwen kunnen hun zelfstandigheid en autonomie versterken binnen heteroseksuele relaties, ook als er sprake is van geweld.

\subsubsection{Asymmetrische machtsverhoudingen binnen man-vrouw relaties}

Het geweld tegen de vrouw uitgeoefend door haar mannelijke partner wordt vanuit feministisch oogpunt geplaatst tegen de achtergrond van macht, zoals al enkele malen is opgemerkt. Deze macht kan op verschillende manieren worden opgevat; duidelijk meetbare macht in de zin van hulpbronnen, ook wel kwantitatieve macht genoemd, en de ideologische en intrapsychische dimensies van macht, de kwalitatieve macht. ${ }^{25}$ Op grond van gezinssociologisch onderzoek naar kwantitatieve machtsverschillen binnen gezinnen wordt menigmaal geconcludeerd dat het symmetrische gezin in opkomst is, omdat vrouwen meer opleiding hebben, vaker beroepsarbeid uitoefenen, de wettelijke gelijkheid tussen de seksen groter is en de anti-conceptie kleine gezinnen mogelijk maakt. Maar wanneer er naar de ideologische en intrapsychische dimensies van macht in de man-vrouw verhouding wordt gekeken, dan ziet de gelijkwaardigheid tussen mannen en vrouwen binnen relaties er veel minder rooskleurig uit. $^{26}$

De meer kwalitatieve machtsaspecten die een rol kunnen spelen binnen een heteroseksuele relatie, zijn onder te verdelen in manifeste macht, latente macht en onzichtbare macht. Manifeste macht betekent dat er op een zichtbare, openlijke wijze getracht wordt veranderingen te bereiken. Het gebruik van invloed of dwang om bij een conflict het eigen gelijk te halen en het gebruik van geweld behoren tot de manifeste macht. De aanwezigheid van latente en onzichtbare macht is af te leiden uit de wijze waarop de minder machtige haar behoeften laat vormen en afstemt op de behoeften van de meer machtige. Bij latente macht zal de vrouw bijvoorbeeld geen poging tot verandering ondernemen uit angst voor conflicten, terwijl er wel ontevredenheid is. De onzichtbare macht schuilt in de vanzelfsprekende normen en verwachtingen over de posities van mannen en vrouwen, zoals opvattingen over superioriteit van mannen en ondergeschiktheid van vrouwen aan mannen. De

23 Van Rappard onderzocht de verschillende manieren waarop vrouwen het geweld van hun partner hebben weten te stoppen, "omdat het me inmiddels duidelijk geworden was dat mishandelde vrouwen zelf initiatief moeten nemen om hun situatie te veranderen." Van Rappard, Tot hier en niet verder, 1988: 9. Zie tevens: Dewil \& Sterkens, Om de lieve vrede, 1994.

24 Dit onderscheid is ook van toepassing op de maatschappelijke positie van vrouwen en de individuele rol die vrouwen hebben: vrouwen hebben maatschappelijk gezien minder macht dan mannen, maar vrouwen kunnen op individueel niveau op allerlei manieren macht uitoefenen.

25 Romkens, Verzet van mishandelde vrouwen, een kwestie van machten onmacht, $T v V$, 1980: 267-293; Blijf van m'n Lijf Amsterdam, Jaarverslag 1976: 3.

26 Komter, Omstreden gelijkheid, 1990: 9-17. Dit is een bewerking van haar proefschrift De macht van de vanzelfsprekendheid; relaties tussen vrouwen en mannen, 1985. 
onzichtbare macht bevindt zich op het ideologische niveau, terwijl manifeste en latente macht zich op het gedragsniveau bevinden, "waarbij manifeste macht uit openlijke gedragingen blijkt en latente macht uit anticipatie op gedrag of uit niethandelen". ${ }^{27}$

Naast het onderscheid in vormen van macht kunnen machtsverschillen tevens worden afgeleid uit verschillen in rechten en plichten. Over het algemeen blijken minder machtigen meer specifieke plichten te hebben terwijl de meer machtige groepen diffuse en algemene plichten hebben. Als het om rechten gaat, is het beeld omgekeerd; de meer machtigen hebben over het algemeen meer specifieke rechten terwijl de minder machtigen diffuse en algemene rechten hebben. ${ }^{28}$

Het onderzoek van Komter naar de onderliggende machtsprocessen in een huwelijk toont aan dat mannen op de verschillende niveaus meer macht hebben. Het populaire idee dat mannen in de buitenwereld meer macht hebben en vrouwen binnenshuis, wordt door haar onderzoek niet bevestigd. Mannen hebben ook binnenshuis een sterke machtspositie. Dit blijkt bijvoorbeeld uit het feit dat mannen meer specifieke rechten hebben en vrouwen meer specifieke plichten. Vrouwen zijn over het algemeen weinig succesvol in hun streven de scheve verdeling tussen rechten en plichten recht te trekken, ondanks herhaalde pogingen daartoe. Manifeste en latente macht ontbreekt hen. Daarnaast is een belangrijke verklaring voor de hardnekkigheid van deze machtsongelijkheid gelegen in de macht van de vanzelfsprekendheid die zich uit in ongelijkheid van waardering, perceptuele vertekening en ogenschijnlijke consensus. In essentie bestaat 'onzichtbare' macht uit een proces van rechtvaardiging en van selectieve waarneming, dat grotendeels onbewust plaatsvindt. $^{29}$

Romkens constateert op grond van haar onderzoek dat verschillen in manifeste macht tussen man en vrouw op het gebied van arbeid, inkomen en opleiding niet systematisch samenhangt met het wel of niet voorkomen van geweld binnen de relatie: "[G]eweld tegen vrouwen komt niet mér voor in relaties met een traditionele arbeidsverdeling dan in relaties met een meer emancipatoire verdeling van werk." $"{ }^{\prime 0}$ Het zijn met name de latente en onzichtbare machtsaspecten die samenhangen met het geweldgebruik door de man in relaties. Wanneer sprake is van herhaald eenzijdig geweld tegen de vrouw door haar partner, zijn vrouwen meestal minder succesvol in het stoppen van het geweld door haar partner dan in gevallen van incidenteel geweld. In het laatste geval is het de vrouwen meestal gelukt om het geweld tegen

27 Komter, Omstreden gelijkheid, 1990: 23-24.

28 Ibidem: 103-105.

29 Ibidem: 105-110. Deze macht van de vanzelfsprekendheid vindt ook in het openbare leven plaats. Komter, De macht van de dubbele moraal, verschil en gelijkheid in de verhouding tussen de seksen, 1990.

30 Römkens, Geschonden grenzen, in: Psychologie van het gezin, 1991: 147. 
haar te stoppen door directe interactie en communicatie, terwijl bij herhaald geweld het vrouwen ontbreekt aan effectief verzet. In plaats daarvan proberen vrouwen te anticiperen op eventueel gewelddadig gedrag van de man. Zij doen dit door hun partner te mijden; het huis verlaten, naar een ander vertrek in huis gaan of een derde persoon aanwezig laten zijn. "[D]oor ogenschijnlijke passiviteit hoopt de vrouw de agressie van de man te ontlopen, zonder dat het gedrag van de man ter discussie komt te staan." ${ }^{\prime 31}$ Tevens proberen vrouwen de man te sussen door vooruit te lopen. op huishoudelijke, emotionele of seksuele wensen van de man. Vermijdingsgedrag en sussen zijn indirecte strategieen en worden het meest toegepast. Daarnaast confronteren vrouwen hun partner soms met de ontstane, bedreigende, situatie door hem erop aan te spreken of door er een brief over te schrijven. Römkens concludeert op grond van haar onderzoek dat van de groep vrouwen die slachtoffer is (geweest) van herhaald geweld, een ruime meerderheid zegt dat de pogingen om het geweld te voorkomen niet effectief zijn geweest. Het vermijden van de partner blijkt nog de meest effectieve manier om aan het geweld te ontkomen. ${ }^{32}$

Naast deze vorm van latente macht is er ook sprake van onzichtbare macht. Denkbeelden over mannen en vrouwen waarbij vrouwen de passieve, verzorgende rol wordt toegekend, dragen eraan bij dat vrouwen zich inleven in de positie van hun partner om conflicten te vermijden. Vrouwen voelen zich vaak verantwoordelijk voor het instandhouden van de relatie ${ }^{33}$ en het stoppen van het geweld. Wanneer het geweld van de man niet stopt, beschouwt de vrouw dit als een falen harerzijds. Hoe ernstiger het geweld, hoe meer verantwoordelijk vrouwen zich voelen voor het stoppen van het geweld. Mannen daarentegen zijn geneigd de verantwoordelijkheid van zich af te schuiven door de vrouw van provocerend gedrag te beschuldigen. ${ }^{34}$ "Zij bagatelliseren meestal de frequentie, de ernst en de gevolgen van hun geweld. Dit gaat vaak gepaard met een gebrek aan inlevingsvermogen wat dit gewelddadig gedrag voor de vrouw betekent, (...) met name de angst die het geweld teweegbrengt lijkt onvoldoende onderkend te worden. ${ }^{335} \mathrm{Zij}$ brengen allerlei rechtvaardigingen naar voren; de alcohol of spanningen op het werk of verbale agressie van de vrouw worden als oorzaak van het geweld aangemerkt. ${ }^{36}$ Römkens noemt dit 'uitbesteding

31 Romkens, Gewoon geweld?, 1992: 152.

32 Ibidem: 150-157.

33 Weeda spreekt van de liefdesplicht voor vrouwen die de onmacht van vrouwen verbloemt en die in elke relatie meer of minder van invloed is. Weeda, Over liefde gesproken, 1987: 9-22.

34 Van Stolk en Wouters wijzen op het verbar.d tussen de superioriteit van de man en de verantwoordelijkheid afschuiven: "'Zo'n instelling verraadt de gepriviligeerde positie van mensen die zich tamelijk ongestraft kunnen veroorloven degenen die sterk op hen zijn aangewezen er pijnlijk aan te herinneren wie er de bass is." Van Stolk \& Wouters, Vrouwen in tweesirijd, 1983: 123.

35 Romkens, Het onbehagen over geweld tegen vrouwen, in: Agressie, 1991: 218.

36 Dat het met name vrouwen zijn die zich verantwoordelijk voelen voor het geweld, blijkt ook uit het hulpzoekend gedrag. Mannen zoeken zelden uit zichzelf hulp voor hun gewelddadig gedrag, en initiatieven van vrouwen om hulp te zoeken stuiten niet zelden op een afwijzende houding van de man of zelfs op repressailles. Römkens, Het onbehagen over geweld tegen vrouwen, in: Agressie, 
van verantwoordelijkheid'. "Waar mannen weigeren de verantwoordelijkheid te nemen voor hun gedrag, lijken vrouwen bereid die op zich (en over) te nemen." Dit uitbestedingspatroon heeft voor beiden voordelen; de man hoeft zijn gedrag niet te veranderen en het verschaft de vrouw een (illusoir) gevoel van controle; onmachtgevoelens worden vermeden en de hoop wordt gewekt dat zij het geweld kan voorkomen. ${ }^{38}$ Tevens spelen denkbeelden over de man als actief, superieur en dominant een belangrijke rol. Het dominantiegedrag blijkt bijvoorbeeld uit plotselinge gewelddadige uitbarstingen naar aanleiding van 'zelfstandig' optreden door de vrouw zoals het alleen boodschappen gaan doen of een cursus gaan volgen. "Mannen die geweld gebruiken onderscheiden zich het sterkst van niet-gewelddadige mannen in de mate waarin ze een beroep doen op traditioneel-ideologische legitimering van de ondergeschiktheid van de vrouw." 39

Uit het hierboven gestelde blijkt dat het gebruik van geweld als manifeste vorm van macht zich tevens vertaalt in Jatente vormen van macht en bovendien op het intra-psychische niveau effect teweegbrengt. "Vrouwen die worden geslagen onderscheiden zich het sterkst van vrouwen die geen geweld hebben ervaren, in de mate waarin zij uit alle macht conflicten proberen te vermijden en gaan anticiperen op behoeften van de man. Ook bij de vrouwen die incidenteel geweld hebben meegemaakt, is dat al te zien. Kennelijk kan én incident voldoende zijn om een kwalitatieve omslag in de machtsverhouding teweeg te brengen door het besef dat de man in staat is geweld te gebruiken. Het leidt er hoe dan ook toe dat vrouwen extra waakzaam worden voor datgene wat de man doet, met name in ruzies." ${ }^{40}$

Gedwongen seks binnen intieme (huwelijkse) relaties onderscheidt zich van fysiek geweld doordat seksualiteit wordt voorondersteld in intieme relaties. Met het aangaan van een huwelijk of een andere vorm van samenleving verbinden man en vrouw zich tot het aangaan van een seksuele relatie waar noties over liefde, vrijwilligheid en gelijkwaardigheid een belangrijke rol spelen. Maar tegelijkertijd is seksualiteit in heteroseksuele relaties problematisch, gezien de verschillen in macht en dominante

1991: 218-223.

37 Römkens, Gewoon geweld?, 1992: 202. Wanneer mannen slachtoffer zijn van seksuele dwang, dan zijn zij goed in staat de schuld bij de dader te leggen. Zij zijn voomamelijk woedend. Stanko \& Hobdell, Assault on men, The British jrnl of criminology, 1993: 400-415.

38 Römkens, Gewoon geweld?, 1992: 201-203. Zij wijst tevens op het verschil tussen schuld en verantwoordelijkheid betreffende het eenzijdige geweld van de man tegen zijn vrouw of vriendin. Het gaat er niet om dat de man als enige schuldig is aan alles wat er mis is gegaan binnen de relatie, maar het gaat er wel om dat de man verantwoordelijkheid draagt voor zijn eigen gewelddadig handelen. Therapeutisch gezien is dit een belangrijk verschil. Vanuit strafrechtelijk oogpunt heeft schuld een andere betekenis. Gewelddadig handelen veronderstelt schuld, tenzij aangetoond kan worden dat de man geen besef kon hebben van de consequenties van zijn handelen.

39 Römkens, Geschonden grenzen, in: Psychologie van het gezin, 1991: 147.

40 Ibidem: 148. 
culturele mannelijke waarden over seksualiteitsbeleving. "[T]he focus on phallic pleasure does not inevitably coincide with the potential of female sexuality.".41

Uit het onderzoek van Komter komt naar voren dat vrouwen over het algemeen meer ontevreden zijn, en minder in staat zijn naar eigen behoeften te vrijen, dan mannen. Vrouwen willen bijvoorbeeld een minder centrale rol van de geslachtsgemeenschap en meer emotionele betrokkenheid. Tevens willen ze hun eigen rol veranderen; zich minder geremd voelen, vaker zin hebben in seks en meer genieten ${ }^{42} \mathrm{Zij}$ wijten de problemen bij het vrijen vooral aan zichzelf. Ook mannen wijten de seksuele belemmeringen met name aan de houding van de vrouwen. De manifeste macht van mannen komt tot uitdrukking in het feit dat vrouwen proberen de wijze van vrijen te veranderen, maar daar weinig succesvol in zijn. Manifeste macht blijkt ook uit het feit dat mannen hun behoefte aan seksualiteit afdwingen door lichamelijk geweld of dreiging met geweld. Latente macht blijkt uit het feit dat vrouwen geen poging doen de wijze van vrijen te veranderen uit angst voor conflicten. Vrouwen vrijen bijvoorbeeld uit angst dat hun partner anders boos zal worden, of haar geen geld voor kleren zal geven. Dit wordt ook wel 'interpersonal coercion' genoemd. ${ }^{43}$ Mannen vrijen daarentegen zelden tegen hun zin. ${ }^{44} \mathrm{De}$ onzichtbare macht van mannen over vrouwen blijkt tenslotte uit de overschatting van de seksuele behoeften van vrouwen door mannen; mannen hebben het idee dat de vrouw wil vrijen terwijl zij niet wil. Of vrouwen vrijen vanuit de idee dat de seksuele behoefte van de man nu eenmaal veel groter is en hij nu eenmaal de veroveraar is. ${ }^{45}$ Het zijn deze sociale normen en gewoonten, verinnerlijkt door de vrouw, die eraan bijdragen dat vrouwen zich 'gedwongen' voelen aan de seksuele behoeften van hun partner te voldoen; het is een vorm van sociale dwang. ${ }^{46}$

Wanneer wordt gekeken naar de rechten en plichten van mannen en vrouwen als het gaat om seksualiteit dan blijkt dat mannen meer dan vrouwen het algemene gevoel hebben dat zij een recht op seks hebben, terwijl vrouwen het vaak als hun specifieke plicht beschouwen om de rechten van mannen te helpen verwezenlijken. ${ }^{47}$ Met het aangaan van een huwelijk of een andere vorm van samenleving verbindt de vrouw zich tot het aangaan van een seksuele relatie waar hij aanspraak op kan maken als hij er behoefte aan heeft. "Sex is part of the sacred glue of this union (of the marriage, $\mathrm{KL}$ ). An implicit bargain exists by which wives make

41 Smart, Feminism and the power of law, 1989: 28.

42 Mannen willen ook veranderingen, namelijk vaker geslachtsgemeenschap, gevarieerdeer en onregelmatiger vrijen en buitenechtelijke contacten. Komter, Omstreden gelijkheial, 1990: 23-24.

43 Finkelhor \& Yllo, Marital Rape and marital sexuality, in: Licence to rape, 1985: 87-88; Beelen, Tussen verleiden en verkrachten, 1989: 44-45.

44 Komter, Omstreden gelijkheid, 1990: 59.

45 Ibidem: $96-99$.

46 Finkelhor \& Yllo, Marital rape and marital sexuality, in: Licence to rape, 1985: 86-87.

47 Komter, Omstreden gelijkheid, 1990: 104. Zie ook: Van Stolk \& Wouters, Vrouwen in tweestrijd, 1983: 124-131. 
themselves sexually available to husbands in return of being supported." ${ }^{.48}$ Wanneer de vrouw uitspreekt dat zij niet wil vrijen dan wordt dit 'neen' van de vrouw vaak als een inbreuk op een (onbewust gesloten) contract ervaren door de man. ${ }^{49} \mathrm{Zijn}$ recht op seks wordt geschonden. Het recht van mannen op geslachtsgemeenschap binnen een huwelijk werd tot 1991 gelegitimeerd door het recht; tot die tijd was gedwongen 'vleselijke gemeenschap' binnen het huwelijk uitgesloten van strafbaarheid. Dit recht op geslachtsgemeenschap was een individueel autonoom recht van de man, waar geen recht van de vrouw tegenover stond, maar wel een algemene plicht van de vrouw om aan dat recht van de man te voldoen. ${ }^{50}$ Hoewel tegenwoordig gedwongen geslachtsgemeenschap, evenals andere vormen van seksuele dwang, in een (huwelijkse) relatie strafbaar zijn, zijn de culturele noties van 'recht op' en 'plicht tot' niet verdwenen. ${ }^{51}$ Deze culturele noties over rechten en plichten hebben hun invloed op de interpretatie van de gebeurtenis. De overgang van verleiden naar aandringen naar verkrachten heeft een glijdende schaal $^{52}$ of anders gezegd de scheidslijn tussen sociale dwang, interpersoonlijke dwang, dwang door dreiging met geweld en dwang door geweld is niet altijd scherp te trekken.

Seksual iteit en geweld kunnen als wezenlijke elementen van verkrachting worden beschouwd, die in een complexe verhouding tot elkaar staan. Verkrachting is weliswaar een geweldsdelict, evenals andere vormen van geweld tegen de vrouw in de privésfeer, maar tegelijkertijd is het een inbreuk op de seksuele integriteit. Schending van de seksuele autonomie is een zeer vernederende ervaring omdat het de meest persoonlijke en intieme sfeer treft. "Rape or sexual assault is not merely physically painful; it is repulsive, humiliating and degrading: the ultimate violation of women's privacy and sense of control over their bodies." ${ }^{\text {s3 }}$ Een extra vernederende ervaring bij verkrachting kan voortkomen uit op gang gebrachte fysiologische processen, zoals het nat worden van de vagina, waardoor afgedwongen gevoelens van seksuele prikkeling zich kunnen manifesteren. ${ }^{54}$ Deze fysiologische processen als het nat worden van de vagina kunnen beschouwd worden als tekenen van genot, en daarmee als teken van toestemming. ${ }^{55}$ Hiermee wordt voorbijgegaan

48 Finkelhor \& Yllo, Marital rape and marital sexuality, in: Licence to rape, 1985: 90.

49 Op een ander niveau is het 'neen' van de vrouw het betwisten van de macht van de man die verder reikt dan seksualiteit; het is op een bepaalde manier het betwisten van de mannelijkheid. Het is een manier van verzet die verder gaat dan de individuele relatie, ook al is het geen politieke daad, zoals bij het politieke lesbianisme en celibatair feminisme. Smart, Feminism and the power of law, 1989: 28-32.

50 Zie: Gunning, Gewaande rechten, 1991.

51 Komter, Omstreden gelijkheid, 1990: 104. Zie ook: Van Stolk \& Wouters, Vrouwen in tweestrijd, 1983: 124-131.

52 Zie hierover bijvoorbeeld: Beelen, Tussen verleiden en verkrachten, 1989.

53 Los, Feminist and rape reform, in: Feminist perspectives in criminology, 1990: 167.

54 Beelen, Tussen verleiden en verkrachten, 1989: 39.

55 Smart, Feminism and the power of law, 1989: 36-38. Ook officieren van justitie, rechters en juryleden kunnen tijdens een terechtzitting zulke fysiologische processen als vorm van toestemming interpreteren. Rowland, Rape, the ultimate violation, 1986: 245-247; NLR, aant 5 op art. 242 Sr: 733. 
aan het vernederende en verwarrende aspect van gedwongen seksuele opwinding. De vermenging van geweld, seksualiteit en eventueel seksuele opwinding kan vergaande traumatiserende consequenties hebben voor het slachtoffer, waarbij haar seksualiteit ook in de toekomst beschadigd kan blijven. ${ }^{56}$ Bovendien kan verkrachting binnen (huwelijkse) relaties zeer traumatisch zijn omdat het vertrouwen en respect voor elkaar ernstig is geschonden. "[W]ife rape can be as terrifying and lifethreatening to the victim as stranger rape. In addition, it often evokes a powerful sense of betrayal, deep disillusionment, and total isolation. (...) When a woman has been raped by her husband she cannot seek comfort and safety at home."

De essentie van verkrachting in (huwelijkse) relaties is hiermee aangegeven; machtsmisbruik door het uitoefenen van dwang vermengd met seksualiteit en eventuele afgedwongen seksuele gevoelens bij de vrouw, waarbij de eigen behoeften en grenzen van de vrouw grof worden overschreden en de vertrouwensbasis tussen haar en haar partner ernstig wordt beschadigd.

\subsubsection{Waarom vrouwen (niet) weggaan}

Waarom gaan vrouwen niet weg bij de partner die geweld pleegt, is een veelgehoorde vraag. Redenen voor de vrouw om niet weg te gaan, of om weg te gaan en weer terug te keren, zijn verschillend van aard. Een belangrijke reden is dat er binnen de relatie niet alleen geweld plaatsvindt. De hand die slaat, is ook de hand die liefkoost. De relatie kent naast het geweld ook positieve aspecten, zoals intimiteit of vertrouwdheid en een gezamelijk sociaal leven; er is sociaal-emotionele betrokkenheid. Tevens kunnen er kinderen zijn waar de man een goede vader voor is. Bovendien is het perspectief om alleen of als alleenstaande ouder verder te moeten, afhankelijk te zijn van een alimentatie of een bijstandsuitkering als de vrouw geen werk en inkomen heeft, of te moeten verhuizen met alle sociale en emotionele consequenties vandien, geen positief perspectief. Wanneer er kinderen zijn, kan het contact in de meeste gevallen niet geheel worden verbroken en die contacten kunnen weer een bron voor ruzie en geweld zijn. Ook angst weerhoudt vrouwen ervan echtscheiding aan te vragen of weg te gaan. ${ }^{58}$ En deze angst is niet geheel ongerechtvaardigd, want weggaan bij de man is geen garantie voor het ophouden van het geweld. Een op de zes gescheiden vrouwen die tijdens hun relatie geweld hadden meegemaakt, werden ook na de scheiding met geweld door hun partner geconfron-

56 Herman laat zien hoe het gevoel van schaamte en schuld de verwerking van een 'objectief gezien' verwerpelijke daad van seksuele dwang zo moeilijk maakt. Trauma en herstel, 1993: 88.

57 Russell, Rape in marriuge, 1990: 198.

58 Wöstmann, Politieoptreden bij vrouwenmishandeling, 1988: 81-82. 
teerd en $4 \%$ van de gescheiden vrouwen werd na de scheiding verkracht. ${ }^{59}$ Dit wordt ook wel 'separation assault' genoemd. "[T]he violent and sometimes lethal attack on a women's attempt to leave a relationship, proves that the power and control quest of the batterer often continues after the women's decision to leave."60 Het weggaan en het blijven hebben beide schaduwzijden, waardoor er sprake is van een dilemma; er is geen goede oplossing.

Daarnaast bestaan er sociaal-psychologische verklaringen voor het blijven van vrouwen. Wanneer sprake is van herhaald (dreigen met) geweld kan de vrouw (ernstige) depressieve en psycho-somatische klachten ontwikkelen en de weerbaarheid en besluitvaardigheid van de vrouw kan worden aangetast. ${ }^{61}$ De theorie van de 'traumatic bonding' laat zien dat de ongelijke machtsverhouding tussen de man en de vrouw tesamen met het feit dat het geweld wordt afgewisseld met perioden van positieve aandacht, een specifieke loyaliteit en afhankelijkheid tussen de partners creěert. $^{62}$ Veel gewelddadige incidenten gebeuren in het eerste jaar van de huwelijkse relatie, wanneer over het huwelijk de gloed van de romantische liefde hangt. Wanneer tevens sprake is van niet ernstig letsel en de man spijt betuigt, wordt het geweld beschouwd als een onregelmatigheid. Toch kan dit het begin betekenen van een affectieve relatie die wordt gekenmerkt door een afhankelijkheidscyclus waarin de vrouw zich steeds negatiever voelt over zichzelf omdat zij niet in staat is het geweld te stoppen en ze elke keer weer zo'n vernederende ervaring moet ondergaan. Tegelijkertijd wordt ze steeds afhankelijker van haar partner die in haar behoeften moet voorzien, mede omdat ze wordt geïsoleerd van andere sociale contacten door het dominantiegedrag van de man. ${ }^{63}$ De ongelijke machtsverhouding brengt zo een eigen machtsdynamiek met zich mee. De perioden van dreiging en geweld worden afgewisseld met perioden van rust en positief gedrag van de man en in die perioden krijgt de vrouw weer geloof in de relatie en hervindt ze het gevoel dat zij de situatie onder controle heeft en dat zij het geweld kan stoppen. ${ }^{64}$ Hoe vaker deze cyclus

59 Romkens, Het onbehagen over geweld tegen vrouwen, in: Agressie, 1991: 216; Zie over geweld na het weggaan van de vrouw en de ernstige vormen die dit geweld kan aannemen bijvoorbeeld: Browne, When battered women kill, 1987: 109-122; Mahoney, Women's lives, violence and agency, in: The public nature of private violence, 1994: 59-92.

60 Ibidem: 60 .

61 Römkens, Het onbehagen over geweld tegen vrouwen, in: Agressie. 1991: 216. Römkens, Gewoon geweld?, 1992: 159-161.

62 De theorie van 'traumatic bonding' geldt ook voor mishandelde en/of seksueel misbruikte kinderen in relatie tot hun ouder(s), of gegijzelden in relatie tot hun gijzelaars. Dutton \& Painter, Traumatic bonding, Victimologv, 1981: 139-155.

63 In dit soort situaties zie je dat de onderdrukte persoon zich gaat identificeren met haar agressor: "[]]n situations of extreme power imbalance where a person of high power is occasionally punitive, persons in low power will adopt the aggressors' assumed perspective of themselves, internalize aggression or redirect it toward others similar to themselves." Ibidem: 147.

64 Zie ook Walker die drie fasen noemt: 1 . de spanning wordt opgebouwd, 2. de actuele gewelddadige gebeurtenis en 3 . kalme, liethebbende periode waarin de man berouw heeft van zijn geweld. Walker, The battered woman, 1979: 55-70. 
zich herhaalt, hoe kleiner de kans dat de vrouw uit deze relatie stapt. "[T]he psychological consequence of the power dynamics during the battering cycle serves to create and strengthen trauma-based emotional bonds between the man and woman which make long-lasting separation difficult or impossible to achieve." 65 De theorie van 'traumatic bonding' geeft inzicht in de dynamiek van vrouwenmishandelingsrelaties; hoe machtsongelijkheid en geweld sterke affectieve banden kan creëren waardoor het weggaan bij de man of het stoppen van het geweld erg moeilijk is.

Toch kan de spiraal worden doorbroken. Er kan een moment komen dat de vrouw zich realiseert hoe haar leven geheel gedomineerd wordt door haar partner en dat zij haar eigen zelf kwijtraakt. Als ze haar eigen zelf wil behouden of terugvinden, moet ze iets doen om uit de gewelddadige relatie te ontsnappen. ${ }^{66}$ Dit is wat van Rappard noemt 'de innerlijke omslag': er gebeurt iets, dit kan de zoveelste mishandeling of vernedering zijn, waardoor de vrouw het heft in eigen hand neemt en haar rol van slachtoffer aflegt. Wat dat 'iets' is, verschilt van persoon tot persoon. ${ }^{67}$ In de zeer ernstige gevallen van vrouwenmishandeling kan het heft in eigen hand nemen betekenen dat de vrouw haar partner doodt; in plaats van zelfmoord wordt het moord of in plaats van gedood worden, wordt het doden. ${ }^{68}$ Het 'bevrijdingsproces' met als startpunt de 'innerlijke omslag' en als eindpunt de 'innerlijke vrijheid', ${ }^{69}$ kan een langdurig proces zijn, waarin politie en openbaar ministerie, wanneer zij betrokken raken bij dit proces, een eigen verantwoordelijkheid hebben.

\subsubsection{Vrouwenmishandeling is een specifiek geweldsdelict}

Vrouwenmishandeling is een geweldsdelict, maar vrouwenmishandeling kan niet worden teruggebracht tot een eendimensionaal beeld over geweld binnen heteroseksuele relaties. Sociaal-psychologische factoren, verschillende vormen van macht en het gebruik van (dreigen met) geweld dragen bij aan de complexiteit van het fenomeen vrouwenmishandeling. Vrouwenmishandeling is daarom geen gewoon geweldsdelict. In drie opzichten kan mannelijk geweld tegen vrouwen in de privésfeer worden onderscheiden van andere geweldsdelicten.

65 Dutton \& Painter, Traumatic bonding, Victimology, 1981: 151. Herman toont aan dat mannen met name getraumatiseerd worden in de publieke sfeer van oorlogen, gijzelingen en politieke gevangenisschap terwijl vrouwen met name worden getraumatiseerd in de privésfeer. Het is pas sinds kort dat de ernst van traumatisering van vrouwen en kinderen in de privésfeer enigszins wordt erkend binnen de hulpverlening. Herman, Trauma en herstel, 1993: 9-74.

66 Ewing, Battered women who kill, 1987: 61-76.

67 Van Rappard, Tot hier en niet verder, 1988: 79-92.

68 Browne, When battered women kill, 1987: 128-130; Ewing, Batlered women who kill, 1987: 61-76; Schneider. Describing and changing, Women's right law reporter, 1986: 195-222.

69 Van Rappard, Tot hier en niet verder, 1988: 82. 
Het belangrijkste onderscheid is het feit dat er een intieme relarie bestaat tussen verdachte en slachtoffer; zij zijn emotioneel en sociaal-economisch afhankelijk van elkaar. Hoe het geweld als vorm van manifeste macht ook op andere niveaus van macht zijn uitwerking heeft, heb ik laten zien in $\S 2.2 .3$. Het geweld tegen de vrouw bevestigt de dominantie van de man, mede doordat vrouwen geneigd zijn de verantwoordelijkheid voor het geweld op zich te nemen. De preventiestrategieen die vervolgens worden gehanteerd, zijn vaak indirect en weinig succesvol, waardoor de negatieve afhankelijkheid wordt versterkt. Het tweede belangrijke onderscheid is het karakter van het geweld: het ernstige geweld vindt herhaaldelijk plaats, en staat vaak in een context van permanent aanwezige dreiging en angst. Dit veroorzaakt (ernstige) depressieve en psycho-somatische klachten en het breekt de weerbaarheid en besluitvaardigheid van de vrouw; het zelfrespect van de vrouw wordt hierdoor ondergraven. Vrouwen die jarenlang zijn mishandeld door hun partner, zijn emstig getraumatiseerd en hebben vaak een lange weg te gaan om te kunnen herstellen. Tot slot wordt het geweld binnen deze relaties zo goed mogelijk verborgen gehouden voor de buitenwereld, zowel door de man als door de vrouw. De privacy van de samenlevingsvorm betekent hier geheimhouding. De vrouw komt erdoor in een isolement, wat nog versterkt kan worden door dominantiegedrag van de man, waardoor wordt voorkomen dat de vrouw een eigen sociaal leven heeft. Een veilige sociale omgeving is een belangrijke voorwaarde om te kunnen herstellen en stappen te kunnen ondememen om uit de gewelddadige relatie te stappen. Maar zolang de dader zich binnen de sociale omgeving van het slachtoffer bevindt, ontbreekt deze veiligheid. "Bij rampen en bij gewone misdrijven spannen familie en vrienden van het slachtoffer zich meestal in om te zorgen voor veiligheid en geborgenheid. Maar bij seksueel geweld en geweld binnen het gezin blijf de onveiligheid van het slachtoffer vaak bestaan na de aanval. ${ }^{170}$ Wanneer de vrouw wel besluit weg te gaan, dan moet zij vaak een (groot) deel van haar sociale leven opgeven om de dader te ontlopen. Ook dan ontbreekt haar een veilige omgeving omdat ze eerst een nieuw sociaal leven moet opbouwen. Juist de combinatie van een toenemende negatieve athankelijkheid, het herhaald voorkomen van geweld en het isolement waarin de vrouw vaak zit, geven het geweld tegen vrouwen een specifiek karakter. ${ }^{71}$

70 Herman, Trama en herstel, 1993: 88.

71 Steinmetz en van Andel wijzen erop dat aangiften van mannen die zijn mishandeld vaak emstiger fysiek letsel betreffen dan aangiften van vrouwen die zijn mishandeld door hun (ex-)parner, maar dat door het regelmatige karakter van de mishandeling door de (ex-)partner de psychische schade voor vrouwen emstig kan zijn. Mishandeling en hulpwerlening, 1994: 18 (onder noot 4). 


\subsection{De inzet van het strafrecht}

In de jaren tachtig heeft een heftige discussie gewoed in de vrouwenbeweging over de inzet van het strafrecht. Grofweg zijn twee posities te onderscheiden: de radicaalkritische ${ }^{72}$ positie en de reformistische positie. De radicalen geloven niet dat het recht gebruikt kan worden om wezenlijke veranderingen te bewerkstelligen; feministische claims als het recht op persoonlijke zelfbeschikking worden door het recht vervormd en beperkt. Radicaal-kritische feministen zullen zich daarom eerder buiten het recht plaatsen of andere wegen dan het recht benadrukken. Dit wordt ook wel de "exit'-benadering genoemd. ${ }^{73}$ Daar tegenover staat de reformistische positie die weliswaar de gevaren erkent die kleven aan de transformatie van behoeften en waarden van vrouwen in rechtsregels, maar desondanks toch de macht van het recht wil gebruiken om de positie van vrouwen te veranderen en andere waarden onder het recht te brengen (het juridiseringsdilemma). Het recht kan ook een positief ondersteunend effect hebben in een sociaal proces waarin de machtsverhoudingen tussen de seksen verschuiven. ${ }^{74}$ Dit wordt ook wel de 'voice'-benadering genoemd, het stem geven aan de ervaringen van vrouwen in het strafrecht. ${ }^{75}$ Het belangrijkste verschil tussen de twee posities over het gebruik van het strafrecht laat zich het beste samenvatten in twee statements: 'vrouwen moeten hun onafhankelijkheid bewaren' en 'liberalisering van het strafrecht zal de onderdrukking van vrouwen verscherpen'.

\subsection{1 'Vrouwen moeten hun onafhankelijkheid bewaren'}

De radicaal-kritisch feministen benadrukken dat het strafrechtelijk systeem als een repressief apparaat functioneert ter handhaving van de maatschappelijke orde. Deze handhaving vindt selectief plaats, aangezien het met name de zwaksten in de samenleving zijn die de gevolgen van strafbaarstelling en bestraffing voelen (klassejustitie). Het opleggen van gevangenisstrafkan geen positieve bijdrage leveren aan het vergroten van de autonomie van vrouwen, aangezien de gevangenisstraf zinloos en vernederend is en de gevangeniscultuur het stereotype beeld van vrouwen als lustobect alleen maar versterkt. ${ }^{76}$ Het strafsysteem kan worden aangeduid met de termen: hiërarchie, dwang, geweld, onderdrukking, bevestiging van rolpatronen,

72 Radicaal feministen zijn zij die vrouwen en mannen als essentieel verschillend definierren, terwijl radicaal-kritische feministen geen essentialistisch mensbeeld hoeven te hebben. Zij propageren een revolutionair andere wereld waar macht over mensen in de zin van overheersing en dominantie als negatief wordt gewaardeerd en macht als creatief proces als positief. Zie: Pessers, Radicalisme versus reformisme, Nemesis, 1994: 177; Bell Hooks, Macht in een ander licht, Nemesis, 1986: 105-110.

73 Hes, Een relatieve buitenstaander aanschouw het veld van juridische vrouwenstudies, 1995.

74 Pessers, Radicalisme versus reformisme, Nemesis, 1994: 177; Goldschmidt \& Holtmaat, Vrouw en recht, 1993: 53-56.

75 Hes, Een relatieve buitenstaander aanschouwt het veld van juridische vrouwenstudies, 1995.

76 Verrijn Stuart, Hakken, hakken, hakken, hakken, De Groene Amsterdammer, 14 maart 1984; Los, Feminism and rape law reform, in: Feminist perspectives, 1990: 168. 
aanpassing en beheersing. ${ }^{77}$ Daarom wordt voor decriminalisering en depenalisering gepleit, dat wil zeggen minder gedragingen als strafbaar gedrag definiëren en vaker buiten het strafrecht om strafrechtelijk gedrag afdoen. Als er al gebruik gemaakt moet worden van het strafrecht, dan moet dit zeer terughoudend gebeuren. ${ }^{78}$

Gewezen wordt op het gevaar van expansie door een beroep te doen op het strafrecht. De vraagkant van het strafrechtssysteem wordt vergroot doordat vrouwen sinds de jaren tachtig sneller aangifte doen van verkrachting en van geweld binnenshuis. ${ }^{79}$ De huidige slachtoffervoorzieningen kunnen deze vraagkant verder vergroten. Bovendien wordt het aantal strafbare gedragingen uitgebreid door strafbaarstelling van verkrachting binnen het huwelijk ${ }^{80}$ en kan door het bestanddeel 'ontucht' ruimer te interpreteren, het aantal gedragingen dat onder de strafwet valt, worden vergroot (criminalisering). Daarnaast worden hogere straffen opgelegd door bijvoorbeeld verkrachting hoger op de schaal van ernst te zetten (penalisering). Deze expansie van het strafrecht verandert niets aan de marginale positie van slachtoffers van vrouwenmishandeling. Vrouwenmishandeling blijft als maatschappelijk probleem gemarginaliseerd en gedepolitiseerd. ${ }^{81}$ Strafrechtelijke afkeuring van geweld tegen vrouwen is daarom niet meer dan een symbolische afkeuring. De wijze waarop geweld tegen vrouwen wordt gedefinieerd binnen de strafwet en de wijze waarop de strafwet zal worden toegepast, zal (ver) afstaan van de definiëring van het geweld door de vrouwenbeweging. ${ }^{82}$ Door (uitbreiding van) strafbaarstelling kan de rol van vrouwen als slachtoffer van geweld worden versterkt, maar het verzet van vrouwen tegen het geweld hen aangedaan zal er door worden gekanaliseerd; er wordt gedacht en gehandeld binnen de marges van het strafrechtelijke systeem. ${ }^{83}$ " $[\mathrm{H}] \mathrm{et}$ verlangen naar autonomie en individualisering loopt uit op vergaande regulering

77 Verrijn Stuart, Vrouwen en strafrecht, het onverzadigbare slachtoffer en de onverzadigbare justitie, in: à Tort et à Travers, 1988: 218

78 In die zin behoren de radicaal-kritische feministen tot de kritische criminologen en strafrechtjuristen, die vanuit de liberaliseringsgedachte hier ook voor pleiten.

79 Van den Brink, Met het straatverbod in kort geding op de goede weg? Recht en Kritiek, 1987: 385. Tussen 1978 en 1982 is de registratie bij de politie van verkrachting met $40 \%$ toegenomen en de registratie van aanranding nam met ongeveer $25 \%$ toe. Soetenhorst-de Savornin Lohman \& Jansz, Seksueel geweld zal de wetgever een zorg zijn, 1986: 100; Van Kalleveen, Geweldsmisdrijven in de statistieken, Kwartaalrechisbescherming en veiligheid CBS, 1994: 18-19.

80 In 1991 is het bestanddeel 'buiten echt' geschrapt uit het verkrachtingsartikel. Sib. 1991, nr. 519

81 Een vorm van marginalisering is de medicalisering. "Je kunt die uitzondering ook gek verklaren. Een verdachte die toegeeft een problematische verhouding met zijn moeder te hebben en dat als verklaring opgeeft voor zijn haat tegen vrouwen in het algemeen wordt als afwijkend beschouwd. Zijn verhaal wordt niet politiek vertaald als sexisme dat geworteld is in onze kultuur, (...)." Verrijn Stuart, Strafrecht tegen seksueel geweld? Een illusie! De Groene Amsterdammer, 13 juni 1984: 9.

82 Los, Feminism and rape law reform, in: Feminist perspectives, 1990: 168. Dit neemt niet weg dat symbolische afkeuring noodzakelijk kan zijn, zegt Dorie Klein in cen interview. Andriessen, We moeten de realiteit van vrouwenlevens begrijpen, $T v C, 1982: 137$.

83 Isarin, Misdaad als straf, straf als misdaad, Nemesis, 1984/85: 351-352. Soetenhorst, Meer dan een belangenstrijd, Nemesis, 1984/85: 358-360. 
en controle." ${ }^{\text {"84 }}$ Deze vergaande regulering en controle weegt, aldus de radicaalkritische feministen, niet op tegen het belang van de waarden-expressieve functie van het strafrecht.

Radicaal-kritische feminsten waarschuwen bovendien tegen het vasthouden aan de slachtofferrol door vrouwen. Gewezen wordt op het gevaar van 'slachtofferisme', ${ }^{85}$ dat wil zeggen dat vrouwen zich beroepen op hun rol van slachtoffer ${ }^{86}$ in plaats van te zoeken naar manieren om hun autonomie te versterken. Een ander kenmerk van slachtofferisme is dat vrouwen een gefragmenteerd wereldbeeld hanteren door zich alleen als belangenbeweging voor bepaalde groepen vrouwen op te werpen: de ene groep vrouwen komt op voor een verbetering van de positie van het slachtoffer van seksueel geweld binnen het strafrecht, de andere groep propageert gelijke behandeling van vrouwelijke en mannelijke verdachten en de derde groep wijst op de dubbele onderdrukking van gedetineerde vrouwen, zonder zich rekenschap te geven van het geheel. De verschillende belangen staan namelijk veelal haaks op elkaar; wat voor de een winst betekent, kan voor de ander verlies betekenen. Dit slachtofferisme leidt tot een onverzadigbare behoefte van slachtoffers aan genoegdoening waar justitiële autoriteiten (en anderen, zoals hulpverleners) zorg voor moeten dragen. Verrijn Stuart pleit ervoor dat vrouwen mede-verantwoordelijkheid op zich moeten nemen voor het strafrecht als geheel, en zich niet alleen moeten opwerpen als belangenbeweging. ${ }^{87}$

Radicaal-kritische feministen benadrukken de kracht en zelfstandigheid van vrouwen, die verder moet worden ontwikkeld door het versterken van zelfrespect en het creatief gebruiken van macht. ${ }^{88}$ Niet het aanpassen aan het systeem, maar de eigen waarden als respect voor persoonlijke zelfbeschikking, zelfrespect, zorg en verantwoordelijkheid voor elkaar, en eigenzinnigheid moeten worden versterkt buiten het bestaande systeem om. Vrouwen moeten zichzelf bevrijden is het motto in de jaren tachtig. ${ }^{89}$ Het strafrecht moet niet worden ingezet als instrument. De vrouwenbeweging behoort als kritische, analyserende, anti-autoritaire groep geen

84 lbidem: 361

85 Degene die deze term introduceerde was Bemadette de Wit in: Het slachtoffer is koning, Nemesis, 1986: 64-65.

86 Het is van belang onderscheid te maken tussen slachtofferpositie, die vrouwen hebben op het moment dat ze worden verkracht of mishandeld, en het innemen van een slachtofferrol, die vrouwen kunnen innemen in situaties waar geen sprake hoeft te zijn van een slachtofferpositie. Het innemen van een slachtofferrol is in zekere zin een keuze.

87 Verrijn Stuart, Vrouwen en strafrecht, het onverzadigbare slachtoffer en de onverzadigbare justitic, in: à Tort et à Travers, 1988: 216-218; Verrijn Stuart, Naar een geciviliseerd recht tegen sexueel geweld, $A A, 1992: 84$.

88 Verrijn Stuart, Vrouwen en strafrecht, het onverzadigbare slachtoffer en de onverzadigbare justitic, in: à Tort et à Travers, 1988: 216. Bell Hooks, Macht in een ander licht, Nemesis, 1986: 105-110.

89 Het vrijheidsbeginsel biedt meer perspectief dan het gelijkheidsbeginsel. "[H]et vrijheidsbeginsel is belangrijker omdat het vrouwen confronteert met hun eigen onderdrukking en met de mogelijkheden die zij zelf hebben om zich een beter bestaan op te bouwen." Prakken, Vrijheid of gelijkheid, Nemesis, 1984/85: 347. 
gebruik te maken van het strafrecht. "Feministen kunnen niet serieus menen dat onderdrukking, dwang en geweld leiden tot de opheffing van onderdrukking, dwang en geweld." 90

\subsection{2 'Liberalisering van het strafrecht zal de onderdrukking van vrouwen verscherpen'}

Aanhangers van de 'voice'-benadering plaatsen een kanttekening bij decriminalisering en depenalisering. Als vrouwen zich afkeren van het strafrecht en decriminalisering en depenalisering bepleiten van die gedragingen waar juist vrouwen onder te lijden hebben, wordt niet de positie van vrouwen versterkt, maar juist de positie van plegers van seksueel geweld en vrouwenmishandeling; zij hebben er baat bij als politie en justitie niet optreden. ${ }^{91}$

Het gebruik van het strafrecht is voor reformistische feministen een van de middelen die vrouwen ter beschikking staan om zich te verdedigen tegen het geweld van mannen; het strafrecht dient de bescherming te bieden die voortvloeit uit het feit dat het hier geweldsmisdrijven betreft. Hoewel erkend wordt dat het strafrecht een beperkte rol heeft ter bescherming van slachtoffers, moet deze bescherming voor mannen en vrouwen gelijk zijn; vrouwen moeten evengoed tegen geweld door hun partner worden beschermd als mannen tegen geweld in de kroeg. Er wordt op gewezen dat criminalisering en penalisering van misdrijven die juist vrouwen betreffen, kan worden verdedigd met het argument dat het hier een groep betreft die in een structureel zwakkere positie zit. "Men zou het nemen van het risico om een bepaalde groep slachtoffer te laten zijn van extra criminalisering kunnen rechtvaardigen met een beroep op het feit dat de voorgestelde maatregel beoogt de allerzwakste binnen die groep te beschermen tegen de relatief sterkere binnen diezelfde groep. ${ }^{192}$ Dit sluit aan bij het citaat in de aanzet van dit hoofdstuk: hoewel aanhangers van de 'voice'-benadering in het algemeen voor decriminalisering zijn, bepleiten ze criminalisering van bepaalde misdrijven tegen vrouwen en kinderen. ${ }^{93}$

Aanhangers van de 'voice'-benadering benadrukken de waarden-expressieve functie van het strafrecht; strafrechtelijke normering geeft aan dat het om maatschappelijk afkeurenswaardig gedrag gaat. Strafrechtelijke regulering van geweld tegen vrouwen door hun partner doorbreekt de ideologie dat dit huiselijke geweld de

90 Verrijn Stuart, Vrouwen en strafrecht, het onverzadigbare stachtoffer en de onverzadigbare justitie, in: à Tort el à Travers, 1988: 218; Zie ook: Soetenhorst, De moeilijke weg, culturele aspecten van het verkrachtingsvraagstuk, in: Vrouwen en Justitie, 1984: 12.

91 Gaikhorst \& Meinen, De omstreden vervolging van een eeuwenoude onderdrukking, in: Vrouwen en justitie, 1984: 22.

92 Wirken, Denken over seksueel geweld, een enclave in het abolitionisme?, Nemesis, 1984/85: 366.

93 Ter Heide bepleitte in 1972 juridisering en criminalisering van bepaalde gedragingen, bijvoorbeeld 'witte-boordencriminaliteit'. Ter Heide, Dejuridisering en dekriminalisering: $D D, 1972 ;$ 72-86. 
privésfeer betreft waar alleen het familierecht een rol zou kunnen spelen." "It is my view that the law has an important symbolic function to play and that a society which presses for changes without at the same time expressing and codifying these sentiments within its legislative framework cannot effect any real change. Indeed, the law is the most symbolically powerful tool we have at our disposal." ${ }^{95} \mathrm{Zij}$ hechten waarde aan de normerende functie van het strafrecht, zowel in de zin van het strafbaargestelde gedrag, als in de zin van strafrechtelijk optreden. "Nonenforcement of the law may convey the message that wife-assault is acceptable, that public sanctions are inappropriate, and that women may remain in a position of powerlessness against their partners' violence and control." ${ }^{16}$ Tot slot wordt gesteld dat een strafrechtelijke reactie eraan kan bijdragen dat daders van geweld worden geconfronteerd met hun gedrag. Over het algemeen zullen zij hun gewelddadige handelingen ontkennen, bagatelliseren of rechtvaardigen (zie $\S 2.2 .3$ ). Toch kan een strafrechtelijke stok achter de deur mannen ertoe bewegen iets aan hun geweldadige gedrag te doen, bijvoorbeeld via de ambulante hulpverlening. ${ }^{97}$

De reformistische feministen gaan ervan uit dat het strafrechtelijke systeem weliswaar de machtsverhoudingen binnen de maatschappij symboliseert, maar dat dit strafrechtssysteem niet statisch en homogeen is; het bestaat uit een veelheid van regels en normen. Dit schept mogelijkheden voor de vrouwenbeweging om als maatschappelijke beweging haar eigen normen en voorwaarden op de voorgrond te plaatsen. Met concrete eisen kan de vrouwenbeweging haar invloed aanwenden op de strafrechtelijke regulering van (seksueel) gewelddadig gedrag. ${ }^{98}$ De rechtswaarborgen van de verdachte ten opzichte van de staat staan niet ter discussie, maar het denken in termen van de verdachte tegenover het openbaar ministerie in het strafproces moet wel worden doorbroken; het gaat niet alleen om rechtswaarborgen voor de verdachte, ook het slachtoffer behoort aandacht te krijgen als een mens met elementaire rechten. Binnen de huidige mogelijkheden van het strafrechtelijke systeem behoren de belangen van slachtoffers een plaats te krijgen. Soms zal wetswijziging, die past binnen het huidige strafrechtssysteem, gewenst zijn. ${ }^{99}$

94 Edwards, Violence against women, in: Feminist perspectives in criminology, 1990: 155.

95 Ibidem: 148.

96 Hilton, One in ten, Canadian jrnl of family law, 1988' 89 : 331.

97 Waits, The criminal justice system's response to battering, Washington Law Review, 1985: 278. Zie voor deze problematiek: Haveman \& Staffeleu, Daders van seksueel ge weld: straffen of behandelen, 1990.

98 Goudt \& van Herk, Vrouwe Justita is geen muurbloempje, De Groene Amsterdammer, 4 juli 1984: 13; Smits, Wie is er bang voor het strafrecht? Nemesis, 1986: 213; Hilton, One in ten, Canadian jinl of family life, 1989: 314-315.

99 Visser, Veranderenddenken over wetstoepassing bijseksuele delicten, in:Strafbare seksualiteit, 1986: 100-111; Smits, Wie is er bang voor het strafrecht? Nemesis, 1986: 213. 


\subsubsection{Van radicale kritiek tot hervorming}

Op het eerste gezicht lijkt er een duidelijke tegenstelling tussen beide visies. Aanhangers van het radicaal-kritische perspectief benadrukken dat het strafrecht slachtoffers van (seksueel) geweld niets heeft te bieden. Elke wettelijke verandering of verandering van beleid zal uiteindelijk worden beoordeeld als aanpassing aan de status quo. De aanhangers van de 'voice'-benadering keren zich niet geheel van het strafrecht af. $\mathrm{Zij}$ beoordelen veranderingen naar de eventuele verschuivingen in de machtsverhoudingen tussen de seksen of de symbolisering daarvan.

$\mathrm{Bij}$ nader inzien hangt het verschil in visie vooral samen met een verschil in analyseniveau. Een analyse van een maatschappelijk fenomeen verschilt van een analyse op individueel of concreet niveau, terwijl de verbinding tussen beide niveaus niet altijd makkelijk te maken is. ${ }^{100}$ Het hangt van het niveau van analyse af hoe ontwikkelingen in het strafrechtelijke beleid of wetswijzigingen worden beoordeeld. Vanuit het radicaal-kritische perspectief worden de nieuwe slachtoffervoorzieningen binnen het strafrecht negatief beoordeeld omdat deze de status quo van het strafrecht niet aantasten. Bovendien wordt het slachtoffer erdoor bevestigd in haar slachtofferrol. Toch kunnen op individueel niveau deze nieuwe slachtoffervoorzieningen slachtoffers soms baat brengen, wat wordt benadrukt vanuit de 'voice'-benadering. ${ }^{101}$ Een ander voorbeeld betreft het strafbaar stellen van gedwongen geslachtsgemeenschap binnen een huwelijkse relatie. Dit is een vorm van criminalisering waardoor de greep van het strafrecht op gedragingen van mensen binnen de privésfeer is vergroot. Toch wordt deze wetswijziging niet alleen door de reformistische feministen positief gewaardeerd, ook radicaal-kritische feministen hebben geen negatief commentaar op deze wetswijziging geschreven. ${ }^{102}$

De vertaling van een feministische analyse naar een juridische procedure is in de praktijk. een proces met haken en ogen. Zodra eisen worden gesteld aan de overheid door de vrouwenbeweging gaat de zeggenschap over de definiëring en aanpak van de problematiek van vrouwenmishandeling verloren. De discussie wordt dan verlegd van de politieke analyse naar de feiten en professionele aanpak. Hilton stelt over de Canadese aanpak van vrouwenmishandeling door de overheid: "Attention was directed to official facts and figures, not on the underlying system which supports abuse: patriarchy. The issue was downplayed as a political question. (...)

100 Dit verschil in analyseniveau komt ook naar voren met betrekking tot geweld tegen vrouwen als sociaal fenomeen: elk geweld is zowel een uiting van een sociaal probleem als een persoonlijke daad van een individu (zie $\$ 2.2$ ).

101 Dat de maatregel op individueel niveau bruikbaar is, wordt overigens wel erkend door radicaalkritische feministen. Kool stelt bijvoorbeeld dat de slachtoffervoorzieningen binnen het strafrecht schijnvoorzieningen zijn, wat niet wegneemt dat het op individueel niveau kritisch gebruik maken ervan onvermijdelijk is. Kool, Over schijn en werkelijkheid, Nemesis, 1989: 7.

102 Wel wordt de symbolische waarde van de wetswijziging, in die zin dat de wet nauwelijks zal worden toegepast, benadrukt. 
Women had raised their voices, they had at least been heard by Parliament and the attention was welcome. However, women's efforts to politicize wife assault was immediately undermined by the governement. The powerlessness to which women had been calling attention was recognized as a problem, but the political response was aimed not at increasing their voice; rather the governement adopted a paternalistic position and acted on behalf of women." ${ }^{103}$ Dit duidt op het "juridiseringsdilemma': ${ }^{104}$ zodra er eisen worden gesteld aan de overheid om het maatschappelijke probleem van vrouwenmishandeling zichtbaar te maken in het strafrecht en adequate maatregelen te nemen, vindt een transformatieproces plaats van een politieke analyse naar een juridisch relevant probleem. In dit proces gaan veel feministische inzichten verloren. Maar geen stem geven aan vrouwenmishandeling binnen het strafrecht betekent dat slachtoffers van vrouwenmishandeling nauwelijks kunnen worden beschermd door strafrechtelijk ingrijpen.

Zowel radicaal-kritische als reformistische feministen erkennen dat het strafrecht niet omgevormd kan worden tot een feministisch instrument ter bescherming van slachtoffers van vrouwenmishandeling. Het verschil in perspectief is daarom meer een verschil in waardering dan een tegenstelling. Dit verschil in waardering uit zich op twee terreinen. De verwachtingen ten aanzien van de vrouwenbeweging verschillen: vanuit de radicaal-kritische benadering zal worden benadrukt dat de vrouwenbeweging zich niet moet richten op het strafrechtelijke stelsel omdat de slachtofferrol van vrouwen erdoor wordt versterkt in plaats van de autonomie van vrouwen, terwijl vanuit de 'voice'-benadering zal worden benadrukt dat de vrouwenbeweging eisen moet stellen aan het justitiële apparaat, zodat justitiěle autoriteiten rekening zullen gaan houden met de specifieke positie en belangen van vrouwen. Tevens zullen radicaal-kritische feminsten met name benadrukken dat de culturele aspiraties van het feminisme niet worden verwezenlijkt met rechtshervormingen, terwijl reformistische feministen, die zich inspannen voor kleine veranderingen in de strafrechtelijke normering of rechtshandhaving ten gunste van slachtoffers van vrouwenmishandeling, kleine veranderingen positief zullen beoordelen.

Beide benaderingen zijn nodig om tot maatschappelijke verandering te komen. Een radicaal-kritische benadering om voeling te houden met de feministische aspiraties, en de 'voice'-benadering om de feministische aspiraties vorm te geven in de alledaagse rechtspraktijk. Radicalisme kan zo overgaan in reformisme, al zal er altijd een spanning tussen beide posities blijven bestaan. ${ }^{105}$

103 Hilton, One in ten, Canadian jrnl of family law, 1989: 327. Zie ook: Los, Feminism and rape law reform, in: Feminist perspectives in criminology, 1990: 165; Ferraro \& Pope, Itreconcilable differences, battered women, police and the law, in: Legal responses to wife abuse, 1993: 98-123.

104 Zie hoofdstuk $1, \S 1.2 .3$.

105 Pessers, Radicalisme versus reformisme, Nemesis, 1994: 177. 


\subsection{Kritiek op de strafrechtelijke aanpak van geweld tegen vrouwen}

Uit de analyse dat vrouwenmishandeling moet worden beschouwd als een geweldsdelict, vloeit voort dat de aandacht zich niet alleen richt op opvang en hulpverlening aan vrouwen die geweld ondervinden door hun partner, maar dat ook het optreden van politie en justitie aan de kaak wordt gesteld. Dit gebeurt in de jaren tachtig door het voeren van acties, het organiseren van congressen en het schrijven van openbare brieven. ${ }^{106}$ Vrouwen eisen een zorgvuldige bejegening en een daadwerkelijke aanpak van geweld in de privésfeer. De meer pamflettistische documenten uit die tijd geven goed de kern van het probleem aan. Met name aan de hand van deze documenten zal de kritiek op politie en openbaar ministerie worden weergegeven. ${ }^{107}$

\subsubsection{Kritiek op politie en openbaar ministerie}

Een belangrijk kritiekpunt in de jaren tachtig betreft de bejegening van vrouwen die aangifte doen bij de politie. Als de vrouw aangifte doet van mishandeling door haar partner of ex-partner, wordt de vrouw ontmoedigd in het doorzetten van de aangifte. "[E]en vrouw moet minstens twee keer naar het bureau komen, willen ze zelfs maar een procesverbaal opnemen." ${ }^{108}$ Wanneer de vrouw de aangifte doorzet, doet de politie in veel gevallen niet veel moeite om meer bewijs te vergaren. ${ }^{109}$ Als het een aangifte betreft van verkrachting, worden door de politie onnodig pijnlijke vragen gesteld, de vrouw wordt soms behandeld alsof het haar eigen schuld is - ze zal wel aanleiding hebben gegeven - en er wordt weinig rekening mee gehouden dat verkrachting door een bekende, evenals verkrachting door een onbekende, een zeer pijnlijke of traumatische ervaring kan zijn. ${ }^{110}$ Ook de wijze

106 Sirijdpunten en akties, Aktiegroep Blijf van m'n Lijf Den Haag 1983.

107 Jaanerslag Blijf van $m$ ' $n$ Lijf Zwolle, 1985: Corten e.a., Geweld tegen vrouwen: (gjeen zaak voor politie en justitie?, 1985: Blijf van m'n Lijf Eindhoven, Vrouwenmishandeling aanklagenswaardig. aanklacht regen een falend politie- en justitiebeleid, 1985; Blijf van m'n Lijf Amsterdam, Thuis geslagen, mevrouw? Dan ... kunnen wij niets doen, 1984; Van Bakel \& Rienstra, Van achter gesloten deuren, 1987.

108 Van Rappard, Vrouwen willen hun man niet in het gevang, ze willen dat het geweld stopt, in: Thuis geslagen mevrouw?, 1984: 26; Etty, Mishandelde vrouwen kunnen het beleid van politie en justitie veranderen, in: Thuis geslagen, mevrouw?, 1984: 96.

Wanneer vrouwen naar het politiebureau gaan om aangifte te doen, wordt hun verhaal in $18 \%$ van de gevallen omgezet in een proces-verbaal. Wanneer mannen aangifte doen van mishandeling door een onbekende wordt er in $50 \%$ van de gevallen een proces-verbaal opgemaakt. Steinmetz \& Andel, Mishandeling en hulpverlening, 1984: 18. Ook Zoomer constateert dat in geval van vrouwenmishandeling minder snel wordt overgegaan tot het opmaken van een proces-verbaal of het aanhouden van de verdachte dan in andere gevallen van mishandeling. Zoomer, Vrouwenmishandeling; politie werk, 1990: 25-27.

109 Corten e.a., Geweld tegen vrouwen: (g)een zaak voor politie en justitie?, 1985: 18.

110 Davelaar-van Tongeren, Verkrachting. Strafrechter wat moet je ermee?, in: Strafrecht in perspectief, 1980: 108-117: Bouw e.a., Samen legen sexueel geweld, 1990: 21. 
waarop de surveillancepolitie omgaat met meldingen van vrouwenmishandeling wordt bekritiseerd; geweld tegen de vrouw door haar man of vriend wordt veelal afgedaan als een 'ruzie tussen echtelieden', 'een huiselijke twist' of 'een uit de hand gelopen ruzie'. De politie sust en bemiddelt en treedt doorgaans terughoudend op als ze na een melding van vrouwenmishandeling op de plaats van bestemming aankomt. ${ }^{111}$

De politie treedt te weinig strafrechtelijk op als er sprake is van vrouwenmishandeling of verkrachting door een bekende, is een ander kritiekpunt. Er wordt zelden ambtshalve proces-verbaal opgemaakt van geconstateerd letsel en geconstateerde ravage en de man wordt zelden meegenomen voor verhoor. ${ }^{112}$ Wanneer wel strafrechtelijk wordt opgetreden, wordt vooral gekeken naar het incident waarvan aangifte wordt gedaan. De politie richt zich op het rond krijgen van het bewijs van die ene mishandeling, vernieling of verkrachting, zonder dit incident in de context van jarenlang geweld te plaatsen. Op die manier wordt te weinig aandacht besteed aan het langdurige karakter van de mishandeling en de specifieke problemen die daarmee samenhangen; de ernst van het geweldsdelict wordt niet onderkend. ${ }^{113}$

De kritiek op het openbaar ministerie betreft de informatievoorziening en het vervolgingsbeleid. Wanneer het slachtoffer aangifte heeft gedaan, wordt het niet op de hoogte gehouden van het verloop van de procedure; het slachtoffer wordt over allerlei zaken, zoals de instelling van een vervolging en de tijd van de terechtzitting, niet of te laat geïnformeerd. ${ }^{114}$ Bovendien houdt het openbaar ministerie te weinig rekening met de belangen van het slachtoffer tijdens de strafrechtelijke procedure. Bijvoorbeeld wordt er te weinig rekening gehouden met het belang dat een slachtoffer heeft bij het wel of niet optreden als getuige. Er is kritiek op de wijze van ondervragen; er worden onnodig pijnlijke vragen gesteld of insinuerende vragen door de advocaat van de verdachte. Ook wordt erop gewezen dat het meerdere keren moeten getuigen voor de vrouw zeer pijnlijk kan zijn omdat ze de verkrachting weer herbeleeft (secundaire victimisatie). ${ }^{115}$ Maar in andere gevallen is het juist van

111 Van Blokland \& Geurts, Thuis geslagen mevrouw? in: Thuis geslagen, mewrouw?, 1984: 46.

112 Corten \& Goudswaard, Geweld tegen vrouwen: (g)een zaak voor politie en justitie?, 1985: 18; Blijf van m'n Lijf Eindhoven, Vrouwenmishandeling aanklagenswaardig, 1985: 21; Van Rappard, Vrouwen willen hun man niet in het gevang, in: Thuis geslagen, mevrouw?, 1984: 24-26.

113 Wostmann, Elke situatie is anders, TvP, 1988: 256-257; Wostmann, Politieoptreden bij vrouwenmishandeling, 1988:49-116; Cachet, Politie en sociale controle, 1990: 193-235.

114 Blijf van m'n Lijf Eindhoven, V'rouwenmishandeling, aanklagenswaardig 1985: 30-35. Doomen, Seksueel geweld - wat vermag het recht?, in: Strajbare seksualiteit, 1986: 89-90.

115 Davelaar-van Tongeren, Verkrachting. Strafrechter wat moetje ermee?, in: Strafrecht in perspectief, 1980: 116. 
belang dat vrouwen die slachtoffer zijn van vrouwenmishandeling wel als getuige ter terechtzitting kunnen optreden als zij dit willen. ${ }^{116}$

Het openbaar ministerie seponeert meestal om de relatie of het gezin in stand te houden, is een veelgehoorde kritiek." "Vrouwenmishandeling heeft een lage prioriteit bij justitie. Bij lichte mishandeling wordt er nauwelijks, bij zware mishandeling wordt er iets vaker vervolgd en bij moord wordt het pas ernstig."118 Hierdoor wordt niet de vrouw beschermd, maar de man. ${ }^{119}$ Ook zaken van verkrachting die niet voldoen aan het stereotype 'enge man uit de bosjes' worden vaak geseponeerd, en als er wel wordt vervolgd, dan wordt het seksuele zelfbeschikkingsrecht niet als uitgangspunt genomen. Bovendien staan de straffen die worden geesist niet in verhouding tot de ernst van het delict. ${ }^{120}$

\subsubsection{Aanbevelingen voor een andere strafrechtelijke aanpak}

Naast het leveren van kritiek, worden ook een aantal aanbevelingen gedaan die een zorgvuldige bejegening, informatieverstrekking, een voortvarender strafrechtelijk ingrijpen en registratie van mannelijk geweld tegen vrouwen in de privésfeer betreffen. Een deel van deze aanbevelingen is eind jaren tachtig en begin jaren negentig omgezet in overheidsbeleid.

Allereerst wordt een zorgvuldiger bejegening van slachtoffers van vrouwenmishandeling en verkrachting geesist. Op het moment dat de vrouw het politiebureau binnenstapt om aangifte te doen is het van belang dat zij goed wordt opgevangen, dat zij haar verhaal rustig mag doen en dat de mogelijkheid wordt geboden verhoord te worden door een vrouwelijke rechercheur. Aan een aangifte van vrouwenmishandeling gaat meestal een melding van vrouwenmishandeling vooraf. Een zorgvuldiger bejegening houdt in dat geval in dat direct assistentie wordt verleend als er een melding 'vrouwenmishandeling' binnenkomt en de agenten ter plekke de gesprekken met de man en de vrouw gescheiden voeren, zodat werkelijk geluisterd kan worden naar het verhaal van de vrouw. ${ }^{121}$ Voorkomen moet worden dat de

116 Jaarverslag Blijf van $m$ ' $n$ Lijf Zwolle, 1985: 41; Ketelaars \& Slotboom, De gevonden waarheid, beelden in het strafrecht bij vrouwenmishandeling, Nemesis, 1993: 108-115; Van Driem, Haar was recht gedaan, in: Het klappen van de zweep, 1994: 119-120.

117 Van Bakel \& Rienstra, Van achter gesloten deuren, 1987: 88, 100; Acker \& Rawie, Seksueel geweld tegen vrouwen en meisjes, 1982: 51; Romkens, Vrouwenmishandeling, 1986: 130; Blijf van m'n Lijf Eindhoven, Vrouwenmishandeling aanklagenswaardig, 1985: 17, 31-35.

118 Van Blokland \& Geurts, Thuis geslagen mevrouw?, in: Thuis geslagen, mevrouw?, 1984: 47.

119 Blijf van m'n Lijf Eindhoven, Vrouwenmishandeling aanklagenswaardig, 1985: 33-35. Van Rappard, Vrouwen willen hun man niet in het gevang, in: Thuis gesiagen, mevrouw?, 1984: 28.

120 Doomen, Aangifte van verkrachting, $N J B, 1982: 453$.

121 In het algemeen ontkent de man zijn verantwoordelijkheid voor het geweld terwijl de vrouw de schuld op zich neemt. Als de aandacht zich richts op het (echt)paar, dan bestaalt het gevaar dat de aandacht wordt afgeleid van de daden van de man naar de activiteiten van de vrouw. Waits, The criminal justice system's response to battering, Washington Law Review, 1985: 305. 
verantwoordelijkheid voor het stoppen van het geweld alleen bij de vrouw komt te liggen, bijvoorbeeld door haar erop te wijzen dat ze naar een opvanghuis kan gaan, of dat zij haar ex-partner niet meer mag binnenlaten. ${ }^{122}$ Bovendien moet de wijkagent op de hoogte worden gebracht zodat hij ondersteunend kan optreden. $^{123}$

Een informatieverplichting over het verloop van de procedure is een tweede vereiste. De vrouw behoort goed te worden geïnformeerd over de consequenties van een strafrechtelijke procedure en gewezen te worden op de civiele mogelijkheid van een kort geding, zodat de vrouw desgewenst een straatverbod of een schadevergoeding kan eisen. Ook moet de vrouw op de hoogte worden gebracht van de mogelijkheid een schadevergoeding te eisen door zich te voegen als benadeelde partij. Daarnaast is informatie over het verloop van de strafprocedure gewenst. ${ }^{124}$ Het is met name van belang dat de vrouw op de hoogte is van de vrijlating van de verdachte of dader, zodat zij tijdig een straat- of contactverbod kan eisen in kort geding als dat noodzakelijk is voor haar verwerking van het gebeurde of voor haar gevoel van veiligheid. ${ }^{125}$ Gepleit wordt voor een versterking van het recht op inzage in de processtukken als de vrouw zich heeft gevoegd in het strafproces. Inzage in psychiatrische- en reclasseringsrapporten is van belang voor het slachtoffer om zicht te krijgen op eventuele recidive van de verdachte en om de immateriële schade te kunnen onderbouwen. ${ }^{126}$ Tot een zorgvuldige bejegening en informatieverstrekking behoort een uitnodiging van de officier van justitie voor een gesprek als het slachtoffer daar behoefte aan heeft. "Het valt te overwegen om bij ernstige seksuele - en ook agressieve - delicten het contact tussen slachtoffer en het openbaar ministerie niet afhankelijk te stellen van de persoon van de officier, maar daar een vaste vorm voor te creëren." 127 In dat gesprek kan de vrouw haar verhaal vertellen, en zij kan te kennen geven welke sanctie haar voorkeur heeft. De officier van justitie kan haar uitleggen wat de mogelijkheden en beperkingen zijn en bij een vervolging kan het verhaal van het slachtoffer doorklinken in het requisitoir. ${ }^{128}$ Juist in zaken van mannelijk geweld tegen vrouwen in de privésfeer (en seksueel misbruik van

122 Zowel Wostmann als Zoomer constateren dat de politie in de praktijk vaker naar oplossingen zoekt waar de vrouw verantwoordelijk voor is. Wostmann, Politieoptreden bij vrouwenmishandeling, 1988: 90-101, met m.n. 92-93;Zoomer, Vrouwenmishandeling; politiewerk, 1990: 29-58, m.n. 58.

123 Ibidem: 78-86. Een wijkagent heeft meer tijd om te luisteren en steun te bieden in het zoeken naar concrete oplossingen of hulpverlenende instanties.

124 Goudswaard, 'Er is toch geen moord gepleegd...', in: Geweld tegen vrouwen: (g)een zaak voor politie en justitie?, 1985: 35 .

125 Van den Brink, Met het straatverbod in kort geding op de goede weg? Recht en Kritiek, 1987: 391.

126 Van Driem, Waarom slachtoffers van seksueel geweld het strafproces moeten mijden, in: Slachioffers van misdrijven, 1989: 59. Blijf van m'n Lijf Eindhoven, Vrouwenmishandeling aanklagenswaardig 1985: 42-43. Landelijke vereniging, Werkgroep Vrouw en Recht, Commentaar op het rapport van de Commissie Wettelijke voorzieningen slachtoffers in het strafproces, februari 1989: 4.

127 Doomen, Seksueel geweld - wat vermag het recht?, in: Strafbare seksualiteit, 1986: 89.

128 Van Driem, Haar was recht gedaan, in: Het klappen van de zweep, 1994: 121. 
kinderen) zou het adagium moeten gelden: "Naarmate de afstand in de relatie tussen dader en slachtoffer kleiner is, zal in de afweging tussen het belang van het slachtoffer en het algemeen belang meer gewicht moeten worden toegekend aan de belangen van het slachtoffer." 29 Aandacht voor de problematiek van mannelijk geweld tegen vrouwen in de privésfeer in de politieopleiding en in nascholingscursussen voor politie en officieren van justitie is voorwaarde voor een zorgvuldige bejegening van slachtoffers van geweld in de privésfeer. Bovendien is deelname door politie en openbaar ministerie aan een samenwerkingsverband gewenst, met als doel informatie uitwisseling tussen de verschillende hulpverlenende instanties, en zonodig het van de grond krijgen van een gezamenlijke aanpak. ${ }^{130}$

Bovendien wordt een voortvarender strafrechtelijk ingrijpen gewenst. De belangrijkste aanbevelingen betreffen het doen van aangifte, arrestatie van de man, het vergaren van bewijs en een actiever vervolgingsbeleid. ${ }^{131}$ De vrouw moet vaker worden gewezen op de mogelijkheid van het doen van aangifte. De politie zou ook ambtshalve proces-verbaal kunnen opmaken als het geweld ernstig is en/of de vrouw uit angst geen aangifte doet, terwijl zij wel een strafrechtelijke reactie wil. ${ }^{132}$ Daarnaast zou de man vaker mee kunnen worden genomen voor verhoor en zo mogelijk langer worden vastgehouden. ${ }^{133}$ Vrouwen willen vaak dat de man wordt meegenomen, maar durven dit in het bijzijn van de man niet hardop te zeggen, want dan zijn zij verantwoordelijk voor zijn aanhouding in plaats van de politie. In zo'n geval kan de politie de man ambtshalve aanhouden. ${ }^{134}$ Wanneer het geweld tegen de vrouw wordt gekwalificeerd als 'eenvoudige' mishandeling of vernieling, dan kan de man alleen worden meegenomen als er sprake is van heterdaad. Door alerter te zijn op verschillende vormen van geweldpleging zoals ernstige bedreiging en poging tot doodslag, staan de politie meer dwangmiddelen ter beschikking zodat de verdachte zo nodig in verzekering kan worden gesteld. ${ }^{135} \mathrm{Om}$ arrestatie bij niet-

129 Bangma, Met begrip en inzicht, $A A, 1989: 648$.

130 Goudswaard, 'Er is toch geen moord gepleegd...', in: Geweld tegen vrouwen: (g)een zaak voor politie en justitie?, 1985: 33-36. Blijf van m'n Lijf Eindhoven, Vrouwenmishandeling aanklagenswaardig 1985: 5-29. Acker \& Rawie, Seksueel geweld tegen vrouwen en meisjes, 1982: 49-51.

131 Blijf van m'n Lijf Eindhoven, Vrouwenmishandeling aanklagenswaardig, 1985: 42-43; Goudswaard, 'Er is toch geen moord gepleegd...', in: Geweld tegen wrouwen: (g)een zaak voor politie en justitie?, 1985: 35-36; Dietze \& Spaninks, Met het oog op de dader, 1990: 61.

132 Vrouwenmishandeling wordt in de praktijk vaak als een klachtdelict beschouwd; pas als er aangifte wordt gedaan, wil de politie wat doen.

133 Sinds eind jaren tachtig mag iemand niet meer worden meegenomen omdat hij eigen of andermans veiligheid in gevaar brengt. Voor situaties van vrouwenmishandeling is het daardoor moeilijker geworden iemand vast te houden voor verhoor; er is geen grond voor als het geweld onder mishandeling of vernieling valt.

134 Blijf van m'n Lijf Eindhoven, Vrouwenmishandeling aanklagenswaardig 1985: 30-31; Zoomer, Vroumenmishandeling; politiewerk, 1990: 94-96; Kijkduin 2, 1993: 101.

135 Goudswaard, 'Er is toch nog geen moord gepleegd...', in: Geweld tegen vrouwen: (g)een zaak voor politie en justitie?, 1985: 35; Ford \& Regoli, The criminal prosecution of wife assaulters, in: Legal responses to wife assault, 1993: 137. 
heterdaad situaties mogelijk te maken, wordt voorgesteld de bevoegdheid tot het in verzekering stellen en in voorlopige hechtenis nemen van verdachten van vrouwenmishandeling te vergroten. ${ }^{136}$ Bovendien kan de politie actiever bewijs verzamelen door met buren, familie, huisarts en andere betrokkenen te praten, waardoor de zaak juridisch sterker wordt. De hiervoor voorgestelde wijze van strafrechtelijk handelen door de politie zou moeten worden vastgelegd in een interne richtlijn of een dienstorder. ${ }^{137}$

Het openbaar ministerie behoort actiever te vervolgen door vaker een sepot onder voorwaarden op te leggen of de verdachte een berisping te geven op het parket. ${ }^{138}$ Het voortbestaan van de relatie na geweld in de privé-sfeer mag geen reden tot nietvervolgen zijn, en officieren van justitie behoren meer tijd te besteden aan het verzamelen van relevante informatie. ${ }^{139} \mathrm{Om}$ de juiste beslissingen te kunnen nemen is het van groot belang dat de politie en het openbaar ministerie in contact staan met elkaar en met andere instellingen die betrokken zijn bij vrouwenmishandeling. ${ }^{140}$ Door het belang van het slachtoffer meer gewicht te geven, en de specifieke achtergrond van deze geweldsdelicten te onderkennen, kunnen de wettelijke mogelijkheden van politie en openbaar ministerie beter op dit belang worden toegesneden. ${ }^{141}$

Een ander punt waarop gewezen wordt, is registratie van alle meldingen van vrouwenmishandeling bij de politie. Van veel situaties van geweld tegen vrouwen

136 Kostwinder, Dader en diender, in: Thuis geslagen, mevrouw?, 1984: 35; Dietze \& Spaninks, Met het oog op de dader, 1990: 61. Kijkduin 2, 1993: 100. In 1993 heeft een werkgroep bestaande uit politiemensen, een officier van justitie en een wetenschapper een brief aan het Ministerie van Jusitite gestuurd met onder andere het voorstel de mogelijkheden tot arrestatie uit te breiden. Onstenk, Slaat de politiek terug?, in: Het klappen van de zweep, 1994: 146.

137 Dietze \& Spaninks, Met het oog op de dader, 1990: 61. In Rotterdam is een concept-dienstorder 'Geweld tegen vrouwen' opgesteld naar aanleiding van een overleg tussen de politie van Rotterdam en de actiegroep 'Stop geweld tegen vrouwen'. Het arrondissementsparket $Z$ wolle heeft een inteme richtlijn of notitie 'Werkwijze in geval van vrouwenmishandeling' opgesteld na gesprekken met Blijf van m'n Lijf Zwolle. Beide dienstorders hebben eenzelfde strekking. Beide richtlijnen zijn gepubliceerd in: Met het oog op de dader, congresmap, 1990.

138 Goudswaard, 'Er is toch nog geen moord gepleegd...', in: Geweld legen vrouwen: (g)een zaak voor politie en justitie?, 1985: 35; Jaarverslag Bliif van m'n Lijf Zwolle, 1985: 7. Acker \& Rawie, Seksueel geweld legen vrouwen en meisjes, 1982: 85.

139 Blijf van m'n Lijf Eindhoven, Vrouwenmishandeling aanklagenswaardig, 1985: $33-34$ \& 42; Jaarverslag Bliff van $m$ ' $n$ Liif Zwolle, 1985: 41; Van Driem, Waarom slachtoffers het strafrecht moeten mijden, in: Slachtoffers van misdrijven, 1989: 61.

140 Van Blokland \& Geurts, Thuis geslagen mevrouw?, in: Thuis geslagen, mevrouw?, 1984: 49. Ook Zoomer wijst, naar aanleiding van de resultaten van haar onderzoek naar het optreden van de politie, op het belang van ontmoetingen tussen politie en (hulpverlenende) instellingen die met vrouwenmishandeling te maken krijgen. Zoomer, Vrouwenmishandeling: politiewerk, 1990: 99.

141 Visser, Veranderend denken over wetstoepassing bij seksuele delicten, in: Strafbare seksualiteit, 1986: 109. Dat slachtoffers van verkrachting en vrouwenmishandeling specifieke aandacht behoeven, wordt overigens in ambtelijke en rechterlijke kring niet algemeen aanvaard. Zie: Commentaar van de NVvR op het rapport Aangifte sexuele geweldsmisdrijven van de werkgroep de Beaufort, Trema, 1984: 162-164. 
door hun (ex-)man of vriend waar de politie mee wordt geconfronteerd, wordt geen aangifte gedaan. Wel wordt het in de dag- en nachtrapporten vermeld. ${ }^{142}$ Met behulp van een verbeterde registratie zou na bijvoorbeeld drie aantekeningen 'geweld tegen (ex-) partner' strafrechtelijk ingegrepen moeten worden door (ambtshalve) een proces-verbaal op te maken en dit door te sturen naar het openbaar ministerie. Bovendien helpt registratie om vrouwenmishandeling meer zichtbaar te maken. ${ }^{143}$

Gebruik de mogelijkheden van het strafrecht als stok achter de deur, is het motto. Het gaat er niet om dat mannen vaker veroordeeld worden, of dat hoge gevangenisstraffen worden opgelegd, het gaat erom dat juristen een bijdrage dienen te leveren "aan het afkeuren en ontmoedigen van geweld tegen vrouwen". ${ }^{144}$ Het wordt tijd de bestaande mogelijkheden te benutten of betere mogelijkheden te creëren. "[P]olitie en justitie (kunnen) op hun terrein bijdragen aan de bestrijding van vrouwenmishandeling en mogelijk maken wat vrouwelijke burgers in onze rechtsstaat veelal moeten ontberen: bescherming tegen geweld. Daar gaat het om. Wat vrouwen zoeken, is niet zozeer dat hun man in het gevang komt, maar veeleer dat het geweld tegen hen stópt." ${ }^{145}$

De roep om meer aandacht voor slachtoffers van seksueel geweld door politie en openbaar ministerie wordt gehoord en opgepakt door de politie, het openbaar ministerie en de politiek. De bejegening van slachtoffers die aangifte doen van (seksuele) geweldsmisdrijven is met meer zorg voor de emotionele belasting voor het slachtoffer omgeven, met name voor slachtoffers van seksuele misdrijven. Daarnaast is een algemeen slachtofferbeleid ontwikkeld, waardoor het recht op informatie en de mogelijkheid tot schadevergoeding is verbeterd (zie $\S 2.5$ ). De politie en in mindere mate het openbaar ministerie nemen regelmatig deel aan een samenwerkingsverband. Deze zijn overigens veelal gericht op gevallen van verkrachting en seksueel misbruik van kinderen, en niet op gevallen van mannelijk geweld

142 Of gevallen van vrouwenmishandeling systematisch worden bijgehouden in de dag-en nachtrapporten verschilt per politiekorps. In Utrecht bijvoorbeeld worden in principe alle meldingen zeer summier en onder de noemer 'huiselijke twist' en 'echtelijke ruzie' in de dag-en nachtrapporten vermeld, terwijl in Zwolle niet systematisch alle meldingen worden vermeld. Wostmann, Politieoptreden bij vrouwenmishandeling, 1988: 21-22, 54-55.

143 Goudswaard, 'Er is toch geen moord gepleggd..., in: Geweld tegen vrouwen: (gleen zaak voor politie en justitie?, 1985: 35; Blijf van m'n Lijf Eindhoven, Vrouwenmishandeling aanklagenswaardig, 1985: 42-43. Wostmann, Politieoptreden bij vrouwenmishandeling, 1988: 112-113. Er wordt ook gepleit voor een centraal meldingspunt. Kostwinder, Dader en diender, in: Thuis geslagen, mevrouw?, 1984: 35.

144 Jaarverslag Blijf van $m$ 'n Liff Zwolle, 1985: 41.

145 Van Rappard, Vrouwen willen hun man niet in het gevang, in: Thuis geslagen, mevrouw?, 1984: 31. 
tegen vrouwen in de privésfeer. ${ }^{146}$ In de politieopleiding wordt meer aandacht besteed aan sociale vaardigheden en kennis over maatschappelijke problemen, waaronder de problematiek van vrouwenmishandeling en de achtergronden van verkrachting. Er is meer dan vroeger aandacht voor de hulpverleningstaak van de politie. ${ }^{147}$ Door deze ontwikkelingen zijn de afgelopen twintig jaar de ergste vooroordelen over verkrachting en vrouwenmishandeling bij de politie verdwenen. ${ }^{148}$ "De scherpe kantjes van het patriarchale denken zijn afgesleten; eigentijdse noties over gelijkheid tussen de seksen zijn onderdeel geworden van de sociale kennis van politiefunctionarissen. (...) De seksespecifieke selectiviteit van waarnemen en handelen is hiermee evenwel niet verdwenen." ${ }^{49}$ Deze positieve veranderingen ten aanzien van seksuele geweldsmisdrijven en mannelijk geweld tegen vrouwen in de privésfeer worden echter bedreigd doordat een groot aantal Jeugd- en Zedenafdelingen bij de politie in 1994 zijn afgebouwd in het kader van het reorganisatieproces binnen de politie, waarbij algemene politietaken zijn verbreed en specialisaties zijn afgebouwd. Veel expertise zal hierdoor langzaam verloren gaan. ${ }^{150}$

\subsection{Een gewijzigde positie van slachtoffers in het strafproces}

De kritiek door de vrouwenbeweging op de bejegening van het slachtoffer in het strafproces valt in de tachtiger jaren in vruchtbare aarde; de tijd is rijp voor een beleidsverandering van strafrechtelijk optreden. Maatschappelijk gezien boet de strafrechtspleging aan gezag in door een toename van de criminaliteit die maar beperkt beheersbaar blijkt te zijn. De resocialisatiegedachte blijkt in de praktijk moeilijk haalbaar. Door een geringer geloof in de resocialisatie, krijgt aandacht voor het slachtoffer meer kans. Aandacht voor het slachtoffer wordt als een van de

146 In 1991 zijn er 75 regionale of stedelijke samenwerkingsverbanden, waar medici, hulpverleners en politiefunctionarissen aan deelnemen. Uit een onderzoek naar samenwerkingsverbanden in 1989 blijkt dat van de 20 onderzochte samenwerkings-verbanden in vijf samenwerkingsverbanden een officier van justitie zitting heeft. Bouw e.a., Samen tegen sexueel geweld, 1990: 111. De vraag is of deze samenwerkingsverbanden zullen blijven functioneren nu veel categorale organisaties op het terrein van seksueel geweld sinds 1992 zijn verdwenen. Meinen, Een kwestle van machr, 1992: 32-33.

147 Wostmann, Politieoptreden bij vrouwenmishandeling, 1988: 113-114.

148 Doomen, Seksueel geweld - wat vermag het recht?, in: Strafbare seksualiteit, 1986: 87-88; Wostmann \& van de Bunt, Verbaliseren van politieoptreden bij vrouwenmishandeling, in: Vrouw en criminaliteit, 1987: 155-167.

149 Ibidem: 158.

150 Visser, Veranderend denken over wetstoepassing bij seksuele delicten, in: Strafbare seksualiteit. 1986: 109-111. Van den Brand, Slachtoffers seksueel geweld wederom de dupe, Dien, 1994: 4-5; De Wit, Interview: Hoofdinspecteur Georgine Acton: Vrouw \& Gezondheidszorg, 1995: 6-9. 
manieren beschouwd om de legitimiteit van de strafrechtspleging te versterken. ${ }^{151}$ Daarnaast past het opkomen voor slachtofferbelangen binnen de algemene tendens van toenemende mondigheid van de burgers. De democratiseringsprocessen in de jaren ' 60 en ' 70 hebben ertoe geleid dat burgers meer rechtsbescherming genieten in de contacten met de overheid (AROB). Ook slachtoffers van misdrijven vinden dat ze recht hebben op goede informatie over hun rechtspositie en op een behoorlijke opvang. De eisen voor een betere bejegening en opvang van slachtoffers van seksueel geweld in brede zin worden van toepassing verklaard op alle slachtoffers van misdrijven. ${ }^{152}$ Deze maatschappelijke ontwikkelingen hebben ook hun weerslag op internationale wetgeving. Zowel in Europees verband, ${ }^{153}$ als op het niveau van de Verenigde Naties, ${ }^{154}$ zijn er aanbevelingen gedaan de positie van het slachtoffer binnen het strafproces te versterken. Deze internationale wetgeving is vervolgens weer van invloed geweest op de nationale wetgeving en strafrechtelijk beleid. Dit alles heeft ertoe geleid dat verschillende werkgroepen zijn ingesteld om een justitieel slachtofferbeleid vorm te geven. Eerst wordt de werkgroep 'aangifte sexuele misdrijven' ingesteld. ${ }^{155}$ Een paar jaar later wordt de werkgroep 'justitieel beleid en slachtoffer'156 ingesteld gevolgd door de commissie 'wettelijke voorzieningen slachtoffers in het strafproces'. ${ }^{157}$ Deze werkgroepen en commissie hebben een belangrijke bijdrage geleverd aan de invulling van het justitiele slachtofferbeleid en versterking van de positie van het slachtoffer in het strafproces. Ook de herziening van de beklagprocedure (art. $12 \mathrm{~Sv}$ ) kan worden beschouwd als een versterking van de positie van het slachtoffer.

151 Van Dijk, Eigen schuld, dikke bult, in: Slachioffers van misdrijven, 1989: 16-18; Groenhuijsen \& Penders, De positie van slachtoffers van delicten in het burgerlijke en het strafrecht, in: Slachroffers van misdrijven, 1989: 25-27; Schalken, De positie van het slachtoffer in het systeem van strafprocesrechtelijke rechtsbetrekkingen, $A A, 1989: 240 ;$ Kool, Over schijn en werkelijkheid, Nemesis, 1989: 6-11; Boutellier, Solidariteit en slachtofferschap, 1993: 23.

152 Van Dijk, De positie van het slachtoffer in het strafproces, $J V$, 1982: 14.

153 Het Verdrag van de Raad van Europa van 24 november 1983 inzake de schadeloosstelling van slachtoffers van geweldsmisdrijven, Trb. 1984, nr. 2. In werking getreden voor Nederland, Luxemburg en Denemarken op 1 februari 1988, Trb. 1987, nr. 187; Tevens: Recommendation No. R.(85)11; The position of the victim in the framework of criminal law and procedure, Strasbourg, Council of Europe,.

154 Declaration of basic principles of justice for victims of crime and abuse of power, General Assembly, R 40/34, 29 november 1985.

155 Deze werkgroep is in 1979 ingesteld door de ministers van Binnenlandse zaken en Justitie. Rapport van de werkgroep aangifte sexuele geweldsmisdrijven, 1981: 2 .

156 Deze werkgroep werd in 1983 ingesteld door de vergadering van procureurs-generaal. Rapport van de werkgroep justitieel beleid en slachtoffer, mei 1984: 1 .

157 Deze werkgroep is in 1985 ingesteld door de minister van Justitie. Rapport van de Commissie wettelijke voorzieningen slachtoffers in het strafproces, Wettelijke voorzieningen slachtoffers in het strafproces, SDU uitgeverij, 's-Gravenhage 1988: 1. 


\subsubsection{Slachtoffers in het strafproces: een nieuw beleid}

De in $\S 2.4$ naar voren gebrachte kritiek op politie en openbaar ministerie heeft een belangrijke rol gespeeld in de totstandkoming van de richtlijn 'Conclusies en aanbevelingen voor de bejegening van slachtoffers van seksuele misdrijven' (voortaan: richtlijn Bejegening slachtoffers van zedenmisdrijven). ${ }^{158}$ Voordat deze richtlijn officieel wordt gepubliceerd in 1986, worden de aanbevelingen van de werkgroep aangifte sexuele misdrijven over een zorgvuldige opvang en bejegening van slachtoffers van zedenmisdrijven ${ }^{159}$ bekend gemaakt om te worden nageleefd door politie en openbaar ministerie. ${ }^{160}$ De richtlijn komt min of meer overeen met de in het rapport opgenomen aanbevelingen. Het uitgangspunt is dat bij de overweging om de aangifte al dan niet door te zetten, vooral aandacht besteed dient te worden aan de specifieke belangen van het slachtoffer tegenover het meer algemene belang dat daders van ernstige seksuele geweldsmisdrijven zoveel mogelijk dienen te worden opgespoord. De belangrijkste aanbevelingen zijn: Aan de vrouw moet gevraagd worden of ze door een vrouwelijke rechercheur verhoord wil worden (7), of ze een vertrouwenspersoon mee wil nemen (8), en als het slachtoffer op een andere plaats dan het politiebureau wenst te worden verhoord, moet daar zoveel mogelijk gevolg aan worden gegeven (15). Tevens moet er voor worden gezorgd dat zij zo snel mogelijk haar verhaal bij een gespecialiseerde zedenrechercheur kan doen $(9 \& 10)$. De vragen die gesteld worden, mogen niet de indruk wekken dat de integriteit van de vrouw in twijfel wordt getrokken (19), herhaalde confrontaties met de verdachte moeten zoveel mogelijk worden voorkomen ( $13 \& 24)$ en als de vrouw niet mee wil werken aan het bewijs van verkrachting, moet worden bezien of er wel bewijs van bedreiging of mishandeling voorhanden is (18). Dit alles om de vrouw zoveel mogelijk te steunen en te voorkomen dat ze door de strafrechtelijke procedure nogmaals wordt getraumatiseerd. Naast deze algemene aanbevelingen over de bejegening van slachtoffers van seksuele misdrijven is er een specifieke aanbeveling voor slachtoffers van een zedenmisdrijf gepleegd door hun partner. In dit geval behoort in het proces-verbaal van aangifte vastgelegd te worden hoe het slachtoffer over een strafvervolging van de dader denkt (20). ${ }^{161}$ De aanbevelingen komen grotendeels overeen met de, door betrokkenen bij de vrouwenbeweging geformuleerde, aanbevelingen voor een betere bejegening en opvang van slachtoffers

158 Stcrt. 1986, nr. 33, 17 februari 1986.

159 De werkgroep aangifte sexuele misdrijven onder voorzitterschap van de Beaufort heeft ter voorbereiding van deze circulaire een rapport uitgebracht in 1981: Rapport van de werkgroep sexuele misdrijven.

160 TK 1985-1986, 19.209, nrs. 1-2: 17.

161 In de circulaire Conclusies en aambevelingen voor de bejegening van slachtoffers van seksuele misdrijven staat dat het aanbeveling verdient deze richtlijn ook te hanteren voor delicten waar sprake is van een of andere vorm van seksueel misbruik van vrouwen en meisjes. Sicrt. 1986, nr. 33, 17 februari 1986. 
van seksuele misdrijven. Doordat de richtlijn zich beperkt tot de bejegening van slachtoffers van seksuele misdrijven, en niet nader ingaat op de problematiek van mannelijk geweld tegen vrouwen in de privésfeer (behalve aanbeveling 20), is de richtlijn niet direct van toepassing op deze groep van slachtoffers. De aandacht voor slachtoffers van zedendelicten breidt zich uit naar aandacht voor alle slachtoffers van misdrijven. De richtlijn Bejegening slachtoffers van zedenmisdrijven wordt tesamen met de richtlijn Slachtofferbeleid gepubliceerd. ${ }^{162}$ In 1993 wordt ter begeleiding van de nieuwe slachtoffervoorzieningen de circulaire 'nieuwe richtlijn slachtofferzorg' gepubliceerd, maar deze voegt in wezen niets toe. ${ }^{163}$ Het slachtofferbeleid berust op drie peilers: een zorgvuldige bejegening van het slachtoffer van een misdrijf, een goede informatievoorziening aan het slachtoffer en zo mogelijk bemiddelen om vergoeding van de schade te bereiken. Dit betekent voor de taak van de politie dat 1 . de aangifte zorgvuldig opgenomen moet worden en het slachtoffer zonodig moet worden doorverwezen naar slachtofferhulp, 2 . het slachtoffer van informatie moet worden voorzien over het verloop van de strafprocedure, 3. de politie zonodig moet bemiddelen bij een schaderegeling of bij conflicten, en 4. alle relevante informatie over het slachtoffer en de bemoeienissen die de politie met het slachtoffer heeft gehad, in het proces-verbaal moeten worden opgenomen. Het openbaar ministerie heeft tot taak het slachtoffer een brief te sturen over de vraag of zij op de hoogte wenst te worden gehouden over het verloop van de procedure, en of zij prijs stelt op schadevergoeding. Wanneer de vrouw slachtoffer is van een ernstig geweldsdelict behoort de officier van justitie na te gaan of het slachtoffer een gesprek wil met de officier van justitie. Bovendien dient het openbaar ministerie zich rekenschap te geven van de bijzondere belangen van het slachtoffer in het strafproces. ${ }^{164}$ Dit betekent dat de officier van justitie verplicht is de vergoeding van de schade door de dader in elke beslissing een centrale rol te laten spelen. ${ }^{165}$ Wanneer het openbaar ministerie het belang van het slachtoffer niet meeweegt in de beslissing om te gaan vervolgen, kan dit worden beschouwd als een inbreuk op het zorgvuldigheidsbeginsel, hetgeen tot schadeplichtigheid van de staat kan leiden. ${ }^{166}$ "Slachtofferzorg door politie en openbaar ministerie komt in wezen hierop neer dat deze instanties bij hun werkzaamheden in een (straf)zaak

162 Richtijn Vaillant I, Sicr. 1986, nr. 33. Deze richtlijn geldt eerst alleen voor slachtoffers van ernstige geweldsmisdrijven, maar in 1987 wordt deze richtlijn van toepassing verklaard voor slachtoffers van alle misdrijven. Richtlijn de Vaillant II: Sicri. 1987, nr. 64.

163 Slachtofferrichtlijn: Nieuwe richtlijn slachtofferzorg, Stcrt. 1993, nr. 60: 12-13, 21.

164 Slachtofferrichtlijn, Stcrt. 1987, nr. 64.

165 TK 21.345, nr. 5: 10, 12. Slachtofferrichtlijn: nieuwe richtlijn slachtofferzorg, Stcrt. 1993, nr. 60. Bijvoorbeeld dient de officier van justitie een zaak niet ad informandum te voegen als een slachtoffer zich benadeelde partij heeft gesteld om schadevergoeding op de terechtzitting te vorderen.

166 NO 10 augustus 1983, nr. 36 (m.nt. EHB). Bangma \& Bröring, De juridische relevantie van de slachtoffercirculaires voor het optreden van politie en Openbaar Ministerie, DD, 1990: 422. 
altijd op een redelijke manier de belangen van het slachtoffer van een strafbaar feit meewegen." 167

Naast de aandacht van politie en openbaar ministerie voor het slachtoffer is een heel netwerk van slachtofferhulp van de grond gekomen met regionale bureaus slachtofferhulp en een overkoepelende landelijke organisatie. Bovendien zijn slachtoffermedewerkers aangesteld bij de politie en het openbaar ministerie. Tevens zijn er regionale samenwerkingsverbanden ontstaan tussen bureaus slachtofferhulp, politie en justitie rond de opvang van slachtoffers van misdrijven. ${ }^{168}$

De aanbevelingen voortkomend uit de vrouwenbeweging zijn deels omgezet in een justitieel slachtofferbeleid, namelijk een zorgvuldige bejegening van slachtoffers door politie en openbaar ministerie, goede informatievoorziening en doorverwijzingsmogelijkheden naar slachtofferopvangvoorzieningen. Bovendien behoren politie en openbaar ministerie rekening te houden met de wens tot schadevergoeding. Dit laatste is aanleiding geweest tot de wet 'voorzieningen ten behoeve van slachtoffers van strafbare feiten' ${ }^{169}$

\subsubsection{Wettelijke regelingen voor slachtoffers in het strafproces}

Met de invoering van de wet slachtoffervoorzieningen is de positie van het slachtoffer als benadeelde partij versterkt op een aantal terreinen: 1. de voegingsmogelijkheden om een schadevergoeding te vorderen in het strafproces, zijn verruimd, 2. er is een nieuwe sanctie ingevoerd, de schadevergoedingsmaatregel (art. 36f Sr) en 3. er is een nieuwe bijzondere voorwaarde in de wet vastgelegd, namelijk het storten van een som geld in een fonds dat de belangen van slachtoffers behartigt (art. 14c $\mathrm{Sr}$ ). Als vierde terrein geldt het Schadefonds geweldsmisdrijven, dat nu een structurele basis heeft gekregen. ${ }^{170}$ Bovendien is door herziening van artikel 12 Sv de beklagprocedure met meer rechtswaarborgen omkleed.

\section{Voeging als benadeelde partij}

De mogelijkheden om een schadevergoeding te vorderen als benadeelde partij zijn met de invoering van de wet Terwee verruimd. Het slachtoffer van vrouwenmis-

167 Slachtofferrichtlijn: slachtofferzorg, Stcrt. 1993, nr. 60: 12.

168 Steinmetz, Hulp aan slachtoffers van misdrijven, 1990: 69-88; Slotboom \& Wemmers, Tevree met de wet Terwee?, 1994.

169 De Wet van 23 december 1992 tot aasvulling van het Wetboek van Strafrecht, het Wetboek van Strafvordering, de Wet voorlopige regeling schadefonds geweldsmisdrijven en andere wetten met voorzieningen ten behoeve van slachtoffers van strafbare feiten (de wet Terwee), Stb. 1993, 29. Deze wet is gefaseerd ingevoerd; vanaf 1 april 1993 in de arrondissementen Dordrecht en Den Bosch en vanaf 1 april 1995 in het gehele land.

170 Dit Schadefonds geweldsmisdrijven laat ik verder buiten beschouwing. 
handeling is benadeelde partij omdat zij rechtstreeks schade heeft geleden door het strafbare feit (art. 5la Sv). ${ }^{173}$ Wanneer zij zich als benadeelde partij heeft gesteld, heeft zij recht op bepaalde informatie, namelijk over het tijdstip waarop de zaak voorkomt, over het besluit van de officier van justitie tot vervolging of seponering (artt. 5 If \& 167 lid $3 \mathrm{~Sv}$ ), en over het intrekken van de dagvaarding (art. $266 \mathrm{~Sv}$ ). Wanneer de zitting is geschorst moet de rechter haar informeren over de nieuwe datum van de rechtszitting (art. $319 \mathrm{~Sv} \& 320 \mathrm{~Sv}$ ), en de procureur-generaal moet haar op de hoogte brengen van het tijdstip waarop het cassatieberoep voorkomt (art. $437 \mathrm{~Sv}){ }^{172}$ De griffier tenslotte behoort haar kosteloos het vonnis te verstrekken (art. $554 \mathrm{~Sv})^{173}$

Het slachtoffer kan zich voegen zodra de officier van justitie de verdachte heeft gedagvaard voor de gewelddaden haar aangedaan, ${ }^{174}$ tijdens het vooronderzoek door een schriftelijk verzoek aan de officier van justitie te richten, en tijdens de terechtzitting door een schriftelijk of mondeling verzoek. Wanneer het slachtoffer zich bedreigd voelt, kan zij zich in de voorfase voegen en haar adres geheimhouden door de naam en het (werk)adres op te geven van degene die haar bijstaat. ${ }^{175} \mathrm{Zij}$ is niet verplicht op de terechtzitting aanwezig te zijn. Wel kan zij daartoe door de rechtbank worden opgeroepen, bijvoorbeeld als het in het belang van de verdachte is dat zij op de terechtzitting verschijnt (artt. $51 \mathrm{~b} \mathrm{~Sv} \& 332 \mathrm{~Sv}$ ). ${ }^{176}$ Voor slacht-

171 Ook nabestaanden kunnen zich als benadeelde partij voegen (art. 51 a lid 2 Sv). De werkgroep Vrouw en Recht heef in haar commentaar op het wetsvoorstel voorgesteld aan te sluiten bij 'rechtstreeks belanghebbende" uit artikel 12 Sv om zo mogelijk te maken dat ook belangenorganisaties zich kunnen voegen. Landelijke vereniging Werkgroep Vrouw en Recht, Commentaar op het rapport van de commissie Wettelijke voorzieningen slachtoffers in het strafproces, 1989: 2. Dit heeft als nadeel dat ook verzekeringsmaatschappijen zich kunnen voegen en dit is afgewezen met het argument dat verzekeringsmaatschappijen voldoende know-how en middelen hebben om een civiele procedure te starten. Van Asbeck, Schadevergoeding voor slachtoffers van delicten, AA, 1994: $22-29$.

172 O.g.v. art 413 lid $2 \mathrm{~Sv}$ wordt het siachtoffer dat zich in eerste aanleg heeft gevoegd schriftelijk op de hoogte gebracht van de dag waarop het hoger beroep voorkomt.

$173 \mathrm{Zij}$ heeft geen recht op informatie over de vrijlating van de man, hoewel dat wel in haar belang is; als zij weet dat hij in bewaring zit, voelt zij zich veiliger dan wanneer hij haar weer elk moment kan komen opzoeken. Zij kan deze informatie wel op grond van de richtlijn Slachtofferbeleid opvragen, maar het is geen recht.

174 Het slachtoffer kan zich niet voegen als de officier van justitie haar zaak ad informandum aan de rechter heeft voorgelegd. Op grond van de richtlijnen slachtofferhulp is de officier van justitie verplicht om een zaak ter berechting aan de rechter voor te leggen als het slachtoffer te kennen heeft gegeven dat zij zich wil voegen om een schadevergoeding te vorderen, zoals ik hiervoor heb uiteengezet.

175 Wanneer het bijvoorbeeld een slachtoffer van verkrachting betreft, die zich emstig bedreigd voelt, hoeft zelfs has naam niet bekend te worden. Op die manier kan anonimiteit worden gegarandeerd. TK 21.345, nr. 4: 13 (vraag D'66) \& nr. 5: 9 (antwoord minister van justitie).

176 Voeging in de voorfase heeft als voordeel voor de verdachte dat hij zich tijdig op de vordering kan voorbereiden. Wanneer de benadeelde partij niet op de terechtzitting verschijnt is dat een nadeel voor de verdachte, omdat hij geen vragen aan de benadeelde partij kan stellen: het onmiddelijkheidsbeginsel wordt geschonden. Overigens is het slachtoffer meestal ook niet aanwezig als de schadevergoeding als voorwaarde bij een straf wordt opgelegd. 
offers van seksueel geweld of vrouwenmishandeling kan het soms heel prettig zijn niet te hoeven verschijnen wanneer de confrontatie met de dader traumatisch is. ${ }^{177}$

Door zich te voegen kan de benadeelde partij een civiele vordering instellen tijdens het strafproces en schadevergoeding eisen. ${ }^{178}$ Deze vordering moet eenvoudig van aard zijn, dat wil zeggen eenvoudig te bewijzen (art. $361 \mathrm{~Sv}$ ), ${ }^{179}$ maar de hoogte van het bedrag is vrij. ${ }^{180}$ Het maakt bijvoorbeeld niet uit of de partner een goedkope vaas van 25 gulden heeft kapotgesmeten of een antieke vaas ter waarde van 5000 gulden; in beide gevallen kan de vordering van eenvoudige aard zijn. ${ }^{181}$ Wanneer een deel van de vordering complex van aard is, kan de benadeelde partij de vordering splitsen, ${ }^{182}$ zodat het meer complexe gedeelte bij de civiele rechter kan worden aangebracht (art. 5la Sv). Splitsing van de vordering is bovendien mogelijk als de rechter een deel van de vordering wegens complexiteit niet ontvankelijk heeft verklaard. ${ }^{183}$ Een vordering van eenvoudige aard in een verkrachtingszaak is bijvoorbeeld vergoeding van de kleren die op de bewuste avond werden gedragen en het psychische leed dat door het misdrijf is veroorzaakt. Deze immateriële schade kan worden toegewezen, zelfs voor een bedrag van 15.000 gulden. ${ }^{184}$

177 De minister van justitie geeft als reden dat het voor de rechterlijke macht extra werk met zich meebrengt als het aanwezig zijn op de terechtzitting voor het slachtoffer emotioneel bezwarend is. Een beslissing o.g.v. een ingediend formulier conform art. $5 \mathrm{lb} \mathrm{Sv}$ zal doorgaans minder werk opleveren. TK $21.345, \mathrm{nr} .3: 14$.

178 Schadevergoeding zou ruimer opgevat kunnen worden. In 1922 werd bijvoorbeeld het aanplakken van een vonnis als een civiele vordering aangemerkt. De enige voorwaarde was dat het de maximale geldelijke limiet niet zou overschrijden. HR 27 november 1922, NJ 1923, 186. Idem: HR 17 november 1967, NJ 1968, 42.

179 Hiermee wordt aangesloten bij art. 369 Sv. Bij complexe vorderingen "moet worden gedacht aan vorderingen die worden betwist en en alleen door een grondig onderzoek met behulp van getuigen en deskundigen kunnen worden beoordeeld. (...) voorkomen moet worden dat het de verdachte een aanknopingspunt biedt om door chicanes het vorderingsrecht van de geleadeerde te frustreren". TK 21.345, nr. 3: 11 .

180 In de vorige voegingsprocedure was de hoogte van de vordering tot schadevergoeding aan een limiet gebonden; de vordering bij het kantongerecht mocht niet hoger zijn dan 600 gulden en bij de rechtbank niet hoger dan 1500 gulden ( $44 \& 56$ RO oud). Het verhogen van de limiet werd niet wenselijk geacht, omdat elke limiet arbitrair is en de complexiteit van cen vordering over het algemeen niet afhankelijk is van de hoogte van de vordering.

181 Binnen het strafproces zijn overigens meer mogelijkheden om betaling van schadevergoeding op te leggen zonder dat een limiet geldt, zoals de voorwaarde de schade te vergoeden bij een transactie (art. $74 \mathrm{Sr}$ ) of een voorwaardelijke veroordeling (art. 14c Sr).

182 Dit is een wijziging ten opzichte van de voegingsprocedure als beledigde partij, waar de Hoge Raad had uitgemaakt, dat niet eerst tot het maximale bedrag schadevergoeding binnen het strafproces kon worden gevorderd, om het restant later bij de civiele rechter te eisen. HR 20 oktober 1941, NJ $1942,59$.

183 Bovendien kan de benadeelde partij, wanneer haar vordering is afgewezen en de verdachte en het openbaar ministerie niet in hoger beroep zijn gegaan, op grond van artikel 421 lid $4 \mathrm{~Sv}$ zelfstandig in hoger beroep gaan bij de rechtbank of het gerechtshof.

184 Rechtbank 's-Hertogenbosch 18 mei 1994, RN 1995, 505. 
Het slachtoffer heeft als benadeelde partij een aantal rechten. Zij kan zich doen bijstaan en zich doen vertegenwoordigen door een advocaat (art. 5le Sv) ${ }^{185}$ Bovendien heeft zij een geclausuleerd recht op inzage in de processtukken (art. 51d Sv). De toestemming kan (deels) worden onthouden, "in het belang van het onderzoek, dan wel in de bescherming van de persoonlijke levenssfeer, de opsporing en vervolging van strafbare feiten of op zwaarwichtige gronden aan het algemeen belang ontleend". ${ }^{186}$ Hiertegen kan binnen veertien dagen een bezwaarschrift worden ingediend (art. 5ld lid $3 \mathrm{~Sv}$ ). Voor slachtoffers van (seksuele) geweldsdelicten kan dit betekenen dat psychiatrische en reclasseringsrapporten aan hen zullen worden onthouden, wat de schrijnende situatie kan opleveren dat slachtoffers met doktersverklaringen over hun lichamelijke en psychische gesteldheid moeten komen om hun (immateriële) schade te bewijzen, terwijl iemand die juist hun persoonlijke levenssfeer ernstig heeft aangetast, geen inzicht hoeft te verlenen in de rapportages die zijn persoonlijke levenssfeer betreffen. Bovendien kan inzage in de rapporten van belang zijn om de schade de onderbouwen: "er kan bijvoorbeeld uit gedestilleerd worden hoe bedreigend iemand (nog) is." "187 Tot slot is de benadeelde partij bevoegd stukken te overleggen ter staving van het bewijs, maar zij is niet bevoegd getuigen en deskundigen aan te brengen (art. $334 \mathrm{~Sv}$ ). Wel kan zij de aanwezige getuigen en deskundigen vragen stellen ter staving van haar vordering tot schadevergoeding. ${ }^{188}$ Tevens kan zij getuigen meenemen naar de rechtszitting en aldaar aan de officier van justitie vragen of hij alsnog wil vorderen de getuigen op de getuigenlijst te plaatsen, zodat de mogelijkheid ontstaat de getuigen te horen (art. $280 \mathrm{~Sv}$ ). Een recht van de benadeelde partij de rechter te verzoeken deze getuigen op de getuigenlijst te plaatsen bestaat niet. ${ }^{189}$

Als de vordering van eenvoudige aard is, kunnen slachtoffers veel baat hebben bij deze regeling. Hoge schadevergoedingen kunnen worden toegewezen en zij hoeven niet, naast de strafprocedure, de gang naar de civiele rechter te maken. Wanneer een deel van de vordering niet ontvankelijk is verklaard, dan kunnen zij een afweging maken of zij tevreden zijn met de wel toegewezen vordering van eenvou-

$185 \mathrm{Zij}$ heeft daarbij geen recht op toevoeging. Dit heeft de benadeelde partij wel als zij een beklagprocedure begint (zie onder Beklagprocedure).

186 De gronden zijn ontleend aan art. $12 \mathrm{f} \mathrm{lid} 2 \mathrm{~Sv}$. Het inzagerecht is beperkter dan het inzagerecht van de beledigde partij o.g.v. art. $333 \mathrm{~Sv}$ oud, waar de inzage in de processtukken alleen de zaak niet mocht ophouden.

187 Landelijke vereniging Werkgroep Vrouw en Recht, Commentaar op het rapport van de commissie Wettelijke voorzieningen slachtoffers in het strafproces, 1989: 4.

188 De beledigde partij mocht alleen vragen stellen omtrent de geleden schade (art. $334 \mathrm{~Sv}$ oud). Van Soest \& Walther, Schadevergoedingsstraf en strafrecht, NJB, 1988: 1338.

189 Gelet op deze mogelijkheden acht de minister het niet nodig de benadeelde partij een zelfstandig recht toe te kennen. TK 21.345 , nr. 5: 5-6. Een motie met de strekking dat de benadeelde partij maximaal twee getuigen en twee deskundigen mag doen oproepen, is niet aangenomen. TK 21.345 , nr. 12. 
dige aard, of dat zij bij de civiele rechter het resterende bedrag zullen vorderen. Als de gehele vordering als complex wordt beoordeeld, dan zal de vordering niet ontvankelijk worden verklaard, en is het aan het slachtoffer of zij vervolgens bij de civiele rechter schadevergoeding zal vorderen.

Op deze manier wordt aan het belang van het slachtoffer op schadevergoeding recht gedaan; zij kan op eenvoudige wijze de materiêle en immateriêle schade, die makkelijk bewijsbaar is, vergoed krijgen. Bovendien wordt aan het belang van de verdachte op een eerlijk proces recht gedaan; omdat complexe vorderingen niet ontvankelijk worden verklaard, wordt de aandacht van de rechter voor het hoofdgeding niet afgeleid door de bewijsproblematiek rond de civiele vordering. Zo blijft de voegingsprocedure accessoir. ${ }^{190}$

\section{Sanctiemodaliteiten ten behoeve van de benadeelde partij}

Naast een versterking van de positie van de benadeelde partij, zijn er in 1995 twee sanctiemodaliteiten ten gunste van slachtoffers ingevoerd. De schadevergoedingsmaatregel (art. 36f Sv), de eerste sanctie binnen het wetboek van strafrecht waarin het belang van het slachtoffer expliciet wordt erkend, en de bijzondere voorwaarde een som geld te storten in een fonds dat de belangen van slachtoffers behartigt (art. 14 onder $4 \mathrm{Sr}$ ), zoals het Schadefonds geweldsmisdrijven of het fonds van de Landelijke Vereniging Blijf van m'n Lijfhuizen ${ }^{191}$ of de stichting Transact. ${ }^{192}$ Deze bijzondere voorwaarde kan worden opgelegd als het slachtoffer geen prijs stelt op schadevergoeding, maar een schadevergoeding gezien het gepleegde delict wel op zijn plaats is.

De schadevergoedingsmaatregel (art. $36 \mathrm{f} \mathrm{Sv}$ ) is een sanctie waarbij de veroordeelde verplicht is geld te betalen aan de staat ten behoeve van het slachtoffer. ${ }^{193}$ De schadevergoeding kan zowel materiêle als immateriële schade betreffen, maar het moet wel een financiële genoegdoening aan het slachtoffer betreffen; herstel van de rechtmatige toestand valt niet onder de schadevergoedingsmaatregel. ${ }^{194}$

De schadevergoedingsmaatregel en de voegingsprocedure hebben beide tot doel dat het slachtoffer haar schade vergoed krijgt door de dader. Maar het initiatief tot

190 TK 21.345, nr. 3: 10-11. Groenhuijsen, De rode draad: goed nieuws voor slachtoffers van delicten, AA, 1989: 747. Groenhuijsen, Schadevergoeding voor slachtoffers van delicten in het strafgeding. 1985: 127-134, 284-289.

191 Bijlage bij de (concept)richtlijn Terwee (Stcrt. 1993, 60). In: Sicrt. 1993, nr. 133: 9.

192 Transact komt op voor de belangen van slachtoffers van seksueel geweld in brede zin

193 Hierin onderscheidt de schadevergoedingsmaatregel zich van de boete, waar de veroordeelde verplicht is geld te betalen aan de staat ten behoeve van de staatskas.

194 Andere vormen van herstel, zoals een straatverbod voor situaties waar de vrouw regelmatig wordt bedreigd en mishandeld door haar ex-partner, kunnen niet als maatregel worden epgelegd. TK 21.345, nr. 4: 19 (vraag van D`66) \& nr. 5: 15 (antwoord minister van justitie). 
een schadevergoedingsmaatregel wordt door de officier van justitie genomen; de officier van justitie behoort bij de afweging of hij een geldboete of een schadevergoedingsmaatregel zal eisen, voorrang te verlenen aan de schadevergoedingsmaatregel. ${ }^{195}$ De rechter neemt vervolgens ambtshalve het besluit om een schadevergoedingsmaatregel op te leggen als de verdachte volgens burgerlijk recht aansprakelijk is voor de schade die door het gewelddadige gedrag is veroorzaakt en als het slachtoffer te kennen heeft gegeven dat zij schadevergoeding wenst. ${ }^{196}$ Bovendien is het openbaar ministerie belast met de executie van de schadevergoedingsmaatregel: als de veroordeelde niet betaalt, kan het openbaar ministerie beslag leggen op goederen of bank/girotegoeden. Als ook dit niets oplevert, kan de man in vervangende hechtenis worden genomen, zonder dat overigens de verplichting tot vergoeding van de schade vervalt. ${ }^{197}$

De schadevergoedingsmaatregel wordt beschouwd als het sluitstuk van een project gericht op schadebemiddeling: het begint bij de politie (schadebemiddeling op vrijwillige basis), het wordt vervolgd bij het openbaar ministerie (schadevergoeding als voorwaarde bij transactie of sepot) en het heeft als eindstation de rechter. ${ }^{198}$ De verschillende vormen om schadevergoeding te verkrijgen kunnen naast elkaar worden toegepast. De rechter kan zowel een schadevergoedingsmaatregel opleggen als een civiele vordering toewijzen. ${ }^{199}$ En het slachtoffer kan tegelijkertijd een voegingsprocedure starten voor een vordering van eenvoudige aard, een civiele procedure starten voor de vordering die meer complex van aard is, en een procedure starten bij het Schadefonds geweldsmisdrijven. ${ }^{200}$

195 TK 21.345, nr. 5: 14; Slachtofferrichtlijn: Nieuwe richtlijn slachtofferzorg, Stcrt. 1993, nr. 60: 12.

196 Slachtofferrichtijn: Nieuwe richtijn slachtofferzorg, Sicrt. 1993, nr. 60: 13. Omdat het een maatregel is en geen straf, hoeft er geen rekening te worden gehouden met de persoonlijke omstandigheden zoals de emst van het feit, de verwijtbaarheid van het gedrag en de draagkracht van de verdachte. Van Asbeck, Schadevergoeding voor slachtoffers, AA, 1994: 27.

197 Ibidem: 23, 26-28. Slachtofferrichtlijn: De nieuwe richtijn slachtofferzorg, Sicrt. 1993, nr. 60: 13. Moerings legt precies de vinger op de zere plek van 'zitten én betalen'. Moerings, PS van een redacteur, Proces, 1995: 206.

198 Slachtofferrichlijn: Nieuwe richtlijn slachtofferzorg, Sicrt. 1993, nr. 60: 13.

199 Ibidem: 13. Volgens de minister van justitie staat het verruimen van de voegingsprocedure los van het invoeren van de schadevergoedingsmaatregel. TK 21.345, nr. 3: 8.

200 Slachtofferrichtlijn: De nieuwe richtlijin slachtofferzorg, Sicrt. 1993, nr. 60: 14; Claassens en StokerKlein gaan in op een aantal aspecten van de wet Terwee aan de hand van hun ervaring met de wet in het arrondissementsparket 's-Hertogenbosch. Het slachtoffer in het strafproces, Trema, 1995: 167-175. 


\section{Beklag tegen niet-vervolgen}

Tot slot biedt de beklagprocedure ex artikel $12 \mathrm{~Sv}$ het slachtoffer, als direct belanghebbende, ${ }^{201}$ een middel om tegen de beslissing van de officier van justitie om niet tot (verdere) vervolging over te gaan, een schriftelijk beklag in te dienen bij het gerechtshof. ${ }^{202}$ Het slachtoffer kan ook beklag doen als de officier van justitie draalt met het nemen van de beslissing, of als de politie en het openbaar ministerie niet voldoende opsporingshandelingen verrichten; niet-opsporen kan nietvervolgen impliceren. ${ }^{203}$

Deze beklagprocedure kan worden beschouwd als een middel in handen van de direct benadeelde ter controle van het openbaar ministerie, die niet alleen het vervolgingsmonopolie heeft, maar bovendien kan afzien van vervolging om redenen van opportuniteit: ook als een schuldigverklaring door de rechter haalbaar is kan een zaak worden geseponeerd. ${ }^{204}$ Deze beklagprocedure heeft daarom niet de bestraffing tot doel, maar strafvervolging. Daarmee is de beklagprocedure een driepartijen geschil; het slachtoffer als klaagster, het openbaar ministerie, en de persoon wiens vervolging wordt verlangd. ${ }^{205}$

De beklagprocedure heeft het karakter van een vol beroep, aangezien het hof de bevoegdheid heeft de beslissing van het openbaar ministerie ten volle te toetsen; zowel de haalbaarheid als de opportuniteit worden beoordeeld (art. 12i lid $2 \mathrm{~Sv}$ ). ${ }^{206}$

201 Een slachtoffer of benadeelde valt altijd onder het begrip rechtstreeks belanghebbende. Een rechtspersoonkan onder het begrip rechtstreeks belanghebbende vallen, wanneer deze rechtspersoon het belang dat door de beslissing om niet te vervolgen is getroffen, krachtens haar doelstelling behartigt. Tevens geldt als criterium dat er geen natuurlijk persoon moet zijn die kan klagen. Dit betekent bijvoorbeeld dat de landelijke vereniging Bliff van $m$ ' $n$ Lijf geen klacht kan indienen voor een bepaald slachtoffer. Wel kan de organisatie in zo'n geval als gemachtigde optreden. Knigge in Melai c.s., aant. 16, 17 \& 18 op art. 12 Sv: $42-52$.

202 Dit artikel is in 1985 uitgebreid met rechtswaaborgen voor de klager. Wet van 8 november 1984 , in werking getreden op 1 januari 1985, Stb. 1984, 551.

203 Knigge in Melai c.s., aantt. 6 \& 7 op art. 12 Sv: 13-17; Corstens, Het Nederlands strafprocesrecht, 1995: 484-485.

Theoretisch beschouwd kan er beklag worden gedaan tegen de beslissing van de officier van justitie om de zaak ad info te voegen. Weliswaar komt de zaak onder ogen van de rechter, maar de zaak wordt niet ten laste gelegd waardoor het slachtoffer zich niet ter zake kan voegen. Als het onderzoek ter terechtzitting in eerste aanleg nog niet is aangevangen, is er een kleine mogelijkheid op succes, maar dan moet het slachtoffer wel een heel zwaarwegend belang hebben. Knigge in Melai c.s., aant. 8 op art. $12 \mathrm{i} \mathrm{Sv:} 18-21$.

204 Corstens, Het Nederlands strafprocesrecht, 1995: 480; Knigge in Melai c.s., aantt. 2 \& 3 op art. 12-13a Sv: 1-9. De beklagregeling was van oorsprong meer tuchtrechtelijk gekleurd, maar in de loop der tijd is het accent naar de individuele klager verschoven en kreeg de regeling een meer administratief-rechtelijke inslag. Van Buuren, Beklag over niet vervolgen van strafbare feiten, $A A$, 1985: 263.

205 Dat het een drie-partijen geschil betref, blijkt tevens uit artikel $250 \mathrm{a}$ Sv; de verdachte kan niet tegen de dagvaarding bezwaar aantekenen als deze naar aanleiding van een bevel van het hof tot (verdere) vervolging is uitgekomen. Corstens, Het Nederlands strafprocesrecht, 1995: 480-488.

206 Knigge in Melai c.s., aant. 3 op art. 12-13a Sv: 9; lbidem, aant. 2 op art. 12i Sv: 2-5. 
Wanneer het beklag ontvankelijk en gegrond is verklaard, ${ }^{207}$ krijgt de procureurgeneraal de opdracht een schriftelijk verslag te maken (art. 12a lid $2 \mathrm{~Sv}$ ). Het slachtoffer wordt opgeroepen (artt. $12 \mathrm{c} \& 12 \mathrm{~d} \mathrm{~Sv}$ ), ${ }^{208}$ en de persoon wiens vervolging wordt verlangd, wordt opgeroepen als het hof overweegt om een bevel tot (verdere) vervolging te geven (art. 12e lid $2 \mathrm{~Sv}$ ). ${ }^{209}$ Het slachtoffer heeft het recht zich als direct belanghebbende te laten bijstaan door een advocaat (art. 12f lid 1 Sv). Dit geldt eveneens voor de persoon wiens vervolging wordt verlangd. ${ }^{210}$ Daarnaast hebben beide partijen een (beperkt) recht op inzage in de stukken als het beklag ontvankelijk en gegrond is verklaard (art. $12 \mathrm{f} \mathrm{lid} 2 \mathrm{~Sv}$ ). ${ }^{211}$ Bovendien kan het slachtoffer al in de voorfase proberen inzage in de stukken te krijgen op grond van artikel S1d Sv, als zij zich als benadeelde partij heeft gevoegd, om te bezien of zij beklag zal indienen. ${ }^{212}$

Wanneer het hof van mening is dat de officier van justitie tot (verdere) vervolging over moet gaan, in de zin van het vorderen van een gerechtelijk vooronderzoek of het dagvaarden van de verdachte, dan kan het hof het openbaar ministerie hiertoe bevelen (art. 12i lid $3 \mathrm{~Sv}$ ). ${ }^{213}$

Een beklagprocedure wordt in de praktijk niet vaak gestart; er vinden per jaar rwim tweehonderd beklagprocedures plaats, wat op de hoeveelheid geseponeerde zaker zeer gering is. ${ }^{214}$ In individuele zaken kan de beklagprocedure ertoe leiden dat

207 Heı beklag zal niet ontvankelijk worden verklaard als de verdachte een kennisgeving van niet verdere vervolging heeft ontvangen (art. 243 Sv) en er geen nieuwe bezwaren naar voren zijn gebrach, of as de termijn van drie maanden bij een transactie waarbinnen het beklag moet zijp ingediend, zijn verstreken (art. 74 lid $3 \mathrm{Sr} \& 12 \mathrm{k}$ Sv). Als de verdachte aan de voorwaarden gesteld bij een sepot heeft voldaan, mag hij ervan uitgaan dat de zaak niet zal worden vervolgd. Het beklag zal in dat geval wel ontvankelijk worden verklaard, maar de kans dat het hof zal bevelen tot strafyervolging is heel klein. Knigge in Melai es., aant. 8 op art. 12: 18-21.

$208 \mathrm{Zij}$ is niet verplicht on te verschinen, noch heef zij een antwoordplicht, zoals een getuige die wel heeft (zie hoofdstuk $4,8,4,2$ ).

209 In de overige gevallen kan deze persoon worden opgeroepen. De man is, evenals het slachtoffer, niet verplicht te versehijnen of anwwoord te geven (art. $12 \mathrm{~g} \mathrm{~Sv}$ ).

210 De rechtsbijstand door de advocaat kan via toevoeging worden geregeld: de klager en de persoon wiens vervolging wordt gewenst, betalen een eigen bijdrage en de staat vult dit aan.

211 Inzage in stukken kan op vordering van de procurcur-generaal of ambtshalve door het hof worden geweigerd in belang van de privacybescherming, de opsporing of vervolging van strafbare feiten en indien er zwaarwichtige argumenten zijn onteend aan het algemeen belang. Dezelfde gronden worden genoemd in artikel $\$ 1$; het inzagerecht van de benadeelde partij.

212 Corstens, Hel Nederlands strafprocesrecht, 1995: 482.

213 Wanneer het hof beveelt tot het instellen van een gerechtelijk vooronderzoek dan moet de officier van justitic toestemming aan het hof vragen om niet tot verdere vervolging over te gaan (art. 246 lid 3 Sv). Knigge in Melai c.s., aant. 12 op art. 12 i Sv: 26-33; Corstens, Het Nederlands strafprocesrechl, 1995: 487. En mochten er nieuwe gegevens zijn, dan kan de officier van justitie het gerechtshof verzoeken om bewilliging van een sepot (analoog aan ant. 240 Sv). Reijntjes in Melai c.s, aant. 2 op art 167 Sv: 19.

214 In 1981 werden 217 , in $1982230 \mathrm{cn}$ in 1983213 procedures aanhangig gemaakt. Van Buuren, Beklag over niet vervolgen van strafbare feiten, $A A, 1985: 263$. 
de officier van justitie alsnog tot strafvervolging moet overgaan, ook als het vrouwenmishandeling betreft. In 1993 besloot een officier van justitie tot sepot van een zaak van vrouwenmishandeling, omdat het geweld paste binnen het patroon van geweld dat volgens klaagster door de man jegens haar werd uitgeoefend. Het beklag is gegrond verklaard en het Hof Amsterdam gelastte dat tegen de man strafvervolging moest worden ingesteld. ${ }^{215}$

Bovendien heeft deze procedure een verderreikend belang dan het individueel belang door haar uitstralende effect. Het bestaan van de procedure heeft invloed op officieren van justitie, omdat zij in hun beslissing rekening zullen houden met de mogelijkheid van beklag. ${ }^{216}$ En als een beklag is ingediend, zal niet alleen bij gegrondverklaring van de klacht, maar ook bij een afwijzing van de klacht, de officier van justitie nog eens zijn geconfronteerd met de motivatie voor de beslissing om niet te vervolgen. En deze aanscherping in de motivatie komt andere beslissingen weer ten goede. "Met de uitoefening van het beklagrecht is niet alleen het persoonlijke belang van de klager, maar ook het algemeen belang gediend. De door het hof op het $\mathrm{OM}$ uitgeoefende controle kan bijdragen tot een rechtvaardige strafrechtspleging en kan het vertrouwen dat de burgers daarin stellen vergroten."217

De hiervoor behandelde slachtoffervoorzieningen kunnen worden beschouwd als een versterking van de positie van het slachtoffer in het strafproces. Deze voorzicningen zijn niet specifiek gericht op vrouwen die slachtoffer zijn van geweld door hun partner of ex-partner. Hoewel ook zij belang hebben bij een zorgvuldige bejegening, informatieverstrekking, de mogelijkheid tot het verkrijgen van een schadevergoeding of het indienen van een klacht tegen de beslissing van het openbaar ministerie niet tot vervolging over te gaan, is het de vraag of deze voorzieningen voldoende zijn toegesneden op de specifieke geweldsproblematiek van vrouwenmishandeling. Naast dit algemene slachtofferbeleid is in de jaren tachtig ook een beleid ter bestrijding van seksueel geweld totstandgekomen. Levert dit beleid een nadere invulling op voor een strafrechtelijke regulering van geweld in de privésfeer?

215 Hof Amsterdam, 3 februari 1993, CDROM Vrouw en Recht: R 469/92. Het betrof emstige mishandeling, verkrachting en wederrechtelijke vrijheidsberoving van de vrouw door haar echtgenoot, en vernieling van de inboedel door haar echtgenoot. Zie tevens: Rechtbank Amsterdam, 25 augustus 1992, RN 1993, 327. In dit geval had de vrouw, nadat zij voor de zoveelste keer emstig, was mishandeld door haar echtgenoot, azijnzuur gedronken, waaraan zij korte tijd later overleed. Het openbaar ministerie besloot haar echtgenoot niet te vervolgen. Naar aanleiding van een beklagprocedure, ingesteld door familie van de vrouw, gelastte het Hof Amsterdam het openbaar ministerie strafvervolging tegen de echtgenoot in te stellen terzake van "opzettelijk aanzetten tot zelfmoord van zijn echtgenote en/of mishandeling van zijn echtgenote terwijl dit feit de dood ten gevolge heef ... en mishandeling van zijn echtgenote meermalen gepleegd".

216 Eenzelfde effect heeft de bezwaarschriftprocedure tegen de dagvaarding. Corstens, Het Nederlands strafprocesrecht, 1995: 480.

217 Knigge in Melai c.s., aant. 9 op art. 12 Sv: 22-24. 


\subsection{3 (G)een strafrechtelijk beleid ter bestrijding van vrouwenmishandeling}

Onder invloed van de vrouwenbeweging is de problematiek van seksueel geweld op de politieke agenda gezet; in $1984 \mathrm{komt}$ de eerste nota Beleid ter bestrijding van sexueel geweld tegen vrouwen en meisjes ${ }^{218}$ uit, gevolgd door verschillende voortgangsrapportages. Seksueel geweld wordt beschouwd als sekse-specifiek geweld; systematisch geweld tegen vrouwen als sexe. De kern is dat een inbreuk wordt gemaakt op het (seksuele) zelfbeschikkingsrecht van de vrouw ${ }^{219}$ en dat deze inbreuk samenhangt met het feit dat vrouwen veelal afhankelijk zijn van degenen die het geweld plegen. ${ }^{220}$ Seksueel geweld wordt, naast sociaal-economische afhankelijkheid, gezien als één van de manieren waarop bestaande machtsverschillen tussen mannen en vrouwen tot uiting komen en waardoor die machtsverschillen worden bevestigd; seksueel geweld is geen individueel probleem, maar een maatschappelijk probleem. Deze omschrijving komt overeen met de opvattingen binnen de vrouwenbeweging. ${ }^{221}$ Een beleid uitsluitend gericht op het economisch meer zelfstandig maken van vrouwen, is niet voldoende om seksueel geweld te voorkomen. Het gaat ook om sociale en culturele zelfstandigheid. ${ }^{222}$ Dit sluit aan bij de bevindingen van Komter en Romkens ( $\$ 2.2 .3$ ) dat juist vormen van onzichtbare macht van grote invloed is op de dominantie van mannen binnen het gezin.

Vrouwenmishandeling, een van de vormen van seksueel geweld, wordt beschouwd als een geweldsdelict, "dat op grote schaal en op alle niveaus voorkomt in het Nederlandse gezinsleven". ${ }^{223}$ In de nota Beleid ter bestrijding van sexueel geweld wordt benadrukt dat "schending van de fysieke en psychische integriteit van vrouwen

218 Nota Beleid ter bestrijding van sexueel geweld tegen vrouwen en meisjes. Deze nota is een vervolg op de voorlopige nota over het beleid ter bestrijding van sexueel geweld tegen vrouwen en meisjes, uitgebracht in 1983, waar verschillende organisaties, waaronder de Emancipatieraad, commentaar op hebben geleverd. De voorlopige nota verschilt niet op principiele punten van de uiteindelijke nota.

219 Het beleid ter bestrijding van seksueel geweld krijgt bovendien een constitutionele basis door de bescherming van de persoonlijke levenssfeer (art. $10 \mathrm{Gw}$ ) en onaantastbaarheid van het menselijk lichaam (art. $11 \mathrm{Gw}$ ) als uitgangspunt voor beleid te nemen. Brunoth, Seksueel geweld tegen vrouwen en meisjes, $N J B, 1984: 579$.

220 Nota Beleid ter bestrijding van sexueel geweld tegen wrouwen en meisjes: 7.

221 De nota wordt positief ontvangen door de vrouwenbeweging wat betreft de visie. Twijfel bestaat er over de concrete uitwerking. Zie: Meinen, Een kwestie van macht, 1992: 23. Kijkduin 2, 1993: 7.

222 Vervolgnola Beleid ter bestrijding van sexueel geweld tegen vrouwen en meisjes: 7.

223 Nota Beleid ter bestrijding van sexueel geweld tegen vrouwen en meisjes: 20 . In de vervolgnots Beleid ter bestrijding van sexueel geweld tegen vrouwen en meisjes is de term vrouwenmishandeling vervangen door 'seksueel geweld binnen partnerrelaties'. Vervolgnota Beleid ter bestrijding van sexueel ge weld tegen vrouwen en meisjes: 20. 
en meisjes, ook als het intieme relaties betreft (cursivering $\mathrm{KL}$ ), onaanvaardbaar is" ${ }^{224}$ De toenmalige staatssecretaris Kappeyne van de Coppello stelt, naar aanleiding van vragen over het voomemen om 'buiten echt' te schrappen: "Als een handeling van de ene partner in strijd komt met de onaantastbaarheid van het menselijk lichaam van de andere partner, dan zal aan de terughoudendheid van de regering een einde komen."225 Bovendien wordt gewezen op het spanningsveld dat bestaat tussen "enerzijds een terughoudende rol van de overheid wat betreft het beperken van de bescherming van de persoonlijke levenssfeer van de burgers en anderzijds de taak van de overheid om voor de bescherming van de fysieke en psychische integriteit van de burgers zorg te dragen". ${ }^{226}$ Politie en justitie hebben ook hier een taak tot opsporing en vervolging, maar strafrechtelijk optreden ligt minder voor de hand, omdat het slachtoffer hier niet aan wil meewerken, of omdat er te weinig bewijs aanwezig is. "Het feit dat strafrechtelijk optreden, vanuit algemene beginselen van strafrecht, is gebonden aan de zeer strakke regels van bewijslevering e.d., maakt het tot een minder geschikt instrument in situaties waarbij het gaat om intieme relaties en waarin het geweld moeilijk is aan te tonen." ${ }^{227}$ De maatregelen die genomen moeten worden zullen daarom meer in de sfeer van de hulpverlening liggen. Een actief opsporings- en vervolgingsbeleid zal wel worden gevoerd als het gaat om vormen van seksueel geweld die zich afspelen in de openbare sfeer en waar de relatie tussen slachtoffer en dader een anoniem karakter heeft. $^{228}$

Strafrechtelijke maatregelen die de specifieke problematiek van vrouwenmishandeling betreffen, zijn niet van de grond gekomen. In de eerste nota Beleid ter bestrijding van sexueel geweld tegen vrouwen en meisjes wordt, in navolging van de aanbevelingen door de vrouwenbeweging, een actiever optreden van de politie bij een vermoeden of melding van vrouwenmishandeling bepleit, evenals een actiever optreden van het openbaar ministerie, door bijvoorbeeld meer gebruik te maken van een voorwaardelijk sepot met voorwaarden die herhaling doen voorkomen. ${ }^{229}$ De concretisering van deze beleidsvoornemens wordt overigens niet ter hand genomen. ${ }^{230}$ Belangrijk argument hiervoor was het ontbreken van gegevens, aangezien de registratie bij de politie zaakgericht is en niet slachtoffergericht.

224 Nota Beleid ter bestrijding van sexueel geweld tegen vrouwen en meisjes: 17. Of: "[H]et recht op bescherming van de persoonlijke levenssfeer, waaronder de bescherming van het gezinsleven valt, vindt zijn grens in ieders verantwoordelijkheid voor de (straf)wet". TK 18.542, nr. 4: 7.

225 UCV 22, 19 november 1984: 49 \& 64.

226 Nota Beleid ter bestrijding van sexueel geweld tegen vrouwen en meisjes: 14. Zie tevens pagina 8 , waar gesteld wordt dat in situaties van seksueel geweld in de privesfeer altijd hulpverlening of opvang moet worden verleend, soms tegelijkertijd met een vorm van strafrechtelijk ingrijpen.

227 Nota Beleid ter bestrijding van sexueel geweld tegen vrouwen en meisjes: 19.

228 Ibidem: 14.

229 Ibidem: 22

230 Voortgangsrapportage beleid ter bestrijding van seksueel geweld tegen vrouwen en meisjes: 9. 
Een motie om deze registratie van de grond te krijgen leidt niet tot resultaten ${ }^{231}$ Het ontbreken van registratie kan een factor zijn geweest waardoor het onderwerp strafrechtelijke afhandeling van geweld tegen vrouwen door hun partner van de politieke agenda is verdwenen. ${ }^{232}$ Op het voorstel uit de Tweede Kamer om vrouwenmishandeling nader te speciferen in het wetboek van strafrecht of strafvordering wordt niet gereageerd door de minister van justitie, ${ }^{233}$ en invoering van een zogenaamde 'protection order ${ }^{234}$ wordt niet nodig geacht. ${ }^{235}$ Ook het voorstel om een circulaire voor situaties van geweld tegen vrouwen in de privésfeer op te stellen wordt, met verwijzing naar de op dat moment op handen zijnde richtlijn Bejegening slachtoffers van zedenmisdrijven, afgewezen. ${ }^{236}$

$\mathrm{Na} 1990$ heerst stilzwijgen over strafrechtelijke maatregelen ten gunste van vrouwen die door hun partner fysiek en seksueel worden mishandeld: in de vervolgnota Beleid ter bestrijding van sexueel geweld tegen vrouwen en meisjes wordt niets vermeld over maatregelen op het terrein van politie en justitie, ${ }^{237}$ noch wordt in de commissievergadering naar aanleiding van de vervolgnota gesproken over de problematiek van fysiek en seksueel geweld tegen de vrouw door haar partner. De problematiek van vrouwenmishandeling staat niet op de politieke agenda. Zelfs een werkgroep van mensen uit de politie, het openbaar ministerie en de wetenschap heeft het onderwerp vrouwenmishandeling en strafrechtelijke regulering niet op de politieke agenda weten te plaatsen. ${ }^{238}$ De strafrechtelijke maatregelen die besproken worden, betreffen voornamelijk maatregelen in verband met seksueel misbruik van kinderen of seksuele delinquenten. ${ }^{239}$ Bovendien wordt verwezen naar het algemene slachtofferbeleid. ${ }^{240}$ Staatssecretaris Kosto: "De Emancipatieraad heeft er in zijn advies op gewezen, dat de aandacht voor de dader op het terrein van seksueel geweld niet ten koste mag gaan van de aandacht voor de slachtofferhulp. Wat de

231 TK 18.542 , nr. 7.

232 Zie ook: Rormkens, Wie is bang voor geweld, in: Het klappen van de zwrep, 1994: 129.

233 TK 19.209, nr. 3: 2, 3. In 1992 wordt opnicuw gepleit voor strafbaarstelling van vrouwenmishandeling op het congres Kijkduin 2. Kijkduin 2, 1993: 100.

234 Dit is een civiele maatregel om de echtgenoot die geweld pleegt uit huis te kunnen zetten, te verbieden in de buurt van het huis te komen (een zogenaamd straatverbod), of te verplichten bepaalde onkosten te betalen, zonder dat er sprake hoeft te zijn van een echtscheidingsprocedure. Door aan overtreding van de 'protection order' een arrestatiebevel te koppelen, heeft de 'protection order' een strafrechtelijk aspect.

235 TK 19.052, nr. 3, vraag en antwoord 163. De minister van Justitie heeft eerder gewezen op de civiele mogelijkheid tot uithuisplaatsing op grond van Boek I BW, art. 83 lid 1, 84 lid 6 \& 85 lid 2. UCV 22, 19 november 1984: 24-25, 59.

236 UCV 22, 19 november 1984: 59.

237 Vervolgnota Beleid ter bestrijding van sexueel geweld tegen vrouwen en meisjes: 19-20.

238 Onstenk, Slaat de politiek terug? in: Het klappen van de zweep. 1994: 145-146.

239 UCV 36, 11 maart 1991: 17. Seksueel misbruik van kinderen wordt over het algemeen beschouwd als de ergste vorm van seksueel misbruik omdat er tussen volwassene en kind een afhankelijkheidsen vaak vertrouwensrelatie bestaat. Mevrouw Doelman verwoordt dit gevoelen. TK 18.542, nr. 18: 3 .

240 Zie bijvoorbeeld UCV 36, 11 maart 1991; Met het oog op 1995: 74-75. 
invalshoek van justitie betreft bij de bejegening van slachtoffers kan juist worden gesteld dat er sprake is van een verdere intensievering en uitbreiding van de aandacht voor het slachtoffer. De beslissing, de vereniging Landelijk Overleg Slachtofferhulp structureel te financieren getuigt daarvan." ${ }^{341}$ Speciale aandacht voor de opvang van slachtoffers van verschillende vormen van seksueel geweld wordt niet nodig geacht door de staatssecretaris. ${ }^{242}$ Bovendien lijken de algemene slachtofferrichtlijnen de specifieke richtlijn Bejegening slachtoffers van zedenmisdrijven te verdringen. ${ }^{243}$ Een strafrechtelijk beleid voor slachtoffers van zedenmisdrijven kwam als eerste van de grond, maar lijkt te zijn ingehaald en overschaduwd door een algemeen slachtofferbeleid.

Op grond van de hiervoor beschreven ontwikkelingen kan naar mijn mening worden gesteld dat het algemene slachtofferbeleid weliswaar een aantal mogelijkheden biedt aan slachtoffers voor het verkrijgen van informatie en schadevergoeding, maar deze algemene slachtoffervoorzieningen lijken niet voldoende te zijn toegesneden op de specifieke problematiek van vrouwenmishandeling. ${ }^{244}$ Ook het beleid ter bestrijding van seksueel geweld levert geen handvatten op voor een strafrechtelijk optreden tegen geweld in de privésfeer, aangezien strafrechtelijk optreden nauwelijks als serieus (nevengeschikt) instrument naar voren is gebracht.

\subsection{Strafrechtelijke regulering van vrouwenmishandeling}

Mannelijk geweld tegen vrouwen in de privésfeer kan worden beschouwd als een geweldsdelict, maar dan wel een specifiek geweldsdelict. Vrouwenmishandeling onderscheidt zich van andere geweldsmisdrijven in drie opzichten. Het geweld speelt zich af in de relationele sfeer, waar emotionele, sociale en/of economische afhankelijkheid heersen. Door het gebruik van geweld en de verschillende machtsmechanismen die daarbij een rol spelen, wordt een negatieve afhankelijkheid van de vrouw van haar partner versterkt. Tevens is het kenmerkende van het geweld tegen de vrouw door haar (ex-)partner dat het gaat om herhaald geweld dat vaak in een context staat van permanent aanwezige dreiging en angst en niet zozeer in de context van een emotionele ruzie. De weerbaarheid van vrouwen kan hierdoor worden gebroken en het zelfrespect ondergraven. Tot slot wordt het geweld over het algemeen goed verborgen gehouden, waardoor het isolement van de vrouw wordt versterkt en de macht van de man wordt vergroot. Het ontbreekt de vrouw zodoende

241 UCV 36, 11 maart 1991: 17.

242 Er worden geen extra financiele middelen voor deskundigheidsbevordering vrijgemaakt. UCV 36 , I] maart 1991: 9, 20.

243 Bangma \& Bröring, De juridische relevantie van de slachtoffercirculaires, $D D, 1990: 422$

244 Zie hoofdstuk $6, \$ 6.3$. 
aan een veilige sociale omgeving waardoor herstel van de traumatische ervaring wordt bemoeilijkt of onmogelijk gemaakt. Vrouwenmishandeling is daarom niet alleen een geweldsdelict, het is bovendien een sociaal probleem, machtsuitoefening over vrouwen door hun partners, en een individueel probleem, afhankelijkheid van elkaar wat gepaard gaat met emotionele conflicten.

Omtrent de wijze waarop het strafrecht kan worden ingezet ter bescherming van de lichamelijke en seksuele integriteit van vrouwen binnen de privésfeer, is geen helderheid. Dat strafrechtelijke regulering is gewenst, heb ik in hoofdstuk 1 uiteen gezet. Ook het debat tussen de radicaal-kritische feministen en de reformistische feministen laat zien dat strafrechtelijke regulering van belang is om vrouwen enige vorm van rechtsbescherming te bieden. Door een beroep te doen op het strafrecht manifesteert de vrouw zich als rechtssubject en claimt bescherming van haar recht op lichamelijke integriteit en privacy. De overheid erkent dat slachtoffers recht hebben op een zorgvuldige bejegening, informatie over het verloop van de strafprocedure en zo mogelijk een schadevergoeding. Dit is in een algemeen slachtofferbeleid en in wettelijke voorzieningen voor slachtoffers in het strafproces vastgelegd. Strafrechtelijke regulering als instrument ter bestrijding van mannelijk geweld tegen vrouwen in de privésfeer lijkt niet als een belangrijk instrument te worden beschouwd door de overheid. Weliswaar wordt door de overheid erkend dat vrouwen recht hebben op lichamelijke integriteit en privacy, ook binnen het gezin of een andere samenlevingsvorm, maar tegelijkertijd wordt het recht op privacy als passief recht benadrukt, waardoor de bescherming van de samenlevingsvorm tegen inbreuken door de overheid van groter belang lijkt te zijn dan de privacy als vrijheidsrecht voor de vrouw. 


\section{Vrouwenmishandeling als strafbaar feit}

"Het onderscheid tussen ervarings- en normatieve aspecten is in zoverre niet erg helder dat woorden die in juridische samenhang van de wet, telastelegging of proces-verbaal worden gebruikt aan die samenhang mede hun betekenis ontlenen. [H]et 'juridificatieproces', waarindehistorischewerkelijkheidgeschikt gemaakt wordt voor het oordeel van de magistratuur [begint] reeds in de fase van de opsporing. Ik vraag mij af of je zelfs wel kunt spreken van een historische werkelijkheid, waaraan niet een juridische of andere (natuurwetenschappelijke, artistieke, politieke enz.) zin is gegeven, een werkelijkheid die aan enige zingeving voorafgaat, maar zal hier niet op deze wijsgerige vraag ingaan. In ieder geval is het zo dat opsporingsambtenaren, ambtenaren van het O.M. en rechters de werkelijkheid zien als een juridische en woorden schrijven en verstaan met in het hoofd wetten en jurisprudentie."1

\subsection{Inleiding}

Uit het oogpunt van rechtsbescherming kan iemand alleen veroordeeld worden voor een gedraging, handelen of nalaten, dat onder een delictsomschrijving valt (het legaliteitsbeginsel, art. $1 \mathrm{Sr}$ ). Dit betekent dat het geweld tegen de vrouw door haar partner of ex-partner moet zijn te kwalificeren als een strafbare gedraging, wil er sprake kunnen zijn van strafrechtelijk optreden; pas bij verdenking van een strafbaar feit kunnen strafrechtelijke bevoegdheden worden ingezet. Een inbreuk op de persoonlijke levenssfeer bestaande uit 'lastig valllen' door elke dag voor het huis van de vrouw te gaan staan en met een stok tegen de ruiten te slaan zonder dat iets wordt vernield, is heel vervelend voor de vrouw, omdat zij psychologisch onder druk wordt gezet. Er wordt in dit geval een recht geschonden, en de vrouw kan hiertegen het civiele recht inroepen, maar er is geen sprake van een strafbaar feit. Dit wordt anders als de man een ruit vernielt, vernieling (art. $350 \mathrm{Sr}$ ), of als de man dreigend met een mes zwaait en stekende bewegingen in haar richting maakt als zij de deur uitkomt, bedreiging (art. $285 \mathrm{Sr}$ ). In die gevallen valt de gedraging wel onder een delictsomschrijving. Het is in eerste instantie de politie die geconfronteerd wordt met gewelddadig gedrag in de privésfeer en die bepaalt of sprake is van een strafbaar feit. 
In het proces van waarheidsvinding gaat het om het vinden van de juridische waarheid, dat wil zeggen dat de waarheidsvinding is gericht op de verificatie of de man zich schuldig heeft gemaakt aan een strafbaar feit. Het feitelijke geweld tegen de vrouw, dat vaak regelmatig in een langere periode heeft plaatsgevonden, word teruggebracht tot één of meerdere incidenten, die te kwalificeren zijn als strafbare feiten. In de telastlegging wordt de gedraging omschreven waarvan de man wordt verdacht en de plaats en het tijdstip waarop het strafbare feit werd begaan (art. 261 Sv). ${ }^{2}$ De telastlegging is de grondslag waarop de rechter beraadslaagt en de formele en materiële rechtsvragen beantwoordt (artt. 348 \& $350 \mathrm{~Sv}$ ). Wanneer de dagvaarding in orde is, de rechter bevoegd, de officier van justitie ontvankelijk, en er geen redenen zijn de vervolging te schorsen (art. $348 \mathrm{~Sv}$ ), wordt nagegaan of de ten laste gelegde geweldpleging door de verdachte is begaan, of de bewezen verklaarde geweldpleging onder een delictsomschrijving valt (kwalificatie), en of de verdachte schuldig is aan het door hem gepleegde gewelddadige gedrag. Pas dan kan over de op te leggen straf (of maatregel) worden besloten (art. $350 \mathrm{~Sv}$ ). De verdachte kan alleen worden veroordeeld voor wat hem is ten laste gelegd. ${ }^{3}$ Hiermee is de telastlegging een belangrijk structurerend principe van het strafproces. ${ }^{4}$ Er wordt ook wel gesproken van 'de tyrannie van de telastlegging'.

In het kader van deze studie zijn twee aspecten van belang, namelijk de kwalificatie van gewelddadig gedrag en het bewijs. Om met het laatste aspect te beginnen, het Nederlandse bewijsstelsel wordt een negatief-wettelijk stelsel genoemd. " "Het is wettelijk omdat de wet de bewijsmiddelen (limitatief) opsomt, en het is negatief omdat de rechter alleen tot bewezenverklaring mag over gaan als hij zelf door de inhoud van de bewijsmiddelen ervan overiuigd is dat de verdachte schuldig is (art. $338 \mathrm{~Sv}$ )."7 Er zijn vijf wettelijke bewijsmiddelen: de eigen waarneming van de rechter, de verklaring van de verdachte, getuigenverklaringen, deskundigenverklaringen en schriftelijke bescheiden (art. $339 \mathrm{~Sv}$ ). In bepaalde gevaller

2 De telastlegging mag niet bestaan uit alleen juridische termen, en moet voldoende feitelijk zijn Bijvoorbeeld: 'dat hij op of omstreeks 25 februari 1995 te Rotterdam opzettelijk mishandelend eer vrouw G.A.B., opzettelijk heeft geslagen en/of gestompt en/of gestoken en/of gesneden en/of gekneper waardoor deze pijnlijk werd getroffen en/of lichamelijk letsel heeft opgelopen'. Sommige bestanddeler hebben een kwalitatieve en een feitelijke betekenis, en als het bestanddeel een voldoende feitelijke betekenis heeft mag deze term zonder nadere feitelijke aanduiding worden gebruikt. Hendriks e.a. Hoofdstukken strafprocesrecht, 1990: 132-135.

3 HR 30 januari 1933, NJ 1933, p. 588; HR 30 januari 1933, NJ 1933, p. 591 m.nt. Taverne. Zie: De Jong, De macht van de telastelegging, 1981: 5-8.

4 Het staat de officier van justitie vrij de verdachte te vervolgen voor een minder emstig delict bijvoorbeeld voor eenvoudige mishandeling in plaats van poging tot doodslag. Reijntjes in Melai c.s. aant. 8 op art. $167 \mathrm{~Sv}: 85$. Alleen als de zwaardere delictsbepaling als een specialis wordt beschouwc van een lichtere bepaling, is de officier van justitie hier niet vrij in; het zwaardere delict moet ter laste gelegd worden. Zie over de grondslagendiscussie: Pelser, Recht in vorm, DD, 1994: 9-27.

5 Melai, De tyrannie van de telastlegging, in: Polariteit en tegenspraak, 1992: 105-117.

6 Corstens, Het Nederlands strafprocesrecht, 1995: 594-652.

7 Jörg \& Kelk, Strafrecht met mate, 1994: 279. 
mag de rechter niet op grond van éen bewijsmiddel tot een bewezenverklaring van de feiten komen. Het ten laste gelegde feit mag niet bewezen worden verklaard op grond van a) de enkele verklaring van de verdachte (art. 341 lid 4 Sv), b) de verklaring van één getuige (art. 342 lid $3 \mathrm{~Sv}$ ), c) de mondeling overgebrachte verklaring van een anonieme getuige (art. $344 \mathrm{a} \mathrm{Sr}$ ), d) een schriftelijk overgebrachte verklaring van een anonieme getuige (art. 344 lid $3 \mathrm{Sr}$ ), en e) schriftelijke bescheiden die niet zijn aan te merken als ambtelijke stukken of deskundigheidsverklaringen (art. 344 lid 1 onder $5 \mathrm{Sr}$ ). Een bewezenverklaring mag daarentegen wel op een enkel proces-verbaal van een opsporingsambtenaar berusten als de opsporingsambtenaar over zelf waargenomen feiten verhaalt (art. 344 lid 2 Sv). ${ }^{8}$ De waardering van de wettige bewijsmiddelen in de concrete zaak ligt bij de rechter (art. $338 \mathrm{~Sv}$ ). "De bewijsmiddelen verschaffen de rechter uitsluitend indrukken; slechts door de waardering van die indrukken kan de rechter tenslotte concluderen tot een bepaalde toedracht." Wanneer aan de voorwaarden van het wettig bewijs niet is voldaan is vrijspraak geîndiceerd (art. 352 lid $1 \mathrm{Sr}$ ). Is het wettig bewijs vastgesteld, dan moet de rechter er tevens van zijn overtuigd dat déze man dit feit heeft gepleegd. Deze overtuiging berust niet alleen op feiten, maar ook op normering van de feiten, en aannemelijkheid en consistentie van naar voren gebrachte verklaringen. ${ }^{10}$ Of iets als aannemelijk wordt beschouwd, is weer gebaseerd op culturele noties en common sense ideeën. Opvattingen over man-vrouw verhoudingen spelen hierbij een rol. In het kader van deze studie naar de strafrechtelijke afhandeling van gevallen van mannelijk geweld tegen vrouwen in de privésfeer is de vraag of het feit dat het geweld in de privésfeer plaatsvindt specifieke problemen oplevert.

Het andere aspect betreft de kwalificatie: de bewezenverklaarde gewelddadige handeling moet vallen onder een strafbepaling. De bewezenverklaring moet in onderdelen overeenstemmen met de bestanddelen van de delictsomschrijving. Is dit niet het geval dan is de bewezenverklaring niet kwalificeerbaar en om die reden is het bewezen verklaarde feit geen strafbaar feit. " Je ziet hier een zogenaamde drietrapsraket: de feitelijke gebeurtenis wordt geabstraheert tot een telastlegging, vervolgens wordt bekeken of deze ten laste gelegde gedraging bewezen kan worden verklaard, en als dit het geval is wordt vervolgens vastgesteld of deze bewezen feiten kunnen worden aangemerkt als strafbare feiten.

Het opzetvereiste speelt hierin een rol. De te bespreken delicten zijn alle misdrijven en dan is opzet vereist; een willens en wetens handelen. ${ }^{12}$ Dit opzetvereiste moet niet zozeer worden beschouwd als een individueel willen en weten,

8 Nijboer, Strafrechtelijk bewijsrecht, 1995: 84.

9 Melai, Het waarheidsprobleem in het strafrecht, in: Polariteit en tegenspraak, 1992: 102-103.

10 Nijboer, Strafrechtelijk bewijsrecht, 1995: 79-84.

11 En volgt ontslag van alle rechtsvervolging. Nijboer, Strafrechtelijk bewijsrecht, 1995: 66; De Jong, Het model van de behandeling ter terechtzitting, in: Leerstukken strafprocesrecht, 1991: 31-32.

12 Wanneer sprake is van een culpoos (schuld) delict, is opzet niet vereist, bijvoorbeeld dood door schuld (art. $307 \mathrm{Sr}$ ). 
maar als een maatschappelijk willen en weten. "Indien de handeling geheel het karakter heeft van een opzettelijke handeling en als zodanig door iedereen wordt aangevoeld, dan is het ook bijna in rechte altijd een opzettelijke handeling. De rechter gaat zich niet bezighouden met ingewikkelde psychische processen." ${ }^{.13}$ Door de aanvaarding van het voorwaardelijke opzet (kansopzet) is opzet flink opgerekt. ${ }^{14}$ Onder voorwaardelijk opzet wordt verstaan dat de dader zich willens en wetens heeft blootgesteld aan de niet te verwaarlozen kans dat een bepaald gevolg van zijn handelen zal intreden. ${ }^{15}$ Door de acceptatie van het kansopzet is het opzet eenvoudiger te bewijzen. De term opzet wordt overigens niet altijd expliciet vermeld in de delictsomschrijving, het opzet kan ook worden afgeleid uit termen als 'wetende', of 'het oogmerk hebbende'. Bovendien geven werkwoorden als opruien, binnendringen of verleiden aan dat er sprake is van opzettelijk handelen. Soms zit het opzet verborgen in het middel, zoals 'het met geweld of een feitelijkheid of bedreiging met geweld of bedreiging met een feitelijkheid dwingen'. ${ }^{16}$ De bewijsbeslissing en de kwalificatiebeslissing worden los van elkaar behandeld, maar hangen in feite samen; het gaat om het vaststellen van materieel strafrechtelijk relevante feiten. ${ }^{17}$

Om te kunnen beoordelen of inbreuken op de lichamelijke integriteit, seksuele zelfbeschikking en persoonlijke levenssfeer van de vrouw vallen onder een delictbepaling, wordt de dogmatiek van de voor deze studie relevante delictsbepalingen onder de loep genomen. Eerst wordt ingegaan op de juridische vereisten voor mishandeling, bedreiging of moord- en doodslag ( $\$ 3.2$ ). Vervolgens wordt de dogmatiek van huisvredebreuk en vernieling besproken ( $\S 3.3$ ). Daarna wordt ingegaan op de bestanddelen 'seksuele handeling' en 'dwang' van de zedenmisdrijven verkrachting en aanranding ( $(3.4){ }^{18}$ Tot slot worden de problemen van deze dogmatiek voor vrouwen die slachtoffer zijn van geweld in de privésfeer besproken in $\S 3.5$.

13 Remmelink, Hazewinkel-Suringa's Inleiding, 1994: 207.

14 Wanneer de term opzet als bestanddeel in de delictsomschrijving voorkomt, moet het opzet bewezen worden. Bij onvoldoende bewijs zal vrijspraak moeten volgen. Wanneer het opzetvereiste, evenals de wederrechtelijkheid, een element is, is bij het ontbreken van opzet, of wederrechtelijkheid, sprake van een strafuitsluitingsgrond.

15 HR 9 november 1954, NJ 1955, 55 (het Cicero-arrest). Het opzetvereiste komt op deze manier dicht in de buurt van het schuldvereiste. De grens ligt bij een simpel bewustzijn van een mogelijkheid, dat is nog geen voorwaardelijk opzet. HR 12 maart 1957, NJ 1957, 386. Zie: Remmelink, Hazewinkel-Suringa's Inleiding, 1994: 205.

16 Remmelink, Hazewinkel-Suringa's Inleiding, 1994: 191-226.

17 Nijboer, Strafrechtelijk bewijsrecht, 1995: 29. De Engelsen en Amerikanen zijn geneigd de kwalificatie mee te nemen in de bewijsbeslissing. Ibidem: 30 (noot 61).

18 De indeling naar titel van het wetboek van strafrecht wordt enigszins doorbroken. Dit lijkt geen bezwaar aangezien de titel waaronder het delict staat gerubriceerd, voor de interpretatic van het delict geen doorslaggevende betekenis heeft. Wedzinga, Openlijke geweldpleging, 1992: 75. Zie ook: Van Bemmelen-van Veen, Ons strafrecht 3, 1990: 53-55. 


\subsection{Van bedreiging tot doodslag}

Lichamelijk geweld tegen de vrouw neemt verschillende vormen aan, van schoppen en slaan tot aan de haren de kamer doorsleuren of sigarettenpeuken op de huid uitdrukken. De zeer ernstige gevallen van lichamelijk geweld, al of niet met gebruikmaking van voorwerpen, kunnen soms als poging tot doodslag worden gekwalificeerd. Wanneer de vrouw dood is, kan sprake zijn van mishandeling met de dood tot gevolg, doodslag of moord. Bovendien gaat in geval van herhaald geweld tegen de vrouw het lichamelijke geweld vaak gepaard met bedreigingen van meer en emstiger geweld of bedreiging met moord.

\subsubsection{Dwang en bedreiging ${ }^{19}$}

Van bedreiging is sprake als de vrijheid van handelen van de vrouw wordt beperkt, of haar gevoel van veiligheid wordt aangetast, doordat de man dreigt met een ernstig misdrijf. ${ }^{20}$ Of er sprake is van bedreiging hangt in belangrijke mate af van het opzet van de man om vrees aan te jagen. Niet vereist is dat de man de wil heeft de bedreiging daadwerkelijk uit te voeren, ${ }^{21}$ noch wordt geěist dat de bedreigingen daadwerkelijk door de man uitgevoerd kunnen worden. ${ }^{22}$ Of de vrouw het als bedreigend heeft ervaren, is minder belangrijk dan het objectieve effect: of een mens in het algemeen zich onder die omstandigheden bedreigd zou voelen. ${ }^{23}$ "Het kan toch niet van de meerdere of minder vatbaarheid voor indrukken van de bedreigde afhangen of er misdrijf is gepleegd."24

19 Dwang (art. 284) en bedreiging met een misdrijf (art. $285 \mathrm{Sr}$ ) zijn strafbaar gesteld in titel XVIII waar de aantasting van de persoonlijke vrijheid centraal staat. Er zijn meer delicten waar de persoonlijke vrijheid wordt aangetast, zoals levensdelicten, diefstal met geweldpleging en seksuele geweldsdelicten, maar daar heeft de wetgever de aantasting van de vrijheid secondair geacht. NLR, aant. 1 op titel XVIII Sr: 879.

20 NLR, aant. 2 op art. 285: 919; Van Bemmelen-van Veen, Ons strafrecht 3, 1990: 49.

21 Simons, Leerboek van het Nederlandsche strafrecht, deel II, 1937-1941:51-53. HR 8 februari 1897, W. 6926; HR 5 januari 1914, NJ 1914, 397; HR 18 oktober 1915, NJ 1915, 1116; Rechtbank Maastricht 28 december 1970, NJ 1971, 174; HR 17 januari 1984, NJ 1984, 479.

Het dreigen met doden kan onder omstandigheden ook worden gekwalificeerd als een poging tot doodslag. Bij poging tot doodslag moet het opzet zijn gericht op de dood, terwijl dit bij bedreiging niet het geval hoeft te zijn. Volgens Remmelink sluiten de beide delicten elkaar uit: je kunt niet iemand pogen te doden en tegelijkertijd bedreigen. Wel zijn andere vormen van samenloop mogelijk, bijvoorbeeld het gooien van stenen of schieten door een ruit. Art. $68 \mathrm{Sr}$ zal dan van toepassing zijn. NLR, aant. 8 op art. 285 Sr: $922 a$.

22 HR 19 oktober 1936, NJ 1937, 163.

23 Minister van Justitie Modderman ten tijde van de kamerbehandeling. Smidt, De Geschiedenis van het Wetboek van Strafrecht, deel II, 189I: 423.

24 NLR, aant. 2 op art. $285 \mathrm{Sr}: 920$. 
Dit geldt eveneens voor het op de hoogte zijn van de bedreiging. Wanneer sprake is van bedreigingen die niet rechtstreeks tegen de vrouw worden geut, kan sprake zijn van het misdrijf bedreiging als de man het oogmerk heeft op het overbrengen van de bedreigingen aan de vrouw. Wanneer een man in aanwezigheid van een aantal mensen in een cafe vertelt dat hij zijn echtgenote gaat vemoorden met het pistool dat hij bij zich heef, kan dit worden beschouwd als bedreiging." Ditzelfde geldt voor de situatie dat een man zijn ex-vriendin een brief schrijf dat hij haar zal verkrachten en van het leven beroven, terwijl de vrouw de brief ongeopend aan de politie geef. ${ }^{27}$ Wanneer de bedreiging (schriftelijk) is geuit en de vrouw op de hoogte kan zijn van de bedreiging, is sprake van een voltooid delict. $^{23}$

Een andere manier waarop de persoonlijke vrijheid kan worden aangetast, is door het uitoefenen van dwang. Er is sprake van dwang als iemand door (bedreiging met) geweld of een andere feitelijkheid wederrechtelijk wordt gedwongen iets te doen of na te laten; de fysieke vrijheidsbeneming staat centraal. ${ }^{20}$ Onder geweld wordt niet alleen fysieke kracht verstaan, ook iemand in staat van onmacht of bewuste-

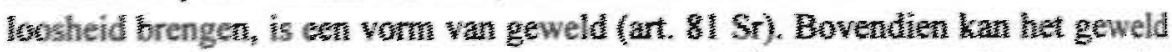

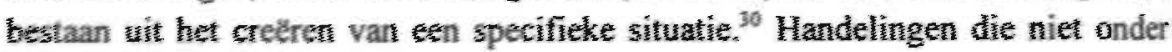

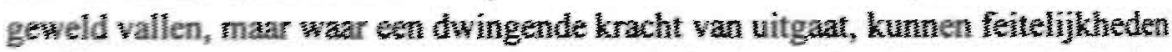

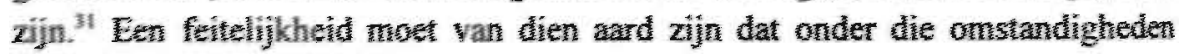

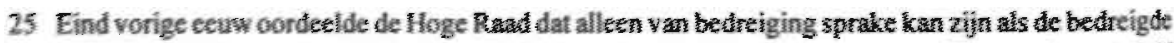

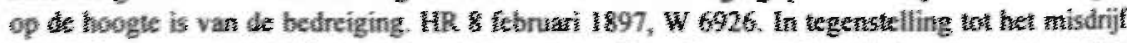

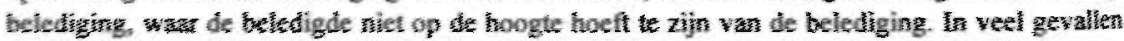

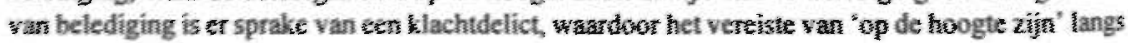
deze visg gelde.

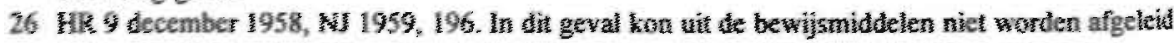
dat de verdactute het oogmet had de betreigingen dwot anderen asn zin echtgenote te laten

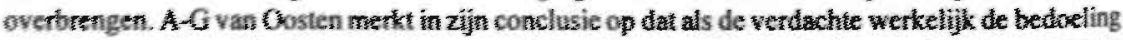
zou hebben gehad zijn echtgenote te vemoorden, hij juist niet de bedoelizg zou hebben gehad de sitlatingen door anderen aan zijn vrouw wer be brengen. Van Oosten suggereert hiermee fat het on sela emotionele opwelling gat, waandoor de mogelijheid dat de bedreiging kas worden uitgevoerd niet als een rețel afternatief lijht te wotden beschouwd.

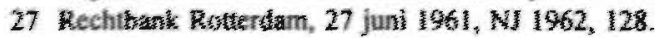

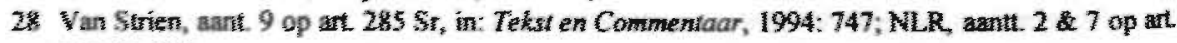
285 sr: 921.

29 Van Femmeler-van Veen, Ons strafrech 3, 1990: 49; Van Strien, ant. 5 op art. 284 Sr, \& Commentaar, 1994: 743 .

34) Van Strien, nant. 9 og art. 294 St, in: Tekst d. Commentad, $1994: 744$.

$31 \mathrm{NL}$. sant. $3 \mathrm{op}$ art. $284 \mathrm{Sr}$. In an. 266 lid $1 \mathrm{Sr}$ (cerwoudige belediging) komt feitelijkheid ook als bestardideel wow. In daz geval guat het on het beledigende karakter, en is de feitelikheid doet op zich. Oorspronikelijk was alleen in art. $266 \mathrm{Sr}$ de ferm feiteljkheid opgenomen. Nas aanleiding van werkstakingen is de term feitelijkheid in art. $284 \mathrm{Sr}$ toegevoegd bij de wet van 11 april 1903 . Dit had tor doel intimidatic door stakers van werkwillgen te kunnen aampakken. Van Bemmelen-van Veen, Ons strafrech! 3, 1990: 50 . 
iemand gedwongen wordt, ${ }^{32}$ maar mag niet bestaan uit een 'krachtdadige feitelijkheid'. Dat is een vorm van geweld. ${ }^{33}$ Een feitelijkheid is meer dan dreigen met woorden, maar minder dan het gebruik van geweld. ${ }^{34}$ Naast dwang als zelfstandig misdrijf kan dwang ook het middel zijn tot iets, bijvoorbeeld de dwang tot het plegen of ondergaan van seksuele handelingen (verkrachting of aanranding). In $\S 3.4 .2$ wordt nader ingegaan op de problematiek van dwang in relatie tot seksuele handelingen.

\subsubsection{Mishandeling ${ }^{35}$}

Mishandelen is het opzettelijk toebrengen van leed, wat kan bestaan uit fysiek letsel, pijn of schade voor de gezondheid. ${ }^{36}$ Psychische mishandeling als sarren, vitten en kleineren vallen niet onder mishandeling. ${ }^{37}$ Mishandeling (art. $300 \mathrm{Sr}$ ) is de hoofdvorm; daarnaast bestaat zware mishandeling (302 Sr). Beide kunnen al dan niet met voorbedachte rade gepleegd worden ( $301 \mathrm{Sr}$ en $303 \mathrm{Sr}$ ). Tevens zijn strafverzwarende gevolgen van de mishandeling strafbaar gesteld, namelijk zwaar lichamelijk letsel (300 lid $2 \mathrm{Sr}$ ) en de dood (300 lid $3 \mathrm{Sr}$ ) bij mishandeling en de dood bij zware mishandeling (302 lid $2 \mathrm{Sr}$ ). Een poging tot mishandeling is niet strafbaar, tenzij de mishandeling met voorbedachte rade is gepleegd ( 300 lid $5 \mathrm{Sr}$ ). Van Veen stelt dat de wetgever zo bagatelzaken buiten de deur heeft willen

32 Volgens Remmelink moet onder 'een andere feitelijkheid' worden verstaan: "Feitelijkheden zijn nu ook hier in het algemeen alle handelingen die niet vallen in het begrip van geweld, anderszijds niet uitsluitend bestaan in het uitspreken van woorden. Om middel tot het plegen van het misdrijf van dit artikel te zijn moeten zij zijn van zulke aard dat zij naar de gegeven omstandigheden beschouwd iemand kunnen dwingen, hem zijns ondanks brengen tot hetgeen van hem wordt verlangd." NL.R aant. 3 op art. 284 Sr: 915.

33 Rechtbank Utrecht, 28 februari 1940, NJ 1940, 528: naast iemand gaan rijden en arm om haar slaan en haar borsten betasten valt niet onder art. $246 \mathrm{Sr}$, wel onder art. $284 \mathrm{Sr}$, want hier was geen sprake van een krachtdadige feitelijkheid. De officier van justitie vorderde 2 jaar op grond van art. 246 $\mathrm{Sr}$, en de rechtbank legde 3 maanden met aftrek op wegens overtreden van art. $284 \mathrm{Sr}$. Nu feitelijkheid is toegevoegd als dwangmiddel in de art. 242 en $246 \mathrm{Sr}$, zou dit geval wel onder art. $246 \mathrm{Sr}$ vallen, behalve als feitelijkheid in deze artikelen een andere betekenis heeft dan onder art. $284 \mathrm{Sr}$. Dit lijkt vooralsnog niet het geval.

34 Onder de term feitelijkheid kunnen zeer verschillende omstandigheden vallen. Het dreigen met inheslagname is bijvoorbeeld beschouwd als bedreiging met een feitelijkheid (Rechtbank Rotterdam, 23 december 1947, NJ 1948, 541) en onder omstandigheden kan het dreigen met openbaar making van documenten waarin belastend materiaal over een bedrijf staat, bedreiging met een feitelijkheid opleveren (HR 22 april 1986, NJ 1986, 827 m.nt. 'tH). Daarentegen wordt niet als een feitelijkheid aangemerkt de dreiging een winkel te boycotten (HR 19 november 1923, NJ 1924: 153) en de dreiging om een valse aangifte van verkrachting te doen (HR 14 maart 1989, NJ 1990, 332).

35 Mishandeling is strafbaar gesteld in titel XX.

36 In het ontwerp werd het omschreven als "hij die aan een ander opzettelijk ligchamelijk leed toebrengt of opzettelijk diens gezondheid benadeelt". Smidt, De geschiedenis wan het Wetboek van Strafrecht, deel II, 1891: 29; Cleiren \& Nijboer, aant. 1 op titel XX Sr, in: Tekst \& Commentaar, 1994: 773.

37 Van. Bemmelen-van Veen, Ons strafrecht 3, 1990: 39. 
houden ${ }^{38}$ Hiermee wordt voorbijgegaan aan het feit dat een poging tot mishandeling geen bagatelzaak hoeft te zijn. Het was beter geweest de poging niet uit te sluiten en het aan het openbaar ministerie over te laten of de zaak ernstig genoeg is om te vervolgen. ${ }^{39}$

Het opzet van de man moet zijn gericht op het toebrengen van leed, letsel of benadeling van de gezondheid. ${ }^{40}$ Het mis kan worden geduid als wederrechtelijk; het handelen moet wederrechtelijk zijn. Wanneer leed wordt toegebracht met een gerechtvaardigd doel, zoals de chirurg die een ontstoken blindedarm verwijderd, is, in die visie, geen sprake van wederrechtelijk handelen, en daarmee ook niet van mishandelen. ${ }^{41}$ Ook ouders kunnen met een gerechtvaardigd, want opvoedkundig doel, leed toebrengen. Eveneens $k a n$ in bepaalde sportsituaties sprake zijn van een gerechtvaardigd doel. ${ }^{42}$ Geweld tegen de vrouw door haar echtgenoot kent sinds de gelijkberechtiging van mannen en vrouwen geen geoorloofd doel meer. ${ }^{43}$ In 1895 was dit nog anders. Toen sprak de Hoge Raad zich uit over een mishandeling van de echtgenote waar niet was gebleken van een gerechtvaardigd doel: "zonder dat bleek van eenige geoorloofde beweegreden". ${ }^{44}$

Over het algemeen kan uit de gedraging worden afgeleid dat sprake is van het opzettelijk toebrengen van letsel of leed, zoals bij slaan, schoppen, bijten en krabben. De gedraging brengt pijn of letsel voort. ${ }^{45}$ Wel moet uit de omstandigheden blijken

38 Van Bemmelen-van Veen, Ons strafrecht 3, 1990: 41.

39 Zie ook: NLR aant. 8 op art. $300 \mathrm{Sr}$ : $970-971$.

40 In het oorspronkelijk regeringsontwerp stond de term opzet in de delictsomschrijving, zoals die ook in de delictsomschrijving van zware mishandeling staat. Er is uiteindelijk voor de term mishandeling gekozen omdat 'het opzettelijk toebrengen van lichamelijk leed' alleen lichamelijk letsel inhoudt, terwijl er in de praktijk meer situaties van mishandeling kunnen zijn. De term mishandeling werd voldoende bepaald geacht, terwijl de rechter tegelijkertijd voldoende mogelijkheden voor interpretatie kreeg. Smidt, Geschiedenis van het Wetboek van Strafrecht, deel II, 189 I: 448-453: Woretshofer, Volgens de regelen van de kunst, 1992: 28-32. Er zijn meer van dit soort termen als mishandeling, bijvoorbeeld vrouwenhandel (art. 250ter Sr). Remmelink, Hazewinkel-Suringa's Inleiding, 1994: 125-126.

41 Remmelink stelt dat er toch minstens toestemming van de patient moet zijn voor de medische behandeling; het feit dat er sprake is van een beroepsdaad, acht hij niet voldoende. Remmelink, Hazewinkel-Suringa's Inleiding, 1994: 358-359. Zie ook: Cleiren \& Nijboer, aant. 11 op art. 300 Sr, in: Tekst \& Commentaar, 1994: 776; NLR, aant. 9 op art. 300 Sr. Woretshofer, Volgens de regelen van de kunst, 1992: 46-47.

42 Indien het toebrengen van lichamelijk letsel niet het doel is, maar het middel tot een geoorloofd doel, is er geen mishandeling. Kastijding van het kind door ouders of onderwijzers kan onder een genorioofd doel vallen, aldus de HR 10 februari 1902, W 7723. Zie over deze problematiek: Van Bemmelen-van Veen, Ons strafrecht 3, 1990: 36-38. Remmelink, Hazewinkel-Suringa's Inleiding, 1994: 354-357; Woretshofer, Volgens de regelen van de kunst, 1992: 32. Zie ook 't Hart in zijn noot onder HR 21 februari 1989, NJ 1989, 668.

43 Remmelink, Hazewinkel-Suringa's Inleiding, 1994: 356-357.

44 HR I april 1895, W. 6640.

45 HR 27 november 1933, NJ 1934, p. 76; HR I december 1970, NJ 1971, 139; NLR, aant. 3 op art. $300 \mathrm{Sr}$. 
dat de handeling van de man gericht is op de vrouw. ${ }^{46} \mathrm{Bij}$ duwen en aangrijpen kan minder snel uit de gedraging worden afgeleid dat er sprake is van opzet leed toe te brengen. ${ }^{47}$ Als geen pijn of letsel is geconstateerd, is er geen sprake van mishandeling. Als wel pijn of letsel aanwezig is, is de volgende vraag of het opzet pijn of letsel toe te brengen kan worden bewezen. In bepaalde gevallen wordt opzet uit de gedraging en omstandigheden afgeleid en in andere gevallen niet. Een voorbeeld hiervan is het in het wilde weg om zich heen slaan: eerst moet worden vastgesteld dat pijn of letsel is veroorzaakt en vervolgens komt de vraag aan bod of het opzet pijn of letsel toe te brengen aanwezig was. Zo werd de verklaring van de verdachte, dat hij in woede in het wilde weg om zich heen sloeg, door de Hoge Raad niet redengevend geacht voor opzettelijk mishandelen, omdat het opzet pijn toe te brengen ontbrak. ${ }^{48}$ Door voorwaardelijke opzet aan te nemen kan onder omstandigheden wel sprake zijn van mishandeling. "Zo zal iemand die in het wilde weg om zich heen slaat ongetwijfeld meer of minder bewust de aanmerkelijke kans aanvaarden dat hij een ander pijn of letsel toebrengt. ${ }^{, 49}$ Het hiervoor beschrevene laat zien dat het opzet om iemand pijn te doen een belangrijke rol speelt in de bewezenverklaring. Of uit de feiten (voorwaardelijk) opzet leed of letsel toe te brengen wordt aangenomen, is mede afhankelijk van hoe de feiten worden geïnterpreteerd.

Ter verduidelijking een voorbeeld. Een vrouw gaat naar haar ex-partner toe om geld terug te krijgen. Zij wordt, nadat ze heeft aangebeld, door haar ex-partner opgepakt en tegen het trottoir geduwd. De man stelt dat er weliswaar lijfelijk contact is geweest, maar dat dit tot doel had de vrouw te verwijderen en niet om haar pijn te doen. Deze casus kan op twee manieren worden geînterpreteerd. Enerzijds kan op grond van dit verweer worden gesteld dat geen wettig bewijs aanwezig is voor het opzet haar pijn te doen. Anderzijds kan tot wettig en overtuigend bewijs worden besloten door de feiten als volgt te benoemen: Het slachtoffer geeft aan krachtig op de grond te zijn geduwd. Verdachte erkent het op de grond duwen. Tevens meldt de vrouw dat er sprake was van pijn in rug en ribben.

Er is sprake van zware mishandeling wanneer de man het opzet heeft de vrouw zwaar lichamelijk letsel toe te brengen. ${ }^{50}$ Zwaar lichamelijk letse] is, niet limitatief, omschreven in artikel $82 \mathrm{Sr}$, en betreft beschadiging van de gezondheid, voortduren-

46 Wanneer bijvoorbeeld een vrouw aangifte doet van mishandeling door haar ex-partner - hij heeft haar gestompt en geslagen, waardoor ze gekneusde ribben heeft opgelopen - kan, ondanks een doktersverklaring, het wettig en overtuigend bewijs ontbreken dat de man veroorzaker is van de gekneusde ribben. Een verklaring van de huisarts zegt namelijk niets over wie die gekneusde ribben heeft veroorzaakt.

47 HR 1 december 1930, NJ 1931, p. 282.

48 HR 9 februari 1965, NJ 1965, 261.

49 Wedzinga, Openlijke geweldpleging, 1992: 115

50 Cleiren \& Nijboer, aant. I op art. 302, in: Tekst \& Commentaar, 1994: 777. 
de arbeidsongeschiktheid en storing van de verstandelijke vermogens die langer dan vier weken heeft geduurd. Bovendien gaat het niet alleen om blijvend letsel, zoals artikel $82 \mathrm{Sr}$ suggereert. Ook tijdelijk en herstelbaar letsel kan onder zwaar lichamelijk letsel vallen. ${ }^{51}$ Factoren als bijzonder levensgevaar, lange duur van het herste $\left.\right|^{52}$ of gevaar voor invaliditeit kunnen van belang zijn voor het aannemen van zwaar lichamelijk letsel. ${ }^{53}$ Tot slot is het gewone spraakgebruik een belangrijke maatstaf om te bepalen of van zwaar lichamelijk letsel gesproken kan worden. ${ }^{54}$

Bij zware mishandeling blijkt, evenals bij mishandeling, het opzet meestal uit de gedraging. Het gebruik van een bepaald voorwerp, zoals een mes, een wapen, of een strijkijzer, kan zo'n gedraging zijn. ${ }^{55}$ Wanneer de man zijn vriendin met een massief stuk hout krachtig op haar hoofd slaat, mag redelijkerwijs worden aangenomen dat de man heeft kunnen inzien dat dit zwaar lichamelijk letsel tot gevolg kan hebben. ${ }^{56}$

Tot slot nog een opmerking over de strafverzwarende bepaling (art. $304 \mathrm{Sr}$ ). Mishandeling binnen een familierechtelijke relatie is één van de strafverzwarende omstandigheden. ${ }^{57}$ Wanneer de man 'zijn echtgenoot' mishandelt, wordt het strafmaximum met een derde verhoogd. De strekking van deze bepaling is, volgens Cleiren en Nijboer, dat de piêteit tegenover naaste verwanten een zwaardere straf rechtvaardigt. ${ }^{58}$ Als achterliggende reden voor deze strafverzwaring wordt beschouwd de toenmalige beschermingsplicht van de man tegenover zijn echtgenote voortkomend uit het feit dat de gehuwde vrouw naar toen geldend recht handelingsonbekwaam was en de man hoofd was van het gezin. De vrouw was geheel aan de macht van haar echtgenoot overgeleverd en door haar te mishandelen schond de man zijn plicht tot bescherming. "De man die zijne vrouw opzettelijk doodt, schendt bovendien den pligt tot bescherming hem door wet en natuur opgelegd; de vrouw

51 Zie bijvoorbeeld: HR 4 mei 1993, DD 93.404. Het zwaar lichamelijk letsel betrof gebroken wervels, gebroken pols en een niercontusie.

52 Een zonder toestemming aangebrachte tatoeage kan zware mishandeling opleveren, HR 22 mei 1990, NJ 1991, 93. Het betrof een vrouw die bij een kennis op bezoek ging, een bedwelmend middel in haar yoghurt kreeg toegediend en tijdens haar bewusteloosheid werd verkracht en getatoeserd.

53 NLR, aant. 2 op art. 82 Sr.

54 HR 22 oktober 1923, p. 1368.

55 NLR, aant. 6 op art. $302 \mathrm{Sr}$; Cleiren \& Nijboer, aant. 9 op art. $302 \mathrm{Sr}$, in: Tekst \& Commentaar, 1994: 778-779.

56 Zie bijvoorbeeld: HR 12 mei 1964, NJ 1965, 26.

57 De andere strafverzwarende omstandigheden zijn: het plegen van het misdrijf tegen een ambtenaar en het plegen van het misdrijf door toediening van schadelijke stoffen.

58 Cleiren \& Nijboer, aant. 2 op art. $304 \mathrm{Sr}$, in: Tekst \& Commentaar, 1994: 780. 
is geheel aan zijne magt overgeleverd." 'Zijn echtgenoot' wordt daarom geïnterpreteerd als 'zijn vrouw' ${ }^{60}$

De achterliggende gedachte van deze strafverzwarende bepaling moet naar mijn mening inderdaad gezocht worden in de beschermingsgedachte, maar tegelijkertijd is naar voren gebracht dat ook vrouwen hun echtgenoot in hun macht konden hebben. Dit blijkt uit de totstandkoming van dit wetsartikel. In het voorontwerp wordt namelijk gesproken van 'zijne vrouw', en dit werd bekritiseerd door de Raad van State en de commissie de Wal: "De reden welke de Memorie van Toelichting geeft om de bijzondere bescherming tot de vrouw te beperken is niet geheel juist. Ten aanzien van vergiftiging b.v. is de man nog meer aan de magt van de vrouw overgeleverd dan omgekeerd. In naburige landen, Frankrijk en België, zijn dan ook de gevallen van vergiftiging van den man door de vrouw, dikwijls met het bezwarende doel om met een minnaar te huwen, niet zeldzaam." N1 Naar aanleiding van deze kritiek is 'zijn vrouw' gewijzigd in 'zijn echtgenoot'. ${ }^{62}$ Dit betekent dat de strafverzwarende bepaling ook kan worden toegepast als de vrouw haar echtgenoot mishandelt.

De plicht tot bescherming van de vrouw lijkt tegenwoordig achterhaald, gezien het feit dat mannen en vrouwen binnen het huwelijk eenzelfde rechtspositie hebben. De strafverzwarende bepaling zou dan alleen zijn gegrond op wat Cleiren en Nijboer noemen 'de piëteit tegenover naaste verwanten'. Dit lijkt mij een wat magere grond gezien het specifieke karakter van mannelijk geweld tegen vrouwen in de privésfeer. Ik kom hier later op terug.

\subsubsection{Van pogingen tot uitgevoerde doodslag of moord ${ }^{63}$}

De hoofdvorm van deze titel is de doodslag, iemand van het leven beroven. Daarom heen bevinden zich moord, kinderdoodslag en -moord, ${ }^{64}$ en levensberoving op

59 Smidt, De geschiedenis van het Wetboek van Strafrecht, deel II, 1891: 428. Zo'n zelfde strafverzwaring gold in het voorontwerp ook bij doodslag, maar deze werd geschrapt om zuiver wetstechnische argumenten; de maximale straf van verkrachting werd verhoogd, en tevens de straf op doodslag, waardoor deze op 15 jaar kwam te staan. NLR, aant. 4 op art. $287 \mathrm{Sr}$

60 NLR, aant. 2 op 304 Sr: 979; Cleiren \& Nijboer, aant. 3 op art. 304, in: Tekst \& Commentaar, 1994: 781.

61 Smidt, De geschiedenis van het Wetboek van Strafrecht, deel II, 1891: 432.

62 Ibidem: 454-456. Tevens was er in het voorontwerp sprake van strafverminderende omstandigheden, namelijk als de dader tot de mishandeling was gekomen omdat de echtgenoot op overspel was betrapt. " $[O]$ nder de onmiddelijke werking van een hevigen toom ten gevolge van betrapping op overspel ontstaan" (Ibidem: 455).

63 Moord en doodslag zijn strafbaar gesteld in titel XIX, misdrijven tegen het leven gericht.

64 Kinderdoodslag en -moord zijn leges speciales van doodslag en moord. Deze delicten kunnen alleen door de moeder worden gepleegd. Het stamt uit de tijd dat ongehuwde moeders hun kind doodden uit angst voor schande van hun moederschap of omdat vrouwen niet de middelen hadden om hun kind groot te brengen. Van Bemmelen-van Veen, Ons strafrecht 3, 1990: 23. Tegenwoordig is ongehuwd moeder zijn geen schande meer. Toch kunnen er situaties zijn waar de baby ervaren wordt 
verzoek. Er is sprake van doodslag als iemand een ander opzettelijk van het leven berooft. Een poging tot doodslag kan feitelijk betekenen dat de vrouw letsel heef. Dat het dan toch geen mishandeling is, maar poging tot doodslag wordt bepaald door het (voorwaardelijk) opzet de vrouw te doden ${ }^{65}$ Wanneer de vrouw dood is, maar de dood van de vrouw is niet beoogd, niet bedoeld en zelfs niet verwacht als een gevolg van het handelen, kan sprake zijn van mishandeling met de dood tot gevolg (art. 300 lid $3 \mathrm{Sr}$ ) of van dood door schuld (art. $307 \mathrm{Sr}$ ). ${ }^{56}$ Het opzet te doden kan blijken uit de aard van de gedraging, zoals het steken met een groot mes in de buik van de vrouw, of uit de omstandigheden waaronder het gedrag plaats vindt, bijvoorbeeld een vrouw - onder invloed van alcohol en nauwelijks gekleed - in de vrieskou achter laten op een verlaten, open terrein. ${ }^{67}$

Van moord is sprake als de man 'opzettelijk en met voorbedachte raad' de vrouw doodt; moord is doodslag met voorbedachte raad begaan. Dat wil zeggen dat enige tijd yoor de handeling sprake is geweest van kalm overleg, van bedaard nadenken. ${ }^{68}$ Tegenover kalm overleg staat handelen in een opwelling; wanneer iemand handelt in een opwelling, kan geen sprake zijn van moord. ${ }^{69}$ Dit kalm overleg moet overigens niet te letterlijk worden genomen. Het gaat erom dat enige tijd voor de uitvoerende handeling het besluit is genomen. ${ }^{70}$ Voorbedachte raad is daardoor geen

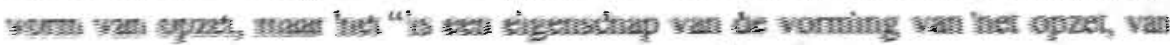
het proces waaronder het opzet tot stand luwam" " Moord is opzettelike levens.

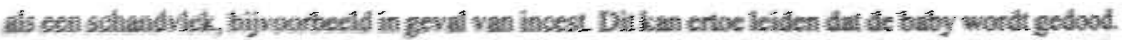
He 25 juni 1960 , $20196 \%, 250$.

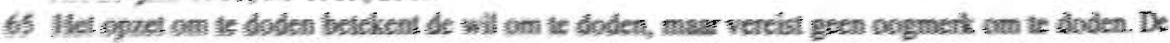

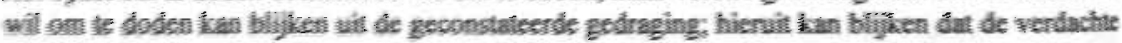

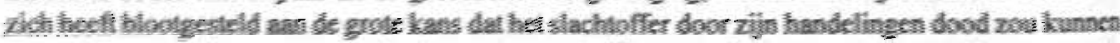

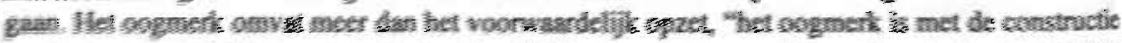

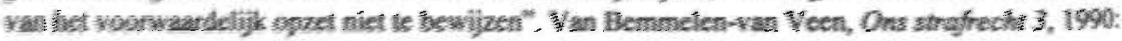
$17-18$.

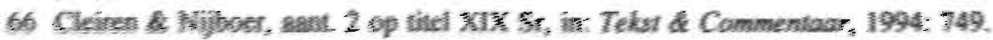

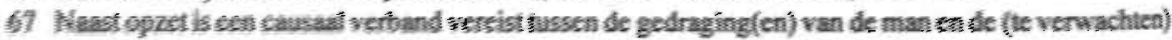
dood sat de srouw volgers het cristerium van de redelijke toercleening. Cleiren sp G6el VIX 3r, in: Tokst a commesstar, 1994: 749-750.

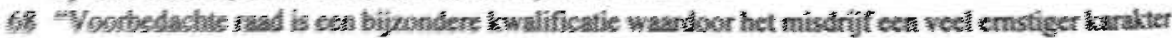

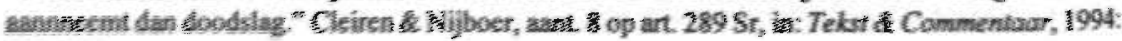
753,756

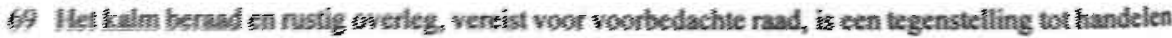

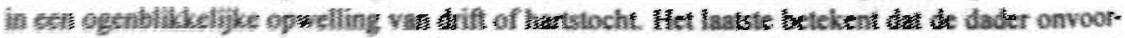

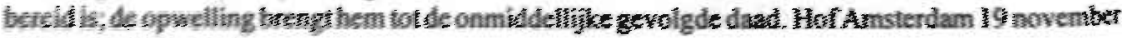
1942 , 赫 1942, 474.

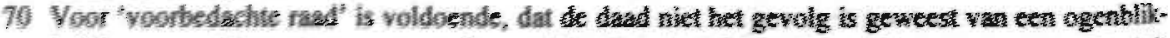

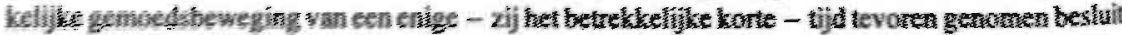

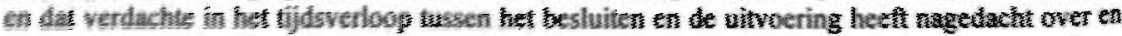

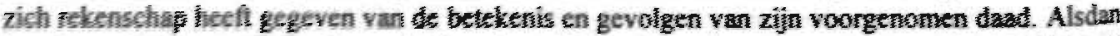

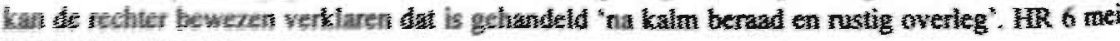
$1975,197 \%$, 416 .

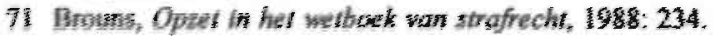


beroving terwijl over de dood als gevolg is nagedacht. ${ }^{72}$ Doodslag in koele bloede kan ook tot moord worden gerekend. ${ }^{73}$ Van voorbedachte raad was sprake toen de man besloot zijn vrouw met een slagersmes te doden als zij zich niet met hem zou verzoenen. Toen zij zich niet met hem verzoende, doodde hij haar. Dit werd beschouwd als moord. ${ }^{74}$ Iemand vergiftigen wordt eveneens beschouwd als een daad met voorbedachte rade.

Het onderscheid tussen mishandeling, doodslag en moord lijkt op het eerste gezicht eenvoudig, maar toch blijken er in de juridische praktijk verschillen in kwalificatie van de feiten; wat de één kwalificeert als een poging tot moord, kwalificeert de ander als een poging tot doodslag of een poging tot zware mishandeling. ${ }^{75}$ Het arrest van de garagehouder die zijn vrouw door vergassing om het leven wil brengen, is hier een mooie illustratie van. ${ }^{76}$ Een garagehouder spuit via een koperen buis uitlaatgassen (koolmonoxide) van zijn stationair draaiende auto in de slaapkamer waar zijn vrouw ligt te slapen. Na ruim een uur roept hij zijn vrouw, maar krijgt geen antwoord. Als hij gaat kijken, ruikt hij een gaslucht. Hij pakt zijn dochtertje uit bed en legt haar buiten op het plat neer. Vervolgens vertrekt hij naar zijn vader en zegt: ze zijn thuis allemaal dood. De vrouw blijkt diep bewusteloos en in levensgevaar. De officier van justitie legt primair poging tot doodslag ten laste, subsidiair zware mishandeling begaan tegen 'zijn echtgenoot' en gepleegd door toediening van voor het leven schadelijke stoffen, en nog meer subsidiair mishandeling bestaande uit opzettelijke benadeling van de gezondheid, zwaar lichamelijk letsel ten gevolge hebbende. De Rechtbank in Middelburg spreekt de garagehouder vrij van poging tot doodslag en veroordeelt voor zware mishandeling (art. 302 juncto $304 \mathrm{Sr}$ ). Het Hof in Den Haag bevestigt dit vonnis. ${ }^{77}$ Doordat de man is vrijgesproken van de poging tot doodslag rijst de vraag of het opzet iemand te doden ook tot bewijs kan dienen van het opzet zwaar te mishandelen. De Hoge Raad bevestigde dit: het opzet te doden kan tot bewijs dienen voor het opzet zwaar te mishandelen. ${ }^{78}$

72 Brouns, Opzet in het wetboek van strafrecht, 1988: 237. Zie ook: Demeersseman, Met voorbedachte rade, 1989.

73 Brouns, Opzet in het wetboek van strafrecht, 1988: 238-239.

74 HR 18 oktober 1983, NJ 1984, 351.

75 NLR, aant. la op art. $289 \mathrm{Sr}: 937$ (noot I).

76 HR 19 augustus 1952, NJ 1953, 102.

77 De man is veroordeeld tot zes jaar gevangenisstraf met aftrek van de tijd in voorlopige hechtenis doorgebracht.

78 Wat hierbij interessant is, is de wijze waarop dit gebeurt; de verklaring van de garagehouder wordt anders geformuleerd. De garagehouder verklaart bij de rechter-commissaris: "Ik beken dat ikgepoogd heb mijn vrouw van kant te maken door de garage beneden onze slaapkamer vol uitlaatgas te laten stromen." De Hoge Raad formuleert dit als volgt: "[E]en bekentenis dat req. ten einde de levensfuncties zijner echtgenote onherstelbaar te verstoren handelde zoals in de verklaring omschreven, welke handeling het opzet tot het bewezen verklaarde misdrijf insloot, (...)." HR 19 augustus 1952, NJ 1953, 102. Zie tevens Pompe in zijn noot onder het arrest. Deze uitspraak moet overigens als een uitschieter worden beschouwd, aangezien mishandeling en doodslag geen gelijksoortige strafbare 
Of hiertoe kan worden besloten is sterk afhankelijk van de inhoud van de beschikbare bewijsmiddelen. Je kunt je afvragen waarom in dit geval de man niet is veroordeeld wegens de primair ten laste gelegde poging tot doodslag. De man had het opzet zijn vrouw te doden en dat de vrouw niet is doodgegaan, is niet te wijten aan een vrijwillige terugtred van de man; dan had hij de vrouw ook buiten op het plat moeten leggen. Overigens geven de feiten eerder aanleiding tot de kwalificatie poging tot moord, nu niet gesproken kan worden van een opwelling. Uit niets blijkt dat de man handelde in een opwelling, of dat er sprake was van een ogenblikkelijke gemoedsbeweging. Maar de officier van justitie had geen poging tot moord ten laste gelegd en de rechter mag dan niet veroordelen voor moord. ${ }^{79}$

Dit voorbeeld laat zien dat de grenzen tussen (zware) mishandeling, poging tot doodslag, en poging tot moord niet eenduidig zijn te trekken. Bovendien komt naar voren dat het feit dat er sprake is van een huwelijkse relatie juridisch niet relevant is. Het ten laste leggen van 'zware mishandeling tegen zijn echtgenoot', betekent alleen dat het strafmaximum met een derde omhoog gaat. De strafmotivering hoeft hier niet op in te gaan. Hierdoor blijft onduidelijk of het feit dat het misdrijf is gepleegd tegen de echtgenote een (strafverzwarende) rol heeft gespeeld in de strafmaat. Bovendien draagt dit eraan bij dat geweld tegen de vrouw in huwelijkse relaties onzichtbaar is. Het is niet noodzakelijk op artikel $304 \mathrm{Sr}$ in te gaan in de juridische handboeken bij de bespreking van de misdrijven tegen de lichamelijke integriteit. Van Veen bijvoorbeeld bespreekt artikel $304 \mathrm{Sr}$ niet vanuit de veronderstelling dat justitie weinig vermeemt van mishandeling binnenshuis. ${ }^{80}$ Deze veronderstelling lijkt gestoeld op de gedachte dat geweld in de privésfeer een privéprobleem is waar de overheid niet in behoort te treden (privacy als passief recht). Door artikel $304 \mathrm{Sr}$ niet te bespreken wordt versterkt dat geweld in de privésfeer onzichtbaar is in het strafrechtelijk denken.

\subsection{Huisvredebreuk en vernieling}

Een andere vorm van geweldpleging is het vermielen van eigendom van de vrouw, zoals voorwerpen waar zij emotioneel aan gehecht is of huisraad. Hoewel deze vorm van geweld niet direct een vorm van lichamelijk geweld tegen de vrouw is, is het wel een vorm van agressie: het geweld richt zich tegen de vrouw door de dreiging die ervanuit kan gaan en doordat de vernieling goederen kan betreffen, waar de

feiten zijn, en vermenging van deze feiten tot een troebele grondslag van de telastlegging leidt. Brouns, Opzet in het wetboek van strafrecht, 1988: 161-162.

79 Zie: Van Bermmelen, Is de dood 'zwaar lichamelijk letsel'?, NJB, 1953: 229-233. Wanneer de officier van justitie moord ten laste legt, terwijl de 'voorbedachte raad' niet bewezen kan worden, mag de rechtbank wel veroordelen voor doodslag. HR 5 december 1932, NJ 1933, 551; Cleiren \& Nijboer, aant. 7 op art. $289 \mathrm{Sr}$, in: Tekst \& Commentaar, 1994: 755.

80 Van Bemmelen-van Veen, Ons strafrecht 3, 1990: 40. 
vrouw emotioneel aan gehecht is. Vernieling kan een vorm van bedreiging door de man zijn. Huisvredebreuk is een van de manieren waarop mannen een inbreuk kunnen maken op de persoonlijke levenssfeer van de vrouw, als sprake is van een ex-relatie of een intieme relatie waar partners niet op én adres wonen. In veel gevallen gaat huisvredebreuk gepaard met vernieling, omdat een ruitje wordt ingeslagen of een deur wordt vernield. Vandaar dat ik deze delicten samen behandel.

\subsection{Huisvredebreuk ${ }^{81}$}

Door strafbaarstelling van het wederrechtelijk binnendringen of wederrechtelijk vertoeven, wordt de huisvrede beschermd; de bescherming van het intieme, private leven, het huisrecht. ${ }^{82} \mathrm{Er}$ is sprake van huisvredebreuk als iemand wederrechtelijk een woning (besloten lokaal of erf) bij een ander in gebruik binnendringt of aldaar aanwezig niet aanstonds verdwijnt op vordering van de rechthebbende. Strafverzwarend is het uiten van bedreigingen of vrees aanjagen ${ }^{83}$ Binnendringen $^{84}$ en onrechtmatig aanwezig zijn, betekent tegen de wil van de rechthebbende en wederrechtelijk betekent zonder daartoe gerechtigd te zijn. ${ }^{85}$ Op twee punten zal ik nader ingaan. Op welke manier moet de rechthebbende haar wil kenbaar maken? En wanneer wordt wederrechtelijk gehandeld?

$\mathrm{Er}$ is sprake van binnendringen als de vrouw uitdrukkelijk te kennen heeft gegeven dat de man niet welkom is, als zij hem verbiedt binnen te komen. Wanneer niet duidelijk is gesteld dat de man niet haar huis in mag, is er sprake van binnentreden (en dit is niet strafbaar). Deze wilsverklaring kan door woorden en door daden worden gegeven, en bovendien kan uit bijzondere omstandigheden worden afgeleid dat het binnengaan tegen de wil van de vrouw indruist. Het binnendringen hoeft niet gepaard te gaan met geweld, een voet tussen de deur zetten is bijvoorbeeld

81 Huisvredebreuk valt onder titel V, misdrijven tegen de openbare orde. In deze titel staan bovendien delicten als opruiing, discriminatie, orde verstoringen en afluisterpraktijken. Het begrip openbare orde houdt meer in dan alleen "pure openbare rust en veiligheid. Er zit ook iets in van de mensen niet hinderen in hun door de rechtsorde gegeven vrijheid van privéleven (...)". NLR, aant. 1 op titel V Sr: 137. Zie ook Van Bemmelen-van Veen, Ons strafrecht 3, 1990: 108.

82 De bescherming van het huisrecht staat voorop en niet de bescherming van een ander zijn (eigendoms)recht. HR 14 december 1914, NJ 1915, 368; HR 27 juni 1927, NJ 1927, 946; HR 2 februari 1971, NJ 1971, 385. Zie ook van Bemmelen-van Veen, Ons strafrech' 3, 1990: 109; Buiting, aant. 6 op art. 138 Sr, in: Tekst \& Commentaar, 1994: 449.

83 Op huisvredebreuk staat maximaal zes maanden gevangenisstraf en op de strafverzwarende omstandigheid maximaal een jaar gevangenisstraf.

84 Binnendringen is zowel een feitelijke term als een rechtsbegrip. NLR, aant. 2 op art. $138 \mathrm{Sr}: 193$.

85 In de term binnendringen zit het opzet besloten, aldus Remmelink. Of opzet ook op de wederrechtelijkheid gericht moet zijn, is punt van discussie. De HR besliste van niet in het arrest van 8 november 1955, NJ 1956, 181. Remmelink neigt naar het andere standpunt. In de praktijk zal er door het bestaan van voorwaardelijke opzet weinig verschil zijn. NLR, aant. $12 \mathrm{op}$ art. $138 \mathrm{Sr}$. Om juridische problemen te voorkomen kan de politie het verhaal van de verdachte zo noteren: 'Ik ben opzettelijk wederrechtelijk de woning van haar binnengedrongen door de voordeur in te trappen.' 
al binnendringen. ${ }^{86}$ Onder huisvredebreuk wordt bovendien verstaan het onrechtmatig aanwezig zijn. Daartoe is vereist dat de vrouw heeft gevorderd dat de man zich verwijdert. "Vaak zullen twee aanmaningen om heen te gaan nodig zijn: de eerste om het wederrechtelijk vertoeven vast te stellen en de tweede om het niet verwijderen te constitueren. ${ }^{187}$ Als de man niet vertrekt op verzoek van de vrouw, kan de hulp van de politie worden ingeroepen. ${ }^{88}$ In aanwezigheid van de politie moet de vrouw opnieuw vorderen dat de man vertrekt. Wanneer zij dat niet doet, kan voldoende bewijs voor huisvredebreuk ontbreken. Zo lijkt huisvredebreuk niet snel te worden aangenomen als de vrouw zozeer van streek is, dat zij niet in staat is te vorderen dat de man zich moet verwijderen.

Het binnendringen of onrechtmatig aanwezig zijn kan gepaard gaan met bedreigingen of middelen om vrees mee aan te jagen; zowel de bedreiging als het middel moeten vrees aan jagen. Het middel kan bijvoorbeeld een wapen zijn. "De ratio der bepaling is dat de tegenstand tegen het binnendringen en de kracht der aanmaning tot het heengaan aan hem die vertoeft wordt verlamd." ${ }^{199}$ Wanneer de ex-partner uitroept 'ik vermoord je als je de deur niet opendoet' of 'als je niet opendoet, trap ik de deur open' kunnen naar mijn mening onder omstandigheden bedreiging in de zin van artikel 138 lid $3 \mathrm{Sr}$ opleveren. Bovendien kunnen bepaalde vreesaanjagende gedragingen de vrouw dermate 'verlammen' dat zij niet in staat is te vorderen dat de man zich verwijdert. Ook dan kan sprake zijn van bedreiging in de zin van artikel 138 lid $3 \mathrm{Sr}$.

Het tweede punt betreft de wederrechtelijkheid. Of het handelen wederrechtelijk is, is afhankelijk van de verhouding tussen de partijen. Binnen een huwelijkse relatie kan geen sprake zijn van huisvredebreuk omdat beide partners bevoegd zijn het huis te betreden, mits sprake is van feitelijke samenwoning. Aangezien het huisrecht wordt beschermd en niet het eigendomsrecht, heeft de man tijdens de echtscheidingsprocedure geen recht het huis te betreden als de vrouw het huis op grond van een voorlopige voorziening toegewezen heeft gekregen; het huis kan eigendom zijn van de man terwijl de vrouw erin woont en dientengevolge een huisrecht heeft. ${ }^{90}$ Als samenwonenden samen het huis huren of hebben gekocht dan is huisvredebreuk, evenals bij gehuwden die samenwonen, niet mogelijk. Niet altijd is duidelijk welke afspraken of regels gelden en dan zullen de regels van het maatschappelijke verkeer een belangrijke rol spelen. Wie als bezoeker in het huis van een ander vertoeft, wordt geacht rechtmatig aanwezig te zijn, totdat de rechthebbende vordert dat de bezoeker het huis verlaat. "Ook familie- en vriendschapsrelaties zullen in vele

86 NLR, aant. 2 op art. $138 \mathrm{Sr}$.

87 Buiting, aant. 9 op art. $138 \mathrm{Sr}$, in: Tekst \& Commentaar, 1994: 450.

88 NLR, aant. 14 op art. 138 Sr: 205.

89 NLR, aantt. 19-2I op 138 Sr: 218-220 (citaat: 219).

90 Zie ook: HR I februari 1926, NJ 1926, 253; HR 9 juni 1941, NJ 1941, 702; HR 8 november 1955, NJ $1956,181$. 
gevallen de aanwezigheid legitimeren." aangenomen als mensen samenwonen, ook als een gezamenlijk huur- of koopcontract niet aanwezig is.

\subsubsection{Vernieling ${ }^{92}$}

Onder vernieling wordt verstaan het opzettelijk en wederrechtelijk vernielen, beschadigen, onbruikbaar maken of wegmaken van een goed dat geheel of ten dele aan een ander toebehoort (art. 350 lid $1 \mathrm{Sr}$ ). Het ongestoorde gebruik van een goed, door de vrouw aan wie het goed (ten dele) toebehoort, is het beschermde belang. ${ }^{93}$ Van belang is dat het goed geheel of ten dele toebehoort aan een ander en dat de dader dit weet. ${ }^{94}$ Wanneer het goed geheel aan de dader toebehoort, is vernieling ervan niet strafbaar, ook al zijn rechten van anderen daardoor geschonden. Het opzet moet zijn gericht op de vernieling van een goed. Dat neemt niet weg dat het vernielen van goederen regelmatig een vorm van agressie is om een ander te benadelen. ${ }^{95}$ Vernielingen aangericht door de man binnen een (huwelijkse) relatie kunnen gericht zijn op het kwetsen en benadelen van de vrouw, bijvoorbeeld door spullen te vernielen die haar zeer dierbaar zijn. Het oogmerk is dan benadeling van een persoon. Dit laatste is geen bestanddeel van het delict en behoeft daarom niet bewezen te worden, ${ }^{96}$ maar kan in geval van vrouwenmishandeling wel beschouwd worden als het meest essentiële aspect van de vernieling (als de vemieling niet het middel is om het huis binnen te komen).

Vernieling van goederen die (deels) toebehoren aan de vrouw is, afhankelijk van de soort relatie die de vrouw met de man heeft, wel of niet strafrechtelijk aan te pakken. Strafvervolging is uitgesloten als de goederen worden vernield door de echtgenoot. De man die goederen van zijn echtgenote vernielt, ongeacht of op huwelijkse voorwaarden is getrouwd of niet, kan voor dit feit niet worden vervolgd (art. $353 \mathrm{Sr}$ ). In de tijd dat deze bepaling totstandkwam was de gehuwde vrouw handelingsonbekwaam en was de man belast met het bestuur van de goederen van de vrouw. Het vervolgingsverbod was een kwestie van het voorkomen van bewijsproblemen betreffende 'toebehoren aan een ander'. Nu de handelingsonbekwaamheid van gehuwde vrouwen is afgeschaft, komt deze bepaling niet overeen met de rechtsverhouding tussen echtelieden. ${ }^{97}$ Uitsluiting van strafvervolging in de periode

91 NLR, aant. 14 op art. 138 Sr: 205.

92 Vemieling valt onder titel XXVII, vernieling of beschadiging van goederen.

93 Van Woensel, aant. 5 op art. $350 \mathrm{Sr}$, in: Tekst \& Commeniaar, 1994: 876.

94 HR 29 januari 1963, NJ 1963, 276.

95 Van Bemmelen-van Veen, Ons strafrech 3, 1990: 182.

96 Het opzet behoeft bovendien niet gericht te zijn op de wederrechtelijkheid. HR 21 december 1914, NJ 1915, p. 376; HR 18 maart 1952, NJ 1952, 314; HR 29 januari 1963, NJ 1963, 276. Remmelink is een andere mening toegedaan. NLR, aant. 2 op art. $350 \mathrm{Sr}: 1213$.

97 Van Dorst, Vervolgingsbeletselen, 1989: 64-66. 
waar de echtscheiding is aangevraagd, maar de voorlopige voorziening nog niet is afgegeven, betekent dat de man goederen in het huis kan vernielen en wegnemen, zonder dat strafvervolging kan worden ingesteld. Wanneer de man van tafel en bed is gescheiden, kan hij alleen worden vervolgd als de vrouw een klacht heeft ingediend (art. $353 \mathrm{Sr}$ ). In geval van samenwoning, tenslotte, ontbreken vervolgingsbeletselen; zowel vernieling van goederen van de vrouw, als vermieling van gezamenlijke goederen - gezamenlijk bezit 'dat ten dele toebehoort' aan de vrouw - is strafbaar en ambtshalve vervolgbaar.

Hiervoor is kort aangegeven wat de juridische eisen zijn om bepaald gedrag te kunnen kwalificeren als huisvredebreuk of vernieling. Geconstateerd kan worden dat het delict 'huisvredebreuk' met name de huiselijke sfeer, de persoonlijke levenssfeer raakt en minder de openbare orde. ${ }^{98}$ Wat betreft vernieling, valt op dat een ongestoord gebruik van goederen het te beschermen belang is. Bovendien is naar voren gekomen dat de gehuwde vrouw achtergesteld wordt ten opzichte van de niet-gehuwde vrouw nu strafvervolging van haar echtgenoot, die haar goederen vernielt, niet mogelijk is.

\subsection{Verkrachting en aanranding ${ }^{99}$}

De laatste veelvoorkomende vorm van geweld binnen relaties en verbroken relaties die ik behandel, is verkrachting en aanranding. In hoofdstuk 2 is ingegaan op de essentie van verkrachting binnen (huwelijkse) relaties; door het uitoefenen van macht wordt de vrouw gedwongen seksuele handelingen te ondergaan of begaan. Er vindt een vermenging plaats van geweld met seksualiteit, waarbij de eigen behoeften en grenzen van de vrouw grof worden overschreden. Bovendien wordt de vertrouwensrelatie ernstig geschonden. In deze subparagraaf staan de juridische vereisten voor seksuele dwang in de zin van verkrachting (art. $242 \mathrm{Sr}$ ) en aanranding (art. $246 \mathrm{Sr}$ ) centraal.

\subsubsection{Seksuele handelingen}

Sinds de gewijzigde zedelijkheidswetgeving ${ }^{100}$ is de wilsvrijheid van de mens in het aangaan van seksuele contacten en de bescherming tegen gedwongen seksuele

98 Huisvredebreuk had wellicht beter, tesamen met bedreiging en dwang, onder de titel 'misdrijven tegen de persoonlijke vrijheid' (titel XVIII) kunnen worden gerubriceerd.

99 Verkrachting (art. $242 \mathrm{Sr}$ ) en aanranding (art. $246 \mathrm{Sr}$ ) zijn strafbaar gesteld onder de titel 'misdrijven tegen de zeden' (titel XIV).

100 Wet van 9 oktober 1991 tot wijziging van de artikelen 242 tot en met 249 van het wetboek van straliecht, Stb. 1991, 519. 
contacten het uitgangspunt van de strafbaarheid van verkrachting en aanranding. ${ }^{101}$ De wil is essentieel; wat de één opvat als liefkozing, kan de ander opvatten als onaanvaardbare aantasting van de lichamelijke of psychische identiteit. Het delict verkrachting (art. $242 \mathrm{Sr}$ ) is gewijzigd door verkrachting niet langer te beperken tot gedwongen 'vleselijke gemeenschap' buiten echt. Onder verkrachting wordt tegenwoordig verstaan: dwingen tot het ondergaan van handelingen die (mede) bestaan uit het seksueel binnendringen. Seksueel binnendringen is een sekse-neutrale term, zodat ook mannelijke slachtoffers worden beschermd. ${ }^{102}$ Bovendien is door het schrappen van 'buiten echt' verkrachting binnen het huwelijk niet meer uitgesloten van strafbaarstelling. ${ }^{103}$ Tevens is het middel waarmee kan worden gedwongen uitgebreid met 'een andere feitelijkheid'. Dit laatste geldt eveneens voor het delict aanranding (art. $246 \mathrm{Sr}$ ).

leder mens, getrouwd of niet, moet zelf in vrijheid kunnen beslissen wanneer en met wie zij of hij wil vrijen. Ook binnen het huwelijk moet de vrouw van dag tot dag kunnen beslissen of en hoe ze wil vrijen. ${ }^{104}$ Het verschil tussen de delicten verkrachting en aanranding zit in de wijze van seksueel handelen; seksueel binnendringen in het lichaam valt onder verkrachting en de andere seksuele handelingen, die als ontuchtig kunnen worden beschouwd, vallen onder aanranding. Wat moet nu onder seksueel binnendringen worden verstaan? Er zijn twee opvattingen te onderscheiden over de uitleg van de term 'seksueel binnendringen'. In de ene, beperkte, opvatting wordt het mannelijke geslachtsdeel als uitgangspunt genomen; seksueel binnendringen is het met het mannelijke geslachtsdeel binnendringen in vagina, anus of mond. ${ }^{105}$ Aangesloten wordt bij het rapport van de commissie-

101 Te samen met de bescherming van de in het maatschappelijke verkeer kwetsbare personen, maar dat valt buiten het kader van dit onderzoek. TK 20.930, nr. 3: 1. Zie ook: Eindrupport van de actiescommissie zedelijkheidswetgeving, 1980: 10.

$102 \mathrm{Er}$ zal in de statistieken een verschuiving plaatsvinden naar een relatief groter aantal verkrachtingen en een relatief lager aantal aanrandingen, doordat een deel van de seksuele handelingen die vroeger als ontuchtig onder aanranding vielen, nu als penetrerende handeling onder verkrachting zullen vallen.

103 Tot 1991 was 'vleselijke gemeenschap' binnen het huwelijk niet strafbaar, maar gedwongen seksuele handelingen binnen het huwelijk die als ontuchtig konden worden aangemerkt, waren wel strafbaar gesteld (art. $246 \mathrm{Sr}$ ).

104 Dat vrouwen een seksueel zelfbeschikkingsrecht hebben, ook binnen het huwelijk, moet worden gezien tegen de achtergrond van gelijkheid tussen mannen en vrouwen (art I Gw). "De veranderde maatschappelijke opvattingen over de rechten en plichten van de partners jegens elkaar sluiten een vermeend recht van de man op natuurlijke geslachtsgemeenschap uit." TK 20.930, nr. 3: 3. Dit is gebaseerd op: Eindrapport Adviescommissie zedelijkheidswetgeving, 1980: 16.

105 Hof 's-Hertogenbosch, 30 december 1992, NJ 1993, 147: Het binnendringen van het lichaam met een vibrator, althans een voorwerp, kan niet worden begrepen onder 'seksueel binnendringen'; Rechtbank Assen, 3 maart 1993, NJ 1993, 391: Met de penis binnendringen in de mond is een vorm van seksueel binnendringen. Remmelink hanteert eveneens een beperkte visie: NI.R, aant 2 bij art. $242 \mathrm{Sr}$. Deze visie kan worden beschouwd als een 'phallocentrische' opvatting door het centraal stellen van de penis als het middel waarmee seksueel kan worden binnengedrongen. 
Melai waarin wordt voorgesteld de verkrachtingsbepaling uit te breiden met 'gedwongen geslachtsgemeenschap en daarmee vergelijkbare seksuele contacten', zodat het discriminerende karakter van de delictsomschrijving van verkrachting wordt opgeheven. ${ }^{106}$ Binnen de andere, ruime, opvatting wordt de ernst van de inbreuk op de lichamelijke en seksuele integriteit van het slachtoffer als uitgangspunt genomen. In die opvatting kunnen allerlei vormen van binnendringen die zeer kwetsend en vernederend zijn voor het slachtoffer, zoals het binnendringen met vingers of vibrator in vagina of anus, onder 'seksueel binnendringen' vallen. ${ }^{107}$ Door deze interpretatie kunnen ook vrouwen dader zijn van verkrachting. ${ }^{108}$ De Hoge Raad sprak zich uit voor de ruime opvatting: 'seksueel binnendringen' omvat ieder binnendringen van het lichaam met een seksuele strekking. ${ }^{109}$ Deze seksuele strekking hangt niet af van de subjectieve beleving van het slachtoffer, noch van de subjectieve bedoeling van de dader, maar van de aard en verschijningsvorm van de handeling; seksueel binnendringen is geobjectiveerd. Het met een schroevedraaier en een soort krik in de anus binnendringen zonder seksuele bedoeling wordt opgevat als seksueel binnendringen. ${ }^{110}$ De grens lijkt te worden gelegd bij de uitwendige aanraking; dit is niet voldoende voor binnendringen. ${ }^{111}$ Een gedwongen tongzoen zou onder 'seksueel binnendringen' kunnen vallen. ${ }^{112}$

106 Voorgesteld wordt het afdwingen van seksueel contact als aanranding strafbaar te stellen en het afdwingen van geslachtsgemeenschap of daarmee vergelijkbare seksuele contacten ais verkrachting - een specifiek en zwaarder delict. Op die manier komt systematisch gezien beter tot uiting dat verkrachting een verbijzondering is van het meer algemene feit van aanranding. In die visie staat overigens nict de penis centraal, maar alle vormen van vaginaal en anaal binnendringen en binnendringen met de penis. Eindrapport van de adviescommissie zedelijkheidswetgeving, 1980: 17-19, 46.

107 Rechtbank 's-Gravenhage, 26 januari 1993, NJ 1993, 341; Hof Amsterdam 2 juli 1993, NJ 1993, 565; Verrijn Stuart, Jacht op het onzegbare, Nemesis, 1993: 143; Smits, Verkrachting, NJB, 1993: 416-417.

108 Van der Landen, Aanranding en verkrachting, $D D, 1994: 555$.

109 HR 22 februari 1994, NJ 1994, 379. Door van 'ieder binnendringen' te spreken en niet vast te houden aan 'vergelijkbaar met afgedwongen geslachtsgemeenschap', wordt de term 'seksueel binnendringen' heel erg ruim. Van der Landen, Aanranding en verkrachting, $D D, 1994: 560-562$

110 HR 2 mei 1995, RN 1996, 541 (m.nt. Kool). "De subjectieve beleving van de dader onderscheidenlijk het slachtoffer kan van belang zijn voor de vraag of sprake is geweest van seksueel binnendringen van het lichaam als bedoeld in art. $242 \mathrm{Sr}$, doch is daarvoor niet beslissend in die zin dat van verkrachting geen sprake zou kunnen zijn indien de dader niet bij (door) de desbetreffende handeling(en) bepaalde seksuele gevoelens heeft ondervonden onderscheidenlijk het slachtoffer die handelingen niet als seksueel heeft ervaren." Het geweldsaspect van verkrachting wordt in deze uitspraak benadrukt. Uit het feit dat met een voorwerp in de anus van de man op en neer is gegaan, wordt afgeleid dat mede van een seksuele strekking sprake is.

111 HR 5 februari 1912, W. 9292; De Hullu, aant. 9 op art. 242 Sr, in: Tekst \& Commentaar, 1994 670.

112 Machielse, De nieuwe zedendelicten, $D D, 1992: 721$; Van der Landen, Aanranding en verkrachting, $D D$, 1994: 557. Zij wijzen op het gevaar dat door een te ruime opvatting van 'seksueel binnendringen' het begrip aanranding nauwelijks nog een zelfstandige betekenis heeft naast verkrachting Een zo ruime interpretatic is volgens van der Landen zelfs contra legem (p. 565); Zie ook: Van der Neut \& Wedzinga. Het eeuwige getob, Nemesis, 1995: 123. 
Ontuchtige handelingen zijn handelingen van seksuele aard die in strijd zijn met sociaal-ethische normen. ${ }^{113}$ Het is niet de aard van de handeling, maar de zinnelijke strekking daarvan en de omstandigheden waaronder de handelingen worden gepleegd, die bepalen of er sprake is van ontucht. ${ }^{1 / 4}$ Deze handelingen omvatten een ruim scala; zelfs handelingen zonder lichamelijk contact kunnen onder omstandigheden ontuchtige handelingen betreffen, zoals het in de mond laten wateren. ${ }^{115}$ Maar ook het seksueel binnendringen, mits op sociaal-ethisch onaanvaardbare wijze, kan worden beschouwd als een ontuchtige handeling. ${ }^{116}$ Zoals moord doodslag is met 'voorbedachte raad', is verkrachting aanranding door 'seksueel binnendringen in het lichaam'. ${ }^{117}$ Wanneer verkrachting ten laste is gelegd, kan de rechter bij het ontbreken van bewijs voor 'seksueel binnendringen in het lichaam' voor aanranding veroordelen als wel bewezen wordt verklaard dat de vrouw is gedwongen tot het ondergaan van ontuchtige handelingen. ${ }^{118}$

Gesteld kan worden dat door de huidige redactie van de artikelen 242 en 246 Sr en de interpretatie van 'seksueel binnendringen' het verkrachtingsartikel zodanig is opgerekt, dat van de oorspronkelijke betekenis van verkrachting niet veel meer is te herkennen. Je zou kunnen zeggen dat door opwaardering van minder emstige gevallen van 'seksueel binnendringen', onvoldoende recht wordt gedaan "aan de sterke morele afkeuring van gedrag dat traditioneel wel als verkrachting wordt bestempeld"." 19 Aan de andere kant hoeft de ernst van de inbreuk op het seksuele en lichamelijke zelfbeschikkingsrecht niet gelegen te zijn in het onderscheid tussen verkrachting en aanranding; gedwongen ontuchtige handelingen kunnen onder bepaalde omstandigheden vernederender en kwetsender zijn dan verkrachting onder bepaalde omstandigheden. ${ }^{120}$ Een werkgever die zijn secretaresse seksueel intimideert met woorden en haar aldus 'dwingt met andere feitelijkheden' tot het in haar

113 De Hullu, aant. 8 op art. $246 \mathrm{Sr}$, in: Tekst \& Commentaar, 1994: 675; Zie over het begrip ontucht: Kool, Ontucht(ig): een rechtsonzeker begrip? DD, 1992: 256.

114 HR 28 mei 1963, NJ 1964, 108.

115 HR 31 oktober 1972, NJ 1973, 39; De Hullu, aant. 8 op art. 246 Sr, in: Tekst \& Commentaar, 1995: 675.

116 De Hullu, aant. 8 op art. $246 \mathrm{Sr}$, in: Tekst \& Commentaar, 1994: 675.

117 Door de wetswijziging is verkrachting geen bijzondere strafbepaling meer van aanranding, zodat de rechter niet meer is gedwongen het verkrachtingsartikel toe te passen als uit de feiten blijkt dat er sprake was van verkrachting, terwijl aanranding ten laste is gelegd. HR 22 november 1994, NJ 1995,157 \& RN 1995, 514.

118 In het arrest van de Hoge Raad waar erkend wordt dat er geen specialis-generalis constructie van verkrachting ten opzichte van aanranding geldt, kwalificeerde de Hoge Raad het bewezenverklaarde als verkrachting terwijl aanranding ten laste was gelegd. Dit is hoogst opmerkelijk; de officier van justitie krijgt de ruimte voor aanranding te vervolgen, maar de rechter wordt gedwongen te kwalificeren als verkrachting. Dat staat op gespannen voet met het geldende systeem van ten laste leggen. Van der Neut \& Wedzinga, Het eeuwige getob, Nemesis, 1995: 124.

119 lbidem: 123. Zie ook: Van der Landen, Aanranding en verkrachting, $D D, 1994: 557$. Het seksespecifieke karakter van verkrachting, wat naar mijn mening nog steeds is gelegen in het feit dat vrouwen zwanger kunnen raken, is geheel verdwenen.

120 Verrijn Stuart, Jacht op het onzegbare, Nemesis, 1993: 145-148. 
mond nemen van zijn penis, zal dienen te worden vervolgd ex art. 242 'als verkrachting', terwijl de man die met gruwelijk geweld - zwepen, sigarettenpeuken - een vrouw dwingt tot het ondergaan van ontuchtige handelingen, voor aanranding wordt vervolgd. ${ }^{121}$ Wat hieruit blijkt, is dat de ernst van de seksuele dwang niet alleen is gelegen in het lichaamsdeel of het voorwerp dat wordt gebruikt om het lichaam mee binnen te dringen, maar ook is de emst van de dwang gelegen in de omstandigheden waaronder en het geweld waarmee wordt gedwongen, en tevens het lichamelijke en psychische letsel dat daarvan het gevolg is. Verkrachting binnen (huwelijkse) relaties, dat gepaard gaat met weinig geweld, maar wel zeer traumatisch is, kan qua ernst overeenkomen met een gewelddadige aanranding door een onbekende dader.

De ernst van de seksuele dwang lijkt niet te vangen in een onderscheid tussen verkrachting en aanranding. Met het formuleren van één strafbepaling 'gedwongen seksuele handelingen' die zowel verkrachting als aanranding omvat, wordt beter tegemoetgekomen aan het uitgangspunt dat de ernst van de inbreuk op het lichamelijke en seksuele zelfbeschikkingsrecht niet wordt bepaald door het wel of niet seksueel binnendringen. ${ }^{122}$

\subsubsection{Dwang door geweld of een feitelijkheid}

Een belangrijk bestanddeel van verkrachting en aanranding is de dwang; zonder dwang is er geen sprake van verkrachting of aanranding. Het middel waarmee wordt gedwongen, is 'geweld of een andere feitelijkheid'. Wat moet onder deze begrippen worden verstaan? ${ }^{123}$

Het begrip geweld omvat meer dan fysieke kracht of een lichamelijke krachtsuitoefening, zoals krachtig vastpakken, slaan, schoppen enzovoort. Van bepaalde situaties kan ook geweld uitgaan: "[H]et geweld en de bedreiging met geweld waarmee dwang wordt uitgeoefend kunnen ook gelegen zijn in het creëren van een specifieke situatie, waarin het fysieke element minder belangrijk is dan de ernst van de eventuele gevolgen en waarin het geweld niet alleen direct kan worden uitge-

121 Dit voorbeeld ontleen ik aan: Verrijn Stuart, Jacht op het onzegbare, Nemesis, 1993: 146.

122 Zie bijvoorbeeld: De Hullu \& van der Neut, Zedelijkheidswetgeving, $N J B, 1991: 391$; Van der Landen, Aanranding en verkrachting, $D D$, 1994: 565-566; Verrijn Stuar, Jacht op het onzegbare, Nemesis, 1993: Van der Neut \& Wedzinga, Seksueel binnendringen, NJB, 1994: 153.

123 In verschillende delictsomschrijvingen komt het bestanddeel geweld voor (bijvoorbeeld: artt. 95, $141,284,317 \mathrm{Sr}$ ). De waardering van het geweld hangt af van het delict dat wordt gepleegd en het rechtsgoed dat wordt bedreigd. Wanneer het geweld doel in zichzelf is, zoals bij openlijke geweldpleging (art. $141 \mathrm{Sr}$ ), zal het geweldsbegrip meer restrictief worden uitgelegd, dan wanneer het geweld een middel is. De interpretatie van het bestanddeel geweld wordt gekleurd door de context van de delictsbepaling; dit wordt ook wel de functionaliteit van geweld genoemd. Wedzinga, Openlijke geweldpleging, 1992: 99-105. Zie ook: Janssen, Het begrip geweld in het matieriele strafrecht, $T v P, 1990: 11-16$. Zie bovendien de bespreking van dwang in $\$ 3.2 .2$. 
oefend tegen degene die gedwongen wordt maar ook indirect, via anderen."124 Dit betekent dat het uitoefenen van geweld tegen een derde, waarbij het slachtoffer aanwezig is, zo'n specifieke situatie kan opleveren of dat door optreden een zodanige gewelddadige sfeer wordt geschapen en de vrouw zodanig onder druk wordt gezet dat de vrouw kan verwachten dat ze mishandeld zal worden als ze hem niet terwille zal zijn. ${ }^{125}$ Soms wordt het geweld afgeleid van gebrek aan toestemming, bijvoorbeeld als het slachtoffer bij verrassing tot seksuele handelingen wordt gedwongen en zij geen tijd heeft zich te verweren. ${ }^{126}$ Het creëren van een bedreigende situatie door de kennelijke bedoeling van de dader, door fysieke overmacht of door het afsnijden van een vluchtweg valt onder bedreiging met geweld als de vrees van het slachtoffer voor geweld van de zijde van de dader gerechtvaardigd is. ${ }^{127} \mathrm{De}$ bedreiging met geweld wordt op die manier ruim geïnterpreteerd; het is zelfs niet noodzakelijk dat er met verbaal geweld wordt gedreigd. ${ }^{128}$ Toch kent bedreiging met geweld wel een grens; bedreiging met het openbaren van geheimen of met het aantasten van de goede naam valt niet onder bedreiging met geweld. ${ }^{129}$

Het hiervoor gestelde geeft aan dat het begrip 'geweld' ruim wordt opgevat. Toch is bij de wijziging van de zedelijkheidswetgeving besloten om het element 'een andere feitelijkheid' in te voegen. Hierbij wordt aangesloten bij artikel 284 $\mathrm{Sr}$, waar de gebruikelijke omschrijving geldt: een feitelijkheid is meer dan dreigen met woorden, maar minder dan het gebruik van geweld. Een feitelijkheid moet van dien aard zijn dat onder die omstandigheden iemand gedwongen wordt. ${ }^{130} \mathrm{De}$ term feitelijkheid, zeker wat betreft artikel $284 \mathrm{Sr}$, heeft binnen de jurisprudentie, en ook binnen de doctrine, geen duidelijke invulling gekregen. ${ }^{131}$ Wat betekent de term 'een andere feitelijkheid' in de delictsomschrijving van verkrachting en aanranding? Uit de parlementaire discussie over het wetsontwerp zedelijkheidswetgeving komt

124 't Hart, noot bij HR 21 februari 1989, NJ 1989, 668. Onder geweld als middel tot diefstal (art. $312 \mathrm{Sr}$ ) wordt bijvoorbeeld verstaan het 'in bedwelmde toestand op een avond in de winter langs de weg leggen van een slachtoffer' (HR 14 juni 1983, NJ 1983, 692). Onder geweld als middel tot afpersing (art. $317 \mathrm{Sr}$ ) wordt begrepen, het aanbieden van flessen met een giftige drank erin voor menselijke consumptie in winkels (HR 19 juni 1979, NJ 1979, 585), dan wel een haarverzorgingsmiddel in de handel brengen met een hardnekkige kleurstof die na gebruik emstig nadeel of hinder voor de consument met zich meebrengt (HR 8 december 1987, NJ 1988, 896, m.nt. G.E.M.).

125 HR 21 februari 1989, NJ 1989, 668 (m.nt. 't H)

126 Delva, De zedenmisdrijven inzake aantasting van de seksuele integriteit, Preadvies, 1967: 123. Zie bovendien HR 5 november 1946, NJ 1947, 17: 'door onverhoeds gewelddadig handelen verzet heeft. weten te voorkomen'. Zie eveneens Remmelink in zijn conclusie bij HR 15 juni 1982, NJ 1983 , 153: 485 .

127 HR 22 maart 1988, NJ 1988, 785 (m.nt. ThWvW). Het creeren van een bedreigende situatie bestond. erin dat twee meisjes werden meegevoerd, in een auto, naar een afgelegen plek waar de kans op ontsnapping minimaal was.

128 Machielse, De nieuwe zedendelicten, $D D$, 1992: 717.

129 Van Bemmelen-van Veen, Ons strafrecht 3, 1990: 189-190.

130 NLR, aant. 3 op art. 284 Sr.

131 Machielse, De nieuwe zedendelicten, $D D, 1992: 718$. Zie tevens $\$ 3.2 .2$ onder Dwang en bedreiging. 
naar voren dat er sprake is van '(bedreiging met een) feitelijkheid' als de feitelijkheid zo bedreigend is dat het slachtoffer er ook echt door wordt gedwongen en geen weerstand kan bieden. ${ }^{132}$ Er moet sprake zijn van een vorm van psychische druk, ${ }^{133}$ bijvoorbeeld doordat een persoon onder invloed is van drugs of alcohol en zo bedreigend overkomt dat men zich niet durft te verzetten. ${ }^{134}$ Een ondergeschikte dwingen tot seksueel contact door te dreigen met gevolgen in de arbeidsrechtelijke sfeer, kan, wanneer het slachtoffer erdoor gedwongen wordt, een 'feitelijkheid' opleveren. ${ }^{135}$ Het vergrendelen van een auto kan onder omstandig. heden 'een feitelijkheid' opleveren, ${ }^{136}$ evenals het afsluiten van de deur van een woning. 137 "Daarvoor is nodig dat de verdachte met die feitelijkheid opzettelijk een zodanige dreiging heeft opgeroepen dat de vrees van het slachtoffer voor geweld van zijn zijde gerechtvaardigd was." 138

Het toevoegen van het bestanddeel 'andere feitelijkheid' kan worden beschouwd als een overwinning voor de feministen die benadrukken dat vrouwen op allerlei manieren kunnen worden gedwongen tot seksuele handelingen. Door het invoeren van het bestanddeel 'andere feitelijkheid' kunnen situaties die vroeger met moeite onder het begrip (bedreiging met) geweld gebracht konden worden, nu gemakkelijker als (bedreiging met) feitelijkheid worden geïnterpreteerd, terwijl situaties met een dwingend karakter tegenwoordig eventueel als (bedreiging met) een feitelijkheid bewezen kunnen worden verklaard. Toch kleven er ook twee bezwaren aan de term 'een andere feitelijkheid'. Het eerste bezwaar is dat de term 'een andere feitelijkheid' erg vaag is, ${ }^{139}$ en de grenzen van het begrip feitelijkheid onduidelijk zijn, waardoor weinig houvast aan de term is te ontlenen. ${ }^{140}$ Het oorzakelijke verband tussen de feitelijkheid en het gedwongen zijn is niet altijd gemakkelijk aan te nemen; het dwingende karakter van een feitelijkheid is minder vanzelfsprekend (de geobjectiveerde rechtswil ligt minder voor de hand), waardoor meer ruimte is voor de

132 TK 20.930, nr. 5: 17. Er wordt aangesloten bij de betekenis die in Noyon-Langemeijer-Remmelink wordt gegeven aan 'dwingen'. TK 20.930, nr. 8: 7-8. Overreden tot het aangaan van seksueel contact valt hier niet onder. TK 20.930, nr. 8: 2 .

133 De Hullu, aant. 9 op art. $242 \mathrm{Sr}$, in: Tekst \& Commentaar, 1994: 669; NLR, aant. 6 bij art. 242 Sr.

134 TK 20.930 , nr. 5: $11 \& 17$.

135 TK 20.930, nr. 4: 14: Zie ook: Van Duyne, Wetgevende klusserij, het opknappen van de zedelijkheidswetgeving, $D D, 1990: 251$.

136 HR 29 november 1994, DD $95.120 \&$ NJ 1995, 201.

137 HR 13 juni 1995, RN 1995, 516.

138 Ibidem. In dit geval vemietigde de Hoge Raad het vonnis van het hof omdat uit de bewijsmiddelen niet bleek dat de vrouw bemerkt had dat de deur op slot werd gedaan. Deze uitspraak is wrang omdat uit de andere bewijsmiddelen - lostrekken van kleren, stevig vastpakken en op de bank duwen - blijkt dat er sprake is van dwang. Na verwijzing zal daarom veroordeling zonder meer kunnen volgen. Van der Neut \& Wedzinga, Het eeuwige getob, Nemesis, 1995: 124-125.

139 Hoewel 'feitelijkheid' een vage term is, blijkt naar mijn mening uit de behandelde jurisprudentie dat 'een feitelijkheid' als middel om tot seksuele handelingen te dwingen eenduidiger kan worden ingevuld dan 'een feitelijkheid' in andere delictsomschrijvingen.

140 Machielse, De nieuwe zedendelicten, $D D, 1992: 720$. 
subjectieve bedoeling van de verdachte. ${ }^{141}$ Hier sluit het tweede bezwaar op aan. Door de huidige omschrijving van de middelen waarmee kan worden gedwongen tot het ondergaan van seksuele handelingen moet uit de bewijsmiddelen volgen door welke middelen het slachtoffer is gedwongen. ${ }^{142}$ " $\mathrm{Het}$ 'psychische omslagpunt' dient te worden vastgesteld." ${ }^{\prime 43}$ Dit levert problemen op, zowel voor de rechter om vast te stellen door welke middelen de vrouw nu werd gedwongen, als voor het slachtoffer die een pijnlijke ondervraging moet doorstaan omdat exact moet worden vastgesteld waardoor ze werd gedwongen.

Aan deze bezwaren kan tegemoet worden gekomen door in de delictsomschrijving de middelen waarmee kan worden gedwongen, weg te laten; in essentie gaat het om de vaststelling van dwang, en niet om de middelen waarmee wordt gedwongen. Helderheid en eenvoud van de delictsomschrijving brengen minder kwalificatie- en bewijsproblemen met zich mee. Door af te zien van verwijzing naar een concreet middel tot dwang worden tragische fouten door een verkeerde keuze in de telastlegging of bewezenverklaring voorkomen en kan een pijnlijke ondervraging van het slachtoffer worden voorkomen. ${ }^{144}$ Het heeft bovendien als voordeel dat de vage term 'een feitelijkheid' wordt afgeschaft, terwijl situaties waardoor de vrouw wordt gedwongen tot het ondergaan van seksuele handelingen binnen de strafrechtspleging een plaats kunnen krijgen.

Maar wanneer kan, in juridische zin, worden gesproken van dwang? Dwingen betekent dat het slachtoffer geen seksuele handelingen zou hebben verricht of ondergaan als het middel waarmee is gedwongen, niet op haar was toegepast: "Dwingen onderstelt dat iemand zonder het dwangmiddel dat op hem (haar, KL) is toegepast niet zou hebben gehandeld of nagelaten, althans niet op het ogenblik waarop en in de omstandigheden waarin hij (zij, KL) thans gehandeld of niet gehandeld heeft."145 De dwang wordt op die manier gekoppeld aan "tegen haar wil'; als blijkt dat de gedraging 'tegen haar wil' plaatsvindt, is er sprake van dwang. Leijten stelt: "Geweld of bedreiging met geweld veronderstelt weerstand die door dat geweld of die bedreiging moet worden overwonnen. En weerstand houdt in dat hetgeen waartegen men zich verzet niet gewild wordt." 146 Dwang loskoppelen van 'tegen haar wil' zou betekenen dat het er niet toe doet of zij wilde of niet, maar

141 Machielse acht het afsluiten van een vertrek in een verlaten woning bijvoorbeeld niet bij voorbaat 'een feitelijkheid', maar het op die manier een claustrofobe vrouw onder druk zetten zal wel 'een feitelijkheid' kunnen zijn'. Ibidem: 719.

142 De Jong, De gewijzigde zedendelicten, $D D$, 1995: 198-199; Van der Neut \& Wedzinga, Het eeuwige getob, Nemesis, 1995: 124-125.

143 Ibidem: 125.

144 Ibidem: 125. In 1985 deden De Hullu en Van der Neut zo'n zelfde voorstel, in hun bespreking van de voorstellen van de commissie-Melai. Zedelijkheidswetgeving in beweging, 1985: 75.

145 NLR, aant. 1a op art. 179 Sr.

146 Conclusie bij HR 16 juni 1987, NJ 1987, 156: 671. 
dat het erom gaat dat ze met geweld word gedwongen. Dit actu Leiten op zagn minst twifelachtig. ${ }^{147}$ Ook de Hoge Rada acht bewezenwerkaring van het middel waamee wordt gedwongen (geweld) niet voldoende woo bewezenweklaring vis dwang; ook het (voowaradelik) opzet, gericht op de onwilwingheid, moer worden bewezen verklaard. "De tem " dingts" in art. 242 Sr dient atdus te worden vertaen dat daaraan slechts is voldaan indien het (eventuel voorwasrdelyk) opzet was do werdachte mede onvat, dat hil de vroww de vleselinke gemeenschap doet ondergasu tegen haar wil. Hoewel ult de onstandigheid dat geweld of bedreiging met gewelu is gebezigd in het algemeen het bestaan van de opzet met betrekhing tot de onvrijwilligheid reds lan voortwoeten kunnen zich onstandigheden vordken

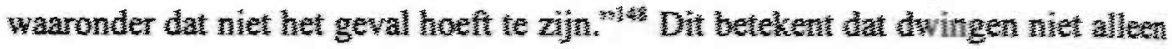
het middel warmee wordt gedwongen inhoudt, wata bovendien de wetenschap van de dader dat het slachtoffer niet vijwillig de seksuele handelingen ondergaat ${ }^{\text {to }}$

Dat dwingen samenhangt met handelen of nalaten tegen de will is evident. De

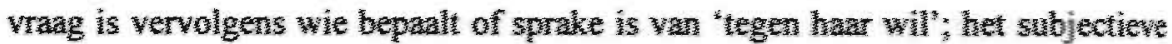
inzicht van de man of de subjectieve beleving van de vruxw. In de formulering wath de Hoge Raad is het uiteindelijk het (geobjectiverde) inzicht van de man dat bepalend is voor beantwoording van de vraay of de vroww de selsuele handelingen ondergaat of pleegt tegen haar wil. Maar het inzicht van de man in wat een vrijwilige vrijpartij is, kan ver af liggen van wat de vrouw ervaart als een vrijwillige vrijpartij, zeker als er sprake is van een of andere intieme relatie (zie hoofdstuk 2, $\S 2.2 .3$ ). Het probleem bij verkrachting schuilt bovendien in het middel waarmee wordt gedwongen. Verkrachting gaat in veel gevallen niet gepaard met zeer ernstige vormen van geweld, maar bestaat uit vastpakken, op de grond of het bed drukken, de kleren van het lijf rukken, en dreigende taal spreken. Wanneer een vreemde man een vrouw in het verlaten park de bosjes intrekt, haar kleren van het lijf rukt en haar vervolgens verkracht, zal de dwang gemakkelijker worden aangenomen op grond van de verklaring van de vrouw en de kapotte kleren, dan als de vrouw door haar vriend op bed wordt gegooid en de kleren van haar lijf worden gerukt, terwijl hij dreigend roept 'ik sla je verrot als je nu niet meewerkt' en hij haar vervolgens 'neemt'. Hoe ernstiger de middelen waarmee dwang wordt uitgeoefend, hoe eenvoudiger het opzet van het tegen de wil doen ondergaan van seksuele handelingen is aan te nemen; de dwang is dan geobjectiveerd. Maar als het middel waarmee

147 Ibidem: 671 .

148 Ibidem. In dit geval waren de omstandigheden het bestaan van een 'knipperlichtrelatie', waardoor de man, naar het hof had vastgesteld, niet heeft kunnen doorzien dat ze echt niet wilde. De objectivering van verkrachting is met deze formulering afgewezen. Mulder, Dwingen in de zin van $242 \mathrm{Sr}, N J B .1988$ : 1009 . Ik kom hier op terug onder $\S 6.2 .1$.

149 Deze formulering is door de Hoge Raad bevestigd in het arrest van 29 november 1994, NJ 1995, 201: "[V]an dwingen kan slechts sprake zijn indien de verdachte door de feitelijkheid opzettelijk heeft veroorzaakt dat het slachtoffer die handelingen tegen haar/zijn wil heeft ondergaan." Zie ook: De Jong, De gewijzigde zedendelicten, $D D, 1995$ : 199. 
wordt gedwongen uit zichzelf geen dwangmiddel is, zoals het op slot draaien van een kamerdeur, zal uit andere omstandigheden moeten blijken dat sprake is van dwang. En dan is weer de vraag vanuit welk gezichtspunt wordt bepaald welke omstandigheden dwingend kunnen zijn; vanuit het gezichtpunt van de man of de vrouw? Als tegenstand als onderdeel van het seksuele spel wordt gezien, ${ }^{150}$ wordt minder snel dwang aangenomen dan als uitgegaan wordt van de wilsvrijheid van de vrouw.

Het probleem hoe dwang wordt vastgesteld, binnen en buiten (huwelijkse) relaties, kan nooit geheel worden opgelost; ook door de dwang te objectiveren en te abstraheren van de subjectieve ervaring van de man of de vrouw, blijft het subjectieve element van de culturele normering een rol spelen. ${ }^{151}$

\subsection{De kwalificatie van geweldsdelicten}

Verschillende verschijningsvormen van geweld tegen de vrouw in de privésfeer zijn de revue gepasseerd. Wat in de concrete werkelijkheid een voor de vrouw pijnlijke en vernederende ervaring is, moet binnen het strafproces een te bewijzen strafbare gedraging zijn. Om tot eventuele strafoplegging te kunnen komen, wordt van de concrete feiten geabstraheerd. Het geweld gepleegd tegen de vrouw door haar (ex-)partner over langere tijd wordt teruggebracht tot een juridisch relevante strafbare gedraging op een bepaald moment. De feiten die relevant kunnen zijn voor de bewezenverklaring van een bepaald geweldsdelict worden uitvergroot en andere feiten, die niet als relevant worden beschouwd, worden uitgezeefd. Juist dit proces, het uitzeven van feiten en het toedichten van juridische waarde aan andere feiten, is geen (sekse-)neutraal proces. ${ }^{152}$ Over hoe het aspect van geweld in de privésfeer wordt meegenomen in de interpretatie van het desbetreffende geweldsdelict zijn geen algemene uitspraken te doen. De reden is dat het aspect privé of openbaar niet relevant is als bestanddeel of element van de delictsomschrijving; het is de toevallige casuïstiek.

Delictsomschrijvingen zijn bij uitstek contrafactisch van aard, omdat een duidelijke omschrijving van strafbare feiten de grondslag vormt voor het garanderen van burgerlijke vrijheden, terwijl tegelijkertijd dedelictsomschrijving openheid moet

150 Oppenhoff stelt het in 1872 zo: "[E] in blosses Widerstreben (Strauben) (welches in vielen Făllen gar nicht ernst gemeint ist) genugt nicht". Geciteerd uit: Paetow, Vergewaltigung in der Ehe, 1986/1987: 99.

151 De discussie of het inzicht van de man in het niet willen van de vrouw moet worden beschouwd als onderdeel van de delictsomschrijving, of dat het ontbreken van het inzicht een strafuitsluitingsgrond oplever, wordt behandeld in hoofdstuk $6, \S 6.2 .1$.

152 Zie bijvoorbeeld: Mossman, Feminism and the legal method, in: At the boundaries of law, feminism and legal theory, 1991: 283-300. 
bieden voor andere werkelijkheidservaringen. ${ }^{153}$ Om de vrouw als rechtssubject binnen de privésfeer meer rechtsbescherming te kunnen bieden is het van belang de interpretatie van de delictsomschrijvingen opnieuw te doordenken vanuit het idee dat de vrouw als burger recht heeft op lichamelijke integriteit, seksuele zelfbeschikking en een persoonlijke levenssfeer binnen de privésfeer. De huidige onderverdeling van strafbepalingen in titels lijkt niet aan te sluiten bij het specifieke karakter van mannelijk geweld tegen vrouwen in de privésfeer. De context van angst en dreiging en de geslotenheid van de samenlevingsvorm zijn van grote invloed op de ernst van het geweld. Vernieling van een vaas en een blauwe plek is buiten deze context een bagateldelict, maar binnen deze context een topje van de ijsberg. Het uitoefenen van agressie door spullen te vernielen is binnen een (huwelijkse) relatie eerder aan te merken als aantasting van de persoonlijke vrijheid (titel XVIII) dan als een vorm van vernieling (titel XXVII). Ditzelfde geldt voor huisvredebreuk. Wanneer de man onrechtmatig de woning van de vrouw binnenkomt, kan dit eerder worden beschouwd als een inbreuk op haar persoonlijke levenssfeer en aantasting van haar persoonlijke vrijheid dan een inbreuk op de openbare orde (titel V).

Als ander aanknopingspunt, voor een meer op de werkelijkheidservaring van de vrouw gestoelde interpretatie, kan de constructie van het (voorwaardelijk) opzet dienen. Uit de beschrijving van de geweldsdelicten blijkt dat het opzetvereiste niet zozeer moet worden beschouwd als een individueel willen en weten, maar een maatschappelijk willen en weten; bij opzet is sprake van een zekere normativering en objectivering. ${ }^{154}$ In geval van bedreiging en verkrachting wordt geobjectiveerd van de subjectieve ervaring van de (bedreigde) vrouw. Toch mag mijns inziens in de objectivering van dwang niet geheel aan de subjectieve ervaring van het slachtoffer voorbij worden gegaan. "De aard van de bedreiging moet niet alleen in het totaal van de situatie worden bezien, maar bovendien behoort de bedreiging - naar vorm en inhoud - niet te worden getoetst aan de indruk die zij in het algemeen op redelijke mensen zou maken: het gaat erom dat de bedreigde persoon inderdaad opzettelijk vrees is aangejaagd voor een handeling die iets ergs zou teweegbrengen." ${ }^{.155}$ Juist door de koppeling van objectivering van dwang en de subjec-

153 Zie hoofdstuk 1, \$1.3.2.

154 Remmelink, Hazewinkel-Suringa's Inleiding, 1994: 206-207.

155 't Hart in zijn noot onder HR 21 februari 1989, NJ 1989, 668. Het betrof hier de vraag of er sprake is van bedreiging met geweld als de requirant vrees aanjaagt door te dreigen magische krachten te gebruiken om bij het slachtoffer een hartaanval of epilepsie-aanval te veroorzaken. De Hoge Raad verwerpt het beroep als zou hier geen sprake zijn van bedreiging met geweld en volgt hierin de conclusie van de Advocaat-Generaal Leijten, die in het midden laat of het hier om een geheel geobjectiveerde beoordeling gaat. "Men kan met name ook van dreigen met geweld spreken als iemand bewerkt, dat de ander, een vrouw, vreest, dat zij door zijn toedoen een emstige ziekte zal oplopen als zij aan zijn wensen om met hem gemeenschap te hebben niet zou toegeven. Dat ligt zo dicht bij dreigen met doodslag, mishandeling etc. dat het evenals in die gevallen kan worden aangemerkt als dreigen met geweld; (...) voor wie aan de magische kracht en macht van de ander gelooft nog veel bedreigender." Zie ook: NLR, aant. 5 op art. $95 \mathrm{Sr}$. 
tieve ervaring van de vrouw, kunnen situaties die voor de vrouw zeer bedreigend zijn (geweest), onder de term dwang worden vervat. Dit geldt voor alle door mij onderzochte geweldsdelicten. Op die manier is de delictsomschrijving zowel een algemeen geldend begrip en biedt het een garantie tegen willekeurig optreden door de overheid, als dat ruimte wordt geboden aan de werkelijkheidservaringen van vrouwen, zodat hun rechtsbescherming kan worden vergroot. ${ }^{156}$

Tot slot nog twee opmerkingen die de kwalificatie betreffen. Zoals ik uiteen heb gezet kan eenzelfde feitencomplex van geweld worden gekwalificeerd als mishandeling, bedreiging met een misdrijf, een poging tot zware mishandeling of zelfs een poging tot doodslag. Hoe het geweld tegen de vrouw moet worden gekwalificeerd, is niet altijd eenduidig vast te stellen. In de voorfase van het strafproces kan de kwalificatie vergaande gevolgen hebben voor het wel of niet in verzekering kunnen nemen van de verdachte. Wanneer het geweld wordt gekwalificeerd als mishandeling, dwang, vernieling en huisvredebreuk is inverzekeringstelling van de man buiten heterdaad niet mogelijk (artt. 58 juncto $67 \mathrm{~Sv}$ ). Deze mogelijkheid bestaat wel wanneer het geweld wordt gekwalificeerd als bedreiging, ${ }^{157}$ zware mishandeling, verkrachting, aanranding, doodslag en moord. Daarnaast bepaalt de officier van justitie met de formulering van de telastlegging de omvang en de aard van de vervolging. Deze strikte 'machtenscheiding' tussen openbaar ministerie en rechterlijke macht is voor de verdachte van groot belang omdat hij ervan uit mag gaan dat het proces alleen over de ten laste gelegde feiten zal gaan. Dit kan worden opgevat als een fundamenteel recht van de verdachte. ${ }^{158}$ Maar ook voor het slachtoffer kan deze bevoegdheid van belang zijn. Wanneer bijvoorbeeld een vrouw is verkracht door haar vriend, kan, afhankelijk van het feitencomplex, verkrachting, aanranding, dwang of mishandeling worden ten laste gelegd. Wanneer de vrouw het moeilijk vindt om over de seksuele details te praten, kan de officier van justitie dwang of mishandeling ${ }^{159}$ ten laste leggen. ${ }^{160}$ Dit hoeft geen (grote) invloed op de te eisen of op te leggen straf hebben. ${ }^{161}$

156 In hoofdstuk 5 wordt nader ingegaan op hoe officieren van justitie het aspect van geweld in de privesfeer meewegen in hun beslissing om wel of niet tot vervolging over te gaan, terwijl in hoofdstuk 6 nader wordt ingegaan op de opvattingen die een rol kunnen spelen bij de interpretatie van de feiten.

157 Hoewel hier geen straf van vier jaar, maar twee jaar op staat, is inverzekeringstelling mogelijk op grond van artikel 67 lid 1 onder b Sv.

158 De Jong, De macht van de telastelegging, 1981: 7. Een fout in de telastlegging kan leiden tot vrijspraak als niet alle onderdelen van de telastlegging bewezen kunnen worden of tot ontslag van alle rechtsvervolging als niet alle bewezenverklaarde feiten de bestanddelen van de delictsomschrijving dekken. Pelser, De naam van het feit, 1995: 105-106.

159 Onder mishandeling valt het benadelen van de gezondheid. Hieronder valt ook de psychische gezondheid. NLR, aant 7 op art. $300 \mathrm{Sr}$.

160 De Beaufort, Met beleid vervolgen van verkrachting en aanranding, in: Strafbare seksualiteit, 1986: 125-127. Zie eveneens: Aanbeveling 18 van de circulaire Conclusies en aanbevelingen voor de bejegening van slachtoffers van seksuele misdrijven, Stcrt. 1986, nr. 33, 17 februari 1986.

161 Het heeft wel invloed op de mogelijkheden tot inverzekeringstelling. 
De keuze voor een bepaald feitencomplex behoort een afweging te zijn van de ernst van de feiten en het algemene belang, waar het belang van het slachtoffer en de verdachte onderdeel van uitmaken. Maar welk feitencomplex ook wordt gekozen, tussen de (vrouwelijke) geweldservaring en de te bewijzen strafbare gedraging ligt een wereld van verschil. 


\section{Het openbaar ministerie en zijn bevoegdheden}

"[H]et openbaar ministerie opereert tussen een aantal polen, die elk hun eigen spanningsveld creëren: enerzijds vertegenwoordiger van het algemeen belang, anderzijds behoeder van de verdachte tegen ongerechtvaardigde maatregelen; pleitbezorger van de staat, maar ook geweten van de overheid zelf; leider van de opsporing, en tevens controleur van de politie; vervolger bij uitstek, maar ook poortwachter bij het gerecht. Het is een roeping, in het spel van deze krachten het juiste evenwicht te vinden."

\subsection{Inleiding}

Het openbaar ministerie staat in de jaren negentig flink in de belangstelling. Het evenwicht tussen de in het citaat genoemde polen, is soms ver te zoeken. De taak van het openbaar ministerie om de rechtsorde te handhaven is ook veelomvattend: "[D]e daadwerkelijke voorkoming, ${ }^{2}$ de opsporing, de beěindiging, de vervolging, de berechting van strafbare feiten, alsmede de tenuitvoerlegging van beslissingen van de rechter of het Openbaar Ministerie in strafzaken."3 Ook de opvang van slachtoffers van een misdrijf valt onder strafrechtelijke handhaving: het opnemen van de aangifte en de bejegening van het slachtoffer, de ondervraging als getuige, het informeren van het slachtoffer over de mogelijkheden om schade te verhalen binnen het strafproces en de verwijzing naar professionele hulpverleningsinstanties. ${ }^{4}$ In een tijd waar de taakbelasting van het openbaar ministerie toeneemt, bijvoorbeeld door toegenomen criminaliteit, toename in het aantal overlegstructuren en extra taken, zoals de taken in het kader van de slachtoffervoorzieningen, waarbij bovendien verschillende vormen van criminaliteit bewijstechnisch zeer ingewikkeld zijn en daardoor tijdrovend, zoals milieufraude, georganiseerde drugscriminaliteit en seksueel misbruik van kinderen, is het moeilijk om aan alle pretenties op het gebied

1 Reijntjes in Melai c.s., aant. 3 op artt. 7-11 Sv: 13.

2 Dit is bijvoorbeeld het voorkomen van een bankoverval door de politie op grond van verkregen informatie. De algemene preventie van misdrijven ligt op het vlak van de bestuurlijke preventie, bijvoorbeeldeen preventiebeleidopscholen. Elzinga e.a., HetNederlandse politierecht, 1995: 194-195.

3 Elzinga e.a., Het Nederlandse politierecht, 1995: 40, 151.

4 Dit wordt ook wel justitiele hulpverlening genoemd. Elzinga e.a., Het Nederlandse politierecht, 1995: $41,196$. 
van de rechtshandhaving te voldoen. ${ }^{5}$ Tevens is de positie van het openbaar ministerie ten opzichte van de minister van Justitie en daarmee de politiek niet eenduidig. Het openbaar ministerie is zowel een bestuursorgaan, uitvoerder van een door de overheid vastgesteld beleid op grond van artikel $5 \mathrm{RO},{ }^{6}$ als een rechterlijk orgaan, de staande rechterlijke macht op grond van artikel $117 \mathrm{Gw}{ }^{7}$ De afgelopen tientallen jaren is flink gediscussieerd over de vraag hoe zelfstandig het openbaar ministerie kan optreden binnen de hiërarchische onderschikking aan de minister van Justitie op grond van artikel $5 \mathrm{RO}^{8}$ Moet het openbaar ministerie vooral worden beschouwd als een 'crime-fighter' en instrument in handen van de politiek, zoals vanuit een instrumentalistische opvatting wordt betoogd, of behoort het openbaar ministerie zich vooral toe te leggen op haar basistaken: het instellen van strafvervolging, het informeren van de rechter en het toezien op de rechtsbescherming. Dit wordt vanuit de relationele opvatting benadrukt.. Daarnaast staat de gezagsuitoefening over de politie ter discussie, zeker als het de bestrijding van de georganiseerde misdaad betreft. ${ }^{10}$ Oplossingen worden gezocht in een reorganisatie die de eenheid binnen het openbaar ministerie moet versterken, stroomlijning van de verschillende fasen in het strafproces en alternatieven voor strafrechtelijk optreden. "De omvangrijke taak van het openbaar ministerie het recht te handhaven moet worden teruggebracht tot de kerntaken, maar wat die kerntaken zijn en hoe die kerntaken moeten worden vormgegeven, is punt van discussie waar de meer relationele opvattingen en de meer instrumental istische opvattingen elkaar beconcurreren.

De discussie in hoeverre het openbaar ministerie moet worden beschouwd als een buitendienst van het ministerie van Justitie, of juist als een orgaan dat enige distantie moet hebben ten opzichte van het bestuur om haar rechtsbeschermende taak goed te kunnen uitvoeren, laat ik hier buiten beschouwing. Ik sluit mij aan bij de

5 Groenhuijsen, Rechtshandhaving aan het einde van de twintigste eeuw, $D D, 1995: 810$.

6 Officieren van justitie zijn tevens ambtenaren in de zin van de ambtenarenwet (artt. 97b, $98 \& 99$ ARAR).

7 Dat officieren van justitie tot de rechterlijke macht behoren wordt ook afgeleid uit de artikelen 8 , $15,16,22$ \& 29 RO.

8 Een overzicht van de discussie wordt gegeven door: Elzinga e.a., Het Nederlandse politierecht, 1995: 177-193; Van den Biggelaar, Buirengerechtelijke afdoening door OM, 1994: 236-271. Zie verder: Trema thema-nummer 'De officier van justitie, magistraat of bestuursambtenaar?' Met bijdragen van Daalder, Donker \& van Eck, Fick, Remmelink, Schalken \& Hirsch Ballin, Trema, 1991: 157200; Schalken e.a. Magistraat met beleid, de officier van justitie en zijn omgeving, 1992; De Doelder, Het $O M$ in positie, 1988 .

9 Met andere woorden, moet het openbaar ministerie meer vanuit een instrumentalistische visie of vanuit een relationele visie haar taak uitvoeren. 't Hart, Justitie aangepaks, $D D, 1995$ : 813-827; Schalken, De fatale schijnoplossing van de commissie-Donner, NJB, 1994: 833-836.

10 Zie de discussie rondom de opsporingsmethoden naar aanleiding van de IRT-affaire.

11 Zie de rapporten: Het functioneren van het Openbaar Ministerie binnen de rechtshandhaving, 's-Gravenhage 1994. Het recht ten uitvoer gelegd: oude en nieuнe instrumenten van rechtshandhaving, 's-Gravenhage 1995. Zie ook het door minister Sorgdrager van Justitie gelanceerde plan: Plan van aanpak reorganisatie openhaar ministerie, 's-Gravenhage 1995. 
relationele opvatting (zie hoofdstuk $1, \S 1.3 .2$ ), waarin wordt benadrukt dat het openbaar ministerie tot taak heeft de rechtsorde te handhaven, dat wil zeggen: het openbaar ministerie staat in dienst van het recht en is georiënteerd op de rechtsstaat; het openbaar ministerie is niet alleen uitvoerder van een door de overheid vastgesteld beleid. "Indien het OM zich bij de uitoefening van al zijn taken, waarvan de strafrechtelijke de voornaamste zijn, moet richten op het dienen van de rechtsorde, heeft het de specifieke verantwoordelijkheid dat ook de inzet van de strafrechtelijke middelen zelf - los van de door een omvattend overheidsbeleid nagestreefde doeleinden - voldoet aan kwaliteitseisen van rechtsstatelijkheid."12 Ik beperk mij in dit hoofdstuk tot de strafrechtelijke mogelijkheden die van belang (kunnen) zijn voor de afhandeling van zaken van geweld tegen de vrouw door haar (ex-)partner.

De bevoegdheid van de officier van justitie tot het instellen van een strafvervolging of om hiervan af te zien op gronden aan het algemeen belang ontleend (artt. $167 \& 242 \mathrm{~Sv}$ ) staat centraal. Deze juridische beschrijving dient ter voorbereiding van het exploratieve onderzoek naar de wijze waarop het openbaar ministerie gebruik maakt van zijn bevoegdheid tot vervolging over te gaan als het een zaak van mannelijk geweld tegen vrouwen in de privésfeer betreft (hoofdstuk 5). Voordat op deze bevoegdheid wordt ingegaan, bespreek ik kort de gezagsbevoegdheid van het openbaar ministerie ten opzichte van de politie $(\$ 4,2)$. Om het beeld van de bevoegdheden te complementeren geef ik in $8,4.4$ een kort overzicht van de bevoegdheden die samenhangen met het dagvaarden van verdachten. Tot slot worden in 4.5 de belangrijkste bevoegdheden kort samengevat.

\subsection{Het gezag wan het openbar ministerie over de politie}

De politie is volgens de wet verplicht ten spoedigste proces-verbaal op te maken Fan opgespoorde straffare feiten en ander ambtswerrichtingen (art. $152 \mathrm{~Sv}$ ). Is er proces-yerbal opgenaakt dan moet dit proces-verbal onverwijld aan de officier van justitie worden toegezonden; de opsporingsanbtenaar is niet bevoegd het opsturen van het proces-verball naar het openbaar ministerie achterwege te laten (art. 155-157 Sv). Naar de letter wan de wet mag de politie niet weigeren een proces-verbaal op te maken als de vrouw uitdrukkelijk aangifte doet of, als het een klachtdelict betreft, zij een klacht indient (art. 160-165 Sv). Wat betreft de strafrechtelihke handhaving staat de politie onder het gezag van officier van justitie (art. 148 Sv 13 PW), ${ }^{14}$ en is de officier van justitie belast met de opsporing

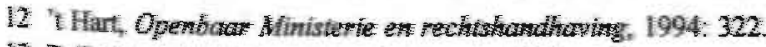

13 Reijnties in Melid cs., ant. Za op art. [67 Sv: 37.

14. De zeggenschap over de politie wordt tevens utgecefend foor het openbaar bestuur als thet de handhaving ran de opentare orde betreft. De gezagggtuchur wordt gekemerkt door een dualisme. Suyver, Politie in de rechtsorde, 1994: 1-3; Reijntjes in Melai c.3., aant. 19, op art. 7-11 Sv: 117. 
(art. $141 \mathrm{~Sv}$ ). De procureurs-generaal en minister van Justitie kunnen via de (hoofd)officier van justitie invloed uitoefenen op de opsporing en richtlijnen uitvaardigen (artt. 5 RO, 140, 148 Sv \& 54 Regl I).

De dagelijkse praktijk werpt een ander licht op deze wettelijke bepalingen. In de praktijk is het doorgaans de politie die het opsporingsonderzoek uitvoert en het onderzoek leidt; alleen in uitzonderlijke, emstige, ingewikkelde of (politiek) gevoelige zaken heeft de officier van justitie in feite de leiding. Over het algemeen toetst de officier van justitie achteraf. ${ }^{15}$ De politie heeft zodoende een grote zelfstandigheid wat betreft de verbalisering ${ }^{16}$ en opsporing van strafbare feiten. Waar geen vervolgingsrichtlijnen aanwezig zijn is het de politie die door haar opsporingshandelingen de handelingsruimte van het openbaar ministerie bepaalt. ${ }^{17}$ De politie kan zowel negatieve controle op het openbaar ministerie uitoefenen, door geen proces-verbaal op te maken zodat het openbaar ministerie niet tot vervolging kan overgaan, als positieve controle door onevenredig veel processen-verbaal van een bepaald soort delict naar het openbaar ministerie te sturen en daarmee druk uit te oefenen op het openbaar ministerie om juist tot vervolging van dit soort zaken over te gaan. ${ }^{18}$

Wanneer door de politie wordt besloten geen proces-verbaal op te maken nadat opsporingshandelingen ${ }^{19}$ zijn verricht of als wordt besloten het proces-verbaal niet door te sturen naar het openbaar ministerie, wordt gesproken van een politiesepot. ${ }^{20}$ Aangezien de politie geen eigen bevoegdheid heeft tot seponeren, en de politie hierrarchisch onder het openbaar ministerie staat, behoort de politie gebonden te zijn aan het inzicht van het openbaar ministerie omtrent verbalisering en opsporing. ${ }^{21}$

121; Elzinga e.a., Het Nederlandse politierecht, 1995: 150-155.

15 Reijntjes in Melai c.s., aant. 19 op artt. 7-11 Sv: 114-125.

$16 \mathrm{Er}$ bestaat geen rechtsplicht altijd proces-verbaal op te maken. Zie het broodjeswinkel arrest: $H R$ 31 januari 1950, NJ 1950, 668. Zie ook: Franken, aant. 3 op art. $152 \mathrm{~Sv}$, in: Tekst \& Commentaar, 1995: 327.

17 Osinga, Transactie in strafzaken, 1992: 29-35.

18 Elzinga e.a., Het Nederlandse politierecht, 1995: 194; Suyver, Politie in de rechtsorde, 1994: 42.

19 Opsporingshandelingen hebben tot doel strafbare feiten op te helderen. Nauwkeuriger: het zijn maatregelen die worden genomen door de politie op grond van de wet zonder tussenkomst van de rechter met als doel te achterhalen of een strafbaar feit is begaan. Handelingen verricht in het kader van de hulpverlening vallen bijvoorbeeld niet onder opsporingshandelingen. Wanneer opsporingshandelingen worden verricht met tussenkomst van de rechter heet het een gerechtelijk vooronderzoek (art 181 Sv). Reijntjes in Melai c.s., aantt. 5 \& 6 op artt. 139-166 Sv: 4. Zie tevens: Schalken, Het politiesepot en de mandaatsverhouding. Trema, 1984: 3.

20 Walther, Een wettelijke regeling voor het politiesepot, $T v P, 1987: 265$. In vergelijkbare zin: Van Rooyen-de Wit, Wie is er eigenlijk nog bang voor het politiesepot, TvP, 1988: 6. Reijntjes vindt de term politiesepot ongelukkig omdat er in strikte zin geen sprake is van een sepot; de beslissing om een strafzaak niet aan de rechter voor te leggen. Een politiesepot is de beslissing om het niet tot een strafzaak te laten komen. Reijntjes in Melai c.s., aant. 2a op art. $167 \mathrm{~Sv}$ : 32-36.

21 Ik laat de discussie over de rechtsgrond van dit zogenaamde 'politiesepot' buiten beschouwing. Zie: De Doelder \& 't Hart, Zeggenschap OM over opsporing en politiesepot, 1985: 2-9; Schalken, Het politiesepot en de mandaatsverhouding, 1984: 4, 7-10. Van den Biggelaar, De buitengerechtelijke afdoening door $O M, 1994: 42-44$. 
Momenteel zijn op lokaal niveau vaak richtlijnen of werkafspraken tussen het openbaar ministerie en de politie over de voorwaarden waaronder kan worden besloten tot het maken van een verkort proces-verbaal, een zogenaamd sepotverbaal. Een belangrijke voorwaarde is dat het om first-offenders moet gaan, die het strafbare feit erkennen. Bovendien moet de schade gering zijn (of deze moet zijn vergoed). Verder geldt soms als grond 'gering feit', 'verhouding tot benadeelde partij geregeld', 'beperkte kring' en 'medeschuld benadeelde partij'. De delicten die hiervoor in aanmerking komen zijn: mishandeling, vernieling, huisvredebreuk, belediging, en over het algemeen ook eenvoudige diefstal, verduistering en lichte vormen van heling. ${ }^{22}$ Op grond van deze 'richtlijnen' kan het geweld tegen de vrouw binnen 'beperkte kring', dat wordt gekwalificeerd als mishandeling, vernieling en huisvredebreuk, met een politiesepot worden afgedaan als aan de andere voorwaarden is voldaan. Je zou kunnen zeggen dat het beleid is, gevallen van vrouwenmishandeling met een politiesepot af te doen, tenzij sprake is van recidive, inverzekeringstelling of emstig geweld. Als tot een sepot wordt besloten zendt de politie het sepotverbaal naar het openbaar ministerie ${ }^{23}$ en wordt een brief, namens het openbaar ministerie, aan de verdachte gestuurd dat de zaak is geseponeerd. ${ }^{24}$ Deze geformaliseerde wijze van seponeren door de politie omvat een gedeelte van wat onder de term politiesepot valt. Daarnaast werpen deze afspraken hun schaduw vooruit naar de fase waarin na constatering van een strafbaar feit geen proces-verbaal wordt opgemaakt.

Zaken van vrouwenmishandeling zullen op grond van deze algemene richtlijn regelmatig door de politie worden geseponeerd. Hoe dit gebeurt in de voorfase valt overigens niet te controleren en zeker niet te registreren, behalve in gevallen waar mutaties van het geweld in de privésfeer zijn gemaakt. ${ }^{25}$ Gezien dit beleid is het niet verwonderlijk dat vrouwen, die aangifte willen doen, door de politie worden geadviseerd hiervan af te zien. Dit wordt wel 'plattrappen' genoemd. ${ }^{26}$ Van de

22 Van Rooyen-de Wit, Wie is er eigenlijk nog bang voor het politiesepot, TvP, 1988; Van den Biggelaar, Buitengerechtelijke afdoening door OM, 1994: 44-47.

$23 \mathrm{Er}$ kan ook besloten worden dat het politiesepot bij de politie wordt geregistreerd. Van der MolenMaesen, OM en politiesepot, $T v P, 1984: 3$; Schalken, Het politiesepot en de mandaatsverhouding, Trema, 1984: 11 .

24 De verdachte kan aan deze sepotmededeling in het algemeen het vertrouwen ontenen dat de zaak niet zal worden vervolgd. Doet hij dat wel, dan zal de rechter het openbaar ministerie niet-ontvankelijk verklaren, tenzij er zwaarwegende argumenten zijn om toch tot vervolging over te gaan. Zie: HR 19 september 1988, NJ 1989, 379 (parkeerwachter). Ik laat deze problematiek verder buiten beschouwing omdat dit de positie van de verdachte betreft, terwijl het mij om de positie van het slachtoffer gaat. Voor meer informatie zie: Van den Biggelaar, Builengerechtelijke afdoening door $O M, 1994: 11-67,329-386$.

25 Van der Molen-Maesen, OM en politiesepot, TvP, 1984: 1; Reijntjes in Melai c.s., aant. $2 \mathrm{a}$ op art. $167 \mathrm{~Sv}: 32-36$.

26 Van Rijn, Politie-sepot: een uitkomst voor het Openbaar Ministerie of voor de politie? TvP, 1983: 622. 
aangiften die worden gedaan, lijkt ongeveer de helft te worden doorgestuurd naar het openbaar ministerie. ${ }^{27}$

Specifieke afspraken kunnen overigens het hiervoor beschreven algemene politiesepotbeleid doorbreken. Voor zover mij bekend is op het arrondissementsparket Zwolle een interne richtlijn 'Werkwijze in geval van vrouwenmishandeling' tot stand gekomen en in Rotterdam is een concept-dienstorder 'Geweld tegen vrouwen' opgesteld naar aanleiding van een overleg tussen de politie van Rotterdam en de actiegroep 'Stop geweld tegen vrouwen'. Beide hebben eenzelfde strekking, namelijk dat de politie zijn strafrechtelijke bevoegdheden in geval van mannelijk geweld tegen vrouwen in de privésfeer behoort te gebruiken. Dit houdt in: bij heterdaad direct assistentie verlenen en de man in de regel meenemen naar het bureau voor verhoor, terwijl buiten heterdaad de man opgeroepen dient te worden voor een gesprek als de vrouw melding heeft gedaan van geweld door haar partner. Doet de vrouw aangifte dan behoort een proces-verbaal te worden opgemaakt, behoudens zwaarwegende contra-indicaties. Van geconstateerd letsel moeten foto's worden gemaakt. Het intrekken van de aangifte is slechts mogelijk als het slachtoffer persoonlijk naar het bureau komt en het proces-verbaal dient door tussenkomst van de Jeugd- en zedenpolitie te worden doorgestuurd naar het openbaar ministerie en te worden voorzien van een bijzonder kenmerk. Desgewenst bemiddelt de politie tussen slachtoffer en verdachte en/of verwijst het slachtoffer door naar een hulpverleningsinstantie of slachtofferhulp. Deze 'richtlijnen' lijken overigens niet te worden uitgevoerd. ${ }^{28}$

Naast een lokale richtlijn kunnen specifieke projecten leiden tot het doorbreken van het algemene politiesepotbeleid, zoals het interventieproject huiselijk geweld in Apeldoorn, waar politie, hulpverlening en openbaar ministerie samenwerken, ${ }^{29}$ of het project Vrouwenmishandeling in Utrecht, waar een speciale medewerkster is aangesteld met als taak politiemensen te ondersteunen die worden geconfronteerd met geweld tegen vrouwen in de relationele sfeer. Daarnaast heeft zij tot taak een protocol op te stellen. ${ }^{30}$

Het is algemeen politiebeleid dat tot 'politiesepot' wordt besloten als sprake is van minder ernstige strafbare feiten, zoals mishandeling, vernieling en huisvredebreuk, die plaatsvinden in beperkte kring. Speciale lokale richtlijnen of specifieke lokale projecten 'mannelijk geweld tegen vrouwen in de privésfeer' kunnen dit algemene beleid echter opzij zetten.

27 Montfort, Politie en vrouwenmishandeling, 1994: 38.

$28 \mathrm{Met}$ het oog op de dader, 1990. In Zwolle was het openbaar ministerie in 1990 niet op de hoogte van het bestaan van deze richtlijn en in Rotterdam is de concept-dienstorder niet officieel geworden.

29 Ter Harmsel, Interventie bij huiselijk geweld, AP, 1995: 6.

30 Dit protocol 'Het ABCDE van geweld in relaties' is te lezen in: Van der Ent \& Evers, Vrouwenmishandeling: een zorg voor de politie, 1996: 51-74. 


\subsection{Bevoegdheden van de officier van justitie in de voorfase}

\subsubsection{Bevoegdheden in het kader van de waarheidsvinding}

De officier van justitie wordt bij een zaak van vrouwenmishandeling betrokken als het proces-verbaal is doorgestuurd naar het arrondissementsparket of als de politie de verdachte heeft aangehouden en meegenomen naar het politiebureau ter voorgeleiding aan de (hulp)officier van justitie, ${ }^{31}$ met als doel de verdachte te doen verhoren. De verdachte kan alleen worden aangehouden als sprake is van een heterdaadsituatie of verdenking van een strafbaar feit waarvoor voorlopige hechtenis is toegelaten (artt. $53 \& 54 \mathrm{~Sv}$ ) ${ }^{32}$ Voorlopige hechtenis is toegelaten in geval van verdenking van een misdrijf waarop een gevangenisstraf van vier jaar of meer is gesteld en een aantal met name genoemde misdrijven, waaronder het voor dit onderzoek van belang zijnde artikel $285 \mathrm{Sr}$ (bedreiging). Bovendien moet uit feiten en omstandigheden ernstige bezwaren blijken (art. $67 \mathrm{~Sv}$ ). ${ }^{33}$ Van heterdaad is sprake wanneer het strafbare feit wordt ontdekt terwijl het begaan wordt (betrapping op heterdaad) of kort nadat het feit is begaan; als het strafbare feit nog vers is (art. $128 \mathrm{~Sv}$ ). Heterdaad kan enige tijd voortduren na het gepleegde delict, waarbij regel is dat hoe geringer de emst van het feit, des te eerder de heterdaad is verlopen. Daarnaast speelt nog een rol of de gerezen verdenking redelijk is en de mate waarin de politie moeite heeft gedaan om de verdachte zo snel mogelijk aan te houden. ${ }^{34}$ In geval van verdenking van mishandeling, vernieling en huisvredebreuk is, buiten heterdaadsituaties, de politie niet bevoegd de verdachte aan te houden en te geleiden naar een plaats van verhoor. De verdachte kan natuurlijk altijd gevraagd worden om zich te laten verhoren door de politie, maar hieraan hoeft geen gehoor te worden gegeven, en tijdens het verhoor mag de verdachte ten alle tijden vertrekken. ${ }^{35}$

Vervolgens kan in het belang van het onderzoek de officier van justitie (of hulpofficier van justitie) de verdachte van een ernstig geweldsdelict in verzekering stellen voor 3 dagen. ${ }^{36}$ Voorwaarde is dat de man verdacht wordt van een gewelds-

31 De hulpofficier van justitie bevindt zich qua bevoegdheden tussen de opsporingsambtenaar en de officier van justitie. Zij heeft bijvoorbeeld de strafvordelijke bevoegdheid tot inverzekeringstelling en het onderzoek aan het lichaam (art. 56 \& $57 \mathrm{~Sv}$ ). Corstens, Het Nederlands strafprocesrecht, 1995: 240.

32 Of bij het geven van valse identiteitsgegevens aan het bevoegd gezag (art. 54 lid 1).

33 Ook als de verdachte geen vaste woon- of verblijfplaats heeft kan een bevel tot voorlopige hechtenis worden gegeven (art. 67 lid $2 \mathrm{~Sv}$ ), en in geval van verdenking van de overtreding omschreven in artikel 432 onder $3 \mathrm{Sr}$ (als souteneur voordeel trekken uit de ontucht van een vrouw) (art. 67 lid 1 onder c Sv).

34 Naeye, Heterdaad, 1990: 50-117; Corstens, Het Nederlands strafprocesrecht, 1995: 352.

35 Corstens, Het Nederlands strafprocesrecht, 1995: 355.

36 De verlenging van de inverzekeringstelling met nogmaals drie dagen moet door de officier van justitie worden beslist, terwijl de rechter-commissaris binnen dric dagen en 15 uur na de aanhouding een oordeel moet hebben gegeven over de rechtmatigheid van de inverzekeringstelling als deze langer zal duren dan drie dagen (art. 58 \& 59a Sv). Wet van 21 april 1994 tot wijziging van enkele 
misdrijf dat valt onder de gevallen van voorlopige hechtenis (art. $57 \mathrm{~Sv}$ juncto art. 67 lid 1a Sv), zoals hiervoor uiteen is gezet. Na de inverzekeringstelling kan de officier van justitie een voorlopige hechtenis ${ }^{37}$ vorderen (artt. $63 \& 65 \mathrm{~Sv}$ ). Voorlopige hechtenis kan worden opgelegd als aan drie extra voorwaarden is voldaan, namelijk ernstige bezwaren tegen de verdachte (art. 67 lid $3 \mathrm{~Sv}$ ), ${ }^{38}$ aanwezigheid van een grond voor voorlopige hechtenis ${ }^{39}$ en tot slot moet een vrijheidsbenemende strafoplegging of maatregel te verwachten zijn (art. 67a Sv). De officier van justitie kan bovendien schorsing van de voorlopige hechtenis vorderen en hieraan voorwaarden verbinden, zoals een straat- of contactverbod, of een of andere vorm van hulpverlening (art. $80 \mathrm{~Sv}$ ).

Naast de bevoegdheden in verband met de voorlopige vrijheidsbeneming van de verdachte, kan de officier van justitie vorderen dat de rechter-commissaris een gerechtelijk vooronderzoek instelt (art. $181 \mathrm{~Sv}$ ). Een gerechtelijk vooronderzoek heeft tot doel meer inzicht te verkrijgen in de toedracht van het feit (waarheidsvinding). Tevens kan het gerechtelijk vooronderzoek tot doel hebben inzicht in de persoonlijke omstandigheden van de verdachte en de persoonlijkheid van de verdachte te verkrijgen. De rechter-commissaris heeft een aantal bevoegdheden die zij in het kader van het gerechtelijk vooronderzoek kan uitoefenen, zoals het horen van getuigen (art. $210 \mathrm{~Sv}$ ), deskundigen (art. $227 \mathrm{~Sv}$ ) of de verdachte (art. $185 \mathrm{~Sv}$ ). Ook kan een deskundigenrapport over de verdachte worden aangevraagd (art. 227 Sv). ${ }^{40}$ Daarnaast heeft de rechter-commissaris bevoegdheden tot het toepassen van dwangmiddelen, zoals de huiszoeking (art. $112 \mathrm{~Sv}$ ), in beslagneming (art. $104 \mathrm{~Sv}$ ) en onderzoek aan lichaam en kleding (art. $195 \mathrm{~Sv}$ ).

\subsubsection{De bevoegdheid van (verdere) vervolging af te zien}

De officier van justitie heeft de bevoegdheid zaken van vrouwenmishandeling met een sepot of een transactie af te doen. In de praktijk beslist de parketsecretaris over de eenvoudige misdrijven, zoals mishandeling, bedreiging, vernieling en huisvrede-

bepalingen van het wetboek van strafvordering omtrent de inverzekeringstelling. In werking getreden op 1 oktober 1994. KB van 17 augustus 1994, Stb. 646.

37 Onder voorlopige hechtenis wordt verstaan (art. $133 \mathrm{~Sv}$ ): vrijheidsbeneming ingevolge van een bevel van bewaring op grond van artikel $63 \mathrm{~Sv}$ (van maximaal tien dagen) of gevangenneming of gevangenhouding op grond van artikel $65 \mathrm{~Sv}$ (voor maximaal drie maal dertig dagen).

38 Er moet een stevige verdenking zijn, niet enkel een vermoeden.

39 De gronden zijn vluchtgevaar, gewichtige redenen van maatschappelijke veiligheid, zoals recidivegevaar van een emstig misdrijf (zes jaar of meer), en emstige geschoktheid van de rechtsorde door het vermoedelijk gepleegde strafbare feit waar een straf van 12 jaar of levenslang op staat. Deze 'geschoktheid' hangt mede af van de emoties die leven bij het slachtoffer en haar omgeving. Ratio achter deze grond is het dempen van de onrust die in de samenleving is ontstaan door het gepleegde delict. Corstens, Het Nederlands strafprocesrecht, 1995: 379.

40 De rechter-commissaris kan de verdachte, die in voorlopige hechtenis zit, voor een onderzoek naar zijn geestesvermogens ter observatie laten overbrengen naar een inrichting, bijvoorbeeld het Pieter Baan Centrum (art. $196 \mathrm{~Sv}$ ). 
breuk. Wanneer het moeilijk is op grond van het dossier een beslissing te nemen, zal de parketsecretaris namens de officier van justitie bij de reclassering een rapport vragen of wordt navraag gedaan bij de politie over eventuele nieuwe meldingen van geweld tegen de vrouw na het doen van de aangifte. Doorgaans wordt aan de hand van het strafdossier beslist of zal worden vervolgd, geseponeerd of getransigeerd. Als de zaak wordt vervolgd, stelt de parketsecretaris de telastlegging op. Op de terechtzitting zelf is alleen de officier van justitie bevoegd op te treden.

De bevoegdheid van de officier van justitie om af te zien van (verdere) vervolging is neergelegd in artikel $167 \mathrm{~Sv}$ en artikel $242 \mathrm{~Sv}$ : van (verdere) vervolging kan worden afgezien op gronden ontleend aan het algemeen belang, het zogenaamde opportuniteitsbeginsel. Artikel $167 \mathrm{~Sv}$ ziet op de fase tusssen opsporingsonderzoek en vervolgingsfase. ${ }^{41}$ De officier van justitie is niet verplicht de verdachte hierover te berichten, maar als hij het slachtoffer een 'sepotbericht' stuurt op haar uitdrukkelijk verzoek om op de hoogte te blijven van het verdere verloop van de procedure, dan zal de officier van justitie zo'n bericht ook naar de verdachte behoren te sturen. ${ }^{42}$ Artikel $242 \mathrm{~Sv}$ betreft de situatie dat de officier van justitie na de resultaten van een gerechtelijk vooronderzoek alsnog besluit de zaak niet verder te vervolgen. Van deze beslissing moet de officier van justitie de verdachte onverwijld in kennis stellen (art. $243 \mathrm{~Sv}$ ). In de praktijk wordt de sepotbeslissing op grond van artikel $167 \mathrm{~Sv}$ niet aan de verdachte medegedeeld. Het wordt daarom wel het informele sepot genoemd en het sepot op grond van artikel $242 \mathrm{~Sv}$ het formele sepot. Zolang het rechtsgeding niet is aangevangen door betekening van de dagvaarding aan de verdachte (art. $258 \mathrm{~Sv}$ ), kan de officier van justitie besluiten niet (verder) te vervolgen. ${ }^{43}$ Wanneer de verdachte van het sepot op de hoogte is, mag hij er in het algemeen op vertrouwen dat er geen vervolging zal plaatsvinden, tenzij zwaarwichtige belangen zich ertegen verzetten. ${ }^{44}$ Tegen de kennisgeving van verdere vervolging of tegen de dagvaarding kan de verdachte een bezwaarschrift indienen bij de rechtbank. Deze regeling heeft tot doel de verdachte te beschermen tegen lichtvaardige vervolging. De rechtbank toetst de beslissing van de officier van justitie slechts marginaal (art. $250 \mathrm{~Sv}$ ). Het slachtoffer kan als rechtstreeks belang-

4) Een daad van vervolging betekent dat de strafrechter wordt ingeschakeld door de officier van justitie binnen een fase van het strafproces. Vervolgingshandelingen zijn het dagvaarden van de verdachte voor het onderzoek ter terechtzitting, het vorderen van een gerechtelijk vooronderzoek en het vorderen van voorlopige hechtenis. Corstens, Het Nederlands strafprocesrecht, 1995: 106.

42 Reijntjes in Melai c.s, aant. 9 op art. 167 Sv: 134-139.

43 Het valt te verdedigen dat er tot een sepot besloten kan worden totdat het onderzoek op de terechtzitting is aangevangen, omdat tot dat moment de dagvaarding mag worden ingetrokken (art. 266 lid 1 Sv). Reijntjes in Melai c.s., aant. 2 op art. 167 Sv: 31

44 Dit geldt voor het sepot op grond van de artt 167 \& 242 Sv. HR 26 juni 1984, NJ 1985, 41 (informeel sepot). Zie voor het vertrouwensbeginsel HR 29 mei 1978, NJ 1978, 358; HR 22 mei 1979, NJ 1979, 301; HR 13 september 1983, NJ 1984, 151. Ook een politieambtenaar kan onder omstandigheden de gerechtvaardigde verwachting wekken dat niet zal worden vervolgd. Zie: HR 19 september 1988, NJ 1989, 379 (parkeerwachter); HR I3 september 1988, NJ 1989, 403. 
hebbende beklag doen bij het hof als tot niet-vervolging is besloten. Deze procedure kan worden gezien als een correctief op het vervolgingsmonopolie en opportuniteitsbeginsel van het openbaar ministerie (zie $\S 2.5 .2$ ).

\section{Sepotgronden}

De beslissing om niet tot vervolging over te gaan is een vrij open beslissing. De officier van justitie heeft een ruime beleidsvrijheid nu hij tot niet-vervolgen kan beslissen op gronden aan het algemeen belang ontleend. Maar deze beleidsvrijheid mag niet willekeurig worden gehanteerd. ${ }^{45}$ Uit de wetsgeschiedenis blijkt dat er twee uiterste grenzen worden genoemd. Enerzijds mag het algemeen belang geen vrijbrief zijn voor willekeur en anderzijds mag niet alleen op grond van individuele belangen worden afgezien van vervolging; er moet tevens sprake zijn van een algemeen belang. ${ }^{46}$ Het particuliere belang kan worden meegewogen, maar als er strijdigheid is tussen het algemeen belang en het individueel belang dan gaat het algemeen belang voor. ${ }^{47}$

Er zijn twee redenen voor een sepot; de officier van justitie kan niet vervolgen en dit leidt tot het technisch sepot of de officier van justitie wil niet vervolgen en dan betreft het een beleidssepot. Het technische sepot betreft die zaken waarvan het waarschijnlijk is dat de rechter niet tot een veroordeling zal komen; de niethaalbaarheid van de zaak is de reden voor het sepot. Hier kunnen verschillende redenen voor zijn, zoals de niet-ontvankelijkheid van het openbaar ministerie, de rechter is niet bevoegd tot kennisneming van het ten laste gelegde feit, het feit en/of de dader is niet strafbaar of iemand is ten onrechte als verdachte aangemerkt. De officier van justitie zal niet-ontvankelijk worden verklaard als hij een zaak van vernieling binnen het huwelijk aanbrengt, omdat vernieling, evenals diefstal en afpersing, niet vervolgbaar is als het binnen een huwelijkse relatie wordt gepleegd. Wanneer verdachte en slachtoffer van tafel en bed zijn gescheiden, zal de officier van justitie niet-ontvankelijk worden verklaard als geen klacht is ingediend door de vrouw (artt. 310 juncto 316 \& 350 juncto $353 \mathrm{Sr}$ ). Ook een door de officier van justitie beoordeeld gebrek aan bewijs leidt tot een technisch sepot. ${ }^{48}$ De officier van justitie maakt zelf een beoordeling van het dossier, en betrekt hierbij een prognose omtrent de opvatting van de rechter. De beslissing of sprake is van voldoende technisch en overtuigend bewijs biedt ruimte voor interpretatie. ${ }^{49}$

45 Corstens, Het Nederlands strafprocesrechi, 1995: 210-211.

46 Corstens, Waarborgen rond het vervolgingsbeleid, 1974: 17-18; Corstens \& Tak, Het Openbaar Ministerie, 1982: 101, 107.

47 Reijntjes in Melai c.s, aant. 5 op ant. 167 Sv: 49.

48 Wanneer wordt besloten tot een technisch sepot na cen gerechtelijk vooronderzoek of voorlopige hechtenis, moet in de kennisgeving van niet-verdere-vervolging de grond worden vermeld (art. 247 Sv).

49 Knigge in Melai c.S., aant. 4 op art. 12i Sv; Reijntjes in Melai c.s., aant. 1 op art. I67 Sv: 2-6. 
Zaken die worden afgedaan met een beleidssepot, kunnen bij de rechter wel tot een veroordeling leiden, maar er zijn redenen van algemene aard om de vervolging niet opportuun te achten. Sinds 1979 maakt de officier van justitie of de parketsecretaris een aantekening op het dossier op welke grond er tot niet-vervolgen is besloten..$^{50}$ Deze sepotgronden zijn voor de interne administratie en worden in de justitiele statistiek geregistreerd. Hierdoor wordt meer inzicht verkregen in de gronden om tot niet-vervolgen over te gaan. Tevens kan het beleid tussen de arrondissementsparketten worden vergeleken en bij gebleken verschillen kan dit leiden tot bijstelling van beleid. ${ }^{51}$

Er zijn vijf sepotgronden die elk weer zijn onderverdeeld. ${ }^{52}$

1. Gronden die samenhangen met maatregelen genomen of nog te nemen door anderen dan de officier van justitie.

Te denken valt aan een ander ingrijpen dan strafrechtelijk, bijvoorbeeld een bestuurlijk of tuchtrechtelijk optreden. Ook kan een civielrechtelijke jeugdmaatregel of een al genomen strafrechtelijke jeugdmaatregel of een reeds lopende tbs reden zijn om niet tot vervolging over te gaan.

2. Gronden die samenhangen met de algemene rechtsorde.

Hieronder vallen landsbelang, wetswijziging en onvoldoende nationaal belang.

3. Gronden die samenhangen met het gepleegde feit.

Hieronder vallen een gering feit ofwel een bagateldelict, een gering aandeel in het feit of een geringe strafwaardigheid van het feit. Daarnaast wordt genoemd een oud feit. ${ }^{53}$ En ook kan tot niet-vervolging worden overgegaan omdat het strafbare feit een uitvloeisel is van een maatschappelijk belangenconflict, zoals een bezetting van bet RIAGG om betere hulpverlening voor mishandelde vrouwen op te eisen. Wanneer sprake is van ernstige strafbare feiten zoals ernstig fysiek geweld, zal in het algemeen wel tot strafvervolging worden overgegaan.

4. Gronden die samenhangen met de persoon van de verdachte.

Genoemd worden: leeftijd, gezondheidstoestand, recente bestraffing, dader is zelf door het feit getroffen, reclasseringsbelang, gewijzigde omstandigheden en de verdachte is onvindbaar.

5. Gronden die samenhangen met de verhouding tussen verdachte en benadeelde. Als de verdachte door verzoening of schadevergoeding de verhouding tot de benadeelde partij heeft geregeld, kan vervolging achterwege blijven. Medeschuld van de benadeelde is een andere grond: als de benadeelde het strafbare feit heeft

$50 \mathrm{Om}$ meer gelijkheid te bevorderen tussen de arrondissementsparketten wordt in 1976 de werkgroep 'Rubricering sepotgronden' ingesteld om tot een goede rubricering van sepotgronden te komen. Deze werkgroep heeft in 1979 een rapport uitgebracht.

5I Corstens \& Tak, Het Openbaar Ministerie, 1982: 100-104.

S2 Ik ontleen de gegeven aan: Corstens \& Tak, Het Openbaar Ministerie, 1982: 108-116; Van den Biggelaar, Buitengerechtelijke afdoening door OM, 1994: 34-36; Reijntjes in Melai c.s., aant. 5 op art. $167 \mathrm{~Sv}$ : $50-66$.

53 Als een feit is verjaard zal de officier van justitie niet-ontvankelijk worden verklaard. 
uitgelokt, de verdachte heeft getergd of het hem zeer gemakkelijk heeft gemaakt het delict te plegen. Tevens kan vervolging in strijd zijn met het belang van de benadeelde en ook dit kan reden voor sepot zijn. Een voor dit onderzoek belangrijke grond is dat de kring waarbinnen het delict zich heeft afgespeeld zo beperkt is dat, mede gelet op de ernst van het feit, er geen sprake is van een zodanig gemeenschapsbelang dat vervolging gerechtvaardigd is. Tot slot wordt als grond genoemd het feit dat de schade die de benadeelde partij heeft geleden beter via het civiele recht geregeld kan worden.

'Beperkte kring' lijkt een indicatie om tot niet-vervolging over te gaan, tenzij de ernst van het feit vervolging indiceert. ${ }^{54}$ Deze regel geldt ook voor het kunnen opstellen van een verkort proces-verbaal, zoals ik in $\S 4.2$ uiteen heb gezet. Vanouds werden zogenaamde bagateldelicten (gering feit) en 'familietwisten' geseponeerd, zelfs toen het opportuniteitsbeginsel nog geen wettelijke grondslag had. In een circulaire van de minister van justitie uit 1893 aan de procureurs-generaals staat bijvoorbeeld met zoveel woorden niet te vervolgen als het een zaak betreft waar noch de openbare orde, noch het algemeen belang noodzaakt tot strafrechtelijk optreden. ${ }^{\text {ss }}$ Dit geeft aan dat geweld in de privésfeer al decennia lang wordt beschouwd als 'familietwisten', waar goede gronden voor zijn om tot een sepot over te gaan. ${ }^{36}$

\section{Berisping en waarschuwing}

Wanneer wordt besloten om niet te vervolgen op gronden aan het algemeen belang ontleend, kan dit in de vorm van een zogenaamd 'kaal sepot'; de zaak wordt afgedaan en het dossier wordt in het archief opgeborgen. De officier van justitie kan de verdachte ook een schriftelijke of mondelinge waarschuwing geven (het zogenaamde parketstandje). ${ }^{57}$ De Nationale Ombudsman is van oordeel dat een waarschuwing en een berisping zich van elkaar onderscheiden: een waarschuwing beoogt informatie te geven over de gevolgen van bepaald gedrag, terwijl een berisping bestaat uit het bestraffend toespreken door de officier van justitie waarbij het woord 'berispen' wordt genoemd. Dit laatste kan worden opgevat als een straf en daartoe is de officier van justitie niet bevoegd. ${ }^{58}$

54 De ernst van het feit is moeilijk te operationaliseren; er zijn geen objectieve factoren aan te wijzen die tot eenduidige aanwijzingen leiden wanneer sprake is van een emstig feit. Zie De Hullu, Het jaarverslag van het OM over 1981, $A A, 1983: 438-442$.

55 Faber, OM richtlijnen, in: Richtlijnen van het openbaar ministerie, 1992: 10-17.

56 In hoofdstuk 5 over het optreden van het openbaar ministerie zal nader worden geanalyseerd op welke gronden het openbaar ministerie zaken van vrouwenmishandeling seponeert.

57 Reijntjes in Melai c.s., aant. 2 op art. 167 Sv: 7.

58 NO 20 december 1990, AB 1991, 158. Zie ook: Van den Biggelaar, Buitengerechtelijke afdoening door OM, 1994: 57-58. 
De officier van justitie kan eveneens aan het sepot voorwaarden verbinden waar de verdachte aan moet voldoen om vervolging te voorkomen of een transactie aanbieden.

Het sepol onder voorwaarden kan worden onderscheiden in een voorwaardelijkniet-verder-vervolgen, wettelijk geregeld in de artikelen 244 lid $3 \mathrm{~Sv}^{59}$ en 245 lid $4 \mathrm{~Sv}^{60}$ en het voorwaardelijk-niet-vervolgen. Dit laatste sepot is niet in een wetsartikel vastgelegd ${ }^{61}$ maar wordt afgeleid uit het opportuniteitsbeginsel op grond van het adagium: wie het meerder mag (vervolgen) mag ook het mindere (seponeren onder voorwaarden). ${ }^{62}$ Het voorwaardelijk-niet-verder-vervolgen wordt ook wel het formele voorwaardelijke sepot genoemd en het voorwaardelijke-niet-vervolgen het informele voorwaardelijke sepot.

Toch is ook de regeling van het formele voorwaardelijke sepot zeer summier. Als enige vereiste wordt genoemd dat het verzoek tot een voorwaardelijk-nietverder-vervolgen uit moet gaan van de verdachte. ${ }^{63}$ In de rechtspraktijk geldt dit niet als hard vereiste; het wordt meer geïnterpreteerd als uitdrukking van de eis dat de verdachte niet mag worden gedwongen of onder ontoelaatbare druk ${ }^{64}$ gezet om een voorwaardelijk sepot te aanvaarden. Er moet sprake zijn van vrijwilligheid. Dit betekent niet dat er sprake is van een vrije keuze. De vrijwilligheid van de verdachte is een beperkte vrijwilligheid door de dreiging van een openbare terechtzitting met de eventuele negatieve gevolgen van een aantekening op het strafblad, een boete of gevangenisstraf en openbaarmaking van het vonnis. ${ }^{65}$ Strikt genomen kan de officier van justitie na het voldoen aan de voorwaarden opnieuw de belangen

59 Voor de gevallen waarin een gerechtelijk vooronderzoek heeft plaatsgevonden.

60 Dit artikel geldt voor de gevallen waarin voorlopige hechtenis is toegepast. In artikel 245 lid 4 Sv wordt verwezen naar artikel 244 lid 3 Sv. Ik noem voortaan alleen artikel 244 lid 3 Sv.

61 Voor het jeugdstrafrecht is dit wettelijk geregeld in artikel $493 \mathrm{~Sv}$ : de officier van justitie heeft een machtiging nodig van de rechter.

62 Hof Amhem 27 mei 1930, W. 12414. De mogelijkheden van de officier van justitie worden begrensd door aan de ene kant het onvoorwaardelijke sepot en aan de andere kant de vervolging. Van den Biggelaar, Buitengerechtelijke afdoening door OM, 1994: 49-50. Lunnemann, Voorwaardelijk sepot, een oplossing voor seksueel geweld?, 1986: 28-30. Reijntjes vat het adagium anders op, namelijk: de officier van justitie mag het meerdere (seponeren), dus ook het mindere (voorwaardelijk seponeren). Vervolgens stelt hij dat een voorwaardelijk sepot een inbreuk op de vrijheid van de verdachte inhoudt, en daarom kan seponeren onder voorwaarden niet worden beschouwd als het mindere. Reijntjes in Melai c.s., aant. 8a op art. $167 \mathrm{~Sv}$ : 85-91.

63 Zoals dit tot 1983 ook gold voor de transactie. Van den Biggelaar, Buitengerechtelijke afdoening door $O M, 1994: 53$. In de praktijk blijkt het verzoek trouwens meestal van de officier van justitie uit te gaan. Groenhuijsen \& van Kalmthout, Transactie en voorwaardelijk sepot, $D D, 1983: 485$.

64 Dit wordt analoog aan de voorwaarden voor een transactie, zoals vastgesteld in het Deweer-arresh, voor het voorwaardelijke sepot aangenomen. Lunnemann, Voorwaardelijk sepot, een oplossing voor seksueel geweld?, 1986; 38. Biggelaar, Buitengerechtelijke afdoening door OM, 1994: 83.

65 Groenhuijsen \& van Kalmthout, De wet vermogenssancties en de kwaliteit van de rechtsbedeling, $D D$, 1983: 8-31. Reijntjes in Melai c.S., aant. 8a op art. $167 \mathrm{~Sv}$ : 97-102. 
afwegen en besluiten of (verder) zal worden vervolgd of van (verdere) vervolging zal worden afgezien. ${ }^{66}$ In de rechtspraktijk wordt echter het vertrouwensbeginsel gehanteerd, dat wil zeggen dat de verdachte ervan uit mag gaan dat de zaak zal worden geseponeerd als hij aan de voorwaarden heeft voldaan. ${ }^{67}$ In feite is er geen verschil tussen het formele en informele voorwaardelijke sepot. In beide gevallen is de officier van justitie bevoegd tot het stellen van voorwaarden, in beide gevallen moet de verdachte vrijwillig de voorwaarden aanvaarden en in beide gevallen wordt het vertrouwensbeginsel gehanteerd. In het vervolg hanteer ik daarom de term voorwaardelijke sepot.

Globaal gelden drie vereisten: a. er kan alleen tot een sepot onder voorwaarden worden besloten als het een beleidssepot betreft, b. er moet sprake zijn van vrijwillige aanvaarding van de voorwaarden en $c$. alleen uit oogpunt van het reclasseringsbelang kan tot een voorwaardelijk sepot worden besloten, dat wil zeggen dat de voorwaarden moeten liggen op het terrein van het gedrag en de levenswijze van de verdachte. Dit hangt samen met het doel van een voorwaardelijk sepot; het voorwaardelijk sepot mag geen leedtoevoeging als doel hebben (dat is voorbehouden aan de strafrechter), het moet een reclasseringsdoel hebben. Als aan voorgaande drie vereisten is voldaan, kan de officier van justitie naar eigen inzicht handelen; er is geen restrictie naar soort delict noch naar de inhoud van de voorwaarden.

Wat betreft de te stellen voorwaarden, wordt aangesloten bij de regeling van de voorwaardelijke veroordeling (art. 14 e.v. Sr). De wettelijke regeling en de daaruit voortvloeiende jurisprudentie gelden als uiterste grenzen. Dit betekent dat de officier van justitie de algemene voorwaarde kan stellen dat de verdachte geen strafbare feiten begaat noch zich anderszins misdraagt binnen een bepaalde periode (art. 14a Sr) ${ }^{68}$ Daarnaast kan de officier van justitie bijzondere voorwaarden opleggen. Deze mogen geen inbreuk maken op de godsdienstige en staatkundige vrijheid. ${ }^{69}$ Tevens moeten de niet-wettelijk vastgelegde voorwaarden - als schadevergoeding en opname in een inrichting ${ }^{70}-$ het gedrag van de verdachte betreffen

66 Artikel 244 lid $3 \mathrm{~Sv}$ spreekt van het nemen van een langere termijn voor het nemen van de beslissing.

67 Van den Biggelaar stelt in navolging van Reijntjes voor een rechtsgevolg te verbinden aan het voldoen aan de voorwaarden analoog aan de transactieregeling; met het voldoen aan de voorwaarden vervalt het recht tot strafvervolging (art. 74 lid I Sr). Van den Biggelaar, Buitengerechielijke afdoening door OM, 1994: 59; Reijntjes, Voorwaardelijk sepot, in: Liber Amoricum Th. W'. van Veen, 1985: 313.

68 De proeftijd bedraagt twee jaar en onder bijzondere omstandigheden drie jaar (art. 14b lid $2 \mathrm{Sr}$ ). De officier van justitie hoeft de algemene voorwaarde niet te stellen. Reijntjes in Melai c.s., aant. 8a op art. 167 Sv: $92-96$.

69 Een ontoelaatbare voorwaarde, in strijd met de beginselen van een goede procesorde, is bijvoorbeeld dat de verdachte geen bezwaarschrift mag indienen tegen de belastingaanslag. Hof 's-Hertogenbosch 18 december 1991, NJ 1993, 60.

70 Hieronder valt ook therapie als het medisch is geindiceerd. HR 18 januari 1955, ongepubliceerd. Naar voren gebracht door: Van Eyk, Persoonlijke vrijheid en voorwaardelijke justitiele beslissingen, NJB, 1955: 873-880. 
(art. 14c Sr). ${ }^{71}$ In de juridische literatuur wordt geen uitsluitsel gegeven over de reikwijdte van de bevoegdheid van de officier van justitie in het stellen van voorwaarden. Reijntjes acht de bevoegdheid voor het stellen van voorwaarden groter bij officieren van justitie dan bij rechters omdat de voorwaarde vrijwillig wordt aanvaard. ${ }^{72}$ Anderen vinden dat officieren van justitie restricter moeten omgaan met het stellen van voorwaarden; ingrijpende voorwaarden mogen alleen door rechters worden opgelegd. ${ }^{73}$

De voorwaarden bij een sepot moeten het gedrag of de levenswijze van de verdachte betreffen. Meestal wordt tot een sepot onder voorwaarden besloten als sprake is van bijzondere omstandigheden, en het strafbare feit te ernstig is om niets te doen. Een sepot onder voorwaarden kan bijdragen aan herstel van de aangerichte schade of op een andere manier conflict-herstellend zijn. In geval van vrouwenmishandeling zou een voorwaardelijk sepot kunnen aansluiten bij de behoeften van het slachtoffer op een snelle strafrechtelijke reactie gericht op het creëren van veiligheid of het stoppen van het geweld, zonder dat dit direct tot een strafrechtelijke veroordeling van haar partner of ex-partner leidt.

Een belangrijke buitengerechtelijke afdoening is de transactie (art. $74 \mathrm{Sr}$ ) ${ }^{74} \mathrm{De}$ officier van justitie kan een transactie aanbieden voor overtredingen en sinds 1983 ook voor misdrijven waar een strafmaat van maximaal zes jaar op staat. ${ }^{75}$ Zaken van mishandeling, vernieling, huisvredebreuk en bedreiging kunnen met een transactie worden afgedaan. ${ }^{76}$ Was het bij de totstandkoming van de wet nog de bedoeling om de rechterlijke macht te ontlasten, zodat alleen in gevallen dat anders zou worden gedagvaard tot het aanbieden van een transactie moest worden overgegaan, alras werd de transactie het instrument om het percentage beleidssepots terug

71 Corstens \& Tak, Het Openbaar Ministerie, 1982: 99.

72 Reijntjes, Voorwaardelijk sepot, in: Liber Amoricum Th.W. van Veen, 1985: 308.

73 De Doelder in Melai c.s., aant. 1 I op art. 244 lid 3 Sv; Mulder \& Schootstra, De voorwaardelijke veroordeling, 1974: 86. Zie over deze problematiek ook de discussie over de de vraag of dienstverlening via het officiersmodel of via het rechtersmodel opgelegd moet worden. Droesen, Het officiersmodel en de mondigheid van de verdachte, Proces, 1985: 116-122; Kalmthout, Het wettelijk kader voor de dienstverlening, $J$, 1984: 59-120; Van Veen, Dienstverlening, $J V, 1984: 47-58$; De Beer \& Kalmthout, Dienstverlening: cok veel zwaluwen maken nog geen zomer (I), $D D, 1982$ : 458475.

74 De transactie, een buitengerechtelijke afdoening, neemt vanaf 1983 een enorme vlucht door de uitbreiding van de transatiemogelijkheden. Wet vermogenssancties, 31 maart 1983, Stb. nr. 153, 1983.

75 Wet vermogenssancties, Sib. nr. 153, 1983. Zoals een officier van justitie kan kiezen voor een telastlegging op een minder emstig delict, zo kan ook worden getransigeerd voor een minder emstig delict Reijntjes in Melai c.s., aant. 8b op art. 167 Sv: 116-120.

76 In de tarieflijst voor transactie- en strafvorderingsbeleid voor enige commune delicten staat voor mishandeling als richtbedrag voor een transactic 250 tot 750 gulden en voor de eis 300 tot 850 gulden. Voor vemielingszaken zijn de bedragen respectievelijk 100 tot 500 gulden en 150 tot 600 gulden. Richtlijn Transactiebeleid misdrijven, Sicrt. 23 juni 1987, nr. 117. 
te dringen. ${ }^{77}$ In de loop der jaren heeft de transactie zich daardoor ontwikkeld tot een zelfstandige afdoeningsmodaliteit tussen dagvaarden en seponeren in. ${ }^{78}$

De officier van justitie kan voor de aanvang van de terechtzitting een transactie aanbieden. Wordt aan de voorwaarden van het voorstel voldaan, dan vervalt het recht van de officier van justitie om tot vervolging van de zaak over te gaan (art. 74 lid $1 \mathrm{Sr}$ ). De te stellen voorwaarden zijn limitatief vastgesteld (art. 74 lid 2).$^{79}$ Over het algemeen betreft de voorwaarde het gireren van een geldbedrag aan de staat. Tegenwoordig wordt tevens schadevergoeding als voorwaarde gesteld als het slachtoffer bij de politie te kennen heeft gegeven dat zij dit wenst. ${ }^{80}$ De officier van justitie moet het slachtoffer mededelen of aan de voorwaarde is voldaan als zij daarom heeft verzocht (art. 74 lid $3 \mathrm{Sr}$ ). Het slachtoffer kan vervolgens tegen de beslissing om niet te vervolgen haar beklag doen bij het hof. Mocht zij in het gelijk gesteld worden, dan beveelt het hof de officier van justitie om alsnog tot vervolging over te gaan (art. 74b Sr). Het recht van de verdachte dat niet zal worden vervolgd als hij aan de transactievoorwaarde voldoet, wordt hierdoor tenietgedaan. Het bedrag dat de verdachte heeft betaald, wordt onverwijld teruggestort (art. 74b lid $2 \mathrm{Sr}$ ). De rechter kan in de straftoemeting vervolgens rekening houden met het feit dat de verdachte in een eerdere fase een transactie heeft betaald of de schade heeft vergoed. $^{81}$

Het voorwaardelijke sepot en de transactie hebben met elkaar gemeen dat het buitengerechtelijke afdoeningen betreffen waarbij de verdachte strafvervolging kan voorkomen door aan bepaalde voorwaarden te voldoen. Hij mag hierbij niet onder ontoelaatbare druk staan om het voorstel te aanvaarden. Als aan de voorwaarde is voldaan, mag de verdachte ervan uitgaan, dat de zaak niet zal worden vervolgd. Voor de transactie is dit wettelijk vastgelegd en voor het voorwaardelijke sepot volgt dit uit het vertrouwensbeginsel. Alleen een klacht van het slachtoffer (art. $12 \mathrm{~Sv}$ ) kan nog tot vervolging leiden. Naast deze overeenkomsten zijn er verschillen, waarvan de belangrijkste is dat de transactie tot doel heeft eenvoudige lichte

77 Jaarverslag Openbaar Ministerie 1985: 71; Van den Biggelaar, Buitengerechtelijke afdoening door OM, 1994: 74-78; Osinga, Transactie in strafzaken, 1992: 8-11. Critici van de Wet vermogenssancties hebben dit effect toendertijd voorspeld. Groenhuijsen \& van Kalmthout, Transactie en voorwaardelijk sepot, $D D, 1983: 474-487$.

78 Circulaire Uitgangspunten transactiebeleid misdrijven, Stcri. 23 juni 1987, nr. 117; Van den Biggelaar, Buitengerechtelijke afdoening door $O M, 1994: 87-89$. In het jaarverslag van het openbaar ministerie over 1992 wordt gesteld dat gestreefd moet worden naar afdoening via een transactie in een derde van de vervolgbare gevallen. Jaarverslag Openbaar Ministerie 1992: 54-55.

79 Van den Biggelaar, Buitengerechtelijke afdoening door OM, 1994: 80; Reijntjes in Melai c.s., aant. 8 b op art $167 \mathrm{~Sv}$ : 115 .

80 In de richtijn Transactiebeleid misdrijven staat het nog sterker: In beginsel kan slechts tot een transactie worden overgegaan indien de schade is vergoed, dan wel een schadevergoedingsregeling tot stand is gekomen. Stcrt. 23 juni 1987, nr. 117.

81 Zie voor informatic over de beklagprocedure hoofdstuk $2, \$ 2.5 .2$ onder Beklag tegen niet vervolgen. 
misdrijven en overtredingen tariefmatig en efficiènt af te doen, terwijl een sepot onder voorwaarden bestemd is voor bijzondere gevallen waar de voorwaarde is toegesneden op de persoonlijke situatie van de verdachte. Het kan beschouwd worden als een meer tijdrovende wijze van afdoening. En hoewel de grens tussen transactie en voorwaardelijk sepot enigszins is vervaagd nu bij een transactie de voorwaarde van schadevergoeding gesteld kan worden, waardoor het uitsluitend punitieve karakter van de transactie verloren is gegaan, ${ }^{82}$ blijft de transactie in de praktijk gericht op een strafeffect, en niet, zoals bij het sepot onder voorwaarden, op een reclasseringsbelang. ${ }^{83}$ Dit betekent dat een transactie in geval van mannelijk geweld tegen vrouwen in de privésfeer minder geschikt lijkt, omdat vrouwenmishandeling een specifieke problematiek betreft die zich niet leent voor een tariefmatige afdoening.

\subsection{Bevoegdheden die samenhangen met dagvaarden}

\subsubsection{Dagvaarden van de verdachte}

Als de officier van justitie op grond van het dossier concludeert dat voldoende bewijs aanwezig is en dat het gewelddadige gedrag strafwaardig is, wordt de verdachte gedagvaard. De officier van justitie legt ten laste wat zij een haalbare kaart acht. Het staat de officier van justitie vrij de verdachte te vervolgen voor een minder ernstig delict, bijvoorbeeld voor mishandeling in plaats van poging tot doodslag (zie hoofdstuk 3, § 3.1). De verdachte wordt met de dagvaarding op de hoogte gebracht van het feit dat een strafzaak tegen hem aanhangig is, wanneer de terechtzitting plaatsvindt en welke rechten hij heeft. ${ }^{84}$

De officier van justitie kan bij de opstelling van de telastlegging de primairsubsidiair constructie gebruiken: primair wordt poging tot doodslag ten laste gelegd, subsidiair zware mishandeling en meer subsidiair mishandeling. De rechter moet zich eerst richten op de primaire telastlegging, en pas als dit niet bewezen kan

82 Reijntjes in Melai c.s., aant. 8b op art. $167 \mathrm{~Sv}$ : 116-121.

83 Van den Biggelaar stelt voor het voorwaardelijke sepot in de regeling van de transactie op te nemen om de rechtspositie van de verdachte te versterken. Van den Biggelaar, Buitengerechtelijke afdoening door $O M, 1994: 59$. Ik bepleit een aparte regeling, omdat de transactie en het voorwaardelijke sepot twee aparte buitengerechtelijke afdoeningswijzen betreffen. Zie hierover mijn doctoraalscriptie Voorwaardelijk sepot, een oplossing voor seksueel geweld?, 1986.

84 Zoals het doen dagvaarden of medebrengen van getuigen en deskundigen (artt. 260 lid 3, 263, 280 lid $6 \mathrm{~Sv}$ ), het kunnen indienen van een bezwaarschrift tegen de dagvaarding (artt. 262 lid 1 jo 260 lid $3 \mathrm{~Sv}$ ) en het recht op toevoeging van een advocaat (art. 44 lid $2 \mathrm{~Sv}$ ). Bovendien wordt de verdachte erop gewezen dat hij een bevel om te verschijnen kan krijgen als hij niet is verschenen op de zitting (art. 272 Sv). 
worden, ${ }^{85}$ op de (meer) subsidiaire. Door deze constructie kan worden voorkomen dat de verdachte niet veroordeeld wordt omdat de delictsomschrijving niet op de bewezen gedraging van toepassing is. De officier van justitie kan namelijk niet nogmaals vervolgen voor eenzelfde feit (art. $68 \mathrm{Sr}$ ) ${ }^{86} \mathrm{De}$ officier van justitie kan ook verschillende feiten voegen ter berechting, bijvoorbeeld zowel mishandeling van de partner als valsheid in geschrifte. Dit wordt ook wel een cumulatieve telastlegging genoemd. ${ }^{87}$

Een andere manier van voegen is de zogenaamde voeging ad informandum. In dat geval worden de feiten niet ten laste gelegd, maar ter informatie bij eenzelfde soort wel ten laste gelegd feit gevoegd (bijvoorbeeld een mishandeling wordt ten laste gelegd, en vijf andere mishandelingen worden ad informandum gevoegd). De rechter kan in de beoordeling van de strafmaat met deze feiten rekening houden voor het wel ten laste gelegde en bewezen verklaarde feit, wanneer op grond van de erkenning door verdachte op de zitting aannemelijk is geworden dat hij deze feiten heeft begaan en wanneer tevens kan worden vastgesteld dat ter zake van deze feiten geen vervolging meer zal worden ingesteld. ${ }^{88}$ Ook als de verdachte niet op de zitting aanwezig is, is voeging ad informandum mogelijk. Voorwaarde is dan dat aannemelijk is dat de verdachte de feiten heeft begaan en dat terzake van deze feiten geen vervolging meer zal worden ingesteld, terwijl de verdachte bovendien tijdig voor de terechtzitting op de hoogte moet zijn gebracht van het feit dat deze zaken ad informandum gevoegd zullen worden ${ }^{89}$ De verdachte kan vervolgens voor deze feiten niet meer gedagvaard worden. ${ }^{90}$ Voor het slachtoffer heeft deze wijze van afdoen het nadeel dat zij zich niet als benadeelde partij kan voegen omdat de rechter de ad informandum gevoegde zaken niet beoordeelt op bewezenverklaring en kwalificatie. Vandaar dat de officier van justitie volgens de richtlijnen Slachtofferhulp een zaak waar het slachtoffer zich heeft gevoegd wel ter berechting mag voegen, maar niet ad informandum.

85 Of de uitspraak is ontslag van rechtsvervolging dan wel nietigverklaring van de dagvaarding, voor wat betreft de primaire telastlegging. Remmelink, Visies op telastlegging, in: Bij deze stand van zaken, 1983: 420.

86 Als een officier van justitie alleen poging tot doodslag ten laste legt en er kan niet worden bewezen verklaard dat er opzet tot doden was, terwijl de mishandeling wel kan worden bewezen, kan de man toch niet worden veroordeeld voor mishandeling. Er volgt ontslag van rechtsvervolging, omdat de bewezen strafbare gedraging niet valt te kwalificeren. Als de strafbare feiten niet te bewijzen zijn, volgt vrijspraak.

87 Door verschillende feiten te voegen hoeft de verdachte maar een keer voor de rechter te komen en de feiten kunnen in een vonnis worden afgedaan. Corstens, Het Nederlands strafprocesrecht, 1995: 526-527.

88 HR 29 november 1983, NJ 1984, 277.

89 HR 25 september 1984, NJ 1985, 317. Zie ook: HR 26 januari 1988, NJ 1988, 817.

90 HR 13 februari 1979, NJ 1979, 243 m.nt. ThWvV. De ad informandum voeging is in de rechtspraktijk ontstaan uit efficientie overwegingen, maar kent geen wettelijke basis. Corstens, Het Nederlands strafprocesrecht, 1995: 665 . 
In geval van heterdaad (art. $53 \mathrm{~Sv}$ ) en een strafbaar feit waartoe de politierechter bevoegd is, kan de officier van justitie de verdachte op zeer korte termijn (dczelfde dag of voor de eerstkomende zitting) dagvaarden (art. 370 lid I Sv). De verdachte blijft tot die tijd van zijn vrijheid beroofd. Naast snelrecht is er sinds 1993 tevens vlugrecht, dat wil zeggen dat de officier van justitie de verdachte op korte termijn kan dagvaarden waarbij een dagvaardingstermijn van minimaal 3 dagen geldt (art. 370 lid 2 Sv). Deze procedures kunnen van belang zijn met het oog op te verwachten krachtige preventieve werking of als gevaar van eigenrichting dreigt. ${ }^{91}$ Een snel- of vlugrechtprocedure zou eventueel mogelijk zijn als het geweld tegen de vrouw door haar ex-partner dermate emstig is (separation assault) dat een snelle reactie uit oogpunt van preventie noodzakelijk is.

\subsubsection{Het oproepen van het slachtoffer als getuige}

De officier van justitie kan in het kader van een gerechtelijk vooronderzoek bij de rechter-commissaris een verhoor van het slachtoffer van vrouwenmishandeling als getuige vorderen (art. $210 \mathrm{~Sv}$ ), of hij kan, al dan niet op verzoek van de verdachte, het slachtoffer oproepen om als getuige te verschijnen op de zitting (art. $280 \mathrm{~Sv}$ ). Het slachtoffer is verplicht om aan die oproep gehoor te geven (artt. $213 \& 282$ $\mathrm{Sv}$ ); niet verschijnen is strafbaar (art. $192 \mathrm{Sr}$ ). $\mathrm{Zij}$ moet tevens naar waarheid antwoorden op de gestelde vragen (artt. 215 \& 284 lid 2 Sv), niet naar waarheid verklaren kan tot vervolging wegens meineed leiden (art. $207 \mathrm{Sr}$ ). ${ }^{92}$ De officier van justitie is verplicht het slachtoffer op te roepen om ter zitting te verschijnen als de verdachte het slachtoffer wil ondervragen op de zitting (art. $263 \mathrm{~Sv}$ ). De officier van justitie kan weigeren het slachtoffer op te roepen, als door het nietoproepen het belang van de verdachte redelijkerwijs niet zal worden geschaad (art. 263 lid $4 \mathrm{~Sv}$ ). De verdachte kan vervolgens op de terechtzitting de voorzitter verzoeken de geweigerde getuige alsnog op te roepen. De rechter komt aan dit verzoek tegemoet, tenzij de verdachte redelijkerwijs niet in zijn verdediging kan worden geschaad omdat de getuige geen noodzakelijke bijdrage zal leveren aan de opheldering van de zaak (overbodigheid), of omdat het onaannemelijk wordt geacht dat de getuige binnen een aanvaardbare termijn zal verschijnen (nutteloos) (art. 280 lid 4 \& 282 lid 2 Sv).${ }^{93}$ Onder deze termen valt tegenwoordig ook het belang van

91 Corstens, Het Nederlands strafprocesrecht, 1995; 746-747.

92 De getuige is niet verplicht bij de politie een verklaring af te leggen, maar is wel verplicht de personalia bekend te maken. HR 11 november 1947, NJ 1948, 126.

93 Corstens, Getuigen op de zitting, $D D, 1992$ : 207; Stolwijk in Melai c.S., aant. 4 op art. 282 Sv. De criteria van artikel 280 lid $4 \mathrm{~Sv}$ worden niet altijd even helder toegepast. HR 1 mei 1990, NJ 1991, 40; HR 1 oktober 1991, NJ 1992, 197; HR 13 oktober 1992, NJ 1993, 143 (m.nt. Kn). 
het slachtoffer. Het opnieuw moeten afleggen van een verklaring kan voor het slachtoffer dermate pijnlijk zijn dat het een gevaar voor haar geestelijke en fysieke gezondheid kan zijn. Dit belang krijgt een wettelijke erkenning binnen het strafproces als het wetsvoorstel herziening gerechtelijk vooronderzoek wet is geworden. ${ }^{94}$ Tegenwoordig wordt in de rechtspraktijk dit belang van 'psychische schade' in de afweging of de getuige moet worden opgeroepen, meegewogen door vast te stellen dat een nader verhoor ter terechtzitting psychisch zeer belastend is voor het slachtoffer waardoor nadere oproeping achterwege kan blijven. Vervolgens wordt de afweging onder de termen nutteloos gebracht door te stellen dat de getuige niet zal kunnen verschijnen wegens psychische schade, of het wordt onder de term overbodig gebracht door in de belangenafweging te betrekken dat de verdediging in een eerder stadium de gelegenheid heeft gehad vragen te (laten) stellen aan de getuige, waardoor de verdachte redelijkerwijs niet in zijn verdediging zal worden geschaad als de getuige niet wordt opgeroepen. ${ }^{95}$

Naast de erkenning van de hiervoor genoemde belangenafweging wordt sinds de invoering in 1994 van de wet getuigenbescherming ${ }^{96}$ wettelijk erkend dat in het strafproces rekening moet worden gehouden met de persoonlijke belangen van de bedreigde getuige; de getuige die anoniem wil blijven uit angst voor represailles van de kant van de verdachte (artt. 226a t/m 226f Sv). ${ }^{97}$ Naast toekenning van volledige anonimiteit kan beperkte anonimiteit worden toegekend als de persoon bang is overlast te ondervinden door het afleggen van een verklaring; er vindt wel een getuigeverhoor op de zitting plaats maar de personalia worden niet bekend gemaakt (art. $360 \mathrm{~Sv}$ ). Het bedreigen van een getuige is strafbaar gesteld in artikel 285a Sr. De regeling van volledige anonimiteit lijkt niet direct toepasbaar gezien het feit dat het slachtoffer direct benadeelde is van de geweldpleging waar de man van wordt verdacht; de verdachte weet wie de getuige is. Wel kan de regeling van

94 Een gegrond vermoeden dat de gezondheidstoestand van de getuige of deskundige door het afleggen van een verklaring ter terech zitting in gevaar wordt gebracht, wordt toegevoegd als grond aan artikel 187 Sv. Wetsvoorstel ter herziening van het gerechtelijk vooronderzock: TK 1992-1993, 23.251, nrs. 1-2: 14-15 \& nr. 3: 39-42. De getuige zal dan worden beedigd, wat anders op de rechtszitting was gebeurd (art. $216 \mathrm{~Sv}$ )

95 HR 10 masrt 1987, NJ 1988, 422; HR 2 februari 1989, NJ 1989, 632; HR 1 oktober 1991, NJ 1992, 197; HR 25 februari 1992, NJ 1992, 555; HR 26 mei 1992, NJ 1992, 680; HR 9 februari 1993, NJ 1993, 603 (m.nt. C). Over het algemeen wordt het belang van de slachtoffer-getuige onder de term nutteloos gebracht. Mols, De niet verschenen getuige, Advocatenblad, 1987: 239; Stolwijk in Melai c.s., aant. 5 op art. 282 Sv: 9.

96 Wet van 11 november 1993, Stb. 603.

97 Een getuige kan de status van een bedreigde getuige krijgen als redelijkerwijs kan worden aangenomen dat het persoonlijke leven zal worden ontwricht als de getuige een verklaring aflegt en de persoon daarom niet als getuige wil optreden. Wanneer de status van bedreigde getuige is toegekend, stelt de rechter-commissaris zich op de hoogte van de personalia, hoort de getuige, beoordeelt de betrouwbaarheid van de getuige en vermeldt dit in het proces-verbaal. Zie voor een bespreking van deze wet: Valkenburg, Enige opmerkingen over de Wet getuigenbescherming, $D D, 1995: 349-365$ Gare, Het onmiddellijkheidsbeginsel in het Nederlandse strafproces, 1994: 158-171. 
de beperkte anonimiteit van belang zijn voor slachtoffers van vrouwenmishandeling, bijvoorbeeld in geval de ex-partner de vrouw achtervolgt, bedreigt en mishandelt. In zo'n situatie kan het adres van de vrouw geheim blijven.

Uit het hiervoor gestelde blijkt dat de officier van justitie rekening kan houden met het belang van het slachtoffer om niet als getuige op de openbare terechtzitting te verschijnen. Hij heeft de mogelijkheid de rechter-commissaris hiervan op de hoogte te stellen en een getuigenverhoor, waarbij de officier van justitie, de verdachte en/of diens raadsvrouw aanwezig zijn (art. $187 \mathrm{~Sv}$ ), voor te stellen. ${ }^{98}$ Het slachtoffer kan een verzoek hiertoe bij de officier van justitie indienen met als grond dat zij niet als getuige ter terechtzitting kan optreden omdat zij een verhoor aldaar psychisch niet aankan. Ter ondersteuning kunnen verklaringen van deskundigen worden overlegd, bijvoorbeeld een medische verklaring. Als de rechter-commissaris het verzoek niet inwilligt, kan de officier van justitie vervolgens weigeren de vrouw als getuige op te roepen als de verdachte redelijkerwijs niet in zijn verdediging zal worden geschaad (art. 263 lid $4 \mathrm{~Sv}$ ): de oproep kan nutteloos zijn of een herhaald verhoor overbodig. ${ }^{99}$ Als de verdachte het niet eens is met de weigering, kan hij op de zitting de rechter verzoeken alsnog tot het oproepen van de getuige over te gaan (art. 280 lid $3 \mathrm{~Sv}$ ). Het is aan de rechter of deze de motivering van de officier van justitie overneemt of aan het verzoek van de verdachte voldoet. ${ }^{100}$

\subsubsection{Het requisitoir van de officier van justitie}

Het requisitoir markeert de overgang van het verzamelen van feiten naar het waarderen van de feiten, ${ }^{101}$ hoewel de feiten ook al bij het verzamelen worden gewaardeerd op hun juridische relevantie. De officier van justitie kan ermee volstaan alleen een vordering over te leggen welk strafbaar feit is begaan en welke straf of maatregel haars inziens opgelegd zal moeten worden (art. 311 lid $1 \mathrm{~Sv}$ ). ${ }^{102}$ Meestal geeft de officier van justitie een toelichting op de bewijsbaarheid van het strafbare feit en de gevorderde straf of maatregel. De laakbaarheid van het gedrag of de ernst van het strafbare feit voor het slachtoffer en de samenleving kunnen worden uiteengezet. Het requisitoir kan, evenals het pleidooi van de advocaat, de oordeelsvorming van de rechter beïnvloeden door de wijze waarop het materiaal wordt geordend en zin gegeven. ${ }^{103} \mathrm{Bij}$ gewelddadig gedrag van de man tegen zijn vrouw kan de officier van justitie de dreiging en de onveiligheid benadrukken, maar zij

98 Zie bijvoorbeeld: HR 9 februari 1993, NJ 1993, 603 (m.nt. C).

99 Donker \& Smit, Slachtoffers vrouwenhandel verdienen meer bescherming, $A P, 1990: 346$.

100 Zie hoofdstuk $6, \S 6.3$ voor een nadere uitwerking van de positie van het slachtoffer als getuige.

101 Van Bemmelen-van Veen, Ons Strafrecht 4, 1993: 261.

102 Dit moet op straffe van substantiele nietigheid op schrift worden gesteld en voorgelezen. HRR 8 december 1941, NJ 1942, 455; HR 12 juni 1984, NJ 1985, 116.

103 Van Bemmelen-van Veen, Ons strafrecht 4, 1993: 265. 
kan ook naar voren brengen dat er enkel wat blauwe plekken zijn geconstateerd en dat het geweld voortkwam uit een emotionele opwelling. Welke opstelling wordt gekozen, hangt af van de persoonlijke oordeelsvorming van de officier van justitie. Tevens zal de officier van justitie het gepleegde delict en de gevorderde straf moeten plaatsen tegen de achtergrond van een aanwezige richtlijn, zeker nu richtlijnen recht in de zin van artikel 99 RO kunnen zijn en de rechter het optreden van de officier van justitie direct kan toetsen aan de richtlijn. De rechter is op geen enkele manier aan de vordering van de officier van justitie gehouden, ${ }^{104}$ noch aan de richtlijnen die er gelden. ${ }^{105}$ Wel moet de rechter sinds 1983 motiveren waarom hij een hogere straf oplegt dan de officier van justitie heeft gevorderd (art. 359 lid $7 \mathrm{~Sv}$ ). ${ }^{106}$

De officier van justitie is verplicht een straf of maatregel te eisen. Een straf heeft voornamelijk vergelding tot doel, een maatregel beveiliging van de maatschappij. De belangrijkste straffen zijn de gevangenisstraf ${ }^{107}$ of hechtenis, ${ }^{108}$ de zogenaamde vrijheidsbenemende straffen, en de geldboete, waarbij men financieel wordt getroffen (art. $9 \mathrm{Sr}$ lid 1a). Daarnaast bestaat de onbetaalde arbeid ten algemene nutte, de dienstverlening, als straf. De dienstverlening is een alternatief voor een korte vrijheidsbenemende straf. ${ }^{109}$ De officier van justitie kan deze straf overigens niet eisen, daar de verdachte zelf (of zijn advocaat) met een voorstel tot dienstverlening moet komen. Wel kan de officier van justitie in haar requisitoir aangeven dat de geřiste gevangenisstraf omgezet mag worden in dienstverlening. Naast deze hoofdstraffen kunnen bijkomende straffen worden geëist, zoals ontzetting van bepaalde rechten, plaatsing in een rijkswerkinrichting of verbeurdverklaring (art. $9 \mathrm{Sr}$ lid lb). De belangrijkste maatregel is de maatregel 'terbeschikkingstelling' (tbs) met of zonder dwangverpleging (op grond van art. $37 \mathrm{Sr}$ ). Wanneer een verdachte niet toerekeningsvatbaar wordt verklaard, met andere woorden als geen schuld kan worden vastgesteld omdat de verdachte geestelijk ziek of gestoord is verklaard, kan de officier van justitie tbs eisen als de verdachte een gevaar voor zichzelf en de samenleving oplevert en gevaar voor herhaling aanwezig is. De andere drie maatregelen zijn: de maatregel onttrekking aan het verkeer (art. 36b Sr), ontneming van het wederrechtelijk verkregen voordeel (art. 36c Sr), en de schadevergoedingsmaatregel (art. $36 \mathrm{f} \mathrm{Sr}$ ). De officier van justitie kan een schadevergoedings-

104 HR 22 februari 1977, NJ 1977, 352.

105 HR 10 maart 1992, NJ 1992, 593; De Doelder, Richtlijnen, justitie en rechter, in: Richllijnen van het openbaar ministerie, 1993: 42-43.

106 Sommigen, zoals Enschedé en Mulder, stellen dat de eis van de officier van justitie als petitum moet dienen; de rechter mag niet boven de eis van de officier van justitie gaan zitten. Informatie uit: Van Bemmelen-van Veen, Ons strafrecht 4, 1993: 262 (noot 90).

107 De gevangenisstraf is levenslang of tijdelijk, dat wil zeggen ten hoogste 20 jaar (art. $10 \mathrm{Sr}$ ).

108 De duur van de hechtenis is maximaal een jaar en vier maanden (art. $18 \mathrm{Sr}$ ).

109 Sinds 1989 kan deze straf worden opgelegd als de rechter van oordeel is dat een gevangenisstraf van minder dan zes maanden passend zou zijn. Vegter, Straffen en andere sancties, in: De staat van justitie, 1992: 152-153. 
maatregel eisen als hij weet dat het slachtoffer graag de schade vergoed ziet (zie hoofdstuk 2, § 2.5.2).

De meest voorkomende straffen in zaken van vrouwenmishandeling zijn de gevangenisstraf en de boete. De hoogte van de boete of vrijheidsbenemende straf die geèist kan worden, hangt af van de strafmaat die op het delict staat. De officier van justitie kan ook een (deels) voorwaardelijke straf eisen in geval hij een geldboete eist of een gevangenisstraf van niet meer dan drie jaar (art. 14c Sr). ${ }^{110}$ Een voorwaardelijke straf bevat in elk geval de algemene voorwaarde dat de veroordeelde zich niet schuldig maakt aan een strafbaar feit tijdens de proeftijd van twee of drie jaar (art. 14b Sr). Daarnaast kunnen als bijzondere voorwaarden worden opgelegd dat de schade wordt vergoed, dat de veroordeelde in een inrichting wordt verpleegd, dat een waarborgsom wordt gestort, of dat geld wordt gestort in het fonds geweldsmisdrijven of ten gunste van een instelling die de belangen van slachtoffers behartigt. Tevens kunnen voorwaarden worden opgelegd die het gedrag van de veroordeelde betreffen (art. 14c Sr). De voorwaarden kunnen conflict-herstellend zijn, waarbij rekening wordt gehouden met het belang van het slachtoffer. Schadevergoeding kan zo'n voorwaarde zijn, maar ook kan gedacht worden aan een straatof telefoonverbod. Een typische voorwaarde die het gedrag betreft is de voorwaarde een hulpverleningsprogramma te volgen of contact te houden met de reclassering (zie ook § 4.3.2 onder Voorwaardelijk sepot en transactie).

\subsection{Kort samengevat}

In dit hoofdstuk zijn de verschillende bevoegdheden van het openbaar ministerie voor het voetlicht gehaald. Het openbaar ministerie is in geval van mannelijk geweld tegen vrouwen in de privésfeer sterk afhankelijk van wat de politie aanlevert. Hoewel de officier van justitie is belast met de opsporing, functioneert in dit soort zaken de politie vrij zelfstandig in het opsporen en verbaliseren. Alleen als de politie het proces-verbaal doorstuurt naar het openbaar ministerie of als de politie de verdachte aanhoudt en naar een plaats voor verhoor leidt, wordt het openbaar ministerie in kennis gesteld.

In de meer ernstige gevallen van geweld tegen de vrouw door haar partner of ex-partner kan de verdachte voor de (hulp)officier van justitie zijn geleid, en kan in het belang van het onderzoek een inverzekeringstelling zijn bevolen. Als aan de gronden voor voorlopige hechtenis is voldaan, kan de officier van justitie een inbewaringstelling vorderen bij de rechter-commissaris en een gevangenhouding bij

110 Als een gevangenisstraf van een jaar wordt opgelegd, kan deze geheel voorwaardelijk zijn, maar als de gevangenisstraf tussen een en drie jaar ligt, kan ten hoogste eenderde van de straf voorwaardelijk zijn. 
de rechtbank. Daarnaast kan de officier van justitie vorderen dat de rechter-commissaris een gerechtelijk vooronderzoek instelt in het kader van de waarheidsvinding.

De minder ernstige geweldszaken in de relationele sfeer zullen doorgaans door de politie worden gekwalificeerd als mishandeling, vernieling, huisvredebreuk of bedreiging. Als de politie het proces-verbaal heeft doorgestuurd zal doorgaans het parketsecretariaat hierover in eerste instantie beslissen. De belangrijkste vraag is of de zaak wordt vervolgd of buitengerechtelijk wordt afgedaan door een sepot of door het aanbieden van een transactie of een sepot onder voorwaarden.

In hoofdstuk 5 wordt ingegaan op de vraag hoe het openbaar ministerie gebruik maakt van zijn bevoegdheid om de verdachte van geweld in de privésfeer wel of niet te dagvaarden, terwijl in hoofdstuk 6 nader wordt ingegaan op de wijze waarop het openbaar ministerie aan het slachtoffer rechtsbescherming kan bieden. 


\section{Vrouwenmishandeling een zaak voor justitie ${ }^{1}$}

"'t Is bij mishandeling zo, dat zo gauw er sprake is van een delikt in een 'beperkte kring' - zoals wij dat noemen-justitie zeer terughoudend is in het algemeen. Dat geldt niet alleen in de relatie man-vrouw, dat geldt ook in geval van burenruzies of bij mensen die dezelfde werkplaats delen en die de hele dag met elkaar geconfronteerd worden. Dat zijn allemaal situaties waarin justitie zegt: waarschijnlijk doen we meer kwaad dan goed, als we hier met het strafrecht tegenaan gaan. Wat $u$ wilt - en ik geloof dat daar reden toe is - is dat we juist moeten afwijken als 't om vrouwenmishandeling gaat en vrouwenmishandeling anders moeten behandelen dan andere mishandelingen in 'beperkte kring'. Omdat hier namelijk sprake is van een struktureel probleem en niet van incidenten op zich, wat in andere situaties natuurlijk wel het geval is."2

\subsection{Inleiding}

Er is weinig bekend over het optreden van officieren van justitie als het gaat om mannelijk geweld tegen vrouwen in de privésfeer. Het algemene politiesepotbeleid en de sepotgronden voor het openbaar ministerie geven aan dat 'beperkte kring' een belangrijke grond is om tot een sepot over te gaan. Gezien dit algemene politiesepotbeleid is de verwachting gerechtvaardigd dat met name de ernstige geweldszaken in de privésfeer het openbaar ministerie bereiken. Daarnaast blijkt uit onderzoek naar het sepotbeleid in de jaren zeventig dat in zaken van mishandeling het openbaar ministerie vaker tot seponering over gaat als dader en slachtoftic familie of bekenden zijn van elkaar. ${ }^{3}$ Maar hoe wordt gereageerd in geval van mannelijk geweld tegen vrouwen in de privésfeer is niet specifiek onderzocht. Dit exploratieve onderzoek heeft tot doel inzicht te verkrijgen in de vervolgingspraktijk van officieren

I Dit hoofdstuk is een bewerking van de working-paper Geweld tegen vrouwen als strafoaar feit: 1992.

2 Officier van justitie Creamer tijdens de forumdiscussie. Etty, Verslag van de forumdiscussie, in: Thuis geslagen, mevrouw? 1984: 73.

3 Zoomer \& Steinmetz, Vrouwelijke slachtoffers van misdrijven: hoe reageert het justitiele systeem daarop? TVC, 1979: Van Straelen, Het seponerings- en strafvorderingsbeleid van het $O M$, in: Beslissingsmomenten in het strafrechtelijke systeem, 1978: 194; Van Straelen \& Van Dijk, Rechtsgelijkheid en sepotpraktijk, 1981; Zoomer, De strafuordering en straftoemeting in gevallen van zware criminaliteit, 1981. 
van justitie in geval van geweld tegen de vrouw door haar partner of ex-partner. De door mij in de inleiding ( $(1.4 .4)$ gestelde vragen zijn:

a. Hoeveel geweldszaken bereiken de door mij onderzochte arrondissementsparketten in 1975 en het eerste kwartaal van 1985, hoeveel daarvan betreffen zaken van vrouwenmishandeling, en verschilt de sepotpraktijk tussen zaken van vrouwenmishandeling, zaken van geweld tegen bekenden en overige geweldszaken?

b. Wat voor soort zaken van vrouwenmishandeling bereikt het openbaar ministerie?

c. Hoe treedt het openbaar ministerie op in zaken van vrouwenmishandeling?

d. Welke invloed hebben bepaalde aspecten op de vervolgingsbeslissing omtrent zaken van vrouwenmishandeling?

Hoe vaak zaken van vrouwenmishandeling in vergelijking met de andere geweldsdelicten binnen zijn gekomen op de arrondissementsparketten Assen, Breda en Rotterdam in 1975 en in het eerste kwartaal van 1985, wordt behandeld in $\S 5.2$. Bovendien wordt de afhandeling van deze geweldsdelicten door het openbaar ministerie uiteen gezet (vraag a). Vervolgens geef ik antwoord op de tweede vraag door de variatie bij vrouwenmishandelingszaken aan te geven, niet alleen tussen de verschillende delictcategorieën, maar ook binnen de delictscategorieën (§ 5.3). In $\S 5.4$ wordt de vervolgingspraktijk van de 150 onderzochte vrouwenmishandeling uiteen gezet (vraag c). Deze vervolgingspraktijk wordt meer reliëf gegeven door de invloed van een aantal aspecten op de beslissing van de officier van justitie om een zaak van vrouwenmishandeling te seponeren of te vervolgen te beschrijven en het afwegingsproces van officieren van justitie nader uiteen te rafelen in $\S 5.5$ (vraag d). In $\S 5.6$ wordt tot slot een samenvatting gegeven en ingegaan op een aantal gesignaleerde knelpunten.

\subsection{De vervolgingspraktijk van geweldsdelicten}

Hoeveel geweldszaken zijn op de door mij onderzochte arrondissementsparketten binnengekomen en hoe heeft het openbaar ministerie deze geweldsdelicten afgehandeld? Eerst wordt deze vraag voor het jaar 1975 beantwoord, en vervolgens voor het eerste kwartaal van 1985. Hierbij wordt een onderscheid gemaakt tussen zaken van vrouwenmishandeling en overige geweldszaken. Bovendien wordt een vergelijking gemaakt tussen de afhandeling van vrouwenmishandelingszaken, zaken van geweld gepleegd door een bekende 4 en zaken van geweld gepleegd in de overige gevallen. Ook het vervolgingsbeleid per delictscategorie wordt beschreven.

4 Onder bekenden wordt verstaan: familie, vrienden en kennissen, huisgenoten en buren. 


\subsubsection{Frequentie en vervolgingspraktijk in 1975}

\section{Frequentie}

In 1975 zijn 1607 geweldszaken op de door mij onderzochte arrondissementsparketten binnengekomen, waarvan 134 een zaak van vrouwenmishandeling betreft. Dit is $8 \%$ van alle geweldsdelicten in de desbetreffende arrondissementsparketten (zie tabel 1). Wanneer we naar delictscategorieën kijken, zien we dat de categorie mishandeling meer dan de helft van het aantal geweldsdelicten omvat $(n=837)$. De categorie vernieling en beschadiging bestaat krap uit eenderde van alle geweldsdelicten $(n=486)$. Het resterende deel omvat de categorieèn bedreiging en huisvredebreuk ( $n=156)$, moord en doodslag ( $n=74)$ en verkrachting en aanranding $(n=54)$ (zie tabel 1).

Tabel 1. Vrouwenmishandeling ( $\mathrm{vm}$ ) en niet-vrouwenmishandeling (n-vm) naar delictscategorie in 1975 in de arrondissementsparketten Assen, Breda en Rotterdam.

\begin{tabular}{lccccccc}
\hline & \multicolumn{2}{c}{$\mathrm{vm}$} & \multicolumn{2}{c}{$\mathrm{n}$-vm } & \multicolumn{2}{c}{ totaal } & freq. \\
& $\mathrm{n}$ & $\%$ & $\mathrm{n}$ & $\%$ & $\mathrm{n}$ & $\%$ & $\%$ \\
\hline $\begin{array}{l}\text { Categorie 1: } \\
\text { moord en doodslag }\end{array}$ & 14 & 19 & 60 & 81 & 74 & 100 & $(5)$ \\
$\begin{array}{l}\text { Categorie 2: } \\
\text { mishandeling }\end{array}$ & 64 & 8 & 773 & 92 & 837 & 100 & $(52)$ \\
$\begin{array}{l}\text { Categorie 3: } \\
\text { verkrachting en aanran- } \\
\text { ding }\end{array}$ & 0 & 0 & 54 & 100 & 54 & 100 & $(3)$ \\
$\begin{array}{l}\text { Categorie 4: } \\
\text { bedreiging en huisvrede- } \\
\text { breuk }\end{array}$ & 31 & 20 & 125 & 80 & 100 & 100 & $(10)$ \\
$\begin{array}{l}\text { Categorie 5: } \\
\text { vemieling }\end{array}$ & 25 & 5 & 461 & 95 & 486 & 100 & $(30)$ \\
\begin{tabular}{l} 
Total geweldszaken \\
\hline
\end{tabular} & 134 & 8 & 1473 & 92 & 1607 & 100 & $(100)$ \\
\hline
\end{tabular}

Wanneer we de categorieën uitsplitsen naar zaken van vrouwenmishandeling en zaken die geen vrouwenmishandeling betreffen, dan zien we dat de verdeling over de geweldsdelicten van elkaar verschilt: vrouwenmishandeling vindt relatief vaker plaats in de categorieën huisvredebreuk/bedreiging, en moord/doodslag, terwijl vrouwenmishandeling niet in de categorie verkrachting/aanranding voorkomt (zie figuur 1). 


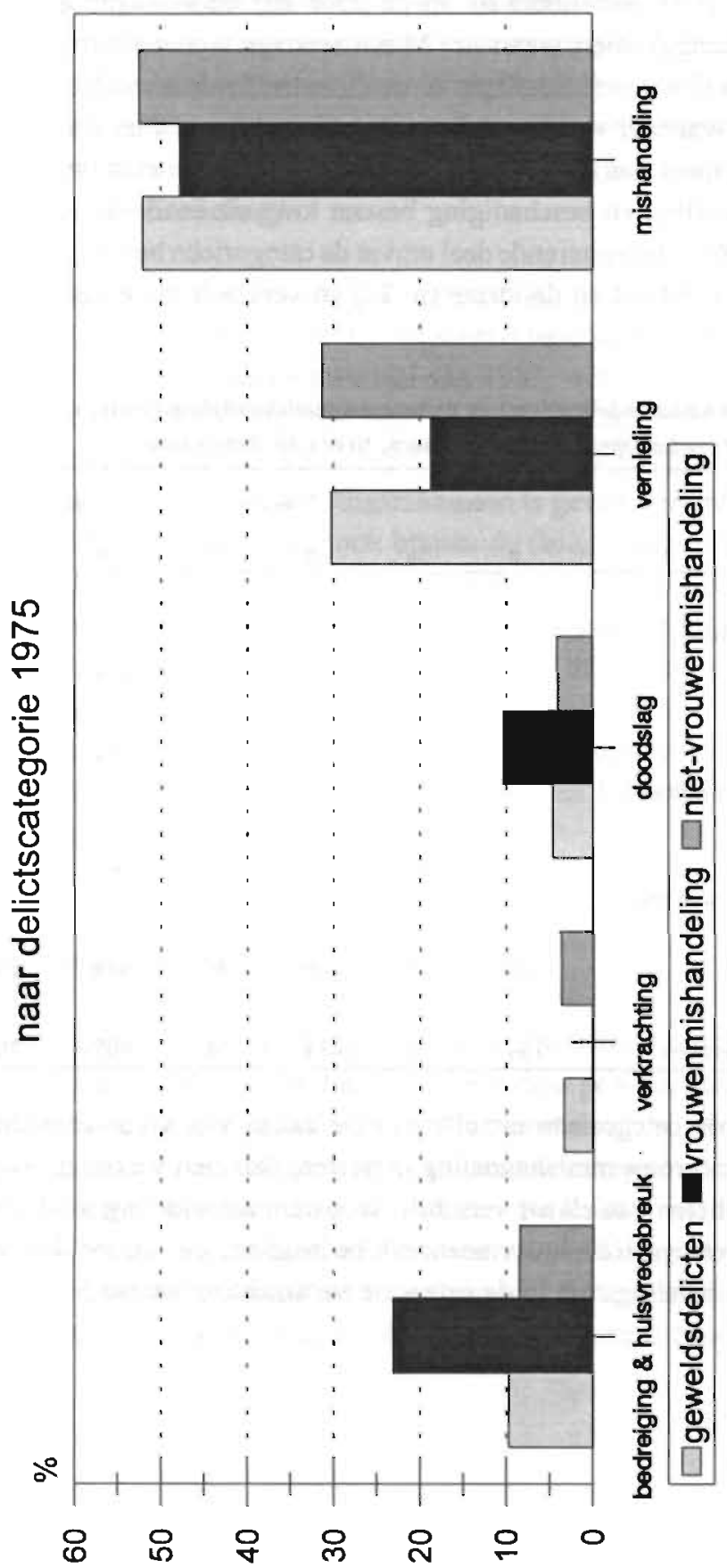


Dit betekent dat vrouwenmishandeling niet over alle delictsoorten evenredig is verdeeld. Kijken we naar tabel 1 dan zien we dat het percentage vrouwenmishandelingszaken per categorie aanmerkelijk verschilt: van $20 \%$ tot $0 \%$. In de categorieën bedreiging/huisvredebreuk en moord/doodslag betreft een vijfde van de geweldszaken vrouwenmishandelingszaken. De categorie mishandeling bestaat voor $8 \%$ uit zaken van vrouwenmishandeling, en de categorie vernieling en beschadiging uit $5 \%$. In de categorie verkrachting en aanrandingen komen in 1975 geen zaken van vrouwenmishandeling voor.

De vervolgingspraktijk

In 1975 wordt de helft van de vrouwenmishandelingszaken geseponeerd en de andere zaken worden vervolgd. De geweldszaken die geen vrouwenmishandeling betreffen, worden in $55 \%$ van de gevallen gedagvaard (zie tabel 2). Vervolgens heb ik de geweldszaken die geen vrouwenmishandeling betreffen, uitgesplitst naar zaken van geweld tussen bekenden en overige geweldszaken. Ook hiervan is de vervolgingspraktijk aangegeven (zie tabel 3).

Tabel 2. De wijze van afdoening door de officier van justitie, seponeren of dagvaarden, van zaken van vrouwenmishandeling (vm) en niet-vrouwenmishandeling (n-vm) in 1975 in de arrondissementsparketten Assen, Breda en Rotterdam.

\begin{tabular}{lrrrr}
\hline & \multicolumn{2}{c}{ vm } & \multicolumn{3}{c}{$\mathrm{n}$-vm } \\
& $\mathrm{n}$ & $\%$ & $\mathrm{n}$ & $\%$ \\
\hline sepot & 67 & $(50)$ & 675 & $(45)$ \\
dagvaarden & 67 & $(50)$ & 798 & $(55)$ \\
totaal & 134 & $(100)$ & 1473 & $(100)$ \\
\hline
\end{tabular}

De vervolgingspraktijk van geweldsdelicten, uitgesplitst naar vrouwenmishandeling, geweld tegen bekenden en geweld tegen overige personen, geeft aan dat er niet gesproken kan worden van grote verschillen tussen de drie deelgroepen. De afhandeling van geweld tegen de vrouw door haar partner en geweld tegen bekenden verschilt weliswaar van de afhandeling van geweld tegen overige personen door een hoger percentage geseponeerde zaken, maar dit verschil is gering. 
Tabel 3. De verhouding seponeren-vervolgen naar soort relatic in 1975 in de arrondissementsparketten Assen, Breda en Rotterdam.

\begin{tabular}{lrrrrrrrrr}
\hline & \multicolumn{2}{c}{ vm } & \multicolumn{2}{c}{ bekenden } & \multicolumn{2}{c}{ overig } & \multicolumn{2}{c}{ totaal } \\
& $\mathrm{n}$ & $\%$ & $\mathrm{n}$ & $\%$ & $\mathrm{n}$ & $\%$ & $\mathrm{n}$ & $\%$ \\
\hline sepot & 67 & $(50)$ & 236 & $(52)$ & 439 & $(43)$ & 742 & $(46)$ \\
vervolgd & 67 & $(50)$ & 221 & $(48)$ & 574 & $(57)$ & 862 & $(54)$ \\
totaal & 134 & $(100)$ & 457 & $(100)$ & 1013 & $(100)$ & 1604 & $(100)$ \\
\hline
\end{tabular}

* van drie niet-vrouwenmishandelingszaken is de relatie niet bekend

\section{Delictsoort}

Er is variatie met betrekking tot de ernst van het geweld, zowel binnen de geweldscategorieën als tussen de geweldscategorieën. In de praktijk van het openbaar ministerie zal in geval van doodslag in principe worden vervolgd, terwijl het in geval van mishandeling van allerlei aspecten afhangt of er zal worden geseponeerd of vervolgd. Hoe ziet de vervolgingspraktijk per delictsoort eruit? Het gaat per categorie om vaak geringe aantallen; daarom kunnen aan de gegevens alleen tentatieve uitspraken worden ontleend. Nog een opmerking vooraf: ook de pogingen tot deze delicten (voornamelijk bij moord en doodslag en de seksuele misdrijven) vallen onder de categorieĕn.

In de categorie moord en doodslag wordt in de onderzochte arrondissementen vaker gedagvaard dan geseponeerd; $78 \%$ van de niet-vrouwenmishandelingszaken wordt gedagvaard en $57 \%$ van de vrouwenmishandelingszaken. De aantallen zijn te klein om hier algemene en definitieve conclusies aan te verbinden.

In de categorie mishandeling wordt in de helft van de gevallen geseponeerd. Bovendien is geen verschil te constateren in vervolgingspraktijk van mishandeling van de vrouw door haar partner of mishandeling door anderen; zaken van vrouwenmishandeling worden voor $50 \%$ geseponeerd en niet-vrouwenmishandelingszaken voor $47 \%$. De conclusie lijkt gerechtvaardigd dat binnen de categorie mishandeling het sepotbeleid voor mannelijk geweld tegen vrouwen in de privésfeer niet afwijkt van het sepotbeleid betreffende mishandeling in het algemeen.

In de categorie verkrachting en aanranding komen in 1975 geen zaken van vrouwenmishandeling voor. 
Tabel 4. Wijze van beslissen door de officier van justitie in zaken van vrouwenmishandeling (vm) en niet-vrouwenmishandeling (n-vm) uitgesplitst naar delictscategorie in 1975 in de arrondissementsparketten Assen, Breda en Rotterdam.

\begin{tabular}{|c|c|c|c|c|c|}
\hline & & \multicolumn{2}{|c|}{$\mathrm{vm}$} & \multicolumn{2}{|c|}{ n-vm } \\
\hline & & $\mathrm{n}$ & $\%$ & $\mathrm{n}$ & $\%$ \\
\hline $\begin{array}{l}\text { Categorie 1: } \\
\text { moord en doodslag }\end{array}$ & $\begin{array}{l}\text { sepot } \\
\text { dagv. }\end{array}$ & $\begin{array}{r}6 \\
8 \\
14\end{array}$ & $\begin{array}{r}(43) \\
(57) \\
(100)\end{array}$ & $\begin{array}{l}13 \\
47 \\
60\end{array}$ & $\begin{array}{r}(22) \\
(78) \\
(100)\end{array}$ \\
\hline $\begin{array}{l}\text { Categorie 2: } \\
\text { mishandeling }\end{array}$ & $\begin{array}{l}\text { sepot } \\
\text { dagv. }\end{array}$ & $\begin{array}{l}32 \\
32 \\
64\end{array}$ & $\begin{array}{r}(50) \\
(50) \\
(100)\end{array}$ & $\begin{array}{l}364 \\
409 \\
773\end{array}$ & $\begin{array}{l}(47) \\
(53) \\
(100)\end{array}$ \\
\hline $\begin{array}{l}\text { Categorie 3: } \\
\text { verkrachting en aanran- } \\
\text { ding }\end{array}$ & $\begin{array}{l}\text { sepot } \\
\text { dagv. }\end{array}$ & $\begin{array}{l}0 \\
0 \\
0\end{array}$ & $\begin{array}{l}(-) \\
(-) \\
(-)\end{array}$ & $\begin{array}{l}28 \\
26 \\
54\end{array}$ & $\begin{array}{r}(52) \\
(48) \\
(100)\end{array}$ \\
\hline $\begin{array}{l}\text { Categorie } 4 \text { : } \\
\text { bedreiging en huisvrede- } \\
\text { breuk }\end{array}$ & $\begin{array}{l}\text { sepot } \\
\text { dagv. }\end{array}$ & $\begin{array}{l}20 \\
11 \\
31\end{array}$ & $\begin{array}{l}(65) \\
(35) \\
(100)\end{array}$ & $\begin{array}{r}66 \\
59 \\
125\end{array}$ & $\begin{array}{r}(53) \\
(47) \\
(100)\end{array}$ \\
\hline $\begin{array}{l}\text { Categorie 5: } \\
\text { vemieling }\end{array}$ & $\begin{array}{l}\text { sepot } \\
\text { dagv. }\end{array}$ & $\begin{array}{r}9 \\
16 \\
25\end{array}$ & $\begin{array}{r}(36) \\
(64) \\
(100)\end{array}$ & $\begin{array}{l}204 \\
257 \\
461\end{array}$ & $\begin{array}{r}(44) \\
(56) \\
(100)\end{array}$ \\
\hline $\begin{array}{l}\text { Totaal: } \\
\text { geweldsdelicten }\end{array}$ & $\begin{array}{l}\text { sepot } \\
\text { dagv. }\end{array}$ & $\begin{array}{r}67 \\
67 \\
134\end{array}$ & $\begin{array}{r}(50) \\
(50) \\
(100)\end{array}$ & $\begin{array}{r}675 \\
798 \\
1473 \\
\end{array}$ & $\begin{array}{r}(45) \\
(45) \\
(100)\end{array}$ \\
\hline
\end{tabular}

Categorie 4 bestaat voomamelijk uit bedreiging en huisvredebreuk. ${ }^{5}$ Er wordt in deze categorie vaker geseponeerd dan gedagvaard, waarbij vrouwenmishandeling vaker met een sepot wordt afgedaan dan niet-vrouwenmishandeling (65\% tegenover $53 \%)$.

Tot slot de zaken van vernieling en beschadiging. ${ }^{6}$ Vemielingszaken worden vaker vervolgd dan geseponeerd. Zaken van vrouwenmishandeling worden in $64 \%$ van de gevallen vervolgd, en niet-vrouwenmishandelingszaken in $56 \%$ van de gevallen.

Tussen de delictscategorieën bij vrouwenmishandelingszaken bestaan grotere verschillen in afdoening dan het geval is bij niet-vrouwenmishandelingszaken. Wanneer moord en doodslag buiten beschouwing worden gelaten, beweegt het sepotpercentage zich tussen $44 \%$ en $55 \%$ bij de niet-vrouwenmishandelingszaken, terwijl dit percentage voor zaken van vrouwenmishandeling schommelt tussen de $36 \%$ en $65 \%$. Tevens valt op dat de categorieèn mishandeling en bedreiging/huis-

5 Oorspronkelijk waren in deze categorie ook dwang en vrijheidsberoving opgenomen, maar deze delicten kwamen weinig voor en als ze voorkwamen dan was dit vaak in samenhang met een ander misdrijf, zoals mishandeling of verkrachting.

6 Vermieling door de echtgenoot valt buiten deze categorie omdat dit is uitgesloten van strafvervolging (art. $353 \mathrm{Sr}$ ), zie hoofdstuk 3, § 3.3.2. 
vredebreuk een groter sepotpercentage aangeven voor zaken van vrouwenmishandeling dan zaken die geen vrouwenmishandeling betreffen, terwijl in geval van vernieling zaken van vrouwenmishandeling vaker worden gedagvaard. Deze uitsplitsing naar delictsoort bevestigt, met uitzondering van de categorie vernieling, het eerder beschreven algemene beeld dat zaken van vrouwenmishandeling enigszins vaker met een sepot worden afgedaan dan zaken van overig geweld.

\subsubsection{Frequentie en vervolgingspraktijk in het eerste kwartaal van 1985}

\section{Frequentie}

In het eerste kwartaal van 1985 heeft het openbaar ministerie in de door mij onderzochte arrondissementsparketten 757 geweldsdelicten afgedaan. Honderd zaken hiervan betroffen vrouwenmishandeling. Dit betekent dat $13 \%$ van de geweldszaken een zaak van vrouwenmishandeling betreft (zie tabel 5). De categorie mishandeling $(n=339)$ bevat bijna de helft van alle geweldsdelicten, en de categorie vernieling $(n=260)$ een derde van de geweldszaken. Bedreiging/huisvredebreuk, moord/doodslag en verkrachting/aanranding kennen elk een kleine celvulling, respectievelijk $n=85$, $n=40$ en $n=33$ (zie tabel 5). Wanneer we de categorieèn uitsplitsen naar zaken van vrouwenmishandeling en zaken van niet-vrouwenmishandeling, dan zien we dat met name de verdeling bij zaken van vrouwenmishandeling afwijkt van het hiervoor geschetste algemene beeld (zie figuur 2).

Kijken we naar tabel 5 dan zien we dat de percentages vrouwenmishandelingszaken aanmerkelijk verschillen per delictscategorie: van $12 \%$ tot $37 \%$. De categorie moord/doodslag springt eruit; ruim een derde van de moord en doodslagzaken betreft vrouwenmishandeling. In de categorie bedreiging en huisvredebreuk is dit een kwart van de geweldszaken. De categorieèn verkrachting en aanranding, mishandeling en vernieling bestaan voor respectievelijk $15 \%, 12 \%$ en $8 \%$ uit zaken van vrouwenmishandeling. 
Tabel 5. Vrouwenmishandeling (vm) en niet-vrouwenmishandeling ( $\mathrm{n}-\mathrm{vm}$ ) naar delictscategorie in het eerste kwartaal van 1985 in de arrondissementsparketten Assen, Breda en Rotterdam.

\begin{tabular}{|c|c|c|c|c|c|c|c|}
\hline & \multicolumn{2}{|c|}{$\mathrm{vm}$} & \multicolumn{2}{|c|}{$n-v m$} & \multicolumn{2}{|c|}{ totaal } & \multirow{2}{*}{$\begin{array}{r}\text { freq. } \\
\quad \%\end{array}$} \\
\hline & $\mathbf{n}$ & $\%$ & $\mathbf{n}$ & $\%$ & $\mathbf{n}$ & $\%$ & \\
\hline $\begin{array}{l}\text { Categorie 1: } \\
\text { moord en doodslag }\end{array}$ & 12 & 37 & 28 & 63 & 40 & 100 & (5) \\
\hline $\begin{array}{l}\text { Categorie 2: } \\
\text { mishandeling }\end{array}$ & 41 & 12 & 298 & 88 & 339 & 100 & (45) \\
\hline $\begin{array}{l}\text { Categorie 3: } \\
\text { verkrachting en aanran- } \\
\text { ding }\end{array}$ & 5 & 15 & 28 & 85 & 33 & 100 & (5) \\
\hline $\begin{array}{l}\text { Categorie } 4 \text { : } \\
\text { bedreiging en huisvrede- } \\
\text { breuk }\end{array}$ & 21 & 25 & 64 & 75 & 85 & 100 & (11) \\
\hline $\begin{array}{l}\text { Categorie } 5 \text { : } \\
\text { vemieling }\end{array}$ & 21 & 8 & 239 & 92 & 260 & 100 & (34) \\
\hline Totaal geweldsdelicten & 100 & 13 & 657 & 87 & 757 & 100 & $(100)$ \\
\hline
\end{tabular}

De vervolgingspraktijk

Vanaf mei 1983 is de mogelijkheid om te transigeren uitgebreid naar misdrijven waarop een geldboete staat en/of een gevangenisstraf van minder dan zes jaar (zie hoofdstuk 4, § 4.3.2). Voor het eerste kwartaal van 1985 heb ik daarom een onderscheid gemaakt tussen seponeren, transigeren en dagvaarden. ${ }^{7}$

Tabel 6. De wijze van afdoening door de officier van justitic, seponeren, transigeren of dagvaarden, van zaken van vrouwenmishandeling ( $\mathrm{vm}$ ) en niet-vrouwenmishandeling (n-vm) in het eerste kwartaal van 1985 in de arrondissementsparketten Assen, Breda en Rotterdam.

\begin{tabular}{lrrrrrr}
\hline & \multicolumn{1}{c}{ vm } & \multicolumn{3}{c}{ n-vm } & \multicolumn{3}{c}{ totaal } \\
& $\mathrm{n}$ & $\%$ & $\mathrm{n}$ & $\%$ & $\mathrm{n}$ & $\%$ \\
\hline sepot & 40 & $(40)$ & 274 & $(42)$ & 314 & $(42)$ \\
transactie & 2 & $(2)$ & 37 & $(5)$ & 39 & $(5)$ \\
dagv. & 58 & $(58)$ & 346 & $(53)$ & 404 & $(53)$ \\
totaal & 100 & $(100)$ & 657 & $(100)$ & 757 & $(1(10)$ \\
\hline
\end{tabular}

7 Uit een onderzoek naar het transactiebeleid in de laatste drie maanden van 1983 blijkt dat ruim $75 \%$ ingaat op het transactievoorstel en aan de voorwaarde voldoet. Voor de mishandelingszaken ligt dit percentage lager, rond de $50 \%$. Wanneer de verdachte niet betaalt, volgt in $90 \%$ van de gevallen een dagvaarding, in $5 \%$ een tweede transactievoorstel en verder wordt het met een beleidssepot afgedaan. De uiteindelijke afdoening heeft daarom een hoger percentage gedagvaarde zaken. Kommer, Essers \& Damen, De transactie in misdrijfaken, 1986: 24-25. 


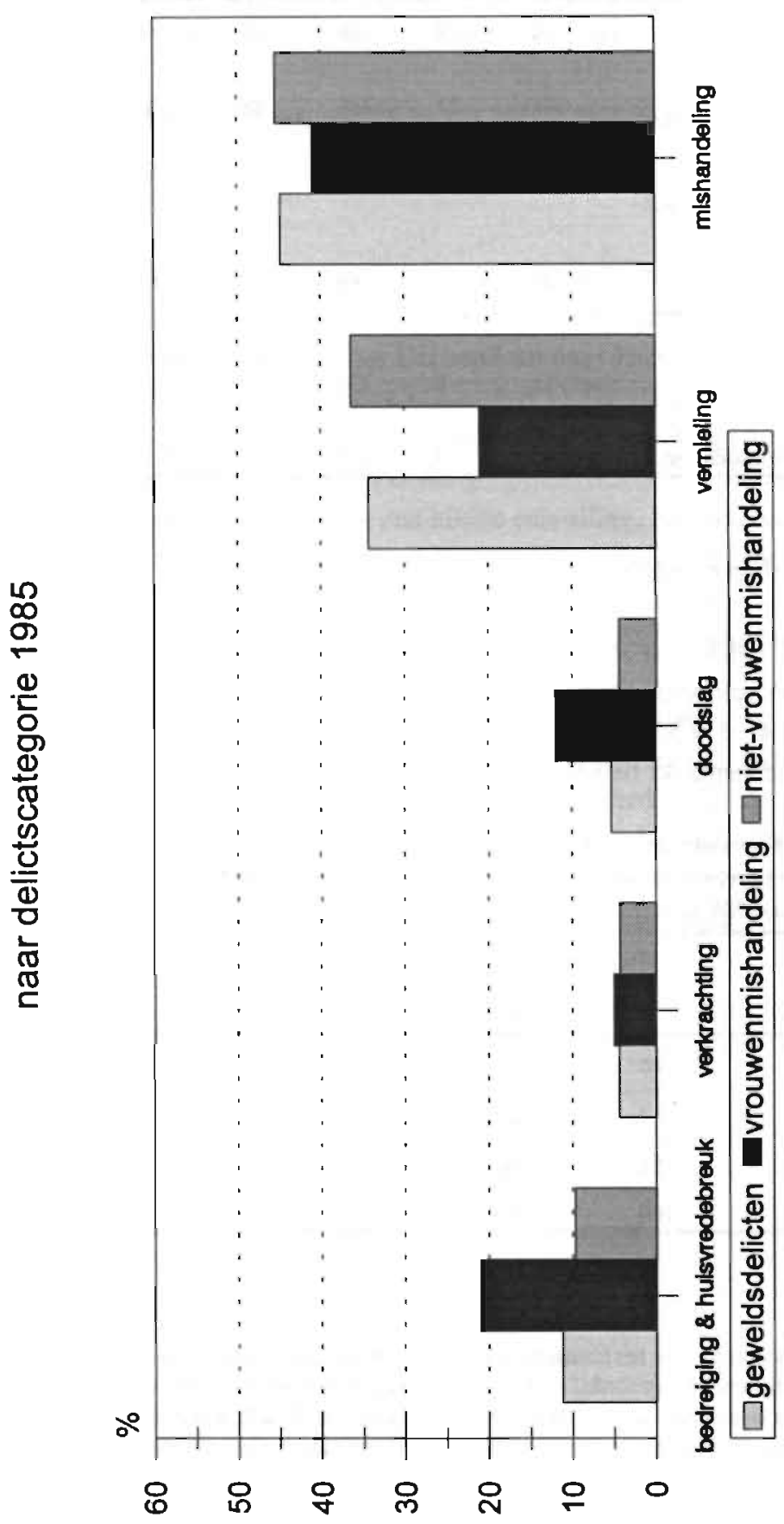


In het eerste kwartaal van 1985 worden zaken van vrouwenmishandeling door het openbaar ministerie even vaak geseponeerd als de andere geweldszaken; het sepotpercentage is voor beide soort zaken nagenoeg hetzelfde ( $40 \%$ en $42 \%$ ). Wel lijkt er in zaken van niet-vrouwenmishandeling vaker een transactie te worden aangeboden, maar de aantallen zijn te klein om hier een algemene uitspraak over te doen; $5 \%$ tegenover $2 \%$ (zie tabel 6 ).

Tabel 7. De verhouding seponeren-vervolgen naar soort relatie in het eerste kwartaal van 1985 in de arrondissementsparketten Assen, Breda en Rotterdam.

\begin{tabular}{lrrrrrrrrr}
\hline & \multicolumn{2}{c}{ vm } & \multicolumn{2}{c}{ bekenden } & \multicolumn{2}{c}{ overig } & \multicolumn{2}{c}{ totaal } \\
& $\mathrm{n}$ & $\%$ & \multicolumn{1}{c}{$\mathrm{n}$} & $\%$ & $\mathrm{n}$ & $\%$ & $\mathrm{n}$ & $\%$ \\
\hline sepot & 40 & $(40)$ & 99 & $(49)$ & 175 & $(39)$ & 314 & $(42)$ \\
transactie & 2 & $(2)$ & 10 & $(5)$ & 27 & $(6)$ & 39 & $(5)$ \\
vervolgd & 58 & $(58)$ & 93 & $(46)$ & 253 & $(55)$ & 404 & $(53)$ \\
total & 100 & $(100)$ & 202 & $(100)$ & 455 & $(100)$ & 757 & $(100)$ \\
\hline
\end{tabular}

Wanneer we de niet-vrouwenmishandelingszaken uitsplitsen naar geweldszaken tussen bekenden en overige personen, en dit vergelijken met de afhandeling van vrouwenmishandeling, dan zien we dat percentueel vaker wordt geseponeerd als de geweldszaak tussen bekenden plaatsvindt ( $49 \%$ tegenover $40 \%$ in geval van vrouwenmishandeling en $39 \%$ van de overige geweldsdelicten). Tevens valt op dat het percentage transacties voor geweldszaken tussen bekenden en overige personen met elkaar overeenkomen ( $5 \%$ en $6 \%$; zie tabel 7 ).

\section{Delictsoort}

Vervolgens heb ik gekeken naar de sepotpraktijk per delictsoort (zie tabel 8). Er wordt vaker vervolgd dan geseponeerd in de categorie moorden doodslag. Driekwart $(75 \%)$ van de vrouwenmishandelingszaken wordt vervolgd en ruim de helft (57\%) van de niet-vrouwenmishandelingszaken. Tevens valt de transactie op. ${ }^{8}$

De categorie mishandeling vertoont ongeveer eenzelfde beeld voor zaken van vrouwenmishandeling en zaken van niet-vrouwenmishandeling; in ruim de helft van de zaken wordt een dagvaarding uitgebracht $(51 \%$ en $52 \%)$, in rond de $5 \%$ van de zaken wordt een transactie aangeboden $(5 \%$ en $7 \%$ ) en de resterende gevallen worden met een sepot afgedaan ( $44 \%$ tegenover $41 \%$ ).

Zaken van verkrachting en aanranding worden vaker geseponeerd dan vervolgd, zowel de vrouwenmishandelingszaken als de zaken waar het niet om vrouwenmishandeling gaat. Van de vijf gevallen van vrouwenmishandeling worden er vier

8 Het betreft een poging tot doodslag, bedreiging en mishandeling. De officier van justitie zal het delict als mishandeling hebben gekwalificeerd en dasrom kon een transactie worden aangeboden. 
gevallen geseponeerd $(80 \%)$ en 19 van de 28 niet-vrouwenmishandelingszaken $(68 \%)^{9}$

In geval van bedreiging en huisvredebreuk is het vervolgingsbeleid voor de vrouwenmishandelingszaken en de niet-vrouwenmishandelingszaken min of meer gelijk; $38 \%$ wordt geseponeerd en er worden weinig transacties aangeboden.

Tot slot de zaken van vernieling. Het percentage vervolgde zaken van vrouwenmishandeling is opvallend, zowel vergeleken met het percentage vervolgde nietvrouwenmishandeling vernielingszaken ( $71 \%$ versus $54 \%)$, als vergeleken met de andere delictscategorieën; nergens komt zo'n hoog vervolgingspercentage voor. Bovendien valt op dat er geen transacties zijn aangeboden in geval van vrouwenmishandeling, in tegenstelling tot de andere vernielingszaken $(5 \%)$.

Tabel 8. Wijze van beslissen door de officier van justitie in zaken van yrouwenmishandeling (vm) en niet-vrouwenmishandeling ( $\mathrm{n}-\mathrm{vm}$ ) uitgesplitst naar delictscategorie in het cerste kwartaal van 1985 in de arrondissementsparketten Assen, Breda en Rotterdam.

\begin{tabular}{|c|c|c|c|c|c|}
\hline & & \multicolumn{2}{|c|}{$\mathrm{vm}$} & \multicolumn{2}{|c|}{$n-v m$} \\
\hline & & $\mathrm{n}$ & $\%$ & $\mathrm{n}$ & $\%$ \\
\hline $\begin{array}{l}\text { Categorie } 1 \text { : } \\
\text { moord en doodslag }\end{array}$ & $\begin{array}{l}\text { sepol } \\
\text { trans. } \\
\text { dagv. }\end{array}$ & $\begin{array}{r}3 \\
0 \\
9 \\
12\end{array}$ & $\begin{array}{r}(25) \\
(-) \\
(75) \\
(100)\end{array}$ & $\begin{array}{r}11 \\
1 \\
16 \\
28\end{array}$ & $\begin{array}{r}(39) \\
(4) \\
(57) \\
(100)\end{array}$ \\
\hline $\begin{array}{l}\text { Catcgorie 2: } \\
\text { mishandeling }\end{array}$ & $\begin{array}{l}\text { sepot } \\
\text { trans. } \\
\text { dagv. }\end{array}$ & $\begin{array}{r}18 \\
2 \\
21 \\
41\end{array}$ & $\begin{array}{r}(44) \\
(5) \\
(51) \\
(100)\end{array}$ & $\begin{array}{r}122 \\
21 \\
155 \\
298\end{array}$ & $\begin{array}{r}(41) \\
(7) \\
(52) \\
(100)\end{array}$ \\
\hline $\begin{array}{l}\text { Categorie 3: } \\
\text { verkrachting en aanran- } \\
\text { ding }\end{array}$ & $\begin{array}{l}\text { sepot } \\
\text { trans. } \\
\text { dagv. }\end{array}$ & $\begin{array}{l}4 \\
0 \\
1 \\
5\end{array}$ & $\begin{array}{r}(80) \\
(-) \\
(20) \\
(100)\end{array}$ & $\begin{array}{r}19 \\
0 \\
9 \\
28\end{array}$ & $\begin{array}{r}(68) \\
(-) \\
(32) \\
(100)\end{array}$ \\
\hline $\begin{array}{l}\text { Categoric } 4 \text { : } \\
\text { bedreiging en huisvrede- } \\
\text { breuk }\end{array}$ & $\begin{array}{l}\text { sepot } \\
\text { trans. } \\
\text { dagv. }\end{array}$ & $\begin{array}{r}8 \\
1 \\
12 \\
21\end{array}$ & $\begin{array}{r}(38) \\
(5) \\
(57) \\
(100)\end{array}$ & $\begin{array}{r}24 \\
2 \\
38 \\
64\end{array}$ & $\begin{array}{r}(38) \\
(3) \\
(59) \\
(100)\end{array}$ \\
\hline $\begin{array}{l}\text { Categorie 5: } \\
\text { vernieling }\end{array}$ & $\begin{array}{l}\text { sepot } \\
\text { trans. } \\
\text { dagv. }\end{array}$ & $\begin{array}{r}6 \\
0 \\
15 \\
21\end{array}$ & $\begin{array}{r}(29) \\
(-) \\
(71) \\
(100)\end{array}$ & $\begin{array}{r}98 \\
13 \\
128 \\
239\end{array}$ & $\begin{array}{r}(42) \\
(5) \\
(54) \\
(100)\end{array}$ \\
\hline
\end{tabular}

De cijfers van het eerste kwartaal van 1985 overziend, valt op dat over het algemeen zaken van vrouwenmishandeling niet anders worden afgedaan dan geweldszaken die geen vrouwenmishandeling betreffen. In de categorie mishandeling, de delictsoort

9 In twee gevallen gaat het om een technisch sepot en in twee gevallen om een sepot onder voorwaarden. Er vindt dus geen kaal beleidssepot plaats om redenen van opportuniteit. Tevens vindt er een vertekening plaats door het kleine aantal. Zie $\$ 5.4$ onder vervolgingspraktijk naar delictscategorie en relatie. 
waar de meeste geweldszaken en de meeste zaken van vrouwenmishandeling onder vallen, en ook in de categorie bedreiging en huisvredebreuk, is dit duidelijk zichtbaar. In de andere drie categorieën kan de wijze van afhandelen voor zaken van vrouwenmishandeling verschillen van zaken van niet-vrouwenmishandeling. De aantallen voor de categorieën moord en doodslag en verkrachting en aanranding zijn te klein om er algemeen geldende conclusies aan te verbinden. De categorie vernieling is wel redelijk gevuld. Zaken van vrouwenmishandeling lijken vaker te worden vervolgd, zowel ten opzichte van de andere vemielingszaken als ten opzichte van de algemene vervolgingspraktijk.

\subsubsection{Enkele concluderende opmerkingen}

Zaken van vrouwenmishandeling maken een twaalfde uit van de geweldsdelicten op de door mij onderzochte arrondissementsparketten in $1975(8 \%)$ en een achtste in het eerste kwartaal van $1985(13 \%)$. Wanneer gekeken wordt naar de frequentie waarop een zaak van vrouwenmishandeling op een arrondissementsparket binnenkomt, dan kan aan de hand van gegevens over 1985 worden gesteld dat op een middelgroot parket als Breda ongeveer twee zaken per week binnenkomen, op een klein parket als Assen een à twee zaken per veertien dagen en op een groot parket als Rotterdam gemiddeld een zaak per dag. ${ }^{10}$

De veronderstelling dat het openbaar ministerie zaken van vrouwenmishandeling over het algemeen seponeert of vaker afdoet met een sepot dan andere geweldszaken, wordt door voorgaande resultaten niet bevestigd. Zowel in het eerste kwartaal van 1985, als in 1975 lijken zaken van vrouwenmishandeling op min of meer dezelfde wijze afgehandeld te worden als andere geweldszaken.

Toch kunnen kleine verschillen duiden op een betekenisvolle verandering. De cijfers over 1975 geven een licht verhoogd sepotpercentage aan voor zaken van vrouwenmishandeling en zaken van geweld tegen bekenden, vergeleken met zaken van geweld tegen overige personen. Resultaten uit ander onderzoek naar het vervolgingsbeleid van het openbaar ministerie in de jaren zeventig, laat eveneens zien dat in geval van mishandeling vaker wordt geseponeerd als slachtoffer en dader familie of bekenden zijn van elkaar. ${ }^{.1}$

Zo'n zelfde conclusie kan niet worden getrokken op basis van de cijfers over het eerste kwartaal van 1985. Als er in 1985 al een andere wijze van afdoening zou zijn voor zaken van vrouwenmishandeling, dan bestaat deze afwijking eerder uit een hoger percentage vervolgde zaken en een lager percentage transacties vergeleken met de afhandeling van niet-vrouwenmishandelingszaken. Bovendien is een licht

10 In Rotterdam zijn in het eerste kwartaal van 198571 zaken van vrouwenmishandeling op het arrondissementsparket binnengekomen, in Breda in het eerste halfjaar 51 zaken en in Assen zijn 42 vrouwenmishandelingszaken in 1985 binnengekomen.

11 Zie de literatuur in de inleiding van dit hoofdstuk $(\$ 5.1)$. 
verhoogd sepotpercentage te constateren voor zaken van geweld gepleegd tegen een bekende in vergelijking met de afhandeling van geweld tegen de (ex-)partner en overige geweldsdelicten.

Dit zou kunnen betekenen dat de vervolgingspraktijk ten aanzien van zaken van vrouwenmishandeling in 1985 verschilt van de praktijk in 1975, terwijl dit niet geldt voor geweldszaken gepleegd door bekenden, noch voor de overige geweldszaken. Hierbij moet overigens wel worden bedacht dat cijfers over het eerste kwartaal van 1985 niet direct mogen worden beschouwd als cijfers over heel 1985. Vooralsnog blijken er overigens geen grote verschillen tussen de cijfers per kwartaal. ${ }^{12}$

Naar aanleiding van de hiervoor gepresenteerde onderzoeksresultaten van het verkennende onderzoek naar de frequentie en afhandeling van zaken van vrouwenmishandeling door het openbaar ministerie, kunnen een drietal voorlopige conclusies worden geformuleerd. Een grootschaliger dossieronderzoek zal de houdbaarheid daarvan moeten uitwijzen.

1. Wanneer geweld tegen vrouwen binnen heteroseksuele relaties of ex-relaties onder de delictscategorie mishandeling valt, zal de vervolgingspraktijk ten aanzien van zaken van vrouwenmishandeling niet anders zijn dan in andere gevallen van mishandeling. Betreft het een vrouwenmishandelingszaak die onder de categorie vernieling valt, dan zal het openbaar ministerie verdachten van vernieling binnen de privésfeer vaker dagvaarden dan verdachten van de andere vemielingszaken.

2. Het verschil in vervolgingspraktijk tussen zaken van vrouwenmishandeling en overige geweldsdelicten kan worden herleid tot een verschil in transactiebeleid. Zaken van vrouwenmishandeling in de categorie vernieling en mishandeling lijken minder snel te worden getransigeerd dan zaken van vernieling en mishandeling die geen vrouwenmishandeling betreffen.

3. De vervolgingspraktijkten aanzien van zaken van vrouwenmishandeling verschilt van de vervolgingspraktijk ten aanzien van zaken die spelen tussen bekenden; geweld gepleegd door een bekende lijkt vaker te worden afgedaan met een sepot dan geweld gepleegd tegen de vrouw door haar (ex-)partner.

\subsection{Een gevarieerd beeld van zaken van vrouwenmishandeling}

Wat voor soort zaken van vrouwenmishandeling bereikt het openbaar ministerie? Zijn het bijvoorbeeld alleen de gevallen waar sprake is van ernstig letsel en langdurig geweld? Zijn het zaken waar de relatie is verbroken? Zijn het zaken waar met name mannen uit een sociaal-economisch laag milieu verdachte zijn? En hoe

12 In Breda werd in het eerste kwartaal van $198563 \%$ geseponeerd en in het eerste half jaar $66 \%$. In Assen werd in het eerste kwartaal van $198545 \%$ van de zaken geseponeerd en in heel $198548 \%$. 
vaak worden mannen die verdacht worden van vrouwenmishandeling in verzekering gesteld? Aan de hand van 150 geselecteerde zaken van vrouwenmishandeling wordt op deze vragen een antwoord gegeven. ${ }^{13}$ Eerst wordt in $\S 5.3 .1$ een aantal kenmerken beschreven die gelden voor deze groep zaken van vrouwenmishandeling. Vervolgens wordt in $\S 5.3 .2$ per delictscategorie op een aantal te onderscheiden typen vrouwenmishandelingszaken ingegaan.

\subsubsection{Kenmerken van zaken van vrouwenmishandeling}

Het zijn met name zaken van vrouwenmishandeling waarbij de relatie is verbroken, die het openbaar ministerie bereiken; driekwart van de gevallen van vrouwenmishandeling betreft een ex-relatie of personen in een echtscheidingsprocedure die niet meer bij elkaar wonen ten tijde van het geweldsincident $(n=111)$. In 39 gevallen is er sprake van een relatie ten tijde van het geweldsincident. Of de relatie voortduurt nadat aangifte is gedaan, blijkt niet altijd uit het dossier. In twaalf gevallen lijkt het erop dat de relatie is verbroken na het doen van de aangifte en in elf gevallen lijkt het erop dat de relatie voortduurt. ${ }^{14}$ In twee gevallen is de relatie beëindigd ten gevolge van de dood van de vrouw. De hoeveelheid zaken van vrouwenmishandeling die een relatie betreft die ook voortduurt na het doen van aangifte, is klein (minimaal 11 gevallen (7\%) en maximaal 25 gevallen $(17 \%)$ ). ${ }^{15}$ Kinderen maken in $42 \%$ van de zaken deel uit van de (verbroken) relatie $(n=63)$. Zeker in geval van verbroken relaties kan dit een bron van conflict en gewelddadig optreden zijn. Zowel voortkomend uit problemen rond de omgangsregeling, als voortkomend uit het feit dat de vrouw de man toelaat in haar leven omdat hij de vader van haar kinderen is.

Wanneer we naar de persoon van de verdachte kijken, dan zien we dat de leeftijdsopbouw de volgende verdeling vertoont: een kwart is jonger dan 30 jaar (27\%), de grootste groep zit in de leeftijdsklasse tussen 30 en 40 jaar (39\%), weer een kwart zit tussen 40 en 50 jaar (26\%), en de rest is ouder dan 50 jaar. (Bij het slachtoffer is deze verdeling respectievelijk $43 \%, 37 \%, 16 \%$ en $4 \%$; duidelijk jonger dan de verdachten.) Een kleine $80 \%$ van de mannen heeft geen of een laag gekwalificeerd beroep. ${ }^{16}$ Op het moment van geweldpleging was de helft van de mannen werkloos of arbeidsongeschikt. Meer dan de helft van de mannen heeft een strafblad

13 In hoofdstuk $1, \S 1.5$ heb ik de methode van onderzoek uiteengezet.

14 Van veertien zaken is niet duidelijk of de relatie daarna voortduurt of dat de relatie wordt verbroken.

15 Uit het dossier is niet op te maken of de relatie is verbroken na het doen van aangifte, vandaar de minimaal-maximaal constructie. Overigens kunnen relaties ook ambivalent zijn: het ene moment is de relatie verbroken en het andere moment is weer sprake van een relatie.

16 Criterium voor laag gekwalificeerd beroep: ongeschoold werk en lagere beroepsopleiding. Hierbij is gebruik gemaakt van de classificatie van Van Tulder, De beroepsbevolking in Nederland van 1919 tor 1954, 1962. 
$(n=82)$ en ruim een derde van de mannen is aangeschoten of dronken tijdens de geweldpleging ( $\mathrm{n}=57$ ). De mannen hebben in de meeste gevallen geen advocaat.

De politie verhoort de verdachte in $75 \%$ van de zaken $(n=113) .{ }^{17}$ De man wordt in $24 \%$ van de gevallen in verzekering gesteld $(n=35)$. Van de in verzekering gestelde mannen is de helft in voorlopige hechtenis genomen $(n=18) .{ }^{18}$ Een gerechtelijk vooronderzoek wordt in $13 \%$ van de gevallen aangevraagd $(n=19)$.

Over de persoon van het slachtoffer is niet zo veel bekend omdat persoonskenmerken van het slachtoffer niet relevant zijn voor de strafprocedure. Uit de dossiers blijkt dat vrouwen soms een advocaat in de hand nemen als sprake is van een echtscheidingsprocedure. In vier gevallen is de vrouw naar een opvanghuis gegaan. ${ }^{19}$ Slachtoffers voegen zich in $13 \%$ van de zaken als benadeelde partij ${ }^{20}$ $(n=20)$, met name als het geweld bestaat uit vernieling $(n=14){ }^{21}$ Hoewel de officier van justitie over het algemeen de verdachte van vrouwenmishandeling dagvaardt als de vrouw zich voegt als benadeelde partij $(n=16),{ }^{22}$ is in veel gevallen de rechter niet aan de vordering toegekomen. De meest voorkomende reden daarvoor is dat het slachtoffer niet op de terechtzitting verschijnt $(n=9) .{ }^{23}$ Een andere reden is dat het slachtoffer zich heeft teruggetrokken $(n=4)$; eenmaal omdat de vrouw een civiele procedure is gestart in verband met het hoge schadebedrag, ${ }^{24}$ en eenmaal omdat de man de schade al had vergoed. Er zijn drie gevallen waarin de vordering in stand blijft tijdens de terechtzitting. Hiervan worden twee vorderingen door de rechter afgewezen en een toegewezen. Dit betekent overigens niet dat het slachtoffer maar één keer een schadevergoeding heeft gekregen voor de geleden schade. Het slachtoffer heeft in negen gevallen een schadevergoeding gekregen, alle wegens

17 Hieronder vallen vier gevallen waar de man ter ontnuchtering of wegens andermans en eigen veiligheid is ingesloten.

$18 \mathrm{Er}$ is sprake van twee missing cases.

19 Uit het onderzoek van Rømkens komt naar voren dat $3 \%$ van de vrouwen die eenzijdig geweld hebben ervaren door hun partner, naar een opvanghuis vlucht. Romkens, Gewoon geweld?, 1992: 151.

20 Tot de invoering van de wet voorzieningen ten behoeve van slachtoffers van strafbare feiten, de wet Terwee (Sib. 1993, 29), heette de benadeelde partij beledigde partij. lk hanteer voor de consistentie van het taalgebruik de term benadeelde partij.

21 In geval van verkrachting is tweemaal en in geval van mishandeling viermaal als benadeelde partij gevoegd.

22 Het is sinds de richtlijn 'slachtofferzorg' uit 1993 beleid dat de officier van justitie rekening moet houden met de wens van het slachtoffer dat zij de schade vergoed wil krijgen, in zijn beslissing hoe de zaak moet worden afgehandeld. Zie hoofdstuk $2, \S 2.5$.

23 Uit het dossier blijkt in elk geval nict dat het slachtoffer is verschenen en dat de rechter een vordering tot schadevergoeding heeft toegewezen. In de gesprekken met officieren van justitie wordt bevestigd dat veel slachtoffers die zich voegen als benadeelde partij, regelmatig niet op de terechtzitting verschijnen. Sinds de invoering van de wet Terwee hoeft het slachtoffer dat zich in de voorfase heeft gevoegd als benadeelde partij niet op de terechtzitting aanwezig te zijn.

24 Sinds de invoering van de wet Terwee is het schadebedrag losgelaten, en moet het daarentegen gaan om een vordering van cenvoudige aard. 
vernieling (dat is $6 \%$ ). ${ }^{25}$ In drie gevallen heeft de man de schade betaald voordat het openbaar ministerie of de rechter een beslissing nam en in een geval betaalde de man de schadevergoeding die de officier van justitie als voorwaarde bij een transactie stelde. In vijf gevallen heeft de rechter een schadevergoeding als bijzondere voorwaarde opgelegd (waarvan twee keer de schadevergoeding niet voor de vrouw was bestemd, maar voor de bouwvereniging wiens eigendom het huis was).

Van de 150 zaken zijn 76 buitengerechtelijk afgedaan en 74 voor de rechter gebracht. Het merendeel van de zaken $(n=59)$ is voor de politierechter gebracht, en een vijfde van de zaken $(n=15)$ voor de Meervoudige kamer. Bij veroordeling door de Meervoudige kamer is een (voorwaardelijke) gevangenisstraf opgelegd, veelal tussen vier en twaalf maanden $(n=12){ }^{26}$ Het gaat dan meestal om een (poging tot) doodslag/moord en verkrachting. In $42 \%$ van de politierechterzaken wordt een (voorwaardelijke) boete opgelegd ( $n=25)$ en in $32 \%$ van de politierechterzaken een (voorwaardelijke) gevangenisstraf $(n=19) .{ }^{27}$ Soms wordt zowel een (voorwaardelijke) gevangenisstraf als een (voorwaardelijke) boete opgelegd $(15 \%$, $\mathrm{n}=9) .^{28} \mathrm{Er}$ zijn 4 verdachten vrijgesproken. ${ }^{29}$

Vier resultaten springen in het oog. Allereerst valt op dat de zaken van vrouwenmishandeling die het arrondissementsparket bereiken met name verbroken relaties betreffen. Dit is geen afspiegeling van de maatschappelijke werkelijkheid waar een op de acht vrouwen binnen haar huidige relatie wordt geconfronteerd met geweld door haar partner. Het is overigens niet verwonderlijk dat vooral de gevallen van geweld die een verbroken relatie betreffen tot het arrondissementsparket doordringen. De meldingen van vrouwenmishandeling bij de politie bestaan voor $50 \%$ uit meldingen van geweld binnen een relatie. ${ }^{30}$ De politie is terughoudend in het opnemen van aangifte van geweld binnen relaties die voortduren, waardoor met name de aangiften van geweld door de ex-partner naar het openbaar ministerie worden doorgestuurd. ${ }^{31}$

25 Uit de resultaten van een dossieronderzoek naar schadevergoeding binnen het strafrecht in 1985 blijkt dat in $6 \%$ van de zaken een schadevergoeding tot stand wordt gebracht. Junger $\&$ van Hecke, Schadevergoeding binnen het strafrecht, 1988: 4 .

26 De gemiddelde (voorwaardelijke) gevangenisstraf is 32 weken. In een zaak vond vrijspraak plaats, en in twee zaken is TBS opgelegd.

27 De gemiddelde (voorwaardelijke) boete door de politierechter opgelegd is 470 gulden, en de gemiddelde (voorwaardelijke) gevangenisstraf is 6 weken.

28 In drie gevallen vond een yrijspraak plaats. Van drie zaken is onduidelijkheid over de beoordeling van de politierechter. De reden hiervan kan zijn dat de zaak ad informandum is gevoegd bij een andere zaak en de uitspraak van de rechter niet meer was te achterhalen.

29 Van drie zaken ontbreekt de uitspraak van de rechter.

30 Uit het onderzoek van Wostmann blijkt dat van de 281 gevallen van vrouwenmishandeling 142 gevallen een relatie betrof ( 79 waren gehuwd, 63 hadden een intieme relatic), dit is bijna $50 \%$. Wostmann, Politieoptreden bij vrouwenmishandeling, 1988: 53.

31 Zoomer, Vrouwenmishandeling; politiewerk, 1990: 52. 
Een tweede opvallende uitkomst is dat $80 \%$ van de verdachte mannen geen of een laag gekwalificeerd beroep heeft en dat de helft van de mannen geen betaalde arbeid verricht; het zijn met name mannen uit de sociaal lagere milieus zonder betaalde arbeid die met het justitięle systeem in aanraking komen. ${ }^{32}$ Deze groep verdachte mannen vormt geen afspiegeling van de groep mannen die geweld plegen binnen hun relatie of tegen hun ex-partner, want vrouwenmishandeling is geen specifiek probleem voor de lagere sociaal-economische milieus. Wel blijken mannen die tijdens de relatie grotendeels werkloos zijn geweest, anderhalf tot twee keer zo vaak geweld tegen hun partner te gebruiken dan mannen die vrij constant een betaald beroep hebben uitgeoefend. ${ }^{33}$ Een reden waarom juist deze groep mannen met het openbaar ministerie in aanraking komt, kan samenhangen met het feit dat het met name mensen uit de lagere milieus zijn die een beroep doen op de politie als er sprake is van geweld binnen het gezin. Bovendien blijkt de politie mensen met een lagere status sneller te arresteren, terwijl voor mensen uit hogere milieus naar andere oplossingen wordt gezocht. ${ }^{34}$

Ten derde valt op dat in $23 \%$ van de aangiften een inverzekeringstelling heeft plaatsgevonden, waarvan de helft in voorlopige hechtenis wordt genomen. In $77 \%$ van de gevallen blijft het politieoptreden beperkt tot een verhoor van de man. Deze cijfers geven aan dat de politie niet alleen bemiddelt en sust; er wordt wel degelijk strafrechtelijk opgetreden.

Tot slot springt in het oog dat het slachtoffer zich in $14 \%$ van de gevallen voegt als benadeelde partij, terwijl maar $2 \%$ daadwerkelijk op de zitting verschijnt. Reden om niet te verschijnen kan zijn dat de schade al is vergoed, of dat de vrouw geen confrontatie met de man wil. Ook praktische problemen kunnen een rol spelen, bijvoorbeeld als de vrouw de zorg voor haar kinderen heeft en geen oppas ter beschikking heeft.

\subsubsection{Vrouwenmishandeling is geen eenduidig begrip}

Op basis van de 150 geselecteerde zaken ga ik nader in op de gevarieerdheid van zaken van vrouwenmishandeling en op het soort vrouwenmishandelingszaken dat het openbaar ministerie bereikt.

32 Dit geldt overigens voor de meeste delicten. Jongman, Vrouwe justitia is ook maar een mens, in: Beslissingsmomenten in het strafrechtelijk systeem, 1978: 11-27. Jongman, Ongelijke kansen in de rechtsgang, in: Klasse elementen in de rechtsgang, 1981: 1-23; Kannegieter, Ongelijkheid in de sirafioemeting, 1994: 17-28.

33 Romkens, Geweld tegen vrouwen in heleroseksuele relaties, 1989: 53-63.

34 Cacheh, Politie en sociale controle, 1990: 201-204. 


\section{Vernieling en huisvredebreuk}

De categorie vernieling en huisvredebreuk bestaat uit 44 zaken, dat is $29 \%$ van de in dit kwalitatieve deel onderzochte zaken. Vemieling en huisvredebreuk wordt gepleegd door ex-partners $(n=42)$; twintig ex-echtgenoten, dertien ex-samenwonenden en negen verbroken LAT-relaties. Zaken van vernieling binnen het huwelijk kunnen niet worden vervolgd, want vernieling is binnen het huwelijk niet strafbaar (art. $253 \mathrm{Sr}$ ). Bovendien kan geen sprake zijn van huisvredebreuk als beide partners in het huis wonen. Ik zal aan de hand van twee voorbeelden ingaan op het privacy-aspect van deze delicten.

Op 36-jarige leeftijd gaat Dick samenwonen met Lianne van 39 jaar. Ze krijgen een dochter. Na vijf jaar te hebben samengewoond, wordt besloten uit elkaar te gaan omdat Dick vaak dronken is. Hij wordt dan zeer agressief en vemielt huisraad.

Op een avond belt Dick aan. Hij is dronken en Lianne doet de deur niet open. Dick blijft bellen en Lianne wordt zo nerveus dat ze de deur opendoet. Dick heeft patat en ijs meegenomen om dit samen met zijn dochtertje van drie op te eten. Het dochtertje wordt door hem uit bed gehaald en Lianne gaat koffie zetten in de hoop dat hij daardoor ontnuchtert. Dan wordt er gebeld en een vriend van hun staat op de stoep. Als Dick deze vriend ziet wordt hij zo boos dat hij met een hamer de televisie kapot slaat. Lianne belt de politie en doet aangifte van vernieling. Het schadebedrag is $f 400,-$. Lianne stelt zich als benadeelde partij.

De officier van justitie besluit te dagvaarden en Lianne krijgt een kennisgeving dat de terechtzitting zal plaatsvinden. Lianne schrijft vervolgens een briefje aan de officier van justitie dat de schade inmiddels is vergoed. De advocaat van Dick vraagt de stukken van zijn cliënt op. Dan besluit de officier van justitie een dag voor de terechtzitting tot een onvoorwaardelijk beleidssepot met als grond 'verhouding tot de benadeelde geregeld'. (dossier 113)

Heleen, 25 jaar, gaat samenwonen met Ronald, 28 jaar. Na twee jaar gaan ze uit elkaar. $\mathrm{Na}$ een jaar komt Ronald bij Heleen aankloppen voor een bord eten. Zijn uitkering is namelijk stopgezet omdat hij zwart heeft bijverdiend. Hij vindt dat Heleen hem nu te eten moet geven, omdat hij haar twee jaar heeft onderhouden. Als hij aanbelt, doet Heleen niet open. Met een meegenomen beitel, hamer en schroevedraaier weet hij binnen te komen. Heleen zegt dat hij weg moet gaan, maar dat weigert hij. Intussen heeft Helcen de politie gebeld. Deze arriveert en als Ronald nog steeds weigert te vertrekken nemen ze hem mee naar het politiebureau.

Ronald heeft in dezelfde periode vernielingen aangericht bij de Sociale Dienst en op een andere plaats een poging tot brandstichting gedaan. Daamaast heeft hij een willekeurig kind van vijf jaar en de moeder mishandeld en heeft hij de Wegenverkeerswet overtreden wegens rijden onder invloed (art. $26 \mathrm{WVW}$ ).

De officier van justitie maakt de zaak aanhangig bij de politierechter tezamen met de zaak van vernieling en brandstichting, valsheid in geschrifte en tweemaal overtreding art. $26 \mathrm{WVW}$. De mishandeling van moeder en kind wordt ter informatie gevoegd. 
De rechter schorst de zitting en er wordt een psychiatrisch rapport aangevraagd. Hieruit blijkt dat hij eenzaam is en enigszins paranoide. Hij is op eigen verzoek ook enige maanden opgenomen geweest in een inrichting. De conclusie van de psychiater luidt: "in de periode van de misdrijven was Ronald sterk verminderd toerekeningsvatbaar." Het advies luidt: 'sepot of sepot onder voorwaarden'. Na een jaar komt de zaak weer voor de politierechter. Deze veroordeelt Ronald tot drie maanden voorwaardelijk, met als bijzondere voorwaarde 100 uur dienstverlening en een vergoeding aan het slachtoffer van $f$ 100,- plus de kosten die de vrouw heeft moeten maken. Ook zijn de schroevedraaier, hamer en houtbeitel, evenals een Simca verbeurd verklaard (dossier 036).

De casus van Dick en Lianne is illustratief voor een verschil tussen de ervaring van de vrouw en de juridisch relevante werkelijkheid. Vanuit het standpunt van Lianne is Dick degene die haar privacy verstoort door niet te accepteren dat hij niet welkom is; hij belt net zo lang aan tot zij open doet. Omdat Lianne zelf de deur open doet, is er in juridische zin geen sprake van huisvredebreuk. Wanneer Dick de deur zou hebben geforceerd, zoals in de casus van Heleen en Ronald, was er wel sprake geweest van huisvredebreuk. Maatschappelijk gezien, is in beide gevallen sprake van een ongewenste binnenkomst van de man, maar alleen in het laatste voorbeeld is sprake van een strafbaar feit. Omdat Dick bovendien de televisie vernielt, kan toch strafrechtelijk worden opgetreden. De vernieling moet worden gezien tegen de achtergrond van het dominerende gedrag van Dick; hij komt ongewenst binnen, houdt geen rekening met de levenswijze van Lianne en, uit boosheid (en jaloezie) vernielt hij de televisie van Lianne. Deze vemieling kan worden beschouwd als een vorm van agressie om Lianne te benadelen. ${ }^{35}$ Dit privacyverstorende gedrag kan voortkomen uit dronkenschap, Dick is alcoholist, of omdat de man psychisch in de war is, Ronald is verminderd toerekeningsvatbaar. Ook kunnen meningsverschillen over de opvoeding van de kinderen of de omgangsregeling aanleiding zijn voor geweldpleging door de man, evenals meningsverschillen over de boedelscheiding. Agressief gedrag van de man komt bovendien regelmatig voort uit jaloersheid van de man vanwege een (vermeende) nieuwe vriend, zoals bij Dick in het eerste voorbeeld.

De casus van Dick en Lianne is illustratief voor veel zaken van vrouwenmishandeling die als vernieling worden gekwalificeerd. De ernst van het geweld lijkt, juridisch gezien, erg mee te vallen: een kapotte televisie, een vernielde deurpost of een gebroken ruit. Maar gezien vanuit het perspectief van de vrouw gaat het niet alleen om de vernieling van de televisie, maar om verstoring van de huisvrede, om een inbreuk op haar persoonlijke levenssfeer. ${ }^{36}$ Deze vernielingen kunnen uiterst

35 Als Dick de vriend had mishandeld dan was dit geval buiten het onderzoek gehouden, omdat het feitencomplex dan niet meer was toegesneden op Lianne; de mishandeling van de vriend is dan onderwerp van beslissing en niet de vermieling van de televisie van Lianne.

36 Van de 44 vemielings/huisvredebreukzaken vond in 21 zaken de kwalificatie huisvredebreuk plasts (48\%), meestal samen met vernieling. 
bedreigend zijn voor de vrouw. ${ }^{37}$ Bovendien gaat het in dit soort gevallen niet om een op zichzelf staand incident, maar is al vaker sprake geweest van agressief gedrag. Mahoney noemt dit geweld door de ex-partner 'separation assault' om aan te geven dat dit een aparte problematiek betreft. ${ }^{38}$

De dossiers van de vernielings- en huisvredebreukzaken bevatten overigens met name informatie die relevant is voor het bewijs van de vernieling en/of huisvredebreuk; zelden wordt informatie gegeven over de achtergrond van het 'incident'. Door de oppervlakkigheid van de dossiers is niet goed in te schatten hoe emstig en privacyverstorend het gedrag van de man is voor het slachtoffer. ${ }^{39}$ Met andere woorden, uit de dossiers komt vaak niet naar voren of vrouwen regelmatig met emstig geweld zijn geconfronteerd voor zij de politie inschakelen. ${ }^{40}$

\section{Mishandeling en bedreiging}

De categorie mishandeling en bedreiging omvat verreweg de meeste vrouwenmishandelingszaken, namelijk 83 van de 150 zaken (55\%). Bedreiging komt regelmatig voor (in $20 \%$ van deze gevallen), al of niet tezamen met mishandeling. In deze categorie komt een gevarieerder beeld naar voren dan in de categorie vernieling/huisvredebreuk, zowel qua relatie, als qua letsel, duur en frequentie van de mishandelingen door de partner of ex-partner. De relatievormen variëren van een huwelijk tot een verbroken verkering. De verbroken relaties zijn in de meerderheid $(n=50){ }^{41}$ De dossiers bevatten vaak meer achtergrondinformatie dan de dossiers uit de categorie vernieling/huisvredebreuk. De volgende voorbeelden geven deze diversiteit in zaken aan.

Bram is 21 jaar als hij gaat samenwonen met Lieke, 20 jaar oud. Na een aantal jaren worden de ruzies frequenter en heviger en Bram begint Lieke te mishandelen. Dit geweld is voor Lieke de reden om bij Bram weg te gaan. Na vijf jaar samenwonen gaat Lieke weer bij haar ouders wonen. Bram kan dit niet verkroppen en komt woedend langs met de bedoeling om koste wat kost binnen te komen. Lieke voelt zich zo bedreigd dat ze de politie belt. Een paar dagen later staat Bram plotseling in de keuken van I.iekes grootvader, waar ze op bezoek is. Bram roept: "en nu ga je met me mee", pakt haar hardhandig vast en sleurt haar over de grond mee naar buiten. De buurman ziet dit en

37 Romkens, Gewoon geweld?, 1992: 128.

38 Mahoney, Women's lives, violence and agency, in: The public nature of private violence, 1994: 60.

39 Wostmann, Politieoptreden bij vrouwenmishandeling, 1988:72-90. Zoomer, Vrouwenmishandeling; politie werk, 1990: 74-87.

40 Uit de dossierstudie komt naar voren dat de helft van de gevallen als incidenteel staat geboekt $(n=22)$. Structureel geweld of meermalig geweld worden elk elf maal genoteerd.

41 De bestaande relaties bestaan uit een huwelijk ( $n=13)$, samenwonend $(n=10)$ of anderszins een relatie $(n=10)$. De verbroken relaties bestaan uit ex-echtgenoten $(n=27)$, ex-samenwonenden $(n=13)$ of anderszins verbroken relaties $(n=10)$. 
zegt dat Bram hiermee moet ophouden. Bram laat vervolgens Lieke los en vertrekt. Lieke heeft pijn en blauwe en rode plekken op haar arm. Zij doet aangifte van mishandeling.

Er wordt door de officier van justitie tot een beleidssepot besloten, en als grond wordt 'gering feit' genoteerd ${ }^{42}$ (dossier 027).

Jaap, 26 jaar oud, is getrouwd en heeft een relatie met Dieneke. Zij is buffetjuffrouw en 21 jaar oud. Op een avond als ze om 4.00 uur thuiskomen van een discobezoek, krijgen ze ruzie. Volgens Dieneke slaat hij haar in het gezicht en trekt een overjas om haar keel zodat zij geen adem kan halen. Dieneke loopt letsel op: een bloeduitstorting in haar gezicht, kneuzingen op het hoofd en striemen en krassen in de nek. Jaap erkent het slaan, en motiveert dit. Hij wil na de onenigheid vertrekken, maar Dieneke wil hem zijn kleren niet geven en hangt om hem heen om te voorkomen dat hij weggaat. Daarom is hij gaan slaan.

Jaap wordt gedagvaard wegens mishandeling. Op de terechtzitting blijkt dat Jaapen Dieneke inmiddels samenwonen en een kind hebben. Jaap wil gaan scheiden van zijn vrouw om met Dieneke te kunnen trouwen.

De officier van justitie eist $f 200$,- boete en vijf weken voorwaardelijk met een proeftijd van twee jaar. De politierechter legt een week voorwaardelijke gevangenisstraf op met een proeftijd van twee jaar (dossier 121).

Maviye en Glenn leren elkaar in Suriname kennen en trouwen. Ze krijgen vier kinderen. Na vijftien jaar huwelijk vertrekt het gezin naar Nederland. Glenn werkt als administratief medewerker bij het openbaar vervoer. Maviye werkt in de gezinshulp en zorgt voor de kinderen, die inmiddels 19, 18, 17 en 9 jaar oud zijn. Glenn oefent regelmatig geweld uit op Maviye. Zoals ze in het proces-verbaal zegt: "Tijdens mijn gehele huwelijk ben ik mishandeld door mijn echtgenoot. Als ik hierdoor letsel bekwam en anderen zagen dit dan loog ik tegen hen. Ik verzon altijd smoesjes en deed alsof het huwelijk goed was. lk deed dit uit angst. (...) Hij heeft me meerdere keren tijdens ruzies gezegd dat hij me zou vermoorden."

Op een avond ontsteekt Glenn in woede omdat er een vetvlek zit op de briefkaart voor de 1,2,3-show. Hij pakt een barknk, slaat en gooit ermee naar Maviye en vemielt het intericur. Ook dreigt hij haar te vermoorden. Maviye voelt zich enorm bedreigd en verlaat samen met haar jongste zoon het huis. $\mathrm{Zij}$ gaat naar de politic en doet aangifte. De politie brengt Maviye met twee van haar kinderen naar een opvanghuis, omdat ze haar relatie met Glenn wil verbreken. Ook gaan twee politieagenten naar het huis van Glenn en Maviye. Glenn is de scherven aan het opruimen. De politieagenten nemen Glenn mee voor verhoor. Glenn ontkent het geweld tegen Maviye, er was sprake van onenigheid. Maviye gaat langs de politiearts die licht letsel constateert: "de vrouw geeft pijn aan, ook bij druk op meerdere plaatsen, op het hoofd en onder de rechterknie en van de rechter-

42 De parketsecretaris schrijft aan de officier van justitie: "kun je dit mishandeling noemen?" Hierop schrijft de officier van justitic terug: "Mijns inziens is strikt genomen het wettig bewijs er wel. Aangeefster en buurman verklaren over vastpakken en over de grond meesleuren terwijl aangeefster bovendien zegt dat dat pijn deed. Ik zou zeggen sepot gering feit," 
pols, zonder waarneembaar letsel. Kleine bloeduitstorting onder rechter kaak. De genezing zal enkele dagen duren."

Maviye blijft drie dagen in het opvanghuis. Daama gaat ze weer terug naar Glenn. Ruim een half jaar na de aangifte schrijft Maviye een brief aan de officier van justitie. Ze schrijft dat ze geen strafvervolging wil. Ook schrijft ze dat zij en haar man nooit derden betrekken bij hun meningsverschillen, maar de dag dat ze aangifte deed van mishandeling was ze bang voor haar man. Ze was niet bang voor haar huwelijk. Ze ontkent nu dat Glenn heeft gezegd dat hij haar zou vermoorden. Tot slot verklaart ze dat er nu een goede verstandhouding is en een prettig gezinsleven. Ze verzoekt om cen sepot.

De officier van justitie heeft ondertussen een reclasseringsrapport aangevraagd en ontvangen. De reclassering schrijft dat de moeilijkheden tussen Glenn en Maviye zijn begonnen toen het gezin in Nederland is gaan wonen. In Nederland leeft men veel minder buiten dan in Suriname. Hierdoor heeft Glenn minder contacten. Maviye, en ook de kinderen, krijgen steeds meer een eigen mening waar ze aan vasthouden. Glenn kan hier steeds minder tegenop, voelt zich steeds eenzamer binnen het gezin en krijgt allerlei kwalen als suikerziekte en last van zijn knieen. Hij voelt zich regelmatig vernederd en gekleineerd. Hierdoor werd de woedeuitbarsting, waarvan aangifte is gedaan, teweeggebracht. De reclassering concludeert: "De echtelieden willen het weer samen proberen, maar dan op gelijkwaardige voet. Hierbij past geen reclasseringscontact. We adviseren om niet tot een strafrechtelijke reactie over te gaan, mede op grond van het intrekken van de aanklacht door Maviye. Als toch tot een justitiele reactie mocht worden besloten, dan verdient een sepot onder voorwaarden de voorkeur." Glenn heeft geen strafblad. Hij is inmiddels 40 jaar en Maviye 37.

De officier van justitie besluit te seponeren op grond van 'gewijzigde omstandigheden' en 'beperkte kring'. Tevens schrijft de officier van justitie een brief aan Maviye; "naar aanleiding van uw brief en het rapport van de reclassering zal ik de zaak tegen uw man niet vervolgen omdat er weer een goed contact is tussen u en uw echtgenoot. Mocht een dergelijk feit zich weer voordoen, aarzel dan niet de politie in te schakelen." (dossier 133)

Het voorbeeld van Maviye en Glenn kan als het klassieke geval van vrouwenmishandeling worden aangeduid: een jarenlang huwelijk, kinderen, en regelmatig ernstig geweld tegen de vrouw. De vrouw loopt weg naar een opvanghuis maar keert weer terug naar haar man. ${ }^{43}$ De casus van Lieke en Bram zou ook goed onder de problematiek van de categorie vernieling/huisvredebreuk passen; het gedrag van Bram is met name een verstoring van de privacy van Lieke. Het voorbeeld laat bovendien zien dat geweldpleging ook in relaties tussen jonge mensen voorkomt. ${ }^{44}$ In het geval van Jaap en Dieneke gaat het om een emstig incident.

43 Vier zaken betreffen een vrouw die in een opvanghuis heeft gezeten.

44 Het onderzoek van Rðmkens geeft aan dat een relatief groot deel (45\%) van de vrouwen die eenzijdig geweld heeft meegemaakt voor hun 25 ste jaar, is geslagen door hun partner. Ook in 'verkeringsrelaties' komt geweld regelmatig voor. Romkens, Gewoon geweld?, 1992: 113, 116, 124. Zie over deze problematiek: Mastenbroek, De illusie van veiligheid, 1995. 
Twee aspecten treden op de voorgrond bij het lezen van de mishandelingsdossiers: de waardering van het voortduren of verbreken van de relatie en de ernst van het geweld. De casus van Maviye en Glenn laat zien dat het voortduren van de relatie een belangrijke reden is om de zaak te seponeren. Ook het voorbeeld van Jaap en Lieneke laat zien dat het voortduren van de relatie een belangrijk aspect is dat als persoonlijke omstandigheid van de verdachte wordt meegewogen door de rechter. ${ }^{45}$ Daarentegen lijkt het gewelddadige verleden van Bram nauwelijks te worden meegewogen in de beslissing van de officier van justitie, terwijl het gewelddadige gedrag van Glenn minder gewicht lijkt te hebben dan het voortduren van de relatie. Ik kom in $\S 5.5$ terug op deze problematiek.

De emst van het letsel varieert, zoals ook de voorbeelden aangeven, van geen letsel ${ }^{46}$ of een paar blauwe plekken tot van onder tot boven onder de bloeduitstortingen, van kneuzingen tot gebroken tanden of ledematen en bloedende wonden. ${ }^{47}$ Echt zware mishandeling in de zin van de wet (blijvend letsel, of letsel en/of ziekte die langer dan zes weken duurt) komt maar zelden voor $(n=5)$. Maar de ernst van het geweld wordt niet alleen bepaald door het letsel, ook de kans op letsel of levensbedreiging is van invloed. Het gebruik van een voorwerp kan zeer bedreigend zijn, zoals het slaan met een glas of stoel en het dreigen met een mes of pistool $(n=22) .^{48}$ De ernst van het letsel en de kans op letsel of levensbedreiging, zijn van belang voor de kwalificatie van het geweld als eenvoudige mishandeling, zware mishandeling of poging tot doodslag.

De juridische kwalificatie 'eenvoudige mishandeling' op grond van het opgelopen letsel en de kans op letsel, lijkt niet altijd overeen te komen met de ernst van het geweld gezien tegen de achtergrond van de relatie. Het verbale geweld kan bijvoorbeeld zeer bedreigende vormen aannemen, ${ }^{49}$ maar lijkt geen belangrijke rol te spelen in het emstoordeel. Ook lijkt er een verschil in ernstoordeel te zijn over de wurgpoging. De wurgpoging is een zeer veelvoorkomende vorm van geweld; deze vorm komt in bijna een vijfde van de mishandelingszaken voor $(n=15)$. Vrouwen kunnen dit als zeer angstaanjagend en levensbedreigend ervaren. ${ }^{50}$ Toch zal een wurgpoging in de ogen van een officier van justitie niet snel een poging tot doodslag

45 Slotboom komt tot dezelfde conclusie naar aanleiding van een verkennend onderzoek naar de wijze waarop rechters beslissen in zaken van vrouwenmishandeling. Slotboom, De gevonden 'waarheid', 1992: 90-91.

$46 \mathrm{Fr}$ is geen letsel als er sprake is van bedreiging en als de mishandeling alleen pijn tot gevolg heeft $(n=13)$.

47 In de helft van de mishandelingsgevallen heeft de vrouw emstig letsel opgelopen, dat wil zeggen kneuzingen en wonden $(n=40)$, en in minder dan een derde van de gevallen licht letsel, dat wil zeggen een (paar) blauwe plek(ken) $(n=25)$.

48 Deze vormen van mishandeling kunnen soms als poging tot doodslag worden gekwalificeerd.

49 Romkens, Gewoon geweld?, 1992: 119.

50 Uit het onderzoek van Romkens komt naar voren dat een op de acht vrouwen bij het meest ingrijpende voorval te maken kreeg met levensbedreigend geweld omdat de man haar keel dichtkneep. Romkens, Gewoon geweld?, 1992: 118. 
of moord opleveren. Een wurgpoging, zoals ook in het geval van Jaap en Dieneke, die niet heeft geresulteerd in een bewusteloze toestand bij het slachtoffer, een gekneusd strottehoofd of duidelijke handafdrukken in de hals, wordt als mishandeling gekwalificeerd (zie ook onder moord en doodslag).

Tot slot wordt de ernst van het geweld bepaald door de frequentie waarmee het geweld plaatsvindt; herhaald geweld tegen de vrouw kan (ernstige) depressieve en psychosomatische klachten bij de vrouw veroorzaken. Hoewel de dossiers in de categorie mishandeling meer achtergrondinformatie bevatten dan in de categorie vernieling/huisvredebreuk, wordt in de processen-verbaal lang niet altijd op de geschiedenis en achtergronden van het geweld tegen de vrouw ingegaan. Ook hier zijn de dossiers toegesneden op de bewijsbaarheid van het incident en niet zozeer op de ernst van het geweld geplaatst tegen de achtergrond van eventueel herhaald geweld binnen de relatie. ${ }^{51}$

\section{Moord en doodslag}

De categorie moord en doodslag omvat 11 zaken, dat is $7 \%$ van de onderzochte zaken in het kwalitatieve deel. Het betreft in de meerderheid verbroken relaties $(64 \%){ }^{52}$ Pogingen tot moord en doodslag, en geweld met de dood tot gevolg hebbende, zijn de uiterste vormen van geweld. Er bestaat een glijdende schaal van bedreiging naar mishandeling naar poging tot doodslag/moord naar daadwerkelijke doodslag/moord. De meest ernstige vormen van geweld in de categorie mishandeling kunnen tevens de eerste pogingen tot doodslag of moord opleveren. ${ }^{53}$ De volgende twee voorbeelden illustreren dit.

Evert trouwt op 23-jarige leeftijd met Mieke, 22 jaar oud. Ze krijgen al snel twee dochters en na tien jaar nog een zoon. Na veertien jaar huwelijk vraagt Mieke echtscheiding aan omdat ze jarenlang lichamelijk en geestelijk is mishandeld. De kinderen zijn in mindere mate mishandeld. Bij voorlopige voorziening wordt het huis aan Mieke en de kinderen toegewezen. Er wordt geen bezoekregeling afgespoken. Evert blijft Mieke en de kinderen bezoeken, ook al is hem door de rechter verboden in het huis te komen. Elk bezoek gaat gepaard met ruzie, bedreigingen en lichamelijk geweld. Mieke is bang dat Evert zijn bedreigingen haar te vermoorden uitvoert, zeker nadat hij haar een keer bij de keel heeft gegrepen. Op een avond als Mieke thuiskomt, vindt ze Evert in de huiskamer. Hij is binnengekomen met een gestolen huissleutel. Als Mieke de trap opvlucht, trekt hij haar van de trap, waarbij haar kleren scheuren. In de huiskamer slaat hij haar en doct weer een poging haar te wurgen. Ondertussen is een dochter wakker geworden. $\mathrm{Zij}$ roept haar

51 Op grond van de dossiers is er in 31 zaken sprake van een incident, in 28 zaken van structureel geweld en in 24 zaken van meermalen gepleegd geweld binnen drie maanden.

$52 \mathrm{Er}$ is sprake van twee samenwonenden, een relatie, een scheiding van tafel en bed, vijf verbroken huwelijken en twee verbroken relaties.

53 Zie hoofdstuk $3, \S 3.2$. 
grootouders, die te logeren zijn en zij zien kans de buren te waarschuwen. Bij de buren wordt de politie gebeld. In het huis van Mieke had Evert namelijk de telefoon kapot getrokken. De politie arriveert en constateert dat "er vermoedelijk een vechtpartij is geweest, want de bank is verschoven, een bloempot is stuk en de telefoonaansluiting is kapotgetrokken. Ook is de kleding van de vrouw gescheurd, haar linkerhand is geschaafd en er zijn rode striemen in haar nek te zien."

Mieke doet aangifte van mishandeling en poging tot doodslag. Ze voelt zich enorm bedreigd en is bang dat Evert haar wil vermoorden.

De politie neemt Evert mee voor een verhoor en belt met de officier van justitie. Vervolgens wordt Evert een dag in verzekering gesteld. Wanneer de officier van justitie deze zaak ziet, wordt eerst met de reclassering gebeld. Uiteindelijk besluit de officier van justitie tot een sepot, omdat Evert contact heeft met de reclassering en het maatschappelijk werk. De reclassering vindt straf als genoegdoening niet zinvol en acht een waarschuwing voldoende. ${ }^{44}$ De zaak wordt afgeboekt onder sepot wegens reclasseringsbelang en gewijzigde omstandigheden (dossier 051).

Boy, lasser, 40 jaar oud, heeft een LAT-relatie met Carol, 42 jaar oud. Na drie en een half jaar maakt Carol een einde aan de relatie in verband met de gokverslaafdheid van Boy. Na enige tijd heeft Carol een nieuwe vriend. Op een dag hoort ze van een kennis dat Boy van plan is haar en daarna zichzelf te vermoorden. Ze neemt dit niet serieus omdat hij haar nooit lastig valt, ook niet telefonisch. Een aantal dagen later hoort ze een vreemd geluid in de gang als ze met haar vriend in bed ligt. Het kan een van haar zonen zijn, maar ze vertrouwt het niet en stapt uit bed. Als ze de deur opendoet ziet ze dat Boy een mes bij de keel van haar zoon houdt. Als Boy haar ziet, komt hij op haar toe en maakt onderhandse steekbewegingen, waarop Carol achteruit springt. De zoon pakt vervolgens Boy van achteren beet, waarop een worsteling ontstaat, en de vriend van Carol pakt het mes af. Boy roept iets in de trant van "de volgende keer doe ik het beter, namelijk met een pistool."

Ondertussen is de politie gebeld. Boy vlucht niet. Als de politie is gearriveerd, nemen ze hem mee en wordt hij in verzekering gesteld. Carol voelt zich vreselijk bedreigd en doet aangifte. De officier van justitie vraagt een reclasseringsrapport aan. Er wordt besloten tot een sepot onder voorwaarden op grond van gewijzigde omstandigheden met een proeftijd van een jaar (dossier 055).

Het gaat in deze categorie om zeer bedreigende situaties voor het slachtoffer. De casus van Mieke en Evert laat zien dat het geweld niet altijd ophoudt als de vrouw weggaat bij de man en echtscheiding aanvraagt. De meerderheid van zaken betrof zo'n soort situatie. Juist in een periode waar de vrouw duidelijk een grens trekt en voor zichzelf kiest, kan het geweld zeer emstige vormen aannemen. ${ }^{55}$ Soms vindt het geweld alleen plaats tijdens de (echt)scheidingsperiode, zoals de casus van Roy

54 Uit een briefje in het dossier blijkt dat iemand (de parketsecretaris vermoed ik, KL) met de reclassering heeft gebeld en zodoende deze informatie heeft achterhaald.

55 Van de groep gescheiden vrouwen die eenzijdig geweld hebben meegemaakt, heeft $17 \%$ ook na de scheiding geweld door de man ondervonden. Romkens, Gewoon geweld?, 1992: 156. 
en Carol laat zien. In de periode dat de scheiding nog vers is, kunnen de woede en verdriet "om hetgeen de man in veel gevallen ervaart als een onterecht verlaten worden, tot ongekend ernstige uitbarstingen leiden". ${ }^{36}$ Een nieuwe vriend kan zulke sterke gevoelens van jaloezie, verlatenheid en woede opwekken dat het zelfs kan leiden tot de dood van het slachtoffer. ${ }^{57}$ Binnen dezelfde categorie komen ook twee andere samenwoningsrelaties voor waar herhaald geweld tegen de vrouw plaatsvindt en waar de vrouw de man verlaat en vervolgens weer terugkomt. Toch kan niet gesproken worden van 'klassieke gevallen van vrouwenmishandeling', omdat het 'gewone' geweld samengaat met alcoholgebruik van beide partners en de ouderlijke macht aan hen is onttrokken. Er lijkt eerder sprake te zijn van een symbiotische en destructieve relatie. ${ }^{58}$ Beide mannen zijn verminderd toerekeningsvatbaar verklaard. ${ }^{59} \mathrm{De}$ andere gevallen van vrouwenmishandeling betreffen allemaal 'gewoon' geweld tegen de vrouw; de meeste mannen die geweld plegen tegen hun (ex-)vrouw of (ex-)vriendin zijn normale, gezonde mannen $(n=8) .^{60}$

Het gaat in bijna alle zaken om een poging tot doodslag ( 9 van de 11 zaken). Het letsel is over het algemeen emstig of zwaar $(n=6)$, of er is sprake van levensbedreigend geweld, zoals het steken met een mes $(n=4){ }^{61}$ Binnen relaties kan de duur van de geweldpleging de ernst van het geweld versterken; vrouwen worden soms urenlang geschopt en geslagen. ${ }^{62}$ Bovendien komt in deze categorie nog duidelijker dan in de categorie mishandeling naar voren dat de wurgpoging een veel voorkomende en ernstige vorm van geweldpleging tegen vrouwen is $(n=7)$. Het feit dat beide dode slachtoffers door wurging om het leven zijn gebracht, toont aan hoe levensbedreigend een wurgpoging kan zijn.

Ondanks de ernst van het geweld en een eerste kwalificatie door de politie als poging tot doodslag, kunnen deze ernstige vormen van geweldpleging ook worden gekwalificeerd als ernstige vormen van mishandeling of bedreiging. De verdachten van een poging tot doodslag die zijn gedagvaard, zijn uiteindelijk geen van allen veroordeeld voor een poging tot doodslag op de vrouw, omdat het opzet haar te doden door de rechtbank niet bewezen werd geacht. ${ }^{63}$ Het opzettelijk mishandelen

56 Ibidem: 156.

57 Dossier 001.

58 De Boer, Parmerdoding, 1990: 18.

59 Een van de mannen heeft de vrouw door wurging om het leven gebracht en is veroordeeld voor het op uitdrukkelijk verzoek van het leven beroven van zijn vriendin (art. $293 \mathrm{Sr}$, euthenasie).

60 Alleen de man, die tijdens de echtscheidingsperiode zijn echtgenoot door wurging om het leven brengt in een vlaag van woede en verdriet, word, ten tijde van het incident, geheel ontoerekeningsvatbaar verklaard.

61 In twee gevallen heeft de vrouw in het ziekenhuis gelegen.

62 Zie dossier 101. Romkens, Gewoon geweld?, 1992: 117.

63 In de gevallen dat de man werd veroordeeld voor mishandeling was het letsel minder emstig (genezing te verwachten binnen 14 dagen) dan in de gevallen van zware mishandeling (o.a. steekwonden; genezingsduur nog niet te beoordelen en o.a. lichte hersenschudding en vrouw zwaar in de war; blijvende beperkingen van geestelijke functies wel in de verwachting). In het geval van de bedreiging had de man zich vermomd met een ijsmuts en dreigde met een mes. 
werd wel bewezen geacht. Dat het om ernstige zaken gaat, blijkt uit het feit dat alle zaken aan de meervoudige kamer zijn voorgelegd. Bovendien zijn alle verdachten in verzekering gesteld en is de man vervolgens in negen gevallen in voorlopige hechtenis genomen.

\section{Verkrachting en aanranding}

Het gaat in deze categorie om twaalf zaken, $8 \%$ van de 150 onderzochte zaken. Ten tijde van het dossieronderzoek was verkrachting binnen het huwelijk niet strafbaar. ${ }^{64}$ Verkrachting binnen niet-huwelijkse relaties was wel strafbaar, evenals aanranding binnen (niet-)huwelijkse relaties. ${ }^{65}$ Toch betreffen alle door mij gevonden verkrachtings- en aanrandingszaken een ex-relatie. ${ }^{66}$ Het ene voorbeeld laat zien dat een verkrachting soms een vorm van geweld is die past binnen het patroon van agressief en bedreigend gedrag van de man tegenover zijn ex-vriendin of exvrouw, terwijl het andere voorbeeld laat zien dat mannen ook na het verbreken van de relatie een recht op geslachtsgemeenschap met de vrouw menen te hebben.

Martin, 40 jaar oud, is gescheiden en heeft drie kinderen. Zijn ex-vrouw is toentertijd naar een Blijf van m'n Lijfhuis gevlucht. De kinderen willen hem niet meer zien.

Hij ontmoet Anneke, 21 jaar. Na een jaar een relatie te hebben, gaan ze samenwonen, omdat Anneke zwanger is. Hun dochter wordt geboren. Het drankgebruik van Martin wordt frequenter en daarmee zijn agressieve gedrag. Als hij dronken is, slaat hij haar bont en blauw. Ook tijdens de zwangerschap was hij agressief; hij schopte met klompen tegen haar buik. Na een jaar gaan ze uit elkaar. Met behulp van de Raad voor de Kinderbescherming wordt een bezoekregeling opgesteld. Anneke is voogd en Martin toeziend voogd.

Het drankgebruik van Martin wordt niet minder. Hij belt Anneke regelmatig dronken op. Martin mag zijn dochter alleen 's ochtends bezoeken omdat hij anders dronken is.

Op een nacht wordt er bij Anneke aan de deur gebeld door Martin. Uiteindelijk laat ze hem binnen; hij mag in de logeerkamer slapen. Hij vraagt om koffie en die zet ze voor hem. Hij is dronken en uit ervaring weet ze dat hij dan heel agressief kan zijn. Na de koffie brengt ze hem naar de logeerkamer en loopt door naar haar eigen kamer. Martin komt achter haar aan, roept dat hij met haar wil neuken en gooit haar op bed. Anneke verzet zich maar delft het onderspit en Martin verkracht haar. Als Martin is klaargekomen, glijdt hij van haar af, kleedt zich aan en belt de politie om zich aan te geven. De politie arriveert en Martin zegt volgens het proces-verbaal: "Ik heb zojuist een vrouw verkracht.

64 Verkrachting binnen het huwelijk is sinds I december 1991 strafbaar. Stb. 1991, nr. 519.

65 Van de vrouwen die slachtoffer zijn van eenzijdig lichamelijk geweld van hun partner wordt $23 \%$ gedwongen tot seks en $26 \%$ heeft seks met haar partner zonder instemming (Romkens, Geweld tegen vrouwen in heteroseksuele relaties, 1989: 132-144 en tabel 6.17). Wostmann concludeert dat in veel gevallen fysiek geweld tegen de vrouw gepaard gaat met seksueel geweld maar dat dit nooit in de dag- en nachtrapporten wordt gemeld, noch doen de geïnterviewde surveillanten melding van verkrachting of aanranding. Wöstmann, Politieoptreden bij vrouwenmishandeling, 1988: 51, 91.

66 Het betreft 5 ex-samenwonenden, 2 ex-gehuwden en 5 ex-relaties. 
Neem mij maar mee, breng me maar naar X (een psychiatrische inrichting) en laat me nooit meer los."

Anneke doet aangifte van verkrachting. Martin wordt in voorlopige hechtenis genomen en er wordt een gerechtelijk vooronderzoek door de officier van justitie gevorderd bij de rechter-commissaris om een psychiatrisch rapport aan te vragen. De psychiater concludeert dat Martin enigszins verminderd toerekeningsvatbaar is en adviseert een gevangenisstraf, waarvan een ruim deel voorwaardelijk met een lange proeftijd. De voorwaarde moet zijn hulpverlening. De officier van justitie besluit de zaak te vervolgen, tezamen met een mishandelingszaak (caféruzie) en bij de meervoudige kamer aan te brengen. De officier van justitie eist achttien maanden onvoorwaardelijke gevangenisstraf met aftrek. De rechtbank neemt de conclusie van het psychiatrische rapport over en veroordeelt Martin tot een jaar gevangenisstraf, waarvan drie maanden voorwaardelijk met bijzondere voorwaarde van CAD-begeleiding ${ }^{67}$ en een proeftijd van twee jaar (dossier 032).

Klaas gaat op 23-jarige leeftijd samenwonen met Lisa, 15 jaar oud. Binnen een jaar is hun zoontje geboren en is Klaas vertrokken. Lisa kan dit vertrek van Klaas nauwelijks aan. Ze staat, evenals haar zoontje, onder voogdij in verband met haar leeftijd. Ze probeert haar eigen leven op te pakken. Dit valt niet in goede aarde bij Klaas, die gewend is te kunnen komen en vertrekken als het hem uitkomt. Want ook nadat hij is weggegaan, komt hij regelmatig langs en blijft slapen. Dit gaat met ruzies gepaard. Klaas dreigt af en toe dat hij het zoontje zal weghalen. Ook komt hij door inklimming haar huis in als ze er niet is. Op een avond staat hij voor haar woning en wil naar binnen. Zij laat hem binnen omdat hij er rustig uitziet. Eenmaal binnen begint hij weer te dreigen dat hij ervoor zal zorgen dat hun zoontje in een pleeggezin terechtkomt. Vervolgens slaat hij haar, sleurt haar mee naar de slaapkamer, gooit haar op bed, trekt haar slipje uit en verkracht haar. Lisa verzet zich door aan zijn haren te trekken maar Klaas is fysiek sterker. Nadat Klaas is klaargekomen, verlaat hij het huis.

Lisa gaat de volgende ochtend naar de huisarts, die haar kalmeringstabletten geeft. Ze gaat ook naar de politie en doet aangifte. In het tweede verhoor van Klaas erkent hij de verkrachting. Volgens het proces-verbaal zegt hij: "Ik kon op dat moment niet verwerken dat Lisa buiten mijn medeweten dingen onderneemt, zoals weggaan met de kleine en vrienden thuis ontvangen. Ikzelf zag Lisa als iemand, waar ik tussendoor altijd terecht kon om te slapen en om vleselijke gemeenschap te hebben. Nu ze zonder mij in te lichten weggegaan was, was ik kwaad geworden."

De officier van justitie besluit Klaas niet vast te houden omdat Lisa en Klaas beiden zeggen dat ze de relatie willen voortzetten. Wel wordt de reclassering ingeschakeld die na een half jaar moet melden hoe de relatie zich heeft ontwikkeld. Binnen die periode is Klaas weer weggegaan bij Lisa, die daarop een zelfmoordpoging doet. De zaak wordt vervolgens voor de politierechter gebracht, geschorst wegens niet verschijnen van de verdachte en een paar maanden daarna doorverwezen naar de meervoudige kamer wegens ingewikkeldheid van de zaak. Er vindt een verhoor plaats door de rechter-commissaris waar Lisa verklaart dat de door haar gedane aangifte van verkrachting vals is. Vervolgens 
vindt een nader onderzoek plaats en Lisa verklaart dan dat ze tot de verklaring dat de aangifte vals was is gekomen onder druk van Klaas die beloofde met haar te trouwen. Een andere reden voor de verklaring van de valse aangifte is het feit dat ze er niet meer tegen kon telkens weer de zaak te moeten oprakelen.

Uiteindelijk besluit de officier van justite de zaak te laten rusten; er wordt besloten de zaak niet verder te vervolgen omdat Lisa wisselende verklaringen heeft afgelegd en om de onderlinge band die er tussen Klaas en Lisa bestaat. De zaak wordt afgeboekt als technisch sepot (dossier 080).

De casus van Anneke en Martin heeft veel overeenkomsten met de casus van Mieke en Evert onder 'moord en doodslag'; geweldplegingen tijdens de relatie die niet stoppen als de vrouw de relatie verbreekt. Verkrachting is een van de manieren waarop de man uiting geeft aan zijn gevoel dat de vrouw geen eigen leven mag leiden. ${ }^{68}$ Ook Martin kan Anneke niet met rust laten, valt haar regelmatig lastig en verkracht haar. In de meerderheid van de verkrachtingszaken staat de verkrachting niet op zichzelf, maar past binnen een patroon van de vrouw lastigvallen en bedreigen. Het voorbeeld van Klaas en Lisa laat nog duidelijker zien hoe de man zijn vriendin als bezit kan beschouwen. Bovendien laat de casus van Klaas en Lisa zien dat een verbroken relatie ambivalent kan zijn; de band is niet geheel verbroken en er zijn tijden van meer en minder intimiteit. ${ }^{69}$ Het zijn doorgaans maatschappelijk normaal functionerende mannen die hun ex-partner verkrachten, hoewel de man in vier gevallen verminderd toerekeningsvatbaar is verklaard, zoals Martin uit de eerste casus. ${ }^{70}$

Anneke en Lisa hebben allebei geen letsel opgelopen. De dwang bestaat in dit soort zaken doorgaans uit meesleuren, op bed gooien, kleren van het lijf rukken, bedreigingen uiten en fysiek overwicht gebruiken, zonder dat sprake is van letsel $(\mathrm{n}=8) .{ }^{71}$ Eenmaal zijn slaapmiddelen toegediend en is de vrouw verkracht tijdens de 'bewusteloosheid'. ${ }^{72}$ Alle vrouwen voelen zich enorm bedreigd. ${ }^{73}$ Wanneer de verdachte ontkent dat hij de vrouw heeft verkracht, maar wel erkent dat hij bij haar is geweest en dat er geslachtsgemeenschap heeft plaatsgevonden, is het bewijs

68 Van de groep gescheiden vrouwen die cenzijdig geweld hebben meegemaakt is $4 \%$ na haar scheiding nog verkracht door hasr ex-echtgenoot. Romkens, Gewoon geweld?, 1992: 156.

69 In een zaak woonden het slachtoffer en de man weer samen ten tijde van de terechtzitting (dossier 103).

70 De meeste daders van seksueel geweld die een bekende verkrachten, zijn 'gewone' mannen. Tegen Haar Wil Amsterdam, Seksueel geweld, iedere vrouw en ieder meisje kan ermee te maken krijgen, 1988. Davelaar-van Tongeren, Verkrachting, strafrechter wat moet je ermee, in: Strafrecht in perspectief, 1980: $99-131$.

71 Ook in de verkrachtingszaken waar geen sprake is geweest van een intieme verhouding bestaat de dwang regelmatig uit het op bed drukken van de vrouw en alleen gebruik maken van fysiek overwicht.

72 Dit was regelmatig voorgekomen tijdens de relatie en ook cenmaal na het verbreken van de relatie. Hiervan is aangifte gedaan (dossier 033).

73 Een vrouw is ongewenst zwanger geworden (dossier 082). 
van de dwang tot geslachtsgemeenschap vaak moeilijk te leveren, zeker als geen medisch rapport van letsel aanwezig is. ${ }^{74}$

Verkrachtingszaken worden als ernstige zaken beschouwd, waar veel tijd en energie in wordt gestoken, zoals uit de beschrijving van de zaak Klaas en Lisa blijkt. Verschillende instanties worden erbij betrokken. In de meeste gevallen wordt de man in verzekering gesteld $(n=8)$ en daarna in voorlopige hechtenis genomen $(n=5)$. De verdachte van verkrachting wordt in het algemeen voor de meervoudige kamer gedagvaard (5 van de 6 vervolgde zaken).

\section{Een gevarieerd beeld}

Dit overzicht naar delictscategorieën laat een gevarieerd beeld zien van gevallen van geweld tegen de vrouw binnen een intieme relatie of door de ex-partner. In geval van vernieling/huisvredebreuk kan gesproken worden van privacy-schendend gedrag door de ex-partner dat zeer bedreigend kan zijn voor de vrouw. De mishandelingszaken kunnen sterk in ernst verschillen. Het kan gaan om gedrag wat min of meer overeenkomt met het privacy-schendende gedrag onder vernieling/huisvredebreuk (separation assault), het kan gaan om een min of meer ernstig incident, of om herhaald (ernstig) geweld binnen een relatie, dat zich kan voortzetten als de vrouw de relatie heeft verbroken. De zaken in de categorie moord/doodslag betreffen met name pogingen tot doodslag en kunnen worden getypeerd als emstige varianten van de mishandelingszaken. Uit de verkrachtingszaken blijkt dat de verkrachting niet op zichzelf staat, maar past binnen een patroon waarin de man niet accepteert dat de vrouw een eigen leven leidt waar hij geen invloed meer op heeft.

\subsection{De vervolgingspraktijk}

De afhandeling door het openbaar ministerie van de 150 onderzochte zaken van vrouwenmishandeling staat hier centraal. Allereerst wordt ingegaan op de vervolgingspraktijk ten aanzien van de onderzochte groep: Hoe vaak wordt een zaak van vrouwenmishandeling geseponeerd, op welke gronden en hoe vaak wordt een zaak van vrouwenmishandeling voor de rechter gebracht? Vervolgens wordt een vergelijking gemaakt tussen de drie arrondissementsparketten. Daarna wordt de vervolgingspraktijk per delictscategorie beschreven en sta ik stil bij de vervolgingspraktijk naar soort relatie.

74 In 3 zaken leidde de ontkenning van de verdachte tot een technisch sepot. 
De vervolgingspraktijk in het algemeen

Bijna de helft van de 150 onderzochte zaken wordt geseponeerd: de officier van justitie besliste in 71 zaken tot een sepot en in vijf gevallen accepteerde de verdachte een transactie. ${ }^{75}$ Dit betekent dat $51 \%$ van de vrouwenmishandelingszaken niet bij de rechter is aangebracht (zie tabel 9). Dit komt overeen met het algemene beeld van de resultaten in $\S 5.2$.

Tabel 9. De wijze van seponeren en vervolgen in geval van vrouwenmishandeling

\begin{tabular}{lcc}
\hline & $\begin{array}{c}\text { frequentie } \\
n=150\end{array}$ & percentage \\
\hline technisch sepot & 16 & 10,7 \\
onvoorwaardelijk beleidssepot & 43 & 28,7 \\
voorwaardelijk beleidssepot & 8 & 5,3 \\
onvoorwaardelijk beleidssepot/berisping & 4 & 2,7 \\
onvoorwaardelijk transactie & 4 & 2,7 \\
voorwaardelijk transactie & 1 & 0,7 \\
ter berechting & 68 & 45,3 \\
voeging ter berechting & 3 & 2,0 \\
voeging ad informandum & 3 & 2,0 \\
\hline
\end{tabular}

Als we deze sepotpraktijk nader bekijken, dan zien we dat zestien zaken als technisch sepot zijn afgeboekt (11\%): meestal is er te weinig bewijs volgens de officier van justitie. Soms heeft de zaak zo lang in de strafrechtelijke molen gezeten dat de officier van justitie niet-ontvankelijk zal worden verklaard. De meeste zaken $(37 \%, n=55)$ worden als beleidssepot afgedaan. Er worden 47 zaken met een onvoorwaardelijk beleidssepot afgeboekt (31\%). Hiervan hebben vier verdachten een schriftelijke of mondelinge berisping gekregen. Van de beleidssepots wordt $15 \%$ onder voorwaarde afgedaan $(n=8)$. Meestal wordt alleen de algemene voorwaarde, dat geen herhaling van het gepleegde feit mag plaatsvinden, opgelegd. Eenmaal is de bijzondere voorwaarde 'onder toezicht van de reclassering' opgelegd. ${ }^{76}$ In $7 \%$ van de zaken $(n=11)$ is een transactie aangeboden en dit transactievoorstel is door vijf mannen geaccepteerd. De sepotpraktijk overziend, blijkt dat in $40 \%$ van de gevallen van vrouwenmishandeling de officier van justitie niet sanctionerend is

75 In elf zaken heeft de officier van justitie een transactievoorstel gedaan, waarvan in vijf gevalien de verdachte het transactievoorstel accepteerde.

76 Het landelijk gemiddelde van het voorwaardelijke sepot is $5 \%$ van het aantal beleidssepots in 1985 . In Assen bedraagt het $11 \%$, in Breda en Rotterdam is het $3 \%$ van het aantal beleidssepots. Jarurerslag $O M$ 1985: 96 . In geval van vrouwenmishandeling lijkt vaker onder voorwaarden geseponeerd. 
opgetreden, in $11 \%$ van de zaken op grond van een technisch sepot en in $29 \%$ van de zaken om redenen van opportuniteit.

Als grond voor het sepot wordt in veruit de meeste gevallen 'beperkte kring" genoemd ( $56 \%$ van de beleidssepots, $n=31$ ). De tweede plaats wordt gedeeld door de grond 'medeschuld benadeelde' $(16 \%, n=9)$, vooral in zaken van mishandeling, en de grond 'gering feit' $(13 \%, n=7)$. Verder worden genoemd: verhouding tot benadeelde geregeld (in geval van vernieling), oud feit, gewijzigde omstandigheden, reclasseringsbelang en gezondheidsredenen.

Van de 74 zaken die de officier van justitie voor de rechter heeft gebracht, zijn drie zaken ter berechting gevoegd en drie ad informandum. Een vijfde van deze zaken is voor de meervoudige kamer gebracht $(20 \%$ van het aantal vervolgde zaken, $\mathrm{n}=15)^{77}$

\section{De vervolgingspraktijk naar arrondissement}

In het arrondissement Breda wordt $74 \%$ van de 50 vrouwenmishandelingszaken met een sepot afgedaan $(n=37) ; 12 \%$ van de 50 vrouwenmishandelingszaken wordt met een technisch sepot afgedaan $(n=6)$ en $62 \%$ met een sepot om redenen van opportuniteit $(n=31)$. In Assen en Rotterdam wordt daarentegen slechts $34 \%$ van de 50 vrouwenmishandelingszaken met een sepot afgedaan $(n=17) ; 10 \%$ wegens gebrek aan bewijs ( $n=5)$ en $24 \%$ om redenen van opportuniteit $(n=12)$. In $68 \%$ van de zaken die met een beleidssepot worden afgedaan in Breda, wordt als grond 'beperkte kring' genoteerd $(n=21)$, terwijl het openbaar ministerie in Assen deze grond voor $50 \%$ van de beleidssepots noteert en Rotterdam voor $33 \%(n=6$ en $n=4)$. Een deel van deze beleidssepots vindt onder voorwaarden of met een waarschuwing dan wel een berisping plaats. Hoewel de transactiepraktijk kleine aantallen betreft, kan een klein verschil in transactiepraktijk worden geconstateerd tussen het arrondissementsparket Assen, waar relatief vaak een transactievoorstel wordt gedaan, ${ }^{78}$ en de arrondissementsparketten Rotterdam ${ }^{79}$ en Breda. ${ }^{80}$

77 Deze verdeling komt overeen met verdeling van misdrijven naar politicrechterzaken-meervoudige kamer zaken in het algemeen. Bal, Dwangkommunikatie in de rechtszaal, 1988: 15.

78 In 8 zaken is een transactievoorstel gedaan, waarvan driemaal onder de voorwaarde van een schadevergoeding. In vier van deze gevallen is de zaak daadwerkelijk met een transactie afgedaan, waarvan in een zaak ook de schade is vergoed. In Assen is het beleid dat bij vernieling de nadruk ligt op het betalen van de schadevergoeding. Dit wordt als voorwaarde bij een transactie gesteld. Wordt de schadevergoeding niet betaald, dan wordt de zaak voor de rechter gebracht. Ditzelfde geldt bij het niet betalen van de transactie. Mijn indruk is dat dit beleid in de praktijk wordt uitgevoerd.

79 In Rotterdam is eén zaak, van de drie voorgestelde schikkingen, getransigeerd.

80 Afgaande op de CBS-statistiek blijkt dat Assen in het algemeen veel transigeert (15\%), daama Rotterdam (10\%) en Breda (9\%). Dit is het percentage transacties van alle rechtbankzaken waarover het openbaar ministerie een beslissing nam in 1985. Jaanverslag OM 1985: 93. 
Tegenover het grote verschil in sepotbeleid, staat eenzelfde verschil in het vervolgingsbeleid. In Breda komt $26 \%$ van de zaken voor de rechter $(n=13)$, in Assen $58 \%(n=29)$ en in Rotterdam 64\% ( $n=32)$. Het verschil tussen Rotterdam en Assen kan worden verklaard uit het feit dat in Assen een zaak vaker wordt getransigeerd en in Rotterdam vaker wordt gevoegd. Geconstateerd kan worden dat het verschil in afhandeling tussen het arrondissementsparket Breda en de andere twee arrondissementsparketten opvallend groot is (zie tabel 10).

Tabel 10. De wijze van seponeren en vervolgen in geval van vrouwenmishandeling voor de drie srrondissementsparketten Assen, Breda en Rotterdam.

\begin{tabular}{lccc}
\hline & Assen & Breda & Rotterdam \\
Afhandeling door openbaar ministerie $(\mathrm{N}=150)$ & 5 & 6 & 5 \\
\hline technisch sepot & 10 & 24 & 9 \\
$\begin{array}{l}\text { onvoorwaardelijk beleidssepot } \\
\text { voorwaardelijk beleidssepot }\end{array}$ & 2 & 4 & 2 \\
onvoorwaardelijk beleidssepolberisping & 3 & 3 & 1 \\
onvoorwagrdelijk transactie & 1 & & 1 \\
voorwaardelijk transactie & 28 & 11 & 29 \\
ter berechting & 1 & & 2 \\
voeging ter berechting & & 2 & 1 \\
voeging ad informandum & & 50 & 50 \\
\hline
\end{tabular}

De afhandeling van zaken van vrouwenmishandeling afgezet tegen de vervolgingspraktijk van de respectievelijke arrondissementsparketten in 1985 laat zien dat de vervolgingspraktijk van vrouwenmishandelingszaken in Rotterdam en Assen niet afwijkt van de algemene vervolgingspraktijk, terwijl dit wel het geval is voor de vervolgingspraktijk van Breda. Hoewel het openbaar ministerie in Breda over het algemeen veel seponeert, worden zaken van vrouwenmishandeling beduidend vaker geseponeerd. ${ }^{81}$

81 Van alle Bredase rechtbankzaken in $1985(n=12.328)$ is $45 \%$ bij de rechter aangebracht, terwijl $26 \%$ van de vrouwenmishandelingszaken voor de rechter zijn gebracht. In Rotterdam is $63 \%$ ( $n=23.237)$ van alle rechtbankzaken voor de rechter gebracht en $64 \%$ van de vrouwenmishandelingszaken. In Assen is $52 \%(n=4.487)$ van de rechtbankzaken voor de rechter gebracht en $58 \%$ van de zaken van vrouwenmishandeling. Bron: Tabel 2.3. Afdoening gewone rechtbankstrafzaken door rechter en $\mathrm{OM}$, 1985, in: Jaarverslag OM 1985: 93. 
Uit de beschrijving naar delictscategorie in $\S 5.3 .2$ is gebleken dat een vrouwenmishandelingszaak die onder vernieling valt, een geheel andere verhaalsstructuur heeft dan een zaak van vrouwenmishandeling die onder verkrachting valt. Toch hoeft dit niet te betekenen dat het vervolgingsbeleid sterk van elkaar verschilt, hoewel de redenen om wel of niet te vervolgen van geheel andere aard kunnen zijn.

Alleen de delictscategorieern mishandeling/bedreiging en vemieling zijn redelijk gevuld. Opvallend is het lage percentage (4\%) technische sepots en het relatief hoge percentage bij de rechter aangebrachte zaken (60\%) bij vernieling. De categorie mishandeling/bedreiging kent de meeste variatie in afhandeling: alleen de voorwaardelijke transactie ontbreekt. Deze zaken van vrouwenmishandeling worden vaker buitengerechtelijk afgedaan: in 4\% van de gevallen met een transactie, in $10 \%$ van de gevallen met een beleidssepot onder voorwaarden of met een berisping, en $34 \%$ van de mishandelingszaken wordt met een onvoorwaardelijk beleidssepot afgedaan. Bovendien wordt $12 \%$ met een technisch sepot afgeboekt. In $41 \%$ van de gevallen wordt de zaak bij de rechter aangebracht, waarvan $2 \%$ door middel van voeging.

Als we naar de categorie verkrachting/aanranding $(n=12)$ kijken, dan valt het hoge percentage (33\%) technische sepots op en het feit dat geen enkele zaak met een onvoorwaardelijk beleidssepot is afgedaan. Wel zijn twee zaken (17\%) onder voorwaarden geseponeerd. In de helft van deze zaken heeft een rechterlijk eindoordeel plaatsgevonden. Zaken van moord- en doodslag worden in $64 \%$ van de gevallen $(n=11)$ gedagvaard, 36\% wordt met een beleidssepot afgedaan, waarvan de helft onder voorwaarden. Een transactie kan niet worden aangeboden als het een moord/ doodslag of verkrachting/aanranding-zaak betreft. Wel wordt relatief vaak een sepot onder voorwaarden opgelegd.

De verwachting is dat het openbaar ministerie vaker zal seponeren als het een zaak van geweld tegen de vrouw binnen een bestaande relatie betreft, zoals in de inleiding van dit hoofdstuk is verwoord.

Wanneer we de cijfers bekijken, dan zien we dat als het geweld tegen de vrouw binnen een bestaande relatie plaatsvindt $(n=39)$, de officier van justitie in zeventien gevallen de zaak zelf afdoet: het sepotpercentage bedraagt $44 \%$. Als het een verbroken relatie betreft $(n=110),{ }^{82}$ vindt vaker een afhandeling door het openbaar ministerie plaats, namelijk in 59 zaken, dat is $54 \%$ (zie tabel 12). Dit komt niet overeen met de verwachting. 
Tabel 11. De wijze van afhandelen door het open baar ministerie in geval van vrouwenmishandeling naar delictscategorie

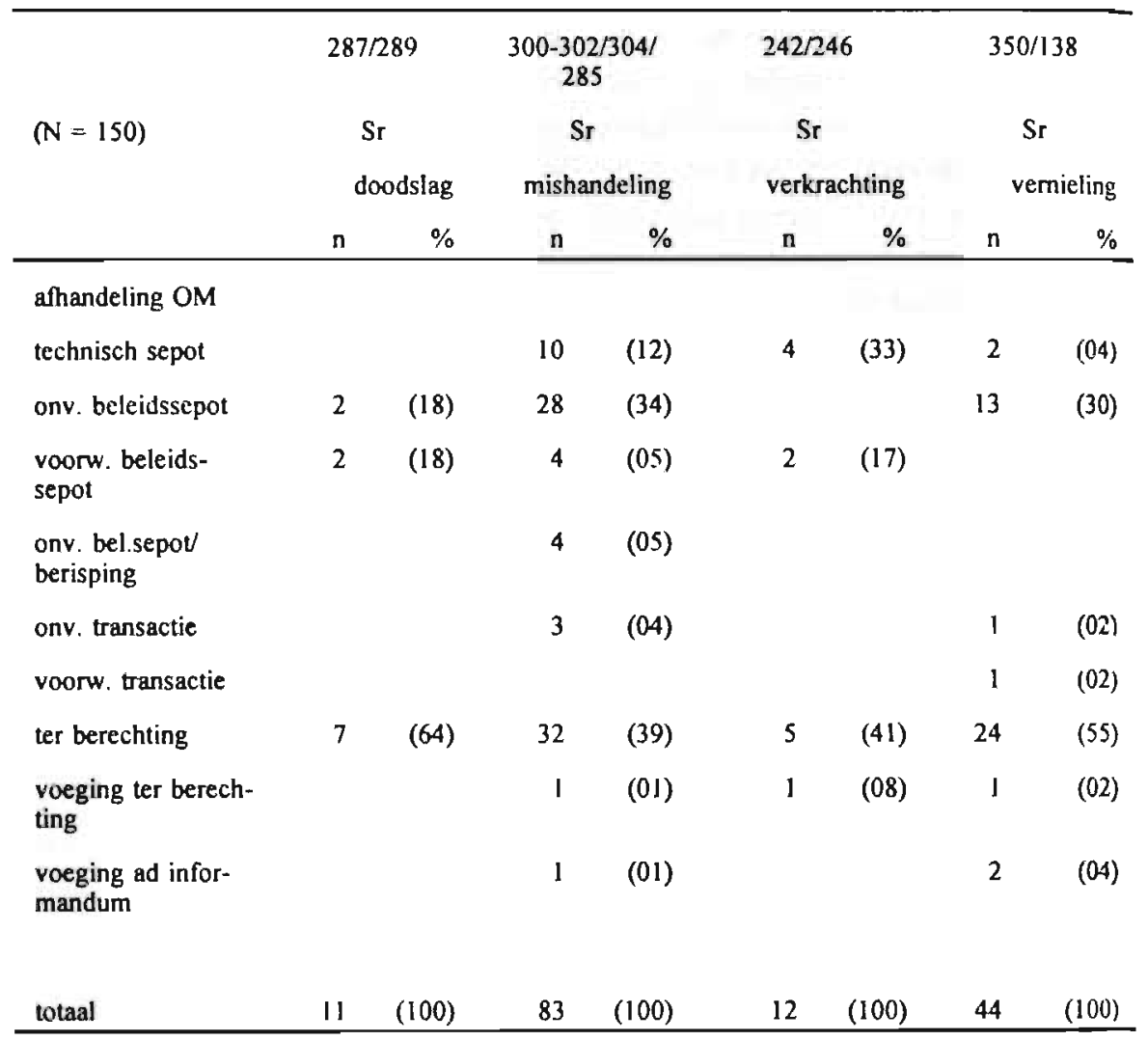

Tabel 12. Afdoening door het openbaar ministerie naar soort relatie

\begin{tabular}{|c|c|c|c|}
\hline \multirow[t]{2}{*}{$(N=149)$} & \multicolumn{3}{|c|}{ vervolgen door het openbaar ministerie } \\
\hline & $\mathrm{ja}$ & nee & totaal \\
\hline \multicolumn{4}{|l|}{ soort relatie } \\
\hline relatie & 22 & 17 & 39 \\
\hline ex-relatie & 51 & 59 & 110 \\
\hline totaal & 73 & 76 & 149 \\
\hline
\end{tabular}




\subsection{De beslissing omtrent vervolging door de officier van justitie}

\subsubsection{Inleiding}

Het eerste oordeel van de officier van justitie over het dossier van vrouwenmishandeling betreft de 'bewijsbaarheid' van de zaak. Pas wanneer de officier van justitie een zaak bewijsbaar acht, wordt gekeken naar de opportuniteit van een vervolging.

In $11 \%$ van de 150 zaken van vrouwenmishandeling is de zaak afgeboekt als technisch sepot $(n=16))$. De bewijsbaarheid van een zaak neemt toe als meer bewijsmiddelen aanwezig zijn. Maar het gaat niet zozeer om de hoeveelheid bewijsmiddelen, als om de kwaliteit en de consistentie van de bewijsmiddelen. ${ }^{83}$ In zaken waar de man zich verweert met een verhaal dat even plausibel is als de aanklacht van de vrouw, ${ }^{84}$ kan dit leiden tot het ontbreken van de overtuiging bij de officier van justitie en zal de zaak als technisch sepot worden afgeboekt. Wanneer bijvoorbeeld het slachtoffer door het steken met een mes is verwond door haar partner, kan het verhaal van de man dat hij het mes van de vrouw wilde afpakken, waardoor een worsteling ontstond, reden zijn voor de officier van justitie om tot een technisch sepot te besluiten. Een ontkenning van het gepleegde geweld tegen de vrouw door de verdachte heeft meestal geen technisch sepot tot gevolg, omdat nog andere bewijsmiddelen aanwezig zijn. Wel worden zaken met een bekennende verdachte vaker gedagvaard $(62 \% ; n=90)$, dan zaken waar de verdachte (gedeeltelijk) ontkent of zwijgt ( $25 \%: n=57$ ). Dat de verklaring van de verdachte van invloed is op de sepotbeslissing blijkt ook uit het volgende: ik veronderstelde dat in zaken van mishandeling in principe wordt vervolgd als de verdachte bekent, er een aangifte ligt en er een medisch rapport is van het letsel. In $75 \%$ van de zaken $(n=20)$ waar deze drie condities gelden wordt vervolgd. Als de verdachte daarentegen gedeeltelijk of geheel ontkent onder dezelfde condities, dan wordt nog maar in $27 \%$ van de gevallen gedagvaard $(n=15)$. Dit onderstreept de constatering dat de kans op een sepot groter wordt als de verdachte (gedeeltelijk) ontkent. De mate van letsel blijkt hierop enigszins van invloed; bij een bekennende verdachte gaat het in $90 \%$ van de gevallen om ernstig tot zwaar letsel en bij de (gedeeltelijk) ontkennende verdachte is dit minder vaak het geval (67\%). Daarom is er een conditie toegevoegd: de mate van letsel is ernstig tot zwaar. Ook dan blijkt er een verband tussen de verklaring van de verdachte en de sepotbeslissing van het openbaar ministerie.

83 Of een zaak te bewijzen is, hangt ook af van de moeite die is gedaan om voldoende bewijs te vergaren. Als een zaak geen hoge prioriteit heef, wordt cr minder tijd en energie in gestoken

84 Een zogenaamd 'Meer en Vaart'-verweer, HR I februari 1972, NJ 1974, 450. 


\subsubsection{Afzien van vervolging om opportuniteitsredenen}

Wanneer een zaak 'bewijsbaar' is, beoordeelt de officier van justitie de opportuniteit. Verschillende aspecten zijn relevant voor de afweging van de officier van justitie of tot dagvaarding zal worden overgegaan. In deze paragraaf wordt beschreven of bij het aanwezig zijn van een bepaald aspect vaker of minder vaak wordt gedagvaard dan wanneer dit aspect niet aanwezig is. ${ }^{85}$ Bovendien wordt weergegeven wat de mening is van officieren van justitie over de invloed van deze aspecten op de beslissing. In $\S 5.5 .3$ wordt aan de hand van drie voorbeelden van vrouwenmishandeling op het afwegingsproces van officieren van justitie ingegaan.

\section{Alcohol, recidive, leeftijd}

In $38 \%$ van de vrouwenmishandelingszaken is de man onder imvloed van alcohol tijdens het plegen van het geweld ( $n=57)$. In $49 \%$ van de gevallen dat de verdachte niet onder invloed stond van alcohol, vervolgde de officier van justitie (38 van de 78 ) en in $71 \%$ van de gevallen dat de verdachte wel onder invloed stond (36 van de 51). ${ }^{86}$ De kans dat tot vervolging wordt overgegaan, lijkt bij alcoholgebruik groter te zijn. (Zie bijlage 5 , tabel I)

Volgens de officieren van justitie is alcoholgebruik weliswaar een aspect dat een rol speelt, maar in samenhang met andere aspecten. Officier van justitie B: "Alcoholgebruik, zo leert de ervaring, leidt vaak tot misdragingen. Dus het draagt bij tot een vergemakkelijking van de bewijsvoering en dat betekent ook dat je eerder tot vervolging komt." Bovendien heeft het gebruik van alcohol indirect invloed op de sanctie of maatregel die wordt voorgesteld. Officier van justitie A: "Alcohol is strafverzwarend. Althans, alcohol op zich is niet strafverzwarend, tenzij het alcoholgebruik een rol heeft gespeeld in de mishandeling. Wat strafverzwarend is, is het recidivegevaar dat daaraan vastzit, er is een grotere kans dat je er een voorwaardelijke straf aan vastkoppelt omdat er een grotere kans is dat hij het weer zal doen." Wanneer sprake is van alcoholisme, kan behandeling gewenst zijn.

Het recidivegevaar wordt ondermeer afgeleid van het strafblad dat een verdachte heeft. ${ }^{87}$ In ruim de helft (55\%) van de onderzochte zaken van vrouwenmishandeling heeft de verdachte een strafblad $(n=82)$. De officier van justitie vervolgde in 48 van de 71 gevallen met strafblad $(65 \%)$, en in 26 van de 58 gevallen zonder strafblad

85 De afweging betreft de bewijsbare zaken, dat wil zeggen dat de zaken die zijn afgedaan met een technisch sepot buiten beschouwing zijn gelaten. Onder het seponeren valt ook het aanbieden van cen transactie.

86 Door het weglaten van de zaken die zijn afgehandeld met een technische sepot, verschilt het aantal verdachten die onder invloed van alcohol waren $(n=57)$ en het aantal zaken waar alcohol een rol speelde $(n=51)$.

87 Zie voor definiering van recidive, hoofdstuk 1, $\S 1.5 .1$, onder Registratie. 
$(45 \%) .^{88}$ De aanwezigheid van een strafblad lijkt de kans op dagvaarden te vergroten (zie bijlage 5 , tabel II).

De officieren van justitie laten een ander licht schijnen op de invloed van het strafblad. Het gaat niet om het strafblad in het algemeen, maar of in het verleden eerder een geweldsdelict is gepleegd (speciale recidive). Officier van justitie F: "Het strafblad is van invloed, maar hoofdzakelijk in de sfeer van speciale recidive. Dat hij wel eens gejat heeft, is niet van invloed, maar geweldsdelicten en alcoholdelicten onder omstandigheden, openlijk geweld, alle agressieve delicten zijn wel van invloed." En officier van justitie B: "Als het (geweld tegen de vrouw binnen een huwelijk, KL) heel erg is en als de verdachte recidivist is dan ben ik niet zo gauw bereid om de zaak te seponeren, want dan gaat de man rustig door."

In de leeftijdscategorie tot 30 jaar wordt $33 \%$ van de zaken om redenen van opportuniteit geseponeerd (12 van de 36), in de leeftijdscategorie van 30 tot 50 jaar $45 \%$ (38 van de 84 zaken) en in de leeftijdscategorie ouder dan 50 jaar 55\% (5 van de 9 zaken). In de leeftijdscategorie tot 30 jaar zijn meer zaken vervolgd dan in de andere twee leeftijdscategorieen (zie bijlage 5 , tabel III).

Uit de gesprekken met de officieren van justitie blijkt dat zij niet zo'n belang hechten aan de leeftijd. Alleen verdachten jonger dan 20 jaar hebben meer kans op een sepot van hun zaak. Dit zijn met name 18- en 19-jarigen, (nog jongere verdachten vallen onder het jeugdstrafrecht). Sommige officieren van justitie seponeren in beginsel verdachten die ouder zijn dan 50 jaar en geen strafblad hebben. Zoals officier van justitie A stelt: "De jongeren zijn dan de 18-, 19-, 20-jarigen en dat is een kleine groep, en de mannen met een hogere leeftijd. Meestal is er dan iets geks aan de hand." De leeftijd van de verdachte kan van invloed zijn op de strafeis. Officier van justitie F: "Net de piepjonge verdachten en de ouderen die al stok beginnen te worden. De 19-jarige zal een lichtere straf krijgen dan een 28-jarige. De zestiger zal waarschijnlijk ook een lichtere straf krijgen dan die van 28 of 40 jaar. Het hangt van verdere omstandigheden af of het ook echt een lichtere straf wordt."

Afgaande op de cijfers lijken recidive en alcohol een belangrijke rol te spelen in de beslissing van het openbaar ministerie. Bovendien bestaat er een samenhang tussen alcohol en recidive. ${ }^{89}$ In de leeftijdscategorie tot 30 jaar wordt vaker tot vervolging overgegaan dan in de andere leeftijdscategorieën. Het feit dat jongere verdachten vaker ernstig letsel veroorzaken, vaker bekennen, vaker alcohol gebruiken

88 Het verschil in aantal tussen verdachten met een strafblad $(n=82)$ en zaken waar dit aspect een rol speelde $(n=71)$ houdt verband met het weglaten van de zaken die zijn afgeboekt met een technisch sepot.

89 Van de 77 verdachten die geen alcohol gebruiken, heeft $38 \%$ een strafblad $(n=29)$, terwijl van de 55 verdachten die alcohol gebruikten $78 \%$ een strafblad heeft $(n=43)$. 
en er iets vaker sprake is van recidive kan een verklaring bieden. Deze samenhang komt ook uit ander onderzoek naar voren. ${ }^{90}$

\section{Duur en frequentie van het geweld}

De duur en frequentie van het geweld binnen de relatie kan tot uiting komen in geregistreerde eerdere contacten met de politie of het openbaar ministerie, en uit informatie in het dossier over eerder geweld. ${ }^{91}$ Het lijkt maar zelden voor te komen dat de verdachte een strafblad heeft èn al eerder in aanraking is gekomen met het openbaar ministerie in verband met vrouwenmishandeling $(n=9)$. In die gevallen is het niet zo dat in principe wordt vervolgd: vier verdachten zijn gedagvaard en vijf zaken zijn geseponeerd.

Een ander punt is of herhaald, structureel geweld tegen de vrouw door haar (ex-)partner vaker tot vervolgen dan seponeren leidt. In geval van structureel geweld wordt in $65 \%$ van de 42 zaken gedagvaard $(n=27)$, in geval van een eenmalige incident wordt in $60 \%$ van de 47 gevallen gedagvaard $(n=28)$ en wanneer meermalen geweld is gepleegd, wordt in $48 \%$ van de 40 zaken gedagvaard $(n=19)$ (zie bijlage 5 , tabel IV).$^{92}$ De officieren van justitie vinden dat herhaald, structureel geweld tegen de vrouw door de man een aspect is waar rekening mee wordt gehouden. Officier van justitie F: "Als er sprake is van structureel of langdurig geweld, zal dit zeker van invloed zijn op de strafmaat. Sneller vervolgen en harder straffen, zeker. Een eenmalige wordt minder hard aangepakt dan een structurele mishandeling." Er zijn officieren van justitie die zich voorzichtiger uitdrukken: "Voor je inschatting van het verhaal kan het belangrijk zijn, maar niet altijd", stelt officier van justitie $\mathrm{E}$.

90 Zie: Van Straelen, Het seponerings- en strafvorderingsbeleid van het OM, in: Beslissingsmomenten in het strafrechtelijke systeem, 1978: 194-195. Uit het dossieronderzoek naar eenvoudige mishandeling en vernieling komt naar voren dat alcoholgebruik vaak samengaat met verdachten van jongere leeftijd die meer hebben gerecidiveerd en dit leidt tot een grotere kans op vervolging. Het letsel speelt volgens $\mathrm{Van}$ Straelen geen rol in de vervolgingsbeslissing. Dit wordt verklaard uit het feit dat slechts een zeer klein deel van de slachtoffers enige tijd naar het ziekenhuis moest en de discriminerende werking van de variabele door dit lage aantal niet aanwezig is. Doordat ik de emst van het letsel anders heb gedefinieerd, lijkt wel invloed van de ernst van het letsel uit te gaan. Zie voor deze samenhang in de straftoemeting: Kannegieter, Ongelijkheid in de strafioemeting, 1994: 195-198, 205-216.

91 Op grond van het documentatieregister bepaalde ik of de verdachte al eerder in aanraking was geweest met justitie in verband met vrouwenmishandeling. Dit blijkt niet duidelijk uit het register, het is meer een kwestie van gissen, bijvoorbeeld wanneer een mishandelingszaak is geseponeerd op grond van 'beperkte kring'. Soms geeft het proces-verbaal een aanwijzing.

92 Zie voor de geschiedenis van de mishandeling naar delictscategorie Bijlage 5, tabel VI. 
Een verbroken of voortdurende relatie

Zaken van geweld tegen de vrouw binnen een bestaande relatie worden niet vaker buitengerechtelijk afgedaan dan zaken van vrouwenmishandeling die een verbroken relatie betreffen (zie $\S 5.4$ onder Vervolgingspraktijk naar delictscategorie en naar relatie). Een verklaring hiervoor kan zijn dat de relatie na het doen van aangifte is verbroken. Van alle vrouwenmishandelingszaken die een relatie betreffen, is een verdeling gemaakt naar (1) voortbestaan van de relatie, (2) verbreken van de relatie na het doen van aangifte, (3) uit het dossier blijkt niet of de relatie voortduurt of is verbroken, en (4) het slachtoffer is dood (zie tabel 13). Bovendien is het onderscheid tussen buitengerechtelijke afdoening wegens een technisch sepot of een beleidssepot en transactie aangegeven.

Tabel 13. Wijze van afhandelen door het openbaar ministerie naar soort relatie nadat aangifte is gedaan.

\begin{tabular}{lccc}
\hline$(\mathrm{N}=149)$ & $\begin{array}{c}\text { vervolgen door het openbaar ministerie } \\
\text { ja }\end{array}$ & $\begin{array}{c}\text { nee } \\
\text { beleidssepot }\end{array}$ & $\begin{array}{c}\text { nee } \\
\text { technischsepot }\end{array}$ \\
\hline relatie na aangifte & 51 & 46 & 13 \\
- ex & 5 & 6 & - \\
- voortbestaan & 8 & 2 & 2 \\
- verbroken & 7 & 6 & 1 \\
- onbekend & 2 & - & - \\
- dood & 73 & 60 & 16 \\
totaal & & & \\
\hline
\end{tabular}

In geval van een ex-relatie kan niet worden gezegd, dat vaker wordt geseponeerd op gronden ontleend aan het algemeen belang: er vindt iets vaker een dagvaarding plaats. Bovendien kan niet worden gezegd dat in principe wordt geseponeerd als het geweld tegen de vrouw binnen een bestaande relatie wordt gepleegd en deze relatie ook na het incident voortduurt: het openbaar ministerie seponeert even vaak om redenen van opportuniteit als dat de zaak wordt vervolgd. Ditzelfde geldt voor de zaken waarvan de relatievorm na het doen van de aangifte onbekend is. Alleen wanneer het geweld binnen een bestaande relatie plaatsvindt en de relatie wordt na de aangifte verbroken, gaat de officier van justitie in $80 \%$ van de gevallen over tot dagvaarding in plaats van een sepot om redenen van opportuniteit $(n=10){ }^{93}$

93 Uit het onderzoek naar de politie bleek eveneens dat de politie de zaak eerder strafrechtelijk aanpakt als de vrouw na het doen van de angifte de relatie verbreekt. Zoomer, Vrouwenmishandeling; politiewerk, 1990: 52 
Alleen in de categorie mishandeling/bedreiging en moord/doodslag komen bestaande relaties ${ }^{94}$ en verbroken relaties voor, in de andere twee categorieën speelt dit onderscheid geen rol: daar is alleen sprake van ex-relaties. Daarom heb ik nogmaals voor alleen de mishandelings-, bedreigings- en poging tot doodslagzaken de relatie onderzocht. Ik verwacht dat vaker om redenen van opportuniteit wordt geseponeerd als sprake is van een duurzame relatie. Officieren van justitie zijn terughoudend als het de privésfeer betreft, vanuit de opvatting dat de vrouw eerst de relatie moet verbreken voor strafrechtelijk kan worden opgetreden; strafrechtelijk optreden kan het conflict verder doen escaleren. Dit argument van escalatie kan overigens ook opgaan als het een ex-relatie betreft, zoals een officier van justitie aan de advocaat van het slachtoffer schreef: "Belangrijker nog (dan de processuele onduidelijkheden, $\mathrm{KL}$ ) is het feit dat vervolging waarschijnlijk de zaak zal escaleren; namelijk koren op zijn molen voor een wraakoefening." Aan de andere kant kan de emst van het letsel de kans op een dagvaarding weer doen toenemen. Er zijn drie hypothesen onderzocht: 1 . als de relatie na het doen van de aangifte wordt verbroken, zal eerder worden gedagvaard dan wanneer de relatie blijft voortbestaan, 2. het letsel zal ernstiger zijn wanneer sprake is van een relatie, aangezien een taboe heerst op het naar buiten brengen van geweld binnen een relatie, ${ }^{95} 3$. de ernst van het letsel zal de kans op dagvaarden vergroten.

De eerste hypothese lijkt te worden bevestigd door de cijfers: in de door mij onderzochte groep wordt vaker gedagvaard wanneer de relatie wordt verbroken, dan wanneer de relatie voortduurt. ${ }^{96}$ De tweede hypothese lijkt eveneens bevestigd te worden door het dossieronderzoek. Het letsel van de vrouw is in $76 \%$ van de bestaande relaties emstig tot $\mathrm{zwaar}^{97}$ en in $50 \%$ van de gevallen waar de vrouw door haar ex-partner is mishandeld. ${ }^{98}$ De derde hypothese wordt niet door het dossieronderzoek bevestigd. De ernst van het letsel lijkt niet bepalend voor de beslissing of zal worden vervolgd. ${ }^{99}$

De gesprekken met de officieren van justitie geven aan dat het voortduren van de relatie na het doen van aangifte de kans op een sepot vergroot. Twee officieren

94 Het betreft vier moord/doodslag-zaken; de overige zijn mishandelingszaken.

95 Romkens, Onder ons gezegd en gezwegen, 1989: 19-30.

96 Zoals ook uit tabel 13 blijkt, wordt in 8 van de 10 relaties die worden verbroken na het doen van de aangifte, de zaak vervolgd ( $80 \%$ ), en in 5 van de 11 relaties die blijven voortbestaan na de aangifte $(46 \%)$.

97 Van de 37 bestaande relaties heeft de vrouw in $76 \%$ gevallen emstig letsel opgelopen $(n=28)$ en $16 \%$ van de vrouwen licht letsel $(n=6)$. Zie Bijlage 5: tabel V.

98 In geval van ex-relaties heeft de vrouw in $50 \%$ van de gevallen licht letsel opgelopen $(n=24)$ en eveneens in $50 \%$ emstig tot zwaar letsel $(n=24)$. Zie Bijlage 5: tabel V. Ter informatie is de mate van letsel naar delictscategorie, naar de geschiedenis van de mishandeling en naar de soort relatie nadat aangifte is gedaan in Bijlage 5, tabellen VII, VIII \& IX aangegeven.

$99 \mathrm{Bij}$ het constant houden van het letsel wordt het verband tussen de relatie en de sepotbeslissing bevestigd, zowel bij de indeling relatie/ex-relatie ten tijde van de geweldpleging, als bij de indeling na het doen van de aangifte; ex-relatie, voorduren van relatie, verbroken relatie en relatie onbekend. 
van justitie stellen dat strafrechtelijk ingrijpen pas zin heeft als de vrouw de relatie heeft beëindigd. Officier van justitie C: "Als zij er keer op keer voor kiest om binnen de relatie te blijven, om wat voor reden dan ook, moet dan het strafrecht degene zijn die tegen die man zegt 'je mag je vrouw niet slaan en als je het wel doet dan krijg je een geldboete of een gevangenisstraf? Kennelijk zit er in die relatie iets dat niet goed is of is er iets bij die man dat niet goed is (...). Maar mensen die er heel bewust weer voor kiezen om samen te gaan daar heb ik het altijd heel erg moeilijk mee, dan denk ik, ik heb daarin geen rol, punt uit." De officieren van justitie zijn het erover eens dat eerder tot dagvaarden wordt overgegaan wanneer het om een verbroken relatie gaat dan wanneer het om een bestaande relatie gaat. Officier van justitie F: "Bij een ex-relatie is er duidelijker het nee geweest van de partner, dat nee is al eerder gevallen. Toen is al gezegd, nee niet doen, afblijven, weg, we gaan uit elkaar. Nou, daarom is het des te verwerpelijker als daar weer inbreuk op wordt gemaakt." Wanneer sprake is van een relatie die voortduurt na de aangifte, lijken officieren van justitie eerder te denken aan hulpverlening of een voorwaardelijke straf. Officier van justitie D: "Als de relatie voortduurt en blijft voortduren denk ik eerder aan hulpverlening dan aan strafrechtelijk ingrijpen, hooguit hulpverlening met strafrechtelijk ingrijpen als stok achter de deur. Bij een ex-relatie komt eerder strafrechtelijk ingrijpen voor."

\section{Intrekken van de aanklacht}

Het intrekken van de aanklacht ${ }^{100}$ komt weinig voor als de zaak eenmaal naar het openbaar ministerie is doorgestuurd. ${ }^{101}$ In $6 \%$ van de vrouwenmishandelingszaken heeft de vrouw de aanklacht ingetrokken $(n=9)$. Het gaat in deze gevallen om mishandeling binnen een bestaande relatie $(n=8) .{ }^{102}$ Als de aangifte wordt ingetrokken door het slachtoffer, besluit de officier van justitie in de helft van de gevallen tot een sepot om redenen van opportuniteit, waarvan een beleidssepot onder voorwaarden. Bovendien krijgt het slachtoffer soms een brief in de trant van 'uit uw brief en het reclasseringsrapport blijkt dat het contact weer goed is tussen u en uw man; mocht zich opnieuw iets voordoen, aarzel dan niet de politie in te schakelen'. In drie gevallen wordt een dagvaarding uitgebracht. Dit betrof ernstige zaken. ${ }^{103}$

100 Hoewel de geweldsdelicten begaan tegen een partner geen klachtdelicten zijn, kunnen slachtoffers wel een brief schrijven dat ze de aangifle willen intrekken of dat het niet zo is gegaan als ze hebben verteld. Dit wordt 'intrekken van de aangifte' genoemd.

$101 \mathrm{Bij}$ de politie trekken vrouwen vaker hun aanklacht in. Cachet, Politie en saciale controle, 1990: 199.

102 Eén zaak betreft een vernieling door de ex-partner. De vrouw trekt de aanklacht in, omdat de man de schade heeft vergoed. De officier van justitie besluit in dat geval tot een sepot. In de andere gevallen van mishandeling duurde de relatie in twee zaken voort, in twee zaken werd de relatie verbroken en in vier gevallen is de relatie na het doen van de aangifte onbekend.

103 Twee zaken zijn bij de meervoudige kamer wegens poging tot doodslag aangebracht en een zaak bij de politierechter. 
De officieren van justitie zeggen allemaal dat het intrekken van de aanklacht door de vrouw een strafverminderende invloed heeft. Bovendien willen de officieren van justitie weten of de vrouw de aanklacht intrekt onder dreiging. Om daarachter te komen kan het slachtoffer door de politie worden gehoord of de officier van justitie kan het slachtoffer op het parket roepen om haar verhaal te horen. Ook wordt wel eens aan de reclassering gevraagd of een gesprek met de verdachte en het slachtoffer kan plaatsvinden. Officier van justitie D: "Als de aanklacht door de vrouw wordt ingetrokken? Ja dan heel goed ernaar kijken, wat doe je er dan nog mee? Waarom heeft ze de aanklacht ingetrokken? Het gebeurt een enkele keer onder bedreiging en dan moet je er vooral niet op ingaan. Maar als er wel redenen zijn, de relatie wordt hersteld of zo, dan moet je kijken of je niet iets anders moet doen dan strafrechtelijk ingrijpen en de mate waarin. Ik denk dan veel eerder aan voorwaardelijk seponeren of voorwaardelijk straffen en inschakelen als dat mogelijk is, als er reden voor is, van de hulpverlening." Officier van justitie E zegt het kort en krachtig: "Dat maakt uit, maar ik wil weten waarom. Ik heb wel eens vervolgd ondanks zo'n brief." 104

\section{Fysiek verweer van het slachtoffer}

Fysiek verweer van het slachtoffer kan onder de sepotgrond 'medeschuld benadeelde' vallen. In elf zaken hebben vrouwen zich fysiek verweerd, en hiervan heeft de officier van justitie in acht zaken besloten tot een beleidssepot. Het slachtoffer dat zich fysiek verweert, lijkt de kansen op een sepot van de zaak te vergroten.

Deze veronderstelling wordt echter niet bevestigd door de gesprekken met de officieren van justitie. Een van de officieren van justitie zegt dat fysiek verweer door het slachtoffer niet sneller tot een sepot leidt. "Integendeel", stelt officier van justitie B, "want als de verdachte, ondanks het verweer doorgaat, is dat extra kwalijk." Andere officieren van justitie vinden het moeilijk om hier antwoord op te geven. Officier van justitie D: "[Het] maakt geloof ik niet zoveel uit. Ik vind het logisch dat iemand zich verweert, iemand die zich willoos in elkaar laat slaan, (...) ik vind het moeilijk om er antwoord op te geven." En weer anderen vinden dat het wel van invloed kan zijn op de strafmaat. Of omdat uit het fysieke verweer blijkt dat de vrouw weerbaar is en daarom minder externe steun nodig heeft, of omdat door het fysieke verweer het letsel minder erg is. Officier van justitie E: “Je krijgt dan misschien sneller een poging, wat tot een wat lagere straf aanleiding zou geven, maar los daarvan maakt het geen verschil. In principe ga ik niet sneller tot een sepot over."

104 Uit het dossieronderzoek blijkt niet dat er altijd zorgvuldig wordt uitgezocht of de aanklacht onder dwang is ingetrokken. 
Een ander punt is dat er sprake kan zijn van een gewelddadige relatie: man en vrouw zijn gewelddadig ten opzichte van elkaar. ${ }^{105}$ Dit kan door officieren van justitie worden beschouwd als 'medeschuld benadeelde', waardoor de kans op een sepot of strafvermindering voor de verdachte wordt vergroot. Of officieren van justitie een situatie beoordelen als wederzijds gewelddadig kan niet uit het dossieronderzoek worden opgemaakt. Het antwoord van officier van justitie $F$ op mijn vraag of het uitmaakt of een vrouw jarenlang is mishandeld en dan eindelijk aangifte doet, laat zien hoe jarenlange mishandeling kan worden geïnterpreteerd als wederzijds gewelddadig optreden. "Daarom zal ik hem wel serieus nemen, maar dat soort excuses heb ik natuurlijk al vaker gehoord; dit was tussen ons gewoon en het was ook nog wederzijds. Want dat hoor je natuurlijk ook vaak, dat moeder de hand ook flink weet te laten wapperen. Wederzijds gaven ze elkaar wel eens een paar klappen. Jaar in, jaar uit is dat zo gegaan en dat wordt dan ook erkend. En dan krijg je een soort escalatie, hij gaat een bepaalde grens over, bijvoorbeeld een schop met klompen aan. Wat mij betreft best strafbaar, best ook te pakken, maar dan denk ik toch dat ik met die omstandigheden, het samen zover hebben laten komen, in de strafmaat rekening zal houden."

In het voorafgaande is beschreven hoe bepaalde aspecten de kans op vervolgen kunnen vergroten of verkleinen. Dit biedt geen verklaring voor de variatie in de sepotpraktijk, wat overigens ook voor een groter opgezet dossieronderzoek geldt. ${ }^{106}$ Naast de informatie die in het dossier staat, zijn ook andere aspecten van invloed op de beslissing van de officier van justitie, zoals indrukken van de officier van justitie opgedaan tijdens telefoongesprekken met advocaten en reclassering, gesprekken met collega's, en een mondeling onderhoud met de verdachte en/of het slachtoffer. ${ }^{107}$ Bovendien heeft elke zaak weer eigen facetten waarmee rekening wordt gehouden en hangt het van de persoon van de officier van justitie af hoe de verschillende aspecten worden gewaardeerd. ${ }^{108}$

105 Wederkerig geweld tussen partners komt veel minder vaak voor dan eenzijdig geweld tegen de vrouw binnen heteroseksuele relaties (5,5\% tegenover $20,8 \%$ van alle door Romkens ondervraagde vrouwen). Het gaat bij wederkerig geweld in de meeste gevallen om licht geweld. Emstig en zeer emstig geweld komt in die groep niet voor. Dit in tegenstelling tot eenzijdig geweld tegen de vrouw, waar ernstig en zeer ernstig geweld wel regelmatig voorkomt. Romkens, Gewoon geweld?, 1992: 109-112.

106 Uit een onderzoek naar sepotbeleid inzake eenvoudige mishandeling in 1974 blijkt ook dat de persoons- en delictsvariabelen uit de strafdossiers geen voldoende verklaring kunnen bieden voor de variatie in het sepotbeleid. Van Straelen \& van Dijk, Rechlsgelijkheid en sepotpraktijk. 1981 : 16.

107 Van Straelen, Het seponerings- en strafvorderingsbeleid, in: Beslissingsmomenten, 1978: 200.

108 Zoomer, De strafuordering en straftoemeting in gevallen van zware criminaliteit, 1981: 91. 


\subsubsection{Het afwegingsproces van officieren van justitie}

"Bij het nemen van vervolgings- en strafvorderingsbeslissingen dienen officieren normatieve oordelen te vellen over de ernst van het feit, de mate van gevaarzetting, de schade toegebracht aan het slachtoffer, de verwijtbaarheid van de verdachte, etc. Vervolgens dienen deze elementen tegen elkaar afgewogen te worden: wat moet men in casu het zwaarste wegen? Welke straf heeft deze verdachte verdiend?"109 Om enig inzicht te krijgen in het afwegingsproces heb ik de zes geïnterviewde officieren van justitie drie verschillende gevallen van vrouwenmishandeling voorgelegd: (1) de zaak 'Maviye en Glenn', die ook wel het klassieke voorbeeld van vrouwenmishandeling kan worden genoemd; (2) de zaak 'Lianne en Dick', een voorbeeld van de ex die de vrouw blijft lastig vallen; en (3) de zaak 'Anneke en Martin', een geval van verkrachting (zie voor een meer uitgebreide beschrijving van deze zaken $\$ 5.3 .2$ ). Nadat de officieren van justitie hebben verteld hoe ze de zaak zouden afdoen, heb ik telkens een bepaald aspect uit de casus gewijzigd, bijvoorbeeld de mate van ernst, of alcoholgebruik. Op die manier is zichtbaar gemaakt hoe bepaalde aspecten van een casus van invloed zijn op de beslissing of vervolgd zal worden en welke straf er geeist zal worden.

\section{Maviye en Glenn: een klassiek geval van vrouwenmishandeling}

Maviye is ruim twintig jaar met Glenn getrouwd. Ze hebben samen vier kinderen. Maviye wordt jarenlang mishandeld en spreekt hier met niemand over. Op een avond wordt ze emstig bedreigd en raakt licht gewond door het geweld van Glenn. Ze gaat naar de politie, doet aangifte, verblijft drie dagen in een opvanghuis, en keert dan weer terug naar huis. Er vindt een gesprek met de reclassering plaats, en zij schrijft de officier van justitie een brief dat het allemaal niet zo ernstig was en dat ze geen strafrechtelijke vervolging wil.

Op mijn vraag wat de beslissing zou zijn, komen verschillende antwoorden. Er is één officier van justitie die opteert voor dagvaarden en het vorderen van een voorwaardelijke straf. Officier van justitie $A$ : "Ik vind het vrij fors wat er is gebeurd. Op zich een onvoorwaardelijke zitstraf waard. Ik zou gelet op het herstel van de relatie en het feit dat de vrouw de aangifte intrekt, van de onvoorwaardelijke zitstraf afzien, ook geen dienstverlening doen. Ik zou een zwaardere stok achter de deur willen dan 'de volgende keer ga ik vervolgen'. Ik zou hem duidelijk willen maken dat de volgende keer gevangenisstraf volgt. Ik vind het ontzettend jammer dat de reclassering het stel niet wil begeleiden, want het feit dat partijen op gelijkwaardige voet verder willen, wil nog niet zeggen dat ze daartoe in staat zijn en de vrouw zou een extra steuntje wel kunnen gebruiken. Daarom maar weer via 
die gevangenisstraf; van 'meneer u heeft het aan mevrouw te danken dat u niet de gevangenis in gaat'. Ik zal het op zo'n manier presenteren waardoor die man in ieder geval weet dat het dankzij mevrouw is dat het niet zover is gekomen, maar anders (...)"

Er zijn drie officieren van justitie die twijfelen tussen voorwaardelijk seponeren of een voorwaardelijke straf bij de rechtbank, afhankelijk van de reactie van de verdachte. Officier van justitie B: "Dan hangt het ten minste erg af van wat de verdachte daarover (over de mishandeling en bedreiging, $\mathrm{KL}$ ) opmerkt en als hij van meet af aan alles ontkend heeft en blijft ontkennen zou ik geen enkele aanleiding zien om de zaak te seponeren. Ik zou de zaak bij de rechter brengen ondanks de wens van het slachtoffer om de zaak wel te seponeren. Als de dader daarentegen zegt: 'akkoord, ik beken ten volle' en hijzelf en ook deskundigen zoals bijvoorbeeld de reclassering aangeven dat uitsluitend de kern van deze problemen is gelegen in de familiesfeer en dat er alle aanwijzingen zijn dat het beter gaat, dat bijvoorbeeld de kinderen er niet al te zeer onder lijden of onder geleden hebben, ${ }^{110}$ zou je in overweging kunnen nemen (en dan druk ik me erg voorzichtig uit) om de zaak voorwaardelijk te seponeren. Een sleutel daartoe geeft met name het gedrag van de verdachte. (...) Ik ben bang dat wanneer je de zaak seponeert de aangeefster morgen weer terugkomt." In dit geval bleef Glenn ontkennen, waarop de officier van justitie besluit tot een fikse boete en een voorwaardelijke gevangenisstraf. De andere twee officieren van justitie besluiten uiteindelijk tot een sepot onder voorwaarden van reclasseringsbegeleiding.

Tot slot zijn er twee officieren van justitie die besluiten tot een sepot op grond van 'beperkte kring', omdat de relatie voortduurt. Officier van justitie C: "Ik denk dat ik het zou seponeren, omdat de zaak niet erg sterk is; ze doet aangifte van mishandeling en bedreiging, dat ontkent hij, dus daar heb je eigenlijk al heel weinig aan, eigenlijk niks. Je hebt een mishandeling waarbij de politie zegt: 'geeft pijn aan ook bij druk op meerdere plaatsen op het hoofd, onder de rechterknie en de rechterpols, zonder waarneembaar letsel.' Kortom, daar kan ik ook niets mee. En een kleine bloeduitstoring onder de rechterkaak, nou ja, dat zou ze inderdaad met een dreun op hebben kunnen lopen. Ze gaat heel kort nadat ze in het opvanghuis is weer terug. Het gezin is weer bij elkaar. Reclassering is van mening dat zij er niet in moeten treden en ik denk dat dit wachten is tot de volgende keer."

Wat opvalt is dat de ernst van het delict verschillend wordt opgevat. De ene officier van justitie vindt het fors en bewijsbaar, de ander vindt het een matige mishandeling en weer een andere officier van justitie acht het geen sterke zaak. Het voortduren van de relatie wordt door de officieren van justitie beschouwd als een reden om niet te dagvaarden of om een voorwaardelijke straf te eisen. Doordat de

$110 \mathrm{Het}$ is opvallend dat de officier van justitie spreekt over de kinderen en niet over de vrouw. 
diverse aspecten verschillend worden gewaardeerd, ontstaat een verschil in afdoening.

Vervolgens heb ik een aantal aspecten van de casus gewijzigd. Eerst heb ik het letsel gewijzigd; er zijn striemen in de hals van Maviye doordat Glenn haar heeft gepoogd te wurgen, en daarna is het letsel nog ernstiger, een beschadiging van het strottehoofd. In beide gevallen is dit letsel geconstateerd door de arts. Verandert de ernst van het letsel de beslissing van de officier van justitie?

Twee officieren van justitie merken spontaan op dat de man had moeten worden vastgezet wegens poging tot moord of doodslag, zeker bij de beschadiging van het strottehoofd. Officier van justitie A: "Een andere telastlegging, poging doodslag, en wel politierechter. Het probleem is dat ik in zo'n geval door de politie zou zijn gebeld en de man zou hebben voorgeleid. Zo'n zaak krijg je niet als loopzaak binnen, zeker niet met de aangetroffen chaos in huis en de vrouw reeds in het Blijf van m'n Lijfhuis is geplaatst. Dan heb je kans dat het onvoorwaardelijke deel van de straf al is uitgezeten voor de zitting. Als dat niet het geval is, dan zou ik in dit geval missschien nog zeggen, dan maar geen zitstraf, maar wel een veel forsere voorwaardelijke straf, een maand of vier, vijf." Hoewel officier van justitie $F$ vindt dat de man in voorlopige hechtenis moet worden genomen, zeker als sprake is van een beschadigd strottehoofd, houdt dit niet vanzelfsprekend in dat hij Glenn zal dagvaarden." "Het hangt ervan af hoe lang hij is vastgehouden, of een contactverbod is opgelegd, en of ze weer in de hiervoor genoemde situatie zitten, wat er dan wordt beslist. Het kan zijn dat hij is geschrokken van het vastzitten, dat is al een stukje bestraffing geweest, en dan de nieuwe ontwikkelingen, dan zou ik op grond daarvan weer tot een voorwaardelijk sepot kunnen beslissen."

De twee officieren van justitie die besloten tot een onvoorwaardelijk sepot zijn niet erg onder de indruk van het letsel; de striemen in de hals en de beschadiging van het strottehoofd maken niets uit voor de beslissing. Hoewel beiden erkennen dat nu de grens dicht wordt genaderd. Een officier van justitie zou uiteindelijk wel willen besluiten tot een voorwaardelijk sepot en de ander tot dagvaarden. Officier van justitie $E$ laat het voortduren van de relatie heel sterk wegen en benadrukt de toevalligheid van het letsel. "Dat strottehoofd is toevallig, dat had ook in het andere geval kunnen gebeuren, dat maakt me niet echt uit." Officier van justitie $C$ weegt een aantal aspecten. "Ik denk dat ik hier heel sterk de cultuur laat wegen en het feit dat het gezin weer samen is. Dat het kennelijk de eerste keer is dat ze weggaat. Hij heeft geen strafblad. Misschien dat ik op den duur zou besluiten tot een voorwaardelijk sepot, naarmate het letsel emstiger wordt."

111 Een officier van justitie is bevoegd een zaak niet verder te vervolgen op grond van $242 \mathrm{~Sv}$. Anderzijds mag voorlopige hechtenis alleen worden opgelegd als een vrijheidsbenemende straf wordt verwacht. 
Het voorafgaande laat zien dat (zeer) ernstig letsel de kans vergroot dat de officier van justitie besluit de zaak te vervolgen, maar het voortduren van de relatie en het ontbreken van een strafblad kunnen ertoe leiden dat toch tot een beleidssepot wordt besloten.

Ten tweede heb ik in de oorspronkelijke casus het aspect van het strafblad veranderd; Glenn heeft nu een strafblad op geweldsdelicten. Deze verandering heeft tot gevolg dat de meeste officieren van justitie sneller tot dagvaarden van Glenn besluiten. Officier van justitie A: "Want dat betekent dat we er niet zijn met 'meneer zal in zijn relatie niet meer mishandelen dus er is niets aan de hand' maar met 'meneer is agressief en gaat ermee door'. Hij heeft een waarschuwing gehad en dat betekent dat niet alleen zijn vrouw risico loopt, en slachtoffer is geworden, maar ook anderen." Alleen officier van justitie $E$ blijft erbij dat in dit soort zaken strafrechtelijk optreden geen zin heeft. "Ik denk nog steeds dat bij dat Blijf van m'n Lijfhuis de boot al dan niet gemist is, dat het daar moet gebeuren, want op dat moment gaat het goed. Ik verander de situatie niet door een 'daar geloof ik niets van', maar stel nu dat ik die vent een maand voorwaardelijk of een week onvoorwaardelijk of voor mijn part een maand onvoorwaardelijk zou kunnen bezorgen, wat hij dan over twee jaar zou moeten uitzitten, wat doe ik dan? Dan gooi ik in een spiegelkamer een steen en ik weet totaal niet wat ik doe en dat weet niemand."

We zien hier dat de afweging om wel of niet te vervolgen sterk lijkt te worden beïnvloed door speciale recidive van de verdachte. Officier van justitie $\mathrm{E}$ geeft aan dat het gevaar van escalatie door een strafrechtelijke aanpak voor haar de reden is om niet tot dagvaarden over te gaan.

Het derde aspect dat ik heb veranderd, is het alcoholgebruik. In de oorspronkelijke casus is Glenn veranderd in een alcoholist. Het alcoholisme van Glenn verandert niet veel aan de beslissing van de officieren van justitie. Ze zullen alleen sneller reclasseringscontact als voorwaarde bij een sepot opleggen of reclasseringscontact eisen bij een voorwaardelijke straf. Alleen officier van justitie $E$ vindt: "Ik vind nog steeds dat die vrouw weg moet. Iets anders is er niet."

Als laatste aspect heb ik het intrekken van de aangifte door Maviye gewijzigd in de oorspronkelijke casus; zij schrijft geen brief dat ze de aangifte intrekt. Officier van justitie B: "Een aanklacht is natuurlijk van belang omdat dat een steunbewijs oplevert. Maar als zij dat heeft gedaan en zij trekt het in dan heb je die verklaring. Als het later ingetrokken wordt maakt het niet veel verschil voor de bewijsvoering en voor de strafmaat maakt het helemaal niks uit. De zaak blijft even ernstig.(..) Nou, het is niet waar wat ik daarnet zei. Het maakt in zoverre wel iets uit dat als zij hem intrekt, zij kennelijk aangeeft het met hem verder te willen proberen. Als zij het (het aangeven, KL) handhaaft, zou het kunnen aangeven dat ze van hem afwil. Dat geeft je iets meer ruimte in de strafmaat." Bij twee officieren van justitie 
wordt de kans groter dat ze een gesprek met het slachtoffer willen. Officier van justitie F: “(...) verder ben ik geneigd om eerst met het slachtoffer te praten en dan met de verdachte over hoe het nu verder gaat. Als ze bij elkaar zijn, is dat voor mij een heel belangrijk criterium, heb ik gemerkt."

Het lijkt erop dat het voortduren van de relatie belangrijker is dan het wel of niet intrekken van de aangifte, hoewel het intrekken van de aangifte er wel toe kan bijdragen dat er sneller wordt geseponeerd of een voorwaardelijke straf wordt geeist.

In het algemeen lijken officieren van justitie veel waarde te hechten aan het voortduren van de relatie nadat aangifte van geweld is gedaan. Maar de afweging van dit aspect tegen andere aspecten van de casus is voor officieren van justitie verschillend.

\section{Lianne en Dick: inbreuk op de privacy}

Lianne heeft vijf jaar met Dick samengewoond en heeft samen met hem een dochtertje, als ze besluit om met hem te breken omdat hij vaak dronken is, wat gepaard gaat met agressie en vernielen van huisraad. Op een avond belt hij met een dronken kop net zo lang aan totdat Lianne de deur opendoet. Hij gaat naar binnen. Als even later een wederzijdse vriend binnenkomt, wordt hij razend en vernielt de televisie. Lianne doet aangifte en stelt zich benadeelde partij.

Alle officieren van justitie zijn het erover eens dat de schade vergoed moet worden. Er zijn officieren van justitie die besluiten tot het aanbieden van een voorwaardelijke transactie met als voorwaarde dat de schade wordt vergoed. Anderen seponeren met als voorwaarde schade vergoeden. Weer anderen brengen de zaak voor de politierechter en eisen een (gedeeltelijk) voorwaardelijke boete of een voorwaardelijke gevangenisstraf met schadevergoeding als voorwaarde. Belangrijk is dan wel dat het slachtoffer op de zitting komt. Officier van justitie D: "Als zij de schade vergoed wil hebben, dan roepen we haar meestal op als benadeelde partij en als ze dan komt dan doen we er wat aan en als ze niet komt dan gaat het over. Meestal komen ze niet."

De officieren van justitie die besluiten te transigeren, zien deze zaak als een gewone vernielingszaak waar met name het schadebedrag van belang is. Officier van justitie B: "Als de kern van de zaak alleen maar gaat om de vernieling die hij heeft gepleegd ten aanzien van een tv, maar niet om alles wat zich in het verleden heeft afgespeeld omtrent zijn agressiviteit en overige vernielingen (...), die zijn dus niet aan de orde, dan zou ik zeker zeggen dat er geen sprake zou zijn van andere bemoeienis dan de transactie. Ik zal een transactie opleggen van iets meer dan $f 400$,- als hij ten minste een vermogens- en inkomenspositie heeft die voldoende is." De andere officieren van justitie willen dat het lastigvallen stopt. Om dit te bereiken zal de éen Dick eens flink willen onderhouden over zijn gedrag op de 
zitting, de ander wil een reclasseringsrapport en aan de hand van het rapport bepalen wat er verder moet gebeuren en weer een ander opteert voor snelrecht. Officier van justitie E: "Eerst moet de schade worden vergoed en het moet ook zo zijn dat hij daar nooit meer op de stoep komt. Zeker niet 's avonds en zeker niet buiten een eventuele omgangsregeling om. Dat moet afgetimmerd worden en verder maakt het me niet zoveel uit. Het zou mogelijk zijn, maar dat hangt af van de indruk die ik heb van die vent, en ook van die vrouw, wat zij wil, je zou dus die voorwaarden kunnen stellen, schade vergoeden en daar niet meer komen behalve in het kader van de omgangsregeling, anders ga ik alsnog vervolgen. Als je dit iets te slap vindt, kan je zeggen dat de rechter dat moet opleggen. Maar verder niet." Officier van justitie F zegt: "De schadevergoeding is het belangrijkste punt, dat zal eerst geregeld moeten worden. Maar op zichzelf zal deze zaak wel naar de politierechter gaan, op korte termijn denk ik. Ik zit zelfs te denken aan snelrecht."

Vervolgens heb ik een aantal aspecten van de casus gewijzigd. Eerst heb ik de wijze waarop Dick binnenkomt, gewijzigd; Dick forceert de deur met een hamer, beitel en schroevedraaier. Alle officieren van justitie beschouwen dit als strafverzwarend en achten de kans groot dat de zaak voor de politierechter wordt gebracht. Sommige officieren van justitie benadrukken dat het element huisvredebreuk erbij is gekomen en anderen benadrukken meer de bedreiging die ervan uitgaat. Officier van justitie E: "Daarmee forceert hij de deur, dan is er natuurlijk ook meer schade. Als hij zo naar binnen knalt, de vrouw is alleen thuis en het meisje ligt te slapen, dan krijg je een heel ander verhaal. Je krijgt een andere aangifte, er komt een bedreiging bij en dan gaat het voor mij een heel stuk naar boven toe. Dan kan het wel weer inzakken en waar ik dan precies uitkom dat weet ik niet. Dat hangt van het naspel af. Het is wel een relevante factor en ik zal dan sneller vervolgen." Officier van justitie F vindt zelfs dat Dick aangehouden en vastgezet moet worden. "Als hij zo probeert binnen te komen, dan bak ik er bedreiging van, dat red ik wel. Ik hoop dat de politie me dan belt en hem vasthoudt. Dan laat ik hem voorgeleiden."112

Vervolgens is het aspect van het alcoholisme gewijzigd; Dick is geen alcoholist meer. Deze wijziging in de casus heeft weinig invloed op de beslissing van de officieren van justitie. In het geval dat Dick geen alcoholist is, maar Lianne wel lastig valt, wordt over het algemeen door de officier van justitie de zaak op dezelfde wijze afgedaan. Officier van justite A: "Dat alcoholprobleem is vooral van belang om te kijken of hij moet worden begeleid door het CAD. Dat is een fijn concreet probleem. Als je dat aanpakt, is een aantal andere problemen ook uit de wereld.

112 De resultaten van het dossieronderzoek geven niet de indruk dat de politie in geval van vernieling en/of huisvredebreuk de officier van justitie direct informeent. 
Als hij haar alleen maar lastig valt, dan moet daar toch ook wat aan worden gedaan."

Het derde aspect dat ik veranderde, is de voeging als benadeelde partij. Wanneer Lianne zich niet voegt als benadeelde partij, vervalt voor sommige officieren van justitie de voorwaarde van het betalen van een schadevergoeding, zonder dat er iets verandert aan de rest van hun beslissing. Voor andere officieren van justitie is het een reden om de politie op Lianne af te sturen met de vraag hoe het nu gaat en of ze de schade vergoed wil hebben. Officier van justitie E: "Dan vraag ik me af waarom niet en dan laat ik de politie vragen waarom niet. Misschien wil ze ook geen geld meer van hem hebben. Zonder meer hem verplichten te betalen, lijkt me ook wat bot."

Het verhogen van het schadebedrag naar minimaal 2500 gulden, het vierde aspect, heeft voor sommige officieren van justitie consequenties voor de hoogte van de schadevergoeding die moet worden betaald. Officier van justite A: "Dan wordt het sparen (...). Verder hetzelfde." Voor andere officieren van justitie kan het ertoe leiden dat in plaats van onder voorwaarde te seponeren, de zaak naar de politierechter gaat, zcker als de verdachte het schadebedrag niet kan betalen. ${ }^{113}$ Officier van justitie B: "Ja, dat is een fiks bedrag. Als hij dat kan betalen dan kun je zeggen ik blijf een voorwaardelijk sepot handhaven. Wordt het problematisch dan denk ik dat je naar de rechter moet en dat dan een straf moet worden opgelegd waarin je als officier niet bevoegd bent. Ik vind dat Dick die schadevergoeding helemaal moet betalen. Als hij dat niet kan, moet er een andere sanctie komen en dan moet hij naar de rechter."

Tot slot is het gedrag van Dick gewijzigd; hij vergoedt de schade uit zichzelf. Door de schade uit zichzelf te vergoeden, doet Dick volgens de officieren van justitie een goede daad. De kans op een sepot is daarmee aanmerkelijk vergroot. Maar het betekent niet dat de meeste officieren van justitie de zaak met een kaal sepot willen afdoen. Het betalen van de schadevergoeding is niet voldoende voor de meeste officieren van justitie omdat men wil dat het lastig vallen van Lianne ophoudt. Er zijn er die Dick op het parket willen onderhouden of wanneer het incident al lang geleden is, de politie erop afsturen. Er is een officier van justitie die zich duidelijk uitspreekt om Dick ook dan te dagvaarden. Officier van justitie D: "(...) als hij erg vervelend is en uit de reclasseringsrapportage, die ik in dit geval wel zou aanvragen, blijkt dat het een heel vervelende man is, dan een maand, waarvan twee weken voorwaardelijk. Zoiets. Het gaat erom wat die Dick voor een vent is."

113 Je ziet hieraan dat mensen die fikse schadevergoedingen kunnen betalen, minder snel worden gedagvaard. 
Het vergoeden van de schade door Dick wordt als belangrijkste aspect naar voren gebracht door de officieren van justitie. Wanneer Dick met een beitel en hamer binnenkomt, lijkt de kans op vervolgen (sterk) te worden vergroot. Daarnaast wordt het aspect van de privacyschending naar voren gebracht.

\section{Anneke en Martin: verkrachting door de ex-partner}

Anneke, 21 jaar, gaat samenwonen met Martin, 40 jaar, omdat ze zwanger is van hem. Het drankgebruik en het daarmee gepaard gaande geweld tegen Anneke wordt frequenter en na een jaar gaan ze uit elkaar. Martin blijft Anneke lastig vallen. Er komt een omgangsregeling en hij mag alleen 's ochtends langskomen. Op een nacht belt hij aan en uiteindelijk laat Anneke hem binnen en mag hij op de logeerkamer slapen. Nadat hij koffie heeft gedronken en zij hem naar de logeerkamer heeft gebracht, loopt hij achter haar aan, smijt haar op haar bed en verkracht haar. Als hij is klaargekomen, belt hij zelf de politie en erkent de verkrachting.

De meeste officieren van justitie gaan ervan uit dat Martin in voorlopige hechtenis is genomen en vragen minimaal een reclasseringsrapport aan. Vaak vorderen officieren van justitie bij de rechter-commissaris ook een deskundigenrapport van een psychiater. Alle officieren van justitie besluiten deze zaak aan te brengen bij de meervoudige kamer en eisen een gevangenisstraf van minimaal een jaar tot maximaal twee jaar. De hoogte van de straf wordt beïnvloed door het gedrag van Martin, waar ze nu te weinig van weten. Als hij schuldbewust is en in therapie wil, zal de straf een stuk lager zijn dan als hij niets wil. Officier van justitie A loopt een aantal factoren langs die de beslissing beïnvloeden: "Strafblad, mishandeling, zware mishandeling, ik zou een jaar gevangenisstraf vorderen. Ik zat nog even te twijfelen of een deel voorwaardelijk zinnig zou zijn en dan zou ik vijftien maanden gevangenisstraf, waarvan vijf maanden voorwaardelijk eisen. Maar gelet op de documentatie en het vonnis voor mishandeling, ja dan denk ik niet dat een voorwaardelijke straf hem van dit soort dingen weerhoudt. Daar zijn andere dingen voor nodig, zoals behandelingsmogelijkheden, maar ervan uitgaande dat daar geen sprake van is, is het een kwestie van de straf geven die hij verdient en dan houdt het daarmee op."

Vervolgens zijn een aantal aspecten in de casus gewijzigd. Allereerst is de bekenten is van Martin veranderd in een ontkenning. Als Martin ontkent dat hij Anneke heeft verkracht en ontkent dat hij bij haar op bezoek is geweest, wordt het bewijs van verkrachting eerder aangenomen dan als Martin ontkent dat hij haar heeft verkracht, maar verklaart dat Anneke vrijwillig met hem naar bed is geweest. Officier van justitie A: "In het eerste geval is voldoende bewijs aanwezig, zijn leugenachtige verklaring kan tegen hem gebruikt worden. In het tweede geval vind ik het bewijs heel twijfelachtig, dan zit het echt op de overtuiging. Het wettig bewijs is er, maar of de overtuiging er is, hangt af van de manier waarop de vrouw het heeft verwoord 
en waarop de man het heeft verwoord. De manier waarop de politie het aantreft, speelt ook een rol." Wanneer Martin verklaart dat zij vrijwillig met elkaar naar bed zijn geweest, wordt het bewijs voor verkrachting sterker geacht door de officieren van justitie als beddegoed of kleding kapot is gescheurd, en als er sporen zijn van geweld, zoals krabsporen op Martin of blauwe plekken bij Anneke. Anders is het al snel een één-één verklaring met matig steunbewijs, bestaande uit de buurvrouw die getuige is van het feit dat Anneke geheel overstuur is. De ene officier van justitie zal sneller de overtuiging hebben dan de andere. Volgens officier van justitie B is er ook voldoende bewijs als Martin zegt dat Anneke vrijwillig met hem naar bed ging: "Nou dat verandert niks aan de verdenking en de bezwaren. Het blijft verkrachting. De gemeenschap kan niet ontkend worden gelet op het sporenonderzoek. Je hebt het wettig bewijs al, alleen het overtuigende ontbreekt. Maar die buurvrouw die allerlei ellende heeft gehoord, dat draagt bij tot het steunbewijs dat er meer is geweest dan alleen maar gemeenschap, ook bedreiging en zo. De eis is hetzelfde. De beslissing omtrent voorgeleiding en dagvaarding is ook dezelfde. En het blijft verkrachting."

Vervolgens heb ik in de oorspronkelijke casus de leeftijd van Martin en het alcoholgebruik gewijzigd; Martin is nu 27 jaar en heeft geen alcoholproblemen. Deze verandering in de casus heeft bij sommige officieren van justitie geen invloed op de oorspronkelijke beslissing. Voor andere officieren van justitie heeft deze wijziging een strafverminderende invloed; zij zullen een deel voorwaardelijk eisen en/of een lagere gevangenisstraf, maar de ondergrens blijft een jaar gevangenisstraf. Officier van justitie E: "Hij heeft dan geen vorige vrouw gehad, dat heeft deze man wel, die heeft al een vrouw gehad die in een Blijf van m'n Lijfhuis heeft gezeten. Die is dus echt onverbeterlijk in mijn ogen. Die jongen van 27 , die is misschien nog niet verloren en misschien dat dat een andere nuance nog met zich mee zou kunnen brengen in de zin van wel preventieve hechtenis, wel echt goed voelen van dit is echt de limiet, je hebt een verkrachting gepleegd. Misschien dat er uit zou kunnen komen iets van vijftien maanden, waarvan vijf voorwaardelijk. Dus iets geplooider, iets minder lang zitten."

Tot slot heb ik wijziging aangebracht in de relatie tussen Martin en Anneke. Anneke is 40 jaar en is herhaaldelijk mishandeld en bedreigd tijdens haar huwelijk (een 'klassiek geval van vrouwenmishandeling'). Uiteindelijk vraagt ze een echtscheiding aan.

Deze wijziging heeft een strafverminderende invloed op de beslissing van de officieren van justitie; allemaal eisen ze een groter deel voorwaardelijke gevangenisstraf, bijvoorbeeld in plaats van achttien maanden gevangenisstraf, achttien maanden gevangenisstraf waarvan zes voorwaardelijk. Officier van justitie E geeft daar een reden voor. "Waar ik wel mee zit, er is een hele lange relatie geweest, want dit is zijn eerste vrouw. Dan heb ik, zonder het op én punt goed te praten, maar je hebt 
natuurlijk toch het idee van (...), die voorgeschiedenis is zo lang, dat ze wel een relatie hadden, die cesuur is zo kort geleden, die schaduw van de relatie is nog zo sterk op een of andere manier (...), hoe vaak zal hij haar zo gepakt hebben toen ze nog niet uit elkaar waren of nog wel getrouwd waren, ik noem maar iets hè? Zou het aspect aan hem leren dat Schluß nu ook echt Schluß betekent, zou dat niet ook belangrijk moeten zijn om uit te drukken in een eventuele sanctie? Snap je? Ook hier zal ik misschien eerder nog geneigd zijn, met uitdrukking aan hem en als doelstelling 'doe het nooit weer' iets meer te nuanceren omdat ze zo lang bij elkaar zijn geweest en nog zo kort uit elkaar zijn. Ik zou hier meer zitten in de situatie van de jongen van 27 , iets in die geest, dus vijftien maanden, waarvan vijf voorwaardelijk."

Voor twee officieren van justitie betekent deze wijziging dat de bedreiging die uitgaat van Martin, op de voorgrond treedt. Door een straatverbod als voorwaarde te eisen willen ze de vrouw meer bescherming bieden. Officier van justitie F: "De nieuwe situatie is qua zitten, qua strafhoogte voor mij niet zo verschillend, maar dan heb je natuurlijk een extra reden om iets voorwaardelijks te doen. Een bijzondere voorwaarde als een straatverbod of een stadverbod of wat dan ook. Hij krijgt in elk geval een half jaar extra voorwaardelijk met wat bijzondere voorwaarden. Zij leeft in angst dus ik moet ervoor zorgen dat hij niet bij haar in de straat komt, of de wijk, of de stad."

Alle officieren van justitie beschouwen verkrachting door een ex-partner als een ernstig misdrijf. Zij besluiten allemaal de verkrachtingszaak aan te brengen bij de meervoudige kamer en vorderen een gevangenistraf van minimaal een jaar en maximaal twee jaar. ${ }^{114}$

\section{Drie manieren van optreden}

Aan de hand van drie concrete zaken is gepraat over de vervolgingsbeslissing die een officier van justitie kan nemen. De meest uiteenlopende antwoorden zijn gegeven over de afhandeling van de mishandelingszaak, ook wel het klassieke geval van vrouwenmishandeling genoemd. Hier kunnen drie manieren van optreden worden onderscheiden: (1) geen of een terughoudend strafrechtelijk optreden, gemotiveerd door de veronderstelling dat strafrechtelijk optreden alleen zin heeft als de relatie wordt verbroken; (2) een of andere vorm van hulpverlening vooropstellen, in eerste instantie via een sepot onder voorwaarden en in tweede instantie, als het letsel heel ernstig is, een voorwaardelijke straf eisen en (3) strafrechtelijk optreden in de zin van de rechter inschakelen en afhankelijk van de ernst van het

114 Binnen het arrondissementsparket vindt overleg plaats over verkrachtingszaken, waardoor cen meer gelijkgestemd oordeel over dit soort zaken tot stand kan komen. Bouw e.a., Samen tegen sexueel geweld, 1990: 112-113. 
geweld alleen een voorwaardelijke straf of ook een gedeelte onvoorwaardelijk straf eisen. Als voorwaarde kan een vorm van hulpverlening worden geëist. Deze driedeling - terughoudend optreden, hulpverlening, strafrechtelijk optreden - is bij de afhandeling van de vernieling/huisvredebreukzaak niet te constateren. Bij de besluitvorming omtrent de verkrachtingszaak is deze driedeling in optreden te constateren in de formulering van de strafeis; de ene officier van justitie legt de nadruk op een voorwaardelijke straf, de ander legt de nadruk op hulpverlening en de derde officier van justitie legt de nadruk op strafoplegging door de rechter.

Het afwegingsproces van officieren van justitie is in de ene vrouwenmishandelingszaak complexer dan in de andere vrouwenmishandelingszaak. In het geval van de 'klassieke vrouwenmishandeling' is het afwegingsproces het meest gecompliceerd en zijn de beslissingen van de officieren van justitie het meest gevarieerd. Het voortduren van de relatie en het intrekken van de aangifte vergroot de kans op een sepot of een voorwaardelijke straf, terwijl de ernst van het letsel en het hebben van een strafblad op geweldpleging leidt tot sneller vervolgen. Alcoholisme is een reden om hulpverlening als voorwaarde te stel len. Wanneer de vrouwenmishandeling een vernielingszaak betreft in de zin van de ex die de vrouw blijft lastigvallen, dan is het afwegingsproces veel simpeler; er is schade geleden en die moet worden vergoed. Wanneer de officier van justitie de dreiging waaronder de vrouw leeft, erkent, wordt bovendien gezocht naar een manier om het lastigvallen door de man te stoppen. Alcoholisme van de verdachte kan ertoe bijdragen dat de officier van justitie hulpverlening als voorwaarde stelt. Wanneer de vrouwenmishandeling een verkrachtingszaak betreft, dan stemt het afwegingsproces van de officieren van justitie vrijwel overeen: als de gewelddadige geslachtsgemeenschap is te bewijzen, dan wordt strafrechtelijk ingegrepen en een eis van een jaar is het minimum. De ernst van het geweld, de verklaring van de verdachte, de voorafgaande relatie, de leeftijd en alcoholgebruik kunnen wel meespelen in de hoogte van de eis die wordt gesteld en de grootte van het voorwaardelijke deel, maar lijken niet van invloed op de beslissing of zal worden vervolgd of niet.

\subsection{Samenvatting en knelpunten}

Vrouwenmishandeling wordt meestal door het openbaar ministerie geseponeerd, in elk geval vaker dan andere gevallen van geweld, zo was de veronderstelling. Zowel de sepotgrond 'beperkte kring', als onderzoek naar het sepotbeleid in de jaren zeventig, als bevindingen van de 'Blijf van m'n Lijfbeweging' geven grond voor deze verwachting. Deze veronderstelling wordt niet door het onderzoek bevestigd. De resultaten van het kwantitatieve dossieronderzoek geven aan dat het vervolgingsbeleid ten aanzien van zaken van vrouwenmishandeling niet afwijkt van het vervolgingsbeleid ten aanzien van de andere geweldsdelicten. 
Een nadere analyse van 150 zaken van vrouwenmishandeling uit 1985 geeft meer inzicht in hoe het openbaar ministerie zaken van vrouwenmishandeling afdoet, zowel per arrondissementsparket, als naar delictscategorie. De cijfers van de vervolgingspraktijk naar arrondissementsparket laten zien dat het arrondissementsparket Breda zaken van vrouwenmishandeling over het algemeen buitengerechtelijk afdoet, terwijl dit niet geldt voor de arrondissementsparketten Rotterdam en Assen. Een vergelijking naar delictscategorie laat zien dat de delicten vernieling/huisvredebreuk en mishandeling/bedreiging het meest voorkomen. Geconstateerd kan worden dat vrouwenmishandelingszaken die onder de categorie vernieling/huisvredebreuk vallen, vaker worden gedagvaard dan zaken van vrouwenmishandeling die onder de categorie mishandeling/bedreiging vallen.

Vervolgens is onderzocht of bij aanwezigheid van een bepaald aspect vaker wordt vervolgd dan zonder aanwezigheid van dat aspect. Bovendien is de mening van officieren van justitie hierover onderzocht aan de hand van interviews. Uit het dossieronderzoek blijkt dat verdachten met een strafblad vaker worden gedagvaard dan verdachten zonder strafblad, verdachten die onder invloed van alcohol zijn, worden vaker gedagvaard dan verdachten die niet onder invloed zijn, en verdachten die jonger zijn dan 30 jaar worden vaker gedagvaard dan verdachten die ouder zijn. Deze aspecten staan overigens niet los van elkaar. De officieren van justitic benadrukken dat speciale recidive de kans op dagvaarden vergroot en dat niet zozeer alcoholisme de kans op dagvaarden vergroot, als wel het recidivegevaar dat door alcoholisme kan worden veroorzaakt. Naast deze algemene aspecten is de invloed van aspecten die specifiek vrouwenmishandeling betreffen, onderzocht. Uit het dossieronderzoek komt naar voren dat het openbaar ministerie geweld tegen de vrouw door de ex-partner hetzelfde afdoet als geweld tegen de vrouw door de partner (in beide gevallen wordt iets vaker gedagvaard dan geseponeerd om redenen van opportuniteit). Maar als de vrouw de relatie verbreekt nadat zij aangifte heeft gedaan van geweldpleging, dan lijkt de kans op dagvaarden aanmerkelijk te zijn vergroot. Ook de officieren van justitie zijn het erover eens dat eerder wordt vervolgd als de relatie wordt verbroken. Het voortduren van de relatie kan voor officieren van justitie reden zijn om zelfs bij (zeer) ernstig geweld niet-sanctionerend op te treden. Het tweede aspect betreft herhaald, structureel, geweld tegen de vrouw. Wanneer sprake is van structureel geweld wordt de zaak niet vaker gedagvaard dan bij incidenteel geweld. Ook uit de interviews komt niet naar voren dat herhaald geweld tegen de vrouw de kans op dagvaarden vergroot. Herhaald, eenzijdig geweld tegen de vrouw lijkt door officieren van justitie soms te worden geïnterpreteerd als wederzijds geweld; de vrouw wordt medeverantwoordelijk geacht voor het geweld dat tegen haar wordt gepleegd. Dit kan ertoe leiden dat de zaak op grond van 
'medeschuld slachtoffer' wordt geseponeerd. ${ }^{115}$ Deze zienswijze kan bovendien een rol spelen in de beoordeling van verkrachting door de ex-partner; als de vrouw jarenlang in haar huwelijk is mishandeld en gedwongen tot seksuele gemeenschap, kan de man moeite hebben om in te zien dat het nee van de vrouw ook werkelijk nee is. ${ }^{116}$ Deze zienswijze hoeft overigens niet te leiden tot een beleidssepot. Andere aspecten, zoals ernstig letsel, een hoog schadebedrag, of een strafblad van geweldszaken kunnen de officier van justitie doen besluiten de verdachte te dagvaarden.

Het afwegingsproces van officieren van justitie is weergegeven aan de hand van drie voorbeelden van vrouwenmishandeling. Uit de beschrijving van het afwegingsproces komt een beeld naar voren van een 'magistratelijke' aanpak, een onpartijdige belangenafweging naar eer en geweten door officieren van justitie. Het dossieronderzoek bevestigt dit beeld niet. Veel zaken van vrouwenmishandeling die in de categorie mishandeling en vernieling/huisvredebreuk vallen, komen niet op het bureau van de officier van justitie terecht omdat de parket-secretaris de zaak afdoet. De informatie in de dossiers geeft de indruk dat op grond van een aantal eenduidige feiten de beslissing wordt genomen, bijvoorbeeld een gebroken ruit, de verdachte erkent, dus wordt een transactie aangeboden of gaat een dagvaarding uit. De achtergronden van het gepleegde feit komen daarbij niet aan bod. De nadruk ligt meer op een efficiěnte manier om de grote hoeveelheid dossiers af te handelen. Dit kan worden geduid als een aanpak van de 'werker': "Het gaat de werker niet primair om het vaststellen van de materiële waarheid, maar om het verkrijgen van een bewijsvoering die door de rechter voldoende wordt bevonden." 117

Uit dit exploratieve onderzoek komen een drietal knelpunten naar voren in de toepassing van de strafrechtelijke mogelijkheden door het openbaar ministerie in geval van vrouwenmishandeling.

Allereerst de problematiek van geweld binnen een relatie die voortduurt nadat de vrouw aangifte heeft gedaan. Hier komt de spanningsverhouding tussen het recht op privacy als actief recht dat strafrechtelijke bescherming verdient door de overheid en het recht op privacy als passief recht dat een terughoudende overheid impliceert als het de privésfeer betreft, het meest pregnant naar voren. Zaken van geweld tegen de vrouw door haar partner komen overigens niet vaak op het arrondissementsparket binnen. Als vrouwen al de politie inschakelen, zal de politie doorgaans de vrouwen niet stimuleren aangifte te doen, zeker niet zolang de relatie voortduurt. Alle

1 Is Een voorbeeld van de zienswijze dat de vrouw medeverantwoordelijk is voor het geweld, is het artikel van Ter Heine, Gewelddadigheid in huwelijk en gezin, $D D$, 1995: 943-955.

116 Deze opvatting over herhaald geweld tegen de vrouw zou als verklaring kunnen dienen voor het feit dat zaken van structureel geweld tegen de vrouw niet vaker worden vervolgd dan vrouwenmishandelingszaken waar sprake is van incidenteel geweld.

117 Van de Bunt, Officieren van Justitie, 1985: 185-240 (citaat p. 189). 
officieren van justitie stellen zich terughoudender op als het geweld plaatsvindt binnen een bestaande relatie die voortduurt na het doen van aangifte. Als sanctionerend wordt opgetreden, zal dit eerder in de sfeer van de voorwaardelijke sancties liggen. De crux in dit soort zaken is een goed inzicht in de ernst van de geweldsproblematiek. Het lijkt erop dat lang niet altijd op grond van de processen-verbaal de ernst van het geweld kan worden beoordeeld, omdat de processen-verbaal focussen op het incident waarvan aangifte is gedaan. Maar zelfs als de ernst van het geweld goed kan worden ingeschat door politie en openbaar ministerie, is de vraag hoe het beste strafrechtelijk kan worden opgetreden en op welke manier de rechtsbescherming van het slachtoffer vorm kan worden gegeven, niet makkelijk te beantwoorden. Een terughoudend optreden door politie en openbaar ministerie als het geweld in de privésfeer betreft, gebaseerd op de opvatting dat de vrouw eerst weg moet gaan bij de man die geweld pleegt, gaat voorbij aan de complexe emotionele en sociale afhankelijkheid en de machtsdynamiek binnen de relatie. Tegelijkertijd wordt met zo'n reactie niet de man verantwoordelijk gesteld voor het geweld dat hij pleegt, maar ligt de nadruk op het handelen van de vrouw; zij moet weggaan. Bovendien wordt voorbijgegaan aan het feit dat weggaan geen garantie is voor het stoppen van het geweld; juist tijdens (echt)scheidingsprocedures kan het geweld hoog oplaaien en dit kan zelfs leiden tot de dood van de vrouw (en haar kinderen). Deze geweldplegingen na het verbreken van de relatie wordt 'separation assault' genoemd. Een terughoudende reactie op grond van voorgaande standpunt is daarom niet in het belang van het slachtoffer. Toch kan een terughoudende reactie gewenst zijn om te voorkomen dat de vrouw ongewenst wordt meegezogen in een strafrechtelijke procedure die noch het stoppen van het geweld tot gevolg heeft, noch andere voor de vrouw positieve gevolgen heeft. Een terughoudende opstelling hoeft niet tegen het belang van slachtoffers van vrouwenmishandeling in te gaan. Het gaat om de argumenten waarop de terughoudendheid is gebaseerd.

Het tweede knelpunt betreft het privacy-schendende gedrag van de ex-partner, het zojuist genoemde 'separation assault'. Ik heb de indruk, uit zowel de gesprekken, als uit het dossieronderzoek, dat veel zaken van vernieling/huisvredebreuk niet als een (zeer) bedreigende situaties voor de vrouw worden herkend, noch door de politie, waardoor de zaak niet tijdig aan de officier van justitie wordt gemeld, noch door de officier van justitie. ${ }^{118}$ Voor officieren van justitie maakt het bijvoorbeeld een groot verschil of de deur wordt geforceerd, of dat de vrouw zelf de deur opendoet, terwijl dit verschil voor vrouwen niet hoeft te gelden. Vrouwen kunnen de deur uit angst open doen; het zelf opendoen is in dat geval een teken van enorme bedreiging. Ook vernielingen kunnen voor vrouwen zeer bedreigend zijn, terwijl officieren van justitie vooral oog lijken te hebben voor de schade die is aangericht.

118 In veel gevallen zal de parketsecretaris deze zaak in eerste instantie afhandelen. En dan hangt het van de wijze van delegeren af of de officier van justitie de door hel parketsecretariaat geseponeerde zaak nog onder ogen krijgt. 
Zaken van vrouwenmishandeling die onder de categorie vernieling/huisvredebreuk vallen, worden vaker gedagvaard dan met een beleidssepot afgedaan. Toch hoeft het dagvaarden van de verdachte niet de meest adequate reactie te zijn. Vrouwen zullen doorgaans behoefte hebben aan een snelle reactie zodat het geweld en de dreiging stoppen, 'safety first'. Een boete of voorwaardelijke gevangenisstraf een jaar na de aangifte zal weinig bijdragen aan de veiligheid van de vrouw.

Het derde knelpunt betreft verkrachting binnen een relatie of door de ex-partner. Uit dit onderzoek blijkt dat (in 1985) geen zaken van verkrachting binnen bestaande relaties door de politie naar het arrondissementsparket zijn doorgestuurd. $\mathrm{Nu}$ verkrachting binnen het huwelijk strafbaar is, kan daar verandering in komen. ${ }^{119}$ De verkrachting staat vaak niet op zichzelf, maar past binnen een patroon van dominantie en geweld door de man. Het juridische probleem betreft de dwang waardoor de vrouw tegen haar wil seksuele handelingen ondergaat of uitvoert. Wanneer de man zegt dat het een vrijwillige 'vrijage' is, en de vrouw zegt dat zij is gedwongen tot seksuele gemeenschap of andere seksuele handelingen, kan alleen voor verkrachting worden veroordeeld als naast de verklaring van de vrouw voldoende ondersteunend bewijs is voor de dwang. Bovendien kan eerder geweld binnen de relatie de overtuiging van de officier van justitie beïnvloeden; het geweld tegen de vrouw kan door het niet weggaan van de vrouw worden geïnterpreteerd als medeverantwoordelijkheid van de vrouw aan het geweld. Deze zienswijze kan afbreuk doen aan de bescherming van het seksuele zelfbeschikkingsrecht van vrouwen.

Deze drie knelpunten duiden op een gebrek aan bescherming van de persoonlijke levenssfeer van vrouwen door het niet uitputtend gebruiken van de mogelijkheden die er zijn. Achtergrond hiervan kan zijn dat de ernst van het herhaalde geweld tegen de vrouw niet wordt onderkend. Ook de opvatting dat eenzijdig geweld wordt beschouwd als wederkerig geweld, waar man en vrouw een even grote verantwoordelijkheid in hebben, kan hieraan ten grondslag liggen.

119 In de jaren 1992 en 1993 zijn 9 aangiften van verkrachting binnen het huwelijk gedaan, waarvan in twee zaken de man en vrouw op hetzeifde adres woonden. In de andere zaken liep nasr waarschijnlijkheid een echtscheidingsprocedure. De Savomin Lohman e.a, Betere en adequate bescherming door de nieuwe zedelijkheidswetgeving?, 1994: 66. 


\section{Rechtsbescherming van slachtoffers}

"Bij de strafoplegging moet in het kader van de rechtsstaat worden uitgegaan van de rechtssubjectiviteit van iedere betrokkene, zowel van de verdachte of de veroordeelde als van het slachtoffer. Steeds gaat het om een juridisch gegarandeerde positie die gedacht moet worden als voorafgaand aan de uitwerkingen van het recht in allerlei positiefrechtelijke regels en procedures. (...) Want de betrekkingen tussen de staat en burgers zijn in een rechtsstaat steeds rechtsbetrekkingen en het respect (onderstreping, $K L$ ), dat inherent is aan de erkenning als rechtssubject, beperkt op voorhand de gerichtheid op doelmatigheid en doeltreffendheid bij het streven naar welke uitwerking, naar welk doel van de straf dan ook. Het ingrijpen in het conflict tussen slachtoffer en dader is, zoals gezegd, tot publieke zaak gemaak, getransponeerd van het private niveau naar dat van de politieke gemeenschap, waarbinnen door het ingrijpen met strafrecht en straf zowel dader als slachtoffer geintegreerd moeten blijven."

\subsection{Inleiding}

Vrouwen die slachtoffer zijn van geweld door hun partner of ex-partner doen aangifte om verschillende redenen, maar in elk geval om een grens te stellen: 'dit geweld pik ik niet (meer)'. ${ }^{2}$ Het doen van aangifte kan op menselijk niveau worden beschouwd als een manier om de machtsdynamiek ten gunste van de vrouw te veranderen. ${ }^{3}$ Juridisch beschouwd komt de vrouw op voor haar burgerschap en wenst bescherming van haar burgerlijke vrijheden. Rechtsbescherming kan worden geboden door bescherming van de persoonlijke levenssfeer van de vrouw; privacy als actief recht. Het creëren van veiligheid is een belangrijke voorwaarde voor het waarborgen van enige autonomie en het kunnen uitoefenen van burgerlijke vrijheden. Bescherming van de persoonlijke levenssfeer van de vrouw kan de weerbaarheid van de vrouw versterken. Het belang van het slachtoffer van vrouwenmishandeling is hiermee aangegeven: het creëren van veiligheid, strafrechtelijke afkeuring van

1 't Hart, Straf, recht en waarden, in: Hoe punilief is Nederland?, 1994: 35-36.

2 Wostmann, Politieoptreden bij vrouwenmishandeling, 1988: 87-90. Van der Ent \& Evers, Vrouwenmishandeling: een zorg voor de politie, 1996: 48; Ford, Prosecution as a victim power resource, Law \& Society Review, 1991: 322-323.

3 Ford, Prosecution as a victim power resource, Law \& Society Review, 1991: 318-320. 
geweld in de privésfeer, en versterking van haar weerbaarheid. Rechtsbescherming kan worden geboden als het slachtoffer van geweld door haar (ex-)partner als rechtssubject wordt erkend en haar recht op privacy binnen de samenlevingsvorm als actief recht wordt beschouwd.

Tegenwoordig wordt het slachtoffer erkend als rechtssubject in het strafproces. ${ }^{4}$ Slachtoffers van een misdrijf hebben recht op een zorgvuldige bejegening, tijdige en juiste informatie over het verloop van de strafzaak, en zonodig een gesprek met een officier van justitie. Bovendien behoort de officier van justitie in zijn beslissing hoe de zaak zal worden afgehandeld, rekening te houden met de wens tot schadevergoeding. De mogelijkheden om de schade vergoed te krijgen zijn bovendien verruimd door de invoering van de schadevergoedingsmaatregel en de verruiming van de bevoegdheid om als benadeelde partij een schadevergoeding te vorderen tijdens het strafgeding. ${ }^{5}$ Deze voorzieningen dragen bij aan een verbetering van de rechtsbescherming van het slachtoffer van geweld door haar (ex-)partner.

Rechtsbescherming van het slachtoffer van vrouwenmishandeling, bezien vanuit de relationele opvatting, omvat echter meer (zie hoofdstuk $1, \S 1.3$ ). Ten eerste is het van belang dat rechtsbescherming wordt geboden, niet alleen binnen een bepaald stelsel, maar ook tegen dat stelsel zelf. Dit betekent dat rechtsbegrippen niet als feitelijke begrippen, maar als contrafactische begrippen moeten worden opgevat. Op die manier wordt het geven van altematieve interpretaties een recht van de burger om zijn burgerschap te vindiceren. De versterking van de rechtsbescherming door een andere opvatting over mannelijk geweld tegen vrouwen in de privésfeer wordt behandeld in $\S 6.2$. Ten tweede betekent rechtsbescherming dat de burger wordt beschermd tegen machtuitoefening door de overheid. Hier wordt doorgaans de bescherming van de burger als verdachte en veroordeelde onder begrepen, maar je zou het breder kunnen opvatten en de rechtspositie van de burger in het strafproces ertoe kunnen rekenen. Dit betekent dat ook de burger in de hoedanigheid van getuige en benadeelde van een misdrijf rechtsbescherming dient te genieten. Door het creëren van rechten wordt inhoud gegeven aan de rechtssubjectiviteit van het slachtoffer in het strafproces. Dit wordt in $\S 6.3$ nader uitgewerkt. Tenslotte betekent rechtsbescherming dat de burger wordt beschermd tegen machtsmisbruik door andere burgers. Dit is tegelijkertijd het instrumentele aspect van de rechtshandhaving. De wijze waarop de politie en het openbaar ministerie gebruik maken van hun bevoegdheden als zij worden geconfronteerd met mannelijk geweld tegen vrouwen in de privésfeer kan hiertoe gerekend worden. Rechtsbescherming kan worden geboden door het nemen van strafrechtelijke maatregelen die in het algemeen tot doel hebben de rechtsvrede te dienen, en meer in het bijzonder, om herhaling van geweld te voorkomen (preventief optreden). Hoe dit optreden door politie en

4 Groenhuijsen, De landelijke invoering van de wet Terwee, Rechtshulp, 1995: 3.

5 In hoofdstuk 2, $\$ 2.5$ zijn de huidige slachtoffervoorzieningen beschreven. 
openbaar ministerie eruit zou kunnen zien als het gaat om mannelijk geweld tegen vrouwen in de privésfeer wordt in $\S 6.4$ behandeld. In $\S 6.5$ vat ik de mogelijkheden tot rechtsbescherming samen in de conclusie.

\subsection{De interpretatie van geweld tegen vrouwen nader bekeken}

Respect voor het slachtoffer van geweld door haar (ex-)partner als rechtssubject betekent dat haar verhaal wordt gehoord, en erkenning plaatsvindt van het geweld jegens haar. In deze $\S$ wordt ingegaan op de opvattingen die ten grondslag kunnen liggen aan de kwalificatie en het ernstoordeel van de feiten omtrent mannelijk geweld tegen vrouwen in de privésfeer. Eerst komt de problematiek van seksuele dwang binnen relaties en de bescherming van de wilsvrijheid aan de orde. Ik neem hiervoor het verkrachtingsarrest van 16 juni 1987 (NJ 1988, 156) als uitgangspunt, omdat aan de hand van dit arrest een aantal opvattingen over geweld en seksualiteit verduidelijkt kan worden. Tevens ga ik nader in op het inzichtvereiste. Vervolgens wordt nader ingegaan op de problematiek van fysiek geweld en beschenning van de persoonlijke levenssfeer.

\subsubsection{Seksuele dwang binnen relaties en bescherming van de wilsvrijheid}

Een belangrijk knelpunt in verkrachtingszaken is de dwang: wanneer kan wettig en overtuigend bewezen worden verklaard dat sprake is van dwang? Het middel tot de dwang moet zijn (bedreiging met) geweld of een andere feitelijkheid. Naast het bewijs van de middelen waarmee is gedwongen, moet bovendien worden bewezen dat de man het (voorwaardelijk) opzet heeft gehad de vrouw tegen haar wil tot seksuele handelingen te dwingen. ${ }^{6}$ Dit betekent dat dwingen naast het middel geweld of een feitelijkheid, eveneens inhoudt de wetenschap van de man dat de vrouw niet wil. Het inzicht van de man wordt op die manier als vereiste ingelezen in de delictsomschrijving (zie hoofdstuk 3, § 3.4.2). Dit kan betekenen dat een vrouw door het aangewende geweld seksuele handelingen ondergaat, maar omdat de man niet inzag dat zij niet wilde, wordt hij van verkrachting vrijgesproken.

\section{Opvattingen over gedwongen seks binnen een relatie}

Met het aangaan van een intieme (huwelijkse) relatie wordt doorgaans verondersteld dat ook een seksuele relatie is aangegaan. Door de verschillen in macht tussen mannen en vrouwen op maatschappelijk en individueel niveau, en het historisch gegroeide verschil in (gevoelde) rechten en plichten tussen mannen en vrouwen als 
het om seksualiteit gaat, is een gelijkwaardige seksuele relatie tussen man en vrouw geen vanzelfsprekendheid. Wanneer sprake is van seksuele dwang jegens de vrouw binnen intieme (huwelijkse) relaties, kan dit verschillende vormen aannemen, zoals sociale dwang, interpersoonlijke dwang, dwang door dreiging met geweld en dwang door geweld (zie hoofdstuk $2, \S 2.2 .3$ ) Alleen de laatste twee vormen van dwang kunnen worden beschouwd als dwang in de juridische betekenis van (dreiging met) geweld of een andere feitelijkheid. Maar het omslagpunt tussen sociale of interpersoonlijke dwang en dwang door (bedreiging met) geweld is niet altijd duidelijk te trekken, zeker niet omdat de beleving van de man, een 'hartstochtelijke of overmoedige vrijage', en de beleving van de vrouw, een 'gedwongen vrijpartij', ver van elkaar verwijderd kunnen zijn. ${ }^{7}$ Aan de hand van het verkrachtingsarrest uit 1987, dat de gemoederen onder juristen flink heeft verhit, ${ }^{9}$ zal ik de verschillende manieren van feiteninterpretatie toelichten. De casus: ${ }^{10}$

Op zondagochtend 27 januari 1985 komt verdachte (ik noem hem Celio) bij het slachtoffer (ik noem haar Gertrude) met wie hij sinds 1978 een buitenechtelijke relatie heeft. Gertrude is toendertijd gescheiden om met Celio een huwelijkse relatie aan te gaan. Celio kon maar niet kiezen tussen zijn echtgenote en Gertrude en dit leverde problemen op binnen de relatie. Gertude is een aantal keren verhuisd om aan de relatie met Celio te ontkomen, maar elke keer wist hij haar weer te vinden en putte zij hieruit de hoop dat hij uiteindelijk voor haar zou kiezen. Hun relatie wordt niet alleen gekenmerkt door ambivalentie, maar ook door geweldplegingen van Celio jegens Gertrude. Op de beruchte zondagochtend komt Celio onuitgenodigd bij Gertrude, hoewel hij zich wel heeft aangekondigd. De vrouw zegt: "Op de 27e kwam hij onuitgenodigd. Hij heeft wel tevoren opgebeld dat hij naar mij toe zou komen. Ik heb toen niet tegengestribbeld omdat dat toch niet hiclp: hij kwam en ging wanneer hem dat uitkwam, daarover had ik geen zeggenschap." "Het bezoek begint met het pakken van haar sleutels die hij vervolgens niet meer wil teruggeven. Na enige tijd wil hij met haar naar bed, en zij weigert. Tot hier komt het relaas van Gertrude overeen met dat van Celio. Volgens Gertrude pakte hij haar bij de bovenarmen, sleurde haar met geweld naar de slaapkamer en gooide haar op bed. Telkens als zij van het bed probeerde af te komen, gooide hij haar weer terug. Ook krabben sorteerde geen effect. Hij dreigde haar de armen te breken als ze bleef tegenwerken. Uiteindelijk staakte ze haar verzet. Na het gebeuren weigerde hij weg te

7 "Wij signaleren even de klassieke moeilijkheid, dat een 'overmoedige vrijage' kan worden omgedefinieerd in een zwaar misdrijf als de vrouw naderhand zegh dat zij niet heef gewild". HR 18 september 1978, NJ 1979, 105, conclusie van Remmelink.

8 HR 16 juni 1987, NJ 1988, 156.

9 De commotie ontstond niet alleen over het arrest van de HR die een uitpraak van het hof in stand hield. De commotic werd ook veroorzaakt door een artikel van Van Maarseveen in het NJB, waarin de raadsheren persoonlijk verantwoordelijk werden gesteld voor deze uitspraak. "Hun portretten verdienen in de galerij der gerechtigheid vooralsnog geen plaats." Van Maarseveen, Een arrest dat schoffeert $N J B, 1988: 820$. Reacties staan in $N J B, 1988: 1005-1017$.

10 De informatie heb ik gehaald uit de beschrijving van deze zaak met een commentaar in Ars Aequi. Basuw, Zuivere verkrachting?, AA, 1988: 575-586.

11 Verklaring van de vrouw bij het Hof, in: Baauw, Zuivere verkrachting?, AA, 1988: 579. 
gaan en na enige tijd herhaalde de gebeurtenis zich. De volgende ochtend, Celio is nog steeds bij Gertrude, vertrekt Gertrude en doet aangifte. Volgens Celio wilde zij na enig aandringen wel met hem naar bed. De krabwondjes zijn ontstaan omdat zij opeens begon te krabben toen hij bijna klaarkwam. Dat vond hij zo gemeen dat hij haar stevig vastpakte bij haar bovenarmen, waardoor blauwe plekken konden ontstaan. In een medisch rapport worden een negental kleine blauwe plekken op armen en benen van Gertrude geconstateerd. Bij Celio worden krabwondjes geconstateerd.

Celio wordt in verzekering gesteld en daama in voorlopige hechtenis. Op 8 maart 1985 wordt deze geschorst onder de bijzondere voorwaarde dat hij geen contact opneemt met Gertrude. De officier van justitie legt verkrachting ten laste en vordert anderhalf jaar gevangenisstraf (met aftrek van het voorarrest). De rechtbank acht het ten laste gelegde feit niet wettig en overtuigend bewezen. Het openbaar ministerie gaat in beroep; de rechtbank had op grond van de verklaring van het slachtoffer, de verdachte en de medische verklaringen wel tot een veroordeling kunnen komen. Met andere woorden, het technische bewijs is er en de officier van justitie acht het bewijs ook overtuigend. Het hof is die mening niet toegedaan en verenigt zich met de uitspraak van de rechtbank. Het hof motiveert dit: "Het hof is er niet eenstemmig van overtuigd dat na de jarenlange relatie tussen de verdachte en G.H.M.T., een proces van aantrekken en afstoten, de verdachte nog voldoende heeft kunnen doorzien dat G.H.M.T. op 27 jan. 1985 definitief de relatie met hem wilde verbreken en mitsdien geen vleselijke gemeenschap meer met hem wilde hebben."12 De procureur-generaal bij het hof stelt cassatie in het belang, van de wet in. De Hoge Raad oordeelt dat het (voorwaardelijk) opzet gericht moet zijn op de onvrijwilligheid, vervolgens dat het hof hierover niet eenstemmig overtuigd was en beslist tenslotte dat de procureur-generaal niet ontvankelijk is in zijn beroep nu het hof niet heeft "blijk gegeven de verdachte van iets anders vrij te hebben gesproken dan hem is telastegelegd". '3

Dit arrest heeft tot veel discussie geleid, zowel over de vraag of de Hoge Raad anders had kunnen beslissen nu de beslissing van het hof van feitelijke aard is, als over de vraag of deze uitspraak betekent dat vrouwen, die door hun partner met geweld worden gedwongen tot seksuele handelingen, vogelvrij zijn verklaard. Over beide aspecten zal ik kort zijn, omdat het mij meer gaat om de veronderstellingen over vrouwen en mannen die achter deze uitspraak schuil kunnen gaan.

Wat het eerste aspect betreft: van een vrijspraak kan de Hoge Raad casseren als sprake is van een verkeerde uitleg van een term in de telastlegging: de onzuivere vrijspraak (art. $430 \mathrm{~Sv}$ ). ${ }^{14}$ Daar was hier geen sprake van, aldus de Hoge Raad, nu dwingen is opgevat als opzettelijk tegen haar wil gemeenschap met haar

12 HR 16 juni 1987, NJ 1988, 156: 670.

13 lbidem. De Hoge Raad moet eerst beslissen of de procureur-generaal ontvankelijk is, aangezien het om een beroep tegen een vrijspraak gaat (art. $430 \mathrm{~Sv}$ ).

14 Van Bemmelen-van Veen, Ons Strafrecht 4, 1993: 403-407. 
hebben. ${ }^{15}$ Wat het tweede aspect betreft, zijn het met name Verrijn Stuart en Van Maarseveen die benadrukken dat deze uitspraak de deur weer wagenwijd openzet voor de opvatting dat binnen een relatie de man recht heeft op seks en dat dit desnoods met geweld kan worden afgedwongen. De op dat moment geldende uitzondering voor verkrachting binnen het huwelijk wordt uitgebreid naar alle relaties. ${ }^{16}$ Anderen benadrukken dat deze conclusie niet kan worden getrokken; de Hoge Raad kon niet anders dan het openbaar ministerie niet-ontvankelijk verklaren. De motivering van het hof is hoogst ongelukkig gekozen, maar het enige dat blijkt is dat in deze casus geen eenstemmigheid was bij het hof dat de man de vrouw willens en wetens had gedwongen tot gemeenschap. ${ }^{17}$ Naar mijn mening kan niet uit het arrest worden afgeleid dat mannen, desnoods met geweld, hun recht op seks binnen intieme relaties kunnen afdwingen. De motivering van het hof moet daarentegen tegen de achtergrond van herhaald geweld binnen een (ambivalente) relaiie worden beschouwd. Dit herhaalde geweld kan vanuit drie gezichtspunten worden beoordeeld: 1. tussen de man en de vrouw is een seksuele relatie waar geweld een onderdeel van is, 2 . door het herhaald voorkomen van geweld kon de man niet doorzien dat de seksuele gemeenschap 'tegen haar wil' was, en 3. de verkrachting van de man past binnen het patroon van dominerend en controlerend gedrag door de man waar de vrouw nauwelijks aan kan ontsnappen.

Wat het eerste gezichtspunt betreft: af en toe duikt de sado-masochistische relatie op. De procureur-generaal bij het hof wijst in zijn cassatieberoep op het aspect dat het jarenlange geweld in de relatie een gebruikelijke en voor beiden aanvaardbare omstandigheid zou kunnen zijn, maar dat "omtrent het in de relatie gebruikelijk zijn van toepassen van geweld niets wordt overwogen en daarvan ter terechtzitting ook niets is gebleken."18 Toch blijft dit aspect van een sado-masochistische verhouding doorzoemen; het lijkt moeilijk voorstelbaar dat, als er sprake is van geweld, de man toch niet kon inzien dat de vrouw niet wilde. In de kamerdebatten over het arrest komt de sado-masochistische relatie naar voren als bijzondere omstandigheid; in

15 Zie over de cassatietechniek betreffende dit arrest: Nijboer, Vrijspraak van verkrachting (HR 16 juni 1987, NJ 1988, 156) betreft een zuivere vrijspraak (van het Hof), NJB, 1988: 1010-1012; Baauw, Zuivere verkrachting?, $A A, 1988$ : 585-586; Van der Neut \& Wedzinga, Kritiek op arrest Hoge Raad raakt kant noch wal, $N J B, 1988$ : 1009-1010.

16 Van Maarseveen, Een arrest dat schoffeert, $N J B, 1988: 819$. Zie ook: Verrijn Stuart, Vrijspraak van verkrachting, Nemesis, 1988: 48.

17 Baauw, Zuivere verkrachting?, $A A$, 1988: 586. Mulder, Dwingen in de zin van $242 \mathrm{Sr}, N J B, 1988$ : 1009; Sjocrona, De verkrachting van een arrest?, $N J B, 1988$ : 1013-1014. Nijboer ziet het zelfs van de optimistische kant; de HR heeft nu expliciet uitgemaakt dat het voorwaardelijke opzet op de onvrijwilligheid voldoende is. Vrijspraak van verkrachting, $N J B, 1988$ : 1010-1012. De Roos stelt dat met de uitspraak van de Hoge Raad niet is beoogd potentiele verkrachters een vrijbrief te geven binnen min of meer vaste relaties, en mocht dit wel zo zijn dat dan de kwestie van de ongehoorzaamheid van lagere rechters direct acuut $z a l$ worden. Het effect van uitspraken van de Hoge Raad op de lagere rechtsprask en op de publicke opinie. $D D, 1988$ : 1014.

18 HR 16 juni 1987, NJ 1988, 156: 669. 
dat geval vloeit uit het geweld niet het (voorwaardelijk) opzet te dwingen voort (binnen die relatie). ${ }^{19}$ Ook De Jong in zijn commentaar op het arrest kan alleen aan sado-masochistische contacten denken: "veel andere dingen kan ik me althans niet voorstellen bij het door de Hoge Raad gemaakte voorbehoud". ${ }^{20}$ Remmelink stelt eveneens dat de Hoge Raad in dit arrest met de mogelijkheid van sadomasochisme rekening lijkt te houden. ${ }^{21}$ En de advocaat-generaal Leijten stelt in zijn conclusie: "Geweld of bedreiging met geweld vooronderstelt weerstand die door dat geweld of die bedreiging moet worden overwonnen. En weerstand houdt in dat hetgeen waartegen men zich verzet, niet gewild wordt. Verder doordenkend komt men dan op het terrein van sadisme/masochisme etc.., maar de vrouw die met geweld genomen wordt, is toch niet dezelfde als die welke met aanwending van geweldsdaden genomen wil worden. Laat ik er vlug over ophouden."22

Wat opvalt, is dat gezien de feiten, niemand beweert dat in deze casus sprake is van een sado-masochistische relatie. ${ }^{23}$ Nergens blijkt van een gelijkwaardige, vrijwillige seksuele relatie waarin geweld weliswaar een rol speelt, maar waar beide partners zeggenschap hebben over de manier waarop het geweld wordt gebruikt en waar beiden plezier hebben in het spel van dominantie en onderwerping door gebruik van geweld in een seksuele setting. ${ }^{24}$ Toch duikt elke keer een sado-masochistische relatie op als uitzondering op de regel dat uit het gepleegde geweld over het algemeen het opzet 'tegen haar wil' te dwingen, is af te leiden. Geeft de beschrijving van de feiten aanleiding voor een veronderstelling dat sado-masochisme in het spel kan zijn? Zeegers heeft hier een mooi betoog over gehouden. ${ }^{25} \mathrm{Zij}$ laat zien dat tijdens de strafprocedure een beeld van de seksuele relatie tussen Celio en Gertrude wordt gecreeerd dat ver af staat van het verhaal van de vrouw. Doordat het hof de gebeurtenissen samenvat met de termen 'een proces van aantrekken en afstoten' wordt een lading van seksuele gepassioneerdheid in de relatie gelegd; het geweld in de relatie wordt geseksualiseerd. Door de relatie tussen Celio en Gertrude te labelen als 'een proces van aantrekken en afstoten' kan een verhaal waarin seks en geweld in elkaars verlengde liggen, een eigen leven gaan leiden. Wanneer de relatie op een andere manier wordt getypeerd, bijvoorbeeld als 'weggaan en achtervolgen', of 'aandringen en toegeven', en op een gegeven moment zelfs als 'dwingen en over zich heen laten komen', had de connotatie met sado-masochisme minder voor de

19 TK 20.930, nr. 8: 2.

20 NRC-Handelsblad, 29 juni 1988.

21 Remmelink, Haze winkel-Suringa's Inleiding, 1994: 355 (noot 2).

22 HR 16 juni 1987, NJ 1988, 156: 671 .

23 Mulder wijst erop, dat niemand van de critici van het arrest zich de theoretische mogelijkheid kan voorstellen dat het verzet hier gespeeld was. Dwingen in de zin van $242 \mathrm{Sr}, N J B, 1988$ : 1008

24 Bibbings \& Alldridge, Sexual expression, body alteration, and the defence of consent, Jrnl of Law and Society, 1993: 359-360.

25 Zeegers, Seksuele vrijheid en dwang in het strafproces, Recht, norm en beeldvorming, het juridische vertoog met andere ogen, 1993 (ongepubliceerd). 
hand gelegen. Bovendien heeft bijvoorbeeld Leijten in zijn conclusie de gedachte aan sado-masochisme wel genoemd, maar niet verder uitgewerkt, waardoor het aspect van sado-masochisme niet duidelijk is afgesneden.

De tweede zienswijze is dat door het herhaald voorkomen van geweld de man niet heeft kunnen doorzien dat de seksuele gemeenschap 'tegen haar wil' was. Ook hier speelt weer het 'proces van aantrekken en afstoten' een belangrijke rol, want door het zo te omschrijven wordt het beeld gecreëerd van gelijkwaardigheid; allebei nemen ze afstand en doen toenaderingspogingen. Maar uit de feiten blijkt dat Celio niet kon accepteren dat Gertrude afstand van hem wilde; zij vertelt hem bewust niet haar nieuwe adres, noch haar nieuwe werkplek, maar door naspeuringen komt Celio erachter. Als hij dan weer contact zoekt, voelt zij zich onmachtig om hem de deur uit te zetten. De vrouw heeft eerder aangifte gedaan van verkrachting door Celio, maar heeft deze aangifte weer ingetrokken nadat de behandelende rechercheur had gewezen op het risico dat de agressie door de aangifte zou kunnen verergeren. Door niet deze, maar andere aspecten als meer relevant te beschouwen, wordt het standpunt van het hof, dat de man niet heeft kunnen doorzien dat de vrouw niet door gewelddadig optreden 'genomen' wilde worden, begrijpelijker. De vrouw verklaart bij het hof: "Desgevraagd verklaar ik U nog dat het wel zo kan zijn dat de verdachte de indruk had dat wanneer hij mij maar serieus benaderde, ik wel met hem naar bed wilde." ${ }^{26} \mathrm{Bij}$ de politie had de vrouw verklaard: "Als hij weer eens geslachtsgemeenschap met mij had, verzette ik mij niet meer: ik kon er niet meer tegen op en liet alles over me heen komen." ${ }^{27}$ Bovendien speelt een belangrijke rol dat seksualiteit wordt voorondersteld in een intieme relatie en (pas) door een relatie te verbreken wordt ook de seksuele relatie verbroken, zoals de motivering van het hof aangeeft. Het feit dat een seksuele relatie wordt voorondersteld, kan ertoe leiden dat de nadruk wordt gelegd op de manier waarop de vrouw aan de man heeft duidelijk gemaakt dat zij geen relatie meer met hem wil; kan de man weten dat Schluss ook werkelijk Schluss is ${ }^{28}$ Of zoals Remmelink stelt: hoewel zelfs in gevallen waarbij partners elkaar al langer kennen, blijft gelden dat de vrouw over haar vrijheid moet kunnen blijven beschikken, zal men "bij dit alles een zekere realiteitszin en 'billijkheid' moeten betrachten. Zo zal geen Officier reageren op de klacht van een vrouw, die maanden of jaren vrijwillig samenleeft met een man, dat zij op een nacht, toen ze niet 'wou', toch door de man 'genomen' werd. Maar

26 Verklaring van de vrouw bij het Hof, in: Baauw, Zuivere verkrachting?, $A A, 1988$ : 579. Niet duidelijk is wat onder 'serieus benaderen' moet worden verstaan.

27 Verklaring van de vrouw bij de politie, in: Ibidem: 576 . Deze passage geeft overigens volgens mij aan hoe de weerbaarheid van de vrouw is gebroken door het herhaalde geweld.

28 Zie voor de zienswijzen van officieren van justitie: hoofdstuk $5, \S 5.5 .3$ onder Anneke en Martin; verkrachting door de ex-partner. Ook rechter-commissarissen lijken in de manier van vragen van deze veronderstelling uit te gaan. Van Driem, Waarom slachtoffers van seksueel geweld het strafrecht moeien mijden, in: Slachtoffersi van misdrijven, 1989: 56. 
formeel is er ook dan verkrachting."29 Dit laat zien dat herhaald geweld binnen de relatie en het feit dat een seksuele relatie voorondersteld wordt, ertoe kunnen leiden dat het niet kunnen inzien van de man dat de vrouw werkelijk niet wilde, begrijpelijk wordt geacht.

Tot slot had het hof de feiten kunnen interpreteren tegen de achtergrond van de problematiek van vrouwenmishandeling: de verkrachting past binnen het patroon van dominerend en controlerend gedrag door de man waar de vrouw zich, ondanks pogingen daartoe, nauwelijks aan kan onttrekken. Uit de casus en de hierboven aangehaalde verklaringen kan een aantal aspecten worden aangewezen die duiden op vrouwenmishandeling. De vrouw heeft de relatie verbroken, en verhuist zelfs om aan de macht van de man te ontsnappen, maar hij achtervolgt haar. Wanneer hij aardig is, put zij hier hoop uit dat hij bij zijn echtgenoot weggaat, voor haar zal kiezen en ophoudt met het plegen van geweld. Maar na een 'positieve' periode volgt dan weer een periode met geweld en seksuele dwang. Door het herhaalde geweld, en doordat Celio haar elke keer wist te vinden, wordt de weerbaarheid van Gertrude en haar besluitvaardigheid aangetast. "Wanneer hij bij mij was, had hij mij volledig in zijn macht, ook op sexueel gebied moest hij altijd zijn zin hebben." ${ }^{30}$ Ze staakt haar verzet, omdat ze uit ervaring weet, dat hij haar emstig mishandelt als hij zijn zin niet krijgt. Ze doet op een gegeven moment zelfs geen moeite meer om haar nieuwe adres geheim te houden omdat hij haar elke keer heeft weten te vinden. Uit de processtukken komt een beeld van de man naar voren als dominerend en obsessief; hij accepteert niet dat de vrouw afstand wil. Hij ontkent de verantwoordelijkheid voor het geweld, en als hij een 'incident' erkent, legt hij de verantwoordelijkheid voor het verliezen van zijn zelfbeheersing bij het 'getreiter' van Gertrude. Ook de dwang tot seksuele gemeenschap ontkent hij, hoewel hij erkent dat Gertrude niet meer wilde vrijen toen hij bijna klaarkwam: "Omdat ik het gemeen vond dat zij opeens niet meer wilde en ik toch klaar wilde komen, heb ik haar wellicht wat te hard in haar bovenarmen geknepen." ${ }^{31}$ Deze verklaring kan worden gebruikt voor het bewijs van het opzet te dwingen, 'tegen de wil' van de vrouw seksueel binnen te dringen, gezien het hier beschreven dominerende en gewelddadige gedrag

29 NLR, aant. 10 op art. 242 Sr: 736-737.

30 Verklaring van de vrouw bij de rechter-commissaris, in: Baauw, Zuivere verkrachting?, $A A, 1988$ : 578.

31 Aldus de verklaring van Celio bij de politie, in: Ibidem: 577. 
van de man. ${ }^{32}$ Het hof lijkt deze verklaring echter te hebben opgevat als een weergave van een 'overmoedige vrijage'.

In het proces van waarheidsvinding is het perspectief, van waaruit feiten worden onderscheiden als relevant en niet-relevant, van groot belang voor de overtuiging en de waardering van de ernst van de feiten. Dit voorbeeld illustreert dat in geval van dezelfde feiten het perspectief van waaruit de feiten worden beoordeeld van grote invloed kan zijn op de beoordeling of de dwang bewezenverklaard kan worden. Het openbaar ministerie vond de dwang wettig en overtuigend bewezen, maar de rechtbank en het hof waren niet deze mening (eenstemmig) toegedaan.

\section{Het inzichtvereiste nader beschouwd}

Celio is vrijgesproken omdat hij, volgens het hof, niet heeft kunnen doorzien dat de seksuele gemeenschap tegen de wil van Gertrude was. "Maar volgt uit het verzet van de vrouw en het geraffineerde dreigement haar arm te breken niet een zodanig grote onverschilligheid voor wat zij al dan niet wilde dat deze als voorwaardelijke opzet kon worden opgevat? (...) Het hof heeft m.i. niet onderzocht of verdachte met voorwaardelijk opzet heeft gehandeld." ${ }^{34}$ Hoeveel belang moet aan dit inzicht van de man worden gehecht ${ }^{35}$ Het arrest van 16 juni 1987 lijkt een uitzondering, ${ }^{36}$ nu voorwaardelijk opzet niet is aangenomen, terwijl de feiten hier wel aanleiding voor geven, zoals het bovenstaande citaat aangeeft. Latere arresten tonen aan dat niet het subjectieve inzicht van de man doorslaggevend is, maar wat de man had kunnen inzien. "Het Hof kon uit de gebezigde bewijsmiddelen de telastgelegde poging tot verkrachting en verkrachting afleiden, met name dat de aan de verdachte verweten handelingen tegen de wil van het slachtoffer hebben plaatsgevonden en dat de verdachte zulks uit de uitlatingen en tegenstrevingen van het slachtoffer moest

32 Naar mijn mening duidt de verklaring van de man erop dat hij het als zijn recht ziet om klaar te komen, ook al weet hij dat de vrouw niet (meer) wil vrijen. Zie over dit 'even afmaken': Beelen, Tussen verleiden en verkrachten, 1989: 40-42.

33 Wat ook van belang kan zijn voor de interpretatie van de feiten, is de interpretatie van het doen van aangiftc. Gezien vanuit het standpunt van de man is de aangifte onrechtvaardig; hij heeft haar eerder geweldadig 'gepakt', en toen liet ze het ook over zich heen gaan, dus hoe kan hij dan weten dat ze geen geweld wil? Voor Gertrude was deze verkrachting de druppel die de emmer doet overlopen en bij haar vindt een innerlijke omslag plaats. Zij ziet in dat Celio haar leven domineert en dat zij haar 'zelf' aan het kwijtraken is. Ze beseft dat ze een daad moet stellen en doet aangifte. Gezien vanuit het perspectief van Gertrude is dit het moment waarop politie en openbaar ministerie haar recht op seksuele en lichamelijke integriteit moeten erkennen, zodat het proces van zelfbevrijding wordt ondersteund. Zie hoofdstuk $2, \S 2.2$.

34 Mulder in zijn noot onder HR 16 juni 1987, NJ 1988, 156: 673.

35 Over de problematiek van het 'mistaken belief' in angelsaksische jurisprudentie is veel literatuur verschenen. Bijvoorbeeld: Temkin, Rape and the legal process, 1987: 76-91; Bienen, Mistakes, Philosophy and Public Affairs, 1978: 224-245; Frohmen, Assumed consent, 1991.

36 De Hullu \& van der Neut, Zedelijkheidswetgeving. $N J B, 1991$ : 392. 
begrijpen." ${ }^{37}$ Het verweer dat het slachtoffer een brief heeft geschreven waarin zij schrijft te kunnen begrijpen waarom de man zich niet in bedwang heeft kunnen houden, wordt niet als bewijs van het kunnen ontbreken van inzicht bij de man geaccepteerd, ${ }^{38}$ evenals het verweer dat ruzies wel vaker door een vrijpartij werden bijgelegd. ${ }^{39}$ Ook uit het dossieronderzoek is niet gebleken dat mannen worden vrijgesproken op grond van gebrek aan inzicht. ${ }^{40}$ Karakteristiek is bijvoorbeeld de volgende overweging: "Verdachte heeft er door de gepleegde delicten blijk van gegeven de wil van de vrouw, die kort daarvoor de tussen verdachte en haar bestaande relatie had verbroken, in het geheel niet te respecteren. Bovendien heeft hij een emstige inbreuk gemaakt op haar lichamelijke integriteit. Verdachte heeft er naar het oordeel van de Rechtbank blijk van gegeven, de ernst van de feiten niet te onderkennen en heeft zich doen kennen als een man, die er sterk toe geneigd is, zijn wil aan anderen op te leggen zonder zich voldoende rekenschap te geven van de situatie, in een eenmaal volgehouden houding te volharden." ${ }^{.41}$

Het beweerde gebrek aan inzicht kan wel in de strafoplegging worden verdisconteerd: "[D]at bij de strafoplegging rekening wordt gehouden met de mogelijkheid dat de verdachte aanvankelijk kan hebben gemeend dat het slachtoffer zijn toena-

37 HR 14 maart 1989, nr. 84.804, verkort gepubliceerd in DD 89 323. Het betreft een zaak van een verkrachting door een bekende (ook wel date-rape genoemd); de verdachte is een kennis van de vrouw en haar echtgenoot. De casus is als volgt: De verdachte en zijn vrouw en het slachtoffer en haar man gaan gezamenlijk uit. Die avond danst de vrouw met de verdachte. Na het avondje uit blijven de verdachte en het slachtoffer samen in het huis van het slachtoffer. Daar doet de man een poging de vrouw door fysieke kracht tot geslachtsgemeenschap te dwingen. Als het dochtertje van de vrouw binnenkomt, stopt hij snel zijn penis weer in zijn broek. De vrouw stuurt het dochtertje weer naar haar kamer. Vervolgens pakt de man de vrouw vast en trekt haar naar buiten, drukt haar tegen een muur aan, trekt haar broek en slipje naar beneden en verkracht haar. Het feit dat de vrouw haar dochtertje weer naar boven heeft gestuurd en het geweld van de man niet tot fysiek letsel heeft geleid, verzwakken het bewijs van de dwang.

38 HR 3 november 1992, nr. 91.943 (ongepubliceerd). Leijten stelt in zijn conclusie: "In de brief lees ik niet meer dan dat het slachtoffer achteraf te kennen geeft dat ze nu begrijpt dat verzoeker indertijd in een zodanige geestelijke toestand heeft verkeerd dat hij zich niet meer in de hand heeft kunnen houden en daar achteraf wel begrip voor kan opbrengen. Ik lees in de brief bepaald niet dat ook zij vindt dat verzoeker zich niet in de hand behoefde te houden." Het is niet duidelijk of dit een geval van vrouwenmishandeling betref, omdat over de relatie tussen dader en slachtoffer geen informatie wordt gegeven.

39 HR 3 november 1992, nr. 91.809 (ongepubliceerd).

40 Zes van de twaalf verkrachtingszaken van het kwalitatieve dossieronderzoek zijn vervolgd. In alle gevallen volgde een veroordeling door de rechter tot gevangenisstraf, in vijf gevallen rond een jaar (met een (groot) deel) voorwaardelijk. De vier zaken die met een technisch sepot zijn afgedaan, zijn niet wegens gebrek aan inzicht geseponeerd.

41 Dossier nummer 103. Het gaat hier om een weduwnaar die drie jaar een relatie heeft met zijn buurvrouw, die weduwe is. $\mathrm{Zij}$ maakt een einde aan de relatie en hij kan dit niet accepteren: hij bedreigt haar, komt ongevraagd binnen en neemt sleutels mee. Op een dag ontvoert hij haar in zijn auto en doet een poging haar te verkrachten. Van deze poging tot verkrachting wordt aangifte gedaan. Ten tijde van de terechzitting hebben ze zich weer verzoend met elkaar en is sprake van herstel van de relatie. De man wordt veroordeeld tot 5 maanden gevangenisstraf met aftek, waarvan 4 voorwaardelijk met als voorwaarde reclasseringsbegeleiding en psychiatrische behandeling. 
deringspogingen niet zou afwijzen". ${ }^{42}$ Dit bleek ook uit de afweging die officieren van justitie maken als het verkrachting door een ex-partner betreft. ${ }^{43}$ Uit het geweld wordt meestal de dwang afgeleid, maar van het feit dat een relatie tussen de man en de vrouw bestaat, mits het geweld niet extreem is, ${ }^{44} \mathrm{kan}$ een strafverminderende invloed uitgaan. ${ }^{45}$ Maar het feit dat de verkrachting plaatsvindt binnen een relatie kan, onder omstandigheden, ook aanleiding zijn tot strafverzwaring, omdat de verkrachting een ernstige inbreuk op de vertrouwensrelatie is. ${ }^{46}$

De hiervoor aangehaalde uitspraken en de 12 onderzochte verkrachtingszaken uit het dossieronderzoek geven aan dat het niet zozeer gaat om wat de man op dat moment heeft ingezien, maar of de man had kunnen inzien dat de vrouw geen seks met hem wilde. Hoe de juridische beoordeling, over de vraag of de man het verzet van zijn (ex-)partner heeft kunnen invoelen, tot stand komt, hangt mede af van het gezichtspunt van waaruit de feiten worden beoordeeld, zoals eerder uiteen is gezet.

\section{Objectivering van de dwang}

Het besef van de man dat de vrouw niet toestemt wordt geobjectiveerd, zo blijkt uit het hiervoor besprokene. Maar omdat het inzichtvereiste wordt ingelezen in de delictsomschrijving, volgt vrijspraak als wordt geoordeeld dat de man niet heeft kunnen inzien dat de vrouw de seksuele handelingen tegen haar wil ondervond. Wanneer het inzichtvereiste niet wordt ingelezen in de delictsomschrijving, volgt daarentegen ontslag van rechtsvervolging. De vraag is "of het ontbreken van een redelijk doel of het ontbreken van een redelijk middel tot een redelijk doel een bestanddeel van het misdrijf is dan wel of de aanwezigheid van een redelijk middel ter bereiking van het redelijke doel een strafuitsluitingsgrond oplevert". ${ }^{47} \mathrm{De}$ rechtvaardiging van het gedrag is in het eerste geval deel van het delict en in het

42 HR 14 maart 1989, nr. 84.804 (ongepubliceerd). De opgelegde straf is 7 maanden gevangenisstraf. waarvan 3 voorwaardelijk.

43 Zie hoofdstuk $5, \S 5.5 .3$.

44 Onder niet extreem geweld valt: het op bed drukken van de vrouw, de arm omdraaien en achter haar rug draaien, dreigen in de trant van 'als je niet doet wat ik wil, breek ik je arm' of dreigen met een voorwerp zoals een bierflesje.

45 In geval van een echtpaar in echtscheiding werd de man door het hof veroordeeld tot 500 gulden boete, omdat hij de vrouw op een bed had geduwd en op bed gedrukt gehouden waama hij geslachtsgemeenschap met haar had: HR 9-2-1988, NJ 1988, 613. In een geval dat verdachte en slachtoffer elkaarkenden, legde de rechtbank een voorwaardelijke gevangenisstraf op van 3 maanden, het hof oordeelde tot 3 maanden onvoorwaardelijke gevangenisstraf. HR 18-9-1978, NJ 1979, 105. In een andere zaak van gedwongen seksuele gemeenschap binnen een intieme relatie veroordeelde het hof de man tot 5 maanden gevangenisstraf, voorwaardelijk met een proeftijd van 2 jaar. HR 3 november 1992, nr. 91.809 (ongepubliceerd).

46 De Beaufort, Het recht "nee" te zeggen, in: Vrouw en recht, 1984: 63.

47 Van Bemmelen, Vergelijking van het Belgische en Nederlandse recht inzake de voomaamste zedendelicten, Preadvies, 1967: 185. Zie voor mishandelen, hoofdstuk 3, § 3.2.2. 
tweede geval ligt de rechtvaardiging van het gedrag buiten het delict; er is sprake van een strafbaar feit, maar het plegen van het strafbare feit kan de verdachte niet worden aangerekend.

Van Bemmelen bespreekt de problematiek van vrijspraak en ontslag van alle rechtsvervolging in zijn preadvies inzake de voornaamste zedendelicten. ${ }^{48} \mathrm{Hij}$ wijst erop dat een delictsomschrijving in het algemeen feitelijke bestanddelen bevat en de vraag of de verboden handeling onder bepaalde omstandigheden gerechtvaardigd is, behoort door de rechter te worden gewaardeerd als strafuitsluitingsgrond. Wanneer de wetgever dit anders wil, behoort het ontbreken van het redelijke doel of middel in de delictsomschrijving te staan. ${ }^{49}$ De bestanddelen van de delictsomschrijvingen verkrachting en aanranding geven bijvoorbeeld geen aanleiding om het inzichtvereiste in te lezen in de delictomschrijving. ${ }^{50}$ Ten tweede wijst Van Bemmelen op de formulering van de telastlegging: het openbaar ministerie hoeft in de telastlegging geen rekening te houden met het verweer van de verdachte dat zijn gedrag gerechtvaardigd is. Pas op de terechtzitting zal over het verweer worden gediscussieerd door rechter, verdachte en openbaar ministerie. ${ }^{51}$ Bovendien heeft dit voor het slachtoffer van verkrachting als positief effect dat tijdens de opsporingsfase in beginsel geen vragen over haar gedrag hoeven te worden gesteld; de aannemelijkheid dat zij geen toestemming heeft gegeven, vloeit voort uit het geweld of een andere feitelijkheid. Op de terechtzitting kan de verdachte, hoewel hij het geweld erkent, een beroep doen op een schulduitsluitingsgrond door aannemelijk te maken dat hij ervan uit mocht gaan dat de vrouw wel seksueel contact met hem wilde. 52

Er pleit een derde argument voor de benadering het inzichtvereiste niet in de delictsomschrijving in te lezen, namelijk de strekking van de artikelen 242 en 246 Sr; bescherming van de wilsvrijheid. Het Hof Amsterdam heeft in 1978 in het

48 Van Bemmelen, Ibidem.

49 Zie dierenmishandeling: hij die zonder redelijk doel of met overschrijding van hetgeen ter bereiking van zodanig doel toelaatbaar is, opzettelijk een dier pijn of letsel veroorzaakt etc. (art. $254 \mathrm{Sr}$ ). Dit geldt ook voor het opnemen van de wederrechtelijkheid in de delictsomschrijving, zoals in opzettelijk wederrechtelijk iemand van haar vrijheid beroven (art. $282 \mathrm{Sr}$ ).

50 In Duitsland is dit wel het geval, omdat daar sprake is van 'ingeblikte opzet' in het begrip 'dwingen' (notigen). Dit betekent dat de man heeft geweten dat de vrouw serieuze tegenstand bood. "In dat geval kan men eerder tot straffeloosheid - in casu vrijspraak wegens afwezigheid van opzet - komen." NLR aant. 4 op art. $242 \mathrm{Sr}$ : 732 . Ook volgens de angelsaksisiche jurisprudentie is "without her consent' onderdeel van de delictsomschrijving. Dit fenomeen is bekend als 'the mistaken belief. zaken; als een man gelooft dat de vrouw toestemde, kan geen veroordeling volgen. Temkin, Rape and the legal process, 1987: 76-91.

51 Van Bemmelen, Vergelijking van het Belgische en Nederlandse recht inzake de voomaamste zedendelicten, Preadvies, 1967: 185-187.

52 De Beaufort, Het recht "nee" te zeggen, in: Vrouw en recht, Leiden 1984: 58-59. Remmelink laat enigszins in het midden of, na de uitspraak van de Hoge Raad, een beroep op dwaling als een strafuitsluitingsgrond moet worden beschouwd of als een beroep op het ontbreken van het ingeblikte opzet, zoals in Duitsland geldt voor 'notigen'. NI.R, aant. 4 op art. 242 Sr: 732. 
'Hell's Angels' arrest de wilsvrijheid van de vrouw als het te beschermen belang erkend: "(...) daar art. 242 WvSr. ertoe strekt een vrouw ertegen te beschermen dat zij door geweld of bedreiging met geweld wordt beroofd van het recht in vrijheid te bepalen of - en zo ja met wie - zij buiten echt vleselijke gemeenschap zal hebben, ongeacht of zij te dien aanzien bepaalde toezeggingen heeft gedaan waarop zij later terugkomt." ${ }^{53}$ Door de inbreuk op de wilsvrijheid centraal te stellen is het bewijs van dwang voldoende; de verkrachting wordt geobjectiveerd. ${ }^{54}$ De dwang kan worden afgeleid uit geobjectiveerde omstandigheden. ${ }^{55}$ Dat wil zeggen dat de aard van de handelingen en de omstandigheden zodanig zijn dat zij in het algemeen bij een ander het gevoel geven in haar of zijn vrijheid te zijn belemmerd. Mocht de verdachte toch hebben kunnen denken dat er sprake was van toestemming, dan kan hij zich beroepen op een schulduitsluitingsgrond. ${ }^{56}$ Door verkrachting te objectiveren wordt zuiverder aangegeven dat het dwingen (door geweld of een andere feitelijkheid) tot seksueel contact een inbreuk betekent op de wilsvrijheid.

De discussie is niet zozeer of dwang 'tegen haar wil' veronderstelt, maar of bewezen moet worden dat het (voorwaardelijke) opzet van de verdachte gericht is op 'tegen haar wil'. De Hoge Raad heeft deze laatste vraag met ja beantwoord en hierdoor is het inzicht in 'tegen haar wil' onderdeel geworden van de delictsomschrijving; de objectivering van verkrachting afgewezen. ${ }^{57}$ Hoewel het hanteren van voorwaardelijk opzet in de praktijk betekent dat het inzicht in het niet willen van de vrouw over het algemeen blijkt uit het gehanteerde dwangmiddel, pleit ik toch voor een objectivering van verkrachting, zoals dit sinds het Hell's Angels-arrest gold, en ook door de procureur-generaal bij het hof is aangehaald in zijn cassatieberoep bij het arrest van 16 juni $1987 .^{58}$

$\mathrm{Nu}$ blijft het de vraag wanneer sprake is van dwang. Is er sprake van dwang als geweld een onderdeel is van de seksuele relatie, waar beide partners plezier in hebben? Of, zoals Leijten schreef, "maar de vrouw die met geweld genomen wordt, is toch niet dezelfde als die welke met aanwending van geweldsdaden genomen wil

S3 Hof Amsterdam, 20 oktober 1978, NJ 1979, 366.

54 Tigchelaar, Vrijage of verkrachting. Nemesis, 1988: 99-103. Dit betekent niet dat 'tegen haar wil' niet meer belangrijk zou zijn, zoals Baauw suggereert in Zuivere verkrachting, $A A, 1988$ : 585 . Het gaat erom dat het (geobjectiveerde) subjectieve inzicht van de man niet bepalend mag zijn voor het wel of niet aanwezig zijn van het opzet 'tegen haar wil' seksuele handelingen te verrichten.

55 Tot deze objectivering kunnen ook handelingen en omstandigheden behoren die specifiek voor die persoon in die context dwingend van karakter kunnen zijn. NLR, aant. 5 op art. $95 \mathrm{Sr}$; 't Hart in zijn noot bij HR 21 februari 1989, NJ 1989, 668. Zie ook hoofdstuk 3, $\S 3.4$.

56 In een zaak betreffende art. $243 \mathrm{Sr}$ sprak de Hoge Raad uit dat het geven van toestemming door de vrouw als rechtvaardigheidsgrond kan dienen. HR 15 juni 1982, NJ 1983, 153.

57 Mulder, Dwingen in de zin van $242 \mathrm{Sr}$, NJB, 1988: 1009. Als 'dwang' wordt opgevat als 'notigung', is dit inzicht onderdeel van het opzet; zonder (geobjectiveerd) inzicht is geen sprake van dwang.

58 Het woord dwingen betekent "dat het slachtoffer door het geweld of door de bedreigingen met geweld wordt beroofd van het recht in vrijheid te bepalen". HR 16 juni 1987, NJ 1988, 156: 668. Ook Remmelink was tot het arrest van HR 16 juni 1987 deze mening toegedaan. Na het arrest is zijn mening hierover minder duidelijk. Aant. la op art. 242 Sr: 732. 
(cursivering, KL) worden" ${ }^{59}$ Dogmatisch gezien, moet opzettelijk worden gedwongen. Als de partners afspraken hebben over de manier van geweldgebruik in het seksuele spel, is er geen sprake van dwang en daarom is er geen sprake van verkrachting. ${ }^{60}$ Maar wat als de man zegt dat er afspraken waren en de vrouw verklaart geen toestemming te hebben gegeven? In dat geval hangt het van de omstandigheden van het concrete geval af of de man erin slaagt aannemelijk te maken dat er afspraken waren; in dat geval is er geen sprake van dwang en volgt vrijspraak. Een andere vraag is of, als de verdachte het verweer voert dat de vrouw seksueel opgewonden was en het geweld lekker vond, dit moet worden opgevat als een verweer dat de dwang ontbreekt. Het lijkt mij van niet. Een aspect van verkrachting kan zijn dat een fysiologisch proces op gang wordt gebracht waardoor sprake is van 'seksuele opwinding'; juist de vermenging van geweld en seksuele opwinding is zo vernederend. ${ }^{61}$ Seksuele opwinding staat los van de vraag of er sprake is van dwang en mag naar mijn mening niet worden geaccepteerd als bewijsverweer. ${ }^{62}$ Een verweer van de verdachte dat hij door de manier waarop de vrouw reageerde het gevoel kreeg dat ze met hem wilde vrijen, kan naar mijn mening onder bepaalde omstandigheden hoogstens als een schuldverweer worden opgevat; aannemelijk wordt dat de verdachte niet kan worden verweten dat hij niet heeft kunnen doorzien dat de vrouw geen seksueel contact met hem wilde. In dat geval is sprake van afwezigheid van alle schuld en wordt de man ontslagen van alle rechtsvervolging.

Het juridische verschil tussen inzichtvereiste als element van de delictsomschrijving of inzichtvereiste als schulduitsluitingsgrond, is vooral van belang voor het rechtsgevoel. ${ }^{63}$ Voor het slachtoffer is het van groot belang dat het haar aangedane seksuele geweld wordt erkend. In het eerste geval wordt tot vrijspraak besloten als het verweer van de verdachte, dat hij niet wist, en ook niet heeft kunnen weten, dat de vrouw niet wilde, gehonoreerd. Vrijspraak geeft aan dat de dwang niet (overtui-

59 HR 16 juni 1987, NJ 1988, 156: 671.

60 In de Verenigde Staten kan sado-masochisme als een geweldsmisdrijf worden vervolgd ( $R$. versus Brown et al. (1992) 94 CAR 302). Niet iedereen is het hiermee eens. De discussie betreft de vraag of sado-masochisme een geweldsmisdrijf is en dus strafbaar of een vorm van vrijwillige seks in de privesfeer. Zie Bibbings \& Alldridge, Sexual expression, body alteration, and the defence of consent, Jrnl of Law and Society, 1993: 356-370; Bamforth, Current topic: Sado-Masochisme and consent, Criminal Law Review, 1994: 661-664.

61 Zie hoofdstuk 2, § 2.2.3.

62 Anders, NLR aant. 5 op art 242 Sr: 733. Deze stelt: "Bij de vis compulsiva kan zich dan echter het moeilijke probleem voordoen van de vrijwilligheid van de toestemming. Ik denk hier nog aan het geval, dat de man de vrouw met geweld in een sexuele opwindingstoestand heeft gebracht in de hoop, dat zij zich alsdan 'vrijwillig' aan hem zal geven. Sch-Schr, 17 e druk, p. 1037 (23ste druk, 1988 , p. 1226) zou in zo'n geval het verkrachtingsartikel niet toepasselijk achten. Het lijkt mij duidelijk, dat het hier om een feitelijke kwestie gaat en dat de rechter aan de hand van allerlei bijzonderheden zal moeten nagaan, of hier werkelijk van vrijwilligheid sprake is."

63 Mulder wijst hierop in verband met euthanasie op pasgeboren zwaar gehandicapte babies met een kortstondige levensverwachting die emstig lijden. De arts die moord ten laste wordt gelegd, krijgt weliswaar ontslag van rechtsvervolging, maar het rechtsgevoel opteert voor vrijspraak, niet schuldig. Mulder, Waarom geen vrijspraak, $D D, 1996: 40-42$. 
gend) is te bewijzen. In het tweede geval wordt de dwang wel bewezen verklaard. Ook de dader erkent het gepleegde geweld, maar beroept zich op een schulduitsluitingsgrond. Wanneer dit beroep wordt gehonoreerd, blijft de erkenning van het seksuele geweld in stand. Het subjectieve element, het inzicht van de verdachte, betreft alleen de dader. In dat geval kunnen de waarheid van de vrouw (er is sprake van seksueel contact tegen haar wil) en de waarheid van de man (ik dacht dat seksueel contact geoorloofd was) naast elkaar staan.

\subsubsection{Fysiek geweld tegen vrouwen als inbreuk op de persoonlijke levenssfeer}

Fysiek geweld tegen vrouwen door hun partner of ex-partner is strafbaar en wordt in het algemeen afgekeurd. De vraag wanneer toestemming omslaat in 'tegen haar wil' is in geval van fysiek geweld nauwelijks relevant; fysiek geweld wordt verondersteld 'tegen haar wil' te zijn. In geval van fysiek geweld tegen de vrouw in de privésfeer draait het meer om het perspectief van waaruit de relatie wordt beschouwd. Opvattingen over gelijkwaardigheid tussen de partners doen een ander licht schijnen op de strafbaarheid en de emst van geweld in de privésfeer dan opvattingen over machtsverschillen binnen (huwelijkse) relaties. In deze $\S$ wordt eerst ingegaan op geweld tegen de vrouw binnen (huwelijkse) relaties, en vervolgens op geweld tegen de vrouw door haar ex-partner.

\section{Fysiek geweld binnen (huwelijkse) relaties}

Geweld tegen de vrouw dat plaatsvindt binnen de (huwelijkse) relatie, waarvan aangifte wordt gedaan en waar het openbaar ministerie mee wordt geconfronteerd, wordt meestal als mishandeling gekwalificeerd (art. $300 \mathrm{Sr}$ ). ${ }^{64}$ Dit geweld tegen de vrouw kent een grote variatie aan ernst van letsel en/of pijn. Vrouwen die bont en blauw worden geslagen, of ernstige kneuzingen oplopen, worden beschouwd als slachtoffers van 'de droge klap'. ${ }^{65}$ Gebroken tanden, tanden door de lip, en (ernstige) wonden zijn vormen van ernstig letsel. Als de vrouw enkele weken in het ziekenhuis heeft gelegen, of levenslang min of meer invalide zal zijn, of psychisch voor langere tijd in de war is, kan zware mishandeling worden aangenomen (zie hoofdstuk 3, § 3.2.2) Een vorm van geweld die weinig letsel met zich mee hoeft te brengen, is de voor vrouwen vaak levensbedreigende wurgpoging (zie hoofdstuk $5, \S 5.3 .2$ ). Ook de wurgpoging wordt doorgaans, als de vrouw geen of weinig letsel heeft opgelopen, gekwalificeerd als mishandeling. Wanneer het strottehoofd is beschadigd, en het (voorwaardelijk) opzet de vrouw te doden, is te bewijzen, kan

64 In de categorie mishandeling \& bedreiging was in 65 zaken sprake van mishandeling en in 5 zaken was sprake van zware mishandeling $(n=83)$. Zie hoofdstuk $5, \S 5.3 .2$.

65 Een droge klap betekent dat er wel sprake is van pijn, maar niet van een bloedende wond. Van Bemmelen-van Veen, Ons Strafrecht 3, 1990: 41. 
het geweld als een poging tot doodslag worden gekwalificeerd. Maar als het voorwaardelijk opzet de vrouw te doden niet uit de bewijsmiddelen wordt afgeleid, kan een voltooide wurging als mishandeling met dood als gevolg worden gekwalificeerd. ${ }^{66}$ Hieruit blijkt dat de kwalificatie mishandeling een groot scala aan letsel omvat, van 'de droge klap' tot zeer ernstige letsel of voor de vrouw levensbedreigend geweld. Hierin verschilt mishandeling van de vrouw door haar partner overigens niet van andere gevallen van mishandeling. Waar de mishandeling van de vrouw door haar partner wel in verschilt, is de context waarbinnen dit geweld plaatsvindt.

Wat betreft de ernst van het letsel, ben ik van mening dat de variatie in emst van het geweld niet tot uiting komt in de kwalificatie mishandeling. Doorgaans wordt gesproken van 'eenvoudige mishandeling' als tegenhanger van 'zware mishandeling'. Eenvoudige mishandeling suggereert 'de droge klap', waardoor alle andere emstige vormen van letsel onzichtbaar worden gemaakt. Het druist in tegen het rechtsgevoel om mishandeling van de vrouw met als gevolg gebroken tanden, van onder tot boven onder de blauwe plekken, en een gekneusde arm, als (eenvoudige) mishandeling te kwalificeren. Naar mijn menig wordt meer recht gedaan aan de grote verschillen in ernst van het letsel als drie vormen van mishandeling in de strafbepaling worden opgenomen: eenvoudige mishandeling, ernstige mishandeling en zware mishandeling. Het feitelijke letsel behoort naar mijn mening meer zichtbaar te zijn, of dit letsel nu is veroorzaakt in de privésfeer of erbuiten. ${ }^{67}$ Bovendien zou lid 5 kunnen worden geschrapt; een poging tot mishandeling behoort niet te worden uitgesloten. ${ }^{68}$

Naast de feitelijke ernst van het letsel, wordt de ernst van het letsel ook gekleurd door de omstandigheden waaronder het letsel tot stand is gekomen. In geval van vrouwenmishandeling is dat de relationele sfeer. Vervolgens hangt het af van de opvatting die wordt gehanteerd, hoe het geweld tegen de vrouw wordt geïnterpreteerd. Een veelvoorkomende opvatting is dat het geweld wordt beschouwd als de escalatie van een gestoorde interactie tussen beide partners. "In geval van echtelijke gewelddadigheid, waarbij de man in juridische zin wordt beschouwd als de geïdentificeerde dader en de vrouw als slachtoffer, speelt ook deze laatste een belangrijke en niet alleen passieve rol. ${ }^{\prime 69}$ Vanuit dat perspectief wordt het gewelddadige gedrag van de man beschouwd als een wanhoopsdaad, bijvoorbeeld omdat de vrouw een

66 Hof Arnhem, 18 februari 1932, NJ 1932, p. 565; HR 3 januari 1978, NJ 1978, 627. In het arrest van HR 9 mei 1961, NJ 1962,83 is het voorwaardelijk opzet te doden door het wurgen van de vrouw wel aangenomen. Zie ook hoofdstuk $3, \S 3.2$.

67 Het gevolg 'ernstig letsel' zou als strafverzwarende omstandigheid aan art. $300 \mathrm{Sr}$ kunnen worden toegevoegd met als strafmaat ten hoogste drie jaar. Dit heeft als bijkomend strafprocesueel gevolg dat de verdachte van emstige mishandeling van zijn (ex-)echtgenote in verzekering kan worden gesteld (art. $304 \mathrm{Sr}$ ).

68 Zie hoofdstuk $3, \S 3.2 .2$.

69 Ter Heine, Gewelddadigheid in huwelijk en gezin, $D D, 1995$ : 947-948. 
andere vriend had, of omdat het gedrag van de vrouw hem buiten zinnen bracht. Het geweld wordt beschreven in termen van 'wanhopig', 'de kluts kwijt', in plaats van 'woedend' en 'agressief'. Op die manier wordt het beeld gecreeerd van een 'crime passionel' ${ }^{70}$ Dit geldt eveneens voor de situatie dat de vrouw is gedood. "Heel globaal gesproken is de moord gepleegd op een naaste relatie dikwijls terug te voeren op conflicten van sterk emotionele aard, die de dader te machtig zijn geworden. Dan rijst niet zelden de vraag in hoeverre de dader toerekeningsvatbaar was." "'1 Een andere manier om het geweld alleen als emotionele opwelling te beschrijven is het gebruik van termen als 'ruzie', 'conflicten' en 'relatieproblemen'. Op die manier wordt het beeld van gelijkwaardigheid gecreèrd, en het geweld wordt verdoezeld. Termen als 'gevecht' en 'worsteling' geven wel aan dat er sprake is van geweld, maar wekken het beeld van gelijkwaardigheid op. Door het benadrukken van de gelijkwaardigheid wordt het eenzijdige geweld tegen de vrouw opgevat als een uitvloeisel "van escalerende echtelijke interacties die uiteindelijk de individuele partners als het ware boven het hoofd zijn gegroeid tot een relatiesysteem met een eigen dynamiek."72

Door de machtsdynamiek binnen de relatie niet te onderkennen, wordt een beeld gecreëerd van een gelijkwaardige relatie waar de vrouw een eigen bijdrage heeft geleverd aan het voortduren van het geweld; als zij dat geweld echt niet wil, dan moet ze weggaan. Maar dat is nu juist het probleem. Vaak heeft de vrouw verschillende pogingen ondernomen om het geweld te stoppen, of zelfs om weg te gaan. Maar in een sfeer van herhaald geweld, dreiging en angst wordt de weerbaarheid van de vrouw aangetast. Haar afhankelijkheid van de man wordt versterkt en haar isolement wordt vergroot. Juist omdat het geweld binnen de relatie plaatsvindt, kan de vrouw niet aan de onveilige omgeving ontsnappen, zoals dat wel kan als het geweld door iemand buiten de gezinssfeer wordt gepleegd. Wanneer geen veilige omgeving aanwezig is om van het trauma te herstellen, wordt de weerbaarheid van de vrouw nog verder aangetast. De ernst van het geweld wordt in zulke gevallen niet zozeer bepaald door de ernst van het incident, maar door de context van permanente aanwezige dreiging en angst en het ontbreken van een veilige omgeving om te kunnen herstellen. ${ }^{73}$

70 Slotboom, De 'gevonden waarheid', 1992: 89.

71 Van Bemmelen-van Veen, Ons Strafrecht 3, 1990: 12. Wanneer de man die zijn vrouw doodt, sterk verminderd toerekeningsvatbaar of ontoerekeningsvatbaar wordt verklaard, leidt dit tot een geringere straf vergeleken bij partnerdoders van geringe verminderde toerekeningsvatbaarheid. Het lijkt erop dat het adagium 'straf naarmate van schuld' wel wordt gehanteerd in geval van partnerdoding, maar in de niet-partnerdodingszaken in veel mindere mate. De reden hiervan kan zijn dat het gevaar voor de openbare orde niet of nauwelijks aanwezig wordt geacht in de partnerdodingszaken. De Boer, Partnerdoding, 1990: 103-117.

72 Ter Heine, Gewelddadigheid in huwelijk en gezin, DD, 1995: 950. Zie ook: De Boer, Parmerdoding. 1990: $15-20$.

73 Herman, Trauma en herstel, 1993: 89-92. Zie ook hoofdstuk 2, \$2.2. 
Uit het verkennende onderzoek is niet naar voren gekomen dat deze zienswijze van invloed is op de beoordeling van de strafbaarheid van het gewelddadige gedrag door officieren van justitie en rechters. ${ }^{74}$ De zienswijze dat geweld tegen de vrouw voortkomt uit relationele problemen, kan wel van invloed zijn op het ernstoordeel. ${ }^{75}$ Het opzet te doden of vermoorden, zal bijvoorbeeld minder snel aanwezig worden geacht als het geweld wordt beschouwd als een emotionele opwelling in het heetst van de (gelijkwaardige) strijd.

Het geweld waarvan aangifte wordt gedaan, behoort te worden geplaatst tegen de achtergrond van de relatie en (eventueel) eerder geweld. Deze achtergrond kan een 'destructieve symbiotische' relatie zijn, waar man en vrouw beiden aandeel hebben in een destructief proces. ${ }^{76}$ Maar de achtergrond lijkt, gezien de resultaten van het dossieronderzoek, vaker te worden gevormd door een context van dreiging en angst, veroorzaakt door het gewelddadige en controlerende gedrag van de man. Wanneer hier sprake van is, zou dit in de strafrechtelijke aanpak moeten doorwerken, en moeten doorklinken in het requisitoir van de officier van justitie. De rechter zou dit in het vonnis tot uiting kunnen laten komen, bijvoorbeeld door te stellen: 'juist in een relatie, die gebaseerd zou moeten zijn op liefde en respect voor elkaar, wordt door de geweldpleging ten opzichte van de partner emstige psychische schade toegebracht aan de vrouw' of woorden van vergelijkbare strekking.

\section{Inbreuk op de privacy door de ex-pariner}

Veel zaken van vrouwenmishandeling die het openbaarministerie bereiken, betreffen de ex-partner die de vrouw 'lastigvalt', door ongevraagd binnen te komen, het huis binnen te breken, de vrouw te bedreigen of haar te mishandelen. Het geweld is meestal niet ernstig, een gebroken ruit, een blauwe plek, maar door de context waarbinnen dit geweld plaatsvindt, kan de vrouw zich emstig bedreigd voelen.

Het verstoren van de huisvrede is een veel voorkomende vorm van aantasting van de privacy van de vrouw. Juridisch gezien is geen sprake van huisvredebreuk als de vrouw slechts zegt dat de man niet welkom is of als zij, na aanhoudend bellen en schreeuwen van de man, de deur uit vrees voor vernieling van de (deur)ruit of

74 Bij de politie speelt dit wel een rol in de beoordeling. Bewijsproblemen en medeschuld van het slachtoffer worden als reden gegeven om niet strafrechtelijk op te treden. Wöstmann, Politieoptreden bij vrouwenmishandeling, 1988: 90; Zoomer, Vrouwenmishandeling; politiewerk, 1990: 30-41.

75 In de door mij onderzochte zaken wordt bijvoorbeeld als strafverminderde omstandigheid in het vonnis genoemd: 'dat het slachtoffer heeft toegegeven zelf de agressie te hebben opgewekt en dat zij zich enige tijd na dit delict weer met verdachte heeft verzoend.' Dossier 107. Slotboom constateert dat deze zienswijze een strafverminderende invloed heeft op de straftoemeting. Slotboom, De 'gevonden waarheid', 1992: 90-91.

76 Ter Heine, Gewelddadigheid in huwelijk en gezin, DD, 1995: 947-951; De Boer, Partnerdoding, 1990: 18. 
ander geweld open doet. De bedreiging die van de man uit kan gaan door uitlatingen in de zin van 'als je de deur niet open doet dan breek ik 'm open' of 'ik vermoord je als je nu niet opendoet' kunnen worden beschouwd als niet gemeende, emotionele uitlatingen. Deze uitlatingen kunnen daarentegen ook, zeker als de man in het verleden heeft laten zien in staat te zijn tot het uitoefenen van (ernstig) geweld, worden beschouwd als bedreigingen uiten in de zin van artikel 138, lid $3 \mathrm{Sr}$. Het openen van de deur gebeurt uit angst en de hoop dat het geweld niet verder zal escaleren.

Het vernielen van goederen, of persoonlijke bezittingen van de vrouw is ook een vorm van bedreiging. Niet de beschadiging van de eigendom is in die situatie het meest relevant, maar de bedreiging die uitgaat van deze vernielingen; de vernieling is een middel om de privacy van de vrouw aan te tasten door gevoelens van onveiligheid te creëren. Ook het vernielen van persoonlijke bezittingen van de vrouw waar zij emotioneel zeer aan gehecht is, is voor de vrouw zeer kwetsend en werkt mee aan een sfeer van dreiging en controle over de vrouw.

Bovendien kan er sprake zijn van bedreiging in de zin van artikel $285 \mathrm{Sr}$. Uitlatingen als 'ik sla je verrot, als je niet bij me terugkomt' of 'ik vermoord de kinderen als je een echtscheiding aanvraagt' kunnen worden beschouwd als de vrouw vrees aanjagen door bedreiging met een ernstig misdrijf, wannneer de bedreigingen worden gezien tegen de achtergrond van dominerend en controlerend gedrag van de man. Het werkelijk bedreigd voelen van de vrouw kan een relevante aanwijzing zijn voor de beoordeling of sprake is van bedreiging. Wanneer de vrouw is verhuisd om aan het geweld van de man te ontkomen, of een geheim telefoonnummer heeft genomen, zijn dit aanwijzingen van ernstige bedreiging. Ook uit eerder gepleegd geweld kan de ernst van de bedreiging worden afgeleid. ${ }^{77}$ Het dominerende gedrag en eerder gepleegd geweld kunnen erop duiden dat de kans reěel is dat de man zijn bedreigingen ook werkelijk zal uitvoeren; een ziekelijke jaloersheid kan uitmonden in het doodschieten van vrouw en kind en tenslotte zichzelf. ${ }^{78}$ Dit geldt eveneens voor het uiten van bedreigingen in aanwezigheid van vrienden of kennissen. ${ }^{79}$

Wanneer man en vrouw uit elkaar zijn, kunnen zij om wat voor reden dan ook. met elkaar verbonden blijven. Ze kunnen elkaar opzoeken, en besluiten weer van elkaar weg te gaan. 'Gescheiden' betekent niet 'nooit meer contact met elkaar'. Dit vormt de context waarbinnen het geweld tegen de vrouw plaatsvindt. Ook hier is

77 HR 12 oktober 1993, NJ 1994, 144. Het betrof hier een man die telefonisch werd bedreigd door een andere man, die in het verleden de bedreigde ernstig had mishandeld.

78 HR 18 oktober 1983, NJ 1984, 351. Van de vrouwen die zijn gedood door hun (ex-)partner blijkt dat zij doorgaans, voordat zij gedood werden, minstens een maal, maar regelmatig vaker, de politic hadden ingeschakeld. Van Rappard, Vrouwen willen hun man niet in het gevang, ze willen dat het geweld stopt, in: Thuis geslagen, mevrouw?, 1984: 29. Asmus, Ritmeester \& Pence, Prosecuting domestic abuse cases in Duluth: Hamline Law Review, 1991: 154-155; Buzawa \& Buzawa, Domestic violence: The criminal justice response, 1990: 51.

79 HR 9 december 1958, NJ 59, 169. Zie ook Boy en Carol in hoofdstuk 5, § 5.3.2. 
het perspectief van waaruit de ernst van de inbreuk op de persoonlijke levenssfeer van de vrouw wordt beoordeeld, van belang. Wanneer wordt uitgegaan van een relatie van 'aantrekken en afstoten' is het oordeel over de huisvredebreuk die wordt gepleegd een andere dan als wordt uitgegaan van 'achtervolgen en over zich heen laten komen' vanuit het perspectief van een gelijkwaardig contact tussen de vrouw en haar ex-partner zal de aangifte van huisvredebreuk als minder emstig worden beoordeeld dan als de huisvredebreuk wordt beschouwd tegen de achtergrond van dominerend gedrag van de man. ${ }^{80}$ Een aanwijzing voor dominant en controlerend gedrag is bijvoorbeeld de verklaring van de vrouw dat de man haar isoleert van anderen. ${ }^{81}$

Controlerend en dominerend gedrag plaatst de huisvredebreuk en (of) de bedreiging in een ander daglicht dan een vrijwillig wederzijds contact. "[T]he extent of the control abusers exercise over women's choices to leave volatile situations has been greatly underestimated." ${ }^{82}$ Door het incident tegen de achtergrond van dominerend en controlerend gedrag van de man te zien, en de inbreuk op de persoonlijke vrijheid als uitgangspunt te nemen, kan het bedreigende karakter van het gedrag beter worden onderkend.

Het ernstoordeel en het bewijsoordeel worden beïnvloed door opvattingen over relationeel geweld. Wanneer wordt uitgegaan van de visie dat het geweld voortkomt uit een destructieve, gelijkwaardige partnerrelatie wordt het geweld anders beoordeeld dan wanneer wordt uitgegaan van verschillen in macht tussen de man en vrouw. Beide visies hebben realiteitswaarde. De kunst is om met open blik het individuele geval te beschouwen en te onderzoeken welke machtsdynamiek aan het geweld ten grondslag ligt. Het (h)erkennen van chronisch en ernstig geweld gepleegd door de man jegens zijn partner of ex-partner kan worden beschouwd als een ander verhaal. Dit verhaal moet doorklinken in de strafrechtspraktijk, zodat de concrete maatschappelijke vrijheid van vrouwen vergroot kan worden en een betere bescherming kan worden geboden tegen inbreuken op hun persoonlijke levenssfeer door hun partner of ex-partner.

80 Een voorbeeld hiervan is dossier 083. De parketsecretaris schrijft: "Aangeefster vorderde in bijzijn van de politie tot twee keer toe van verdachte de woning te verlaten. Overigens is het niet duidelijk hoe de verdachte aan de sleutel kwam (van de woning van aangeefster, KL). Van beide is bekend dat ze regelmatig contact met elkaar hebben." Besloten werd tot een beleidssepot op grond van 'gering feit' en 'beperkte kring'.

81 "Ik bedoel daarmee te zeggen dat ik dan nergens meer van hem naar toe mag gaan." Dossier 083.

82 Asmus, Ritmeester \& Pence, Prosecuting domestic abuse cases in Duluth, Hamline Law Review, 1991: 119. 


\subsection{Rechtsbescherming door versterking van de rechtspositie}

Het slachtoffer heeft twee hoedanigheden in het strafgeding, die van benadeelde van een misdrijf en die van getuige. Versterking van de rechtspositie van het slachtoffer omvat beiden.

\subsection{De rechtspositie van het slachtoffer als benadeelde van een misdrijf}

Het slachtoffer dat zich voegt als benadeelde partij om een schadevergoeding te vorderen tijdens het strafgeding heeft een aantal rechten. Allereerst het recht een vordering van eenvoudige aard in te stellen teneinde schadevergoeding te krijgen. Daarnaast heeft zij recht op informatie over het verloop van de strafprocedure, ${ }^{83}$ het recht op rechtsbijstand (art. Sle Sv) en een geclausuleerd recht op inzage in de processtukken (art. 5ld Sv). Alle benadeelden van een misdrijf kunnen op grond van de slachtofferrichtlijnen aanspraak maken op een zorgvuldige bejegening, een goede informatievoorziening en zo mogelijk bemiddeling tot schadevergoeding. ${ }^{84}$

Voor versterking van de rechtspositie van het slachtoffer in het strafproces kan worden aangesloten bij het recht op een fair trial (art. 6 EVRM). Daamaast zou een beroep op het folterverbod (art. 3 EVRM) kunnen worden gedaan: ${ }^{85}$ niemand mag aan foltering, onmenselijke of vernederende behandeling of bestraffing worden onderworpen. Dit kan positief worden geformuleerd door te stellen: de burger heeft recht op een zorgvuldige bejegening en geen onnodige inbreuken op de vrijheidsrechten van het slachtoffer mogen plaatsvinden. Het recht op een fair trial geformuleerd in artikel 6 EVRM kan voor het slachtoffer van belang zijn als het gaat om de redelijke termijn waarbinnen een beslissing moet vallen, het recht op informatie, op rechtsbijstand en op een tolk. ${ }^{86}$ Deze algemene rechten constitueren de benadeelde van een misdrijf als rechtssubject in het strafproces. Evenals de verdachte heeft de benadeelde van een misdrijf recht op een eerlijk strafproces. Dit geldt voor het slachtoffer in het algemeen en ook voor slachtoffers van geweld in de privésfeer.

De positie van de benadeelde partij kan op een aantal punten concreet worden versterkt. Het recht op schadevergoeding zou kunnen worden uitgebreid tot het recht schadeloosstelling te vorderen. De nadruk ligt op herstel van de aangerichte schade. Dit kan zijn het daadwerkelijk herstellen van de beschadigde goederen, of de vrouw

83 Dit is vastgelegd in verschillende artikelen: $51 \mathrm{f}, 167$ lid $3,266,319,320 \& 437 \mathrm{~Sv}$.

84 Zie hoofdstuk $2, \S 2.5$.

85 Prakken, Over slachtoffers, pro-actieve politie en de grondrechten van de verdachte, $N J B, 1995$ : 829-833.

86 Deze rechten zijn overigens ook vastgelegd in de VN declaratie: Declaration of basic principles of justice for victims of crime and abuse of power, R 40/34, 29 november 1985. 
enige tijd met rust laten, zodat zij kan herstellen van de emotionele schade. ${ }^{87}$ Aangesloten zou kunnen worden bij artikel 6:103 BW: schadevergoeding kan ook in een andere vorm dan betaling van een geldsom worden toegekend. Straatverboden of andere ge- of verboden zouden dan op grond van dit artikel kunnen worden gevorderd door de benadeelde partij. ${ }^{88}$ De beperking blijft dat het moet gaan om een vordering van eenvoudige aard. Tevens kan het recht op inzage worden aangescherpt door het verzoek tot inzage te richten aan de rechter-commissaris in geval er een gerechtelijk vooronderzoek loopt, in plaats van aan de officier van justitie. Inzage in de psychiatrische en reclasseringsrapporten kunnen op grond van het recht op privacy van de verdachte aan de benadeelde partij worden geweigerd. Conform de huidige wet kunnen verzoeken tot inzage worden afgewezen op gronden aan de wet ontleend en hiertegen kan een bezwaarschrift worden ingediend (art. 5Id Sv). Gezien het feit dat deze stukken van groot belang kunnen zijn ter ondersteuning van de vordering tot schadeloosstelling zou de advocaat van de benadeelde partij in principe inzage moeten kunnen krijgen. Duidelijk moet zijn dat de benadeelde partij recht heeft op inzage en dat alleen in uitzonderlijke situaties, met een goede motivatie, van dit recht kan worden afgeweken. Tot slot kan een recht op het aanbrengen van getuigen en deskundigen, en een zelfstandige beroepsmogelijkheid tegen de uitspraak over de ingediende vordering, worden vastgelegd. ${ }^{89}$

Deze rechtspositionele wijzigingen werk ik niet verder uit, omdat deze een verfijning van de huidige regeling betekenen. Zo'n regeling van de positie van de benadeelde partij is niet het belangrijkste instrument om de rechtsbescherming van slachtoffers van vrouwenmishandeling te versterken, aangezien het verkrijgen van schadevergoeding het te beschermen belang is, terwijl slachtoffers van geweld door hun partner of ex-partner vooral gediend zijn met bescherming van de persoonlijke levenssfeer. En zelfs als de vordering wordt uitgebreid tot schadeloosstelling kan dit pas aan het einde van de strafprocedure worden gevorderd, terwijl juist in de voorfase het creëren van veiligheid voor de vrouw van groot belang is.

Een andere vraag is of door het creëren van een zelfstandige vervolgingsbevoegdheid voor het slachtoffer de bescherming van de persoonlijke levenssfeer van de vrouw wordt versterkt. Juist omdat slachtoffer en dader sociaal en emotioneel betrokken

87 Zie ook: Sagel-Grande, Schadevergoeding en strafrecht, $D D, 1992: 66$. "In de hiervoor geschikte gevallen, (...), dient de schade door werkzaamheden, dienst- en hulpverlening hersteld te worden indien en zoverre het slachtoffer daarmede accoord gaat."

88 Van Maanen, Dading in plaats van strafrecht? in: Dading in plaats van strafrech, 1993: 70. Dit is niet mogelijk als het een schadevergoedingsmaatregel betreft; alleen financikle genoegdoening is mogelijk. Zie hoofdstuk $2, \$ 2.5 .2$ onder Sanctiemodaliteiten ten behoeve van de benadeelde partij.

89 Ik heb gebruik gemaakt van 'De voorgestelde aanpassingen in het wetboek van strafvordering', opgesteld door de Van Bon-Moors en Van Dijk, gepresenteerd tijdens de werkgroep 'De positie van het slachtoffer van zedenmisdrijven in het strafrecht' op het congres Hoe punitief is Nederland? op 21 oktober 1995 (ongepubliceerd). 
zijn bij elkaar, zal de beslissing die wordt genomen door de officier van justitie (of rechter) niet alleen van invloed zijn op het leven van de verdachte, maar ook, direct of indirect, op het leven van het slachtoffer. Het in voorlopige hechtenis nemen van de partner kan betekenen dat er problemen ontstaan met het inkomen, wat direct zijn weerslag kan hebben op de vrouw, of het aanbieden van een transactie betekent dat het geld van het huishoudgeld wordt afgetrokken. De veiligheid van de vrouw kan worden verstoord doordat de voorlopige hechtenis wordt geschorst. Dit pleit voor invloed van het slachtoffer op strafprocessuele beslissingen: naarmate de afstand in de relatie tussen slachtoffer en dader kleiner is, behoort het slachtoffer meer invloed te hebben op strafprocessuele beslissingen ${ }^{90}$ Maar hoever moet deze zeggenschap gaan? Kan een zelfstandig vervolgingsrecht voor slachtoffers van vrouwenmishandeling hun weerbaarheid vergroten? En is het formuleren van geweld tegen de vrouw door haar partner als klachtdelict gewenst?

\section{Zeggenschap over strafvervolging?}

Een van de manieren om aan het belang van het slachtofffer tegemoet te komen zou kunnen zijn haar de mogelijkheid te geven zelf een vervolging te entameren om haar partner of ex-partner te dagvaarden. ${ }^{91}$ Ik zal kort ingaan op het principiële bezwaar tegen een zelfstandige vervolgingsbevoegdheid, om het vervolgens toe te spitsen op slachtoffers van vrouwenmishandeling. In het kader van dit onderzoek is het vooral van belang of het slachtoffer van vrouwenmishandeling gebaat is bij een zelfstandig vervolgingsrecht.

Het belangrijkste argument tegen een zelfstan dige vervolgingsbevoegdheid berust op het onderscheid tussen publiek- en civielrecht. Vervolging vindt plaats op gronden aan het algemeen belang ontleend. De vervolgingsbeslissing kan niet worden overgelaten aan bijzondere personen die op grond van een bijzonder belang vervolging instellen. Dit zou betekenen dat een individuele burger op andere gronden tot vervolging kan overgaan dan het openbaar ministerie. "In al die gevallen zou een volgens vaste criteria beheerste en gecontroleerde praktijk - nogmaals: men spreekt dan van beleid - doorkruist kunnen worden door de vervolging afhankelijk

90 Bangma, Met begrip en inzicht, $A A$, 1989: 648; De Beaufort, De rol van het slachtoffer bij opsporing en vervolging, $J, 1982: 32$.

91 In de landen om ons heen, Belgie, Luxemburg, Duitsland en Frankrijk, bestaat wel in een of andere vorm zo'n zelfstandig vervolgingsrecht met als doel een civiele vordering tot schadeherstel in te dienen bij de strafrechter, of om een straf te eisen (Privatklage). Zo'n zelfstandig vervolgingsrecht heeft alleen betrekking op minder ernstige delicten. Groenhuijsen, Schadevergoeding voor slachioffers van delicten in het strafgeding, 1985: 205-259. De Beaufort, Slachtoffer en straftoemeting, in: De vrijheidsstraf, 1986: 212. De Beauforh, De rol van het slachtoffer bij opsporing en vervolging, $J V, 1982: 28-29$. 
te maken van de puur persoonlijke wensen van de beledigde partij." ${ }^{92}$ De eisen van een behoorlijke procesgang kunnen hierdoor worden geschaad. Te denken valt aan een inbreuk op het minimumvereiste van artikel 27 lid $1 \mathrm{~Sv}$ : om tot vervolging te kunnen overgaan, moet sprake zijn van een redelijk vermoeden van schuld aan een strafbaar feit. ${ }^{93}$ Ook kan het adagium dat iemand onschuldig is totdat het tegendeel is bewezen, worden aangetast. De positie van het slachtoffer als civiele partij binnen het strafrecht is niet verenigbaar met het onschuldprincipe; zij is ervan overtuigd dat hij het strafbare feit heeft begaan en stelt dat zij daar schade van heeft geleden. Het is dan aan de verdachte zich hiertegen te verweren. ${ }^{94} \mathrm{Om}$ de verdachte tegen een dubieuze particuliere vervolgingsdaad te beschermen zou de benadeelde partij een verzoek tot vervolging moeten instellen bij de rechterlijke macht, die vervolgens toetst aan de beginselen van een behoorlijke procesorde of het verzoek kan worden gehonoreerd. ${ }^{95}$ Dit heeft echter als bezwaar dat de rechterlijke macht structureel meer zeggenschap krijgt over de selectie van zaken die worden gedagvaard. Tevens is de rechterlijke toetsing een inbreuk op het vervolgingsrecht van de benadeelde. "[D]e waarborgen die nodig zijn om een redelijke bescherming van de verdachte te verzekeren, brengen zelf zó grote bezwaren met zich mee dat het veruit de voorkeur verdient om het vervolgingsmonopolie van de overheid te handhaven". ${ }^{96}$ Het principiêle bezwaar is daarmee gegeven: een particulier vervolgingsrecht maakt inbreuk op het vervolgingsbeleid dat gebaseerd is op het algemeen belang. Bovendien kan het een inbreuk betekenen op een eerlijke rechtsbedeling of de beginselen van een goede procesorde, waardoor een inbreuk plaatsvindt op de rechtsbescherming van de verdachte. ${ }^{97}$ Vergaande invloed van het slachtoffer stuit af "op de karakteristieken en subjecten van de strafrechtelijke rechtsbetrekking". 98

92 Groenhuijsen wijst op het vervolgingsbeleid omtrent abortus provocatus gedurende het parlementaire besluitvormingsproces. De maatschappelijke tegenstellingen zouden aanzienlijk zijn verscherpt als particuliere belanghebbendeneenstrafvervolginghadden kunnenentameren. Groenhijsen, Schadevergoeding voor slachtoffers van delicten in het strafgeding, 1985: 290 (noot 302).

93 Schalken, De rechtspositie van de benadeelde partij in het systeem van de nederlandse rechtsvordering, $D D, 1980: 275$.

94 Tevens kan de procesvrijheid van de verdachte worden aangetast omdat het gebruik van het zwijgrecht vaker in zijn nadeel kan uitwerken terwijl er geen alternatief is. Van Dijk, Victim rights, in: Criminal law in action, 1986: 358-362; Groenhuijsen, Schadevergoeding voor slachloffers van delicten in het strafgeding, 1985: 130.

95 Een andere manier is het inbouwen van een bezwaarschriftprocedure voor de verdachte en het openbaar ministerie tegen de particuliere vervolgingsdaad, zoals in het ontwerp Benelux verdrag. Het bezwaar hiertegen is dat dan het kwaad al is geschied; iemand is op onterechte gronden vervolgd en kan hiertegen bezwaar maken. Dit druist in tegen het al eerder genoemde onschuldprincipe.

96 Groenhuijsen, Schadevergoeding voor slachtoffers van delicten in het strafgeding, 1985: 291.

97 Ik ga niet nader in op de discussie hoe in de verschillende landen de zelfstandige vervolgingsbevoegdheid van de benadeelde partij is geregeld en wat de voor- en nadelen ervan zijn; dit valt buiten het kader van dit onderzoek.

98 Cleiren, Strafrecht als object van verlangen, in: Lof der verscheidenheid, 1993: 47. 
Maar draagt een zelfstandige vervolgingsbevoegdheid voor slachtoffers van vrouwenmishandeling bij aan rechtsbescherming? Meer zeggenschap over de wijze van vervolging kan worden beschouwd als een positief aspect van de zelfstandige vervolgingsbevoegdheid; de vrouw is niet afhankelijk van de officier van justitie of er wordt vervolgd. Daarnaast heeft de vrouw, afhankelijk van de concrete regeling, (enige) zeggenschap over de te eisen straf. Bovendien kan, door meer actief bij het strafproces betrokken te zijn, het zelfrespect en het zelfvertrouwen van het slachtoffer van vrouwenmishandeling worden versterkt. ${ }^{99}$ Haar weerbaarheid kan erdoor worden vergroot doordat zij wordt gerespecteerd als rechtssubject.

Naast deze positieve aspecten kleven naar mijn mening vooral bezwaren aan een zelfstandige vervolgingsbevoegdheid voor het slachtoffervan vrouwenmishandeling. Het slachtoffer staat bijvoorbeeld meer bloot aan chantage door haar partner of expartner om geen vervolging in te stellen ${ }^{100}$ en tijdens het proces bestaat de kans dat zij vaker aan de tand wordt gevoeld over haar rol tijdens het strafbare gebeuren door de verdachte of diens advocaat, met het risico van secundaire victimisatie. Wanneer het slachtoffer meer 'partij' wordt binnen het strafproces zullen ook haar plichten toenemen; de druk om herhaalde malen te getuigen wordt bijvoorbeeld vergroot, alsmede de plicht om aan een deskundigenonderzoek mee te werken of over haar persoonlijke achtergrond informatie te verschaffen. ${ }^{101}$ Tevens is de vraag of het slachtoffer wel in staat is tot een meer actieve rol binnen het strafproces. Door het haar aangedane leed kan zij (tijdelijk) zo in de war zijn dat zij emotioneel niet in staat is actief op te treden. ${ }^{102}$ Maar zelfs als het slachtoffer het entameren van een strafprocedure wel emotioneel aankan, kan zij, om wat voor reden dan ook, geen behoefte hebben aan een initiërende rol. Het doen van aangifte en het doorzetten ervan kan voor deze vrouwen een hele stap zijn. ${ }^{103}$ Kortom, slachtoffers van vrouwenmishandeling lijken veelal geen behoefte aan een eigen vervolgingsbevoegdheid te hebben, ${ }^{104}$ want dit vervolgingsrecht maakt hen extra kwetsbaar

99 Dit argument wordt ook gebruikt om de waarde van een civiele (kort geding) procedure voor slachtoffers van vrouwenmishandeling aan te geven. Van Dijk, Victim rights, in: Criminal law in action, 1986: 358.

100 Asmus, Ritmeester \& Pence, Prosecuting domestic abuse cases in Duluth, Hamline Law Review; 1991: 118-1 19; Ford, Prosecution as a victim power resource, Law \& Society Review, 1991: 320, 326.

101 Verrijn Stuart, Naar een geciviliseerd recht, $A A$, 1992: 87. Bovendien is denkbaar dat de vrouw wordi verplicht zich te onderwerpen aan een vaginaal onderzoek in het kader van een sporenonderzoek naar sperma op grond van artikel $195 \mathrm{~Sv}$. Nacye, De reikwijdte van fundamentele rechten in strafzaken - enkele thema's, in: De reikwijdte van fundamentele rechten, 1995: 262.

102 Van Dijk, Victim rights, in: Criminal law in action, 1986: 360-361. Dutton, The domestic assaull of women, 1995: 216.

103 Wostmann, Politieoptreden bij vrouwenmishandeling, 1988: 94.

104 In de landen waar wel een vorm van citation directe geldt, blijkt overigens dat hiervan weinig gebruik wordt gemaakt, met uitzondering van rechtspersonen zoals verzekeringsmaatschappijen. Groenhuijsen, Schadevergoeding voor slachtoffers van delicten in het strafgeding, 1985: 210; Polak, De 'beledigde partij' in ere hersteld, $N J B, 1980: 26$. 
voor geweld door hun (ex-)partner. Het probleem is nu juist dat zij niet de macht hebben het geweld te stoppen. ${ }^{105}$ Dit brengt me bij een belangrijk maatschappelijk bezwaar.

Met de invoering van een bevoegdheid voor het slachtoffer tot het instellen van een strafvervolging dreigt het gevaar dat de officier van justitie geen zaken van vrouwenmishandeling meer zal vervolgen als de vrouw niet zelf de vervolging entameert. Het gevaar bestaat dat het niet entameren van een strafvervolging door de vrouw wordt beschouwd als een teken dat zij geen vervolging wil. Vrouwenmishandeling wordt op die manier teruggebracht tot de privésfeer, waarin de overheid zich in beginsel niet mengt (art. $10 \mathrm{Gw}$, art. 8 EVRM). Dit kan tot gevolg hebben dat vrouwen die slachtoffer zijn van vrouwenmishandeling nog verder in hun isolement worden gedrukt en dat de machtsuitoefening door de man niet wordt doorbroken. Een laatste argument dat pleit tegen een zelfstandige vervolgingsbevoegdheid is dat het doel waartoe de zelfstandige vervolgingsbevoegdheid kan worden gebruikt, het vorderen van schadeloosstelling, veelal niet het doel is dat de vrouw voor ogen staat. $\mathrm{Zij}$ wil dat het geweld tegen haar stopt en dat een veilige omgeving wordt gecreěerd. Een zelfstandige vervolgingsbevoegdheid lijkt daar geen bijdrage aan te leveren.

Een andere manier om enige zeggenschap over de strafvervolging te creëren is vrouwenmishandeling als klachtdelict te formuleren. ${ }^{106}$ "Met name huisvredebreuk en mishandeling die zich zo dikwijls in de relationele sfeer voordoen, zouden in de rij van Nederlandse relatieve klachtdelicten niet misstaan." 107 Het slachtoffer $k a n$ in dat geval vervolging voorkomen door geen klacht in te dienen of de klacht binnen acht dagen in te trekken (art. $67 \mathrm{Sr}$ ). ${ }^{108}$ Wanneer een klacht is ingediend, is het vervolgens aan de officier van justitie of tot vervolging zal worden overgegaan. Het voordeel van deze optie zou kunnen zijn dat de vrouw het indienen van de klacht en het kunnen intrekken van de klacht als machtsmiddel kan gebruiken met als doel te bewerkstelligen dat de man geen geweld meer gebruikt. ${ }^{109} \mathrm{Zij}$ kan bijvoorbeeld dreigen een aanklacht in te dienen als hij haar nog eenmaal mishandelt. ${ }^{110} \mathrm{Ze}$ kan ook beloven de anklacht in te trekken als de man in therapie gaat en haar niet meer mishandelt. Het gebruik van de aanklacht als machtsmiddel heeft

105 Wanneer de vrouw wel een initierende rol wenst, kan ze gebruik maken van het civiele recht.

106 In de parlementaire discussie over het schrappen van 'buiten echt' uit de verkrachtingsbepaling is voorgesteld om verkrachting door de echtgenoot als klachtdelict te formuleren. Dit is ondermeer afgewezen op grond van de emst van het feit. TK 20.930, nr. 4: 12 \& nr. 5: 10. Zie ook: Van Dorst, Verkrachting binnen huwelijk: een klachtmisdrijf?, $N J B, 1989: 456$. Reactie crop door: Van den Broek, NJB, 1989: $918-919$ (naschrift Van Dorst).

107 De Beaufort, De rol van het slachtoffer bij opsporing en vervolging, $J V$, 1982: 31 .

108 De klacht moet binnen drie maanden nadat het delict is gepleegd worden ingediend (art. $66 \mathrm{Sr}$ ).

109 Ford, Prosecution as a victim power resource, Law \& Society Review, 1991: 318-321.

110 Het doen van aangifte kan op dezelfde manier als machtsmiddel worden gebruikt. 
overigens alleen effect als de vrouw langere tijd de mogelijkheid heeft om de aanklacht in te trekken. ${ }^{\text {III }}$ De termijn voor het intrekken van de aanklacht zou in geval van vrouwenmishandeling beduidend langer moeten worden gesteld dan acht dagen.

Maar ook in dat geval zou ik niet pleiten voor het formuleren van vrouwenmishandeling als klachtdelict. Het slachtoffer heeft weliswaar meer zeggenschap over het voorkomen van vervolging, maar daardoor ligt ook de verantwoordelijkheid voor een eventuele vervolging geheel bij de vrouw. Dit maakt haar positie extra kwetsbaar, zoals hiervoor uiteen is gezet; de man kan zijn macht gebruiken om het intrekken van de aanklacht te bewerkstelligen. In dat geval wordt de macht van de vrouw erdoor verzwakt en de macht van de man over de vrouw versterkt. Bovendien zijn er situaties van dermate ernstig geweld tegen de vrouw in de privésfeer dat de mogelijkheid benut moet kunnen worden om ambtshalve een proces-verbaal op te maken en door te sturen naar het openbaar ministerie. ${ }^{112}$ Laatste argument tegen het formuleren van een klachtdelict is de maatschappelijke waardering die spreekt uit de formulering van een klachtdelict: het symboliseert dat vrouwenmishandeling een privéprobleem is in plaats van een ernstig maatschappelijk probleem. ${ }^{113}$

Invloed op strafprocessuele beslissingen kan als voordeel hebben dat de vrouw het inzetten van strafrechtelijke sancties enigszins kan gebruiken als machtsmiddel, als stok achter de deur. Daarnaast kan erdoor worden voorkomen dat zij nogmaals slachtoffer wordt, maar nu door de genomen strafprocessuele beslissingen (secundaire victimisatie). Anderzijds kan meer zeggenschap haar positie meer kwetsbaar maken, omdat zij kan worden bedreigd en gechanteerd door haar (ex)partner om dit machtsmiddel niet in te zetten. Een grote invloed op strafprocessuele beslissingen kan een inbreuk op het vervolgingsbeleid betekenen evenals een inbreuk op de rechtsbescherming van de verdachte. Het slachtoffer moet daarom geen zeggenschap hebben over strafprocessuele beslissingen. Wel lijkt het van belang dat de vrouw enige invloed heeft op de strafprocedure, zodat de strafprocedure ingezet kan worden als stok achter de deur. Strafrechtelijke interventie zou een bijdrage kunnen leveren aan het verminderen van de machtsongelijkheid tussen de man en de vrouw, door in de afweging welke beslissing genomen zal worden, het belang van de vrouw (strafrechtelijke afkeuring van het geweld, bescherming van de persoonlijke levenssfeer en versterking van haar weerbaarheid) als uitgangspunt te nemen. ${ }^{114}$

111 Ford, Prosecution as a victim power resource, Law \& Society Review, 1991: 320.

112 Ter Harmsel, Interventie bij huiselijk geweld, $A P, 1995: 6$.

113 Vernieling en diefstal door de echtgenoot is momenteel niet vervolgbaar en door de van tafel en bed gescheiden partner niet dan op klacht (arth $316 \& 353 \mathrm{Sr}$ ). Deze bepaling dient te worden afgeschaft op grond van bovenstaande argumenten. Daarnaast kan als argument naar voren worden gebracht dat deze bepaling strijdig is met de bescherming van de persoonlijke levenssfeer. Zie hoofdstuk 1, § 1.2 .2 \& hoofdstuk 3. \$ 3.3.2.

114 Dutton, The domestic assault, 1995: 240-249. 
Rechtsgrond hiervoor is de, in de circulaire Conclusies en aanbevelingen voor de bejegening van slachtoffers van seksuele misdrijven vastgelegde, aanbeveling, ${ }^{115}$ dat de wensen van het slachtoffer van (seksueel) geweld door haar partner over een eventuele strafvervolging relevant kunnen zijn voor de afweging van de officier van justitie of tot vervolging zal worden overgegaan.

\subsubsection{Rechtsbescherming van de slachtoffer-getuige}

Het slachtoffer van geweld door haar partner of ex-partner is vaak de enige 'oog'getuige van het geweld. Haar verklaring wordt als een belangrijk bewijsmiddel beschouwd, naast de verklaring van de verdachte, en is van groot belang voor het rondkrijgen van het bewijs. Ook is haar verhaal van belang om zicht te krijgen op de achtergrond van het relationele geweld; de interactie die zich in het verleden heeft afgespeeld en de machtsverhoudingen binnen de relatie. Doorgaans wordt de verklaring van het slachtoffer, vastgelegd in het proces-verbaal van aangifte, later ter terechtzitting als wettig bewijsmiddel gebruikt (art. 344 lid $1 \mathrm{~Sv}$ ), tesamen met ander materiaal dat in het voorbereidende onderzoek is verzameld door de politie, en eventueel tijdens een gerechtelijk vooronderzoek door de rechter-commissaris. Het onderzoek ter terechtzitting heeft eerder een evaluerend en toetsend karakter, doordat de rechter zich meestal een oordeel vormt over het bewijs op grond van gereproduceerd bewijs, en niet op grond van de directe bron, onmiddellijk bewijs. ${ }^{116}$ Dit schriftelijke karakter van het strafproces heeft tot gevolg dat het slachtoffer van vrouwenmishandeling doorgaans niet wordt opgeroepen om als getuige op de zitting te verschijnen. Alleen in de emstige vrouwenmishandelingszaken, zoals de zware mishandelingszaken, de (poging tot) doodslagzaken en de verkrachtingszaken komt het voor dat vrouwen worden opgeroepen als getuige. ${ }^{117}$ Het verhaal van het slachtoffer kan zo geheel naar de achtergrond verdwijnen. Een manier om haar verhaal in het strafproces te laten horen, is door op te treden als getuige. Maar aan het vertellen van het verhaal als slachtoffer-getuige kleven verschillende bezwaren.

In deze $\S$ wordt aandacht geschonken aan twee belangrijke knelpunten in de praktijk. Allereerst de situatie dat de vrouw een getuigenverklaring af wil leggen op de terechtzitting, maar hier geen gelegenheid voor krijgt, en ten tweede de situatie dat de vrouw, om verschillende redenen, niet kan of wil getuigen, terwijl de verdachte van zijn recht om haar als getuige op te roepen, gebruik wil maken.

115 Aanbeveling 20, Stcri. 1986, nr. 33, 17 februari 1986.

116 Het 'de auditu'-arrest, HR 20 december 1926, NJ 1927, 85 heeft dit mogelijk gemaakt. Garé. Het zwaartepunt in het strafproces, in: Schaduwen vooruit, 1992: 1.

117 Uit mijn dossieronderzoek blijkt dat zelden de vrouw als getuige is opgetreden. Uit het onderzoek van Slotboom blijkt dat van de 18 zaken die zij heeft onderzocht, in drie zaken het slachtoffer als getuige is opgetreden. Slotboom, De 'gevonden waarheid', 1992: bijlage III. 
Hieraan voorafgaand nog enkele opmerkingen over de betrouwbaarheid van de slachtoffer-getuige.

De slachtoffer-getuige wordt ondervraagd over de door de slachtoffer-getuige waargenomen of ondervonden feiten en omstandigheden. Alleen uitspraken over 'feiten en omstandigheden' kunnen voor het bewijs worden gebruikt (art. 342 lid $1 \mathrm{~Sv}$ ). Oordelen, vermoedens, gissingen of uitspraken die haar deskundigheid te boven gaan, kunnen niet voor het bewijs worden gebruikt; ${ }^{118}$ het is aan de rechter om conclusies te trekken uit de feitelijke informatie. De rechter oordeelt echter niet alleen over de 'feitelijkheid' van de verklaring, maar ook over de betrouwbaarheid van de verklaring en daarmee de betrouwbaarheid van de getuige. Is de verklaring, gezien de persoon van de getuige, de omstandigheden waaronder de getuigenis tot stand is gekomen en de feitelijke informatie die het bevat, voldoende betrouwbaar en aannemelijk om als bewijsmiddel te worden gebruikt. ${ }^{119}$ In de gevallen waar de verdachte (deels) ontkent, kan de betrouwbaarheid en de geloofwaardigheid van de slachtoffer-getuige(verklaring) een belangrijke rol spelen in de vorming van die overtuiging. ${ }^{120}$ De verklaring kan als onbetrouwbaar worden beschouwd op grond van het idee dat de vrouw uit is op wraak. ${ }^{121}$ Tijdens het strafproces betwist de verdediging vaak de betrouwbaarheid van de slachtoffer-getuige door bijvoorbeeld de aangifte van de vrouw als een daad van agressie en wraak voor te stellen. "Het slachtoffer wordt ervan beschuldigd haar (ex-)partner ten onrechte slachtoffer te maken van de 'justitięle macht'. ${ }^{122}$ Een wisselend verhaal door het slachtoffer ${ }^{123}$ kan eveneens afbreuk doen aan haar geloofwaardigheid. Slachtoffers die ernstig zijn getraumatiseerd, kunnen vaak moeilijk een chronologisch juiste weergave geven van de verschillende (seksueel) gewelddadige feiten, waardoor de betrouwbaarheid van hun verklaring in twijfel kan worden getrokken. ${ }^{124}$ Een andere manier om de betrouwbaarheid aan te tasten is het benadrukken dat de vrouw ook geweld heeft

118 Zie bijvoorbeeld de Maurikse incestzaak, HR 4 juni 1991, NJ 1991, 790. De verdediging diende als cassatiemiddel in dat bepaalde uitspraken van een als getuige beedigde hulpverleenster uit een opvanghuis als conclusies moesten worden opgevat en derhalve had zij als getuige-deskundige moeten worden gehoord. De Hoge Raad wees dit middel af: de aangehaalde passages kunnen worden beschouwd als mededelingen over wat de getuige heeft waargenomen en ondervonden.

119 Nijboer, Strafrechtelijke bewijsrecht, 1995: 233.

120 Van Bavel \& Verbunt, Slachtoffer/getuige in zedenzaken en verhoor ter zitting, NJB, 1990: 13991400.

121 In het rappon 'Bedreigde getuigen' wordt de ex-echtgenoot als voorbeeld genomen van een anonieme getuige, die uit wraak zou kunnen handelen. Hier wordt overigens gedoeld op de situatie dat de man verdacht wordt van een ernstige strafbaar feit niet gericht tegen zijn vrouw. Rapport Bedreigde getuigen, juni 1986: 80.

122 Ketelaars \& Slotboom, De gevonden waarheid, Nemesis, 1993: 113.

123 Als de verklaring wordt beoordeeld als leugenachtig, mag de verklaring van de getuige niet meewerken voor het bewijs. HR 14 september 1992, NJ 1993, 54.

124 Deze problematiek heeft vooral aandacht gekregen rond zaken van seksueel misbruik. Frenken, De geloofwaardigheid van een incestslachtoffer, $M G v$, 1988: 968-979. 
gebruikt of het geweld heeft uitgelokt. ${ }^{125}$ In feite betreft dit meer de schuldvraag en de vraag van strafwaardigheid. ${ }^{126}$ Als het de verdachte lukt om de geloofwaardigheid van de getuigenis van het slachtoffer aan te tasten, wordt zijn verhaal sterker. ${ }^{127}$ Het zal doorgaans niet tot gevolg hebben dat het bewijs wordt aangetast, maar de strafwaardigheid van het gedrag kan er wel door worden verminderd. ${ }^{128}$

\section{Het recht te spreken}

Een getuige heeft de plicht om in het proces van waarheidsvinding mee te werken aan het verkrijgen van bewijs voor de in de dagvaarding ten laste gelegde feiten. Maar de getuige heeft geen recht om te mogen spreken. ${ }^{129}$ Het slachtoffer kan belang hebben bij het afleggen van een verklaring als getuige om haar verhaal zichtbaar te maken. ${ }^{130}$ Haar verhaal wordt tijdens het strafproces verzwakt door de technisch-juridische taal waarin het proces-verbaal is geformuleerd. Op de terechtzitting kan haar verhaal nogmaals worden verzwakt omdat de verdachte alle ruimte heeft om het verhaal van het slachtoffer naar zijn visie te interpreteren. "Enerzijds blijft haar beleving van het geweld onderbelicht, haar verklaring wordt weergegeven door de verbalisanten in 'klinische', 'objectieve' termen, anderzijds zwakt de verdachte de emst van het geweld af." "31 Hoewel zij nooit helemaal haar eigen verhaal zal kunnen vertellen (het verhaal moet relevant zijn voor het te bewijzen strafbare gedrag) kan zij wel het afgevlakte en juridische verhaal in het proces-verbaal tot leven brengen. ${ }^{132}$

125 Ketelaars \& Slotboom, De gevonden waarheid, Nemesis, 1993: 113. Zic ook de Unterpertinger-zaak, door mij becommentarieerd (noot onder het Asch-arrest, RN 1993, 340).

126 De door de officier van justitie gepercipieerde schuld van de verdachte in relatie tot die van het slachtoffer lijkt een (belangrijke) rol te spelen in de beslissing om te vervolgen of te seponeren. Zie hoofdstuk 5, \$5.5. Zie ook Van Eck, Strafrechtelijke conflictbeheersing, in: Beslissingsmomenten in het strafrechtelijke systeem, 1978: 184. Hij heeft onderzoek gedaan naar zaken van interpersoonlijke conflicten waarbij sprake was van mishandeling en openlijke geweldpleging.

127 De geloofwaardigheid van de getuige kan daarentegen worden versterkt door de onbetrouwbare indruk die de verdachte wekt als hij elke keer een ander verhaal vertelt. Een leugenachtige verklaring van de verdachte kan aan het bewijs meewerken. HR 24 maart 1987. NJ 1987, 893; HR 8 juni 1993, DD 93.469; HR 3 november 1993, Strafkamer nr. 91.809 (ongepubliceerd).

128 Zie ook hoofdstuk $5, \S 5.5$ en $\$ 6.2$ van dit hoofdstuk.

129 Dit recht is evenmin op het niveau van de Europese Unie of de Verenigde Naties vastgelegd. Van Dijk, Victim rights, in: Criminal law in action, 1986: 353-354. Overigens kan artikel 6, onder b van de Declaration of basic principles of justice for victims of crime and abuse of power (General Assembly, R 40/34, 29 november 1985) wel een handvat bieden: "Allowing the views and concerns of victims to be presented and considered at appropriate stages of the proceedings where their personal interests are affected, without prejudice to the accused and consistent with the relevant national criminal justice system."

130 Van Driem, Haar was recht gedaan, in: Het klappen van de zweep, 1994: 120.

131 Ketelaars \& Slotboom, De gevonden washeid, Nemesis, 1993: 111.

132 Ibidem: 111-112. 
Als het slachtoffer als getuige optreedt, kan zij een verklaring afleggen over de wijze waarop het geweld is gepleegd en welke invloed dit heeft gehad op haar (geestelijke) gezondheid en sociale functioneren. De ondervraging kan bijdragen aan de verwerking van het haar aangedane leed. ${ }^{133}$ De vragen die worden gesteld, kunnen weliswaar (zeer) pijnlijk zijn, of confronterend omdat niet alleen het gedrag van de verdachte, maar tevens haar eigen gedrag ter discussie staat, maar tegelijkertijd kan deze ondervraging een positief effect hebben. Voorwaarde is wel dat de ondervraging op een onbevangen, niet veroordelende en zorgvuldige manier gebeurt. Alleen dan kan secundaire victimisatie worden voorkomen, en kan de ondervraging de vrouw meer inzicht geven in het hoe en waarom van het geweld haar aangedaan. ${ }^{134}$ Haar gevoel van eigenwaarde en autonomie kan worden versterkt als zij ervaart dat haar pijn wordt erkend. Ook de ervaring dat haar verklaring van belang is voor het bewijs, zeker als de verdachte wordt veroordeeld, kan bijdragen aan de verwerking van het haar aangedane leed. ${ }^{135}$ Door de getuige als volwaardig individu te beschouwen en niet als een te beschermen slachtoffer, kan het slachtoffer van vrouwenmishandeling zich losmaken van haar slachtofferstatus en als geèmancipeerd slachtoffer ${ }^{136}$ haar verantwoordelijkheid in het proces van waarheidsvinding op zich nemen door naar waarheid te verklaren over het geweld haar aangedaan.

Het beroep op verschoning en 'gevaar voor de lichamelijke en geestelijke gezondheid"

Slachtoffers van vrouwenmishandeling kunnen op verzoek van de verdachte ${ }^{137}$ worden opgeroepen om als getuige te verschijnen. $\mathrm{Zij}$ zijn verplicht aan deze oproep gehoor te geven (artt. 213 juncto $282 \mathrm{~Sv}$ ). ${ }^{138}$ Soms wil het slachtoffer niet als getuige optreden, bijvoorbeeld uit angst voor haar partner of omdat een verhoor op de terechtzitting dermate pijnlijk is voor haar dat het haar geestelijke en fysieke gezondheid ernstig kan schaden. Wanneer het slachtoffer van vrouwenmishandeling wordt opgeroepen om te getuigen, terwijl zij niet kan of wil getuigen, zijn er twee mogelijkheden.

Als de vrouw in een familierechtelijke verhouding staat tot haar partner, kan zij een beroep op haar verschoningsrecht doen (artt. 217 \& $218 \mathrm{~Sv}$ ). Wanneer geen sprake is van een familierechtelijke verhouding, kan de vrouw een verzoek indienen bij de officier van justitie om haar niet als getuige op te roepen.

133 Claasssens \&toker-Klein, Het slachtoffer in het strafproces, Trema, 1995: 168.

134 Doomen, Aangifte van verkrachting, $N J B, 1982: 454$.

135 Van Driem, Haar was recht gedaan, in: Het klappen van de zweep, 1994: 120.

136 Boutellier, Het geemancipeerde slachtoffer, in: Hoe punitief is Nederland?, 1994: 207.

137 De verdachtc heeft uit het oogpunt van de "equality of arms" het recht getuigen te doen oproepen (artt. 260 lid 3 juncto 263 leden 1 \& 2 Sv, 6 lid 3 sub d EVRM).

138 Bovendien moet zij naar waarheid antwoorden op de gestelde vragen (artt. 215 \& 284 lid 2 Sv). Zie ook hoofdstuk $4, \S 4.4 .2$. 
Zij kan een beroep doen op het verschoningsrecht wegens verwantschap tijdens een verhoor ter terechtzitting of binnen een gerechtelijk vooronderzoek bij een verhoor door de rechter-commissaris (art. $217 \mathrm{~Sv}$ ). De vrouw die door de politie wordt gehoord tijdens de voorfase, heeft geen spreekplicht. Uit dien hoofde is er geen verschoningsrecht. ${ }^{139}$ De rechter moet het beroep van het slachtoffer van vrouwenmishandeling op het verschoningsrecht honoreren als sprake is van een huwelijk of de huwelijkse betrekking is verbroken. Als de vrouw samenwoont of heeft samengewoond, is verschoning niet mogelijk; het verschoningsrecht wordt strikt geïnterpreteerd. ${ }^{140} \mathrm{Er}$ bestaat overigens geen plicht voor rechters ter terechtzitting en in een gerechtelijk vooronderzoek om het slachtoffer van geweld door haar echtgenoot te wijzen op haar verschoningsrecht. ${ }^{141}$

Het doel van het verschoningsrecht is de getuige een innerlijk conflict te besparen over de vraag of zij de waarheid zal verklaren, waarbij de belastende verklaring de relatie onherstelbaar kan verstoren, of dat zij de verdachte zal sparen en meineed plegen. ${ }^{142}$ In dat licht bezien behoort de getuige op de hoogte te zijn van het verschoningsrecht zodat zij een juiste afweging kan maken. ${ }^{143}$ In de situatie waarin de vrouw aangifte heeft gedaan van het geweld haar aangedaan door haar echtgenoot, heeft zij er in eerste instantie voor gekozen om een belastende verklaring af te leggen bij de politie. Later kan zij zich om verschillende redenen toch op haar verschoningsrecht beroepen. ${ }^{144}$ Haar eerder afgelegde verklaring bij de politie kan wel worden gebruikt voor het bewijs. ${ }^{145}$ Als deze vrijwillig afgelegde verklaring niet zou mogen worden gebruikt voor bewijs, zou aan het verschoningsrecht meer gevolgen zijn verbonden dan de wetgever heeft bedoeld: het gaat er dan niet meer om dat de wetgever aan de getuige een pijnlijk conflict heeft willen besparen. Het inroepen van het verschoningsrecht zou dan tot gevolg kunnen hebben dat het openbaar ministerie geen vervolging meer kan instellen wegens gebrek aan bewijs. $^{146}$

139 Dit juridische verschil is overigens voor getuigen niet helder; zij hebben het idee dat er cen plicht tot getuigen bestaat in elke fase van het strafproces. Mols, Getuigen in strafzaken, 1993: 9-11.

140 Dit verschoningsrecht geldt alleen voor bloedverwanten en aangehuwden. Verburg in Melai c.s., aant. 2 op art. $217 \mathrm{~Sv}$. Mols pleit ervoor het verschoningsrecht ook voor samenwonenden te regelen. Mols, Getuigen in strafzaken, 1993: 7, 18.

I41 HR 8 november 1977, NJ 1978, 536; HR 10 januari 1984, NJ 1984, 421.

142 Verburg in Melai c.s, aant. 2 op art. 217 Sv: 2-3.

143 Mols, Getuigen in strafzaken, 1993: 13.

144 Het doen van aangifte mag niet worden beschouwd als een expliciete afwijzing van het gebruik van het verschoningsrecht. HR 20 februari 1990, NJ 1990, 635. Het betrof hier een zaak van mishandeling en afpersing van de moeder door de zoon.

I45 Dit is vaste jurisprudentie: HR 8 februari 1932, NJ 1932, p. 620; HR 2 juni 1936, NJ 1936, 992; HR 27 juni 1938, NJ 1939, 60; HR 20 februari 1990, NJ 1990, 635.

146 " $[\mathrm{B}] \mathrm{ut}$ the right on which she relied in order tot avoid giving evidence cannot be allowed to block the prosecution". Asch, EHRM 26 april 1991, Serie A 203, rechtsoverweging 28. Zie tevens de noot van Taveme, HR 30 september 1929, NJ 1929: 1549. Bovendien zou de positie van het slachtoffer worden verzwakt omdat haar partner druk zal kunnen uitoefenen om te voorkomen dat 
Het gebruik van de eerder afgelegde verklaring bij de politie past binnen het schriftelijke karakter van het strafproces. Maar het gebruik van de schriftelijke verklaring, omdat de vrouw niet op de terechtzitting wil getuigen, kan worden beschouwd als een miskenning van het fundamentele recht van de verdachte om voor hem belastende getuigen te ondervragen of te doen ondervragen. ${ }^{147}$ Binnen de rechtspraak wordt een inbreuk op het fair trial beginsel alleen aangenomen als de verdachte op een eerder moment in het strafproces niet in de gelegenheid is geweest om de getuige vragen (te doen) stellen. Heeft de verdachte van deze gelegenheid geen gebruik gemaakt, dan wordt een beroep op schending van het 'onmiddellijkheidsbeginsel' niet gehonoreerd. ${ }^{148}$ Is de verdachte niet in de gelegenheid geweest de vrouw (of de politieagent of rechter-commissaris die het procesverbaal heeft opgemaakt van een eerder verhoor van de slachtoffer-getuige), vragen te (doen) stellen, dan mag de bewezenverklaring niet in overwegende mate op het proces-verbaal van de verklaring van de getuige berusten. ${ }^{149}$ Dan moet de verdachte wel te kennen hebben gegeven de getuige te willen horen. ${ }^{150}$

Voor het slachtoffer van vrouwenmishandeling heeft het verschoningsrecht als groot voordeel dat dit een absoluut recht is dat elk moment kan worden ingeroepen zonder het te motiveren. De reden kan gelegen zijn in een vrees voor verslechtering van de relatie. Maar ook andere redenen kunnen een rol spelen, zoals chantage van de man of omdat het moeten getuigen de gebeurtenis weer opnieuw oprakelt terwijl ze haar leven hier juist van wil losmaken. ${ }^{\text {Is1 }}$ Slachtoffers van vrouwenmishandeling die niet met de verdachte zijn gehuwd (geweest), kunnen geen beroep doen op het verschoningsrecht. Het recht op verschoning zou kunnen worden uitgebreid voor (ex-)samenwonenden. ${ }^{152}$ Maar ook als het verschoningsrecht voor (ex-)samenwonenden geldt, blijft er een groep van slachtoffer-getuigen die geen beroep op dit verschoningsrecht kan doen, zoals vrouwen die een LAT-relatie hebben.

zij zal getuigen, waardoor wegens gebrek aan bewijs een veroordeling kan worden voorkomen. Asmus, Ritmeester \& Pence, Prosecuting domestic abuse cases in Duluth, Hamline Law Review: 1991: 119.

147 Mols, Getuigen in strafzaken, 1993: 10 (noot 10).

148 HR 14 september 1987, NJ 1988, 301; HR 26 september 1995, NJ 1996, 42.

149 Unterpertinger, EHRM 24 november 1986, Serie A 110 \& NJ 1988, 745; Asch, EHRM 26 april 1991, Serie A 203 \& RN 1993, 340 (m.nt. Lünemann); HR 17 november 1992, NJ 1993, 274: HR 9 februari 1993, NJ 1993, 603 (m.nt. C).

150 Stolwijk in Melai c.s., aant. 3 op art. 282: 5; HR 3 maart 1987, NJ 1987, 850; HR 14 september 1987, NJ 1988, 301 (m.nt. AMJS); HR 30 november 1993, NJ 1994, 247.

151 Asmus, Ritmeester \& Pence, Prosecuting domestic abuse cases in Duluth, Hamline Law Review, 1991: 129-131, 135-137.

152 Mols, Getuigen in strafzaken, 1993: 7, 18. Zie voor de vraag of het verschoningsrecht ruim kan worden geinterpreteerd: Verburg in Melai c.S., aantt. $5 \mathrm{tm} 9$ op art. $217 \mathrm{~Sv}: 4-10$. Van belang is een formeel criterium om te vermijden dat een concreet onderzoek naar de hoogst persoonlijke relatie tussen de verdachte en de getuige moet worden ingesteld. Aangesloten kan worden bij de ontwikkelingen in het familierecht door het samenlevingscontract als criterium te nemen. 
Deslachtoffer-getuige die niet ter terechtzitting wil getuigen om gezondheidsredenen of redenen van privacy, kan de officier van justitie verzoeken haar niet op te roepen omdat een verhoor in het openbaar voor haar te belastend zal zijn. Zij beroept zich op 'gevaar voor de lichamelijke of geestelijke gezondheid'. Aansluiting kan worden gezocht bij artikel 3 EVRM: "No one shall be subjected to (...) inhuman or degrading treatment (..)". En ook artikel 8 EVRM, het recht op privacy, kan worden ingeroepen. ${ }^{153}$ Als de verdachte het slachtoffer op de terechtzitting toch wil horen, kan worden gesproken van een botsing van grondrechten.

Het belang van het slachtoffer om niet in het openbaar ter zitting te worden gehoord wordt vanaf de jaren negentig expliciet erkend binnen de rechtspraak. ${ }^{154}$ Voor de bedreigde getuige bestaat een aparte regeling, ${ }^{155}$ maar ook buiten die gevallen om moet rekening worden gehouden met de bescherming van de persoonlijke levenssfeer omdat grondrechten een zekere gelding blijven behouden: het feit dat de op de privacy inbreukmakende handeling een uitvoering is van het recht om getuigen te horen (het fair trial beginsel), betekent niet dat het uitoefenen van dat recht altijd gerechtvaardigd is. ${ }^{156}$ "Er moet ruimte blijven voor afweging van de op het spel staande belangen in het strafproces. Bij bescherming van de rechten van de mens, dient te worden bedacht dat de verdachte niet de enige mens is, die in het strafproces een rol speelt." ${ }^{\prime 157}$

De belangenafweging die hier plaatsvindt, kan uitmonden in het niet oproepen van de getuige; de oproeping is 'nutteloos' of 'overbodig' (art. 282 lid $2 \mathrm{~Sv}$ ). ${ }^{158}$ Toch kleeft aan deze (creatieve) oplossing ook een nadeel, namelijk dat een grond 'gevaar voor de lichamelijke of geestelijke gezondheid' als 'nutteloos' of 'overbodig' wordt aangemerkt, terwijl er geen sprake is van het niet kunnen verschijnen van de slachtoffer-getuige (nutteloos), noch van niet-relevante getuigen (overbodig). Dit kan betekenen dat de grond waarop de weigering om de slachtoffer-getuige niet op te roepen berust, wordt bekritiseerd, terwijl dit niet de kern van het probleem raakt. ${ }^{159}$ De kern van de weigering getuigen op te roepen is dat een getuige een rechtssubject is dat door een getuigenverhoor ernstig in haar lichamelijke integriteit

153 Myjer, Naschrift bij Van der Pol, Straatburgse rechtsbescherming, NJB, 1996: 804-805.

I54 HIR 25 februari 1992, NJ 1992, 555; HR 26 mei 1992, NJ 1992, 680; HR 9 februari 1993, NJ 1993, 603 (m.nt. C). Zie over de Europese rechtsbescherming van slachtoffers van zedendelicten: Myjer, Slachtoffers van zedendelicten en Straatburgse rechtsbescherming, NJB, 1996: 437-447. En de reactie erop: Van der Pol, Straatburgse rechtsbescherming, NJB, 1996: 804.

$155 \mathrm{Zie}$ hoofdstuk 4, \$ 4.4.2. Wanneer de vrouw wordt bedreigd door haar ex-partner, kan beperkte anonimiteit worden toegekend: een getuigenverhoor vindt plaats, maar de personalia (nieuwe adres) worden niet bekend gemaakt (art. $360 \mathrm{~Sv}$ ).

156 De Lange, Botsing van grondrechten voor de rechter, 1994: 33

157 Van Veen in zijn noot onder HR 2 juli 1990, NJ 1990, 692 (vrouwenhandel).

158 Zie hoofdstuk 4, § 4.4.2.

159 Corstens stelt bijvoorbeeld dat de slachtoffer-getuige op onterechte gronden is afgewezen in de Finkensieperzaak (NJ 1992, 1), omdat het geen totaal irrelevante getuige betrof en er dus geen sprake was van overbodigheid. Corstens, Getuigen op de zitting, DD, 1992: 208. Die constatering lijkt mij juist, maar treft niet de kern van het probleem. 
kan worden aangetast. Dit belang behoort expliciet in de wet te worden vastgelegd. Het voorkomen van secundaire victimisering van slachtoffers door opnieuw te moeten getuigen, krijgt op die wijze een eigen plaats in de wet, waardoor de positie van de slachtoffer-getuige als rechtssubject wordt versterkt. ${ }^{160} \mathrm{Ik}$ pleit daarom voor aanvulling van artikel 282 lid 2 Sv met een extra grond 'gevaar voor de lichamelijke en geestelijke gezondheid'; ${ }^{161}$ analoog aan het wijzigingsvoorstel voor artikel 187 Sv: ${ }^{162}$ 'wanneer een gegrond vermoeden bestaat dat de gezondheidstoestand van de getuige in gevaar wordt gebracht door het afleggen van een verklaring in het openbaar, kan oproeping van de getuige achterwege blijven' ${ }^{163}$ Wanneer niet aan het recht van de verdachte op een fair trial is voldaan, omdat hij niet eerder in het strafproces de mogelijkheid heeft gehad de getuige vragen (te doen) stellen, kan de slachtoffer-getuige alsnog door de rechter-commissaris worden gehoord (art. 187 Sv). Mocht dit voor haar psychisch te belastend zijn, dan heeft dit consequenties voor de bewijswaarde van haar verklaring; de bewezenverklaring kan niet hoofdzakelijk op deze verklaring berusten. ${ }^{164}$ Door een aparte grond te formuleren wordt de getuige als rechtssubject erkend; zij heeft rechten en plichten. Haar plicht is om een bijdrage te leveren aan de waarheidsvinding en haar recht is om beschermd te worden door de overheid tegen een vergaande inbreuk op haar privacy.

Daarnaast kan worden gedacht aan een eigen rechtsingang voor de getuige. Via een bezwaarschriftprocedure tegen de oproeping als getuige kan het slachtoffer haar

160 Bovendien kunnen discussies worden voorkomen die niet de kem van de afwijzing van het horen van de getuige ter terechtzitting raken. Zie voor een soortgelijk standpunt Schalken in zijn noot onder HR 1 oktober 1991, NJ 1992, 197: 743 (Finkensieperzaak).

161 Het gerechtvaardigde belang van de slachtoffer-getuige 'gevaar voor de lichamelijke of geestelijke gezondheid' zou ook als expliciete grond onder het criterium 'nutteloos' of 'overbodig' gebracht kunnen worden, maar ook dan wordt een verkeerde suggestie gewekt naar mijn mening. 'Gevaar voor de lichamelijke of geestelijke gezondheid' hoort niet onder 'nutteloos', omdat het belang van de slachtoffer-getuige moet worden afgewogen; de getuige kan wel verschijnen, maar gezien het traumatische karakter van het verhoor en de wijze waarop aan het fair trial beginsel voor de verdachte is voldaan, is het niet wenselijk de slachtoffer-getuige op te roepen. Deze belangenafweging zou onder het criterium 'overbodig' kunnen worden gebracht, maar dan wordt iets als overbodig benoemd wat in feite niet overbodig is; het kan om een voor de verdediging zeer relevante getuige gaan.

162 Wetsvoorstel ter herziening van het gerechtelijk vooronderzoek, TK 23.251 (in januari 1996 was het wetsontwerp in het stadium van de Tweede Nota van Wijziging, 31 mei 1995, TK 23.251, nr. 14).

163 In het wetsvoorstel Herziening onderzoek ter terechtzitting (TK 1995-1996, 24.692, nrs. 1-3) wordt iets soortgelijks voorgesteld. In het voorgestelde artikel $264 \mathrm{~Sv}$ krijgt de officier van justitic de bevoegdheid het verzoek van de verdachte om een getuigen op te roepen te weigeren 'als een gegrond vermoeden bestaat dat de gezondheidstoestand van de getuige door het afleggen van een verklaring ter terechteitting ernstig in gevaar wordt gebracht'. De zittingsrechter krijgt deze bevoegdheid in het voorgestelde artikel $288 \mathrm{~Sv}$.

164 Unterpertinger EHRM 24 november 1986, Serie A 110 \& NJ 1988, 745; HR 26 mei 1992, NJ 1992 , 680; HR 22 september 1992, NJ 1993, 85; HR 9 februari 1993, NJ 1993, 603 (m.nt. C); HR 30 november 1993, NJ 1994, 247. 
bezwaren uiteenzetten tegen het moeten getuigen. ${ }^{165}$ Deze procedure kan worden beschouwd als een erkenning van de getuige als rechtssubject; zij heeft het recht bezwaar aan te tekenen tegen het moeten optreden als getuige omdat het een inbreuk betekent op haar persoonlijke levenssfeer. Door mogelijkheden te scheppen de bezwaren naar voren te brengen wordt de slachtoffer-getuige serieus genomen. Het kan ertoe leiden dat de slachtoffer-getuige alsnog wil getuigen, na het uiten van angst en onvrede en het verkrijgen van meer informatie over het belang van haar getuigenis. ${ }^{166}$ Nadat de raadkamer ook de verdediging heeft gehoord, komt het tot een afweging van belangen. Wanneer geen sprake is van een van de gronden van artikel 282 lid 2 Sv nieuw, is de slachtoffer-getuige verplicht gehoor te geven aan de oproep te getuigen.

Het slachtoffer van vrouwenmishandeling kan belang hebben bij het in de rechtszaal getuigen over het leed haar aangedaan; door haar verhaal, binnen de grenzen van de juridische waarheidsvinding, voor het voetlicht te brengen kan zij zich gesteund voelen in haar recht op lichamelijke integriteit en privacy. Tegelijkertijd kunnen de regels van juridische waarheidsvinding ertoe leiden dat een verhoor in het openbaar een dermate pijnlijke ervaring is dat daardoor haar lichamelijke integriteit emstig geschaad kan worden. Beide belangen behoren in het strafprocesrecht zichtbaar te zijn. Door 'gevaar voor de lichamelijke en geestelijke gezondheid' als aparte grond toe te voegen aan artikel 282 lid $2 \mathrm{~Sv}$, en de getuige een eigen rechtsingang te bieden, wordt het laatse belang zichtbaar gemaakt binnen het strafprocesrecht. Door een recht op fair hearing vast te leggen, kan het eerste belang meer zichtbaar worden gemaakt binnen het strafprocesrecht.

\section{Het recht op fair hearing ${ }^{167}$ en rechtsbijstand}

Het afleggen van een getuigenverklaring kan positieve effecten hebben en bijdragen aan de weerbaarheid van de vrouw. Bovendien komt het oproepen van het slachtoffer als getuige de kwaliteit van de waarheidsvinding ten goede; in plaats van een snelle en efficiěnte procesvoering door op de zitting zoveel mogelijk schriftelijke bewijsmiddelen te toetsen, krijgt de getuige de gelegenheid op vragen te antwoorden. ${ }^{168}$ Een recht op fair hearing voor het slachtoffer komt zowel de waarheidsvinding, als de rechtsbescherming van de verdachte en de rechtsbescherming van

I65 Mols, Geruigen in strafzaken, 1993: 26.

166 Ibidem: 26.

167 Deze term ontleen ik aan Mols, Geruigen in strafzaken, 1993: 16.

168 Bovendien kan de verdachte zijn recht op het horen van de getuige uitoefenen, de rechter kan zich door eigen waameming een oordeel vormen over de betrouwbaarheid van de verklaring van de getuige en de openbaarheid van het strafproces wordt erdoor gediend. Mols, Staande de zilting, 1989: 6-9; Mols, Getuigen in strafzaken, 1993: 22. 
het slachtoffer ten goede. Zodoende past dit binnen het uitgangspunt van de relationele visie.

Dit recht op fair hearing betekent dat de vrouw 1. het recht krijgt een getuigenverklaring af te leggen als zij dit wenst, 2. op een zorgvuldige wijze behoort te worden opgeroepen en 3 . op een behoorlijke manier behoort te worden ondervraagd.

Het belang van de slachtoffer-getuige om op de zitting haar verhaal te doen zou ondergebracht kunnen worden in het algemene slachtofferbeleid door de huidige slachtofferrichtlijn aan te vullen met een passage over de rol van slachtoffergetuigen. ${ }^{169}$ Ook kan worden aangesloten bij de wetsbepalingen die de getuige betreffen door naast de plichten van de getuige ook rechten vast te leggen. Bijvoorbeeld een recht om de officier van justitie te verzoeken op de getuigenlijst te worden geplaatst, welk verzoek niet kan worden geweigerd tenzij de getuige niet in haar belang kan worden geschaad door de niet-oproeping. ${ }^{170}$ Wordt aan het verzoek niet voldaan, dan zou hiertegen bezwaar kunnen worden gemaakt via een bezwaarprocedure bij de raadkamer, zoals dit ook zou kunnen gelden voor bezwaar tegen het wel oproepen van de slachtoffer-getuige.

Een recht op fair hearing houdt eveneens in dat het slachtoffer op een zorgvuldige wijze wordt opgeroepen. Dit kan door in een begeleidende brief in te gaan op de plicht om te verschijnen, het afleggen van de eed, en wat het betekent om als getuige à (dé)charge te worden opgeroepen. Bovendien behoort gewezen te worden op de mogelijkheid buiten aanwezigheid van de verdachte (art. $292 \mathrm{~Sv}$ ) of met gesloten deuren (art. $273 \mathrm{~Sv}$ ) een verklaring af te leggen. ${ }^{171}$ Ook dient erop gewezen te worden dat een advocaat kan worden geraadpleegd en meegenomen naar de terechtzitting. ${ }^{172}$

Tot slot behoort de (slachtoffer-)getuige op zorgvuldige wijze te worden verhoord. "Strafrechtspleging is voor een niet onbelangrijk deel ook een kwestie van respect voor elkaar en fatsoen in de omgang onder erkenning van de verschillende processuele posities." in de wijze van vragen stellen het slachtoffer enigszins de ruimte kan geven om haar verhaal te vertellen. ${ }^{174}$ Bovendien kan de officier van justitie uitlokken dat de rechter belet dat bepaalde vragen worden gesteld aan de slachtoffer-getuige (art.

169 Zie hoofdstuk $2, \S 2.5$.

170 Voorkomen moet kunnen worden dat een getuige misbruik maakt van de regeling.

171 Van Driem, Haar was recht gedaan, in: Het klappen van de zweep, 1994: 120.

172 Penders, Slachtofferhulp en rechtshulp I, Advocatenblad, 1990: 47.

173 Mols, Getuigen in strafzaken, 1993: 17.

174 Slotboom beschrijft een situatie waarin het slachtoffer als getuige optreedt en haar verhaal wil doen. Hoewel de officier van justitie en rechter begripvol reageren, wordt het relaas van het slachtoffer zoveel mogelijk tot het incident beperkt. Slotboom, De 'gevonden waarheid', 1992: 64. 
$288 \mathrm{~Sv}$ ) en ervoor waken dat de getuige een speelbal wordt tussen de verdediging en het openbaar ministerie. ${ }^{175}$

Dit recht op fair hearing voor de getuige behoort vergezeld te gaan met een recht op rechtsbijstand, waardoor de slachtoffer-getuige zowel juridisch als emotioneel gesteund kan worden. ${ }^{176}$ Een advocaat kan voor het slachtoffer van belang zijn om ervoor te zorgen dat de richtlijnen en de wet daadwerkelijk worden toegepast. Naast juridische ondersteuning kan een advocaat belangrijke emotionele steun bieden door het verhaal van het slachtoffer serieus te nemen. Een recht op rechtsbijstand voor het slachtoffer is daarom van groot belang. ${ }^{177}$ Een advocatenbalie op het politiebureau waar niet alleen verdachten, maar ook slachtoffers van juridisch advies worden voorzien, kan de toegang tot de advocatuur vergemakkelijken. ${ }^{178}$

\subsubsection{Rechtsbescherming door verbetering van de rechtspositie van het slachtoffer}

Kleine rechtspositionele veranderingen kunnen de positie van het slachtoffer versterken. Hoewel deze wijzigingen zijn bepleit naar aanleiding van de problematiek van vrouwenmishandeling, kunnen deze rechtspositionele veranderingen ook andere slachtoffers van misdrijven ten goede komen. Deze rechtsbescherming gaat naar mijn mening niet ten koste van de rechtsbescherming van de verdachte en past binnen de relationele opvatting. Hoewel in sommige gevallen een botsing kan optreden tussen rechtsbescherming van de verdachte en rechtsbescherming van het slachtoffer, en in die gevallen een belangenafweging moet plaatsvinden, zal toch over het algemeen de rechtsbescherming van het slachtoffer niet botsen met de rechtsbescherming van de verdachte.

Een zorgvuldige bejegening van het slachtoffer van vrouwenmishandeling, het tijdig voorzien van informatie over het verloop van de strafprocedure, de slachtoffergetuige via een informatieve brief oproepen om ter zitting te verschijnen, is in het belang van het slachtoffer, maar doet niets af aan de rechtsbescherming van de verdachte. Een recht waar beiden belang bij hebben, is bijvoorbeeld het recht op afhandeling van de zaak binnen een redelijke termijn. Bovendien kan een versterking van de rechtspositie van het slachtoffer binnen het strafproces het proces van waarheidsvinding ten goede komen. Het slachtoffer als getuige op de zitting horen, geeft de vrouw de mogelijkheid haar verhaal te vertellen, en tevens kan de rechter

175 Davelaar-van Tongeren, Verkrachting. Strafrechter, wat moet je ermee, in: Strafrecht in perspectief, 1980: 116.

176 Mols, Getuigen in strafzaken, 1993: 17. Alleen de rechtsbijstand aan de gegijzelde getuige is expliciet geregeld in artikel $225 \mathrm{~Sv}$. Penders, Slachtofferhulp en rechtshulp III, Advocatenblad, 1990: 101.

177 Ibidem: 101-102. Dit kan analoog aan de regeling voor de rechtstreeks belanghebbende in de artikel $12 \mathrm{~Sv}$-beklagprocedure (art. 12f Sv)

178 Naeye, Een advocatenbalie op het politiebureau?, in: De advocaat bij het politieverhoor, 1988: $119-120$ 
een zelfstandig oordeel vellen over de betrouwbaarheid van de verklaring. Bovendien heeft de verdachte de mogelijkheid vragen te stellen. Op die manier wordt meer recht gedaan aan het onmiddellijkheidsbeginsel. ${ }^{179}$ Ook het recht op rechtsbijstand is niet alleen in het belang van het slachtoffer; het kan ten goede komen aan het proces van waarheidsvinding omdat slachtoffers juridisch en emotioneel worden ondersteund en daardoor beter voorbereid zijn.

\subsection{Een strafrechtelijke aanpak gericht op herstel van de rechtsvrede: enkele aanbevelingen}

Herstel van de rechtsvrede omvat zowel een behoorlijke strafproces als herstel van de door het strafbare feit teweeggebrachte sociale onrust. Tot deze maatschappelijke onrust behoort het leed dat aan het slachtoffer en haar directe omgeving (bijvoorbeeld kinderen binnen de relatie) is toegebracht. In geval van mannelijk geweld tegen de vrouw in de privésfeer is het belangrijkste doel het stoppen van het geweld (speciale recidive), gezien de (grote) kans op herhaling, waarbij ook het slachtoffer van dit geweld bekend is. Daarnaast kan genoegdoening en/of conflictoplossing als doel worden gesteld. Dit vraagt om een open, niet-oordelende houding door politie en officieren van justitie, als zij worden geconfronteerd met geweld in de privésfeer, ${ }^{180}$ evenals een op de persoon van de verdachte en het slachtoffer gerichte specifieke aanpak. "[A] prosecutor's task is not only to pursue convictions, but also to seek safety and justice for the victim and community."181 Dit kan worden verwezenlijkt door een humane aanpak, dat wil zeggen dat de mens achter de daad en de mens achter het leed dat is berokkend door de daad, moet worden gerespecteerd. Door respect voor de mens als rechtssubject en communicatief handelen, kan inhoud worden gegeven aan de rechtsbescherming (zie hoofdstuk 1, § 1.3.3). Bescherming van de persoonlijke levenssfeer van vrouwen die geweld ondervinden van hun (ex-)partners wordt in eerste instantie geboden door de politie. Het optreden van het openbaar ministerie kan daarom niet los worden gezien van het optreden van de politie. ${ }^{182}$

179 Mols, Siaunde de zitting, 1989: 6-9, 24.

180 Rumkens, Wie is bang voor geweld, in: Het klappen van de zweep. 1994: 138.

181 Asmus, Ritmeester \& Pence, Prosecuting domestic abuse cases in Duluth, Hamline Law Review, 1991: 131.

182 Bovendien kan, gezien de gezagsverhouding tussen politie en openbaar ministerie, het openbas ministerie invloed uitoefenen op het optreden van de politie (zie hoofdstuk 4, \$4.2). 


\subsubsection{Erkenning van vrouwenmishandeling als strafrechtelijk probleem}

Het erkennen en herkennen van de ernst van het geweld dat is gepleegd tegen de vrouw in de privésfeer is een eerste vereiste om adequaat te kunnen optreden. "Criminal justice professionals must recognize the psychological issues facing intimately assaulted women - the complex factors that often make following through with charges and testimony extremely difficult." ${ }^{\text {183 }}$ Dit geldt voor zowel geweld in een bestaande relatie als in geval van geweld gepleegd door de ex-partner. ${ }^{184}$

Officieren van justitie zijn voor hun inschatting van de ernst van het geweld doorgaans afhankelijk van de informatie die zij hebben gekregen van de politie (zie hoofdstuk 4, §4.2). Op arrondissementsniveau kunnen afspraken worden gemaakt over de informatie die in een proces-verbaal behoort te worden vastgelegd. Niet alleen juridische informatie inzake het bewijs van het incident is van belang, ook achtergrondinformatie. ${ }^{185}$ "It is crucial that police officers effectively document the emotional state of the victim; thereby providing the prosecutor with facts necessary to prepare and try the case." ${ }^{186}$ Tevens behoren de mutaties van eerder optreden door de politie bijgevoegd te worden. ${ }^{187}$ Op die manier wordt een meer werkelijkheidsgetrouw beeld verkregen van de ernst van de situatie. Daarnaast behoren afspraken te worden gemaakt over het telefonisch informeren van de officier van justitie en/of het inschakelen van de slachtoffermedewerkster werkzaam op het arrondissementsparket. Het openbaar ministerie kan een kader bieden waarbinnen het politieoptreden in geval van mannelijk geweld tegen vrouwen in de privésfeer behoort plaats te vinden. Uitgangspunt zou een procesmatige aanpak in plaats van een incidentgerichte aanpak moeten zijn met als doel bescherming van de persoonlijke levenssfeer van de vrouw. Voor de politie zou het 'ABCDE van geweld in relaties' (de aanpak van Ask-Believe-Call-Document-Ensure) als uitgangspunt kunnen worden genomen. ${ }^{188}$ Het optreden van het openbaar ministerie zou hierop moeten aansluiten.

Een op herstel van de rechtsvrede gerichte aanpak houdt in eerste instantie een zorgvuldige bejegening in; respect voor de vrouw als rechtssubject. Dit draagt op

183 Dutton, The domestic assault, 1995: 217.

184 Asmus, Ritmeester \& Pence, Prosecuting domestic abuse cases in Duluth, Hamline Law Review, 1991: 129. Zie: $\S 6.2$.

185 Wat in het proces-verbaal moet worden vermeld wordt uiteen gezet in: Van der Ent \& Evers, Vroukenmishandeling: een zorg voor de politie, 1996: 64-67.

186 Asmus, Ritmeester \& Pence, Prosecuting domestic abuse cases in Duluth, Hamline Law Review, 1991: 143.

187 Tegenwoordig worden de mutaties in de computer verwerkt, zodat makkelijk informatie is te verkrijgen over eerder optreden. Ter Harmsel, Handleiding bij het geven van voorlichting over vrouwenmishandeling, 1995: 85.

188 Van der Ent \& Evers, Vrouwenmishandeling: een zorg voor de politie, 1996:51-74. Zowel de wijze van taxatie van de geweldsituatie, als de wijze van optreden, hulpverlenend, strafrechtelijk of beide, worden hierin beschreven. 
menselijk niveau bij aan de erkenning van het leed. De politie is de eerst aangewezene; een open benadering, het verhaal van de vrouw serieus nemen, haar van goede informatie voorzien en haar eventueel doorsturen naar slachtofferhulp of een andere vorm van hulpverlening. Toch kan ook de officier van justitie een bijdrage leveren, door bijvoorbeeld het slachtoffer desgewenst uit te nodigen voor een gesprek, of het slachtoffer een brief te schrijven over de genomen beslissing en begrip voor haar situatie tonen. De slachtoffermedewerkster op het arrondissementsparket kan hierbij als intermediair optreden. Met deze benadering wordt bovendien uitvoering gegeven aan de slachtofferrichtlijnen.

Wanneer besloten is de verdachte te dagvaarden, kan de officier van justitie in zijn requisitoir aandacht besteden aan de achtergrond van het geweld en het leed dat het slachtoffer is aangedaan. Het incident waarvan aangifte is gedaan, behoort te worden geplaatst in de context van de relatie; ander gewelddadig en controlerend gedrag van de man behoort te worden aangegeven omdat alleen tegen die achtergrond de ernst van de bedreiging kan blijken en het gedrag van het slachtoffer beter invoelbaar wordt. "The element of intent to cause fear of immediate bodily harm requires and invites a different, more extensive form of proof because the alleged actions occured within the context of developed meanings and threatening past actions in a relationship." 189 Tevens kan de officier van justitie aangeven dat dit gewelddadige gedrag een negatieve invloed heeft op de ontwikkeling van de kinderen, ${ }^{190}$ en in nog breder verband op de maatschappij.

\subsubsection{Preventief optreden ter bescherming van de persoonlijke levenssfeer}

De politie en het openbaar ministerie kunnen bijdragen aan herstel van de veiligheid in de persoonlijke levenssfeer door in de eerste plaats (strafrechtelijke) afkeuring van het geweld, normhandhavend optreden. Daarnaast door maatregelen die voorkomen dat de man in de buurt van de vrouw kan komen.

Afkeuring van het geweld door politie en openbaar ministerie betekent dat de man verantwoordelijk wordt gesteld voor het geweld. ${ }^{191}$ Het opmaken van een proces-verbaal symboliseert dat het geweld als strafwaardig wordt beschouwd. "Het opmaken van een proces-verbaal en confrontatie met de wet kan de dader - die in

189 Asmus, Ritmeester \& Pence, Prosecuting domestic abuse cases in Duluth, Hamline Law Review. 1991: 138.

190 Jaffe e.a., The impact of police laying charges, in: Legal responses to wife assault, 1993: 92.

191 De man wordt niet verantwoordelijk gesteld voor het geweld als de politie gedragsregels voorschrijft aan de vrouw. Dit speelt bijvoorbeeld in situaties van geweld door de ex-partner waar de vrouw krijgt aangeraden zich niet meer op plaatsen te vertonen waar de man ook kan komen of de man nooit binnen te laten. Deze aanwijzingen zijn afgeleid van het gedrag van de man, waardoor de man wordt gesteund in plaats van dat de vrouw wordt beschermd. Wostmann, Politieoptreden bij vrouwenmishandeling, 1988: 92-93. 
de regel zijn daden bagatelliseert - wel degelijk de ogen doen openen." 192 Dit proces-verbaal behoeft niet altijd te worden doorgestuurd naar het openbaar ministerie. Dat hangt af van de ernst van het geweld, de feitelijke omstandigheden en de wens van het slachtoffer.

Als het openbaar ministerie met een zaak van vrouwenmishandeling wordt geconfronteerd, is een gesprek met de verdachte, waarin de man erop wordt gewezen dat het een strafbaar feit betreft en dat een herhaling van geweldpleging kan leiden tot vervolging, een manier van sanctionerend optreden waarbij de man verantwoordelijk wordt gesteld voor het gepleegde geweld. Een zwaardere sanctionering is het seponeren onder voorwaarden. De voorwaarde moet het gedrag van de man betreffen en een reclasseringsdoel hebben. ${ }^{193}$ Door het stellen van de algemene voorwaarde kan een bijdrage worden geleverd aan het voorkomen van geweld. Als bijzondere voorwaarde kan contact met de reclassering worden gesteld. Gezien de resultaten in de Verenigde Staten en Canada is het daarnaast van groot belang daderhulpverlening te ontwikkelen voor mannen die fysiek (en seksueel) geweld gebruiken. ${ }^{194}$ Dit kan eventueel als voorwaarde bij een sepot worden gesteld. Zo'n programma kan tot doel hebben mannen te confronteren met hun agressieve gedrag en de wijze waarop zij dit gedrag rechtvaardigingen. ${ }^{195}$ Het strafrecht functioneert op die manier als stok achter de deur om de man te bewegen de verantwoordelijkheid voor zijn agressieve gedrag te nemen. Het kan bovendien de vrouw ondersteunen die haar relatie niet wil verbreken, maar wel verlangt dat de man hulp zoekt voor zijn agressieve gedrag. ${ }^{196}$

Normhandhavend optreden kan bovendien op menselijk niveau als effect hebben dat de weerbaarheid van vrouwen wordt vergroot, wat de kans op herhaling van het geweld verkleint. De kans op het stoppen van geweld wordt vergroot als de vrouw haar angst voor geweld omzet in woede en voor zichzelf kiest. ${ }^{197}$ Een 'firm, emphatic and rational approach' blijkt de meest effectieve houding om toekomstig geweld te voorkomen. ${ }^{198}$ Het openbaar ministerie kan aan de versterking van de weerbaarheid bijdragen door rekening te houden met de wensen van het slachtoffer.

192 Ter Harmsel, Handleiding bij het geven van voorlichting over vrouwenmishandeling, 1995: 88.

193 Ook de staatkundige en godsdienstige vrijheid wordt er niet door beperkt, noch wordt een andere overheidsmaatregel doorkruist (art. 14c lid I Sr).

194 Momenteel bestaan geen speciale hulpverleningsprogramma's voor mannen die hun partner mishandelen. Beelen \& van Elst, Daderhulpverlening: niet zonder slag of stoot, in: Het klappen van de zweep, 1994: 79. Wel zijn enkele initiatieven genomen. Van der Ent \& Evers, Vrouwenmishandeling: een zorg voor de politie, 1996: 69.

195 Dutton, The domestic assault, 1995: 247, 250-279. Buzuwa \& Buzuwa, Domestic violence, 1990: 129-135. In de Verenigde Staten en Canada zijn verschillende daderhulpverleningsprogramma's, zowel zelfhulpprojecten als professioneel psychotherapeutisch georienteerde projecten. Romkens, Geweld tegen vrouwen in heteroseksuele relaties, 1989: 251.

196 Ford, Prosecution as a victim power resource, Law \& Society Review, 1991: 327-328.

197 Van Rappard, Tot hier en niet verder, 1988: 83-84.

198 Ford, Prosecution as a victim power resource, Law \& Society Review, 1991: 313-314. 
Uit onderzoek in de Verenigde Staten en Canada blijkt dat als het slachtoffer van geweld door haar (ex-)partner helemaal geen invloed heeft op het strafproces, dit leidt tot 'disempowering' van het slachtoffer. ${ }^{199}$ Alleen al het doen van aangifte kan de machtsbalans ten gunste van de vrouw veranderen doordat zij een grens trekt en het geheim verbreekt. ${ }^{200}$ Wanneer vervolgens de vrouw de aangifte niet meer kan intrekken, kan ze het doorzetten van de aangifte niet meer als machtsmiddel gebruiken. Enige invloed op het wel of niet intrekken van de aanklacht vergroot de kans op het stoppen van het geweld door hun (ex-)partner. ${ }^{201}$ Maar de vrouw moet geen volledige zeggenschap hierover hebben, omdat de kans op pressie door de man erdoor wordt vergroot en er situaties zijn dat het geweld dermate ernstig is dat, ondanks het feit dat de vrouw geen strafvervolging wil, de ernst van de feiten het achterwege laten van vervolging niet toelaat (zie § 6.3.2). Hoewel doorgaans de politie wordt geconfronteerd met het verzoek van de vrouw het proces-verbaal niet naar het openbaar ministerie door te sturen, kunnen ook officieren van justitie geconfronteerd worden met een brief van het slachtoffer dat zij niet wil dat de man wordt vervolgd. Officieren van justitie kunnen met deze wens rekening houden door de man (voorwaardelijk) niet te vervolgen of een voorwaardelijk straf te eisen als de ernst van de feiten aanleiding geeft tot het dagvaarden van de verdachte over te gaan. ${ }^{202}$

Een andere manier waarop de weerbaarheid van de vrouw kan worden versterkt, is haar wensen omtrent het wel of niet optreden als getuige serieus te nemen. Wanneer zij haar verhaal op de zitting wil vertellen, behoort hier, binnen het kader van de waarheidsvinding, ruimte voor gemaakt te worden. Wanneer zij geen getuigenis wil afleggen, dient dit te worden gerespecteerd, tenzij haar verklaring van groot belang is in het kader van de waarheidsvinding of de verdachte haar als getuige wil oproepen. Dan dient een belangenafweging plaats te vinden (zie $\S 6.3 .3$ ).

Het hierboven beschreven normhandhavend optreden kan bijdragen aan het creëren van een veilige omgeving voor de vrouw. Een andere mogelijkheid is een straatof contactverbod, dat met name van belang kan zijn voor vrouwen die door hun ex-partner worden bedreigd en mishandeld. Ook aanhouden en inverzekeringstelling van de man kan (op korte termijn) veiligheid creëren. Bovendien kan de vrouw naar een plaats van tijdelijke opvang (familie, vrienden, opvanghuis) worden verwezen of gebracht door de politie.

199 lbidem: 316.

200 Dutton, The domestic assault, 1995: 241-242; Hes, Het straatverbod in kort geding als 'ultimum remedium', Nemesis, 1985: 134-135.

201 Ford, Prosecution as a victim power resource, Law \& Society Review, 1991: 318-321; Dutton, The domestic assault, 1995: 233-234; Ford \& Regoli, The criminal prosecution of wife assaulters, in: Legal responses to wife assault, 1993: 157-158.

202 Zie hoofdstuk 5, $\$ 5.5 .2$ onder Intrekken van de aanklacht \& $\$$ 5.5.3. 
De man meenemen naar het politiebureau of hem in verzekering stellen creëert op korte termijn veiligheid. Toch kleeft een aantal haken en ogen aan de inverzekeringstelling. Vanuit juridisch oogpunt kan het doel van de inverzekeringstelling een probleem opleveren. Wanneer aan de voorwaarden van inverzekeringstelling is voldaan (art. $57 \mathrm{~Sv}$ juncto art. 67 lid la Sv), speelt de vraag of de inverzekeringstelling is gewenst uit oogpunt van het belang van het onderzoek (waarheidsvinding) of alleen om de vrouw enige rust te bieden. Wanneer de man alleen in verzekering wordt gesteld om de vrouw enige rust te geven, kan worden gesproken van misbruik van bevoegdheden. Alleen als inverzekeringstelling noodzakelijk is in het kader van de waarheidsvinding, kan daarnaast het doel van de veiligheid een rol spelen om tot inverzekeringstelling over te gaan.

Een tweede aspect betreft de vraag van de effectiviteit van inverzekeringstelling. Door de man mee te nemen naar het politiebureau en hem in verzekering te stellen, wordt op korte termijn veiligheid gecreëerd. Inverzekeringstelling kan ertoe leiden dat de man gaat beseffen dat het gewelddadige gedrag strafbaar is en blijkbaar zo emstig is dat inverzekeringstelling mogelijk is. Inverzekeringstelling kan een signaal afgeven dat de maatschappij geweld in de privésfeer zeer afkeurenswaardig vindt. "[A]rrest also serves; to teach perpetrators that society considers their acts to be wrong; to correct a power imbalance in a family; to bring awareness of their behavior (and thus social sanctions) to their social circle; and so on."203

Maar de effecten van inverzekeringstelling op wat langere termijn zijn omstreden. ${ }^{204}$ Bovendien kan inverzekeringstelling ook kort na de invrijheidstelling leiden tot extra agressie. In plaats van verantwoordelijkheid te nemen voor zijn agressieve gedrag projecteert de man zijn gevoelens op de vrouw. "To the extent that a wife assaulter believes that (1) his wife's injuries were minimal, or (2) she was to blame for the conflict, or (3) his use of violence was justified, to such an extent he is likely to view his subsequent arrest and conviction as unjust."205

203 Dutton, The domestic assault, 1995: 246.

204 Uit onderzoek blijkt dat op korte termijn arrestatie (inverzekeringstelling) leidt tot minder recidivisme vergeleken met de groep daders van vrouwenmishandeling waar niet werd gearresteerd, maar op langere termijn draait de curve; na een half jaar blijkt in de groep van gearresteerde mannen meer geweld voor te komen dan in de groep van niet-gearresteerde mannen. Dutton, The domestic assaull, 1995: 239; Buzuwa \& Buzuwa, Domestic violence, the criminal justice response, 1990: 90-91. Een onderscheid naar korte en langere inverzekeringstelling laat zien dat een drie-uurs arrestatie de kans vergroot op lange termijn recidive, maar in geval van arrestatie voor langer dan twaalf uur was dit effect niet (duidelijk) aanwezig. Jaffe e.a., The impact of police laying charges, in: Legal responses to wife asscult, 1993: 87-88.

205 Dutton, The domestic assault, 1995: 247; Hes, Het straatverbod in kort geding als 'ultimum remedium', Nemesis, 1985: 135-136. 
Inverzekeringstelling kan positieve effecten hebben, zeker op korte termijn, maar zij is niet het instrument bij uitstek om ook op lange termijn recidive te voorkomen. ${ }^{206}$ Alleen als inverzekeringstelling is ingebed in een pakket van maatregelen, waaronder daderhulpverlening, kan inverzekeringstelling ook op wat langere termijn een veilige omgeving voor het slachtoffer tot effect hebben. ${ }^{207}$

Een andere manier om veiligheid te creëren is het opleggen van een straat- of contactverbod aan de ex-partner. De officier van justitie kan schorsing van de voorlopige hechtenis bij de rechter vorderen met als voorwaarde het naleven van een straatverbod (art. $80 \mathrm{~Sv}$ ). In de praktijk zal dit niet vaak voorkomen, omdat de meeste mannen die hun (ex-)partner gewelddadig bejegenen niet in voorlopige hechtenis (kunnen) worden genomen. Daarnaast kan de officier van justitie als voorwaarde bij een veroordeling een straatverbod vorderen. Dit kan met name soelaas bieden als een vlug- of snelrechtprocedure is gevolgd. ${ }^{208}$ In het kader van een zogenaamde AU-traject kan in bepaalde, technisch eenvoudige gevallen, de man binnen de termijn van de aanhouding of eventuele inverzekeringstelling een dagvaarding voor de politierechter aangereikt krijgen. ${ }^{209}$

De vraag is of de officier van justitie een straatverbod als voorwaarde bij een sepot kan opleggen. Het straatverbod betreft het gedrag van de dader en vindt haar grond in het gepleegde delict. De argumenten die het opleggen van een schadevergoeding rechtvaardigen, kunnen ook het straatverbod rechtvaardigen: het bewustzijn te moeten instaan voor gevolgen van eigen handelen wordt erdoor versterkt, als ook het respect voor het belang waar inbreuk op is gemaakt. Bovendien dient het straatverbod ter conflictoplossing. ${ }^{210}$ Het straatverbod als voorwaarde kan daarom worden beschouwd als een reclasseringsmaatregel; het heeft tot doel dat de man inziet dat zijn gedrag een ernstige inbreuk heeft gemaakt op de lichamelijke integriteit van het slachtoffer. ${ }^{211}$ Gezien vanuit dat gezichtspunt lijkt een straatverbod als voorwaarde bij een sepot mogelijk. Daartegenover staat het feit dat een straatverbod een inbreuk is op de bewegingsvrijheid van de man (art. 12 IVBPR, art. 2 van het vierde protocol EVRM). Een inbreuk op dit recht is alleen toegestaan

206 Het effect van arrestatie op kinderen is ook omstreden. Aan de ene kant wordt gewezen op de 'traumatische' invloed die arrestatie op aanwezige kinderen kan hebben. Buzuwa \& Buzuwa, Domestic violence, 1990: 92. Anderzijds wordt gewezen op een positief effect ondat de kinderen zien dat tegen gewelddadig gedrag wordt opgetreden. Hirschel e.a, Review essay on the law enforcement response to spouse abuse, Justice Quarterb, 1992: 276-277.

207 Dutton, The domestic assault, 1995: 247; Asmus, Ritmeester \& Pence, Prosecuting domestic ahuse cases in Duluth, Hamline Law Review, 1991: 127; Hirschel e.a., Review essay law enforcement response to spouse abuse, Justice Quarterb; 1992: 263-278. Een goed overzicht van de verschillende experimenten met arresteren in geval van vrouwenmishandeling in de Verenigde Staten en de dilemma's die daarbij spelen, geeft het boek: Sherman, Policing domestic violence, 1992.

208 De vrouw kan ondertussen ook zelf via de kort-gedingprocedure een straatverbod hebben gevorderd.

209 Van der Ent \& Evers, Irouwenmishandeling: een zorg voor de politie, 1996: 70.

210 Groenhuijsen, Schadevergoeding voor slachroffers van delicten in het strafgeding, 1985: 142-146.

211 Ook de staatkundige en godsdienstige vrijheid wordt er niet door beperkt, noch wordt een andere overheidsmaatregel doorkruist (art. $14 \mathrm{c}$ lid I Sr). 
als rechten en vrijheden van anderen beschermd moeten worden en dit bij de wet is voorzien. Aan de eerste voorwaarde wordt voldaan, maar de vraag is of de bevoegdheid van de officier van justitie om een zaak onder voorwaarden te seponeren voldoende grond biedt. Het straatverbod is een ingrijpende voorwaarde en dat pleit ervoor alleen de rechter deze bevoegdheid te geven. Anderzijds kan worden gesteld dat de man deze voorwaarde vrijwillig accepteert om zo een strafvervolging te voorkomen. ${ }^{212}$ Ik zou wegens de ingrijpendheid van de voorwaarde de officier van justitie niet bevoegd achten. Bovendien pleit het aspect van de handhaving ook tegen het straatverbod als voorwaarde bij een sepot. Wanneer de vrouw zelf via een civiele (kort-geding)procedure een straatverbod krijgt toegewezen, kan zij zelf beslissen of zij de dwangmiddelen wil hanteren die aan het naleven van het straatverbod zijn verbonden: executie van de dwangsom en politiedwang (sterke arm). ${ }^{213}$ De vrouw is dan niet afhankelijk van de inschatting van de politie en de officier van justitie of het niet naleven van het straatverbod zal leiden tot het alsnog gaan vervolgen van de man. De rechtsbescherming van de vrouw is door de problemen van handhaving van het straatverbod niet zo sterk. ${ }^{214}$

Binnen het huidige instrumentarium lijkt mij, gezien de voomoemde argumenten, een straatverbod een te ingrijpende maatregel om als voorwaarde bij een sepot op te leggen. Aangezien het straatverbod een van de meest effectieve instrumenten lijkt om veiligheid te creëren voor het slachtoffer als zij door haar ex-partner regelmatig wordt bedreigd en gewelddadig wordt bejegend, is het wenselijk dat de politie het slachtoffer voorlicht over de mogelijkheid van een kort-gedingprocedure. Bovendien behoort een afweging te worden gemaakt tussen een kort-gedingprocedure of een snelrechtprocedure. Deze afweging dient in samenspraak tussen de politie, het slachtoffer en de officier van justitie te worden genomen. ${ }^{215}$

Het creëren van tijdelijke veiligheid voor de vrouw kan ook geschieden door de vrouw naar een veilige plek te brengen, zoals familie of een opvanghuis. De politie kan hierbij behulpzaam zijn. In een veilige omgeving kan de vrouw (met haar eventuele kinderen) tot rust komen. Wanneer tegelijkertijd normstellend jegens de man wordt opgetreden door politie en openbaar ministerie kan dit een bijdrage leveren aan het doorbreken van de geweldscyclus.

212 Dit gaat voorbij aan de (dwang)positie waarin de verdachte zit. Zie hoofdstuk 4, $\$ 4.3 .2$ onder Voorwaardelijk sepot en transactie.

213 Doomen \& Kotting, Straatverboden in kort geding, NJB, 1985: 111.

214 Verrijn Stuart, Straatverboden in kort geding, Nemesis, 1984: 105; Doomen \& Kotting, Straatverboden in kort geding, $N J B, 1985: 112$; Hes, Het stratverbod in kort geding als 'ultimum remedium', Nemesis, 1985: 135.

215 In verschillende Staten van de Verenigde Staten bestaat de mogelijkheid een civiel (straat)verbod te vorderen, terwijl overtreding van dat verbod gekoppeld is aan een strafrechtelijke reactie. Zie: Lerman, Statute: a model state act, Harvard Jml on Legislation, 1984: 61-143; Asmus, Ritmeester \& Pence, Prosecuting domestic abuse cases in Duluth, Hamline Law Review, 1991: 125-127. 


\subsubsection{Een humane aanpak door officieren van justitie}

Herstel van de rechtsvrede vraagt om een humane aanpak, omdat alleen dan de verdachte en het slachtoffer als gerespecteerde rechtssubjecten worden aangesproken en er sprake kan zijn van rechtsbescherming. Officieren van justitie hebben verschillende mogelijkheden om een bijdrage te leveren aan de rechtsbescherming van slachtoffers van vrouwenmishandeling, zoals hiervoor is beschreven. Duidelijk is dat niet één manier zaligmakend is. Daarvoor verschillen de situaties van vrouwenmishandeling te veel van elkaar. Niet alleen is er een verschil tussen situaties van geweld binnen bestaande relaties en gewelddadigheden door de expartner, maar ook is er variatie in de ernst van het incident, de geschiedenis van het geweld en de machtsdynamiek binnen de relatie. Er kan sprake zijn van een incidentele (ernstige) gewelddadigheid jegens de vrouw door haar (ex-)partner, of juist van chronisch geweld binnen de relatie. Ook herhaaldelijke verstoring van de privacy door de man die zijn ex-partner niet kan loslaten, komt veelvuldig voor.

Een belangrijke voorwaarde voor een adequate strafrechtelijke reactie is samenwerking tussen verschillende betrokkenen, zoals politie, openbaar ministerie, advocatuur, reclassering, slachtofferhulp en hulpverlening. Alleen dan kan de emst van het geweld worden onderkend en kan vrouwenmishandeling vanuit verschillende optieken worden aangepakt. Dit betekent overleg, maar ook het opstellen van protocollen en het maken van werkafspraken. ${ }^{216}$ Door overleg en 'casusbespreking' kan meer inzicht ontstaan in het effect van bepaald strafrechtelijk optreden. Het openbaar ministerie kan hierin een stimulerende rol vervullen door een lokaal netwerk op te zetten en beleid te ontwikkelen voor een meer effectieve aanpak. Door samenwerking kan beter worden afgewogen wat de consequenties kunnen zijn van een bepaald strafrechtelijk optreden voor het slachtoffer en kunnen verschillende maatregelen naast elkaar bestaan. ${ }^{217}$ Bijvoorbeeld zowel een kort-gedingprocedure. als een sepot met als voorwaarde dat de man niet in herhaling treedt. Ook kan worden gedacht aan een of andere vorm van bemiddeling tussen slachtoffer en verdachte door politie of slachtofferhulp en reclassering. ${ }^{218}$ Daarnaast is het ontwikkelen van hulpverleningsprogramma's voor mannen die hun partner mishandelen van groot belang om de kans op herhaling te verkleinen. Deze hulpverleningsprogramma's kunnen analoog aan de 'incestdaderprojecten' worden ontwikkeld. Hulpverlening in een justitieel kader is voor mannen van belang die hun agressieve gedrag niet problematiseren; het strafrecht werkt dan als stok achter de deur. In

216 Ibidem: 149-150, Een protocol voor het politieoptreden is ontwikkeld door Van der Ent en Evers: Vroutumishandeling: een zorg voor de politie, 1996.

217 Asmus, Ritmeester \& Pence, Prosecuting domestic abuse cases in Duluth, Hamline Law Review: 1991: 127-128 \& 154.

218 Dit kan in sommige arrondissementen in de vorm van een dadingsexperiment. Wiewel e.a., Dading in plaats van strafrecht, 1993. Over de problematiek van vrouwenmishandeling in dit kader: Verrijn Stuart, Dading tussen civielrecht en strafrecht, in de gelijknamige bundel: 33-44. 
hoeverre hulpverlening als voorwaarde bij een sepot of als voorwaarde bij een veroordeling of in de vorm van een taakstraf behoort te worden opgelegd, zal nader moeten worden uitgewerkt. ${ }^{219}$

Wat uiteindelijk de doorslag geeft dat de man niet meer recidiveert, is voor elke individuele man verschillend, zoals voor elke vrouw het moment dat ze voor zichzelf kiest verschillend is. De reacties van politie en openbaar ministerie kunnen hieraan hebben bijgedragen. Soms leidt het inschakelen van de politie tot inkeer bij de man omdat de vrouw heeft laten zien dat zij in staat is stappen te ondernemen tegen het geweld. Waar het om draait, is dat er gezocht wordt naar een zinnige aanpak die bijdraagt aan de rechtsvrede; een behoorlijk strafproces voor verdachte en slachtoffer.

\subsection{Rechtsbescherming is meer dan het versterken van de rechtspositie}

Het strafrecht is van belang om concrete vrijheid van mensen als rechtssubject te garanderen, zowel van de verdachte, van de veroordeelde, als van het slachtoffer. Rechtsbescherming van het slachtoffer in het strafproces betekent dat zij, evenals de verdachte, wordt erkend als rechtssubject. Maar gezien het feit dat haar positie in het strafproces van een geheel andere aard is dan die van de verdachte, is haar rechtsbescherming ook van een andere aard. De rechtsbescherming van het slachtoffer heb ik uitgewerkt naar drie deelgebieden; delictsinterpretatie en ernstoordeel, rechtspositie van benadeelde partij en getuige, en strafrechtelijk optreden.

Om vrouwen die geweld ondervinden door hun partner of ex-partner adequate rechtsbescherming te kunnen bieden, is het van belang dat het geweld wordt beoordeeld tegen de achtergrond van de relatie, waarbinnen de machtsdynamiek tussen de partners van (grote) invloed is op de emst en dreiging van het gebruikte geweld. Erkenning van mannelijk geweld tegen vrouwen in de privésfeer als een specifieke geweldsproblematiek en een juiste inschatting en kwalificatie van het geweld door politie en openbaar ministerie is een eerste voorwaarde. Daarnaast is de erkenning van het slachtoffer als rechtssubject met rechten en plichten van belang om burgerlijke vrijheden te kunnen vindiceren. Vergaande versterking van rechten voor het slachtoffer van geweld door haar (ex-)partner als benadeelde van een misdrijf wijs ik af, niet alleen omdat het vervolgingsmonopolie van het openbaar ministerie erdoor wordt aangetast en het een (vergaande) inbreuk op de rechtsbescherming van de verdachte met zich mee zal brengen, maar ook omdat deze rechten de vrouw meer kwetsbaar maakt en vatbaar voor chantage door haar (ex-)partner. Wel kan de rechtspositie van het slachtoffer als benadeelde partij op een aantal punten worden versterkt. Bovendien acht ik het van belang dat de 
erkenning van de getuige als rechtssubject in het wetboek van strafvordering nader wordt vastgelegd, zowel het recht om te spreken als het recht op 'verschoning' als spreken een vergaande aantasting tot gevolg kan hebben van de lichamelijke integriteit en de persoonlijke levenssfeer. Een recht op rechtsbijstand is noodzakelijk om deze rechten ook daadwerkelijk in individuele gevallen te kunnen waarmaken.

Naast een bescheiden rechtspositionele versterking van het slachtoffer als benadeelde van een misdrijf en als getuige komt het er vooral op aan rechtsbescherming te bieden door de wijze van strafrechtelijk optreden. Het openbaar ministerie kan hierin een belangrijke rol vervullen door een kader te scheppen waarbinnen het optreden van de politie behoort plaats te vinden. Uitgangspunt behoort een procesmatige aanpak te zijn waar de bescherming van de persoonlijke levenssfeer van de vrouw (en haar eventuele kinderen) als belangrijkste doel wordt gesteld. Een humane aanpak biedt zeker in gevallen van geweld in de privésfeer handvatten om de geweldsspiraal te doorbreken. Rechtsbescherming wordt niet alleen geboden door het creëren van rechten voor het slachtoffer, maar juist ook door een strafrechtelijke aanpak gericht op het bieden van hulp en ondersteuning: een rechtenmodel en een hulpverleningsmodel zijn onlosmakelijk met elkaar verbonden. ${ }^{220}$ 


\section{Conclusie: humaan strafrecht}

"Om zich aan de verantwoordelijkheid voor zijn misdrijven te onttrekken doet de dader alles wat in zijn vermogen ligt om het vergeten te bevorderen. Geheimhouding en zwijgen zijn daarbij zijn eerste verdedigingslinie. Als het niet lukt om het misdrijf geheim te houden, probeert de dader de geloofwaardigheid van zijn slachtoffer aan te tasten. Als hij haar niet volledig tot zwijgen kan brengen, probeert hij ervoor te zorgen dat niemand luistert. Met het oog daarop komt hij aanzetten met een reeks indrukwekkende argumenten, die variëren van de meest botte ontkenning tot de meest geraffineerde en fraaie rationalisatie. Elke wreedheid wordt steevast gevolgd door dezelfde voorspelbare verontschuldigingen: het is nooit gebeurd; het slachtoffer liegt; het slachtoffer overdrijft; het slachtoffer heeft het aan zichzelf te wijten; en trouwens, het is tijd om het verleden te laten rusten en vooruit te kijken. Hoe meer macht de dader heeft, hoe groter zijn privilege is om de werkelijkheid te benoemen en te definiëren en hoe vollediger zijn argumenten zegevieren."

De problematiek van geweld in de privésfeer is vanaf de jaren tachtig steeds meer geplaatst in een rechtenvertoog: de vrouw is een rechtssubject en heeft vrijheidsrechten die ook binnen de privésfeer gerespecteerd dienen te worden. Geweld tegen de vrouw door haar partner of ex-partner is een inbreuk op haar lichamelijke integriteit en persoonlijke levenssfeer. De vraag is hoe veiligheid kan worden gecreeerd, zodat vrouwen hun vrijheidsrechten kunnen uitoefenen. In het kader van deze studie is de vraag beperkt tot de rol van het strafrecht, toegespitst op het openbaar ministerie; hoe kan het openbaar ministerie bijdragen aan de rechtsbescherming van slachtoffers van geweld door hun partner of ex-partner. Deze rechtsbescherming omvat drie aspecten: bescherming tegen machtsuitoefening door de overheid, bescherming tegen inbreuken op vrijheidsrechten door andere burgers en bescherming door openheid naar de maatschappelijke context binnen de geslotenheid van het rechtssysteem. 


\section{Een terugblik}

Gezien het publieke en punitieve karakter van het strafrecht is het individuele rechtsbeschermende vermogen van het strafrecht beperkt. Tegelijkertijd draagt juist dit publieke en punitieve karakter eraan bij dat het strafrecht kan worden ingezet als stok achter de deur om de man aan te zetten tot het nemen van de verantwoordelijkheid voor het gepleegde geweld. Een adequate rechtsbescherming houdt in dat zowel verdachte als slachtoffer als rechtssubject worden behandeld. De man wordt benaderd als een mens die verantwoordelijkheid draagt en in staat is tot schuldverwerking als hij met respect wordt behandeld. Hij wordt verantwoordelijk gesteld voor de schending van zijn plichten en bezit daarbij rechten tegen willekeurig overheidsoptreden. ${ }^{2}$ Het slachtoffer wordt als rechtssubject behandeld door haar recht op lichamelijke integriteit en privacy binnen de samenlevingsvorm te erkennen en haar te informeren over haar rechten en plichten als benadeelde partij of getuige in het strafproces. Dit vergt een humane aanpak gericht op herstel van de rechtsvrede en meer specifiek op het voorkomen van recidive, gezien de (grote) kans op herhaling waarbij ook het slachtoffer van dit geweld bekend is. Hierin onderscheidt het slachtoffer van vrouwenmishandeling zich van veel andere slachtoffers, die geen kans lopen opnieuw slachtoffer te worden van geweld door dezelfde dader. ${ }^{3}$

Hoe het openbaar ministerie gebruik maakt van zijn vervolgingsbevoegdheid, is onderzocht door het verrichten van een verkennend onderzoek naar de afhandeling van zaken van vrouwenmishandeling door het openbaar ministerie. De resultaten van dit onderzoek geven aan dat zaken van vrouwenmishandeling regelmatig op een arrondissementsparket binnenkomen. In 1985 worden op het middelgrote parket Breda ongeveer twee zaken van vrouwenmishandeling per week geregistreerd, op het kleine parket Assen ongeveer een á twee zaken per veertien dagen en op het grote parket Rotterdam ongeveer een zaak per dag. De meeste zaken van vrouwenmishandeling vallen in de categorie mishandeling gevolgd door de categorie vernieling. Dit zijn de zogenaamde veelvoorkomende, niet ernstige delicten. Zaken van vrouwenmishandeling die in de categorie mishandeling vallen, worden op dezelfde manier afgedaan als andere zaken van mishandeling, en zaken van vrouwenmishandeling die in de categorie vernieling vallen, worden vaker gedagvaard dan de andere vernielingszaken. De verwachting dat zaken van vrouwenmishandeling vaker worden geseponeerd dan andere geweldszaken, wordt door dit onderzoek niet bevestigd. Dit geldt eveneens voor de afhandeling van de emstige misdrijven verkrachting/aanranding en moord/doodslag.

2 Kelk, De menselijke verantwoordelijkheid in het strafrecht, 1994: 4.

3 In dat geval kan schadevergoeding het meest voor de hand liggende belang zijn dat door strafrechtelijk optreden wordt gediend. 
Achter deze algemene cijfers gaat een grote variatie schuil aan gevallen van vrouwenmishandeling: variatie in ernst en duur van het geweld, variatie in het gepleegde strafbare feit en variatie in duur en soort relatie. Binnen deze variatie valt op dat het merendeel van de vrouwenmishandelingzaken die het openbaar ministerie bereiken, geweld door de ex-partner betreffen. Daarnaast zijn het met name mannen uit de sociaal lagere milieus, in de helft van de gevallen eveneens zonder betaalde arbeid, die met het justitiěle circuit in aanraking komen. Dit betekent dat de zaken die het openbaar ministerie bereiken geen afspiegeling vormen van de maatschappelijke werkelijkheid waar één op de acht vrouwen wordt geconfronteerd met eenzijdig geweld door haar partner, verspreid over alle milieus.

Wanneer we kijken naar de aspecten die van invloed zijn op de beslissing van de officier van justitie om te vervolgen of te seponeren, kan worden geconstateerd dat algemene aspecten als alcoholgebruik en recidive de kans op vervolgen vergroten. Van de aspecten die specifiek vrouwenmishandeling betreffen, kan worden gesteld dat het openbaar ministerie geweld tegen de vrouw door haar ex-partner even vaak vervolgt als geweld dat plaatsvindt binnen een relatie, maar dat de kans op dagvaarden aanmerkelijk wordt vergroot als de vrouw na het doen van aangifte haar relatie verbreekt. Wanneer de vrouw een brief schrijft aan de officier van justitie dat zij geen vervolging wenst, lijkt de kans op een sepot te worden vergroot. Geen onderscheid in afdoening is te constateren tussen zaken van incidenteel geweld tegen de vrouw en herhaald geweld tegen de vrouw. De reden hiervoor kan zijn dat herhaald geweld wordt geïnterpreteerd als wederzijds geweld: beiden hebben het zover laten komen, beiden zijn verantwoordelijk voor het geweld. Daarnaast is de ernst van het letsel, de grootte van het schadebedrag, het uit zichzelf betalen van de schade aan het slachtoffer, en de houding van verdachte van invloed op de beslissing om te gaan vervolgen of niet.

De reden dat geweld tegen vrouwen in de privésfeer niet anders wordt afgedaan dan elk ander geweld, is naar mijn mening gelegen in het niet herkennen van de specifieke problematiek van vrouwenmishandeling: de machtsdynamiek in een relatie, het chronische geweld, het toegenomen isolement van de vrouw en een afname van de weerbaarheid van de vrouw door het dominerende en gewelddadige gedrag van de man, en de specifieke traumatisering. Ook lijkt het geweld gepleegd door de ex-partner, ondanks het feit dat deze zaken vaak worden gedagvaard, niet als ernstig privacy-schendend gedrag te worden herkend. Dit privacy-schendende gedrag, ook wel 'separation assault' genoemd, kan zeer bedreigend en zelfs levensgevaarlijk zijn voor de vrouw.

Een aantal 'stereotype' opvattingen kunnen eraan bijdragen dat de specifieke problematiek niet wordt herkend. Een veelvoorkomende opvatting is dat de vrouw weg moet gaan bij haar partner als hij geweld pleegt. Deze opvatting gaat voorbij aan de complexe emotionele en sociale afhankelijkheid en de machtsdynamiek in een relatie. Bovendien gaat deze opvatting voorbij aan het feit dat juist in de periode dat de vrouw net is weggegaan en er sprake is van een (echt)scheidingsprocedure 
de kans op geweld het grootst is. Een andere opvatting, die verband houdt met de eerste, is dat de vrouw medeverantwoordelijk is voor het herhaaldelijk voorkomen van geweld; de vrouw heeft het zelf zo ver laten komen (door niet weg te gaan). De opvatting dat strafrechtelijk optreden leidt tot escalatie wordt naar voren gebracht om niet strafrechtelijk in te grijpen in geval van een bestaande relatie. Maar ook als de vrouw weg is bij haar partner, kan dit argument naar voren worden gebracht. Door uit te gaan van een gelijkwaardige relatie tussen man en vrouw, waar emoties hoog kunnen oplopen en waar beiden evenveel aandeel hebben in de escalatie van het conflict, wordt de machtsdynamiek in een (huwelijkse) relatie onvoldoende erkend. Deze opvatting over gelijkwaardigheid kan verhinderen dat dominerend en gewelddadig gedrag van de man wordt (h)erkend, bijvoorbeeld in geval de vrouw probeert te ontsnappen aan de macht van de man; als de man haar achtervolgt, kan dit worden opgevat als een proces van aantrekken en afstoten.

Deze opvattingen spelen weliswaar een rol, maar behoeven niet te leiden tot nietsanctionerend optreden door officieren van justitie. Wel dragen deze opvattingen ertoe bij dat de ernst van het geweld en de kans op herhaling niet (altijd) goed worden ingeschat. Het feit dat het geweld tegen de vrouw in de privésfeer wordt afgedaan als elk ander geweldsdelict, geeft aan dat in geval van de minder ernstige misdrijven als mishandeling, vernieling en huisvredebreuk de kans op een gestandaardiseerde afhandeling groot is, of de zaak nu buitengerechtelijk wordt afgedaan of door de rechter. Ook in geval van een ernstiger misdrijf als zware mishandeling, poging tot doodslag of verkrachting, lijkt de specifieke problematiek van vrouwenmishandeling niet (altijd) te worden herkend, waardoor een aanpak gericht op het voorkomen van speciale recidive niet plaatsvindt. Het optreden van het openbaar ministerie is gezien vanuit het gezichtspunt van de rechtsbescherming van het slachtoffer van vrouwenmishandeling, niet adequaat (hoofdstuk 5).

In het kader van de rechtsbescherming is het noodzakelijk dat het specifieke belang van slachtoffers van vrouwenmishandeling wordt meegewogen in de besluitvorming, zowel tijdens de strafprocedure, als tijdens de straftoemeting. Dit kan door een humane aanpak tot uiting worden gebracht. Binnen het huidige strafrechtelijke instrumentarium is zo'n aanpak naar mijn mening mogelijk. Om deze aanpak te stimuleren is enige formalisering in de zin van richtlijnen en protocollen van de belang. Niet om een bureaucratische formele gelijkheid te bewerkstelligen, maar om politie en openbaar ministerie handvatten te bieden voor een strafrechtelijke aanpak die recht doet aan de specifieke problematiek van mannelijk geweld tegen vrouwen in de privésfeer. Een samenwerkingsverband 'Geweld in de privésfeer' op arrondissementsniveau, waar politie, justitie, hulpverlening, reclassering, slachtofferzorg en advocatuur overleg hebben, lijkt een belangrijke voorwaarde om de ernst van het geweld te kunnen inschatten en de verschillende aanpakken meer 
op elkaar te kunnen afstemmen ( $\S 6.4) .{ }^{4}$ Het openbaar ministerie kan hiertoe het voortouw nemen, of de politie die als eerste schakel van het strafproces wordt geconfronteerd met vrouwenmishandeling. ${ }^{5}$ Ook de politiek kan een kader scheppen door beleid te formuleren. Druk vanuit maatschappelijke groeperingen om de specifieke problematiek van vrouwenmishandeling als serieus maatschappelijk probleem aan te pakken, is hiervoor overigens noodzakelijk.

Naast rechtsbescherming van slachtoffers van vrouwenmishandeling door een specifieke strafrechtelijke aanpak, kan de rechtsbescherming worden vergroot door de positie van het slachtoffer van vrouwenmishandeling als benadeelde van een misdrijf en als getuige in het strafproces te versterken. Het slachtoffer van vrouwenmishandeling behoort in de gelegenheid te worden gesteld haar wensen over de strafrechtelijke aanpak kenbaar te maken, omdat, gezien de relationele context, de strafrechtelijke aanpak van invloed is op haar persoonlijke levenssfeer. Deze invloed behoort niet vergaand te zijn: één of andere vorm van zeggenschap over de strafvervolging of straftoemeting is niet gewenst. Niet alleen omdat de bemiddelende functie van het strafrecht daardoor wordt aangetast, maar ook omdat de kwetsbaarheid van de vrouw ten opzichte van haar partner of ex-partner erdoor zal worden vergroot. Bovendien verdwijnt vrouwenmishandeling als maatschappelijk probleem erdoor naar de achtergrond. Deze argumenten pleiten ook tegen het formuleren van vrouwenmishandeling als een klachtdelict; vrouwenmishandeling wordt op die manier teruggebracht tot een privéprobleem. Nu de positie van de benadeelde partij sinds de slachtofferrichtlijnen en de wet-Terwee is versterkt, lijkt een verdergaande versterking van de rechtspositie van het slachtoffer van vrouwenmishandeling als benadeelde van een misdrijf niet noodzakelijk, hoewel een aantal verfijningen van de huidige regeling kunnen worden aangebracht. De rechtsbescherming van slachtoffers van vrouwenmishandeling als getuige dient te worden versterkt door het recht om te spreken in het kader van de waarheidsvinding te erkennen, en in de wet een recht op 'fair hearing' vast te leggen. Daarnaast is van belang dat het recht op lichamelijke integriteit en privacy van slachtoffer-getuigen wordt erkend door het wettelijk vastleggen hiervan: wanneer een gegrond vermoeden bestaat dat de lichamelijke of geestelijke gezondheidstoestand in gevaar wordt gebracht door het afleggen van een getuigenis in het openbaar, kan oproeping achterwege blijven." Een eigen rechtsingang voor de getuige, zodat het mogelijk is bezwaar te maken tegen de oproeping als getuige, betekent een erkenning van de getuige als rechtssubject. Tot slot is een recht op rechtsbijstand van belang om slachtoffer-getuigen

4 Ook overleg op arrondissementsniveau, zoals dit gebeurt over zedenzaken, zou de grote verschillen in opvatting kunnen mitigeren en de aanpak zou kunnen verbeteren door te zoeken naar bepaalde criteria waaraan een zaak wordt afgemeten.

5 Zie voor een protocol op politieniveau: Van der Ent \& Evers, Vrouwenmishandeling: een zorg voor de politie, 1996.

6 Dit lijkt te worden verwezenlijkt met het wetsvoorstel Herziening onderzoek ter terechuitting (TK 24.692). 
en het slachtoffer als benadeelde partij de gewenste juridische en emotionele ondersteuning te kunnen bieden ( $\$ 6.3$ ).

\section{Getiteld: 'Geweld in de privésfeer'}

Rechtsbescherming wordt tot slot geboden door de wijze waarop strafbepalingen zijn geformuleerd en worden geïnterpreteerd. Een wetsbepaling geeft uiting aan een inhoudelijke waardering van belangen. Een strafbepaling die effectief is ten opzichte van de normadressaat en een oriêntatiepunt biedt voor degene die de wet interpreteert, heeft 'symboolwerking'. Symboolwerking ontbreekt als het onderwerp dat de wet pretendeert te regelen, geen deel uitmaakt van het juridische debat. ${ }^{7} \mathrm{Je}$ zou kunnen zeggen dat geweld in de privésfeer weliswaar een onderwerp is dat het wetboek van strafrecht pretendeert te regelen, maar omdat geweld in de privésfeer nauwelijks onderdeel uitmaakt van het juridische debat, gaat er geen symboolwerking uit van de verschillende strafbepalingen waar mannelijk geweld tegen vrouwen in de privésfeer onder kan vallen. Om de symboolwerking, en daarmee ook de rechtbescherming van slachtoffers van vrouwenmishandeling, te versterken is het formuleren van een titel 'Geweld in de privésfeer' in het wetboek van strafrecht gewenst. Door het ontbreken van duidelijke en coherente strafwetgeving van gewelddadigheden gepleegd in de privesfeer is deze specifieke geweldsproblematiek onzichtbaar in het strafrecht. ${ }^{8}$

Een aparte titel geeft aan dat geweld in de privésfeer een specifieke geweldsproblematiek betreft. Het te beschermen belang, aantasting van de persoonlijke vrijheid binnen de privésfeer, wordt door de huidige strafwetgeving onvoldoende beschermd. Een aparte titel 'Geweld in de privésfeer' behoeft een eigen juridisch-dogmatische interpretatie. Bovendien wordt de normatieve afkeuring van geweld in de privésfeer ermee tot uitdrukking gebracht, zowel van geweld in bestaande relaties, als privacyschendend gedrag door de ex-partner (separation assault). Ook mishandeling en seksueel misbruik van kinderen in de privésfeer kan onder de titel 'Geweld in de privésfeer' worden gerangschikt. De uitzondering dat vernieling, diefstal en afpersing door de echtgenoot niet vervolgbaar zijn en door de van tafel en bed gescheiden partner alleen op klacht, zou daarmee zijn afgeschaft (zie hoofdstuk $3, \S 3.3$ ). Een

7 Witteveen, Evenwicht van machten, 1991: 74-79. Symboolwerking onderscheidtzich van symbolische wetgeving in het gangbare spraakgebruik waar gedoeld wordt op wetgeving die niet gehandhaafd wordt maar alleen dient als symbolisch gebaar. Ibidem: 75 .

8 Weliswaar wordt in artikel $304 \mathrm{Sr}$ aangegeven dat mishandeling van naaste bloedverwanten strafvercwarend is, maar hiermee wordt allerminst de problematiek van vrouwenmishandeling gedekt. Bovendien voldoet deze bepaling niet omdat de strekking 'pieteit tegenover naste verwanten' of 'schending van de plicht tot bescherming van zijn echtgenoot' niet overeenkomt met de strekking dat geweld in de privésfeer als een specifieke aantasting van de persoonlijke vrijheid kan worden beschouwd (zie $\$ 3.2 .2$ ). 
ander voordeel van een aparte titel is dat de mogelijkheid tot inverzekeringstelling aan deze specifieke strafbaarstellingen kan worden gekoppeld, waarmee de mogelijkheid voor de politie om strafrechtelijk op te treden, voor specifiek deze geweldsproblematiek wordt vergroot. Door verschillende strafbepalingen onder één titel te groeperen wordt aan de ernst en de varietteit van de problematiek 'geweld in de privésfeer' beter recht gedaan dan door een losse strafverzwarende bepaling (art. $304 \mathrm{Sr}$ ) en komt het te beschermen belang, de persoonlijke vrijheid, beter tot zijn recht. ${ }^{9}$ Een ander argument dat voor een aparte titel pleit, betreft de zichtbaarheid van deze specifieke problematiek binnen de strafrechtstatistiek. Momenteel 'verdwijnt' vrouwenmishandeling, omdat relationeel geweld de toevallige casuirstiek is. Tot slot kan met het creëren van een aparte titel 'Geweld in de privésfeer' de discussie over de maatschappelijke ernst van dit specifieke geweld worden gestimuleerd; politici, juristen, journalisten en andere betrokkenen zullen zich uitspreken over de voor- en nadelen van wetgeving en de wijze waarop de strafbepalingen worden vormgegeven.

Naast deze voordelen zijn ook nadelen verbonden aan het creerren van een aparte titel. Een belangrijk nadeel is dat de politieke analyse van geweld tegen vrouwen in de privésfeer getransformeerd moet worden naar een juridisch relevant probleem. Deze vertaalslag gaat gepaard met een (sterke) reductie van het probleem. Ook speelt het probleem of geweld in de privésfeer sekse-specifiek of sekse-neutraal moet worden geformuleerd. Een sekse-neutrale formulering gaat voorbij aan het seksespecifieke aspect van vrouwenmishandeling; de angel wordt uit vrouwenmishandeling getrokken. Tegelijkertijd draagt specifieke strafbaarstelling ter bescherming van vrouwen maatschappelijk gezien het grote gevaar in zich dat het beeld dat vrouwen altijd in een zwakkere positie zitten en eeuwig slachtoffer zijn, erdoor wordt versterkt. Op die manier wordt geen recht gedaan aan het feit dat de machtsverhouding tussen de seksen niet statisch is maar dynamisch (het differencedilemma). Bovendien heeft iedereen op individueel niveau recht op speciale bescherming tegen geweld gepleegd binnen de relationele sfeer, zowel vrouwen als mannen, zowel binnen heteroseksuele als homoseksuele relaties. Dit geeft aan dat in beide gevallen - een sekse-neutrale of sekse-specifieke formulering - geen recht kan worden gedaan aan de specifieke problematiek van vrouwenmishandeling. We zien dit ook in de wetgeving betreffende verkrachting; door de sekse-neutrale wetgeving is verkrachting van vrouwen onzichtbaar geworden. Bovendien lijkt de nadruk te worden gelegd op het gewelds- en machtsaspect van verkrachting. waardoor het aspect van de beschadiging van de seksualiteit en de fallocentrische cultuur waarin verkrachting van vrouwen plaatsvindt, naar de achtergrond wordt

9 De door mij in hoofdstuk 3 voorgestelde strafverzwarende omstandigheid 'ernstig letsel tol gevolg" maakt de specifieke problematiek van vrouwenmishandeling niet zichtbaar (§ 3.2.2). 
gedrongen. ${ }^{10}$ Maar verkrachting niet seks-neutraal formuleren zou het beeld van de vrouw als eeuwig slachtoffer versterken.

Een ander probleem betreft de feitelijke omschrijving van de strafbepaling. De term intieme heteroseksuele relatie is niet voldoende feitelijk voor een strafbepaling, en zal daarom worden teruggebracht tot 'een (gewezen) huwelijkse of samenwonings-relatie'. Een LAT-relatie of een 'verkering' zullen buiten de definitie vallen, omdat de vaststelling van deze intieme relaties gepaard kan gaan met een te grote inbreuk op de persoonlijke levenssfeer van verdachte en slachtoffer. Een ander reductieprobleem doet zich voor in de omschrijving van het geweld dat strafbaar is. Gekozen zal moeten worden welke geweldsdelicten binnen de privésfeer aparte strafbaarstelling behoeven, mishandeling en bedreiging, of ook vernieling, vrijheidsberoving, doodslag, moord en seksuele misdrijven, of zelfs diefstal en brandstichting? Bovendien moet worden gekozen tussen een strafverzwarende bepaling analoog aan artikel $304 \mathrm{Sr}$ of voor elk geweldsmisdrijf een aparte strafbepaling. Welke oplossing ook wordt gekozen, er zal altijd een reductie van de problematiek plaatsvinden. "What transpires from this analysis is the essential tension between legal and feminist discourse."'1 Het laatste argument dat tegen wetgeving pleit, betreft de uitvoering van de wet. Door een aparte titel 'Geweld in de privésfeer' wordt het probleem van de grote invloed van common sense-ideeën over geweld tegen vrouwen op de interpretatie van de delictsbepalingen en de toepassing van de wet niet ondervangen.

Deze voor- en nadelen duiden op een dilemma: geen aparte titel 'Geweld in de privésfeer' draagt bij aan de onzichtbaarheid van de problematiek in het strafrecht. Wel een aparte titel 'Geweld in de privésfeer' betekent een transformatie van de specifieke problematiek naar een juridisch hanteerbare problematiek, waardoor ontpolitisering van de problematiek plaatsvindt (het juridiserings-dilemma).

$\mathrm{Na}$ afweging van alle argumenten bepleit ik een aparte titel 'Geweld in de privésfeer' omdat ik van mening ben dat zichtbaarheid van deze specifieke problematiek in het wetboek van strafrecht een vooruitgang betekent ten opzichte van de huidige situatie. Door relationeel geweld specifiek strafbaar te stellen worden de feiten die samenhangen met het relationele geweld niet als toevallige casurstiek terzijde geschoven, maar als relevante feiten in het juridische vertoog naar voren gehaald. Het te beschermen belang, de persoonlijke vrijheid binnen de privésfeer, wordt uitdrukkelijk vastgelegd. Dit kan worden beschouwd als een verbetering van de rechtsbescherming van slachtoffers van geweld door hun partner of ex-partner. Om de kans te vergroten dat het een wet met symboolwerking zal zijn en geen symbolische wet, is het noodzakelijk dat de wetswijziging gepaard gaat met een

10 Zie bijvoorbeeld de problematick van verkrachting tijdens de slaap: Verrijn Stuarh Verkrachting op breukvlak van twee eeuwen, Nemesis, 1996: 97-98; Rechtbank Leeuwarden, 4 april 1996, RN 1996, 593.

11 Los, Feminism and rape law reform, in: Feminist perspectives in criminology, 1990: 165. 
programma van maatregelen. Zonder effectieve programmering heeft de wetswijziging hooguit ideologische betekenis of worden niet beoogde effecten teweeggebracht, waardoor geen verbeterde rechtsbescherming wordt bereikt. ${ }^{12}$

\section{Een humane aanpak in een tijd van 'nieuwe zakelijkheid'?}

Een humane aanpak van mannelijk geweld tegen vrouwen in de privésfeer, met of zonder een aparte titel 'Geweld in de privésfeer', lijkt haaks te staan op de efficiënte, zakelijke en tariefmatige aanpak in de huidige tijd van 'nieuwe zakelijkheid'. Het openbaar ministerie is meer en meer een bestuursorgaan geworden waar het management meer macht krijgt. Efficiēntie, beheersbaarheid van problemen door het kwantificeren van het probleem en het zoeken naar slagvaardige oplossingen lijken belangrijker dan een kwalitatieve, op de mens gerichte aanpak; lik-op-stuk wordt belangrijker dan resocialisatie. Richtlijnen spelen in deze ontwikkeling een belangrijke rol. Onder het mom van gelijkheid wordt slagvaardig aan de hand van eenduidige criteria beslist; een bureaucratische, formele gelijkheid in plaats van een materiêle gelijkheid die recht doet aan de ongelijkheid van de individuele gevallen. ${ }^{13}$ De mens achter de verdachte verdwijnt steeds verder uit het zicht van de officier van justitie, en de mens achter het slachtoffer krijgt geen kans te verschijnen. Een op de concrete situatie afgestemde belangenafweging past niet in een gestandaardiseerde wijze van afdoening. De gestandaardiseerde wijze van afdoening geldt zeker voor de zogenaamde eenvoudige en minder emstige misdrijven, zoals zaken van mishandeling, bedreiging, vernieling en huisvredebreuk, waar het gros van de zaken van vrouwenmishandeling toe gerekend kunnen worden. Tegenwoordig beslist het parketsecretariaat doorgaans in eerste instantie over deze zaken en wordt een groot deel van de zaken met een transactie afgedaan. ${ }^{14}$

Tegelijkertijd is echter een sterke groei te constateren van alternatieve wijzen van afdoening voor bepaalde categorieën van verdachten. Een op de persoon en omstandigheden toegesneden strafrechtelijke reactie vindt plaats, die vergezeld gaat van een positieve bekrachtiging van gewenst gedrag, zonder dat dit hoeft te leiden tot het ondergaan van gevangenisstraf of het betalen van een boete. Deze altematieve

12 Zie: Peters, Recht als project, AA, 1979.

13 Kelk, De menselijke verantwoordelijkheid in het strafrecht, 1994: 11-15, 47-51.

14 Deze gestandaardiseerde wijze van afhandelen zal worden versterkt als het plan van de commissieKorthals Altes om naast overtredingen en misdrijven de categorie misdragingen in te voeren. werkelijkheid wordt. Zaken van eenvoudige mishandeling en vemieling zouden tot de misdragingen behoren en op een vereenvoudigde manier worden afgedaan. Groenhuijsen, Rechtshandhaving aan het einde van de twintigste eeuw, $D D, 1995: 810$. Dit is voor de afhandeling van zaken van vrouwenmishandeling een negatieve ontwikkeling omdat de kans op een magistratelijke afdoening daarmee wordt verkleind. Bovendien vindt ik het onbegrijpelijk dat een geweldsdelict als mishandeling, waar het gevolg emstig letsel kan zijn, over eten kam wordt geschoren met eenvoudige diefstal. 
sancties hebben tot doel bij te dragen aan vermindering van recidive en verbetering van iemands maatschappelijke perspectief. ${ }^{15}$ Alternatieve sancties kunnen door de rechter worden opgelegd, maar ook officieren van justitie hebben mogelijkheden tot alternatieve manieren van afdoening. Deze alternatieven bieden een aanknopingspunt voor de door mij bepleite humane aanpak waar het voorkomen van recidive voorop staat evenals het herstel van het zelfrespect van dader en slachtoffer.

Aan vergaande uitbreiding van alternatieve sancties kleeft echter ook een gevaar. Het private leven wordt op die manier meer transparant, de disciplinering van mensen op verschillende niveaus door maatschappelijke instellingen wordt verfijnd en uitgebreid. ${ }^{16}$ Door een gestage uitbreiding van het sanctiearsenaal kan het punitieve gehalte van de samenleving wel eens een zó hoge graad van alomvattendheid en intensiteit gaan aannemen, dat de leefbaarheid van de samenleving in het geding komt. ${ }^{17}$ Mensen worden niet aangesproken op het schenden van hun plichten, met als doel dat zij zich ontwikkelen tot vrije en sociale burgers, maar mensen worden gedwongen zich aan te passen aan wat de overheid als goede gedragsregels beschouwd. In plaats van de 'verkilling en onverschilligheid' ${ }^{18}$ van de bureaucratische strafrechtelijke regulering, is er sprake van een 'verstikkende en moraliserende' normhandhavende aanpak. De ruimte voor een eigen leefwijze wordt steeds verder beperkt. Bovendien worden strafbare gedragingen, die eerst niet of gestandaardiseerd werden afgedaan, nu via alternatieve sancties die diepgaander in het leven van de dader ingrijpen, afgedaan. Dit wordt de aanzuigende werking van alternatieve sancties genoemd. ${ }^{19}$

Het hiervoor beschreven gevaar acht ik reëel en voorzichtigheid is geboden met het uitbreiden van het alternatieve sanctiearsenaal voor alle delictsoorten. Maar in geval van geweld in de privésfeer bepleit ik, ondanks de hiervoor genoemde bezwaren, een uitbreiding van alternatieve sancties. Juist deze problematiek leent zich voor schuldverwerking omdat de man belang heeft bij een respectvolle relatie en vergroting van de sociale binding met zijn partner en eventuele kinderen. Een humane aanpak kan ertoe bijdragen dat de man de verantwoordelijkheid voor zijn agressieve gedrag neemt, waardoor de veiligheid van de vrouw (en eventuele kinderen) wordt vergroot. Hierbij is wel van belang dat de strafrechtelijke aanpak met voldoende rechtswaarborgen is omkleed, aangezien deze meer op de persoon gerichte sancties vaak gepaard gaan met afhankelijkheid van therapeuten of reclasseringsmedewerkers. ${ }^{20}$

15 De Beer, Het politieke kader voor de taakstraf, Proces, 1996: 14.

16 't Harh, Recht als schild van Perseus, 1991: 133-142.

17 Kelk. De menselijke verantwoordelijkheid in het strafrecht, 1994: 55.

18 Ibidem: 54.

19 Ibidem: 221.

20 Kelk gaat in op de rechtsbescherming van de verdachte die vrijwillig, of door de rechter opgelegd, aan een alternatieve sanctie moet voldoen. Kelk, De menselijke verantwoordelijkheid in her strafrecht. 1994: 219-234. 


\section{Zoeken naar bescherming}

De vrouw die slachtoffer is van geweld door haar partner of ex-partner wordt op menselijk niveau leed aangedaan, wat verstrekkende gevolgen kan hebben voor haar (geestelijke) gezondheid en sociale functioneren. Juridisch beschouwd wordt haar persoonlijke vrijheid en lichamelijke integriteit aangetast en worden de voorwaarden voor het uitoefenen van haar burgerschap verkleind. Het recht is een noodzakelijk instrument ter bescherming van de burgerlijke vrijheden, maar is tegelijkertijd zeer beperkt in de mate waarin het respect voor burgerlijke vrijheden kan garanderen. De wijze waarop door strafrechtelijk ingrijpen de rechtsbescherming van vrouwen die slachtoffer zijn van geweld door hun partner of ex-partner kan worden vergroot, is hiervoor uiteengezet. Maar strafrechtelijk optreden is een beperkt en zwaar middel door het publieke en punitieve karakter daarvan. Het kan als 'stok achter de deur' (soms) een geweldsspiraal doorbreken, maar het is niet het meest voor de hand liggende instrument om een geweldvrije privésfeer te creerren. Het familierecht en het kort geding zijn naast het strafrecht belangrijke rechtsinstrumenten om een veilige persoonlijke levenssfeer te creëren. Maar het recht kan niet meer dan een sluitstuk zijn van een pakket aan maatregelen op een groot aantal terreinen. Goede opvangmogelijkheden zijn nodig om in een veilige omgeving te kunnen herstellen van het geweld en hulpverlening is van belang om het trauma te kunnen verwerken en zelfrespect te herwinnen. Een tijdige signalering door mensen werkzaam binnen de gezondheidszorg en andere welzijnsinstellingen is nodig om ernstiger geweld te voorkomen. Mogelijkheden van tweede-kans onderwijs zijn noodzakelijk om ook op latere leeftijd door scholing de kansen op de arbeidsmarkt te kunnen vergroten en goede bijstandsvoorzieningen zijn noodzakelijk om economische zelfstandigheid te garanderen na het verbreken van de relatie. Een zelfstandige verblijfstitel voor migrantenvrouwen is, tot slot, een noodzakelijke voorwaarde om aan een gewelddadige relatie een einde te kunnen maken.

Vrouwen die geweld ondervinden in de privésfeer zoeken naar bescherming, in kleine kring, bij de hulpverlening en het maatschappelijk werk, en (tot slot) bij het (straf)recht. Het (straf)recht kan de bescherming van de persoonlijke levenssfeer niet garanderen, maar politie en openbaar ministerie hebben wel mogelijkheden om de veiligheid binnen de privésfeer te vergroten. 



\section{Bijlage 1}

\section{Operationalisatie vrouwenmishandelingszaken}

De wijze waarop vrouwenmishandeling is geoperationaliseerd, gaf een aantal problemen bij de selectie van de zaken tijdens het dossieronderzoek. Hieronder zal $\mathrm{ik}$, per criterium, ingaan op de moeilijkheden.

- Het eerste criterium, een vrouwelijk slachtoffer en een mannelijke verdachte, blijkt nagenoeg altijd uit de processen-verbaal en levert nauwelijks problemen op. - Het tweede criterium, het bestaan van een relatie tussen slachtoffer en verdachte: wanneer uit het dossier blijkt dat betrokkenen spreken over hun 'partner', dan is dat een voldoende voorwaarde om een relatie aan te nemen. Een huwelijk is ook een voldoende voorwaarde om een relatie aan te nemen. Een voldoende voorwaarde voor een ex-relatie is dat er door betrokkenen wordt gesproken van 'ex-partner'. Ook is er sprake van een voldoende voorwaarde bij scheiding van tafel en bed en bij een echtscheiding. Dit is meestal uit de processen-verbaal te halen. Als één van de twee een relatie ontkent, dan is er geen sprake van een relatie en wordt de zaak niet beschouwd als een vrouwenmishandelingszaak.'

Door de ruime definitie van relatie of ex-relatie bestaan er allerlei soorten relaties in geval van vrouwenmishandeling: zij verschillen in duur (van een paar maanden tot tientallen jaren), in manier van samenleven (van gehuwd samenwonen tot apart wonen) en in 'intensiteit' (elkaar voor eeuwig trouw beloven tot een regelmatige, maar vrijblijvende relatie). Het is niet mogelijk om hier nauwkeurige informatie over te krijgen. Het hangt van de politie af welke informatie er in het proces-verbaal is gekomen. De ene politiefunctionaris vraagt hierover meer dan de andere politiefunctionaris, waardoor de informatie in de processen-verbaal verschilt. Er kan alleen worden vastgesteld of er sprake is van een relatie of ex-relatie; over de duur, wijze van samenwonen en intensiteit zijn geen harde gegevens te verkrijgen.

- Het laatste criterium is een of andere vorm van (dreigen met) fysiek geweld. Alle vormen van fysiek geweld en dreiging ermee gericht op de vrouw vallen onder de definitie van vrouwenmishandeling. Van belang is, dat het (dreigen met) fysiek geweld nauw samenhangt met de relatie tussen het slachtoffer en de dader. Dreiging met fysiek geweld kan bijvoorbeeld blijken uit het vernielen van meubilair., Puur het vernielen van meubilair valt niet onder vrouwenmishandeling, in samenhang met de relatie wel. Voorwaarde hierbij is dat de vrouw slachtoffer is van de vernieling door haar (ex-)partner. Dit levert de meeste problemen op, namelijk in

I Er zijn zaken waar de verdachte last heef van 'liefdesverdriet'. De onbeantwoorde liefde is voor de man reden om geweld op de vrouw uit te oefenen. Dit soort zaken heb ik niet als vrouwenmishandelingszaken gedefinieerd, omdat de vrouw ontkent dat er sprake is (geweest) van een relatie. 
die gevallen waarin het fysieke geweld niet alleen op de vrouw is gericht, maar ook op derden. Er komen nogal eens zaken binnen waar een ex-relatie aanleiding is voor geweldpleging, maar waar het geweld niet direct op de vrouw is gericht. Te denken valt aan zaken waar de ex-man naar het huis van de vrouw gaat en slaags raakt met de nieuwe vriend of het naambordje van de nieuwe vriend vernielt of een ruit vernielt van het huis waar de ouders van de vrouw wonen. Soms komt het ook voor dat er een soort familievete tussen de familie van de vrouw en de familie van de man ontstaat naar aanleiding van een echtscheiding. In al dat soort situaties is de vrouw niet direct slachtoffer van geweld. Wel kan dit gedrag bedreigend zijn, maar de dreiging is niet direct gericht op de vrouw en daarom laat ik deze zaken verder buiten beschouwing. Er zijn ook situaties die minder duidelijk zijn. Bijvoorbeeld, de man vernielt een ruit bij zijn ex-schoonouders, waar de vrouw is ingetrokken of de man mishandelt zijn ex-vrouw en haar moeder. Het eerste geval reken ik niet tot vrouwenmishandeling omdat het om eigendom van de ouders gaat en niet kan worden vastgesteld of de ex-vrouw werkelijk slachtoffer is van het geweld. Het tweede geval is wel een zaak van vrouwenmishandeling, omdat het geweld duidelijk op de vrouw is gericht. Een vrouw is dus slachtoffer van vrouwenmishandeling als haar (ex-)partner zich (mede) richt op de vrouw zelf of op bezittingen van haar.

Tot slot zijn er nog gevallen van vrouwenmishandeling die wel aan bovengenoemde criteria voldoen, maar die ik toch niet tot mijn onderzoekspopulatie heb gerekend. Dit zijn gevallen van vrouwenmishandeling die overschaduwd worden door een ander geval van mishandeling. Te denken valt aan situaties waarin de politie is geroepen om in te grijpen in een geval van vrouwenmishandeling en de politiefunctionaris vervolgens door de man wordt geschopt. Wanneer de vrouw geen aangifte doet van mishandeling en de politiefunctionaris wel, dan komt het incident vaak als 'wederspannigheid aan de politie' bij het OM. Ook wanneer de ex-partner zowel de vrouw als de nieuwe vriend van de vrouw mishandelt en alleen de vriend aangifte doet, zal de officier van justitie alleen over de mishandeling van de vriend beslissen. Met andere woorden, het feitencomplex waarover de officier van justitie beslist, is in zulke gevallen geen vrouwenmishandeling. Dus hoewel uit het dossier blijkt, dat er sprake is van vrouwenmishandeling, wordt de zaak niet tot de vrouwenmishandelingszaken gerekend, omdat de officier van justitie een beslissing neemt over een ander feitencomplex: mishandeling tussen bekenden of wederspannigheid aan de politie.

Hierbij wil ik de kanttekening plaatsen dat het doen van aangifte door de vrouw voor de politie meestal van doorslaggevend belang is om proces-verbaal op te 
maken. ${ }^{2}$ Ook de officier van justitie zal, ondanks het feit dat hij of zij wel van de vrouwenmishandeling op de hoogte is, vrouwenmishandeling niet expliciet in de beslissing betrekken als de vrouw geen aangifte heeft gedaan. Op die manier wordt door de politie en het OM vrouwenmishandeling als klachtdelict behandeld; een delict dat niet ambtshalve door de officier van justitie kan worden vervolgd, maar alleen als het slachtoffer een aanklacht heeft ingediend. ${ }^{3}$

2 Wostmann, Politieoptreden bij vrouwenmishandeling, 1988: 74. Dit neemt niet weg dat het af en the voorkomt dat de politic een proces-verbaal opmaakt en dit doorstuurt naar het openbaar ministerie in geval van vrouwenmishandeling zonder dat de vrouw hiervan aangifte heeft gedaan. Van de 150 zaken in 1985 was dit vier keer voorgekomen (en twee keer was de vrouw dood en kon geen aangifte doen).

3 Belediging is zo'n delict dat alleen op klacht vervolgbaar is (artt. 261, $169 \mathrm{Sr}$ ) evenals geslachtsgemeenschap met een meisje tussen 12 en 16 jaar (art. $245 \mathrm{Sr}$ ). Er zijn ook relatieve klachtdelicten, dat wil zeggen dat er alleen bij een nauwe familierelatie tussen dader en slachtoffer sprake is van een klachtdelict. Hiervan is bijvoorbeeld sprake bij diefstal (artt. 310 jo, 316 lid $2 \mathrm{Sr}$ ), vernieling en beschadiging (art. $353 \mathrm{Sr}$ ), verduistering (art. $324 \mathrm{Sr}$ ) en afpersing (art. $319 \mathrm{Sr}$ ). Dit betekent dat vernieling en beschadiging door de van tafel en bed of goederen gescheiden echtgenoot een klachtdelict is. Vernieling en beschadiging door de echtgenoot is helemaal niet vervolgbaar. 



\section{Bijlage 2 \\ Selectieprocedure}

De selectieprocedure om zaken van vrouwenmishandeling te vinden verliep in twee fasen: eerst werden de geweldsdelicten geselecteerd en daarna werden uit de geweldsdelicten de vrouwenmishandelingszaken gehaald.

\section{Fase 1}

Elk proces-verbaal dat naar het openbaar ministerie werd gestuurd, werd eerst geregistreerd in het parketregister onder een parketnummer. Er is een apart parketregister voor de misdrijven, uitgezonderd de economische delicten. ' Het parketnummer vormde de ingang voor het vinden van het dossier in het archief van het openbaar ministerie of de rechtbank. Ook de hoger beroep- en cassatiezaken van de geregistreerde misdrijven in dat arrondissement zijn in het archief van de rechtbank te vinden. ${ }^{2}$

Uit dit parketregister werden de voor het onderzoek relevante parketnummers geselecteerd. Deze selectie was allereerst gebaseerd op het wetsartikel; alleen de wetsartikelen 278-289, 300-304, 242, 246, 282, 284, 285, 138, 350 en 352 Sr waren voor het onderzoek van belang. Als het delict in vereniging is gepleegd, werd de zaak verder buiten het onderzoek gehouden, omdat in het algemeen vrouwenmishandeling niet door meer daders wordt gepleegd. ${ }^{3}$ Ook de door minderjarigen gepleegde delicten werden buiten het onderzoek gehouden. Zaken die wel aan deze criteria voldeden, konden toch nog buiten het onderzoek vallen, namelijk als de zaak was overgedragen aan een ander arrondissement of een andere rechtsgang (bijvoorbeeld militaire rechtspraak) of het kantongerecht. ${ }^{4}$

Kortom, het ging om een voor het onderzoek relevant delict, gepleegd door een volwassen verdachte en niet gepleegd in vereniging. Daarbij moest het gaan om een zaak waar de rechtbank toe bevoegd was en de zaak moest worden afgehandeld in het arrondissement dat wordt onderzocht.

l In het parketregister wordt vermeld wat de personalia van de verdachte zijn, of het delict in vereniging is gepleegd, om welk misdrijf het gaat (wetsartikel), de datum waarop het delict is gepleegd en de datum waarop de zaak in het register is ingeschreven, de wijze van afhandelen door de officier van justitie of de rechter, en of er sprake is van hoger beroep of cassatie.

2 Het dossieronderzoek betreft de afhandeling van zaken in eerste aanleg.

3 Geweld in vereniging tegen de vrouw komt in de praktijk wel voor, maar het is heel moeilijk om in dit soort zaken vast te stellen of de man het geweld specifiek tegen zijn (ex-)vrouw of (ex-)vriendin pleegt, of dat er sprake is van een familievete waar de (ex-)relatie ook cen rol in speelt.

4 De categorie 'overig' onder 'wijze van afhandelen door het OM' is hiermee komen te vervallen. 
De geselecteerde parketnummers werden vermeld op speciale lijsten naar soort delict. De gegevens die op de lijsten staan vermeld zijn: het parketnummer, de datum van inschrijving in het parketregister, het wetsartikel, wie het afhandelt (openbaar ministerie of rechtbank) en wanneer het wordt afgehandeld, sekse van verdachte en slachtoffer en of het een zaak van vrouwenmishandeling betreft.

Het parketnummer was, zoals hierboven is vermeld, van belang voor het vinden van het dossier in het archief en de datum van inschrijving voor het bepalen van de periode waarin de eerste 50 gevallen van vrouwenmishandeling worden gevonden. De datum waarop het delict is gepleegd, lag (ver) voor de datum van inschrijving in het parketregister. Dit kon variëren van een week tot enkele maanden.

Het wetsartikel is het delict waarop de politie het geval heeft gekwalificeerd. De officier van justitie kan, als besloten wordt om tot vervolging over te gaan, een ander (vaak minder emstig) delict ten laste leggen. Ook kan de officier van justitie subsidiair een minder ernstig misdrijf ten laste leggen. Hierdoor kan een verschil ontstaan tussen het delict waarop de zaak op het parket binnenkomt en het delict waarop de verdachte wordt veroordeeld of vrijgesproken. Op de door mij gebruikte lijsten staan alleen de wetsartikelen waarop de zaak in het parketregister werd ingeschreven. $^{\text {s }}$

De afhandeling door openbaar ministerie of rechtbank is, evenals het parketnummer, van belang voor het vinden van de dossiers: een door het openbaar ministerie afgehandelde zaak ligt op het arrondissementsarchief en een door de rechter afgehandelde zaak in het rechtbankarchief. In het hokje onder openbaar ministerie werd de soort beslissing aangegeven ${ }^{6}$ en onder rechtbank of de zaak door de politierechter of de meervoudige kamer was behandeld. De gevoegde zaken kregen een kruisje onder rechtbank.

De datum van afhandeling leek van belang in verband met de tijdsduur van de strafprocedure. Ik heb dit, wat het openbaar ministerie betreft, niet consequent gedaan; de gegevens waren niet altijd te vinden. Omdat het geen informatie is die noodzakelijk is voor mijn onderzoek, zijn deze gegevens in het vervolg buiten beschouwing gelaten.

5 Soms staan er verschillende wetsartikelen vermeld. Als het relevante en niet-relevante artikelen betrefh, dan is er geen probleem als de relevante wetsartikelen eén delictsoort betreffen. Betreft het meer delictsoorten, dan nam ik die categorie waar de meeste wetsartikelen toe behoorden en als het evenveel wetsartikelen per categorie waren, dan gebruikte ik het eerstgenoemde wetsartikel als uitgangspunt. Dus bij de artikelen ' $350 \mathrm{Sr}, 300 \mathrm{Sr}, 310 \mathrm{Sr}$ ' plaatste ik het bij vemieling en bij ' $350 \mathrm{Sr}, 300 \mathrm{Sr}$, $302 \mathrm{Sr}^{\prime}$ zet ik het bij mishandeling.

$6 \mathrm{~B}=$ =beleidssepot, $\mathrm{Bv}=$ voorwaardelijk beleidssepot, $\mathrm{Bb}=$ =beleidssepot met berisping, $\mathrm{T}=$ technisch sepot en Tr=transactie.

7 Omdat het dossier niet was te vinden onder het parketnummer waarop het was ingeschreven, maar het parketnummer van de zaak waar het dossier bij was gevoegd, werd dit nieuwe parketnummer duidelijk op de lijst geschreven. 
Fase 2

De hiervoor besproken gegevens betreffen alleen de eerste fase van de selectieprocedure en zijn alleen uit het parketregister te halen. De tweede fase van het dossieronderzoek ging in als de dossiers uit het archief waren gehaald, zodat de dossiers konden worden bekeken.

Het vinden van de dossiers die in het parketregister van het arrondissement waren ingeschreven, leverde geen moeilijkheden op. De dossiers waren of in het archief van het openbaar ministerie of in het rechtbankarchief op parketnummer opgeborgen. Toch waren niet alle dossiers in de archieven te vinden: van het eerste kwartaal van $1985 \mathrm{mis}$ ik $8 \%$ van de dossiers. Het percentage niet-gevonden vervolgde zaken is groter dan het percentage niet-gevonden geseponeerde zaken. ${ }^{8}$ Dit betekent dat rekening moet worden gehouden met een lichte vertekening: in werkelijkheid wordt iets vaker gedagvaard. Dit geldt min of meer voor alle categorieën. Tot de categorie 'onvindbare dossiers' reken ik de niet aanwezige dossiers omdat ze bijvoorbeeld zijn uitgeleend, en de dossiers die zo onvolledig zijn dat uit de gegevens niet kon worden afgeleid of sprake was van vrouwenmishandeling. ${ }^{9}$

Als de dossiers zijn gevonden kunnen de sekse van de verdachte en het slachtoffer worden vastgesteld door het lezen van de informatiestaat ${ }^{10}$ van de verdachte en de processen-verbaal. Uit de processen-verbaal blijkt nu eveneens of het een geval van vrouwenmishandeling betreft.

8 In 1985 is $4 \%$ van de geseponeerde en $11 \%$ van de vervolgde zaken niet gevonden. Het hoge percentage vervolgde zaken kan te maken hebben met het feit dat een extra justitiele gang werd doorlopen met een extra kans op kwijtraken, en tevens zijn de zaken die in hoger beroep zijn gegaan, moeilijker terug te vinden omdat het dossier naar het hof werd gestuurd.

9 Dit laatste kwam overigens niet vaak voor. Men moet bedenken dat het hier gat om alle dossiers betreffende geweldsdelicten. Deze informatie is van belang omdat van de gevonden vrouwenmishandelingszaken gezien deze informatie het sepotcijfer in werkelijkheid lager kan liggen.

10 De informatiestaat is een A4-velletje waarop de personalia van de verdachte staan, zoals naam, adres, geboortedatum en -plaats, nationaliteit, sekse, beroep en inkomen. 



\section{Bijlage 3 \\ Dossieronderzoek Justitie en Vrouwenmishandeling}

Inhoud vrouwenmishandelingszaken.

Parketnummer:

Datum binnenkomst parket:

Datum afhandeling parket:

Datum binnenkomst rechtbank:

Datum afhandeling rechtbank:

Datum binnenkomst Hof:

Datum afhandeling Hof:

Datum binnenkomst HR:

Datum afhandeling HR:

Officier van Justitie:

Wetsartikel:

Plaats van delict:

Tijd van plegen delict:

Personalia dader

Leeftijd: Beroep:

Nationaliteit:

Verh/verz/voorl.hech/gvo

Geboren:

Strafrechtelijk verleden:

Personalia slachtoffer

Leeftijd: Beroep:

Nationaliteit:

Voeging als beledigde partij:

Geboren:

Soort relatie en duur

$\square$ gehuwd

口 samenwonend

ㅁ ex-huwelijk

$\square$ anders:

c ex-samenwonend

ㅁ samen kinderen

\section{Afhandeling door OM}

$\square$ beleidssepot (o/v)

ㅁ technisch sepot

$\checkmark$ met waarschuwing/berisping

口 transactie

口 proeftijd/voorwaarden

口 proeftijd/voorwaarden

口 voorwaarde(n):

व vervolging

口 eis:

口 voorwaarde(n): 
Afhandeling door Rechtbank
$\square$ veroordeling
口 vrijspraak
$\square$ gevangenisstraf $(o / v)$ :
口 ovar
口 proeftijd/voorwaarden:
a avas
$\square$ boete $(\mathrm{o} / \mathrm{v})$ :
口 proeftijd/voorwaarden:
$\square$ anders:

Factoren die een rol spelen bij de beslissing

\section{BEWIJS}
$\square$ verklaring van getuige
a schriftelijke bescheiden
$\square$ verklaring van verdachte
$\square$ proces verbaal
$\square$ verklaring van deskundige
$\square$ medisch rapport
口 verklaring van aangeefster
$\square$ anders

LETSEL SLACHTOFFER
ㅁ fysiek
ㅁ geestelijk

GEWELDGEBRUIK VAN DE DADER
口 voorwerp(en)
lichamelijk geweld
$\square$ anders 


\section{VERWEER VAN HET SLACHTOFFER}
口 woorden
ㅁ lichamelijk verweer
a voorwerpen

\section{GEESTESTOESTAND DADER}
$\square$ toerekeningsvatbaar
ㅁ ontoerekeningsvatbaar
$\square$ drugs
a alcohol

$\begin{array}{ll}\text { GEESTESTOESTAND SLACHTOFFER } & \\ \square \text { toerekeningsvatbaar } & \square \text { ontoerekeningsvatbaar } \\ \square \text { drugs } & \square \text { alcohol }\end{array}$

GESCHIEDENIS VAN DE MISHANDELING
$\square$ eenmalig
口 structureel

TENLASTELEGGING
口 ja
$\square$ nee 
BIJLAGE 3

BUJZONIDERHEDEN

Casus 


\section{Bijlage 4}

\section{Interviewlijst 27-7-1990}

\section{Algemeen}

1. Hoe vaak behandelt u een zaak van seksueel geweld of vrouwenmishandeling?

2. Hoe lang werkt u bij het OM? Is het aantal zaken van seksueel geweld en vrouwenmishandeling in de loop der tijd veranderd?

3. Heeft u hiervoor ander werk verricht?

4. Welke rang binnen het OM neemt $u$ in? Wat betekent dat voor uw werk, het soort zaken waarover $\mathrm{u}$ moet beslissen?

5. Heeft u een speciale taak, bv. milieu, seksueel geweld? Bestaat er een aparte officier van justitie voor seksueel geweld of incest? Vindt u dat zinvol?

\section{OVERLEG}

1. Is er overleg over zaken van seksueel geweld en/of vrouwenmishandeling en/of incest, zijn er interne richtlijnen of afspraken over, zowel op parket als op ressortniveau?

2. Hoe is het overleg met de parketsecretaris?

3. Is er overleg met de politie of hulpverlening i.v.m. incest, seksueel geweld of vrouwenmishandeling? Zo ja, is dat gestructureerd overleg of informeel? Wat wordt er tijdens het overleg besproken?

4. Zit er iemand van het $O M$ in een samenwerkingsverband?

5. Heeft er de laatste tien jaar een verandering in beleid plaatsgevonden ten aanzien van seksueel geweld, zowel qua seponeren, als qua eis of straf die wordt opgelegd? En voor incest en vrouwenmishandeling?

\section{SLACHTOFFER}

1. Hebben de huidige richtlijnen slachtofferhulp invloed op de afhandeling van zaken van seksueel geweld en vrouwenmishandeling, in welke zin? (formalisatie, materieel)

2. Werkt er op het parket een beleidsmedewerker slachtofferhulp en weet u wat de taak is van de beleidsmedewerker slachtofferhulp?

3. Heeft u regelmatig contact met de beleidsmedewerker slachtofferhulp, met name over seksueel geweld en vrouwenmishandeling, of neemt zij/hij ook wel eens contact met u op?

4. Op welke manier wordt er meer aandacht gegeven aan het slachtoffer binnen het parket, is het geformaliseerd en/of heeft u meer persoonlijk contact met het slachtoffer? 


\section{SEKSUEEL GEWELD}

\section{A: Informerend}

1. Onderscheiden zaken van seksueel geweld zich van andere misdrijven? Waarom?

2. Heeft er de laatste tien jaar een verandering in uw kijk op de problematiek van seksueel geweld plaatsgevonden? Is dit van invloed geweest op de beslissing om te seponeren, en de eis die u stelt?

3. Er wordt wel gesteld dat het bewijs in zaken van verkrachting en aanranding enorm is opgerekt. Wat vindt $u$ daarvan? Wat is voor $u$ een minimum aan bewijs bij een ontkennende verdachte en bij een bekennende verdachte? Vindt u dat een verdachte verplicht mag worden om bloed af te staan (of wangslijm/haarwortels) voor een DNA-analyse in verband met het rond krijgen van het bewijs? Vindt $u$ dat het wettelijk moet worden geregeld?

4. Spreekt $u$ in zaken van seksueel geweld de verdachte? En spreekt u het slachtoffer?

5. Vraagt het slachtoffer regelmatig om een gesprek in dit soort zaken?

6. Welke straf eist $u$ in geval van verkrachting of aanranding? Maakt u verschil tussen verkrachting en aanranding? En tussen incest en verkrachting? In welke zin?

7. Heeft u wel eens een sepot onder voorwaarde opgelegd in geval van seksueel geweld? Kunt u er een voorbeeld van geven? Wat vindt $u$ van het incestexperiment? Zou zoiets ook voor seksueel geweld kunnen?

8. Wat vindt u van een richtlijn of indicatielijst 'seksuele misdrijven' voor het $O M$ ?

9. Vindt $u$ dat een of twee officieren zich speciaal met zaken van seksueel geweld moeten bezighouden?

B: Factoren

1. Hoe vaak per maand beslist u over een zaak van verkrachting of aanranding? Heeft u wel eens een verkrachtingszaak gehad waarbij sprake was van een relatie? En een ex-relatie? Hoe vaak gaat het om bekenden? En de geheel onbekende dader?

2. Heeft u een bepaald stereotype van de verkrachter, waaraan u de andere verkrachtingen meet in verband met de ernst en de eis die u stelt? Heeft u een 'standaardbeslissing'?

3. Wanneer vraagt $u$ een reclasseringsrapport aan, of een psychiatrisch onderzoek en een gerechtelijk vooronderzoek?

4. Kunt $\mathrm{u}$ iets vertellen over de laatste verkrachtingszaak waarover $\mathrm{u}$ hebt beslist; de casus, de beslissing en de factoren die een rol speelden bij de beslissing?

5. Ik wil met u tot slot een rijtje factoren langslopen die eventueel van invloed zijn op uw beslissing omtrent een zaak van seksueel geweld. Wilt u aangeven of de factor van invloed is en zo ja, ten gunste van vervolgen of ten gunste van een sepot?

- strafblad 
- alcohol

- relatie/geen relatie/ex-relatie

- leeftijd

- verklaring van de verdachte

- ernst van het letsel

- verweer van het slachtoffer

- ernst van het geweld

- toerekeningsvatbaar

- verdachte heeft nog een misdrijf gepleegd

\section{VROUWENMISHANDELING}

\section{A: Informerend}

Uitleggen wat er onder vrouwenmishandeling wordt verstaan.

1. Is er een richtlijn voor het afdoen van mishandeling/vernielingsdelicten? Zo ja, wat staat er in die richtlijn? Maakt u gebruik van deze richtlijn?

2. Hoe vaak beslist $u$ over een zaak van vrouwenmishandeling per maand, denkt u? Hoe vaak mishandeling/doodslag/vernieling?

3. Wanneer is er sprake van zware mishandeling?

4. Wanneer levert een wurgpoging een poging tot doodslag op?

5. Vindt $u$ het moeilijker om in zaken van vrouwenmishandeling te beslissen dan in zaken tussen een verdachte en een slachtoffer die geen relatie met elkaar hebben, of die elkaar niet kennen? Waarom?

6. Er wordt wel gesteld dat strafrechtelijk ingrijpen de relatie zal verslechteren, of zelfs onherstelbare gevolgen met zich meebrengt. Wat vindt u hiervan?

7. Gaat u na of het geweld tegen de vrouw is gestopt? Hoe? En of de schade is vergoed?

8. Heeft u wel eens een zaak van vrouwenmishandeling onder voorwaarden geseponeerd? Doet u dit sneller dan wanneer het om geweld tussen onbekenden gaat? Wat vindt u van een straatverbod als voorwaarde bij een sepot? Idem voor een berisping en een brief aan het slachtoffer?

9. Zou u soms een beslissing willen nemen die juridisch niet mogelijk is in dit soort gevallen? Kunt u daar een voorbeeld van geven?

\section{B: Factoren}

1. Heeft u een bepaald stereotype vrouwenmishandeling in uw hoofd, waaraan u de andere vrouwenmishandelingszaak meet in verband met de ernst en de eis die u stelt? Heeft u een 'standaardbeslissing'?

2. Wanneer vraagt $u$ een voorlichtingsrapport aan, wanneer een gerechtelijk vooronderzoek? Heeft u daar een voorbeeld van?

3. Wanneer stelt $u$ iemand in verzekering en/of voorlopige hechtenis? Heeft u daar een voorbeeld van? 
4. Kunt $u$ zich een zaak herinneren van de afgelopen maand, wilt $u$ iets daarover vertellen: de casus, wat u heeft besloten en welke factoren een rol hebben gespeeld?

5. Evenals bij seksueel geweld wil ik nu een aantal factoren nalopen om te kijken of die van invloed zijn op uw beslissing om een zaak te seponeren of niet:

- strafblad

- alcohol

- relatie/ex-relatie

- leeftijd van de verdachte/slachtoffer

- verklaring van de verdachte

- emst van het letsel/ernst van de dreiging/hoogte van het schadebedrag

- verweer van het slachtoffer

- frequentie en duur van het geweld, lastig vallen na scheiding

- toerekeningsvatbaar

- intrekken aanklacht door slachtoffer

- verdachte heeft nog een misdrijf gepleegd, bv. diefstal, verkeersdelict

- slachtoffer spant k-g aan

- slachtoffer en dader zien elkaar nog regelmatig (onder dwang)

- de dynamiek van de relatie. 


\section{Bijlage 5}

Tabel I. Alcoholgebruik dader en afhandeling door OM

\begin{tabular}{|c|c|c|c|c|c|c|}
\hline \multirow[t]{3}{*}{$(N=129)$} & \multicolumn{6}{|c|}{ afhandeling door $\mathrm{OM}$} \\
\hline & \multicolumn{2}{|c|}{ beleiddssepot } & \multicolumn{2}{|c|}{ dagvaarden } & \multicolumn{2}{|c|}{ totaal } \\
\hline & $\mathrm{n}$ & $\%$ & $\mathbf{n}$ & $\%$ & n & $\%$ \\
\hline \multicolumn{7}{|c|}{ alcoholgebruik } \\
\hline geen & 40 & 51 & 38 & 49 & 78 & 61 \\
\hline wel & 15 & 29 & 36 & 71 & 51 & 39 \\
\hline totaal & 55 & 43 & 74 & 57 & 129 & 100 \\
\hline
\end{tabular}

Tabel II. Recidive dader en afhandeling door OM

\begin{tabular}{lcccccc}
\hline \multirow{2}{*}{$(\mathrm{N}=129)$} & \multicolumn{3}{c}{ afhandeling door $\mathrm{OM}$} \\
& \multicolumn{2}{c}{ beleiddssepot } & \multicolumn{2}{c}{ dagvaarden } & \multicolumn{2}{c}{ totaal } \\
& $\mathrm{n}$ & $\%$ & $\mathrm{n}$ & $\%$ & $\mathrm{n}$ & $\%$ \\
\hline Recidivi & & & & & & \\
geen & 32 & 55 & 26 & 45 & 58 & 45 \\
wel & 23 & 32 & 48 & 68 & 71 & 55 \\
totaal & 55 & 43 & 74 & 57 & 129 & 100 \\
\hline
\end{tabular}


Tabel III. Leeftijdsklasse dader en afhandeling door OM

\begin{tabular}{|c|c|c|c|c|c|c|}
\hline \multirow[t]{3}{*}{$(N=129)$} & \multicolumn{6}{|c|}{ afhandeling door $\mathrm{OM}$} \\
\hline & \multicolumn{2}{|c|}{ beleiddssepot } & \multicolumn{2}{|c|}{ dagvaarden } & \multicolumn{2}{|c|}{ totaal } \\
\hline & $\mathrm{n}$ & $\%$ & $\mathrm{n}$ & $\%$ & $\mathrm{n}$ & $\%$ \\
\hline \multicolumn{7}{|l|}{ Leeftijdsklasse } \\
\hline tot 30 jaar & 12 & 33 & 24 & 67 & 36 & 28 \\
\hline $30-50$ jaar & 38 & 45 & 46 & 55 & 84 & 65 \\
\hline boven 50 jaar & 5 & 56 & 4 & 44 & 9 & 7 \\
\hline totaal & 55 & 43 & 74 & 57 & 129 & 100 \\
\hline
\end{tabular}

Tabel IV. Geschiedenis van de mishandeling en afhandeling door OM

\begin{tabular}{lcccccc}
\hline \multirow{2}{*}{$(\mathrm{N}=129)$} & \multicolumn{3}{c}{ afhandeling door OM } & & \\
& beleiddssepot & \multicolumn{2}{c}{ dagvaarden } & \multicolumn{2}{c}{ totaal } \\
& $\mathrm{n}$ & $\%$ & $\mathrm{n}$ & $\%$ & $\mathrm{n}$ & $\%$ \\
\hline mishandeling & & & & & & \\
eenmalig & 19 & 40 & 28 & 60 & 47 & 36 \\
meermalig & 21 & 53 & 19 & 47 & 40 & 31 \\
structureel & 15 & 36 & 27 & 64 & 42 & 33 \\
totaal & 55 & 43 & 74 & 57 & 129 & 100 \\
\hline
\end{tabular}


Tabel V. Mate van letsel naar soort relatie, voor delictscategorieẽn 1 en 2

\begin{tabular}{|c|c|c|c|c|c|c|c|c|c|c|c|c|}
\hline \multirow[t]{3}{*}{$(\mathrm{N}=94)$} & \multicolumn{12}{|c|}{ mate van letsel } \\
\hline & \multicolumn{2}{|c|}{ geen } & \multicolumn{2}{|c|}{ licht } & \multicolumn{2}{|c|}{ emstig } & \multicolumn{2}{|c|}{ zwaar } & \multicolumn{2}{|c|}{ dood } & \multicolumn{2}{|c|}{ totaal } \\
\hline & $\mathrm{n}$ & $\%$ & $\mathrm{n}$ & $\%$ & $\mathrm{n}$ & $\%$ & $\mathbf{n}$ & $\%$ & $n$ & $\%$ & $n$ & $\%$ \\
\hline \multicolumn{13}{|l|}{ soort relatie } \\
\hline relatie & 1 & 3 & 6 & 16 & 23 & 62 & 5 & 14 & 2 & 5 & 37 & 39 \\
\hline ex-relatie & 14 & 25 & 20 & 35 & 21 & 37 & 2 & 3 & - & - & 57 & 61 \\
\hline totaal & 15 & 16 & 26 & 28 & 44 & 47 & 7 & 17 & 2 & 2 & 94 & 100 \\
\hline
\end{tabular}


Tabel VI. Geschiedenis van de mishandeling naar delictscategorie

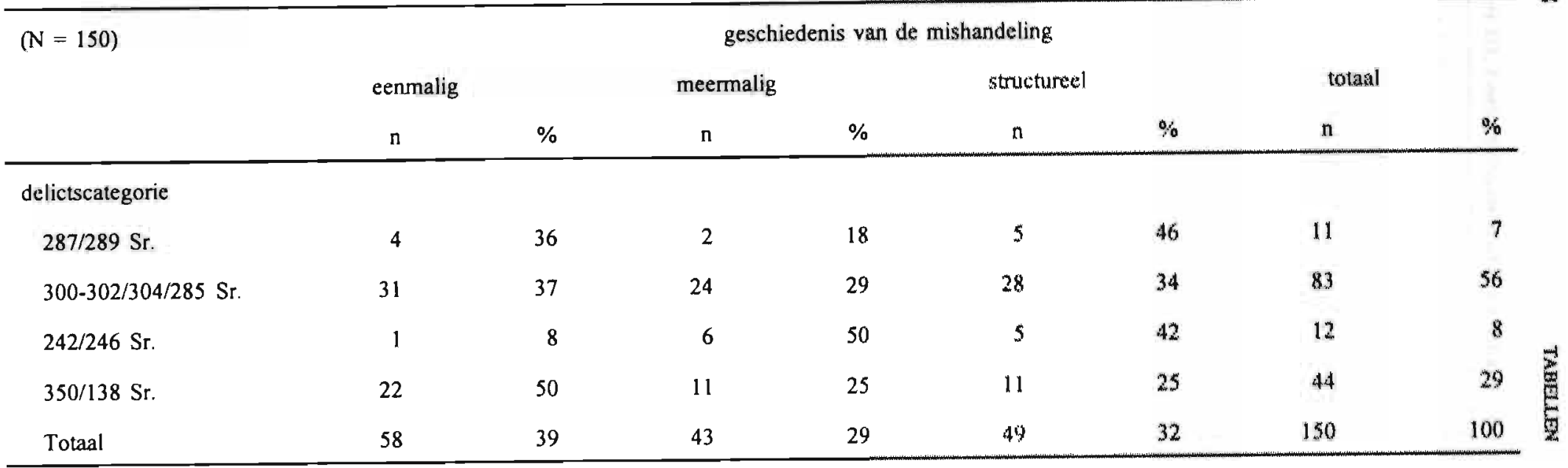


Tabel VII. Mate van letsel naar delictscategorie

\begin{tabular}{|c|c|c|c|c|c|c|c|c|c|c|c|c|}
\hline \multirow[t]{3}{*}{$(N=150)$} & \multicolumn{12}{|c|}{ mate van letsel } \\
\hline & \multicolumn{2}{|c|}{ geen } & \multicolumn{2}{|c|}{ licht } & \multicolumn{2}{|c|}{ emstig } & \multicolumn{2}{|c|}{ zwaar } & \multicolumn{2}{|c|}{ dood } & \multicolumn{2}{|c|}{ totaal } \\
\hline & $\mathrm{n}$ & $\%$ & $\mathrm{n}$ & $\%$ & $\mathbf{n}$ & $\%$ & $\mathrm{n}$ & $\%$ & $n$ & $\%$ & $n$ & $\%$ \\
\hline \multicolumn{13}{|l|}{ delictscategorie } \\
\hline $287 / 289 \mathrm{Sr}$ & 2 & 18 & 1 & 9 & 4 & 36 & 2 & 18 & 2 & 18 & 11 & 7 \\
\hline $300-302 / 304 / 285 \mathrm{Sr}$ & 13 & 16 & 25 & 30 & 40 & 48 & 5 & 6 & - & - & 83 & 56 \\
\hline $242 / 246 \mathrm{Sr}$ & 8 & 67 & 3 & 25 & - & - & 1 & 8 & - & - & 12 & 8 \\
\hline $350 / 138 \mathrm{Sr}$ & 43 & 98 & 1 & 2 & - & - & - & - & - & - & 44 & 29 \\
\hline totaal & 66 & 44 & 30 & 20 & 44 & 30 & 8 & 5 & 2 & 1 & 150 & 100 \\
\hline
\end{tabular}


Tabel VIII. Mate van letsel naar geschiedenis van de mishandeling

\begin{tabular}{|c|c|c|c|c|c|c|c|c|c|c|c|c|}
\hline \multirow{3}{*}{$(N=94)$} & \multicolumn{12}{|c|}{ mate van letsel } \\
\hline & \multicolumn{2}{|c|}{ geen } & \multicolumn{2}{|c|}{ licht } & \multicolumn{2}{|c|}{ ernstig } & \multicolumn{2}{|c|}{ zwaar } & \multicolumn{2}{|c|}{ dood } & \multicolumn{2}{|c|}{ totaal } \\
\hline & $\mathrm{n}$ & $\%$ & $\mathrm{n}$ & $\%$ & $\mathrm{n}$ & $\%$ & $\mathrm{n}$ & $\%$ & $\mathrm{n}$ & $\%$ & $\mathrm{n}$ & $\%$ \\
\hline \multicolumn{13}{|l|}{ mishandeling } \\
\hline eenmalig & 5 & 14 & 7 & 20 & 20 & 57 & 3 & 9 & - & - & 35 & 37 \\
\hline meermalig & 3 & 12 & 11 & 42 & 8 & 31 & 3 & 11 & 1 & 4 & 26 & 28 \\
\hline structureel & 7 & 21 & 8 & 24 & 16 & 29 & 1 & 3 & 1 & 3 & 33 & 35 \\
\hline totaal & 15 & 16 & 26 & 28 & 44 & 47 & 7 & 7 & 2 & 2 & 94 & 100 \\
\hline
\end{tabular}


Tabel LX. Mate van letsel naar soort relatie nadat aangifte is gedaan, voor delictscategorieēn 1 en 2

\begin{tabular}{|c|c|c|c|c|c|c|c|c|c|c|c|c|}
\hline \multirow[t]{3}{*}{$(\mathrm{N}=94)$} & \multicolumn{12}{|c|}{ mate van letsel } \\
\hline & \multicolumn{2}{|c|}{ geen } & \multicolumn{2}{|c|}{ licht } & \multicolumn{2}{|c|}{ emstig } & \multicolumn{2}{|c|}{ zwaar } & \multicolumn{2}{|c|}{ dood } & \multicolumn{2}{|c|}{ totaal } \\
\hline & $\mathrm{n}$ & $\%$ & $\mathbf{n}$ & $\%$ & $\mathrm{n}$ & $\%$ & $\mathrm{n}$ & $\%$ & $\mathrm{n}$ & $\%$ & $n$ & $\%$ \\
\hline \multicolumn{13}{|l|}{ soort relatie } \\
\hline relatie voortbestaan & - & - & 1 & 9 & 8 & 73 & 2 & 18 & - & - & 11 & 12 \\
\hline relatie verbroken & - & - & 2 & 17 & 9 & 75 & 1 & 8 & - & - & 12 & 12.5 \\
\hline relatie onbekend & 1 & 8 & 3 & 25 & 6 & 50 & 2 & 17 & - & - & 12 & 12.5 \\
\hline relatie gestopt & - & - & - & - & - & - & - & - & 2 & 100 & 2 & 2 \\
\hline ex-relatie & 14 & 25 & 20 & 35 & 21 & 37 & 2 & 4 & - & - & 57 & 61 \\
\hline totaal & 15 & 16 & 26 & 28 & 44 & 47 & 7 & 7 & 2 & 2 & 94 & 100 \\
\hline
\end{tabular}




\section{Summary}

Since the Eighties the issue of domestic violence has become more and more a legal issue: the woman is a legal subject and has freedom rights which must be respected within the home as well as outside. Violence against the woman by her partner or ex-partner constitutes a breach of her physical integrity and personal privacy. The question is how to provide sufficient security to allow women to exercise their freedom rights within or without the home. Respect for privacy is usually considered a passive right: non-intervention by the state. Violence against women in the home is individualized and reduced to a man-woman relationship where issues of power aren't recognized as relevant. Male battering of women is perceived as a private problem for which society has no responsibility. Respect for the privacy means in that case protecting the privileges and prerogatives of battering man and failing to protect the battered women: not the privacy of the home but the privacy of the man is respected. On the other hand the concept of privacy may also be interpreted as a right to freedom, as an affirmative concept of liberty. Privacy is an important prerequisite for the development of self-respect, self-expression and self-assurance, in other words to ensure some degree of autonomy. It is women's right to take their own decisions. If privacy is interpreted as an active right, state intervention to protect the woman battered by her partner becomes a necessary precondition for the woman to be able to exercise her freedom rights.

The question now is how to provide the security which will allow women to exercise their rights to freedom. Within the framework of this study that question is limited to criminal law, and especially the role of the Public Prosecutions Department in these matters: How may the Public Prosecutions Department enhance the legal protection of victims of violence by their partner or ex-partner? This legal protection covers three aspects: protection against abuse of power by the administration, protection against breaches of personal freedom rights by other citizens and protection by openness to social contexts within the closed legal system (this is called legal protection in a relational sense). Because of the public and punitive nature of criminal law its capacity for individual legal protection is limited. At the same time this public and punitive aspect may be used as a means to pressurize the man into accepting responsibility for the violence committed. Adequate legal protection means that both the victim and the suspect are treated as legal subjects. The man is treated as a human being responsible for his own behaviour and capable of dealing with guilt if he is treated with respect. He is held responsible for forsaking his duties and has as such a right to proper treatment by the administra- 
tion. The victim is treated as a legal subject in that her right to physical integrity and privacy within the relationship is recognized and she is informed of her rights and duties as the injured party or witness to a criminal law case. This requires a humane approach aimed at restoring the peace and more specifically aimed at preventing recidivism for there is a substantial chance of recurrence of battering the women. This is where the victim of wife abuse differs from the many other victims who do not run the risk of again becoming the victim of violence by the same perpetrator.

\section{The Role of the Public Prosecutions Department}

The way in which the Public Prosecutions Department avails itself of its prosecuting competences has been researched by means of an exploratory study into the way in which women abuse cases are dealt with by the Department. The results of this study indicate that complaints of wife abuse are a regular item with the district courts. In 1985 the average sized court of Breda registered 2 instances of wife abuse per week on average, the smaller court of Assen one to two cases per fortnight and the court of Rotterdam about one case a day. Most women abuse cases are within the category of (simple) assault followed by the category of vandalism. These are so-called frequent, non-serious offences. Women abuse cases in the assault category are treated like other cases of assault, and women abuse cases in the vadalism category are prosecuted more often than other instances of vandalism. The expectation that women abuse cases are dismissed more often than other cases of abuse has not been confirmed by this research. The same holds true for the way in which the serious offences of rape and murder/manslaughter are dealt with.

These general statistics hide a vast variation in cases of wife abuse: a variation in seriousness and duration of the violence, the nature of the offences committed as well as a variation in duration and nature of the relationships. With all this variation what draws the attention is that most cases of wife abuse presented to the Public Prosecutions Department concern instances of violence by ex-partners. And, furthermore, it are mostly men from lower social strata, one in two of whom are also without paid work, that come into contact with the prosecutor. This means that the cases that are presented to the Public Prosecutions Department are no reflection of the social reality that one in every eight women, from all social strata, is confronted with unilateral violence from her partner.

Considering the various factors that influence a prosecutor's decision whether to prosecute or to dismiss, we find that general aspects such as alcohol abuse and recidivism increase the chance of prosecution. As regards factors which specifically concern male battering of women one may say that prosecutors make no difference between cases of violence by the ex-partner and violence within a relationship. However, the chance that the prosecutor opts for prosecution increases if the woman 
ends her relationship with the man after filing the complaint. In case the woman informs the public prosecutor in writing that she does not want prosecution, there is a big chance that the case is dismissed. There is no obvious difference between the ways in which cases of incidental violence and cases of repeated violence are dealt with. A reason for this phenomenon may be that repeated violence is interpreted as mutual violence: both partners let it get this far, both are responsible for the violence. Further aspects taken into account when deciding whether to prosecute or not include the seriousness of the injuries, the extent of the damage, whether damages are paid voluntarily, as well as the general attitude of the suspect.

The reason why domestic violence is dealt with in the same way as any other form of violence is the fact that the specific problems related to wife abuse are not acknowledged: the issue of power within a relationship, the chronic violence, the increased isolation of the woman, the reduced resilience of the woman due to the dominating and violent behaviour of the man, and, finally, the specific traumatization. Nor is violence by the ex-partner recognized as seriously privacy-invading behaviour, although such cases tend to get prosecuted more often. This privacyinvading behaviour, also known as 'separation assault', can be highly threatening for the woman or even lethal.

A number of stereotype ideas may be the reason why this specific issue is not recognized for what it is. One such widespread idea is that the woman should leave her partner if he is violent. This opinion completely disregards the complex emotional and social dependency and issues of power within a relationship. It furthermore ignores the fact that especially in the period immediately after the woman has left, during the separation process, the chance of (serious) violence is largest. Another idea, related to the first, is that the woman too is to blame in case of repeated violence: she let it come this far (by not leaving). The argument that police intervention will lead to escalation of the situation is used to avoid judicial intervention in existing relationships. But even if the woman has left the man, this argument may still be used. Assuming a relationship between man and woman as a relationship of equality in which emotions may run high and where both take an equal share in the escalation of conflicts, underrates the power struggle within (marital) relationships. This idea of equality may prevent recognition of the man's dominating and violent behaviour, even in case the woman tries to escape from the man's power. If the man pursues the woman, for instance, this may be interpreted as a process of attraction and rejection. These ideas of course play a certain role but they need not necessarily result in non-punitive reactions by the public prosecutors. However, these opinions are, among other things, the reason why the seriousness of domestic violence and the chance of recidivism is not (always) adequately understood. The fact that domestic violence against women is dealt with like any other instance of violence indicates that in case of less serious offences such as simple assault, vandalism and trespassing the chance of standardized procedures being applied is significant, whether the case is settled out of court or by the 
judiciary. Even in case of more serious offences such as grievous bodily harm, attempted manslaughter or rape the specificity of battered women seems to go (usually) unnoticed so that there is no official approach especially aimed at preventing recidivism. The Public Prosecutions Department's attitude is insufficient from the point of view of legal protection for the victim of wife abuse.

\section{Legal Protection for Victims of Wife Abuse}

In order to provide legal protection it is necessary to include the specific interests of victims of wife abuse in the final decision-making, both as regards the procedures and sentencing. This may be done by chosing a humane approach. Current criminal law remedies allow for such an approach. In order to stimulate this humane approach certain formalization via directives and protocols is needed, not to achieve bureaucratic formal equality but to provide the police and the Public Prosecutions Department with the means to adopt an approach which duly recognizes the specific issues involved in male domestic violence against women. Establishing a cooperative body on Domestic Violence at district court level, in which police, judiciary, social workers, probation officers, victims aid organizations, barristers and solicitors get to gether and discuss the issues and individual cases, seems an important precondition to achieve adequate understanding of the seriousness of the violence and to better attune the various approaches. The Public Prosecutions Department may take the initiative in this matter or perhaps the police, being the first link in the criminal procedure chain to be confronted with domestic violence against women. Government, of course, too should draft outlines for future policies. Attention drawn by social pressure groups to the specific problem of male battering of women, however, is necessary to force an adequate approach to this serious social problem.

Besides legal protection of victims of wife abuse via specific criminal law procedures, this protection may also be enhanced by reinforcing the victim's position as the injured party to a case and as a witness in the legal procedures. The victim of male abuse should be allowed to present her wishes as regards the criminal procedure in her case because this procedure has an immediate impact on her personal circumstances due to the relational context of the matter. The victim's influence on procedure should not reach too far: exercising controll over matters of prosecution or sentencing is not desirable. Not only because this would undermine the arbitration function of criminal law, but also because it would increase the woman's dependency as regards her partner or ex-partner. Furthermore, it would push male battering of women as a social issue to the background. These arguments also plead against treating wife abuse as an offence prosecutable only on complaint; male battering of women would then be reduced to a private problem. Now that the position of injured parties has been improved by the directives on victims of crime and the Terwee Act, a further strengthening of the legal position of victims 
of domestic violence as injured parties seems superfluous, although a number of refinements might be added to the current regulation.

The position of victims of wife abuse as witnesses should be reinforced by recognizing their right to speak within the context of fact finding and to include in the law a right to 'fair hearing'. It is furthermore important that the right to physical integrity and privacy of victim-witnesses should be acknowledged by codification thereof in statutes: if it is reasonably to be expected that the physical or mental health of the victim will be endangered in case she testifies in public, the court can decide not to call her. The possibility for the witness to commence action which allows her to appeal against being called to testify, entails recognition of the witness as a legal subject instead of a legal object within the criminal procedure. Finally, a right to legal aid is of importance in order to ensure proper legal and emotional support for victim-witnesses and victims as injured parties.

Legal protection can, finally, also consist of the way in which offences are formulated and interpreted. A statutory clause expresses an evaluation of the essence of interests involved. An offence which is effective towards the addressee and which offers a point of reference to whoever has to interpret the law, has symbolic value. Symbolic value is lacking if the issue the act claims to regulate is no part of the legal debate. One might say that although domestic violence is an issue the Criminal Code claims to regulate, the various offences which could cover male domestic violence against women have no symbolic value because domestic violence is hardly an issue in the legal debate. In order to enhance the symbolic value and thus also the legal protection of victims of domestic violence a separate title 'Domestic Violence' should be incorporated in the Criminal Code. By specifically criminalizing relational violence the facts related to this violence can no longer be cast aside as incidental case aspects, but have to be discussed as relevant facts in the legal debate. The interest to be protected, personal freedom within the privacy of a relationship, will be clearly codified. This would form a substantial improvement of the legal protection provided for victims of violence by their partners or ex-partners. To increase the chance of the act having symbolic value instead of being merely a symbolic act, its introduction will have to be accompanied by a whole set of measures. Without adequate practical measures the statutory change will at best only have ideological meaning or the intended results will not be achieved, thus failing to bring improved legal protection. 



\section{Literatuurlijst}

Acker, H. \& M. Rawie, Seksueel geweld legen vrouwen en meisjes, Ministerie van Sociale Zaken en Werkgelegenheid, Directie Coorrdinatie Emancipatiezaken, 1982.

Allen, A.L., Uneasy access. Privacy for women in a free society, Rowman \& Littllefield Publishers, Totowa, New Jersey 1988.

Andriessen, M.F., We moeten de realiteit van vrouwenlevens begrijpen, Tijdschrift voor Criminologie, jrg. 24, nr. 3, 1982: 131-144.

Asbeck, F.D. van, Schadevergoeding voor slachtoffers van delicten, Ars Aequi, 1994, jrg. 43, nr. 1: 22-29.

Asmus, M.E., T. Ritmeester \& E.L. Pence, Prosecuting domestic abuse cases in Duluth: developing effective prosecution strategies from understanding the dynamics of abusive relationships, Hamline Law Review, 1991, jrg. 15: 115-166.

Baauw, P.J., Zuivere verkrachting? Ars Aequi, 1988, jrg. 37, nr. 9: 575-586.

Bakel, M. van \& J. Rienstra, Van achter gesloten deuren, Blijf van m'n Lijf Utrecht 1987.

Bal, P.L., Dwangkommunikatie in de rechtszaal, Gouda Quint, Amhem 1988.

Bamforth, N., Current topic: Sado-Masochisme and consent, Criminal Low Review, 1994: 661-664.

Bangma, K., Met begrip en inzicht, Serie: Rode draad 'slachtoffers van delicten', Ars Aequi, 1989, jrg. 38, nr. 7/8: 644-652.

Bangma, C. \& M.E. Bröring, De juridische relevantie van de slachtoffercirculaires voor het optreden van politie en Openbaar Ministerie, Delikt en Delinkwent, 1990 , jrg. 20, nr. 5: 410-423.

Bavel, C.J. van \& R.P.G.L.M. Verbunt, Slachtoffer/getuige in zedenzaken en verhoor ter zitting, $N J B, 1990$, jrg. 66, nr. 36: 1399-1404.

Beaufort, L.A:R.J. de, De rol van het slachtoffer bij opsporing en vervolging, Justitiële Verkenningen, 1982, nr. 6: 21-38.

Beaufort, L.A.R.J. de, Het recht 'nee' te zeggen, in: Vrouw en recht; juridisch instrumentarium ter verbetering van de rechtspositie van vrouwen in Nederland, Stichting NJCM Boekerij nr. 5, Leiden 1984: 55-66.

Beaufort, L.A.R.J. de, Met beleid vervolgen van verkrachting en aanranding, in: J. Frenken \& J. Doomen, Strafbare seksualiteit, Van Loghem Slaterus, Deventer 1986 (eerste druk 1984): 119-137.

Beaufort, L.A.R.J. de, Slachtoffer en straftoemeting, in: D.H. de Jong e.a. (red.), De vrijheidsstraf, Gouda Quint, Amhem 1986: 201-224.

Beelen, J., Tussen verleiden en verkrachten, An Dekker, Amsterdam 1989.

Beelen, J. \& T. van Elst, Daderhulpverlening: niet zonder slag of stoot, in: J. de Lima (red.), Het klappen van de zweep, 20 jaar Blijf van m'n Lijf Amsterdam, Van Arkel, Utrecht 1994: 79-90. 
Beer, A.P.G. de \& A.M. Kalmthout, Dienstverlening: ook veel zwaluwen maken nog geen zomer (I), Delikt en Delinkwent, 1982, jrg. 12, nr. 7: 458-475.

Beer, A. de, Het politieke kader voor de taakstraf, Proces, 1996, jrg. 75, nr. 1: 13 18.

Beleid ter bestrijding van sexueel geweld tegen vrouwen en meisjes, TK 1983-1984, 18.542, nrs. 1-2.

Bemmelen, J.M. van, Is de dood 'zwaar lichamelijk letsel'? $N J B, 1953$, jrg. 28, nr. 11: 229-233.

Bemmelen, J.M. van, Vergelijking van het Belgische en Nederlandse recht inzake de voornaamste zedendelicten, Preadvies, Serie: Vereniging voor de Vergelijkende Studie van het Recht van België en Nederland, nr. 69, W.E.J. Tjeenk Willink, Zwolle 1967: 172-201.

Bemmelen, J.M. van, \& Th.W. van Veen, Ons Strafrecht 3: Bijzondere delicten (achtste druk), Samson HD Tjeenk Willink, Alphen aan de Rijn 1990.

Bemmelenn, J.M. van, Ons Strafrecht 4: Strafprocesrecht (elfde druk), Gouda Quint, Amhem 1993.

Bibbings, L. \& P. Alldridge, Sexual expression, body alteration, and the defence of consent, Journal of Law and society, 1993, jrg.. 20, nr. 3: 356-370.

Bienen, L., Mistakes, Philosophy and Public Affairs, 1978, jrg. 7, nr. 3: 224-245.

Biggelaar, G.J.M. van den, De buitengerechtelijke afdoening van strafbare feiten door het openbaar ministerie, Gouda Quint, Arnhem 1994.

Blijf van m'n Lijf Amsterdam, Jaarverslag 1976: 3.

Blijf van m'n Lijf Eindhoven, Vrouwenmishandeling aanklagenswaardig, aanklacht tegen een falend politie- en justitiebeleid, 1985.

Blijf van m'n Lijf Amsterdam, Thuis geslagen, mevrouw? Dan ... kunnen wij niets doen, 1984.

Blokland, E. van, \& A. Geurts, Thuis geslagen mevrouw? Dan ... kunnen wij niets doen, in: Thuis geslagen mevrouw? Dan ... kunnen wij niets doen; 'Blijf van m'n Lijf' Amsterdam over politie, justitie en overheid, december 1984: 45-50.

Boek, J. \& J.F. Nijboer, De bekentenis als de koningin van het bewijs, Delikt en Delinkwent, 1994, jrg. 24, nr. 1: 41-58.

Boer, A.P. de, Partnerdoding: Een empirisch forensisch-psychiatrisch onderzoek, Gouda Quint, Amhem 1990.

Bon-Moors, A. van, \& G. van Dijk, De voorgestelde aanpassingen in het wetboek van strafvordering, presentatie tijdens de werkgroep 'De positie van het slachtoffer van zedenmisdrijven in het strafrecht' op het congres Hoe punitief is Nederland op 21 oktober 1995 (ongepubliceerd).

Boutellier, H., Solidariteit en slachtofferschap: De morele betekenis van criminaliteit in een postmoderne cultuur, SUN, Nijmegen 1993.

Boutellier, H., Het geëmancipeerde slachtoffer, in: M. Moerings (red.), Hoe puniticf is Nederland? (Pompe reeks, dl 14), Gouda Quint, Arnhem 1994: 195-209.

Bouw, M., L. Jacobs \& M. Wegelin, Samen tegen sexueel geweld: een onderzoek naar de effecten van samenwerkingsverbanden van verschillende beroepsgroepen inzake de hulpverlening aan slachtoffers van sexueel geweld, Vuga (Ministerie van Sociale Zaken), 's-Gravenhage 1990. 
Brand, A. van den, Slachtoffers seksueel geweld wederom de dupe, Jeugd- en zedenzaken gaat ten onder in reorganisatie-golf, Dien, jrg. 9, nr. 3, 1994: 4-5. Braun, M., De prijs van de liefde, de eerste feministische golf, het huwelijksrecht en de vaderlandse geschiedenis, Het Spinhuis, Amsterdam 1992.

Breines, W. \& L. Gordon, The new scholarship on family violence, Signs, 1983, jrg. 8, nr. 3: 491-531.

Brink, E. van den, Met het straatverbod in kort geding op de goede weg? Recht en Kritiek, 1987, jrg. 13, nr. 4: 373-404.

Broek, J.L. van den, Reactie op van Dorst, Verkrachting binnen huwelijk: een klachtdelict, $N J B, 1989$, jrg 64, nr. 25: 918-919 (met naschrift Van Dorst).

Bronkhorst, C., lets over bewijs en rechtsvinding in de strafrechtspraak, in: Rechtsvinding: Opstellen aangeboden aan prof. dr. J.M. Pieters, Kluwer, Deventer 1970: 35-47.

Brouns, P.J.H.M., Opzet in het wetboek van strafrecht, Gouda Quint, Amhem 1988. Browne, A., When battered women kill, The free press, New York/London 1987. Brughuis, J.G.M., Vrouwenmishandeling in justitieel perspectief, in: Met het oog op de dader, congresverslag, Rotterdam juli 1990.

Brunott, L., Seksueel geweld tegen vrouwen en meisjes, $N J B, 1984$, jrg. 59, nr. 19: 578-584.

Bunt, H.G. van de, Officieren van Justitie, verslag van een participerend observatieonderzoek, W.E.J. Tjeenk Willink, Zwolle 1985.

Bunt, H.G. van de, J.F.L. Roording \& M.J.M. Verpalen (red.), Richtlijnen van het openbaar ministerie, (reeks strafrecht en criminologie 8), Ars Aequi Libri, Nijmegen 1993.

Buruma, Y., Victimalisering van het strafrecht, in: M. Moerings (red.), Hoe punitief is Nederland? (Pompe reeks, dl 14), Gouda Quint, Arnhem 1994: 211-233.

Bussemaker, J., Individualisering als paradox: zelfstandigheid en persoonlijke levenssfeer naar aanleiding van de Algemene Bijstandswet, in: Publiek geheim: Deprivatisering van het vrouwenleven, Nemesis Essays 1995: 31-43.

Buuren, P.J.J. van, Beklag over niet vervolgen van strafbare feiten, Ars Aequi, 1985, jrg. 34, nr. 5: 263-267.

Buzawa, E.S. \& C.G. Buzawa, Domestic violence: The criminal justice response, Studies in crime, law and justice, Sage publications, Newbury Park/London/New Delhi 1990.

Cachet, A., Politie en sociale controle, Gouda Quint, Arnhem 1990.

Claassens, J.C.A.M. \& B.A. Stoker-Klein, Het slachtoffer in het strafproces: De wet Terwee en de ervaringen in de arrondissementsrechtbank 's-Hertogenbosch, Trema, 1995, nr. 6: 167-175.

Cleiren, C.P.M., De openheid van de wet, de geslotenheid van het recht, Gouda Quint, Amhem 1992.

Cleiren, C.P.M., 'Kruisbestuiving': procespositie in strafrecht en privaatrecht, in: A.M. Hol \& C.J.J.M. Stolker, Over de grenzen van strafrecht en burgerlijk recht, Kluwer, Deventer 1995: 83.

Cleiren, C.P.M. \& J.F. Nijboer, Strafrecht: tekst \& commentaar; de tekst van het Wet boek van Strafrecht en enkele aanverwante wetten voorzien van commentaar, Kluwer, Deventer 1994. 
Cleiren, C.P.M. \& J.F. Nijboer, Strafvordering: tekst \& commentaar: de tekst van het Wetboek van Strafvordering en enkele aamverwante wetten voorzien van commentaar, Kluwer, Deventer 1995.

Commentaar van de NVvR op het rapport Aangifte sexuele geweldsmisdrijven van de werkgroep De Beaufort, Trema, 1984, nr. 4: 162-164.

Corstens, G.J.M. \& J.P.J. Tak, Het Openbaar Ministerie, W.E.J. Tjeenk Willink, Zwolle 1982.

Corstens, G.J.M., Waarborgen rondom het vervolgingsbeleid, Vermande, IJmuiden 1974.

Corstens, G.J.M., Getuigen op de zitting, Delikt en Delinkwent, 1992, jrg. 22, nr. 3: 205-211.

Corstens, G.J.M., Het Nederlands strafprocesrecht, Gouda Quint, Amhem 1995 (tweede druk).

Corten, M. e.a. (red.), Geweld tegen vrouwen: (g)een zaak voor politie en justitie?, Kongresbundel, Werkgroep Seksueel Geweld, Delft 1985.

Corten, M \& A. Goudswaard (red.), Geweld tegen vrouwen: (g)een zaak voor politie en justitie?, Kongresverslag, Werkgroep Seksueel Geweld, Delft 1985.

Dahl, T.S., Taking women as starting point: Building women's law, Working paper in women's law, nr. 4, 1986 (conferentie Feminist perspective on law, ECCLS, London, 3-5 april 1986).

Davelaar-van Tongeren, V.H., Verkrachting. Strafrechter, wat moet je ermee?, in: V.H. Davelaar-van Tongeren e.a. (red.), Strafrecht in perspectief, Gouda Quint, Amhem 1980: 99-131.

Demeersseman, H.A., Met voorbedachte rade, Gouda Quint, Amhem 1989.

Delva, J., De zedenmisdrijven inzake aantasting van de seksuele integriteit, Preadvies, Serie: Vereniging voor de Vergelijkende Studie van het Recht van Belgie en Nederland, nr. 69, W.E.J. Tjeenk Willink, Zwolle 1967: 97-169

Decew, J., The feminist critique of privacy, APA Newsletters, 1995: 42-45.

Dewil, I. \& A. Sterkens, Om de lieve vrede, over geweld tegen vrouwen, EPO, Berchem 1994.

Dietze, A. \& A. Spaninks (red.), Met het oog op de dader, congresverslag, Vrouwen Opvang Rijnmond, 1990.

Dijk, J. van, De positie van het slachtoffer in het strafproces: achtergronden en perspectieven, Justitiële Verkenningen, 1982, nr. 6: 10-20.

Dijk, J. van, Victim rights: a right to better services or a right to active participation? in: J. van Dijk c.s. (eds.), Criminal law in action, Gouda Quint, Amhem 1986: 351-375.

Dijk, J. van, Eigen schuld, dikke bult? Over de neiging om het slachtoffer verantwoordelijk te stellen voor zijn/haar eigen lot, in: J. Soetenhorst-de Savornin Lohman (red.), Slachtoffers van misdrijven, ontwikkelingen in hulpverlening, recht en beleid, Gouda Quint, Amhem 1989: 11-24.

Dingwall, R. \& J.M. Eekelaar, Families and the state: An historical perspective on the public regulation of private conduct, Law \& Policy, 1988, jrg. 10, nr. 4: 341 361 .

Dobash, R.P., R.E. Dobash, M. Wilson \& M. Daly, The myth of sexual symmetry in marital violence, Social Problems, 1992, jrg. 39, nr. 1: 71-91. 
Doelder, H. de \& A.C. 't Hart, De zeggenschap van het OM over de opsporing en het politiesepot, in: J.C.H. Blom e.a. (red.), Redenen van wetenschap: Opstellen over de politie veertig jaar na het politiebesluit 1945, Gouda Quint, Amhem 1985: 1-9.

Doelder, H. de, Het OM in positie, Gouda Quint, Amhem 1988.

Doelder, H. de, Richtlijnen, justitie en rechter, in: H.G. van de Bunt, J.F.L. Roording \& M.J.M. Verpalen, Richtlijnen van het openbaar ministerie, Ars Aequi Libri, Nijmegen 1993: 42-43.

Doelder, H. de, Het OM na Donner, Trema, 1994: 445-451.

Donker, H.J. \& G. Smit, Slachtoffers vrouwenhandel verdienen meer bescherming, Algemeen Politieblad, 1990, jrg. 139, nr. 15: 344-348.

Doomen, J., Aangifte van verkrachting, $N J B, 1982$, jrg. 57, nr. 15: 453-458.

Doomen, J., Seksueel geweld - wat vermag het recht?, in: J. Frenken \& J. Doomen (red.), Strafbare seksualiteit, opvattingen en aanpak van politie, justitie en hulpverlening, Serie: Recht en Welzijn 18, Van Loghum Slaterus, Deventer, (eerste druk 1984) 1986: 85-99.

Doomen, J. \& R. Kotting, Straatverboden in kort geding, $N J B, 1985$, jrg. 60, nr. 4: 109-115.

Dorst, A.J.A. van, Vervolgingsbeletselen (Studiepockets strafrecht nr. 19), W.E.J. Tjeenk Willink, Zwolle 1989.

Dorst, A.J.A. van, Verkrachting binnen huwelijk: een klachtmisdrijf?, $N J B, 1989$, jrg. 64, nr. 14: 455-456.

Driem, G. van, Waarom slachtoffers van seksueel geweld het strafproces moeten mijden, in: J. Soetenhorst-de Savornin Lohman (red.), Slachtoffers van misdrijven, ontwikkelingen in hulpverlening, recht en beleid, Gouda Quint, Amhem 1989: 51-68.

Driem, G. van, Haar was recht gedaan, vrouwenmishandeling en de gerechtelijke procedures, in: Het klappen van de zweep, 1994: 117-125.

Droesen, H.W.J., Het officiersmodel en de mondigheid van de verdachte, Proces, 1985, jrg. 64, nr. 4: 116-122.

Dumaresq, D., Rape - sexuality in the law, $m / f$, 1981, nr. 5/6: 41-59.

Dutton, D. \& S.L. Painter, Traumatic bonding: the development of emotional attachments in battered women and other relationships of intermittent abuse, Victimology: an international journal, 1981, jrg. 6, nr. 1: 139-155.

Dutton, D.G, The domestic assault of women: Psychological and criminal justice perspectives, UBPPress, Vancouver 1995.

Duyne, P.C. van, Wetgevende klusserij, het opknappen van de zedelijkheidswetgeving, Delikt en Delinkwent, 1990, jrg. 20, nr. 3: 236-253.

Eck, J. van, Strafrechtelijke conflictbeheersing, in: L. Gunther Moor \& E. Leuw, Beslissingsmomenten in het strafrechtelijke systeem, Ars Aequi Libri, Utrecht 1978: 173-189.

Edwards, S., Violence against women: feminism and the law, in: L. Gellsthorpe \& A. Morris (eds.), Feminist perspectives in criminology, Open University Press, Buckingham 1990: 145-159.

Eindrapport van de adviescommissie zedelijkheidswetgeving, 1980. 
Elliot, F.R., The family: private arena or adjunct of the state?, Journal of law and society, jrg. 16, nr. 4, 1989: 443-463.

Elzinga, D.J. e.a., Het Nederlandse politierecht, W.E.J. Tjeenk Willink, Zwolle 1995.

Ent, D.W. van der \& Th.D. Evers, Vrouwenmishandeling: een zorg voor de politie, Politie Regio Utrecht 1996.

Etty, E., Mishandelde vrouwen kunnen het beleid van politie en justitie veranderen, in: Thuis geslagen, mevrouw? Dan ... kunnen wij niets doen, 'Blijf van m'n Lijf' Amsterdam over politie, justitie en overheid, december 1984: 95-104.

Etty, E., Verslag van de forumdiskussie op 26 oktober 1984, in: Ibidem: 65-93.

Eyk, D. van, Persoonlijke vrijheid en voorwaardelijke justitiële beslissingen, $N J B$, 1955, jrg. 30, nr. 59: 873-880.

Ewing, C.P., Battered women who kill, psychological self-defence as legal justification, Lexington Books, Lexington 1987.

Faber, S., OM-richtlijnen: geen nieuw verschijnsel, in: H.G. van de Bunt, J.F.L. Roording \& M.J.M. Verpalen, Richtlijnen van het openbaar ministerie, Ars Aequi Libri, Nijmegen 1993: 5-23.

Ferraro, K.J. \& L. Pope, Irreconcilable differences, battered women, police and the law, in: N.Z. Hilton (ed.), Legal responses to wife abuse. Current trends and evaluations. Sage, London 1993: 98-123.

Fineman, M.A. \& N.S. Thomadsen, At the boundaries of law, feminism and legal theory, Routledge, New York 1991.

Finkelhor, D. \& K. Yllø, Marital Rape and marital sexuality, in: D. Finkelhor \& K. Yllo (eds.), Licence to rape. Sexual abuse of wives, Holt, Rinehart \& Winston, New York 1985: 84-98.

Foqué, R. \& A.C. 't Hart, Instrumentaliteit en rechtsbescherming, Gouda Quint/ Kluwer Rechtswetenschappen, Amhem/Antwerpen 1990.

Ford, D.A., Prosecution as a victim power resource: a note on empowering women in violent conjugal relationships, Law \& Society Review, 1991, jrg. 25, nr. 2: 313-334.

Ford, D.A. \& M.J. Regoli, The criminal prosecution of wife assaulters: Process, problems, and effects, in: N.Z. Hilton (ed.), Legal responses to wife assault, Sage, Newbury Park/London/New Delhi 1993: 127-164.

Forder, C., Over positieve verplichting en art. 8 EVRM, NJCM, 1992, jrg. 17, nr. 6: 611-637.

Freeman, M.D.A., But if you can't rape your wife, who(m) can you rape? Family Law Quarterly, 1981, jrg. 15, nr. 2: 1-29.

Frenken, J., De geloofwaardigheid van een incestslachtoffer, $M G v, 1988$, nr. 9: 968979.

Frohmen, L., Assumed consent: The prior social relationship as a scheme of interpretation in fling acquaintance rape cases, Paper Law and Society Association, Amsterdam 26-29 juni 1991.

Frijns, J., Boeten, ontmoeten, verzoenen, Proces, 1992, jrg. 71, nr. 3: 72-78.

Gaikhorst, C. \& A. Meinen, De omstreden vervolging van een eeuwenoude onderdrukking, in: Vrouwen en justitie, leesmap, Uitgave Stichting Tegen Haar Wil, Amsterdam 1984: 20-23. 
Garé, D.M.H.R., Het zwaartepunt in het strafproces, in: G.P.M.F. Mols (red.), Schaduwen vooruit, Gouda Quint, Arnhem 1992: 1-10.

Garé, D.M.H.R., Het onmiddellijkheidsbeginsel in het Nederlandse strafproces, Gouda Quint, Arnhem 1994.

Gerbrandy, Tj. \& M. Kroes, Grondrechten evaluatie onderzoek, documentatierapport 3, NJCM, Leiden 1991.

Goldschmidt, J.E., We need different stories, W.E.J. Tjeenk Willink, Zwolle 1993.

Goldschmidt, J.E. \& R. Holtmaat, Vrouw en recht, DCE/STEO Trendrapport 5, 'sGravenhage 1993.

Goudswaard, A., 'Er is toch geen moord gepleegd...', Politie-assistentie in de praktijk, In: M. Corten e.a. (red.), Geweld tegen vrouwen: (g)een zaak voor politie en justitie?, Delft 1985: 33-36.

Goudt, M. \& B. van Herk, Vrouwe Justitia is geen muurbloempje, De Groene Amsterdammer, 4 juli 1984: 13.

Groenhuijsen, M.S., Schadevergoeding voor slachtoffers van delicten in het strafgeding, Ars Aequi Libri, Nijmegen 1985.

Groenhuijsen, M.S., De rode draad: goed nieuws voor slachtoffers van delicten, Ars Aequi, 1989, jrg. 38, nr. 9: 740-751.

Groenhuijsen, M.S., De landelijke invoering van de wet Terwee, Rechtshulp, 1995 , nr. 4: 3-8.

Groenhuijsen, M.S., Rechtshandhaving aan het einde van de twintigste eeuw, Delikt en Delinkwent, 1995, jrg. 25, nr. 8: 805-812.

Groenhuijsen, M.S. \& A.M. van Kalmthout, Transactie en voorwaardelijk sepot, Delikt en Delinkwent, 1983, jrg. 13, nr. 6: 474-487.

Groenhuijsen, M.S. \& A.M. van Kamlthout, De wet vermogenssancties en de kwaliteit van de rechtsbedeling, Delikt en Delinkwent, 1983, jrg. 13, nr. 1: 8-31.

Groenhuijsen, M.S. \& L. Penders, De positie van slachtoffers van delicten in het burgerlijke en het strafrecht, in: J. Soetenhorst-de Savomin Lohman (red.), Slachtoffers van misdrijven, ontwikkelingen in hulpverlening, recht en beleid, Gouda Quint, Amhem 1989: 25-50.

Gunning, M., Gewaande rechten. Het denken over vrouwen en gelijkheid van Thomas van Aquino tot de Batadsche Constitutie, W.E.J. Tjeenk Willink, Zwolle 1991.

Harmsel, S. ter, Interventie bij huiselijk geweld: afspraken tussen politie en justitie, Algemeen Politieblad, 1995, jrg. 144, nr. 6: 6 \& 23.

Harmsel, S. ter, Handleiding bij het geven van voorlichting over vrouwenmishandeling, Nederlands centrum sekse-specifieke zorgvernieuwing en bestrijding seksueel geweld TransAct, Utrecht 1995

Hart, A.C. 't, Recht als schild van Perseus, voordrachten over strafrechtstheorie, Gouda Quint, Amhem 1991.

Hart, A.C. 't, Openbaar Ministerie en rechtshandhaving; een verkenning, Gouda Quint, Amhem 1994.

Hart, A.C. 't, Straf, recht en waarden, in: M. Moerings (red.), Hoe punitief is Nederland? (Pompe reeks, dl 14), Gouda Quint, Amhem 1994: 31-44.

Hart, A.C. 't, Justitie aangepakt, Delikt en Delinkwent, 1995, jrg. 25, nr. 8: 813-827. 
Hart, J. 't, M. van Rappard \& M. Robben, Visies op vrouwenmishandeling, Lover, 1979, jrg. 6, nr. 1: 11-13.

Haveman, R. \& J. Staffeleu, Daders van seksueel geweld: straffen of behandelen, Bohn Stafleu/van Loghum, Houten/Antwerpen 1990.

Heide, J. ter, Dejuridisering en dekriminalisering: de proto- en metajuridische factoren in de rechtsbeslissing, Delikt en Delinkwent, 1972, jrg. 2, nr. 2: 73-86.

Heine, B.G.T.J. ter, Gewelddadigheid in huwelijk en gezin, een forensisch-psychologische bijdrage, Delikt en Delinkwent, 1995, jrg. 25, nr. 9: 943-955.

Hendriks, L.E.M. e.a., Hoofdstukken strafprocesrecht, Samson HD Tjeenk Willink, Alphen aan de Rijn 1990.

Herman, J.L., Trauma en herstel: de gevolgen van geweld, van mishandeling thuis tot politiek geweld, Wereldbibliotheek, Amsterdam 1993.

Hes, J., Het straatverbod in kort geding als 'ultimum remedium', Nemesis, 1985, jrg. 1, nr. 3: 130-139.

Hes, J., Een relatieve buitenstaander aanschouwt het veld van juridische vrouwenstudies, Inleiding tijdens JOV-vergadering, Utrecht 18 mei 1995. Ongepubliceerd.

Hes, J. \& K. van Ringen, Blijf uit mijn buurt, het straatverbod in kort geding, VUGA, 's-Gravenhage 1986.

Hilton, N.Z., One in ten: the struggle and disempowerment of the battered women's movement, Canadian journal of family law, 1988/89, jrg. 7: 311-335.

Hilton, N.Z., Police intervention and public opinion, in: N.Z. Hilton (ed.), Legal responses to wife assault, Sage, Newbury Park/London/New Delhi 1993: 37-61.

Hirschel, J.D., J.W. Hutchison, C.W. Dean \& A. Mils, Review essay on the law enforcement response to spouse abuse: past, present and future, Justice Quarterly, 1992, jrg. 9, nr. 2: 247-283.

Hoekman, J. \& G. Loman, Schadevergoeding door onvermogende daders, Delikt en Delinkwent, 1995, jrg. 25, nr. 1: 49-56.

Holtmaat, R., Met zorg een recht? een analyse van het politiek-juridische vertoog over bijstandsrecht, W.E.J. Tjeenk Willink, Zwolle 1992.

Holtrust, N. \& I. de Hondt, Gezin, geweld en recht, in: E. Singer \& M. Wegelin, De familieband verbroken? Opstellen over gezinsgeweld, autonomie en loyaliteit, Uitgeverij Jan van Arkel, Utrecht 1991.

Hooks, B., Macht in een ander licht, Nemesis, 1986, jrg. 2, nr. 3: 105-110.

Hullu, J. de, Het jaarverslag van het OM over 1981; op de rand van het opportunisme, Ars Aequi, 1983, jrg. 32, nr. 5: 438-442.

Hullu, J. de \& J.L. van der Neut, Zedelijkheidswetgeving in beweging, (Serie Strafrecht en criminologie), Ars Aequi Libri, Nijmegen 1985.

Hullu, J. de \& J.L. van der Neut, Zedelijkheidswetgeving. Partiële herziening slechts ten dele geslaagd, $N J B, 1991$, jrg. 66, nr. 10: 389-396.

Isarin, J., Misdaad als straf, straf als misdaad, Nemesis, 1984/85, jrg. 1, nr. 8: 351352.

Jaarverslag Blijf van m'n Lijf Zwolle, 1985.

Jaarverslag Openbaar Ministerie 1985, TK 1986-1987, 19.700, hoofdstuk VI, nr. 3.

Jaarverslag Openbaar Ministerie 1992. 
Jaffe, P.G. e.a., The impact of police laying charges, in: N.Z. Hilton (ed.), Legal responses to wife assault, Sage, Newbury Park/London/New Delhi 1993: 62-95.

Jansen, G., Aanrander op vrije voeten, overwegingen bij een actie, Tijdschrift voor Vrouwenstudies, 1984, jrg. 5, nr. 4: 508-520.

Janssen, H.P.J., Het begrip geweld in het matieriele strafrecht, Tijdschrift voor Politie, 1990, jrg. 52, nr. 1: 11-16.

Jong, D.H. de, De macht van de telastelegging, Gouda Quint, Arnhem 1981.

Jong, D.H. de, Het model van de behandeling ter terechtzitting, in: G. Knigge (red.), Leerstukken strafprocesrecht, Wolters Noordhoff, Groningen 1991: 29-37.

Jong, D.H. de, De gewijzigde zedendelicten, Delikt en Delinkwent, 1995, jrg. 25, nr. 3: 193-201.

Jongman, R.W., Vrouwe justitia is ook maar een mens, in: L.G. Moor \& E. Leuw (red.), Beslissingsmomenten in het strafrechtelijk systeem, Ars Aequi Libri, Utrecht 1978: 11-27.

Jongman, R.W., Ongelijke kansen in de rechtsgang, in: R.W. Jongman, Klasseelementen in de rechtsgang, Kriminologisch instituut, Groningen 1981: 1-23.

Jorg, N. \& C. Kelk, Strafrecht met mate, Gouda Quint, Amhem 1994.

Junger, M. \& T. van Hecke, Schadevergoeding binnen het strafrecht, daders en slachtoffers van misdrijven, WODC-reeks 82, Ministerie van Justitie, Staatsuitgeverij, 's-Gravenhage 1988.

Kalleveen, P. van, Geweldsmisdrijven in de statistieken, Kwartaalrechtsbescherming en veiligheid, CBS, 1994, nr. 1: 17-25.

Kalmthout, A.M., Het wettelijke kader voor de dienstverlening, Justitiële Verkenningen, 1984, nr. 6: 59-119.

Kannegieter, G., Ongelijkheid in de straftoemeting: de imvloed van de sociale positie van de verdachte op strafrechtelijke beslissingingen, Serie Geschriften van de Juridische Faculteit der Rijksuniversiteit Groningen: 9, Wolters Noordhoff, Groningen 1994.

Kelk, C., De doorleving van de schuld in de strafrechtspleging, in: J.A. Janse de Jonge \& C. Kelk (red.), Met schuld beladen: De kern en de actuele betekenis van het werk van G.Th. Kempe over straf en reclassering, (Pompe reeks, dl 9) Gouda Quint, Arnhem 1992: 13-47.

Kelk, C., De menselijke verantwoordelijkheid in het strafrecht, (Pompe reeks, dl 16), Gouda Quint, Amhem 1994.

Ketelaars, G. \& H. Slotboom, De gevonden waarheid, beelden in het strafrecht bij vrouwenmishandeling, Nemesis, 1993, jrg. 9, nr. 4: 108-115.

Kijkduin 2: stand van zaken en toekomstig beleid seksueel geweld, congresverslag van gelijknamig congres op 12 november 1992, Medusa publicaties, Utrecht 1993.

Kleijn, G.P. \& M. Kroes, Mensenrechten in de Nederlandse rechtspraktijk, W.E.J. Tjeenk Willink, Zwolle 1986.

Kommer, M.M., J.J.A. Essers \& W.A.F. Damen, De transactie in misdrijfzaken, een beleidsevaluatie, WODC-reeks 68, Ministerie van Justitie, Staatsuitgeverij, 's-Gravenhage 1986.

Komter, A., Omstreden gelijkheid, De macht van de vanzelfsprekendheid in huwelijksrelaties, SUA, Amsterdam 1990. 
Komter, A., De macht van de dubbele moraal, verschil en gelijkheid in de verhouding tussen de seksen, Van Gennep, Amsterdam 1990.

Kool, R., Over schijn en werkelijkheid: Het rapport wettelijke voorzieningen slachtoffers in het strafproces, Nemesis, 1989, jrg. 5, nr. 1: 6-11.

Kool, R., Ontucht(ig): een rechtsonzeker begrip? Het begrip ontuchtige handelingen getoetst aan art. 1 Wetboek van Strafrecht, Delikt en Delinkwent, 1992, jrg. 22, nr. 3: 251-269.

Kool, R., Onvolmaakte genoegdoening, Nemesis, 1993, jrg. 9, nr. 5: 149-157.

Kool, R., Beleidswaarde van het slachtofferschap, Nemesis, 1995, jrg. 11, nr. 2: 3643.

Koolen, L.J.M., C.J. Wiebrens \& E.A.I.M. van den Berg, Geschikt of niet geschikt, WODC-uitgave, 's-Gravenhage 1989.

Kostwinder, G., Dader en diender, in: Thuis geslagen, mevrouw? Dan ... kunnen wij niets doen; 'Blijf van m'n Lijf' Amsterdam over politie, justitie en overheid, december 1984: 33-35.

Landelijke vereniging Werkgroep Vrouw en Recht, Commentaar op het rapport van de Commissie Wettelijke voorzieningen slachtoffers in het strafproces, februari 1989.

Landen, D. van der, Aanranding en verkrachting, Delikt en Delinkwent, 1994, jrg. 24, nr. 6: 553-567.

Lange, R. de, Botsing van grondrechten voor de rechter, (Serie: Ars Aequi cahiers Staats- en bestuursrecht dl 5), Ars Aequi Libri, Nijmegen 1994.

Lensing, J.A.W. \& G.E. Mulder, Hoofdbeginselen van strafprocesrecht, W.E.J. Tjeenk Willink, Zwolle 1994.

Lerman, L.G., Statute: a model state act: remedies for domestic abuse, Harvard Journal on Legislation, 1984, jrg. 21: 61-143.

Leuw, E., De traditionele en de feministische visie op (fysieke) seksuele victimisering, Tijdschrift voor Criminologie, 1982, jrg. 24, nr. 5/6: 257-278.

Linden, A. van de \& T. Walaardt Sacré, Eintverslag Entameringsstudie 'Opvang van mishandelde vrouwen', Wetenschapswinkel RUL, Leiden 1987.

Linden, A. van de \& T. Walaardt Sacré, Als je straks alleen woont, Wetenschapswinkel RUL, Leiden 1987.

Los, M., Feminism and rape law reform, in: L. Gelsthorpe \& A. Morris (eds.), Feminist perspectives in criminology, Open University Press, Milton Keynes \& Philadelphia 1990: 160-172.

Lünnemann, K.D., Voorwaardelijk sepot, een oplossing voor seksueel geweld?, doctoraalscriptie, Universiteit van Amsterdam 1986.

Lünemann, K.D., Geweld tegen vrouwen als strafbaar feit: Hoe reageert het Openbaar Ministerie op zaken van geweld tegen vrouwen binnen een heteroseksuele relatie of ex-relatie, Working Paper 40, Recht en Beleid, Rijksuniversiteit Leiden 1992.

Maanen, G.E. van, Dading in plaats van strafrecht? Enkele civielrechtelijke haken en ogen, in: P.G. Wiewel e.a (red.), Dading in plaats van strafrecht, Gouda Quint, Amhem, 1993: 69-80.

Maarseveen, H.Th.J.F. van, Een arrest dat schoffeert, $N J B, 1988$, jrg. 63, nr. 23: 819-820. 
MacKinnon, C.A., Feminism unmodified, discourses on life and law, Harvard University Press, Cambridge 1987.

Machielse, A.J., De nieuwe zedendelicten, Delikt en Delinkwent, 1992, jrg. 22, nr. 7: 715-731.

Mahoney, M.R., Women's lives, violence and agency, in: M.A. Fineman \& R. Mykitiuk (eds.), The public nature of private violence: the discovery of domestic abuse, Routledge, New York/London 1994: 59-92.

Mastenbroek, S., De illusie van de veiligheid, Jan van Arkel, Utrecht 1995.

Meinen, A., Van slachtoffer naar boze vrouwen, Katijf, 1985, jrg. 5, nr. 28: 10-13. Meinen, A., Een kwestie van macht, strategieën van vrouwen tegen seksueel geweld, Stichting Burgerschapskunde, Leiden 1992.

Meinen, A. \& I. van der Vlugt, Strategieën in de strijd tegen seksueel geweld en vrouwenmishandeling, doctoraalscriptie, Universiteit van Amsterdam, IWA, juli 1986.

Meinen, A. \& I. van der Vlugt, Hebben we geen stenen meer? 15 jaar strijd tegen seksueel geweld, hoe nu verder? in: Karin Dekker e.a. (red.), Mishandelen, Uitgave Zomer Universiteit Vrouwenstudies Groningen, Groningen 1987: 5-21.

Melai, A.L., c.s., Artikelsgewijs commentaar op het wetboek van strafvordering, losbladig, Gouda Quint, Amhem.

Melai, A.L., Inleiding: Het strafgeding: polariteit en tegenspraak in: Artikelsgewijs commentaar op het wetboek van strafuordering, losbladig, 1981: 1-172.

Melai, A.L., Het waarheidsprobleem in het strafrecht, in: Polariteit en tegenspraak, een selectie uit het werk van A.L. Melai, Gouda Quint, Amhem 1992: 85-104.

Melai, A.L., De tyrannie van de telastlegging, in: Polariteit en tegenspraak, een selectie uit het werk van A.L. Melai, Gouda Quint, Arnhem, 1992: 105-117.

Met het oog op de dader, congresmap, Vrouwen Opvang Rijnmond, 14 mei 1990. Met het oog op 1995: Beleidsprogramma 1995, TK 1992-1993, 22.913, nr. 2.

Minow, M., The Supreme court 1986 term. Foreword: justice engendered. Harvard Law Review, 1987: 10-97.

Moerings, M., PS van een redacteur, Proces, 1995, jrg. 74, nr. 11/12: 206.

Molen-Maesen, P.M.H. van der, O.M. en politie-sepot, Tijdschrift voor de politie, jrg. 1984, nr. 1: 1-4.

Moller Okin, S., Justice, gender and the family, Basic Books, Inc., Publishers, New York 1989.

Moller Okin, S., Justice and gender, Philosophy \& Public Affairs, 1987, jrg. 16, nr. 1: 42-72.

Mols, G.P.M.F., De niet-verschenen getuige: enkele gedachten n.a.v. recente jurisprudentie, Advocatenblad, 1987, jrg. 67, nr. 11: 237-241.

Mols, G.P.M.F., Staande de zitting: Een beschouwing over het onmiddellijkheidsbeginsel, Gouda Quint, Arnhem 1989.

Mols, G.P.M.F., Getuigen in strafzaken, Nieuwenhoflezing VI, Kluwer, Deventer 1993.

Montfoort, A. van, Het topje van de ijsberg: kinderbescherming en de bestrijding vankindermishandeling in sociaal-juridischperspectief, Uitgeverij SWP, Utrecht 1994. 
Montfoort, A. van, Justitißle interventie bij geweld in het gezin, Tijdschrift voor Criminologie, 1995, jrg. 37, nr. 4: 360-373.

Montfort, S.H.H., Politie en vrouwenmishandeling. Een onderzoek naar aangiften en processen-verbaal met betrekking tot vrouwenmishandeling bij de vier stadsdistricten van de Regio Politie Utrecht, afstudeeronderzoek, Universiteit Utrecht 1994.

Mossman, M.J., Feminism and legal method: the difference it makes, in: M.A. Fineman \& N.S. Thomadsen, At the boundaries of law, feminism and legal theory, Routledge, New York 1991: 283-300.

Mulder, G.E. \& H. Schootstra, De voorwaardelijke veroordeling, Preadvies NJV, Hand.I, 1974.

Mulder, G.E., Dwingen in de zin van 242 Sr, $N J B, 1988$, jrg. 63, nr. 28: 1008-1009. Mulder, G.E., Waarom geen vrijspraak, Delikt en Delinkwent, 1996, jrg. 26, nr. 1: 40-42.

Myjer, E., Slachtoffers van zedendelicten en Straatsburgse rechtsbescherming, $N J B$ 1996, jrg. 71, nr. 12: 437-442.

Myjer, E., Naschrift bij Van der Pol, Straatburgse rechtsbescherming, $N J B, 1996$, jrg. 71, nr. 21: 804-805.

Naeyé, J., Een advocatenbalie op het politiebureau? Juridische consultatie voor aangehouden verdachten en slachtoffers, in: C.J.C.F. Fijnaut \& G.N.M. Blonk (red.), De advocaat bij het politieverhoor: verslag van de conferentie van 25 en 26 februari 1988, Van den Brink, Lochem 1988: 114-125.

Nacyé, J., Heterdaad, politiebevoegdheden bij ontdekking op heterdaad in theorie en praktijk, Gouda Quint/Slaterus, Arnhem/Lochem 1990 (tweede druk).

Naeyé, J., De reikwijdte van fundamentele rechten in strafzaken - enkele thema's, in: De reikwijdte van fundamentele rechten, Preadvies NJV, W.E.J. Tjeenk Willink, Zwolle 1995: 223-302.

Naffine, N., Feminist excavations, in: N. Naffine, Law and the sexes. Explorations in feminist jurisprudence, Allen \& Unwin, Sydney 1990: 1-23.

Neut, J.L. van der \& W. Wedzinga, Kritiek op arrest Hoge Raad raakt kant noch wal, $N J B, 1988$, jrg. 63, nr. 28: 1009-1010.

Neut, J.L. van der \& W. Wedzinga, Seksueel binnendringen, $N J B, 1994$, jrg. 77, nr. 5: 149-153.

Neut, J.L. van der \& W. Wedzinga, Het eeuwige getob, Nemesis, 1995, jrg. 11, nr. 5: $122-125$.

Noyon, T.J. en G.E. Langemeijer, Het Wetboek van strafrecht, losbladig, bewerkt door J. Remmelink, Gouda Quint, Amhem.

Nijboer, J.F., De schijngestalte van de materiële waarheid, $N J B, 1978$, jrg. 53, afl 35: 749-757.

Nijboer, J.F., Vrijspraak van verkrachting (HR 16 juni 1987, NJ 1988, 156) betreft een zuivere vrijspraak (van het Hof), $N J B, 1988$, jrg. 63, nr. 28: 1010-1012.

Nijboer, J.F., Strafrechtelijke bewijsrecht, Ars Aequi Libri, Nijmegen 1995.

Onstenk, A., Slaat de politiek terug? in: J. de Lima (red.), Het klappen van de zweep, 20 jaar Blijf van m'n Lijf Amsterdam, Van Arkel, Utrecht 1994: 143-151.

Osinga, P., Transactie in strafzaken; een onderzoek naar de positie van de transactie in het strafrechtelijk systeem, Gouda Quint, Amhem 1992. 
Pactow, B., Wergewaltigung in der Dhe: Eine Strafrechis vergleichende Untersuchung unter besonderer Bericksichtigung des rechts der Vereinigte Staten, Dissertation, Freiburg $1986 / 1987$.

Pelser, CM.s Recht ait vorm: de Commissie Moons en het aladerende cinde van de grondslagenleer, Deliki en Delinkweni, 1994, jrg. 24, ne. 1: 9-127.

Pelser, CM. De naam wan het feit, (Pompe reeks, di 17), Gouda Quint, Arnhem 1995.

Ponders, AS, Slachtofferhulp en rechtshulp 1, Advocatenblad, 1990, irs. 70 , m. 3. $43-4$ :

Fenders, A.S. Slachtofferhulp en rechtshulp II, Advocalenblad, 1990, jrg. 70, nr. 4: $101-105$.

Fesuars, D., De wijheid was oorverdovende selsuele expressie, NJB, 1991, jg. 66 , afl 4al: 1782-178\%,

Pessers, $D_{s}$ Radicalime versas reformisme, Nemesis, 1994 , jre 10 , nir. $6: 17 \%$. Peters, A.A.G. Het rechtskanalder wan hes atruffrecht, Kluwer, Deventer 1972.

Peters, A.A.G, Recht als vals bewustzijn, in: C. Relk es. (red.), Recht, macht en manipulatie, Utrecht/Antwerpen 1976: 189-220.

Peters, A.A.O. Redis als projed, Ars Aequi, 1979, jne. 28, nt. 11: 245-256.

Pitlo, A., bewerkt door PHM. Gerver E.a.. Het systeem van het nederlandse privaatrecht, elfde druk, Gouda Quint, Amhem 1995.

Plan van aduppak reorganisatie openbaat ministerie, "s-Grawenhage 1995.

Pol, van der, Straatburgse rechtsiseschertining, NJB, 1996, jrg. 71, nr. 21: 804.

Polak, N.J., De 'beledigde partij' in ere hersteld, NJB, 1980, jrg. 55, nr. 2: 21-29.

Prakken, T., Vrijheid of gelijkheid, Nemesis, 1984/85, jrg. 1, nr. 8: 347-348.

Prakken, T., Naar een tweesporig strafproces?, $N J B, 1992$, jrg. 67, nr. 40: 12941300.

Raes, K., Variaties op het verschil-dilemma, voorbij universele verschillen van particuliere rechtstheorie, Nemesis, 1991, jrg. 7, nr. 5: 5-21.

Raes, K., Minow, Okin, Rawls, Habermas en 'de anderen', in: E.A. Alkema \& A.Ph.C.M. Jaspers (red.), Lof de verscheidenheid: Rechtsgeleerden over vrouwen en recht, W.E.J. Tjeenk Willink, Zwolle 1993: 151-166.

Rappard, M. van, Tot hier en niet verder, verzet van mishandelde vrouwen, Ambo, Baarn 1988.

Rappard, M. van, Vrouwen willen hun man niet in het gevang, ze willen dat het geweld stopt, in: Thuis geslagen mevrouw? Dan ... kunnen wij niets doen, 'Blijf van m'n Lijf' Amsterdam over politie, justitie en overheid, december 1984: 23 . 31.

Rapport van de werkgroep aangifte sexuele geweldsmisdrijven, 1981.

Rapport van de werkgroep justitieel beleid en slachtoffer, mei 1984.

Rapport Bedreigde getuigen, juni 1986.

Rapport van de Commissie wettelijke voorzieningen slachtoffers in het strafproces, Wettelijke voorzieningen slachtoffers in het strafproces, 's-Gravenhage 1988.

Rapport van de Commissie Donner, Het functioneren van het Openbaar Ministerie binnen de rechtshandhoving, 's-Gravenhage 1994.

Rappport Het recht ten uitvoer gelegd: oude en nieuwe instrumenten van rechtshandhoving, 's-Gravenhage 1995. 
Remmelink, J., Visies op telastlegging, In: Bij deze stand van zaken: Bundel opstellen aangeboden aan A.L. Melai, Gouda Quint, Amhem 1983: 405-439.

Remmelink, J., Mr. D. Hazewinkel-Suringa's Inleiding tot de studie van het Nederlandse strafrecht, Gouda Quint, Amhem 1994 (dertiende druk).

Reijntjes, J.M., Voorwaardelijk sepot, in: Liber Amoricum Th.W. van Veen, Gouda Quint, Amhem 1985: 295-316.

Rodrigues, P.R., Het strafrecht als hek van de dam, Nemesis, 1993, jrg. 9, nr. 6: 187-189.

Romkens, R., Verzet van mishandelde vrouwen, een kwestie van macht en onmacht, Tijdschrift voor Vrouwenstudies, 1980, jrg. 1, nr. 3: 267-292.

Römkens, R., Vrouwenmishandeling: het miskende geweld in de familie Doorsnee, in: M. Corten e.a. (red.), Geweld tegen vrouwen, (g)een zaak voor politie en justitie?, Kongresbundel, Delft 1985: 18-25.

Romkens, R., Vrouwenmishandeling: over geweld tegen vrouwen in heterosexuele partnerrelaties, Ministerie van WVC, Rijswijk juni 1986.

Römkens, R., Onder ons gezegd en gezwegen, Ministerie van WVC, Rijswijk juni 1989.

Romkens, R., Geweld tegen vrouwen in heteroseksuele relaties. Een landelijk onderzoek naar de omvang, de aard, de gevolgen en de achtergronden, Stichting tot Wetenschappelijk Onderzoek bij de Universiteit van Amsterdam omtrent Sexualiteit en Geweld, Amsterdam 1989.

Römkens, R., Het onbehagen over geweld tegen vrouwen, projectie en internalisering van verantwoordelijkheid en schuld, in: P.B. Defares \& J.D. van de Ploeg (red.), Agressie. Determinanten, signalering en interventie, Van Gorcum, Assen / Maastricht 1991: 211-227.

Römkens, R., Geschonden grenzen, in: E. Spruijt (red.), Psychologie van het gezin. Zicht op huwelijk en relaties. Stichting Teleac, Utrecht 1991.

Romkens, R., Gewoon geweld? omvang, aard, gevolgen en achtergronden van geweld tegen vrouwen in heteroseksuele relaties, Swets \& Zeitlinger, Amsterdam / Lisse 1992.

Romkens, R., Wie is bang voor geweld?, in: J. de Lima (red.), Het klappen van de zweep, 20 jaar Blijf van m'n Lijf Amsterdam, Van Arkel, Utrecht 1994: 127-141.

Rook, A., Openingsrede, in: Met het oog op de dader, congresverslag, Rotterdam juli 1990: 3

Roos, Th. de, Strafrecht en democratische legitimatie, Delikt en Delinkwent, 1983, jrg. 13, nr. 10: 869-877.

Roos, Th. de, Strafbaarstelling van economische delicten, Gouda Quint, Arnhem 1987.

Roos, Th. de, Het effect van uitspraken van de Hoge Raad op de lagere rechtspraak en op de publieke opinie. De macht en de hulpeloosheid van de cassatierechter. Delikt en Delinkwent, 1988, jrg. 18, nr. 10: 1007-1018.

Rooyen-de Wit, C.M. van, Wie is er eigenlijk nog bang voor het politiesepot, Tijdschrift voor de Politie, jrg. 1987, nr. 1: 6-13.

Rowland, J., Rape, the ultimate violation, Pluto Press, London / Sydney 1986. Russell, D., Rape in marriage, Indiana University Press, Bloomington / Indianapolis 1990 (tweede druk). 
Rijn, J.H.C. van, Politie-sepot: een uitkomst voor het Openbaar Ministerie of voor de politie? Tijdschrift voor de Politie, jrg. 1983, nr. 12: 621-625.

Sagel-Grande, I., Schadevergoeding en strafrecht, Delikt en Delinkwent, 1992, jrg. 22, nr. 1: 58-66.

Savornin Lohman, J. de, e.a., Betere en adequate bescherming door de nieuwe zedelijkheidswetgeving? Evaluatieonderzoek naar de effecten en de doelbereiking van de nieuwe zedelijkheidswetgeving, Verwey-Jonker Instituut, Utrecht 1994.

Scales, A.C., The emergence of feminist jurisprudence: an essay, Yale Law .Journal 1986, jrg. 95: 1373-1403.

Schalken, T.M., De rechtspositie van de benadeelde partij in het systeem van de nederlandse rechtsvordering, Delikt en Delinkwent, 1980, jrg. 10, nr. 4: 266-278.

Schalken, T.M., Het politiesepot en de mandaatsverhouding, Trema, 1984, VII, nr. 1/2: $5-11$.

Schalken, T.M., Strafrecht als systeem van rechtsbetrekkingen, Gouda Quint, Amhem 1987.

Schalken, T.M., De positie van het slachtoffer in het systeem van strafprocesrechtelijke rechtsbetrekkingen, Ars Aequi, 1989, jrg. 38, nr. 4: 238-245.

Schalken, T.M., De fatale schijnoplossing van de commissie-Donner, $N J B, 1994$, jrg. 69, nr. 25: 833-836.

Schalken, T.M. e.a. (red.), Magistraat met beleid, de officier van justitie en zijn omgeving, Gouda Quint, Amhem 1992.

Schneider, E.M., Describing and changing: Women's self-defence work and the problem of expert testimony on battering, Women's right law reporter, 1986. jrg. 9, nrs. 3 \& 4: 195-222.

Schneider, E.M., The violence of privacy, in: M.A. Fineman \& R. Mykitiuk (eds.), The public nature of private violence: the discovery of domestic abuse, Routledge, New York/London 1994: 36-58.

Schuyt, K., Emancipatie en autonomie: een wijsgerig-sociologische reflectie op een oud probleem, in: Publiek geheim: Deprivatisering van het vrouwenleven, Nemesis Essays 1995: 15-29.

Schuyt, K., Sturing en het recht, in: M.A.P. Bovens \& W.J. Witteveen (red.), Het schip van staat: Beschouwingen over recht, staat en sturing, W.E.J. Tjeenk Willink, Zwolle 1985: 113-124.

Serrarens, J., T. Spronken \& R. Wolleswinkel, Beperking van individuele (grond)rechten verdachten in het strafproces leidt tot repressie, $N J B, 1992$, jrg. $67, \mathrm{nr}$. 16: 521 .

Sevenhuijsen, S., Vadertje staat, moedertje thuis? Vrouwen, reproductie en de staat, Socialisties-feministiese teksten 1, Uitgeverij Sara, 1978: 18-64.

Sherman, L.W., Policing domestic violence: experiments and dilemmas, The Free Press, New York 1992.

Simons, D., Leerboek van het Nederlandsche strafrecht, Deel II: Bijzondere strafbare feiten, bijgewerkt door W.P.J. Pompe, Noordhoff, Groningen 19371941 , zesde druk.

Sjocrona, J.M., De verkrachting van een arrest? Reactie op Van Maarseveen, $N J B$, 1988, jrg 63, nr. 28: 1013-1014. 
Slotboom, A. \& J. Wemmers, Tevree met de wet Terwee? samenvattende rapportage van de evaluatie-onderzoeken, Centrale directie wetenschapsbeleid en ontwikkeling, Justitie, Den Haag 1994.

Slotboom, H., De 'gevonden waarheid': beelden in het strafrecht. Een exploratief onderzoek naar beeldvorming in strafzaken betreffende vrouwenmishandeling, afstudeeronderzoek, Universiteit van Utrecht 1992.

Smart, C., Feminism and the power of law, Routledge, London / New York 1989.

Smart, C., The woman in legal discourse, oratie RUU, 16 mei 1991. Nederlandse vertaling: De vrouw in het juridische vertoog, Tijdschrift voor Vrouwenstudies, 1991, jrg. 12, nr. 1: 499-514.

Smidt, H.J., Geschiedenis van het Wetboek van Strafrecht. Volledige verzameling van regeeringsontwerpen, gewisselde stukken, gevoerde beraadslagingen enz., Tweede Deel, Haarlem 1891.

Smits, M., Wie is er bang voor het strafrecht? Nemesis, 1986, jrg. 2, nr. 5: 212-214.

Smits, V.M., Verkrachting, NJB, 1993, jrg. 68, nr. 12: 416-417.

Soest, H. van \& S. Walther, Schadevergoedingsstraf en strafrecht. Een commentaar op het rapport van de Commissie wettelijke voorzieningen slachtoffers in het strafproces, $N J B, 1988$, jrg. 63, nr. 37: 1336-1341.

Soetenhorst, J., Meer dan een belangenstrijd, Nemesis, 1984/85, jrg. 1, nr. 8: 358360.

Soetenhorst, J., De moeilijke weg, culturele aspecten van het verkrachtingsvraagstuk, in: Vrouwen en Justitie, leesmap, Uitgave Stichting Tegen Haar Wil Amsterdam 1984: 11-17.

Soetenhorst-de Savomin Lohman, J. Doe wel en Zie om: Maatschappelijke hulpverlening in relatie tot het recht, Swets \& Zeitlinger, Amsterdam/Lisse 1990.

Soetenhorst-de Savomin Lohman, J. \& U. Jansz, Seksueel geweld zal de wetgever een zorg zijn; herziening van de zedelijkheidswetgeving in Denemarken, Zweden en Nederland, Gouda Quint, Amhem 1986.

Stanko, E., Everyday violence, how women and men experience sexual and physical danger, Pandora, London 1990.

Stanko, E.A. \& K. Hobdell, Assault on men; masculinity and male victimization, The British journal of criminology, 1993, jrg. 33, nr. 3: 400-415.

Steen, W. van der \& A. Geurts, Politie en justitiebeleid in cijfers, een onderzoekje naar ervaringen van mishandelde vrouwen met politie- en justitieoptreden, in: Thuis geslagen mevrouw? Dan ... kunnen wij niets doen, 'Blijf van m'n Lijf' Amsterdam over politie, justitie en overheid, december 1984: 53-55.

Steinmetz, C.H.D. \& H.G. van Andel, Mishandeling en hulpverlening, (Serie: WODC nr. 49), Staatsuitgeverij, 's-Gravenhage 1994.

Steinmetz, C.H.D., Reacties op intrafamiliaal geweld, Justitiële Verkenningen, 1986, jrg. 12, nr. 4: 475-513.

Steinmetz, C.H.D., Hulp aan slachtoffers van ernstige misdrijven, effecten van slachtofferhulp en primaire opvang, (Serie: onderzoek en beleid nr. 98), Gouda Quint, Amhem 1990.

Sterk, C. Vieze kereltjes, zedenpolitie en vrouwen, Vermande, IJmuiden 1984.

Stolk, B. van \& C. Wouters, Vrouwen in tweestrijd: tussen thuis en tehuis, Van Lochum Slaterus, Deventer 1983. 
Stolker, C.J.J.M., Straffen met privaatrecht - of juist verzoenen?, in: A.M. Hol \& C.J.J.M. Stolker, Over de grenzen van strafrecht en burgerlijk recht, Kluwer, Deventer 1995: 29-41.

Straelen, F.W.M. van, Het seponerings- en strafvorderingsbeleid van het Openbaar Ministerie, in: L.G. Moor \& E. Leuw, Beslissingsmomenten in het strafrechtelijke systeem, Ars Aequi Libri, Nijmegen 1978: 191-210.

Straelen F.W.M.van \& J.J.M. van Dijk, Rechtsgelijkheid en sepotpraktijk, verslag van een onderzoek naar het sepotbeleid in het Hofressort 's-Gravenhage, WODC-reeks 23, Staatsuitgeverij, 's-Gravenhage 1981.

Strijdpunten en akies, Aktiegroep Blijf van m'n Lijf Den Haag 1983.

Stutterheim, R.H. \& P.G. Wiewel, Een variatie op het thema slachtofferbescherming:

De dader-slachtofferschaderegeling, in: P.G. Wiewel e.a (red.), Dading in plaats van strafrecht, Gouda Quint, Amhem 1993: 13-26.

Suyver, J.J.H., Politie in de rechtsorde, W.E.J. Tjeenk Willink, Zwolle 1994.

Tegen Haar Wil Amsterdam, Seksueel geweld, iedere vrouw en ieder meisje kan ermee te maken krijgen, 1988.

Temkin, J., Rape and the legal process, Modern legal studies, Sweet/Maxwell, London 1987.

Thomas, D.Q. \& M.E. Beasley, Domestic Violence as a human rights issue, Human Rights Quarterly, 1993, jrg. 15, nr. 1: 36-62.

Thornton, M., Feminist jurisprudence, illusion or reality, Australian journal of law and society, 1986, jrg. 3: 5-29.

Thornton, M., Feminism and the contradictions of law reform, International Journal of the sociology of law, 1991, jrg. 19: 453-474.

Tigchelaar, J., Vrijage of verkrachting. Inzicht in dwang, Nemesis, 1988, jrg. 4, nr. 3: 99-103.

Tong, R., Women, sex and the law, Rowman/Allanheld, Totowa/New Yersey 1984.

Trema thema-nummer 'De officier van justitie, magistraat of bestuursambtenaar?' Trema, 1991, XIV: 157-200.

Tulder, J.J.M. van, De beroepsbevolking in Nederland van 1919 tot 1954, H.E. Stenfert Kroese NV, Leiden 1962.

Valkenburg, W.C.E.A., Enige opmerkingen over de Wet getuigenbescherming, Delikt en Delinkwent, 1995, jrg. 25, nr. 4: 349-365

Veen, Th.W. van, De betekenis van het 'subsociale' voor het straffen en het strafrecht, Tijdschrift voor Strafrecht, 1952: 122-138.

Veen, Th.W. van, De betekenis van het strafproces voor onze samenleving, Tijdschrift voor Strafrecht, 1969: 121-147.

Veen, Th.W. van, Dienstverlening, Justitiële Verkenningen, 1984, jrg. 10, nr. 6: 47 58.

Veen, Th.W. van, Inleiding Rode draad: Materieel strafrecht in beweging, Ars Aequi, 1994, jrg. 43, nr. 1: 5-13.

Vegter, P., Straffen en andere sancties, in: J. Fiselier e.a. (red.), De staal van justitie, SUN, Nijmegen 1992: 137-158.

Verhey, L.F.M., Horizontale werking van grondrechten, in het bijzonder van het recht op privacy, W.E.J. Tjeenk Willink, Zwolle 1992. 
Verrijn Stuart, H., Straatverboden in kort geding. Een ordemaatregel, Nemesis, 1984, jrg. 1, nr. 1: 104-106.

Verrijn Stuart, Hakken, hakken, hakken, hakken, De Groene Amsterdammer, 14 maart 1984.

Verrijn Stuart, H., Strafrecht tegen seksueel geweld? Een illusie! Een interview met Ties Prakken, De Groene Amsterdammer, 13 juni 1984.

Verrijn Stuart, H., Vrouwen en strafrecht, het onverzadigbare slachtoffer en de onverzadigbare justitie, in: R. van Swaaningen e.a. (red.), à Tort et à Travers, Liber Amoricum Herman Bianchi, VU Uitgeverij, Amsterdam 1988: 215-221. Verrijn Stuart, H., Vrijspraak van verkrachting. 'Als je blijft tegenwerken breek ik je arm', Nemesis, 1988, jrg. 4, nr. 2: 47-49.

Verrijn Stuart, H., Naar een geciviliseerd recht tegen sexueel geweld, Ars Aequi, 1992, jrg. 41, nr. 2: 82-92.

Verrijn Stuart, H., Dading tussen civielrecht en strafrecht, in: P.G. Wiewel e.a. (red.), Dading in plaats van strafrecht, Gouda Quint, Arnhem 1993: 33-44.

Verrijn Stuart, H., Jacht op het onzegbare, Nemesis, 1993, jrg. 9, nr. 5: 141-148. Verrijn Stuart, H., Via onschuld naar macht, Justitiele Verkenningen, 1994, jrg. 20, nr. 2: 94-114.

Verrijn Stuart, H., Verkrachting op het breukvlak van twee eeuwen, Nemesis, 1996, jrg. 12, nr. 4: 97-98.

Vervolgnota Beleid ter bestrijding van sexueel geweld tegen vrouwen en meisjes, TK 1990-1991, 18.542, nr. 20.

Visser, A.S.C., Veranderend denken over wetstoepassing bij seksuele delicten, in: J. Frenken \& J. Doomen, Strafbare seksualiteit, opvattingen en aanpak van politie, justitie en hulpverlening, Van Loghum Slaterus/ W.E.J. Tjeenk Willink, Deventer/Zwolle 1986 (eerste druk 1984): 100-111.

Voortgangsrapportage Beleid ter bestrijding van sexueel geweld tegen vrouwen en meisjes, TK 1985-1986, 19.209, nrs. 1-2.

Vrij, M.P., Ter effening, het subsociale als het derde element van het delict, Wolters, Groningen 1948.

Vrouwenrechten, mensenrechten, vechten om de grenzen, Nemesis Essays 1996.

Waits, K., The criminal justice system's response to battering: understanding the problem, forging the solutions, Washington Law Review, 1985, jrg. 60:267-329.

Walaardt Sacré, T. \& W. Portegijs, Wat komt zal de tijd wel leren, Wetenschapswinkel RUL, Leiden 1986.

Walker, G.A., Family violence and the women's movement, University of Toronto Press, Toronto/Buffalo/London 1990.

Walker, L.E., The battered woman, Harper \& Row, New York 1979.

Walther, S.R.B., Een wettelijke regeling voor het politiesepot, Tijdschrift voor de Politie, 1987, jrg. 49, nr. 6: 264-270.

Weeda, I., Over liefde gesproken, dynamiek en dilemma in menselijke verhoudingen, De Haan, Houten 1987 (vierde druk).

Wedzinga, W., Openlijke geweldpleging, Gouda Quint, Arnhem 1992.

Wirken, J.J., Denken over seksueel geweld, een enclave in het abolitionisme?, Nemesis, 1984/85, jrg. 1, nr. 8: 363-366. 
Wiewel, P.G., e.a. (red.), Dading in plaats van strafrecht, Gouda Quint, Amhem 1993.

Wit, B. de, Het slachtoffer is koning, Nemesis, 1986, jrg. 2, nr. 2: 64-65.

Wit, M. de, Interview: Hoofdinspecteur Georgine Acton: 'Als je vrouwenmishandeling goed aanpakt krijg je een beter politieprodukt', Vrouw \& Gezondheidszorg, 1995, november/december: 6-9.

Witteveen, W.J., Evenwicht van machten, W.E.J. Tjeenk Willink, Zwolle 1991.

Witteveen, W.J., Afdaling in de versteende wereld van het recht, Boekbespreking: A.C. 't Hart, Recht als schild van Perseus, voordrachten over strafrechtstheorie, Deliket en Delinkwent, 1991, jrg. 21, nr. 10: 1108-1117.

Woretshofer, J., Volgens de regelen van de kunst, Gouda Quint, Amhem 1992.

Wöstmann, M. \& H.G. van de Bunt, Verbaliseren van politieoptreden bij vrouwenmishandeling, In: G. Bruinsma e.a. (red.), Vrouw en criminaliteit, Boom, Meppel/Amsterdam 1987: 155-167.

Wostmann, M., Politieoptreden bij vrouwenmishandeling, Van den Brink \& Co, Lochem 1988.

Wostmann, M., Elke situatie is anders, knelpunten in het politieoptreden bij vrouwenmishandeling, Tijdschrift voor de Politie, 1988, jrg. 50, nr. 6: 255-258.

Zeegers, N., Seksuele vrijheid en dwang in het strafproces, lezing gehouden op het Symposium Recht, norm en beeldvorming, het juridische vertoog met ander ogen, 10 juni 1993 (ongepubliceerd).

Zoomer, O.J. \& C.H.D. Steinmetz, Vrouwelijke slachtoffers van misdrijven: hoe reageert het justitiěle systeem daarop? Tijdschrift voor criminologie, 1979, jrg. 21, nr. 5: 243-256.

Zoomer, O.J., De strafvordering en straftoemeting in gevallen van zware criminaliteil, een overzicht van de jaren 1973-1976 en een analyse van de beslissingen van officieren van justitie, WODC-reeks 25, Staatsuitgeverij, 's-Gravenhage 1981.

Zoomer, O.J., Vrouwenmishandeling; politiewerk, Gouda Quint, Amhem 1990. 



\section{Trefwoordenregister}

Aangifte $17,30,31,37,68,70,72,123,125,127,128,131,163,188,202,204$. $206,207,214,225,236,250,259$

Arbeidsdeling naar sekse 3,4

Autonomie $5,7,9,11,14,24,51,61-63,67,207,238$

- seksuele 56

Aanranding 29, 35, 41, 110-119, 174-177, 258

Arrestatie (zie ook inverzekerinjgstelling) 72

Bedreiging 29, 35, 41, 72, 93, 97-98, 107, 108, 120, 121, 129, 137, 146, 167-171. 197, 226, 265

Beginselen van goede procesorde 16, 231

Bekenden 31, 32, 148,157, 159, 160

Beklagprocedure (art. $12 \mathrm{~Sv}$ ) $85-87,131,138$

Beleid ter bestrijding van seksueel geweld 10,88-90

Benadeelde partij 23, 80-87, 140,162, 196, 208, 228, 229, 258, 261

Berisping 73, 134

Bewijs 16, 68, 69, 72, 82, 89, 94, 108, 109, 113, 132, 143, 167, 176, 199, 200, 206, 215, 235, 239

- bewijsmiddelen $36,94-95,183,216,223,235,236,340$

- bewijsoordeel 227

- bewijsproblemen 117

- bewijsstelsel 94

Blijf van m'n Lijfhuis (zie Opvanghuis)

Buiten echt $89,111,220$

Buitengerechtelijke afdoening 130-139, 203, 260

Buiten justitiële conflictregulering 14

Burgerschap 15, 23, 207, 208, 267

Civiele recht $11,12,14,15,93,162$

Contactverbod $11,130,145,194,229,250,252$

- buurt II

- straat $11,12,71,130,145,201,229,250,252,253$

- telefoon 11,145

Contrafacticiteit $21,24,26,119,208$

Crime passionel 224

(De)criminalisering $62,64,66$ 
(De)juridisering 27

(De)penalisering 62,64

Delictsomschrijving 28, 93,117, 221, 264

Deskundigen $17,82,130,143,229$

- onderzoek slachtoffer 232

- rapport 40,71, 82,130,189,197, 199, 229

Difference-dilemma 9,263

Doodslag 29, 35, 41, 72, 103-106, 121, 139, 171-174, 194, 223, 235, 258

Dwang

- art. $284 \mathrm{Sr} 35,41,98-99$

- dwang als bestanddeel 99, 114-119, 120-121, 209-222

- psychische 28

- seksuele 46, 48, 54-57, 114, 176, 206

- sociale en interpersoonlijke 55, 210

Dwangmiddelen 72,130

Echtscheiding 12, 161, 162, 172, 205, 259

'Exit'-benadering (zie feminsten, radicaal-kritische)

Fair trial 16, 228, 231, 240-242

Feitelijkheid

- als bestanddeel $98,111,113-117,220$

Feministen 116

- radicaal-kritische $61-64,66-68$

- reformistische $61,64-68$

Feministische rechtswetenschap 25-27

Folterverbod 228, 241

Fysieke en psygische integriteit (zie Grondrechten)

Geestelijke en lichamelijke gezondheid (zie Grondrechten)

Gerechtelijk vooronderzoek 16, 86, 130,131,141, 146, 162, 229, 235, 239

Getuige $14,17,69,70,82,95,130,141-143,208,229,232,235,250,258,261$

- anonieme getuige 95

- bedreigde getuige 142,24I

- betrouwbaarheid 236-237

- eigen rechtsingang 242-243, 245

- fair hearing 243-245, 256, 261

- niet verschijnen wegens gezondheidsredenen 142-143, 241-243, 255

- verschoningsrecht $238-240,255$

Geweld

- eenzijdig geweld $46-48$

- wederkerig geweld 48,191,203, 259

Geweld tegen kinderen $1,2,262$

- seksueel misbruik van kinderen 71, 74, 90, 123, 262 
Grondrechten

- botsing van 241

- eerbieding van de persoonlijke levenssfeer $1,4,8,14,17,18,24,28,82,89,93$, $96,107,120,166,207,209,227,229,241,243,246,247,256,257,267$

- onaantastbaarheid van het lichaam $5,8,10,13,14,17,24,88,89,92,96,112$, $120,217,238,241,243,252,256-258,261,267$

- huisrecht 5, 107

Heterdaad $72,73,121,129$

Huisvredebreuk 29, 35, 41,107-110,120,121, 127-129,137, 146, 165-166, 197, $202,204,205,225,233,265$

- binnen huwelijk 108

Hulpverlening $11,14,65,89,260,267$

- aan daders 10,130,145,190,202,249,252, 254

- aan slachtoffers 10,248

Humane aanpak 23, 24, 33, 246, 254, 256, 258, 260, 265-266

Huwelijk 5, 6, 9, 12, 29, 52, 54, 55, 103, 108, 111, 204, 209, 239, 240, 262

- gehoorzaamheidsplicht van de vrouw 5

- hoofd van het gezin 6

- handelingsbekwaamheid van de vrouw 5, 109

- huwelijkswetgeving 3

Informatie

- verstrekking $70,87,123,245$

- plicht tot 71,75

- recht op $80,92,208,228$

Instrumentalistische opvatting 20, 124

Inverzekeringstelling $17,72,73,121,127,129,145,162,164,174,177,250-252$, 263

Inzichtvereiste $118,209,217-222$

Jeugd- en Zedenpolitie 75,128

Juridiseringsdilemma 9,67, 264

Klachtdelict $125,230,233-234,261$

Kwalificatie 95, 106, 117, 119,121-122, 223

Kort geding $11,12,71,253,254$

Legaliteit 15

Legaliteitsbeginsel 93

Legitiem 15

Letsel $30,36,40,46,47,58,69,99-101,104,128,170,173,176,177,183,188$, 194, 201, 204, 222, 223, 259

- zwaar lichamelijk 101-102, 170

Maatregel $94,143,144$

- tbs 144 
- schadevergoedings $83-84,144$

Macht

- kwantitatieve 51

- kwalitatieve 51

- latente 6, 5I-55

- manifeste $6,51,52,54,55,60$

- onzichtbare 6, 51-55

Machtskritische opvatting 20

Machtsongelijkheid tussen mannen en vrouwen $3,5,8,12,25-28,49,50,57,58$, $61,88,222,224,227,263$

Medische verklaring $40,143,177,183$

Meineed 141, 239

Minister van Justitie 124,126

Mishandeling 28, 29, 31, 35, 36, 41, 69, 70, 72, 99-105, 121, 127-130, 137, 139, $146,167-171,173,192-196,199,201,204,215,222-224,233,258,265$

- door echtgenoot 29,100,105, 106

- zware 29, 36, 70, 99, 101-102, 105, 106, 121, 139, 170, 199, 222, 235

- poging tot 99

- psychische 99

Moord 29, 35, 41, 103-106, 171-174, 258

Mutatie 37, 127, 247

Normhandhaving $17,248-250,266$

Omgangsregeling 161,166,197

Onmiddellijkheidsbeginsel 240,246

Onrechtmatige daad 11

Ontucht(ig) $111,113,114$

Opportuniteitsbeginsel $131,132,134,135$

Opsporing 89

- opsporingsonderzoek 126

Opvanghuis $28,48,83,162,169,194,195,200,253$

Opvangmogelijkheden 10

Opzetvereiste $95,101,120,225$

- voorwaardelijke opzet 96, 101,104,118, 120, 209, 213, 216, 220, 222

Overheidsinterventie 10

Parketsecretaris 130,131, 146, 204, 265

Persoonlijke vrijheid (zie Privacy als actief recht)

Politie $1,13,16,17,24,30,31,32,37,59,64,68-69,70,73,74,77,84,85,89$, $93,108,124-128,138,162,164,167,173,186,190,197,205,208,235,239,240$, $246,247,250,253-256,260,263,267$

- opleiding 72,75

Positieve verplichting $7-8$ 
Preventiemaatregelen 10

Privacy $4,6,10,13,24,92,165,166,169,226,229,241,261$

- als passief recht $6,8,9,15,60,92,106,204,233$

- als actief recht (zelfbeschikking) 5, 7-9, 15, 61, 63, 88, 92, 204, 207, 242.

$246-248,256,258,262,264,267$

- schending 167, 199, 205, 254, 262

Privésfeer/publieke sfeer 2-4, 5

Proces-verbaal 72

Protection order 90

Psychiatrische rapporten (zie deskundigenrapport)

Recht

- sekse-neutraal 26,111,119, 263

- seksistisch 26

- mannelijk 26

- 'gendered' 26

Rechter(lijke macht) $13,16,31,38,84,121,140,143,144,162,197,230,231$, 260

- politierechter $38,141,163,194,196-198,252$

- meervoudige kamer 38, 163, 174, 177, 199, 201

Rechter-commissaris 17, 130,141,143,145,199,229,235, 239, 240, 242

Rechtsbescherming $16,17,65,76,92,93,232,246,253,254,258,262$

- van slachtoffer 18,19,22, 33, 120,205,207,244,245,255,257,260, 267

- van verdachte $18,20,22,33,231,234,243,245,255$

Rechtsbijstand 228,256, 261

Rechtsobject 18

Rechtssubject $9,11,15,18,22,24,92,208,228,232,241-243,246,254,255$, $257,258,261$

Rechtsvrede (zie strafdoel)

Recidive 71, 127, 184, 246, 258, 266

Reclassering 131,133,145,169,172,175,178,179,190-193, 249, 254, 260, 266

- begeleiding 193

- belang 136, 139, 249, 252

- rapport (zie deskundigenrapport)

Registratie $70,73,74,89,90$

Relationele opvatting $19-22,124,125,208,244,245$

Requisitoir 17, 71, 143-145, 225, 248

Resocialisatie 75,265

Richtlijn 127, 134, 144,244,245,260, 265

- landelijk $77,78,90,91,134,140,228,235,248$

- dienstorder 73,128

- vervolgingsrichtlijn 126 
Sado-masochisme 212-214

Samenwerkingsverband $72,74,79,254,260$

Samenwoning $5,12,49,108-110,165,173,239,240$

Sanctie 13

- civiele 13

Schade

- vergoeding $11,71,74,81-83,87,92,136,138,145,162,197,198,209,228$

- herstel II

Schadevergoedingsmaatregel $83-84,208$

Schadeloosstelling 228, 229, 233

Secundaire victimisatie $69,234,238,242$

Seksueel binnendringen 111-113

Seksuele misdrijven 74,77

Seksuele zelfbeschikking 70, 96, 112, 120, 206

Separation assault 58,141,167, 177, 205, 259, 262

Sepot 31, 70, 130-132

- beleids 132, 133,136,187, 204

- bericht 131

- informeel 131

- formeel 131

- onder voorwaarden 73, 89, 135-137, 138-139, 146, 189, 190, 193, 194, 196, 198, $249,250,252,254,255$

- politiesepot $126-128$

- technisch $132,183,187$

Sepotgronden 127,133-134

- gering feit 127,133

- verhouding tot benadeelde geregeld 127

- beperkte kring 127, 128, 134, 147, 193, 202

- leeftijd 133

- medeschuld benadeelde 127, 133, 190-191, 204

- gezondheidstoestand 133

- reclasseeringsbelang 133

Slachtofferbeleid 74-79,90-92, 244

Slachtofferhulp 79, 128,248, 254

Slachtofferpositie 17

Slachtofferisme 63

Slachtoffermoraal 19

Slachtoffervoorzieningen 79-84, 87, 92, 123

Snelrecht 141, 197, 252, 253

Straatverbod (zie contactverbod)

Straf $13,14,94,134,143,144$ 
- gevangenisstraf $144,145,163,193,201,206,265$

- geldboete 144, 145, 163,193, 206, 265

- dienstverlening 144

Strafbepaling (zie Delictsomschrijving)

Strafblad 37-38, 161, 185, I86, 195, 199, 203, 204

Strafdoel

- afschriking 22

- speciale preventie 22, 208

- vergelding 22,144

- conflictoplossing 22, 137, 145, 246

- rechtsvrede $22,23,33,208,246,247,254,255,258$

Strafrechtelijke normstelling 12

Strafrechtelijk verleden (zie strafblad)

Telastlegging $17,38,94,121,131,211,219$

- primair-subsidiair 139

- cumulatieve 140

Toerekeningsvatbaarheid $37,166,173,224$

Transactie $36,130,135,137-139,146,155,157-160,163,187,196,230,265$

Traumatic bonding 58,59

Trechterfunctie van het strafrecht 30

Vergelding 13

Verkrachting 29, 35, 41, 47, 48, 56, 68-70, 74, 81, 110-120, 174-177, 199-202, $206,235,258$

- binnen het huwelijk $54-57,111,114,174,201,206,212$

- tijdens bewusteloosheid 176

Vernieling $29,35,41,69,72,93,106,109-110,127-129,137,146,165-167,196$ $199,202,204,205,226,258,265$

- binnen huwelijk $109,110,120,132,165,262$

- van tafel en bed gescheiden $110,132,262$

Verschoningsrecht

- wegens verwantschap 238-240

Vertrouwensbeginsel 136,138

Vervolgingsmonopolie 13, 132, 231, 255

Vervolgingspraktijk $\quad 148-206$

- naar delictscategorie 151-154, 155-159

- van 150 zaken $178-182$

Vlugrecht 141,252

Voeging

- ad informandum 140

- ter berechting 140

- door benadeelde in het strafproces $13,79-84,162,164,198$ 
'Voice'-benadering (zie feministen, reformistische)

Voorbedachte raad 104, 105, 113

Voorlopige hechtenis 40,73, 129-130,145, 164, 174, 177, 194, 211, 230, 252

Voorlopige voorziening $12,108,110$

Vrouwenmishandelingsdelict

- art. $304 \mathrm{Sr} 29,102-103,106$

- formuleren van 90,263

Waarden-expressieve functie 63,64

Waarheidsvinding $16,94,130,216,242,243,245,250,251,261$

Waarschuwing 134, 198, 249

Weerbaarheid $60,91,207,215,224,230,232,234,243,249,250,259$

Wilsvrijheid $110,119,219,220,227$,

Wraak $13,18,236$

Wurgpoging 170,171, 173, 194, 222, 223

Zedelijkheidswetgeving 110

Zelfbeschikking (zie privacy als actief recht)

Zelfstandige vervolgingsbevoegdheid slachtoffer 229, 232

Zorgvuldige bejegening $70,71,75,77,87,92,123,208,228,245,247$ 


\section{Curriculum vitae}

Katinka Lunnemann is geboren op 12 november 1958 te Vlissingen. In 1977 behaalde zij haar Atheneum-A diploma aan het Herman Jordan Lyceum in Zeist. $\mathrm{Na}$ haar studie sociologie aan de Universiteit van Amsterdam, afgerond met een kandidaatsexamen in 1981, is zij rechten gaan studeren. Dit is in 1986 afgerond met een doctoraalbul.

Direct aansluitend is zij als toegevoegd onderzoeker aangesteld aan de Rechtenfaculteit Leiden, afdeling Vrouw en Recht om een onderzoeksvoorstel omtrent justitiele afhandeling van zaken van vrouwenmishandeling te schrijven. Vervolgens heeft de Rechtenfaculteit Leiden in samenwerking met het toenmalige onderzoekscentrum Sturing en Samenleving (tegenwoordig Recht en Beleid) het tot promotieonderzoek omgezette onderzoeksvoorstel gefinancierd tot 1992. Zij was werkzaam op het onderzoekscentrum Sturing en Samenleving tot 1992. In 1992 is zij aangesteld als toegevoegd onderzoeker aan de Rechtenfaculteit Utrecht bij de sectie Juridische Vrouwenstudies (vakgroep ISEP). Sinds 1996 heeft zij hier een (part-time) aanstelling als universitair docent.

Zij woont samen met Jos Teunen en is moeder van twee kinderen, Jonathan en Milou. 
Vrouwen die slachtoffer zijn van geweld door hun partner of expartner zijn op zoek naar bescherming van zichzelf en eventueel van hun kinderen. Bescherming kan op verschillende manieren worden geboden. De auteur richt zich op de wijze waarop het strafrecht, en met name het openbaar ministerie, rechtsbescherming kan bieden aan slachtoffers van vrouwenmishandeling.

Worden zaken van vrouwenmishandeling vaker met een sepot afgedaan dan andere geweldszaken? Welke aspecten spelen een rol in de afweging die een officier van justitie maakt als hij of zij over een zaak van geweld tegen de vrouw door haar partner of ex-partner beslist? En wat betekent de roep om meer rechtsbescherming van vrouwen die slachtoffer zijn van geweld in de privésfeer? Door zowel het beslissingspatroon van officieren van justitie te beschrijven aan de hand van de resultaten van een exploratief onderzoek, als de juridische aspecten van rechtsbescherming te analyseren, wordt helderheid verschaft over de mogelijkheden en onmogelijkheden van strafrechtelijk optreden als het gaat om mannelijk geweld tegen vrouwen in de privésfeer. 